\title{
Rachunki sekwentowe w logice klasycznej
}

\section{Andrzej Indrzejczak}


Andrzej Indrzejczak - Katedra Logiki i Metodologii Nauk

Uniwersytet Łódzki, 90-232 Łódź, ul. Kopcińskiego 16/18

\section{RECENZENT}

Andrzej Pietruszczak

\section{PROJEKT OKŁADKI}

Jakub Michalski

Wydrukowano z gotowych materiałów dostarczonych do Wydawnictwa UŁ

(C) Copyright by Uniwersytet Łódzki, Łódź 2013

Wydane przez Wydawnictwo Uniwersytetu Łódzkiego

Wydanie I. W.06120.13.0.M

ISBN 978-83-7525-812-7

Wydawnictwo Uniwersytetu Łódzkiego

90-131 Łódź, ul. Lindleya 8

www.wydawnictwo.uni.lodz.pl

e-mail: ksiegarnia@uni.lodz.pl

tel. (42) 66558 63, faks (42) 6655862

Druk i oprawa: Quick Druk 


\section{Spis treści}

Wprowadzenie $\quad$ v

1 Klasyczny Rachunek Zdań 1

1.1 Język . . . . . . . . . . . . . . . . . . . . . . 1

1.2 Aksjomatyczne ujęcie KRZ . . . . . . . . . . . . . . . . 3

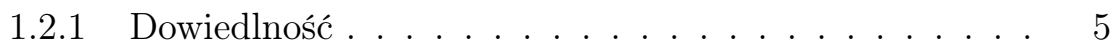

1.2 .2 Reguły wtórne . . . . . . . . . . . . . . . . . . . . 7

1.2 .3 Sprzeczność . . . . . . . . . . . . . . . . 8

1.3 Semantyka KRZ . . . . . . . . . . . . . . . . . . . . 9

1.4 Adekwatność H-KRZ . . . . . . . . . . . . . . . . . 11

1.4.1 Dowody twierdzenia o pełności - uwagi ogólne: . . . . 12

1.4.2 Zbiory maksymalnie niesprzeczne . . . . . . . . . . . 13

1.4.3 Inne metody dowodzenia pełności . . . . . . . . . . . . . 16

1.4.4 Pełność H-KRZ . . . . . . . . . . . . . . . . . 19

1.5 Wybrane własności KRZ . . . . . . . . . . . . . . . . . . . . . . . . . . . . 22

1.6 Dedukcja Naturalna . . . . . . . . . . . . . . . . 23

2 Sekwenty, reguły, rachunki $\quad 27$

2.1 Ogólne pojęcie rachunku sekwentowego. . . . . . . . . . . 27

2.1 .1 Rodzaje sekwentów . . . . . . . . . . . . . . . . 28

2.1 .2 Alternatywy RS . . . . . . . . . . . . . . . . . . . . 29

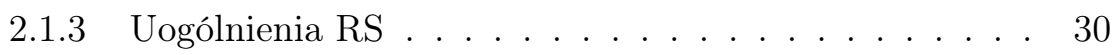

2.2 Reguly sekwentowe . . . . . . . . . . . . . . . . . . . . . . . . . . . . . . . . . . . .

2.2 .1 Rodzaje reguł . . . . . . . . . . . . . . . 33

2.2 .2 Warianty i typy RS . . . . . . . . . . . . . . . . . 36

2.3 Interpretacje sekwentów . . . . . . . . . . . . . . . . . 38

2.4 RS a relacje konsekwencji . . . . . . . . . . . . . 40 
3 LK Gentzena dla KRZ $\quad 46$

3.1 Rachunek sekwentów LK Gentzena . . . . . . . . . . . . . . . 46

3.1.1 Reguły....................... 47

3.1.2 Dowody ..................... 50

3.2 Adekwatność LK . . . . . . . . . . . . . . . . . . . . 57

3.3 Semantyczna interpretacja . . . . . . . . . . . . . . 59

4 Warianty standardowego RS dla KRZ $\quad 61$

4.1 Warianty regul . . . . . . . . . . . . . . . . . 61

4.1.1 Aksjomaty uogólnione ............... . 63

4.1.2 Warianty reguł dwuprzesłankowych . . . . . . . . . . 64

4.1.3 Reguły Ketonena ................. 65

4.2 Odwracalność reguł . . . . . . . . . . . . . . . 66

4.3 Eliminacja reguł strukturalnych . . . . . . . . . . . . . . . . 71

4.4 Równoważność reguł . . . . . . . . . . . . . . . . . . . . 77

4.5 Własności reguł . . . . . . . . . . . . . . . . . . . 81

4.6 Klasyczny RS na int-sekwentach . . . . . . . . . . . . . . . 84

5 Dowody twierdzenia o eliminacji cięcia $\quad 88$

5.1 Uwagi wprowadzajace .................. . 89

5.1.1 Eliminacja czy dopuszczalność . . . . . . . . 90

5.1.2 Ogólna strategia dowodu . . . . . . . . . . . . . . 91

5.2 Dowód Gentzena . . . . . . . . . . . . . . . . . . . . 94

5.2.1 Kroki wstępne .................... 95

5.2.2 Dowód . . . . . . . . . . . . . . . . . . . . . 98

5.3 Dowody oparte na lokalnych przekształceniach . . . . . . . . 108

5.3.1 Dowód Dragalina . . . . . . . . . . . . . . . . 109

5.3 .2 Dowód Smullyana . . . . . . . . . . . . . . 112

5.3.3 Dowód metodą Schüttego . . . . . . . . . . . 115

5.4 Dowody oparte na globalnych transformacjach dowodu . . . . 118

5.4.1 Dowód Curry'ego . . . . . . . . . . . . . . . . . 118

5.4.2 Dowód metodą Taita-Bussa . . . . . . . . . . . . . 122

5.5 Porównanie ...................... 126

6 Konsekwencje eliminacji cięcia $\quad 129$

6.1 Analityczność . . . . . . . . . . . . . . . . . . 130

6.1.1 Własność podformuł . . . . . . . . . . . . 130

6.1.2 Własność podformuł a analityczność . . . . . . . . . 132

6.2 Rozstrzygalność KRZ . . . . . . . . . . . . . . . . . . . . 134

6.2.1 Zbieżność ................... . . 138 
6.2.2 Algorytmy . . . . . . . . . . . . . . . . . 140

6.3 Twierdzenie o interpolacji . . . . . . . . . . . . . . . 142

7 Metody semantyczne w RS $\quad 146$

7.1 Pełność ARS z (Cut) metodą Henkina . . . . . . . . . . . . 147

7.1.1 Alternatywne dowody . . . . . . . . . . . . . 151

7.2 Dowód analityczny pełności . . . . . . . . . . . . . 152

7.2.1 Metoda bezpośrednia . . . . . . . . . . . . . 153

7.2 .2 Dowód pośredni . . . . . . . . . . . . . . . . . 155

7.3 Pełność RS z analitycznym (Cut) . . . . . . . . . . 157

7.4 ARS a postacie normalne . . . . . . . . . . . . . 159

8 Klasyczny Rachunek Kwantyfikatorów 161

8.1 Zagadnienia syntaktyczne . . . . . . . . . . . . . . 161

8.1 .1 Języki pierwszego rzędu . . . . . . . . . . . . . . . 162

8.1.2 Zmienne indywiduowe . . . . . . . . . . . . 166

8.1 .3 Podstawianie i zastępowanie . . . . . . . . . . . . 168

8.2 Teorie pierwszego rzędu . . . . . . . . . . . . . . . . 171

8.2.1 Aksjomatyzacja KRK . . . . . . . . . . . . 171

8.2.2 Aksjomatyzacje teorii elementarnych . . . . . . . . 174

8.3 Semantyka . . . . . . . . . . . . . . . . . 177

8.3.1 Struktura Interpretacyjna - ogólne pojęcie: . . . . . . 178

8.3.2 Ważne pojęcia semantyczne: . . . . . . . . . . . . . . 179

8.4 Adekwatność H-KRK . . . . . . . . . . . . . . . . . . 186

8.4.1 Przystosowanie . . . . . . . . . . . . 186

8.4 .2 Pełność . . . . . . . . . . . . . . . . 187

8.4.3 Pełność KRKI . . . . . . . . . . . . . . . . . . . . 191

8.5 Wybrane własności KRK . . . . . . . . . . . . . . . . . . 192

8.6 Dedukcja naturalna . . . . . . . . . . . . . . . . . . 194

9 RS dla KRK i teorii elementarnych $\quad 196$

9.1 Zagadnienia językowe . . . . . . . . . . . . . . . . 197

9.2 LK dla logiki pierwszego rzędu. . . . . . . . . . . . . . . . . 200

9.3 PV-dowody . . . . . . . . . . . . . . . . . . . 203

9.3.1 Podejście Kleene'go . . . . . . . . . . . . . . . . . . . . 204

9.3.2 Alternatywne podejście . . . . . . . . . . . . 206

9.4 Eliminacja cięcia w LK . . . . . . . . . . . . . . . . . . 208

9.5 ARS dla KRK . . . . . . . . . . . . . . . . . . . . . . . . . . 211

9.6 Metody semantyczne w ARS . . . . . . . . . . . . 217

9.6.1 Dowód adekwatności ARS . . . . . . . . . . . 217 
9.6 .2 Istnienie modelu . . . . . . . . . . . . . . . . . 218

9.6 .3 Saturacja . . . . . . . . . . . . . . . . 221

9.7 Wzmocnienie twierdzenia o eliminacji (Cut) . . . . . . . . 224

9.8 Teorie elementarne . . . . . . . . . . . . . . . . . . 227

9.8.1 Systemy RS z dodanymi aksjomatami . . . . . . . . 228

9.8.2 RS z dodatkowymi regułami . . . . . . . . . . . . . 230

9.8.3 RS-KRKI . . . . . . . . . . . . . . 235

10 Niestandardowe typy RS $\quad 237$

10.1 Regułowe systemy RS . . . . . . . . . . . . . . . 238

10.1.1 Sekwentowy DN Gentzena i jego warianty . . . . . . 238

10.1.2 Systemy DN logików rosyjskich . . . . . . . . . . . 240

10.1.3 DN Andrewsa . . . . . . . . . . . . . . . . . . 241

10.1.4 Systemy DN Suppesa i Lemmona . . . . . . . . . . . . 242

10.1.5 Systemy Hermesa i Ebbinhgausa, Fluma, Thomasa . . 243

10.1.6 System Leblanca . . . . . . . . . . . . . . . . . 245

10.1.7 Strukturalny system Došena . . . . . . . . . . . . . 246

10.2 Typ strukturalny RS Hertza . . . . . . . . . . . . . . . 248

10.2.1 System Suszki . . . . . . . . . . . . . . . . . . 249

10.3 Typ mieszany . . . . . . . . . . . . . . . . . . 256

10.3.1 Kleene i sekwentowe DN . . . . . . . . . . . . 257

10.3.2 System Hasenjaegera . . . . . . . . . . . . . . . 258

10.3.3 System Riegera . . . . . . . . . . . . . . . . . . . 259

10.4 RS a inne systemy dedukcyjne . . . . . . . . . . . 261

11 Dodatek $\quad 264$

11.1 Zbiory, relacje, funkcje . . . . . . . . . . . . . . 264

11.2 Indukcja matematyczna . . . . . . . . . . . . . . . . 269

11.2.1 Stosowanie dowodów indukcyjnych w logice . . . . . 272

$\begin{array}{ll}\text { Bibliografia } & 276\end{array}$

$\begin{array}{ll}\text { Skorowidz } & 286\end{array}$

$\begin{array}{ll}\text { Summary } & 297\end{array}$ 


\section{Wprowadzenie}

W 1934 roku ukazały się dwie przełomowe prace poświęcone dedukcji naturalnej (DN). Jedna napisana przez Stanisława Jaśkowskiego [76], druga przez Gerharda Gentzena [50]. W obu zaprezentowano sposób formalizacji logiki alternatywny do aksjomatycznego, a w zamierzeniu obu autorów, oparty na naturalnych sposobach wnioskowania stosowanych w matematyce. Systemy dedukcyjne zaproponowane $\mathrm{w}$ obu pracach zrobiły w ubiegłym stuleciu zawrotną karierę i doczekały się ogromnej ilości wersji dostosowanych do formalizacji ogromnej ilości logik nieklasycznych. Dedukcja naturalna stosowana jest dziś powszechnie, przede wszystkim w nauczaniu logiki, ale również w teoretycznych badaniach z zakresu teorii dowodu. Jednak to nie dedukcja naturalna jest tematem niniejszej publikacji.

Praca Gentzena wprowadzała jeszcze jeden rodzaj formalizacji logiki, który na gruncie teorii dowodu okazał się nawet popularniejszy od dedukcji naturalnej. Skonstruowany przez Gentzena rachunek, a raczej rachunki, sekwentów (RS) określane też - ze względu na nazwisko autora - systemami lub rachunkami Gentzena, to bez wątpienia jedno z najważniejszych dokonań na polu logiki. Współczesne RS to niezwykle sprawne, eleganckie i powszechnie dziś używane narzędzie teorii dowodu, które pozwala ujawnić wiele interesujących własności systemów logiki i teorii dedukcyjnych. Jednak w Polsce, kraju o wielkich tradycjach logicznych, znajomość systemów formalnych wywodzących się z badań Gentzena wydaje się niewystarczająca i nie należą one do zestawu popularnych narzędzi uprawiania logiki. Mam nadzieję, że niniejsza publikacja przyczyni się do większej popularyzacji RS.

Nazwa RS pochodzi od podstawowych jednostek, na których zdefiniowane są reguły. Gentzen zapożyczył ten pomysł od Hertza [65], ale dokonał jego daleko idącej modyfikacji. Oryginalny RS Gentzena okazał się bardzo efektywnym środkiem realizacji programu Hilberta, głównie w zakresie dowodzenia niesprzeczności teorii matematycznych, jednak szybko odkryto wiele innych możliwości zastosowań. Obecnie systemy RS znajdują zastosowanie przede wszystkim w rozważaniach teoretycznych z zakresu (strukturalnej) 
teorii dowodu. Konstruowanie jednak nowych rachunków tego typu, np. dla logik nieklasycznych, ma również znaczenie praktyczne, m.in. w konstrukcji programów automatycznego dowodzenia twierdzeń. Poszukiwania zadowalających formalizacji sekwentowych doprowadziło również do rozwinięcia pewnej filozofii znaczenia stałych logicznych oraz powstania uogólnionych form RS. Wspomnieć też można o teoretycznych badaniach nad problematyką (uogólnionych) operacji konsekwencji rozwiniętych na bazie analizy RS. To tylko hasłowe wywołanie kilku ważnych punktów związanych z problematyką RS; niektóre z nich zostaną rozwinięte w książce.

Wspomnieliśmy wyżej, że systemy RS wywodzą się z badań Gentzena nad utworzeniem formalizmów alternatywnych do aksjomatycznych systemów. Badania te zaowocowały stworzeniem dwóch rodzajów takich systemów: dedukcji naturalnej i rachunku sekwentów. Poszukiwanie pierwszego było właściwym celem Gentzena, natomiast drugi rodzaj formalizacji był przez niego postrzegany jako pomocniczy i czysto techniczny środek, m.in. dla udowodnienia równoważności systemu DN z systemem aksjomatycznym (dla logiki intuicjonistycznej i klasycznej) oraz, przede wszystkim, dla wykazania pewnej własności dowodów w DN. Sam Gentzen tak o tym pisał:

"Bliższe badania specjalnych własności rachunku naturalnego (tj. DN) doprowadziły mnie do bardzo ogólnego twierdzenia, które będzie dalej określane jako 'Hauptsatz'. [...] Aby wysłowić i dowieść Hauptsatz w dogodnej formie, musiałem skonstruować rachunek logiczny specjalnie do tego celu przygotowany. Rachunek naturalny okazał się niedostosowany dla tego celu [...] dlatego skonstruuję nowy rachunek dedukcji logicznej, posiadający wszystkie wymagane własności"1

Gentzenowi chodziło o wykazanie, że każdy dowód w DN można sprowadzić do pewnej normalnej postaci. Mając trudności z bezpośrednim dowodem dla DN, Gentzen wykazał ten wynik droga pośrednią, poprzez skonstruowanie RS jako pewnej teoretycznej ramy dla wyrażania rezultatów dotyczących DN. Twierdzenie o normalizacji (dowodów) DN wykazali niezależnie w latach 60-tych bezpośrednio dla DN Prawitz [113] i Raggio [116] ${ }^{2}$ Jednak to właśnie rachunek sekwentów i udowodniony przez Gentzena Hauptsatz, czyli twierdzenie o eliminacji cięcia otworzył drogę do rozwoju nowoczesnej teorii dowodu oraz konstrukcji pierwszych systemów automatycznego dowodzenia twierdzeń.

\footnotetext{
${ }^{1}$ Gentzen [50], tłum. autora za angielską wersją w Szabo [139].

${ }^{2}$ Faktycznie, sam Gentzen też dowiódł go bezpośrednio dla DN, ale jedynie dla logiki intuicjonistycznej i ostatecznie nie opublikował tego wyniku - por. von Plato [107].
} 
Prezentowana praca jest pomyślana jako wprowadzenie do niezwykle bogatej i złożonej problematyki związanej z teorią i zastosowaniami rachunków sekwentowych. Chcąc zachować rozsądne rozmiary książki siłą rzeczy dokonano w niej wyboru zagadnień, które w przekonaniu autora są najważniejsze czy po prostu interesujące. Nacisk został położony na metodologiczne aspekty RS, toteż nie jest to praca z zakresu teorii dowodu, w której RS jest narzędziem do prezentacji wyników tej teorii. Doskonałe wykłady tej problematyki można znaleźć w wielu pracach, np. Takeuti [143], Troelstra i Schwichtenberg [145], Buss [20], Negri i von Plato [101]. W tej pracy badamy RS, a nie teorię dowodu z pomocą RS, co ma zasadniczy wpływ na jej charakter i zawartość. Książka zawiera detaliczną prezentację podstawowych zastosowań RS, najważniejszych twierdzeń i technik dowodzenia tych rezultatów. W szczególności, czytelnik może znaleźć poniżej różne dowody podstawowych twierdzeń oraz ich porównanie. Najwięcej uwagi poświęcamy dowodzeniu fundamentalnego twierdzenia o eliminowalności (Cut), czyli reguły cięcia, które często traktowane jest jako najważniejszy wynik z zakresu teori dowodu. W pracy poświęcamy też sporo miejsca wyjaśnieniu dlaczego wynik ten jest tak ważny.

Staraliśmy się by praca była przystępnie napisana, ale nie kosztem nadmiernego upraszczania czy poświęcania rygorów formalnych. Adresatem jest czytelnik z pewnym przygotowaniem formalno-logicznym ale nie przekraczającym poziomu standardowego kursu logiki w zakresie oferowanym na studiach filozoficznych czy wstępu do matematyki (dyskretnej) na studiach matematycznych lub informatycznych. Zamierzeniem naszym jest by czytelnik mógł nauczyć się samodzielnie stosować RS jako narzędzie własnych badań, toteż prezentujemy detalicznie standardowe techniki dowodowe. Nie zamieściliśmy w pracy osobnych zadań, ale czytelnik znajdzie wystarczająco dużo materiału ćwiczeniowego jeżeli zechce samodzielnie uzupełnić indukcyjne dowody większości twierdzeń według pokazanego wzorca. Ze względów objętościowych ograniczamy się do rezultatów i technik związanych z logiką klasyczną, ale planujemy przygotowanie kolejnego tomu, w którym omówimy problematykę zastosowań RS do logik nieklasycznych. Jest to bardzo dynamicznie rozwijający się dział teorii dowodu, który doprowadził do powstania wielu interesujących uogólnień standardowych rachunków sekwentowych.

Ponieważ praca ma charakter elementarny, więc zamieszczamy w niej dwa rozdziały poświęcone klasycznemu rachunkowi zdań i kwantyfikatorów, które zawierają skrótowy wykład podstawowych rezultatów wykorzystywanych w pracy. Ponadto w Dodatku można znaleźć podstawowe informacje z zakresu wykorzystywanych pojęć teorii mnogości, dowodów indukcyjnych itp. "preliminariów technicznych". 
Innym wyróżnikiem prezentowanej pracy jest to, że pojęcie rachunku sekwentowego jest $\mathrm{w}$ niej traktowane szerzej niż w innych opracowaniach. Oprócz form RS skonstruowanych przez Gentzena i ich rozmaitych wariantów powszechnie stosowanych $\mathrm{w}$ badaniach z zakresu teorii dowodu, omawiamy też rozmaite mniej znane systemy dedukcyjne również wykorzystujące sekwenty jako podstawowe jednostki ale dopuszczające inne rodzaje reguł od tych, które wprowadził Gentzen. Istnieje też wiele systemów dedukcyjnych, w których uogólniono pojęcie sekwentu, chcąc formalizm Gentzena lepiej dostosować do specyficznych badań, np. nad logikami nieklasycznymi. Można więc mówić o wielu odmianach RS choć w literaturze przedmiotu zazwyczaj preferuje się systemy Gentzenowskie. W tej książce pojęcie RS rozumiane jest na tyle szeroko by uwzględnić zarówno inne typy RS jak i ich uogólnienia. Chociaż w przypadkach konkretnych formalizacji mogą pojawić się wątpliwości natury klasyfikacyjnej, to systemy RS, zwłaszcza w klasycznej postaci, wyraźnie odróżniają się od systemów aksjomatycznych, dedukcji naturalnej, rezolucji, czy systemów tablicowych. Systemy RS mają też znacznie dłuższą historię od innych popularnych rodzajów formalizacji, takich jak systemy rezolucji, czy systemy tablicowe. RS łączy zresztą z tymi rodzajami systemów dedukcyjnych bardzo bliski związek; zwrócimy na to uwagę w ostatnim rozdziale.

W pracy można wyróżnić dwie części: jedna poświęcona klasycznemu rachunkowi zdań (w skrócie KRZ), a druga klasycznemu rachunkowi kwantyfikatorów (KRK), zwanemu też logika pierwszego rzędu, i formalizacji teorii elementarnych na gruncie RS. Rozdzielenie tych dwóch partii wydaje się sprzyjać bardziej przystępnej prezentacji materiału. Rozdział 1 zawiera krótkie wprowadzenie do klasycznego rachunku zdań, w którym podajemy wszystkie informacje wykorzystywane w dalszej części książki. Rozdział 2 zawiera ogólne wprowadzenie do problematyki RS, w którym omawiamy m.in. rodzaje sekwentów, reguł i rachunków. W szczególności, staramy się wprowadzić pewne teoretyczne rozróżnienia natury klasyfikacyjnej dla lepszej orientacji w problematyce. Omawiamy też kwestę rozmaitych interpretacji pojęcia sekwentu, która - w naszym przekonaniu - ma kluczowe znaczenie dla zrozumienia uniwersalności zastosowań RS. Ostatni podrozdział rozwija jedną z tych interpretacji, która doprowadziła do powstania pewnych uogólnień teorii konsekwencji Tarskiego. Czytelnik zainteresowany konkretnymi zastosowaniami RS może w zasadzie pominąć lekturę zarówno rozdziału 1 jak i 2 (lub przejrzeć je pobieżnie) i zacząć od razu od rozdziału 3, a dwa pierwsze konsultować w miarę potrzeb. Zwłaszcza podrozdział 2.4 zawiera materiał, który nie jest dalej wykorzystywany, ale może być interesujący dla osób obeznanych z teorią konsekwencji Tarskiego. 
Rozdział 3 rozpoczyna właściwą, formalną prezentację standardowej wersji RS pochodzacej od Gentzena. Omawiamy tam oryginalny RS Gentzena dla logiki klasycznej nazwany przez niego LK (Logische Kalkül), a w rozdziale 4 jego podstawowe warianty wypracowane z myślą o specjalnych zastosowaniach. Szczególnie ważny, ze względu na zastosowania praktyczne jest system ARS (analityczny rachunek sekwentów). Rozdział 4 zawiera też rozważania na temat istotnych własności reguł oraz prezentację ogólnego wyniku dotyczącego równoważności dedukcyjnej różnych typów reguł. Oba te rozdziały to kompendium podstawowych informacji o standardowych RS w sensie Gentzena i ich podstawowych własnościach.

Kluczowy fragment książki to rozdział 5, który zawiera detaliczne omówienie kilku różnych wersji dowodu twierdzenia o eliminacji cięcia, które - jak wyżej wspomieliśmy - często, i nie bez racji, uchodzi za najważniejszy wynik teorii dowodu. W następnym rozdziale analizujemy wybrane konsekwencje tego twierdzenia, zwłaszcza rozstrzygalność KRZ. Rozdział 7 pokazuje w jaki sposób można RS wykorzystać w dowodzeniu rezultatów o charakterze semantycznym, w szczególności twierdzeń o pełności. Prezentujemy w nim cztery różne wersje dowodu twierdzenia o pełności.

Następnie przechodzimy do problematyki klasycznego rachunku kwantyfikatorów (KRK) i teorii elementarnych. W rozdziale 8, podobnie jak w pierwszym, prezentujemy podstawowe informacje o KRK niezbędne w lekturze dalszej części. Rozdział ten można pominąć i odwoływać się do niego w miarę potrzeb. Rozdział 9 to obszerna prezentacja podstawowych rezultatów uzyskanych z pomocą RS dla KRK i teorii elementarnych. Wątki, które stanowią proste rozwinięcie rezultatów dowiedzionych w części pierwszej potraktowane są bardziej skrótowo, nacisk postawiony jest na zagadnienia swoiste dla zastosowań RS w KRK.

Ostatni rozdział poświęcony jest omówieniu rozmaitych mniej znanych systemów RS, które wykraczają poza standardowy rachunek Gentzena będący zasadniczym tematem książki. Systemy te reprezentują rozmaite warianty trzech typów RS wyróżnionych w rozdziale 2. Całości dopełnia dodatek o techniczno-terminologicznym charakterze. W rozdziale 10 wykorzystany został artykuł Indrzejczak [73] poświęcony systemom Suszki oraz fragment artykułu Indrzejczak [72].

Praca ta nie powstałaby zapewne bez wsparcia wielu osób oraz instytucji, którym pragnę w tym miejscu serdecznie podziękować.

Fragmenty pracy referowałem systematycznie na seminarium Katedry Logiki UŁ prowadzonym przez Prof. dr hab. Grzegorza Malinowskiego, któ- 
remu w tym miejscu pragnę podziękować za wieloletnią pomoc i współpracę. Uczestnikom seminarium oraz moim studentom, cierpliwie uczęszczającym na moje zajęcia monograficzne, zawdzięczam wiele cennych uwag, które starałem się wykorzystać przygotowując finalną wersję rozprawy. Szczególnie dziękuję Paniom Kai Bednarskiej i Marzenie Łebedowskiej, oraz profesorowi Andrzejowi Pietruszczakowi, recenzentowi wydawniczemu, którego wnikliwe uwagi ustrzegły mnie od wielu błędów.

Ukończenie i publikacja książki było możliwe dzięki przyznanej mi przez Narodowe Centrum Nauki dotacji z grantu nr. UMO-2011/03/B/HS1/04366.

Na koniec chciałbym podziękować moim Bliskim za Wsparcie, Miłość i Wyrozumiałość.

Łódź 2012 Andrzej Indrzejczak 


\section{Rozdział 1}

\section{Klasyczny Rachunek Zdań}

W rozdziale tym przypomnimy krótko, i zazwyczaj bez dowodu, najważniejsze fakty dotyczące Klasycznego Rachunku Zdań (w skrócie KRZ), do których będziemy odwoływali się w dalszych rozdziałach. W kolejnych podrozdziałach omawiamy: język zdaniowy (1.1), aksjomatyczną formalizację KRZ (1.2), semantykę (1.3) oraz podstawowe sposoby dowodzenia pełności (1.4). Krótkie omówienie pewnych wybranych własności KRZ, jak rozstrzygalność czy własność interpolacji (1.5) oraz jego charakterystyki w terminach dedukcji naturalnej (1.6) zamyka rozdział, który zamieszczony jest głównie po to by lektura książki nie wymagała sięgania po inne opracowania. Poza podrozdziałem 1.1, w którym wprowadzamy terminologię i notację, resztę rozdziału można pominać przy pierwszym czytaniu i konsultować w miarę potrzeb podczas lektury całości.

\subsection{Język}

Niech $Z Z=\left\{p, q, r, \ldots, p_{1}, q_{1}, r_{1}, \ldots\right\}$ oznacza przeliczalny zbiór zmiennych zdaniowych, które w języku KRZ są formułami atomowymi (atomami). Do budowy formuł złożonych używać będziemy operacji (spójników) zdaniowych: $\neg$ oznacza jednoargumentową operację (spójnik) negacji, a $\wedge, \vee, \rightarrow$ dwuargumentowe operacje koniunkcji, alternatywy i implikacji. Dowolne formuły języka przedmiotowego oznaczać będziemy w metajęzyku małymi literami greckimi $\varphi, \psi, \chi, \ldots$ a ich zbiory (oraz multizbiory i ciągi ${ }^{1}$ w następnych rozdziałach) za pomoca wielkich liter $\Gamma, \Delta, \Pi, \ldots$.

\footnotetext{
${ }^{1}$ Objaśnienie notacji i pojęć teoriomnogościowych wykorzystywanych w książce zawiera dodatek.
} 
Definicja 1.1 (Definicja zbioru formuł KRZ) FOR jest najmniejszym zbiorem spetniajacym warunki:
1. $Z Z \subset F O R$
2a. jeżeli $\varphi \in F O R$, to $\neg \varphi \in F O R$
2b. jeżeli $\varphi, \psi \in F O R$, to $(\varphi \wedge \psi),(\varphi \vee \psi),(\varphi \rightarrow \psi) \in F O R$

Uwaga 1.1: Podana definicja jest standardową definicją rekurencyjną, co umożliwia stosowanie dowodów indukcyjnych przez tzw. indukcję strukturalną lub przy wykorzystaniu miar takich, jak długość (iolść symboli) lub złożoność (ilość stałych logicznych) formuły. Czytelnik słabo obeznany z instrumentarium logiki matematycznej może znaleźć objaśnienie tych pojęć i technik w dodatku.

Ponadto będziemy sporadycznie używać symboli $\leftrightarrow, \perp$ i $\top$ (dwuargumentowy spójnik równoważności, stałe zdaniowe falsum i verum) jako definicyjnych skrótów:

- $(\varphi \leftrightarrow \psi):=((\varphi \rightarrow \psi) \wedge(\psi \rightarrow \varphi))$

- $\perp:=(p \wedge \neg p) ; \quad \top:=\neg \perp$

Uwaga 1.2: W praktyce stosujemy konwencję pomijania zbędnych nawiasów, w szczególności zewnętrznych. Aby jeszcze bardziej zredukować ich liczbę stosujemy konwencję odnośnie siły wiązania spójników, wg. kolejności $\neg, \wedge, \vee, \rightarrow, \leftrightarrow$. Dodatkowo omijać będziemy wewnętrzne nawiasy w przypadku wielokrotnego powtórzenia operacji łącznych, tj. koniunkcji i alternatywy. Konwencje te pozwalają formułę:

$$
((p \vee(\neg q \wedge r)) \rightarrow((p \wedge \neg s) \vee(q \wedge(s \wedge t))))
$$

zapisać następująco:

$$
p \vee \neg q \wedge r \rightarrow p \wedge \neg s \vee q \wedge s \wedge t
$$

Wyróżnijmy pewne typy formuł o specjalnej postaci:

Definicja 1.2 (Postacie normalne) - Kazddy atom lub jego negacja to literat (pozytywny lub negatywny).

- Koniunkcja literałów to koniunkcja elementarna. 
- Alternatywa literatów to alternatywa elementarna (klauzula).

- Klauzula Horna to klauzula, w której jest co najwyżej jeden literał pozytywny (atom).

- Formuła jest w postaci normalnej koniunkcyjno-alternatywnej (krótko KA) wtw jest koniunkcja klauzul.

- Formuła jest w postaci normalnej alternatywno-koniunkcyjnej (krótko AK) wtw jest alternatywa koniunkcji elementarnych.

Uwaga 1.3: W przypadku klauzul, koniunkcji elementarnych oraz postaci normalnych obu typów dopuszczamy przypadek jednoargumentowej koniunkcji i alternatywy. Np. $p$ jest zarazem klauzulą (w tym klauzula Horna), koniunkcją elementarną oraz formułą w dowolnej postaci normalnej; $p \vee q$ jest zarazem klauzula (ale nie klauzulą Horna) jak i formułą w postaci normalnej koniunkcyjno-alternatywnej (jednoelementowa koniunkcja) i zarazem alternatywno-koniunkcyjnej (dwuelementowa alternatywa jednoelementowych koniunkcji elementarnych).

Zbiór zmiennych występujących $\mathrm{w}$ danej formule lub zbiorze formuł będziemy zaznaczać odpowiednio przez $Z Z(\varphi)$ lub $Z Z(\Gamma)$. Zbiór podformuł danej formuły $\varphi$ lub zbioru formuł $\Gamma$, oznaczany przez $S F(\varphi)(S F(\Gamma))$, definiujemy następująco:

Definicja 1.3 (Podformuły) $\quad$ dla $\varphi \in Z Z, S F(\varphi)=\{\varphi\}$

- dla $\varphi:=\neg \psi, S F(\varphi)=\{\varphi\} \cup S F(\psi)$

- dla $\varphi:=\psi \odot \chi$, gdzie $\odot \in\{\wedge, \vee, \rightarrow, \leftrightarrow\}, S F(\varphi)=\{\varphi\} \cup S F(\psi) \cup$ $S F(\chi)$.

- $S F(\Gamma)=\bigcup\{S F(\varphi): \varphi \in \Gamma\}$

$\psi$ i $\chi$ to bezpośrednie podformuły $\varphi$.

\subsection{Aksjomatyczne ujęcie KRZ}

Najpopularniejszym sposobem formalnego ujęcia dowolnej logiki, w tym klasycznej, są systemy aksjomatyczne, które w dalszym ciągu będziemy krótko określać jako H-systemy (od Hilberta). Systemy takie definiujemy podając zbiór aksjomatów, czyli formuł (lub ich schematów) przyjętych bez dowodu 
oraz zbiór reguł inferencji, które pozwalają z uznanych wcześniej formuł dedukować kolejne. Reguły takie będziemy przedstawiać za pomocą schematów $\varphi_{1}, \ldots, \varphi_{n} / \psi$, gdzie $\varphi_{i}, i \leq n$, to przesłanki, a $\psi$ to wydedukowany wniosek.

Istnieje wiele wersji H-systemów dla KRZ, poniżej przypomnimy wersję H-KRZ z regułą MP jako jedyną regułą inferencji oraz z następującą listą schematów aksjomatów.

1. $\varphi \rightarrow(\psi \rightarrow \varphi)$

2. $(\varphi \rightarrow(\psi \rightarrow \chi)) \rightarrow((\varphi \rightarrow \psi) \rightarrow(\varphi \rightarrow \chi))$

3. $\varphi \wedge \psi \rightarrow \varphi$

4. $\varphi \wedge \psi \rightarrow \psi$

5. $\varphi \rightarrow(\psi \rightarrow \varphi \wedge \psi)$

6. $\varphi \rightarrow \varphi \vee \psi$

7. $\psi \rightarrow \varphi \vee \psi$

8. $(\varphi \rightarrow \chi) \rightarrow((\psi \rightarrow \chi) \rightarrow(\varphi \vee \psi \rightarrow \chi))$

9. $(\neg \varphi \rightarrow \neg \psi) \rightarrow(\psi \rightarrow \varphi)$

Jedyną reguła jest reguła MP (Modus Ponens, reguła odrywania) postaci: $\varphi \rightarrow \psi, \varphi / \psi$.

Uwaga 1.4: Podany wyżej H-KRZ jest przykładem formalizacji inwariantnej, tj. takiej, w której zamiast skończonego zbioru aksjomatów wyrażonych w języku przedmiotowym danej logiki używamy zbioru schematów wyrażonych w metajęzyku. W rezultacie zbiór aksjomatów jest nieskończony, ale nie musimy wprowadzać do zbioru reguł, jako pierwotnej, reguły podstawiania za zmienne zdaniowe. Dla krótkości w dalszym ciągu aksjomatami będziemy nazywać zarówno same schematy jak i ich konkretne instancje w języku przedmiotowym.

Uwaga 1.5: W podanym zestawie aksjomatów wystarczy wymienić aksjomat 9 na jego słabszą wersje $(\varphi \rightarrow \psi) \rightarrow(\neg \psi \rightarrow \neg \varphi)$ aby otrzymać H-INT, czyli aksjomatyczną formalizację zdaniowej logiki intuicjonistycznej. Pominięcie tego aksjomatu daje H-POZ, czyli aksjomatyczną formalizację zdaniowej logiki pozytywnej (bez negacji). 


\subsubsection{Dowiedlność}

Poniżej podajemy definicje kluczowych pojęć logiki, mianowicie: relacji dowiedlności lub dedukowalności zachodzącej między zbiorami formuł a pojedynczymi formułami $(\vdash \subseteq \mathcal{P}(F O R) \times F O R)$, tezy $(\vdash \varphi)$ i sprzecznego zbioru formuł.

Definicja $1.4 \quad-\Gamma \vdash \varphi$ wtw istnieje skończony ciag formut (dowód), w którym ostatnim elementem jest $\varphi$ i gdzie każdy element jest:

1. podstawieniem aksjomatu lub

2. elementem zbioru $\Gamma$ (założeniem) lub

3. wynikiem zastosowania MP do poprzedzajacych wyrazów ciagu

$\bullet \vdash \varphi w t w \varnothing \vdash \varphi$

- $\Gamma$ jest sprzeczny wtw $\Gamma \vdash \perp$, w przeciwnym wypadku jest niesprzeczny.

Uwaga 1.6: Powyżej przyjęliśmy, jako wygodniejsze dla naszych celów, ujęcie pochodzące od Tarskiego [144], w którym logikę pojmuje się jako pewną relację (operację) konsekwencji, którą można rozmaicie zdefiniować. W szczególności, w ujęciu aksjomatycznym definiuje się logikę czysto syntaktycznie jako relację dowiedlności a pojęcie tezy jest wtórne, podobnie jak pojęcie zbioru sprzecznego. Abstrakcyjne ujęcie KRZ, i dowolnych logik, jako operacji konsekwencji omawiamy w podrozdziale 2.4. Zauważmy też, że definicja dowiedlności ma również charakter rekurencyjny, co pozwala na stosowanie w tym przypadku dowodów indukcyjnych (por. dodatek).

Warto zauważyć, że przy tradycyjnym podejściu logikę utożsamia się ze zbiorem tez czyli wszystkich aksjomatów i formuł dedukowalnych ze zbioru aksjomatów za pomocą reguł pierwotnych (w tym przypadku tylko MP). W takim ujęciu pierwotnym pojęciem jest pojęcie dowodu charakteryzowanego jako ciąg (lub drzewo) formuł spełniających warunek 1 i 3 z definicji 1.4. Tezy są definiowane jako formuły mające dowód, natomiast definicję relacji dowiedlności wprowadza się na koniec, jako uogólnienie pojęcia dowodu przez dopuszczenie jako dodatkowych elementów dowodu formuł z $\Gamma$. Można zresztą wtedy inaczej zdefiniować relację dowiedlności odwołując się do pojęcia tezy jako pierwotnego:

$$
\Gamma \vdash \varphi \text { wtw } \vdash \psi_{1} \wedge \ldots \wedge \psi_{n} \rightarrow \varphi\left(\text { gdzie }\left\{\psi_{1}, \ldots, \psi_{n}\right\} \subseteq \Gamma\right)
$$

Obie podane charakterystyki $\vdash$ generalnie nie muszą być równoważne (w tych H-systemach, w których występują inne reguły pierwotne oprócz MP), 
ale dla podanej przez nas aksjomatyzacji KRZ dają ten sam wynik. Wrócimy do tej kwestii w rozdziale 8. przy okazji aksjomatycznej charakteryzacji KRK (Klasycznego Rachunku Kwantyfikatorów).

Uwaga 1.7: Zazwyczaj symbol $\vdash$ występuje z indeksami oznaczającymi w jakiej logice, lub w jakim systemie/teorii zachodzi ta relacja, np. $\vdash_{H}, \vdash_{H-L}, \vdash_{L}^{S}$; ponieważ zajmujemy się tu tylko logiką klasyczną i (w danym momencie) tylko systemem aksjomatycznym $\mathrm{H}$, więc te dodatki pomijamy. W dalszym ciągu będą używane wtedy, gdy niezbędne będzie odróżnienie relacji generowanych przez różne systemy dedukcyjne.

Uwaga 1.8: Będziemy używać symbolu $C n(\Gamma)$ na określenie zbioru wszystkich formuł dedukowalnych z $\Gamma$ (zbioru jego logicznych konsekwencji), tj.

$$
C n(\Gamma)=\{\varphi: \Gamma \vdash \varphi\}
$$

Zauważmy, że w oryginalnym ujęciu Tarskiego to właśnie operacja $C n$ : $\mathcal{P}(F O R) \longrightarrow \mathcal{P}(F O R)$ jest pierwotna, natomiast odpowiadającą jej relację $\vdash$ można zdefiniować następująco:

$$
\Gamma \vdash \varphi:=\varphi \in C n(\Gamma)
$$

Odnotujmy następujące własności relacji dowiedlności:

Lemat 1.1 1. jezeli $\varphi \in \Gamma$, to $\Gamma \vdash \varphi$

2. jeżeli $\Gamma \vdash \varphi$ i $\Gamma \subseteq \Delta$, to $\Delta \vdash \varphi$

3. $\vdash \varphi$ wtw $\Gamma \vdash \varphi$, dla dowolnego zbioru $\Gamma$

4. jeżeli $\Gamma \vdash \varphi$ i $\Delta, \varphi \vdash \psi$, to $\Gamma, \Delta \vdash \psi$

5. $\Gamma \vdash \varphi$ wtw $\Delta \vdash \varphi$, dla pewnego skończonego $\Delta \subseteq \Gamma$

6. $\Gamma, \varphi \vdash \psi w t w \Gamma \vdash \varphi \rightarrow \psi$

7. jeżeli $\Gamma, \neg \varphi \vdash \varphi$, to $\Gamma \vdash \varphi$

8. jeżeli $\Gamma, \varphi \vdash \neg \varphi$, to $\Gamma \vdash \neg \varphi$

9. $\Gamma, \neg \varphi \vdash \perp w t w \Gamma \vdash \varphi$

10. jeżeli $\Gamma, \varphi \vdash \psi i \Delta, \neg \varphi \vdash \psi$, to $\Gamma, \Delta \vdash \psi$

11. jeżeli $\Gamma, \varphi \vdash \psi$ i $\Delta, \varphi \vdash \neg \psi$, to $\Gamma, \Delta \vdash \neg \varphi$ 
12. jeżeli $\Gamma \vdash \varphi$ i $\Delta \vdash \neg \varphi$, to $\Gamma, \Delta \vdash \psi$, dla dowolnego $\psi$

13. $\Gamma, \varphi, \psi \vdash \chi w t w \Gamma, \varphi \wedge \psi \vdash \chi$

14. jeżeli $\Gamma \vdash \varphi \vee \psi i \Delta, \varphi \vdash \chi i \Pi, \psi \vdash \chi$, to $\Gamma, \Delta, \Pi \vdash \chi$

Proste dowody tych własności pomijamy; dowód implikacji w prawo dla 6 to twierdzenie o dedukcji (TD), którego dowód podajemy w dodatku. Implikacja odwrotna z 6 (konwers TD) w istocie rzeczy wyraża domkniętość relacji $\vdash$ na MP; równoważnie można to podać następująco:

1. $\varphi, \varphi \rightarrow \psi \vdash \psi$ (inferencyjny MP)

2. jeżeli $\Gamma \vdash \varphi$ i $\Delta \vdash \varphi \rightarrow \psi$, to $\Gamma, \Delta \vdash \psi$ (dedukcyjny MP)

\subsubsection{Reguły wtórne}

Chociaż MP jest regułą wystarczającą dla dedukcji wszystkich tez KRZ czy wyprowadzalności wszystkich konsekwencji z dowolnych założeń $\Gamma$, to konstrukcja dowodów bywa ekstremalnie trudna. Użycie pewnych własności $\vdash$ podanych w powyższym lemacie, zwłaszcza TD czy 9 (twierdzenie o dedukcji nie wprost) znacznie upraszcza pracę. Wprowadzenie dodatkowych reguł do systemu aksjomatycznego jeszcze bardziej ułatwia i skraca konstrukcję dowodów. Wyróżniamy dwa typy reguł wtórnych:

- $\psi_{1}, \ldots, \psi_{n} / \varphi$ jest schematem reguły wyprowadzalnej wtw $\psi_{1}, \ldots, \psi_{n} \vdash \varphi$

- $\psi_{1}, \ldots, \psi_{n} / \varphi$ jest schematem reguły dopuszczalnej wtw jeżeli $\vdash \psi_{1}, \ldots, \vdash$ $\psi_{n}$, to $\vdash \varphi$

Zachodzi następujący:

Lemat 1.2 Każda reguła wyprowadzalna jest dopuszczalna

DowóD: Załóżmy, że $\psi_{1}, \ldots, \psi_{n} / \varphi$ jest regułą wyprowadzalną, zatem $\psi_{1}, \ldots, \psi_{n} \vdash$ $\varphi$. Załóżmy też, że $\vdash \psi_{1}, \ldots, \vdash \psi_{n}$. Przez przechodniość $\vdash$ (lemat 1.1, własność

4) zastosowaną $n$ razy otrzymamy $\vdash \varphi$.

Uwaga 1.9: Zależność w drugą stronę zachodzi tylko dla niektórych systemów dedukcyjnych. Nazywamy je strukturalnie zupełnymi.

Przykładem przydatnej reguły wtórnej (dowód w dodatku) jest reguła ekstensjonalności 
$\mathrm{RE}: \vdash \varphi \leftrightarrow \psi / \vdash \chi \leftrightarrow \chi[\varphi / / \psi]$

gdzie $\chi[\varphi / / \psi]$ oznacza zastąpienie co najmniej jednego wystąpienia $\varphi$ (jako podformuły $\chi)$ przez $\psi$

Dopuszczalność RE w KRZ pozwala nam łatwo udowodnić:

Twierdzenie 1.1 (Post) Dla dowolnej $\varphi$ istnieje równoważne jej $\varphi^{\prime} w$ postaci normalnej koniunkcyjno-alternatywnej

\subsubsection{Sprzeczność}

Pojęcie sprzeczności/niesprzeczności (syntaktycznej) jest równie istotne jak pojęcie dowiedlności. Poniższy lemat wylicza alternatywne definicje sprzeczności:

Lemat 1.3 (Zbiory sprzeczne) Podane niżej warunki są równoważne na gruncie logiki klasycznej:

1. $\Gamma \vdash \perp$

2. $\Gamma \vdash \neg \varphi \wedge \varphi$, dla pewnego $\varphi$

3. $\Gamma \vdash \varphi$ i $\Gamma \vdash \neg \varphi$, dla pewnego $\varphi$

4. $\Gamma \vdash \varphi$, dla dowolnej $\varphi$

5. $C n(\Gamma)=F O R$

6. $\vdash \neg\left(\varphi_{1} \wedge \ldots \wedge \varphi_{n}\right)$, dla pewnego $\left\{\varphi_{1}, \ldots, \varphi_{n}\right\} \subseteq \Gamma$

Łatwy dowód pomijamy.

Uwaga 1.10: Analogicznie jek relację dowiedlności, pojęcie (nie)sprzeczności też relatywizujemy do konkretnej logiki bądź systemu mówiąc, np. o KRZniesprzeczności. Tutaj pomijamy ten dodatek, gdyż ograniczamy się do logiki klasycznej w ujęciu aksjomatycznym.

Uwaga 1.11: Warunki podane wyżej w lemacie 1.3 są w odniesieniu do KRZ równoważne zatem każdy z nich może posłużyć jako definiens w definicji zbioru sprzecznego. Nie są one jednak równoważne dla każdej logiki, w szczególności, definicje z użyciem warunków 4 i 5 mogą być stosowane do logik bez negacji (lub z negacją słabszą od klasycznej).

Uwaga 1.12: Definicje niesprzecznych zbiorów uzyskujemy przez negację definicji zbiorów sprzecznych - w szczególności: 
- dla 2. nie istnieje takie $\varphi$, że $\Gamma \vdash \neg \varphi \wedge \varphi$ (lub $\Gamma \nvdash \neg \varphi \wedge \varphi$, dla dowolnego $\varphi$, gdzie $\nvdash$ oznacza zaprzeczenie dowiedlności);

- dla 4. istnieje takie $\varphi$, że $\Gamma \nvdash \varphi$.

- dla 6. każdy skończony podzbiór $\Gamma$ jest niesprzeczny, tj. dla każdego $\left\{\varphi_{1}, \ldots, \varphi_{n}\right\} \subseteq \Gamma, \nvdash \neg\left(\varphi_{1} \wedge \ldots \wedge \varphi_{n}\right)$

Bez dowodu przytoczmy dla KRZ kolejny:

Lemat 1.4 (Własności (nie)sprzeczności:) 1. jeżeli $\Gamma$ jest sprzeczna $i \Gamma \subseteq \Delta$, to $\Delta$ jest sprzeczna

2. jeżeli $\Gamma$ jest niesprzeczna $i \Gamma \supseteq \Delta$, to $\Delta$ jest niesprzeczna

3. $\Gamma$ jest niesprzeczna wtw $\Delta$ jest niesprzeczna, dla dowolnego skończonego $\Delta \subseteq \Gamma$

4. $\Gamma \cup\{\neg \varphi\}$ jest sprzeczna wtw $\Gamma \vdash \varphi$

5. $\Gamma \cup\{\neg \varphi\}$ jest niesprzeczna wtw $\Gamma \nvdash \varphi$

6. $\Gamma$ jest sprzeczna wtw $\Gamma \cup\{\varphi\}$ jest sprzeczna $i \Gamma \cup\{\neg \varphi\}$ jest sprzeczna, dla dowolnej $\varphi$

7. $\Gamma$ jest niesprzeczna wtw $\Gamma \cup\{\varphi\}$ jest niesprzeczna lub $\Gamma \cup\{\neg \varphi\}$ jest niesprzeczna, dla dowolnej $\varphi$.

\subsection{Semantyka KRZ}

Oprócz charakteryzacji syntaktycznej dla danej logiki, którą w tym przypadku ograniczyliśmy do ujęcia aksjomatycznego (i dedukcji naturalnej omówionej w ostatnim podrozdziale), potrzebujemy również ujęcia semantycznego. W rozważaniach metalogicznych nad logikami zdaniowymi wygodne są semantyki algebraiczne, jednak ze względu na łatwość poszerzenia do semantyki dla logiki 1-go rzędu wygodniejsze będzie dla nas ujęcie teorio-modelowe. $\mathrm{Z}$ racji prostoty języka pojęcie modelu dla KRZ redukuje się do pojęcia waluacji (wartościowania) dla zmiennych. To ostatnie jest dowolną funkcją postaci $V: Z Z \longrightarrow\{1,0\}$, która każdej zmiennej przyporządkowuje jedną z wartości logicznych: prawdę -1 lub fałsz - 0 . Każda waluacja wyznacza jednoznacznie strukturę interpretacyjną (model) dla FOR w następujący sposób: 


$$
\begin{array}{lll}
\mathfrak{M} \vDash \varphi & \text { wtw } & V(\varphi)=1, \text { dla dowolnej } \varphi \in Z Z \\
\mathfrak{M} \vDash \neg \varphi & \text { wtw } & \mathfrak{M} \vDash \varphi \\
\mathfrak{M} \vDash \varphi \wedge \psi & \text { wtw } & \mathfrak{M} \vDash \varphi \text { i } \mathfrak{M} \vDash \psi \\
\mathfrak{M} \vDash \varphi \vee \psi & \text { wtw } & \mathfrak{M} \vDash \varphi \text { lub } \mathfrak{M} \vDash \psi \\
\mathfrak{M} \vDash \varphi \rightarrow \psi & \text { wtw } & \mathfrak{M} \vDash \varphi \text { lub } \mathfrak{M} \vDash \psi
\end{array}
$$

$\mathfrak{M} \not \models \varphi$ oznacza fałszywość formuły $\varphi \mathrm{w}$ danym modelu. Dla zbiorów formuł używać będziemy zapisu $\mathfrak{M} \vDash \Gamma$, gdy $\mathfrak{M} \vDash \psi$ dla dowolnego $\psi \in \Gamma$. $\mathfrak{M} \not \models \Gamma$ oznacza fałszywość co najmniej jednego elementu $\Gamma \mathrm{w}$ tym modelu. Poniższa definicja wprowadza najważniejsze pojęcia semantyczne symultanicznie dla formuł i ich zbiorów (w nawiasie).

Definicja 1.5 $\bullet \varphi(\Gamma)$ jest spetnialna $w$ modelu $\mathfrak{M} w t w \mathfrak{M} \vDash \varphi(\mathfrak{M} \vDash \Gamma)$.

- $\varphi(\Gamma)$ jest spetnialna (spójna, semantycznie niesprzeczna) wtw istnieje model, w którym jest spełnialna.

- $\varphi(\Gamma)$ jest sfalsyfikowana $w$ modelu $\mathfrak{M} w t w \mathfrak{M} \not \models \varphi(\mathfrak{M} \not \models \Gamma)$ inaczej: $\mathfrak{M}$ falsyfikuje $\varphi(\Gamma)$.

- $\varphi(\Gamma)$ jest sfalsyfikowana wtw istnieje model, w którym jest sfalsyfikowana.

- $\varphi(\Gamma)$ jest niespetnialna (niespójna, semantycznie sprzeczna) wtw nie istnieje model, w którym jest spetnialna.

- $\varphi$ jest tautologia $(\mid=\varphi) w t w \forall_{\mathfrak{M}}, \mathfrak{M} \vDash \varphi$

- $\varphi$ wynika $z \Gamma(\Gamma \mid=\varphi)$ wtw $\forall_{\mathfrak{M}}, \mathfrak{M} \vDash \Gamma$ implikuje $\mathfrak{M} \vDash \varphi$

$\not \models \varphi$ oznacza formułę nietautologiczną a $\Gamma \not \models \varphi$ brak wynikania.

Odnotujmy następujące przydatne i oczywiste fakty:

Fakt $1.1 \quad \bullet \forall \varphi$ wtw $\varphi$ jest falsyfikowalna wtw $\neg \varphi$ jest spetnialna.

- $\Gamma \models \varphi$ wtw $\Gamma \cup\{\neg \varphi\}$ jest niespetnialna.

Dla $=$ można łatwo dowieść odpowiedniki własności $\vdash$, a dla (nie)spełnialności odpowiedniki własności dla (nie)sprzeczności; pozostawiamy to zadanie czytelnikom. Reguły inferencji można kwalifikować również semantycznie. Analogicznie jak w przypadku reguł wtórnych wyróżniamy dwa typy:

- reguły normalne: $\psi_{1}, \ldots, \psi_{n} / \varphi$ wtw $\psi_{1}, \ldots, \psi_{n} \models \varphi$ 
- reguły niezawodne: $\psi_{1}, \ldots, \psi_{n} / \varphi$ wtw jeżeli $\models \psi_{1}, \ldots, \models \psi_{n}$, to $\models \varphi$

Zachodzą następujące zależności, które łatwo wykazać:

Lemat 1.5 1. Każda reguta normalna jest niezawodna.

2. Każda reguła wyprowadzalna jest normalna.

3. Każda reguła dopuszczalna jest niezawodna.

Faktycznie, w przypadku podanego przez nas H-systemu, punkty 2. i 3. można wzmocnić do równoważności. Nie jest to jednak prawidłowość ogólna gdyż pojęcie reguły wyprowadzalnej i dopuszczalnej zrelatywizowane jest nie tylko do logiki ale i do konkretnej formalizacji tej logiki. Przykładem reguły niezawodnej, która nie jest normalna może być reguła podstawiania.

Odnotujmy też następujący:

Fakt 1.2 1. Dla dowolnej klauzuli $\varphi, \models \varphi$ wtw należy do niej pewien atom $i$ jego negacja.

2. Dla dowolnej $\varphi$ w postaci koniunkcyjno-alternatywnej, $\models \varphi$ wtw $\models \psi$, dla dowolnej klauzuli $\psi$, która do niej należy.

\subsection{Adekwatność H-KRZ}

Mając do czynienia z niezależnymi ujęciami syntaktycznymi i semantycznymi musimy ustalić, czy faktycznie charakteryzują tę samą logikę. Standardowo robimy to poprzez udowodnienie adekwatności danego systemu dedukcyjnego (w tym wypadku systemu aksjomatycznego) względem danej semantyki. Wyróżnić można dwie formy adekwatności:

- Adekwatność słaba: $\vdash \varphi$ wtw $\models \varphi$

- Adekwatność mocna: $\Gamma \vdash \varphi$ wtw $\Gamma \models \varphi$

Uwaga 1.13: Oczywiście w drugim przypadku dopuszczamy nieskończone $\Gamma$; inaczej byłyby to twierdzenia równoważne na mocy TD. Zauważmy, że niektóre metody dowodu tego twierdzenia (np. metoda Posta) pozwalają tylko na dowód słabej postaci - dalej skupimy się na dowodzie postaci mocnej.

Twierdzenie o adekwatności rozpada się na dwie składowe: 
Twierdzenie 1.2 (Twierdzenie o przystosowaniu (soundness)) Jézeli $\Gamma \vdash \varphi$, to $\Gamma \models \varphi$.

Twierdzenie 1.3 (Twierdzenie o pełności (completeness)) Jeżeli $\Gamma \models$ $\varphi$, to $\Gamma \vdash \varphi$.

Dowód twierdzenia o przystosowaniu jest prosty dla systemów aksjomatycznych, natomiast w przypadku twierdzenia o pełności istnieją różne, czasem dość złożone, strategie. Dlaczego łatwiej dowieść twierdzenie o przystosowaniu? Bo zbiór tez jest zdefiniowany induktywnie (por. dodatek), a zbiór tautologii nie (i analogicznie dla $\vdash \mathrm{i} \models$ ). Aby otrzymać dowód twierdzenia o przystosowaniu wystarczy dowieść dwa lematy:

Lemat 1.6 Kazddy aksjomat jest tautologia

Lemat 1.7 Każda reguła pierwotna jest reguła normalna

Na ich podstawie otrzymujemy dowód twierdzenia o przystosowaniu przez indukcję po długości dowodu $\Gamma \vdash \varphi$.

\subsubsection{Dowody twierdzenia o pełności - uwagi ogólne:}

Znane dowody twierdzenia o pełności dla KRZ można podzielić na konstruktywne i niekonstruktywne, oraz analityczne i nieanalityczne:

- konstruktywne pokazują jak skonstruować dowód dla konkretnego przypadku wynikania (tautologii) - np. dowody Posta, Kalmara, Hintikki;

- niekonstruktywne wykazują ogólnie, że taki dowód w każdym wypadku istnieje, ale nie pokazuja jak go skonstruować - np. dowody Gödla, Henkina, Assera.

W pierwszym przypadku można wyróżnić dodatkowo dowody analityczne, które pozwalają w przypadku logik rozstrzygalnych na skonstruowanie skończonego modelu dla zbioru niesprzecznego (np. Hintikka [66]). Dowody niekonstruktywne prowadzą zawsze do konstrukcji modeli nieskończonych (np. Gödel [55], Asser [6])

Jeżeli interesuje nas dowód słabej postaci twierdzenia o pełności, to twierdzenie Posta dostarcza bardzo prostego argumentu: 
1. $\models \varphi$

2. $\vdash \varphi \leftrightarrow \varphi^{\prime}$, gdzie $\varphi^{\prime}$ jest $\mathrm{w}$ postaci KA Tw. Posta

3. $\models \varphi \leftrightarrow \varphi^{\prime}$

4. $\models \varphi^{\prime}$

2., Tw. o przystosowaniu

5. $\vdash \varphi^{\prime}$

1,3

6. $\vdash \varphi$

4, Fakt 1.2.

2,5

Jedyne przejście, które może budzić wątpliwość to dedukcja wiersza 5 . Zakłada ona istnienie algorytmicznej procedury budowania dowodu dla tautologii w postaci KA. Nie będziemy tutaj takiej procedury dla H-KRZ przedstawiać (por. np. Batóg [10]) ale wrócimy do tematu w rozdziale 7, gdzie pokażemy jak budować taki dowód w rachunku sekwentów.

W dalszym ciągu skupimy się na twierdzeniu o pełności w mocnej postaci. Jest ono zazwyczaj formułowane następująco:

Twierdzenie 1.4 (O istnieniu modelu) Każdy zbiór niesprzeczny jest spetnialny (ma model).

DowóD równoważności obu sformułowań, gdzie TP oznacza twierdzenie o pełności, a TIM o istnieniu modelu.

$\mathrm{TP} \Longrightarrow$ TIM: Załóżmy, że $\Gamma$ jest niesprzeczna, czyli $\Gamma \nvdash \perp$. Wtedy dla pewnego $\varphi \in \Gamma, \Gamma-\{\varphi\} \nvdash \neg \varphi$, co przez TP daje $\Gamma-\{\varphi\} \not \models \neg \varphi$. Wtedy, przez fakt 1.1. mamy, że $\Gamma$ jest spełnialna.

TIM $\Longrightarrow$ TP: Zalóżmy, że $\Gamma \models \varphi$, przez fakt 1.1. mamy, że $\Gamma \cup\{\neg \varphi\}$ jest niespełnialna, a zatem, przez TIM i sprzeczna. Ale wtedy $\Gamma \vdash \varphi$ przez lemat 1.4, własność 4 .

Najpopularniejszym sposobem dowodzenia pełności wielu logik jest spopularyzowana przez Henkina strategia oparcia go na lemacie Lindenbauma o niesprzecznych zbiorach maksymalnych. Przyjrzymy się dokładniej tej konstrukcji.

\subsubsection{Zbiory maksymalnie niesprzeczne}

W latach 30-tych ubiegłego wieku A. Lindenbaum udowodnił twierdzenie, powszechnie zwane lematem Lindenbauma, które znalazło szerokie zastosowania. Jest to twierdzenie o istnieniu pewnego typu zbiorów niesprzecznych zwanych maksymalnymi ${ }^{2}$.

\footnotetext{
${ }^{2}$ Inne określenia to zbiory zupełne, nasycone, teorie.
} 
Definicja 1.6 Zbiór $\Gamma$ jest maksymalnie niesprzeczny (MNSP) wtw:

- jest niesprzeczny

- jest zupetny: jeżeli $\Gamma \subset \Delta$, to $\Delta$ jest sprzeczny.

Uwaga 1.14: Drugi warunek definiowany jest często w inny sposób. Np. na gruncie KRZ następujące warunki są równoważne dla dowolnego niesprzecznego $\Gamma$ :

1. $\Gamma$ jest zupełny

2. jeżeli $\Gamma \cup\{\varphi\}$ jest niesprzeczny, to $\varphi \in \Gamma$, dla dowolnej formuły $\varphi$

3. jeżeli $\Gamma \subseteq \Delta$ i $\Delta$ jest niesprzeczny, to $\Gamma=\Delta$

4. dla dowolnej formuły $\varphi, \varphi \in \Gamma$ lub $\neg \varphi \in \Gamma$ ( $\Gamma$ jest $\neg$-zupełny $)$

Dowody pominiemy, podobnie jak w przypadku następnego:

Lemat 1.8 Dowolny zbiór maksymalnie niesprzeczny $\Gamma$ ma następujace własności:

1. $\varphi \in \Gamma w t w \Gamma \vdash \varphi$

2. jeżeli $\vdash \varphi$, to $\varphi \in \Gamma$

3. $\perp \notin \Gamma$

4. jeżeli $\varphi \rightarrow \psi \in \Gamma i \varphi \in \Gamma$, to $\psi \in \Gamma$

5. $\neg \varphi \in \Gamma w t w \varphi \notin \Gamma$

6. $\varphi \wedge \psi \in \Gamma w t w \varphi \in \Gamma i \psi \in \Gamma$

7. $\varphi \vee \psi \in \Gamma w t w \varphi \in \Gamma l u b \psi \in \Gamma$

8. $\varphi \rightarrow \psi \in \Gamma w t w \varphi \notin \Gamma l u b \psi \in \Gamma$

Wiemy, że istnieją zbiory niesprzeczne, ale czy istnieją zbiory maksymalnie niesprzeczne? Odpowiedź pozytywną na to pytanie daje właśnie lemat Lindenbauma:

Twierdzenie 1.5 (Lindenbaum) Jeżeli $\Gamma$ jest niesprzeczny, to istnieje jego maksymalnie niesprzeczne poszerzenie (tzn. istnieje takie $\Delta$, że $\Gamma \subseteq \Delta i$ $\Delta$ jest MNSP) 
Lemat Lindenbauma można udowodnić konstruktywnie lub niekonstruktywnie (przez odwołanie się do mocnych twiedzeń teorii mnogości jak lemat Kuratowskiego-Zorna, lemat Tukeya itp.), ponadto można łatwo wzmocnić go do równoważności. Poniżej naszkicujemy dowód konstruktywny. Opieramy się w nim na dwóch faktach z teorii mnogości (por. dodatek):

Fakt 1.3 1. Każdy przeliczalny zbiór można uporzadkować liniowo.

\section{Zbiór FOR jest przeliczalny.}

Dla danego zbioru niesprzecznego może istnieć nawet nieskończenie wiele maksymalnie niesprzecznych poszerzeń - zależy to m.in. od przyjętego uporządkowania FOR. Problemu tego nie będziemy tu rozważać; zakładamy, że mamy dane dowolne, ale określone, uporządkowanie zbioru FOR:

$$
\varphi_{1}, \varphi_{2}, \varphi_{3}, \ldots
$$

Definiujemy na jego podstawie indukcyjnie nieskończony ciąg zbiorów formuł:

$$
\begin{aligned}
& \Delta_{0}, \Delta_{1}, \Delta_{2}, \ldots \\
& \Delta_{0}=\Gamma
\end{aligned}
$$

$$
\Delta_{n+1}:= \begin{cases}\Delta_{n} \cup\left\{\varphi_{n+1}\right\} & \text { jeżeli } \Delta_{n} \cup\left\{\varphi_{n+1}\right\} \\ & \text { jest niesprzeczna } \\ \Delta_{n} & \text { w przeciwnym wypadku } \\ & \text { (tzn. jeżeli } \Delta_{n} \cup\left\{\varphi_{n+1}\right\} \\ & \text { jest sprzeczna) }\end{cases}
$$

Uwaga 1.15: Jest to definicja indukcyjna, w której warunek indukcyjny ma postać alternatywy - jest to częsta forma definicji indukcyjnej.

$\mathrm{Z}$ podanej definicji mamy:

Fakt 1.4 Dla dowolnego $n \geq 0, \Delta_{n}$ jest niesprzeczny.

Rozważmy nieskończoną sumę $\bigcup \Delta_{n}$ po wszystkich zbiorach w ciągu. Zachodzi dla niej

Fakt 1.5 (Własności $\bigcup \Delta_{n}$ ) 1. $\Delta_{n} \subseteq \bigcup \Delta_{n}$, dla dowolnego $n \geq 0$;

2. $\Gamma \subseteq \cup \Delta_{n}$; 
3. dla dowolnego $0 \leq k \leq n, \Delta_{k} \subseteq \Delta_{n}$;

4. dla dowolnego $k>0$, jeżeli $\varphi_{k} \in \bigcup \Delta_{n}$, to $\varphi_{k} \in \Delta_{k}$;

5. dla każdego skończonego $\Delta^{\prime} \subseteq \bigcup \Delta_{n}$ istnieje takie $k \geq 0$, że $\Delta^{\prime} \subseteq \Delta_{k}$.

W następnym kroku definiujemy maksymalne niesprzeczne poszerzenie $\Gamma$ jako nieskończoną sumę po wszystkich zbiorach w ciągu, tzn. $\Delta=\bigcup \Delta_{n}$ i dowodzimy:

Fakt 1.6 $\Delta$ jest maksymalnie niesprzecznym poszerzeniem $\Gamma$.

Kończy to dowód lematu Lindenbauma. Odnotujmy jeszcze jego dwie proste konsekwencje:

Fakt 1.7 Jeżeli $\Gamma$ jest niesprzeczny, to:

1. $\Gamma \vdash \varphi$ wtw $\varphi \in \Delta$, dla dowolnego $\Delta \supseteq \Gamma$, które jest MNSP

2. $\vdash \varphi$ wtw $\varphi \in \Delta$, dla dowolnego $\Delta$, które jest MNSP

\subsubsection{Inne metody dowodzenia pełności}

Strategia Lindenbauma spopularyzowana przez Henkina w latach 40-tych XX w. sprowokowała pewne alternatywne podejścia. Do najważniejszych można zaliczyć następujące:

- W latach 50-tych G. Asser udowodnił twierdzenie o zbliżonym charakterze, które bardziej bezpośrednio prowadzi do dowodu twierdzenia o pełności.

- J. Hintikka w latach 50-tych wprowadził pojęcie zbioru nasyconego w dół (downward-saturated set), które jest istotnie słabsze od pojęcia zbioru maksymalnie niesprzecznego ale wystarczające dla dowodów twierdzeń o pełności i to w dodatku konstruktywnych.

- W latach 60-tych R. Smullyann zaproponował bardzo ogólne ujęcie, w którym wyabstrahowuje się pewne własności niesprzeczności (tzw. consistency properties), które pozwalają na jednolite dowody wielu metalogicznych twierdzeń dla różnych systemów dedukcyjnych.

Twierdzenie Assera [6] o relatywnych zbiorach maksymalnych można sformułować następująco: 
Twierdzenie 1.6 (Asser) Jeżeli $\Gamma \nvdash \varphi$, to istnieje takie $\Delta$, że:

1. $\Gamma \subseteq \Delta$

2. $\varphi \notin \Delta$

3. jeżeli $\Delta \vdash \psi$, to $\psi \in \Delta$

4. jeżeli $\psi \notin \Delta$, to $\Delta, \psi \vdash \varphi$

Podobieństwo zbioru relatywnie maksymalnego do zbioru MNSP jest widoczne, jeżeli w powyższej charakterystyce zastąpimy $\varphi$ przez $\perp$. Zbiór MNSP staje się wtedy szczególnym przypadkiem zbioru relatywnie maksymalnego. Dowód twierdzenia Assera można przeprowadzić analogicznie do dowodu lematu Lindenbauma.

Najważniejszą, z punktu widzenia dalszych zastosowań, konstrukcją są tak zwane zbiory Hintikki [66], zwane także często zbiorami nasyconymi w dół.

Przypomnijmy, że zbiory MNSP czy zbiory relatywnie maksymalne są nasycone ze względu na stałe logiczne, tj spełniają następujące warunki:

1. $\neg \varphi \in \Gamma$ wtw $\varphi \notin \Gamma$

2. $\varphi \wedge \psi \in \Gamma$ wtw $\varphi \in \Gamma$ i $\psi \in \Gamma$

3. $\varphi \vee \psi \in \Gamma$ wtw $\varphi \in \Gamma$ lub $\psi \in \Gamma$

4. $\varphi \rightarrow \psi \in \Gamma$ wtw $\varphi \notin \Gamma$ lub $\psi \in \Gamma$

Ze względu na dowód twierdzenia o pełności są to konstrukcje bardzo silne. Hintikka pokazał, że wystarczy konstrukcja słabsza - zbiór nasycony w dół (downward saturated), który spełnia następujące warunki:

1. jeżeli $\varphi \in \Gamma$, to $\neg \varphi \notin \Gamma$

2. jeżeli $\neg \neg \varphi \in \Gamma$, to $\varphi \in \Gamma$

3. jeżeli $\varphi \wedge \psi \in \Gamma$, to $\varphi \in \Gamma$ i $\psi \in \Gamma$

4. jeżeli $\neg(\varphi \wedge \psi) \in \Gamma$, to $\neg \varphi \in \Gamma$ lub $\neg \psi \in \Gamma$

5. jeżeli $\varphi \vee \psi \in \Gamma$, to $\varphi \in \Gamma$ lub $\psi \in \Gamma$

6. jeżeli $\neg(\varphi \vee \psi) \in \Gamma$, to $\neg \varphi \in \Gamma$ i $\neg \psi \in \Gamma$ 
7. jeżeli $\varphi \rightarrow \psi \in \Gamma$, to $\neg \varphi \in \Gamma$ lub $\psi \in \Gamma$

8. jeżeli $\neg(\varphi \rightarrow \psi) \in \Gamma$, to $\varphi \in \Gamma$ i $\neg \psi \in \Gamma$

Uwaga 1.16: W przeciwieństwie do zbiorów nasyconych, zbiory Hintikki mogą być skończone, dzięki czemu można je wykorzystać do konstruktywnych dowodów pełności (i zarazem rozstrzygalności) np. dla systemów tablicowych.

Na koniec naszkicujmy krótko konstrukcję Smullyana [131].

Niech $C O N$ (Consistency Property) oznacza dowolną rodzinę zbiorów formuł, która spełnia nastȩpujące warunki dla każdego $\Gamma \in C O N$ :

1. $\perp \notin \Gamma$

2. jeżeli $\neg \neg \varphi \in \Gamma$, to $\Gamma \cup\{\varphi\} \in C O N$

3. jeżeli $\varphi \wedge \psi \in \Gamma$, to $\Gamma \cup\{\varphi, \psi\} \in C O N$

4. jeżeli $\neg(\varphi \wedge \psi) \in \Gamma$, to $\Gamma \cup\{\neg \varphi\} \in C O N$ lub $\Gamma \cup\{\neg \psi\} \in C O N$

5. jeżeli $\varphi \vee \psi \in \Gamma$, to $\Gamma \cup\{\varphi\} \in C O N$ lub $\Gamma \cup\{\psi\} \in C O N$

6. jeżeli $\neg(\varphi \vee \psi) \in \Gamma$, to $\Gamma \cup\{\neg \varphi, \neg \psi\} \in C O N$

7. jeżeli $\varphi \rightarrow \psi \in \Gamma$, to $\Gamma \cup\{\neg \varphi\} \in C O N$ lub $\Gamma \cup\{\psi\} \in C O N$

8. jeżeli $\neg(\varphi \rightarrow \psi) \in \Gamma$, to $\Gamma \cup\{\varphi, \neg \psi\} \in C O N$

$C O N$ jest finitarne, jeżeli dodatkowo spełnia nastȩpujący warunek dla każdego $\Gamma \in C O N$ :

$\Gamma \in C O N$ wtw dla dowolnego skończonego $\Delta \subseteq \Gamma, \Delta \in C O N$

Można udowodnić ogólnie, że dowolne CON może być poszerzone do finitarnego lub, bardziej konkretnie, wykazać dla odpowiednio zdefiniowanych zbiorów, że tworzą finitarną $C O N$. W szczególności można dowieść dla zbiorów $H N S P=\{\Gamma: \Gamma \nvdash \perp\}$ i $H N S P_{\varphi}=\{\Gamma: \Gamma \nvdash \varphi\}$ :

\section{Twierdzenie 1.7 1. HNSP jest finitarna $C O N$}

2. $\mathrm{HNSP}_{\varphi}$ jest finitarna $\mathrm{CON}$ 
DowóD: Trzeba wykazać, że dowolny element $H N S P\left(H N S P_{\varphi}\right)$ spełnia warunki definiujące $C O N$.

Finitarność HNSP wynika z lematu 1.1, własność 3.

Warunek 1. Gdyby $\perp \in \Gamma$, to przez zwrotność $\vdash, \Gamma \vdash \perp-$ sprzeczność.

Warunek 2. Niech $\neg \neg \varphi \in \Gamma \in H N S P$ ale $\Gamma \cup\{\varphi\} \notin H N S P$, czyli $\Gamma \nvdash \perp$ ale $\Gamma, \varphi \vdash \perp$. Przez lemat 1.1, własność $9, \Gamma \vdash \neg \varphi$, a ponieważ $\neg \neg \varphi \vdash \varphi$, to, przez lemat 1.1, własność $4, \Gamma, \neg \neg \varphi \vdash \perp$, ale to znaczy, że $\Gamma \vdash \perp-$ sprzeczność.

Warunek 8. Załóżmy, że $\varphi \rightarrow \psi \in \Gamma \in H N S P$ ale $\Gamma \cup\{\neg \varphi\} \notin H N S P$ i $\Gamma \cup\{\psi\} \notin H N S P$. Czyli $\Gamma \nvdash \perp$ ale $\Gamma, \neg \varphi \vdash \perp$ i $\Gamma, \psi \vdash \perp$. Zatem $\Gamma \vdash \varphi$ (lemat 1.1), a ponieważ $\varphi, \varphi \rightarrow \psi \vdash \psi$, więc przez przechodniość $\vdash$ mamy $\Gamma, \varphi \rightarrow \psi \vdash \psi$, co (znów przez przechodniość) daje $\Gamma, \varphi \rightarrow \psi \vdash \perp=\Gamma \vdash \perp-$ sprzeczność.

Warunek 9. Załóżmy, że $\neg(\varphi \rightarrow \psi) \in \Gamma \in H N S P$ ale $\Gamma \cup\{\varphi, \neg \psi\} \notin$ $H N S P$. Czyli $\Gamma \nvdash \perp$ ale $\Gamma, \varphi, \neg \psi \vdash \perp$. Zatem $\Gamma, \varphi \vdash \psi$ przez lemat 1.1, a przez DT $\Gamma \vdash \varphi \rightarrow \psi$, co (znów przez lemat 1.1) daje $\Gamma, \neg(\varphi \rightarrow \psi) \vdash \perp=$ $\Gamma \vdash \perp-$ sprzeczność.

Dowód pozostałych warunków przebiega podobnie. Analogicznie dla $H N S P_{\varphi}$.

Dla dowolnego finitarnego $C O N$ zachodzi analogon lematu Lindenbauma:

Twierdzenie 1.8 Jeżeli $\Gamma \in C O N$, to istnieje maksymalne $\Delta \in C O N$, takie, że $\Gamma \subseteq \Delta$.

Dowód można przeprowadzić analogicznie do dowodu lematu Lindenbauma. Musimy tylko wstȩpnie dowieść, że dla dowolnego cia̧gu $\Gamma_{1}, \Gamma_{2}, \Gamma_{3}, \ldots$ elementów $C O N$, takiego, że $\Gamma_{1} \subseteq \Gamma_{2} \subseteq \Gamma_{3} \subseteq \ldots$, również $\bigcup \Gamma_{n} \in C O N$.

\subsubsection{Pełność H-KRZ}

Każda z rozważanych wyżej konstrukcji pozwala na dowód pełności dla HKRZ. Jak pokazaliśmy w paragrafie 1.4.1 wystarczy w tym celu udowodnić twierdzenie 1.4. (TIM). Ograniczymy się do pokazania, w jaki sposób konstruować model na bazie konstrukcji Lindenbauma i Hintikki zachęcając czytelnika do przeprowadzenia podobnego dowodu w oparciu o konstrukcję Assera i Smullyana. 
Udowodnimy najpierw TIM w oparciu o lemat Lindenbauma. Ponieważ wynika z niego, że każdy zbiór niesprzeczny zawiera się w jakimś zbiorze MNSP, więc wystarczy wykazać, że każdy zbiór MNSP ma model, gdyż wtedy jest to również model dla jego podzbiorów.

Lemat 1.9 (Lemat Prawdziwościowy L) Dla dowolnego zbioru MNSP $\Gamma$ istnieje model $\mathfrak{M}_{\Gamma}$ taki, że:

$$
\varphi \in \Gamma \text { wtw } \mathfrak{M}_{\Gamma} \vDash \varphi
$$

DowóD: Zdefiniujmy wartościowanie $V_{\Gamma}$ dla zmiennych zdaniowych.

$$
V_{\Gamma}(\varphi):= \begin{cases}1 & \text { jeżeli } \varphi \in \Gamma \\ 0 & \text { jeżeli } \varphi \notin \Gamma\end{cases}
$$

Dowodzimy przez indukcję strukturalną po kształcie formuł (por. dodatek), że model wyznaczony przez $V_{\Gamma}$ spełnia podaną wyżej równoważność:

1. baza oczywista z definicji $V_{\Gamma}$ :

$\varphi \in \Gamma$ wtw $V_{\Gamma}(\varphi)=1$ wtw $\mathfrak{M}_{\Gamma} \vDash \varphi$

Dla dowodu kroku indukcyjnego zakładamy, że każda formuła krótsza od $\varphi$ spełnia dowodzoną równoważność i wykazujemy ją dla $\varphi$ rozważając różne przypadki. Dla przykładu, niech $\varphi:=\psi \wedge \chi$ :

$$
\begin{array}{rll}
\psi \wedge \chi \in \Gamma \text { wtw } & \psi \in \Gamma \mathrm{i} \chi \in \Gamma & \text { Lemat 1.8., w.6 } \\
\text { wtw } & \mathfrak{M}_{\Gamma} \vDash \psi \mathrm{i} \mathfrak{M}_{\Gamma} \vDash \chi & \text { z zał. ind. } \\
\text { wtw } & \mathfrak{M}_{\Gamma} \vDash \psi \wedge \chi & \text { z def. } \vDash .
\end{array}
$$

Pozostałe przypadki podobnie.

Dowód przez zbiory Hintikki przebiega podobnie, dowodzimy:

Lemat 1.10 (Lemat Prawdziwościowy H:) Dla dowolnego zbioru Hintikki $\Gamma$ istnieje model $\mathfrak{M}_{\Gamma}$ taki, że:

- jeżeli $\varphi \in \Gamma$, to $\mathfrak{M}_{\Gamma} \vDash \varphi$

- jeżeli $\neg \varphi \in \Gamma$, to $\mathfrak{M}_{\Gamma} \not \models \varphi$

Dowód: Wartościowanie $V_{\Gamma}$ dla zmiennych zdaniowych definiujemy tak samo jak w dowodzie lematu prawdziwościowego L. Lematu dowodzimy przez indukcję po długości formuł; osobno dla formuł niezanegowanych i zanegowanych. 
1. baza $-\varphi$ jest zmienną:

$$
\begin{aligned}
& \varphi \in \Gamma \Longrightarrow V_{\Gamma}(\varphi)=1 \quad \text { z def. } V_{\Gamma} \\
& \Longleftrightarrow \mathfrak{M}_{\Gamma} \vDash \varphi \quad \text { z def. } \vDash . \\
& \neg \varphi \in \Gamma \Longrightarrow \varphi \notin \Gamma \quad \text { z def. zb. Hintikki w1. } \\
& \Longrightarrow V_{\Gamma}(\varphi)=0 \quad \text { z def. } V_{\Gamma} \\
& \Longleftrightarrow \mathfrak{M}_{\Gamma} \not \models \varphi \quad \text { z def. } \vDash \text {. }
\end{aligned}
$$

Dla dowodu kroku indukcyjnego zakładamy, że każda formuła krótsza od $\varphi$ spełnia dowodzoną implikację (1 lub 2) i wykazujemy ją dla $\varphi$ :

1. $\varphi:=\neg \neg \psi:$

$$
\begin{aligned}
& \neg \neg \psi \in \Gamma \Longrightarrow \psi \in \Gamma \quad \text { z def. zb. Hintikki w2. } \\
& \Longrightarrow \mathfrak{M}_{\Gamma} \vDash \psi \quad \text { z zal. ind. } \\
& \Longleftrightarrow \mathfrak{M}_{\Gamma} \not \models \neg \psi \quad \mathrm{z} \text { def. } \vDash \text {. }
\end{aligned}
$$

2. $\varphi:=\psi \wedge \chi$ :

$$
\begin{aligned}
\psi \wedge \chi \in \Gamma & \Longrightarrow \psi \in \Gamma \mathrm{i} \chi \in \Gamma & & \text { z def. zb. Hintikki w3. } \\
& \Longrightarrow \mathfrak{M}_{\Gamma} \vDash \psi \mathrm{i} \mathfrak{M}_{\Gamma} \vDash \chi & & \text { z zal. ind. } \\
& \Longleftrightarrow \mathfrak{M}_{\Gamma} \vDash \psi \wedge \chi & & \text { z def. } \vDash
\end{aligned}
$$

3. $\varphi:=\neg(\psi \wedge \chi)$ :

$$
\begin{aligned}
\neg(\psi \wedge \chi) \in \Gamma & \Longrightarrow \neg \psi \in \Gamma \text { lub } \neg \chi \in \Gamma & & \text { zb. Hintikki w4. } \\
& \Longleftrightarrow \mathfrak{M}_{\Gamma} \not \models \psi \text { lub } \mathfrak{M}_{\Gamma} \not \models \chi & & \text { z zał. ind. } \\
& \Longleftrightarrow \text { nieprawda, że }\left(\mathfrak{M}_{\Gamma} \vDash \psi \text { i } \mathfrak{M}_{\Gamma} \vDash \chi\right) & & \text { DeMorgan } \\
& \Longleftrightarrow \mathfrak{M}_{\Gamma} \not \models \psi \wedge \chi & & \text { z def. } \vDash .
\end{aligned}
$$

Analogicznie pozostałe przypadki.

Dowód TIM wymaga jedynie wykazania, że każdy niesprzeczny zbiór da się poszerzyć do zbioru Hintikki, gdyż model spełniający ten ostatni spełnia również jego podzbiory. Można to zrobić na co najmniej trzy sposoby (por. Hodges [68]):

1. za pomocą konstrukcji Lindenbauma (przez maksymalizację)

2. za pomocą bezpośredniej konstrukcji zbioru Hintikki

3. za pomocą rozgałęzionej konstrukcji zbioru Hintikki

Nie będziemy tu omawiać tych sposobów gdyż zilustrujemy te strategie w rozdziale 7 po uprzednim dostosowaniu konstrukcji Hintikki dp rachunków sekwentowych. 


\subsection{Wybrane własności KRZ}

Na koniec odnotujmy dwie ważne własności KRZ: rozstrzygalność i własność interpolacji.

Własność rozstrzygalności w najogólniejszym sformułowaniu można wyrazić następująco:

Definicja 1.7 (Rozstrzygalność) Dla zbioru $X$ i własności $P$ istnieje efektywna procedura (algorytm), która w skończonej liczbie kroków pozwala ustalić dla dowolnego $x \in X$ czy posiada własność $P$.

Tak ogólne sformułowanie obejmuje rozliczne problemy szczegółowe. Najbardziej interesujące dla nas to problem tautologiczności i spełnialności. Pierwszy sprowadza się do pytania czy dla każdej $\varphi \in F O R$ możemy roztrzygnąc czy jest tautologią; drugi do tego czy w każdym przypadku możemy ustalić spełnialność. Oba te problemy są komplementarne gdyż $=\varphi$ wtw $\neg \varphi$ jest niespełnialna. $\mathrm{W}$ obu wypadkach dla KRZ prostym rozwiązaniem jest popularny test tabelkowy.

Nieco inaczej wygląda problem rozstrzygalności w ujęciu syntaktycznym, tzn. jeżeli pytanie o tautologiczność zastąpimy pytaniem o to czy dana formuła jest tezą (problem dowiedlności). W ogólnym ujęciu możemy się odwołać do twierdzenia o adekwatności i rozstrzygalność problemu tautologiczności implikuje roztrzygalność problemu dowiedlności. Jeżeli jednak rozważamy problem na gruncie konkretnego systemu dedukcyjnego i konkretnej definicji dowodu to sytuacja się różnicuje. W systemach aksjomatycznych trudno konstruować dowody i proces ich poszukiwania z trudnością poddaje się algorytmizacji (choć nie jest to niemożliwe, np. dowód twierdzenia o pełności metodą Kalmara dostarcza pewnego sposobu). Dla odmiany, w rachunku sekwentów czy w pochodnych od niego systemach tablicowych (por. rozdział 10), stosunkowo łatwo jest proces szukania dowodu dla KRZ zautomatyzować. Zajmiemy się tym w rozdziale 6 .

Nie będziemy tutaj precyzować pojęcia algorytmu, które pojawiło się $\mathrm{w}$ definicji. Istnieje wiele formalnych modeli (np. w terminach maszyn Turinga, funkcji rekurencyjnych, algorytmów Markowa, automatów Posta), a zaawansowane badania nad nimi należą do teorii obliczalności i złożoności obliczeniowej. Na potrzeby niniejszej pracy wystarczy podkreślić, że metoda rozstrzygania musi być mechaniczna (nie wymaga wyobraźni), poprawna (udziela poprawnej odpowiedzi dla każdego $x \in X$ ) i skończona (daje odpowiedź w skończonym czasie). Algorytmy sformułowane w dalszych rozdziałach będą opisane w sposób nieformalny, ale na tyle dokładny by był możliwy 
ich precyzyjny przekład. Nie będziemy też zazwyczaj poruszali kwestii ich wydajności poza marginalnymi uwagami.

Twierdzenie Craiga o interpolacji jest jednym z ciekawszych wyników metalogicznych. Pierwotnie udowodniono je dla logiki klasycznej, potem dla wielu logik nieklasycznych. Równocześnie odkryto, że wiele logik tej własności nie posiada. W sformułowaniu zdaniowym i semantycznym brzmi:

Twierdzenie 1.9 (Craig) Jeżeli $\models \varphi \rightarrow \psi i Z Z(\varphi) \cap Z Z(\psi) \neq \varnothing$, to istnieje $\chi$ takie, $\dot{z} e$ :

- $Z Z(\chi) \subseteq Z Z(\varphi) \cap Z Z(\psi)$

$\bullet \models \varphi \rightarrow \chi$

$\bullet \vdash \chi \rightarrow \psi$

Zauważmy, że jeżeli w języku dopuścimy jako pierwotną stałą $\perp$, to założenie $Z Z(\varphi) \cap Z Z(\psi) \neq \varnothing$ można pominąć. $\chi$ jest często określane jako formuła interpolacyjna (lub krótko interpolant). Wtedy Twierdzenie Craiga można krótko wysłowić: Jeżeli implikacja jest tautologią, to ma interpolant.

Istnieje wiele różnych dowodów tego twierdzenia, w rozdziale 6 podamy konstruktywny dowód uogólnienia tego twierdzenia korzystający z pewnych własności rachunku sekwentów.

\subsection{Dedukcja Naturalna}

Dla dalszych rozważań przyda nam się krótkie przypomnienie podstawowych informacji o charakteryzacji KRZ w terminach dedukcji naturalnej. Najprościej rzecz ujmując ${ }^{3}$ systemy DN charakteryzują się tym, że:

1. Pozwalają na wprowadzanie dodatkowych założeń oraz ich eliminowanie (co związane jest z zamykaniem odpowiednich poddowodów).

2. Zamiast aksjomatów używają reguł inferencji, które pozwalają wprowadzać i eliminować stałe logiczne z dowodu.

3. Dopuszczają różne formy dowodu i strategie jego poszukiwania (wprost, niewprost, rozgałęzione itp.).

\footnotetext{
${ }^{3}$ Dokładniejsze omówienie w Indrzejczak [74].
} 
Punkt 1 i 3 powyższej charakterystyki powoduje, że w skład systemów DN, oprócz reguł inferencji wchodzą specjalne reguły konstrukcji dowodu. W ten sposób struktura systemu jest bardziej skomplikowana niż w przypadku H-systemów ale za to konstrukcja dowodów jest znacznie prostsza. Chociaż współcześnie istnieje duża mnogość systemów tego typu, na pozór różniących się znacznie nie tylko doborem reguł, ale i sposobem budowy dowodu, to w istocie wszystkie można sprowadzić do trzech typów, z których dwa wywodzą się z prac Gentzena [50, 51], a jeden od Jaśkowskiego [76]. Tak zwane sekwentowe DN, wprowadzone przez Gentzena w 1936, scharakteryzujemy w rozdziale 10, obecnie ograniczymy się do omówienia dwóch typów DN operujacych na formułach: Gentzenowskiego z dowodami w kształcie drzew (T-dowody) i Jaśkowskiego z dowodami liniowymi (L-dowody). W obu przypadkach reguły inferencji (p. 2) zdefiniowane są na formułach a nie na sekwentach, podobnie jak w przypadku H-systemów. Jeżeli chodzi o dobór reguł inferencji i konstrukcji dowodu to systemy Jaśkowskiego i Gentzena różnią się nieznacznie. Oto reguły DN Gentzena:

Reguły inferencji:

$$
\begin{array}{ll}
(\perp) & \varphi, \neg \varphi / \perp \mathrm{i} \perp / \varphi \\
(\wedge D) & \varphi, \psi / \varphi \wedge \psi \\
(\wedge E) & \varphi \wedge \psi / \varphi \mathrm{i} \varphi \wedge \psi / \psi \\
(\vee D) & \varphi / \varphi \vee \psi \text { i } \psi / \varphi \vee \psi \\
(\rightarrow E) & \varphi \rightarrow \psi, \varphi / \psi
\end{array}
$$

Reguły konstrukcji dowodu:

$$
\begin{array}{ll}
(\neg D) & \text { Jeżeli } \Gamma, \varphi \vdash \perp, \text { to } \Gamma \vdash \neg \varphi \\
(\vee E) & \text { Jeżeli } \Gamma, \varphi \vdash \chi \text { i } \Delta, \psi \vdash \chi, \text { to } \Gamma, \Delta, \varphi \vee \psi \vdash \chi \\
(\rightarrow D) & \text { Jeżeli } \Gamma, \varphi \vdash \psi, \text { to } \Gamma \vdash \varphi \rightarrow \psi
\end{array}
$$

Reguły konstrukcji dowodu wyrażają (słaby) dowód nie wprost, dowód rozgałęziony i dowód warunkowy (twierdzenie o dedukcji). W każdym przypadku schemat wyraża zależność następującą: jeżeli poddowód zainicjowany dodatkowym założeniem $\varphi$ (w przypadku $(\vee E)$ dwa poddowody; drugi zaczęty przez $\psi$ ) zakończy się sukcesem, to w nadrzędnym dowodzie dopisujemy odpowiednią formułę (np. $\chi \mathrm{w}(\vee E)$, która już od dodatkowych założeń nie zależy a tylko od wyjściowych $(\Gamma, \Delta)$.

Zestaw ten daje adekwatną charakterystykę logiki intuicjonistycznej. Aby uzyskać DN-KRZ trzeba dołączyć jako aksjomat prawo wyłączonego środka lub regułę $\neg \neg \varphi / \varphi$. Jaśkowski uzyskuje DN-KRZ od razu poprzez użycie mocnej reguły konstrukcji dowodu nie wprost: 
$(\neg E)$ Jeżeli $\Gamma, \neg \varphi \vdash \perp$, to $\Gamma \vdash \varphi$

Główna różnica między DN Gentzena a Jaśkowskiego leży w definicji dowodu. Gentzen używa formy drzewa, w którym każdy liść jest założeniem, względnie aksjomatem, a korzeń dowodzoną formułą. Przejścia między węzłami regulowane są przez podane wyżej reguły. Oto przykład dowodu:

Przykład 1.1.

$$
\begin{gathered}
\frac{[p] \quad[p \rightarrow q]}{\frac{q \quad[q \rightarrow r]}{r}} \\
\left.\frac{\frac{p \rightarrow r}{(q \rightarrow r) \rightarrow(p \rightarrow r)}}{(p \rightarrow q) \rightarrow((q \rightarrow r) \rightarrow(p \rightarrow r)}\right)
\end{gathered}
$$

W podanym przykładzie każde założenie zamknięte jest w [ ], co oznacza, że stosowny poddowód zainicjowany tym założeniem został zamknięty przez zastosowanie odpowiedniej reguły konstrukcji dowodu. Reprezentacja w postaci drzewa dobrze przedstawia strukturę gotowego dowodu, ale jest niepraktyczna przy jego poszukiwaniu, ponadto często zmusza do wielokrotnego powtarzania tych samych partii dowodu, gdyż w dowodzie takim używamy nie tyle formuł, co ich konkretnych wystąpień. Poniższy przykład zilustruje ten problem:

Przykład 1.2.

$$
\begin{gathered}
\frac{[q] \quad \frac{[p \wedge(q \wedge p \rightarrow r)]}{p}}{q \wedge p} \quad \frac{[p \wedge(q \wedge p \rightarrow r)]}{q \wedge p \rightarrow r} \\
\left(p \wedge \left(q \wedge \frac{r}{\frac{q \rightarrow r}{p \rightarrow r)) \rightarrow}}(q \rightarrow r)\right.\right.
\end{gathered}
$$

Jak widać założenie $p \wedge(q \wedge p \rightarrow r)$ i zależne od niego dedukcja musi pojawić się dwukrotnie. W DN Jaśkowskiego dowód konstruowany jest jako ciąg formuł co jest wygodniejsze i bardziej ekonomiczne (używamy formuł, a nie ich wystąpień), ale zmusza do zastosowania dodatkowych środków graficznych w celu odseparowania zamkniętych poddowodów od dowodu nadrzędnego. Jaśkowski używał w tym celu najpierw prostokątów [75], a potem indeksów wierszy; większość obecnie używanych w praktyce systemów DN wykorzystuje tego typu rozwiązania. Oto przykład dowodu powyższej tezy: 
Przykład 1.3.

1. $1: \quad p \wedge(q \wedge p \rightarrow r)$

2. $1: p$

3. $1: q \wedge p \rightarrow r$

4. $1.1: q$

5. $1.1: q \wedge p$

6. $1.1: r$

7. $1: \quad q \rightarrow r$

8. $\quad(p \wedge(q \wedge p \rightarrow r)) \rightarrow(q \rightarrow r)$ założenie

$\mathrm{z} 1$.

$\mathrm{z} 1$.

założenie

z 2. i 4.

z 3. i 5 .

4. -6 .

1. -7 .

W powyższym dowodzie zastosowaliśmy technikę prefiksowania założeń i zależnych od nich partii dowodu (poddowodów), którą zastosował Jaśkowski w [76]. I tak prefiks '1:' jest wprowadzony z pierwszym, a '1.1:' z drugim założeniem. Dwa zastosowania $(\rightarrow D)$ zamykają w wierszu 7 i 8 kolejne poddowody, toteż dowiedziona w wierszu 8 teza nie posiada prefiksu (nie jest zależna od żadnych założeń). W przeciwieństwie do dowodu w DN Gentzena z przykładu 1.2. pierwsze założenie pojawia się raz. Liniowy format dowodu w stylu Jaśkowskiego zdominował podręcznikowe zastosowania DN, natomiast drzewne dowody Gentzena są stosowane przede wszystkim w teoretycznych opracowaniach.

Relację dowiedlności $\Gamma \vdash \varphi$ definiujemy przez odniesienie do posiadania dowodu w systemie DN, w którym elementy $\Gamma$ występują jako założenia aktywne (poddowód przez nie rozpoczęty nie został zamknięty przez żadną regułę konstrukcji dowodu). Pozostałe pojęcia i rezultaty przedstawione dla H-KRZ przenoszą się na DN-KRZ. W szczególności zachodzi

Twierdzenie $1.10 \Gamma \vdash \varphi w$ systemie $D N w t w \Gamma \varphi w$ systemie aksjomatycznym

Dowód równoważności obu formalizacji pomijamy. 


\section{Rozdział 2}

\section{Sekwenty, reguły, rachunki}

Rozdział ten pomyślany jest jako ogólne i nieformalne wprowadzenie do problematyki rachunków sekwentowych (RS). W szczególności, przedstawimy w nim pewną propozycję typologii rachunków sekwentowych. W podrozdziale 2.1 omówimy rozmaite rodzaje sekwentów i ich uogólnienia oraz oparte na nich podziały form RS. Kolejny podrozdział jest poświęcony charakterystyce rodzajów reguł sekwentowych i wyróżnieniu podstawowych typów RS. Na koniec omówimy różne sposoby interpretowania sekwentów (2.3) oraz związek RS z teorią konsekwencji oparty na jednej z tych interpretacji (2.4). Ostatni podrozdział ma bardziej zaawansowany charakter i można go całkowicie pominąć, gdyż zawiera informacje nie wykorzystywane w dalszych rozdziałach. Podrozdziały 2.1 - 2.3 zawierają informacje wykorzystywane dalej, ale ich dokładna lektura może być bardziej przydatna po zapoznaniu się z kolejnymi rozdziałami.

\subsection{Ogólne pojęcie rachunku sekwentowego.}

Przyjmijmy wstępnie, że dowolny rachunek sekwentów (krótko RS) to pewien skończony zbiór schematów (pierwotnych) reguł sekwentowych postaci:

$S_{1}, \ldots, S_{n} / S_{n+1}, n \geq 0$, gdzie $S_{i}, i \leq n+1$ oznacza schemat sekwentu.

W dalszym ciągu będziemy dla krótkości nazywali regułami i sekwentami zarówno schematy jak i ich konkretne instancje w języku przedmiotowym. Sekwenty po lewej stronie / to przesłanki, a $S_{n+1}$ to wniosek reguły. Zauważmy, że $n$ czyli ilość sekwentów-przesłanek może być równa 0 ; w takim przypadku zamiast o regule będziemy po prostu mówić o sekwencie (aksjomatycznym lub pierwotnym). 
W ramach tej ogólnej charakterystyki można wyróżnić rozmaite wersje RS w oparciu o różne kryteria. Do najważniejszych zaliczymy rodzaj stosowanych sekwentów i charakter reguł.

\subsubsection{Rodzaje sekwentów}

Standardowe pojęcie sekwentu to para uporządkowana postaci $\varphi_{1}, \ldots, \varphi_{k} \Rightarrow$ $\psi_{1}, \ldots, \psi_{n}, \mathrm{z} k \geq 0, n \geq 0$, gdzie formuły $\varphi_{1}, \ldots, \varphi_{k}$ tworza poprzednik, a $\psi_{1}, \ldots, \psi_{n}$ następnik sekwentu. Dla oznaczenia sekwentów będziemy też używali zapisu $\Gamma \Rightarrow \Delta$. W przypadku, gdy w schemacie sekwentu pewne formuły są wyróżnione będziemy je określali jako zasadnicze (lub główne) a resztę jako kontekst albo formuły parametryczne (lub krótko, parametry), np. w $\varphi, \Gamma \Rightarrow \Delta$ wyróżnione w poprzedniku $\varphi$ jest formułą główną, a $\Gamma$ i $\Delta$ to konteksty (parametry).

Często używa się notacji $\Gamma \vdash \Delta \mathrm{w}$ zapisie sekwentów co od razu sugeruje pewien sposób ich rozumienia (schematy inferencji). Nie będziemy takiej notacji używać, gdyż narzuca ona interpretację sekwentów jako wyrażeń mówiących o zachodzeniu pewnej relacji konsekwencji między poprzednikiem i następnikiem. Jest to wprawdzie interpretacja naturalna, ale nie jedyna. Powiemy o tym więcej w podrozdziale 2.3 .

Precyzyjną definicję standardowego sekwentu, w sensie Gentzena, podamy w rozdziale 3, należy jednak już na wstępie podkreślić, że nie ma jednej obowiązującej postaci sekwentu. Dla przykładu, w ogólnikowej charakterystyce tu podanej nie sprecyzowaliśmy czym jest poprzednik i następnik zbiorem formuł czy też innego typu strukturą. Z drugiej strony, podana charakterystyka jest i tak zbyt wąska, jeżeli chcielibyśmy wziąć pod uwagę wiele obiektów, które w literaturze określane są jak sekwenty. W szczególności przesądziliśmy tu dwie kwestie:

1. Sekwent jest uporządkowaną parą.

2. Elementy argumentów sekwentu to formuły.

Chcąc uwzględnić całe bogactwo propozycji formalnych należałoby przedstawić znacznie bardziej ogólną charakterystykę sekwentu, która dopuszcza zarówno inną ilość argumentów sekwentu, jak i inne rodzaje danych jako elementy tych argumentów. Ponieważ sekwenty można rozmaicie definiować, więc możliwe są różne klasyfikacje form RS, które odwołują się jedynie do kryteriów strukturalnych, mianowicie: 
1. charakter argumentów sekwentu;

2. ilość formuł (ew. innych struktur danych) w argumentach sekwentu;

3. budowa (np. ilość argumentów) sekwentu;

4. charakter obiektów tworzących argumenty sekwentu.

Dla naszych potrzeb istotne będą jedynie dwa pierwsze kryteria. Dwa ostatnie wykraczają poza podaną wyżej charakterystykę sekwentu, ale związane są z różnego rodzaju niestandardowymi formalizacjami logik nieklasycznych, których w tej pracy nie omawiamy. W następnym paragrafie skoncentrujemy się na podziałach form RS wynikających z dwóch pierwszych kryteriów, natomiast w paragrafie 2.1.3. krótko wspomnimy o ważniejszych uogólnienich RS opartych o kryteria 3 i 4.

\subsubsection{Alternatywy RS}

Pierwsze kryterium (charakter argumentów sekwentu) pozwala dokonać podziału systemów RS na takie, w których obiekty tworzące argumenty sekwentu to:

- zbiory (formuł)

- multizbiory

- ciągi

Oryginalny system Gentzena, który omówimy w kolejnym rozdziale, używał sekwentów zbudowanych ze skończonych ciągów formuł. Jednak dla większości zastosowań wystarczające i wygodniejsze są multizbiory lub zbiory formuł. W szczególności multizbiory są popularniejsze w strukturalnej teorii dowodu, natomiast zbiory $\mathrm{w}$ zastosowaniach RS jako narzędzia poszukiwania dowodu lub w semantycznych badaniach. Te trzy sposoby definiowania sekwentów są podstawowe i wyznaczają trzy podstawowe alternatywy RS: ${ }^{1}$ z-systemy (zbiory), m-systemy (multizbiory) i c-systemy (ciągi).

Drugie kryterium - ilości formuł (względnie innych struktur danych) w argumentach sekwentu pozwala rozróżnić:

- tzw. intuicjonistyczne sekwenty (krótko int-sekwenty), w których następnik zawiera co najwyżej jedną formułę (many-one, single-conclusioned)

\footnotetext{
${ }^{1}$ Zastosowaliśmy tu, za Poggiolesi [108], terminologię Casariego [22].
} 
- tzw. klasyczne sekwenty dopuszczające więcej formuł w następniku (many-many, multi-conclusioned)

- inne, np. z pojedynczą formułą w poprzedniku i następniku (typu oneone - por. system Riegera [119] omówiony w rozdziale 10).

Uwaga 2.1: Rozróżnienie sekwentów na intuicjonistyczny/klasyczny oparte jest na konstrukcji oryginalnego RS Gentzena, gdzie logika intuicjonistyczna sformalizowana była za pomocą int-sekwentów, a klasyczna za pomocą sekwentów dopuszczających wiele formuł w następniku. Rozróżnienie to ma jednak charakter umowny, gdyż istnieją wersje RS dla logiki intuicjonistycznej zbudowane z sekwentów typu klasycznego, a z kolei KRZ ma wiele formalizacji RS opartych na int-sekwentach, czy nawet typu one-one (por. rozdział $10)$.

Zauważmy też, że w każdym przypadku, nie wyłączając ostatniego, mówimy o co najwyżej jednej (wielu) formułach co znaczy, że dopuszczamy puste poprzedniki i następniki. Te szczególne przypadki sekwentów mają, jak pokażemy dalej, duże znaczenie.

\subsubsection{Uogólnienia RS}

Co do trzeciego i czwartego kryterium - budowy sekwentu i charakteru elementów - to dotyczy on głównie problemu formalizacji rozmaitych logik nieklasycznych (np. wielowartościowych, modalnych), gdzie pojawiają się sekwenty o innej ilości argumentów lub o bardziej złożonym charakterze. Zatem można rozróżnić sekwenty:

- standardowe (czyli pary argumentów)

- niestandardowe, w tym m.in. sekwenty jako:

- $n$-tki $(\geq 1)$ (zbiorów, multizbiorów,...) obiektów

- hipersekwenty ((multi)zbiory sekwentów)

- sekwenty zagnieżdżone

Zauważmy, że w punkcie sekwenty jako $n$-tki dopuszczamy sytuację $n=$ 1. W następnym podrozdziale opiszemy nieformalnie dwa różne sposoby interpretowania sekwentów, które pozwalają na redukcję poprzednika do następnika lub odwrotnie. Oba są ważne w zastosowaniach RS jako systemów poszukiwania dowodu. W obrębie tej grupy (sekwenty jako $n$-tki) przy $n>2$ 
można zresztą dodatkowo rozróżnić pomiędzy takimi podejściami, w których zachowuje się wprawdzie rozróżnienie między poprzednikiem a następnikiem, ale wprowadza w nich więcej (multi)zbiorów formuł, a takimi, gdzie rozróżnienie to zostaje zarzucone. Pierwsze podejście jest stosowane np. w formalizacji logik modalnych (Blamey i Humberstone [16]) i temporalnych (Nishimura [103]) w celu rozróżnienia modalności formuł lub ich czasowej lokalizacji. Drugie jest charakterystyczne dla formalizacji logik wielowartościowych (Rousseau [121], Carnielli [21]), gdzie $n>2$ odpowiada $n$-wartościom logicznym lub - w bardziej wyrafinowanej wersji - zbiorom tych wartości (Hähnle [57]).

Hipersekwenty są strukturami postaci $\Gamma_{1} \Rightarrow \Delta_{1}|\ldots| \Gamma_{i} \Rightarrow \Delta_{i}$, gdzie każdy składnik to standardowy sekwent. Znalazły one zastosowanie $\mathrm{w}$ formalizacji wielu logik nieklasycznych (por. Avron [8]). Jeszcze inne uogólnienie oferują sekwenty zagnieżdżone, w których elementami poprzednika (następnika) sekwentu głównego mogą, oprócz formuł, być sekwenty, zawierające inne sekwenty itd. Podejście to, zapoczątkowane przez Došena [29], było głównie stosowane w formalizacji logik modalnych i temporalnych (Kashima [80], Poggiolesi [108]).

Jeżeli chodzi o elementy składowe argumentów sekwentów, to najpopularniejsze są różne wersje RS, w których używa się formuł z różnego rodzaju etykietami. Ogólną teorię dowodu dla systemów etykietowanych zawiera Gabbay [46]; przegląd rozmaitych rozwiązań stosowanych na gruncie logik modalnych znaleźć można w Indrzejczak [74]. Łatwo zauważyć, że moc ekspresywna etykiet jest na tyle silna, że nie wymaga użycia innych rodzajów sekwentów niż standardowe dwuargumentowe. Inną ważną propozycją w tej grupie jest tzw. display calculus skonstruowany przez Belnapa [12], w którym argumenty sekwentu są zbudowane ze struktur danych będących kombinacjami formuł i specjalnych strukturalnych stałych. Znalazł on również rozliczne zastosowania $\mathrm{w}$ charakteryzacji logik nieklasycznych (por. np. Wansing [148]).

Podsumowując, w związku z budową sekwentów można systemy RS podzielić na standardowe i uogólnione, które używają reguł zdefiniowanych na sekwentach niestandardowych w sensie ich struktury, lub elementów składowych. Do uogólnionych RS można też zaliczyć takie systemy, które używają łącznie różnych rodzajów sekwentów (formalizacje wielosekwentowe Indrzejczak [70]). W prezentowanej pracy skupimy się na standardowych RS, gdyż są one wystarczajęcym narzędziem do badań nad logiką klasyczną. Obszerne omówienie różnych uogólnionych form RS można znaleźć np. w Wansing [149]. 


\subsection{Reguły sekwentowe}

Podane wyżej kryteria podziału form RS dotyczyły tylko charakteru jednostek, z których budujemy rachunki sekwentowe. Analiza kształtu reguł pozwala dodatkowo na wyróżnienie rozmaitych typów i wariantów rachunków sekwentowych. Najbardziej popularny podział reguł rachunków sekwentowych to podział na reguły logiczne i strukturalne.

Reguły strukturalne dotyczą wyłącznie manipulacji elementami sekwentów, w ich schematach nie występują żadne stałe logiczne. Typowe przykłady takich reguł to:

$$
\begin{aligned}
& (W \Rightarrow) \Gamma \Rightarrow \Delta / \varphi, \Gamma \Rightarrow \Delta \\
& (C u t) \Gamma \Rightarrow \Delta, \varphi ; \varphi, \Gamma \Rightarrow \Delta / \Gamma \Rightarrow \Delta^{2}
\end{aligned}
$$

W pierwszym przypadku mamy we wniosku dołączenie $\varphi$ do poprzednika przesłanki, jej osłabienie (weakening - stąd nazwa). W drugim "wycinamy" z obu przesłanek $\varphi$, która w jednej występuje w następniku, a w drugiej w poprzedniku - stąd nazwa (Cut). Zauważmy, że jeżeli przyjmiemy wspomnianą w paragrafie 2.1.1. wykładnię sekwentu jako wyrażenia prezentującego schemat inferencji, to $(W \Rightarrow)$ reprezentuje monotoniczność, a (Cut) przechodniość relacji konsekwencji. Pełny zestaw takich reguł strukturalnych niezbędny do scharakteryzowania KRZ przedstawimy w następnym rozdziale.

Uwaga 2.2: Podane tu znaczenie terminu "strukturalny" należy odróżnić od tego, który stosowany jest w badaniach nad teorią konsekwencji, czyli domknięcie na regułę podstawiania. Dla odróżnienia tamto znaczenie określamy terminem "inwariantny" (por. uwaga 1.4.).

Reguły logiczne dla odmiany zawierają w schemacie reguły konkretne stałe logiczne określając zazwyczaj warunki wprowadzenia do (poprzednika lub następnika) sekwentu lub eliminacji dla formuł z tą stałą logiczną. Pogłębione badania nad formami takich reguł wiążą się ściśle z badaniami nad teoriami znaczenia stałych logicznych rozwijanymi przez wielu logików jako alternatywa dla teoriomodelowej semantyki. Przykłady takich reguł logicznych podamy niżej; teraz omówimy najważniejsze kryteria podziału systemów RS oparte na analizie występujących tam reguł:

\footnotetext{
${ }^{2}$ Ponieważ, w przeciwieństwie do reguł w H-systemach lub w DN, elementami reguły nie są formuły lecz sekwenty, więc używamy ';' dla odseparowania przesłanek (sekwentów) tam gdzie użycie przecinka mogłoby prowadzić do nieporozumień. W dalszym ciągu reguły RS będziemy częściej prezentowali w formie ułamkowej.
} 
- dopuszczalny kształt reguł logicznych;

- rodzaj reguł logicznych;

- udział reguł strukturalnych (eliminowalne/nieeliminowalne);

- proporcje ilości sekwentów do reguł sekwentowych w rachunku.

\subsubsection{Rodzaje reguł}

Mówiąc o dopuszczalnym kształcie reguł logicznych mamy na myśli to czy system dopuszcza tylko reguły wprowadzania czy również eliminacji stałych logicznych, oraz czy operacje te mają miejsce w poprzedniku czy w następniku sekwentu.

Dla przykładu podamy pewne możliwe abstrakcyjne schematy wprowadzania dowolnej stałej logicznej - oznaczmy ją symbolem *. Dla uproszczenia rozważań ograniczamy się tylko do reguł z jednym wystąpieniem stałej $* \mathrm{w}$ sekwencie standardowym (tj. parze), gdzie symbol $\Rightarrow$ oddziela poprzednik od następnika, pomijamy też kontekst (tj. struktury danych występujące w sekwentach oznaczane przez $\Gamma, \Delta$ ).

1. przypadek $n=0$ (brak przesłanek, tylko sekwenty-wnioski czyli aksjomatyczne)

(a) $\Rightarrow *$ (wprowadzanie) lub (b) $* \Rightarrow$ (eliminacja)

2. przypadek $n>0$ (reguły sekwentowe z $n$ przesłankami)

(c) $\Rightarrow, \ldots, \Rightarrow / \Rightarrow *$ (wprowadzanie do następnika)

(d) $\Rightarrow, \ldots, \Rightarrow / * \Rightarrow$ (wprowadzanie do poprzednika)

(e) $\Rightarrow * / \Rightarrow$ (eliminacja z następnika)

(f) $* \Rightarrow / \Rightarrow$ (eliminacja z poprzednika)

Oczywiście możliwe są też reguły gdzie * występuje kilka razy i nie tylko we wniosku, gdzie obecne są dodatkowo inne stałe itd. Rozważymy takie możliwości w dalszych rozdziałach, ale na razie przyjmujemy, że podane wyżej typy schematów reguł to podstawowe instrumentarium. Intuicyjnie, w przypadku sekwentów: (a) podaje z czego można formułę z $*$ wyprowadzić, a (b) co można z niej wydedukować. Podobnie w przypadku reguł: (c) podaje kiedy formuła $\mathrm{z} *$ jest dedukowalna, a (d) podaje warunki, przy których $\mathrm{z}$ niej jest coś dedukowalne. Sens (e) jest podobny do (b) i (d), choć (b) i (e) bardziej bezpośrednio przedstawiają eliminację *. 
Zilustrujmy podane wyżej schematy dopuszczalnych kształtów reguł logicznych na przykładzie koniunkcji:

1. przypadek $n=0$ (sekwenty)

(a) $\varphi, \psi \Rightarrow \varphi \wedge \psi$ (wprowadzanie)

(b) $\varphi \wedge \psi \Rightarrow \varphi$ lub $\varphi \wedge \psi \Rightarrow(\psi)$ (eliminacja)

2. przypadek $n>0$ (reguły sekwentowe)

(c) $\Rightarrow \varphi, \Rightarrow \psi / \Rightarrow \varphi \wedge \psi($ wprowadzanie do następnika)

(d) $\varphi, \psi \Rightarrow / \varphi \wedge \psi \Rightarrow$ (wprowadzanie do poprzednika)

(e) $\Rightarrow \varphi \wedge \psi / \Rightarrow \varphi$ lub $\Rightarrow \varphi \wedge \psi / \Rightarrow \psi$ (eliminacja z następnika)

(f) $\varphi \wedge \psi \Rightarrow / \varphi, \psi \Rightarrow$ (eliminacja z poprzednika)

Zauważmy, że (c) i (e) oraz (d) i (f) to wzajemne konwersy, ale możliwe są też inne warianty. Ponadto, dołączając konteksty możemy otrzymać rozmaite uszczegółowienia, np.

$\left(\mathrm{a}^{\prime}\right) \Gamma, \varphi, \psi \Rightarrow \varphi \wedge \psi$ (sekwent many-one, int-sekwent)

$\left(\mathrm{a}^{\prime \prime}\right) \Gamma, \varphi, \psi \Rightarrow \varphi \wedge \psi, \Delta$ (sekwent many-many, klasyczny)

Oczywiście, w zależności od wybranej alternatywy (por. paragraf 2.1.2), $\Gamma, \Delta$ mogą oznaczać zbiory, multizbiory lub ciągi.

Dodatkowo, jeżeli weźmiemy pod uwagę kolejne kryterium, czyli podział według rodzaju reguł logicznych, otrzymamy jeszcze inne warianty reguł. Jedno z najważniejszych rozróżnień dotyczy tego, czy w przesłankach, jeżeli jest ich więcej niż jedna, mamy takie same konteksty czy różne. W pierwszym przypadku mówimy o regułach k-jednolitych (kontekstowo-jednolitych, context-sharing), w drugim o k-niezależnych (context-free, context-independent). Ponownie zilustrujmy to na przykładzie koniunkcji.

Reguła (c) w wersji k-niezależnej na sekwentach klasycznych (manymany) wygląda następująco:

$\left(\mathrm{c}^{\prime}\right) \Gamma \Rightarrow \varphi, \Delta ; \Pi \Rightarrow \psi, \Sigma / \Gamma, \Pi \Rightarrow \varphi \wedge \psi, \Delta, \Sigma$

a w wersji k-jednolitej:

$\left(c^{\prime \prime}\right) \Gamma \Rightarrow \varphi, \Delta ; \Gamma \Rightarrow \psi, \Delta / \Gamma \Rightarrow \varphi \wedge \psi, \Delta$

Przy interpretacji sekwentów jako par zbiorów formuł lub przy pewnym standardowym zestawie reguł strukturalnych dodanych w przypadku m- lub c-systemów, łatwo wykazać, że obie reguły są równoważne w tym sensie, że mając jedną jako pierwotną wydedukujemy druga (por. rozdział 4). Oczywi- 
ście z praktycznego punktu widzenia nie jest wszystko jedno, której wersji użyjemy; jak pokażemy niżej, reguły k-niezależne są lepsze dla celów teoretycznych, a k-jednolite dla praktycznych (szukanie dowodu). Tym niemniej można przyjąć, że na gruncie logiki klasycznej reguły te definiują tę samą stałą logiczną - w tym przypadku klasyczną koniunkcję.

Uwaga 2.3: Wprawdzie w tej pracy ograniczamy się tylko do zastosowań RS do logiki klasycznej, warto jednak w tym miejscu skomentować ostatnie zdanie o "równoważności" obu reguł. Otóż należy zaznaczyć, że przyjęcie Gentzenowskiego c-systemu otwiera szersze perspektywy (faktycznie dla większości zastosowań m-systemy są wystarczające). Jeżeli zrezygnujemy z niektórych reguł strukturalnych przy jednoczesnym zatrzymaniu takich samych reguł logicznych, to możemy otrzymać formalizacje wielu interesujących nieklasycznych logik, słabszych od logiki klasycznej, zwanych od lat 90-tych logikami podstrukturalnymi (zob. Došen i Schroeder-Heister [31], Paoli [106]). Termin "podstrukturalne" nawiązywał do faktu budowania takich logik nie przez modyfikacje reguł logicznych, lecz przez osłabianie bazy strukturalnej. Faktycznie wiele logik podstrukturalnych znanych było znacznie wcześniej, a badania nad ich formalizacjami RS jedynie ujawniły ich teoriodowodowe pokrewieństwo. Jako przykład logik tego typu można wskazać pewne logiki relewantne i wielowartościowe.

W szczególności, okazuje się, że reguły k-jednolite i k-niezależne nie są równoważne (wzajemnie wyprowadzalne) w logikach podstrukturalnych, zatem można ich użyć do zdefiniowania różnych stałych logicznych. Jak się okazało $\left(c^{\prime}\right)$ definiuje koniunkcję w wersji multiplikatywnej a $\left(c^{\prime \prime}\right)$ w wersji addytywnej ${ }^{3}$. Oczywiście użycie reguł typu (c) nie daje pełnej charakterystyki danej stałej; trzeba dodać odpowiednie reguły np. typu (d). W przypadku schematu (d) wersja multiplikatywna wymaga jedynie dodania kontekstu:

$\left(\mathrm{d}^{\prime}\right) \Gamma, \varphi, \psi \Rightarrow \Delta, / \Gamma, \varphi \wedge \psi \Rightarrow \Delta$

podczas gdy dla formalizacji addytywnej koniunkcji musimy użyć pary reguł:

$\left(\mathrm{d}^{\prime \prime} 1\right) \Gamma, \varphi \Rightarrow \Delta, / \Gamma, \varphi \wedge \psi \Rightarrow \Delta \mathrm{i}$

$\left(\mathrm{d}^{\prime \prime} 2\right) \Gamma, \psi \Rightarrow \Delta, / \Gamma, \varphi \wedge \psi \Rightarrow \Delta$

Podsumowując nasze rozważania nad dopuszczalnymi kształtami i rodzajami reguł przyjmujemy, że RS oparty na regułach typu (c) i (d) to standar-

${ }^{3}$ Terminologia pochodzi od Girarda [53] i oparta jest na pewnej semantyce podstrukturalnej logiki linearnej, rozwiniętej przez niego w latach 70-tych. Na gruncie logik relewantnych określano takie stałe odpowiednio jako intensjonalne/ekstensjonalne; inne terminy to internal/combining. 
dowy system RS typu Gentzenowskiego, który będzie głównym przedmiotem naszych rozważań. Możliwe są też jednak inne rodzaje systemów RS, w szczególności, RS oparty na regułach typu (c) i (e) to sekwentowy system dedukcji naturalnej. Pozostałe rodzaje systemów RS dopuszczają jeszcze inne kombinacje, a nawet wykorzystują wszelkie typy reguł podpadające pod schematy (a) - (f) (np. system Hermesa [64]). Systemy takie omówimy w rozdziale 10. Warto jednak podkreślić, że w przypadku standardowych RS problem analizy rodzajów reguł wcale się nie kończy. Istotne są pewne własności reguł, które w grupie reguł typu (c) i (d) pozwalają odróżnić "dobre" reguły od "niedobrych". Własności te mają wpływ zarówno na techniczny problem dowodzenie pewnych cech danego systemu RS, jak i na filozoficzne kwestie związane z problemem teoriodowodowego charakteryzowania stałych logicznych. Wybrane własności reguł omówimy w podrozdziale 4.5.

\subsubsection{Warianty i typy RS}

Kryterium udziału reguł strukturalnych jest również przydatne w dzieleniu systemów RS. Rozważania dotyczące logik podstrukturalnych (uwaga 2.3) pokazują jak ważną funkcję pełnią reguły strukturalne w budowie RS dla rozmaitych logik. Z drugiej strony, z punktu widzenia praktycznych zastosowań, gdzie RS wykorzystuje się jako narzędzie szukania dowodu (lub falsyfikowania) sekwentu, warianty bez reguł strukturalnych są wygodniejsze. W związku z tym warto ich udział minimalizować nawet w przypadku logiki klasycznej. Zauważmy, że istnieje zależność między alternatywami RS a udziałem reguł strukturalnych; z-system z natury rzeczy minimalizuje udział reguł strukturalnych. Omówimy te kwestie dokładniej w rozdziale 4.

Ze względu na stopień udziału reguł strukturalnych, przynajmniej w obrębie standardowego RS, rozróżnimy 3 najważniejsze warianty:

- ogólny, w którym występują zarówno reguły strukturalne jak i logiczne;

- logiczny, w którym reguły strukturalne są wyeliminowane na rzecz logicznych;

- strukturalny, w którym zmniejszony jest udział reguł logicznych na rzecz strukturalnych.

Ponadto można wyróżnić wiele podwariantów, w zależności od doboru konkretnych reguł. W rozdziale 4 zaprezentujemy te warianty standardowego RS, które będą dla nas szczególnie ważne. 
Wreszcie podział według proporcji sekwenty/reguły sekwentowe pozwala wyróżnić następujące typy RS:

- przewaga reguł; w szczególności typ jeden sekwent aksjomatyczny/wiele reguł (RS w stylu Gentzena);

- przewaga sekwentów; w szczególności typ z regułami tylko strukturalnymi (RS w stylu Hertza [65]);

- typ mieszany

Dodatkowo, w typie pierwszym charakterystyka stałych logicznych zawarta jest w regułach, natomiast sekwenty aksjomatyczne mają charakter strukturalny. W typie drugim odwrotnie, reguły majac charakter strukturalny natomiast stałe są scharakteryzowane w sekwentach aksjomatycznych. W obrębie typu mieszanego stałe są charakteryzowane zarówno przez sekwenty jak i reguły. W ramach typu pierwszego wyróżniliśmy już wyżej standardowe RS (Gentzen [50]) oparte na regułach typu (c) i (d) oraz sekwentowe DN (Gentzen [51]) oparte na regułach typu (c) i (e) ale możliwe są też inne systemy.

Podsumowując powyższe rozważania o różnych formach systemów RS przypominamy, że rozróżniliśmy:

1. alternatywy RS - wg. rodzaju argumentów sekwentów (paragraf 2.1.2);

2. warianty RS - wg. udziału reguł strukturalnych (2.2.2);

3. typy RS - wg. stosunku sekwentów do reguł sekwentowych (2.2.2);

4. uogólnione RS - budowane na niestandardowych sekwentach (hipersekwenty itp.) (2.1.3).

Tymi ostatnimi nie będziemy się dalej zajmować gdyż znajdują zastosowanie w formalizacji logik nieklasycznych, które nie są przedmiotem niniejszej pracy. Zdecydowana większość pracy poświęcona jest teorii i zastosowaniom rozmaitych wariantów i alternatyw standardowego RS Gentzena, który stanowi odmianę typu pierwszego. W rozdziale 10 omówimy pokrótce przykłady systemów RS reprezentujących pozostałe dwa typy. 


\subsection{Interpretacje sekwentów}

Aby lepiej zrozumieć uniwersalność RS, i jego związki z innymi systemami dedukcyjnymi, podamy niżej kilka stosowanych powszechnie sposobów interpretowania sekwentów i zdefiniowanych na nich reguł. Propozycje te znajdą rozwinięcie i uzasadnienie w kolejnych rozdziałach.

Wspomnieliśmy w paragrafie 2.1.1., że wielu autorów do zapisu sekwentów używa notacji $\Gamma \vdash \Delta$. Sugeruje to, a nawet przesądza, popularną interpretację sekwentów jako obiektów wyrażających pewną relację konsekwencji zachodząca między $\Gamma$ a $\Delta$. Tym niemniej, taki inferencyjny sposób rozumienia sekwentów nie jest jedynym możliwym. W szczególności, Gentzen traktował sekwenty nie jako metajęzykowy sposób wyrażania twierdzeń o dedukowalności, ale jako elementarne obiekty swojego systemu LK wyrażone w języku przedmiotowym. Sam zaś system był pomyślany tylko jako techniczne narzędzie do wyrażenia ważnych własności dowodów w systemie dedukcji naturalnej, która stanowiła właściwy przedmiot studiów w Gentzen [50]. Można wyróżnić następujące sposoby interpretacji sekwentów:

1. Oryginalna interpretacja sekwentu jako implikacji użyta przez Gentzena dla wykazania równoważności z systemem aksjomatycznym.

2. Interpretacja sekwentu jako koniunkcji z pustym następnikiem; reguły czytane odwrotnie (w terminach falsyfikowalności); drzewo dowodowe staje się formalnym zapisem sprawdzania niewprost.

3. Interpretacja sekwentu jako alternatywy z pustym poprzednikiem; reguły czytane odwrotnie (w terminach weryfikowalności); drzewo dowodowe staje się formalnym zapisem procedury Posta.

4. Interpretacja $\Rightarrow$ jako symbolu relacji inferencji $\vdash$.

Interpretacja 1 zostanie przez nas dokładnie omówiona w następnym rozdziale, natomiast 2 i 3 poddamy analizie w rozdziale 10 . Zauważmy jedynie, że interpretacja 3 możliwa jest dzięki odwracalności wszystkich reguł w RS dla KRZ - własność tę omówimy dokładniej w podrozdziale 4.2. Dla odmiany, w interpretacji 2 odwracalność reguł nie jest konieczna - ma to wpływ na uogólnienia RS dla logik nieklasycznych, gdyż w wielu wypadkach reguły w tych systemach nie są odwracalne.

Obecnie skupimy się na interpretacji 4, która - jak wyżej wspomnieliśmy - jest dziś jedną z najbardziej rozpowszechnionych. Zauważmy, że można ją uszczegółowić na różne sposoby. Sam Gentzen w [50] zauważał, że sekwenty, 
zwłaszcza int-sekwenty można rozumieć jako sposób wyrażenia reguł inferencji DN. W naturalny sposób pozwala to w sekwentowej formie przedstawić reguły DN z podrozdziału 1.6. Otrzymany system za pomoca sekwentów (aksjomatycznych) typu (a) i (b) (por. paragraf 2.2.1) wyraża reguły inferencji eliminacji i dołaczania, a za pomocą reguł sekwentowych - reguły konstrukcji dowodu. W tych ostatnich $\Rightarrow$ odpowiada $\vdash$, a ukośnik oddziela stopnie dowodu, tzn. sekwent-wniosek odpowiada dowodowi nadrzędnemu, a sekwenty-przesłanki poddowodom. W terminologii z poprzedniego podrozdziału zaliczymy taki system do typu mieszanego, a dokładniej omówimy w podrozdziale 10.3 .

Nie jest to jedyny możliwy sposób wyrażania DN za pomocą sekwentów. Interpretacja $\Rightarrow$ jako $\vdash$, ale nie $\mathrm{w}$ takim sensie, że sekwent wyraża schemat inferencji, ale raczej zależność dedukcyjną formuły (następnik) od założeń (poprzednik), prowadzi do skonstruowania sekwentowego systemu DN na bazie RS, który zaprezentował Gentzen w [51], ale który implicite obecny był już w dowodzie równoważności dla RS, DN i systemu aksjomatycznego w [50]. Tym razem wszystkie reguły DN są wyrażane przez reguły sekwentowe typu (c) i (e), czyli wprowadzania i eliminacji w następniku. Dokładnie omówimy taki system i jego pochodne w podrozdziale 10.1.

Interpretacja $\Rightarrow$ jako symbolu relacji inferencji nie musi być zresztą związana z konkretnym systemem dedukcyjnym. Potraktowana w sposób abstrakcyjny prowadzi do ujęcia RS jako formalizacji teorii konsekwencji. Interpretacja taka pochodzi od Curry'ego [26], a rozwinięta została przez Scotta [125] i pod różnymi nazwami badana m.in. przez Shoesmitha i Smileya [127] (multiple conclusion relations), Zygmunta [153] i Czelakowskiego [28] (entailment relations), Avrona [9] (Scott relations), Dunna i Hardegree [36] (symmetric relations). W pewnym sensie takie podejście jest bardzo naturalnym sposobem rozumienia sekwentów, choć wątpliwości budzić może sposób rozumienia kolekcji formuł w następniku. W relacjach konsekwencji Tarskiego (inferencyjnych - por. rozdział 1) w następniku mamy tylko jedną formułę; w konsekwencjach Scotta - wiele. Czy wyrażenie $\Gamma \vdash \Delta$ rozumieć tak, że z $\Gamma$ dedukowalne są wszystkie elementy $\Delta$, czy co najmniej jeden. Jedno rozumienie można nazwać koniunkcyjnym, drugie alternatywnym. Reguły rachunku Gentzena w naturalny sposób prowadziły do tej drugiej intepretacji.

W przypadku interpretowania sekwentów jako wyrażeń ustalających zachodzenie relacji konsekwencji między poprzednikiem a następnikiem pojawia się następna, oprócz wielości formuł w następniku, różnica w stosunku do relacji konsekwencji Tarskiego. W tej ostatniej operujemy zbiorami formuł, podczas gdy w podejściu Gentzenowskim możemy zamiast zbiorów użyć multizbiorów, a nawet ciągów formuł. Jak pokażemy w następnym podrozdziale, 
nawet w przypadku operowania sekwentami zbudowanymi ze zbiorów formuł można, stosując interpretację inferencyjną sekwentów, uzyskać narzędzie formalizacji logik potencjalnie silniejsze niż operacja konsekwencji Tarskiego. Odpowiada za to tylko sam fakt dopuszczenia wielu formuł w następniku, ale rozumianych alternatywnie, a nie koniunkcyjnie. Jak wspomnieliśmy w uwadze 2.3 zastąpienie zbiorów multizbiorami lub ciągami pozwala uzyskać jeszcze bardziej ogólne narzędzie dzięki możliwości osłabiania zestawu reguł strukturalnych, które w podejściu Tarskiego są nieusuwalne.

Należy jednak pamiętać, że RS jako taki nie jest systemem metalogicznym w takim sensie, w jakim jest nim teoria operacji konsekwencji Tarskiego. W ramach RS nie zdefiniujemy pojęć takich jak teoria, niesprzeczność, pełność itp., i nie dowiedziemy twierdzeń o nich, tak jak robi się to w ramach teorii Tarskiego. Tym niemniej konstrukcja reguł i struktura RS powoduje, że nawet w klasycznych pracach, w których korzysta się generalnie z Hilbertowskiej charakteryzacji logiki, dla przejrzystego i precyzyjnego przedstawienia wyników teoriodowodowych wprowadza się specjalnie formalizm sekwentowy (por. np. Kleene [83], Lyndon [95]). Naturalnym kolejnym krokiem było przejście do badań nad operacjami czy też relacjami konsekwencji generowanymi przez RS. Ze względu na zasygnalizowaną wyżej jedną z różnic (tzn. jedna czy wiele formuł w następniku) zachodzi pytanie czy jest to taka sama konsekwencja, tzn. czy konsekwencje w sensie Tarskiego i Scotta są tym samym. Problem ten zasadniczo wykracza poza zakres materiału poruszanego w książce. Dla zainteresowanych podajemy najważniejsze informacje $\mathrm{w}$ następnym podrozdziale; jego lektura nie jest niezbędna do zrozumienia następnych rozdziałów.

\subsection{RS a relacje konsekwencji}

Analizując kwestię czy aparat Gentzena daje potencjalnie mocniejszą teorię konsekwencji od teorii Tarskiego musimy pamiętać, że mamy do rozważenia co najmniej 3 możliwe sposoby generowania relacji konsekwencji przez RS:

1. Konsekwencja w sensie Scotta, czyli generowana przez $\Rightarrow$ w sekwentach złożonych ze zbiorów.

2. Konsekwencja w sensie Avrona, czyli generowana przez $\Rightarrow w$ sekwentach złożonych z multizbiorów i z osłabionym zestawem warunków strukturalnych.

3. Konsekwencja w sensie Jansany, czyli generowana przez sekwenty, $\vdash \subseteq$ $\mathcal{P}(S e k) \times S e k$ gdzie $S e k$ to zbiór wszystkich sekwentów. 
Można oczywiście rozważać jeszcze inne możliwości, np. w punkcie 2 z multizbiorów przejść na ciągi, a w $3 \mathrm{w}$ następniku $\vdash$ też przyjąć zbiory sekwentów, a nie sekwenty. Co więcej, raz uogólniwszy pojęcie konsekwencji z formuł na sekwenty można rozbudowywać tę hierarchię dalej i rozważać konsekwencje, które zachodzą między zbiorami reguł sekwentowych itd. (por. Zucker, Tragesser [154]).

Porównując konsekwencje w sensie Scotta z operacjami konsekwencji w sensie Tarskiego przypomijmy, że operacja konsekwencji w sensie Tarskiego $C n: \mathcal{P}(F O R) \longrightarrow \mathcal{P}(F O R)$ ma następujące podstawowe własności strukturalne:

- $(\mathrm{ZWR}) \Gamma \subseteq C n(\Gamma)$

- $(\mathrm{MON})$ Jeżeli $\Gamma \subseteq \Delta$, to $C n(\Gamma) \subseteq C n(\Delta)$

- $(\mathrm{TR}) C n(C n(\Gamma)) \subseteq C n(\Gamma)$

Które można w ujęciu relacyjnym wyrazić następująco (poprzez $\Gamma \mid \varphi$ := $\varphi \in C n(\Gamma))$ :

- $(\mathrm{ZWR}) \varphi \models \varphi$

- $(\mathrm{MON})$ Jeżeli $\Gamma \models \varphi$, to $\Gamma, \psi \models \varphi$

- (TR) Jeżeli $\Gamma \models \varphi$ oraz $\varphi, \Gamma \models \psi$, to $\Gamma \models \psi$

Konkretnym przykładem takiej relacji zdefiniowanym syntaktycznie była relacja dowiedlności $\mathrm{w}$ systemie aksjomatycznym podana $\mathrm{w}$ paragrafie 1.2.2. Dodatkowo konsekwencja jest finitarna wtw dla dowolnego $\varphi$ i $\Gamma$, jeżeli $\varphi \in C n(\Gamma)$, to można znaleźć skończony zbiór $\Delta \subseteq \Gamma$, którego $\varphi$ jest konsekwencją.

Charakterystyka klasycznych stałych logicznych w teorii operacji konsekwencji wygląda następująco:

- $(\neg) \varphi \in C n(\Gamma)$ wtw $C n(\Gamma \cup\{\neg \varphi\})=F O R$

- $(\wedge) C n(\{\varphi, \psi\})=C n(\{\varphi \wedge \psi\})$

- ( $\vee C n(\{\varphi\}) \cap C n(\{\psi\})=C n(\{\varphi \vee \psi\})$

- $(\rightarrow) \psi \in C n(\Gamma \cup\{\varphi\})$ wtw $\varphi \rightarrow \psi \in C n(\Gamma)$

lub (w ujęciu relacyjnym): 
- (ᄀ) $\Gamma \models \varphi$ wtw $\Gamma, \neg \varphi \models$

- $(\wedge) \varphi, \psi \models \gamma$ wtw $\varphi \wedge \psi \models \gamma$

- ( $\vee$ ) $\Gamma, \varphi \models \gamma$ i $\Gamma, \psi \models \gamma$ wtw $\Gamma, \varphi \vee \psi \models \gamma$

- $(\rightarrow) \Gamma, \varphi \models \psi$ wtw $\Gamma \models \varphi \rightarrow \psi$

Dowolna relacja konsekwencji Scotta $=\subseteq \mathcal{P}(F O R) \times \mathcal{P}(F O R)$ jest charakteryzowana następująco:

- $(\mathrm{ZWR}) \varphi \models \varphi$

- $(\mathrm{MON})$ Jeżeli $\Gamma \subseteq \Gamma^{\prime}$ i $\Delta \subseteq \Delta^{\prime}$ oraz $\Gamma \models \Delta$, to $\Gamma^{\prime} \models \Delta^{\prime}$

- (TR) Jeżeli $\Gamma \models \Delta, \varphi$ i $\varphi, \Gamma \models \Delta$, to $\Gamma \models \Delta$

Charakterystykę stałych logicznych można ująć za pomocą następujących warunków:

- $(\neg) \mid=\varphi, \neg \varphi$, oraz $\varphi, \neg \varphi \mid=$

- $(\wedge) \Gamma, \varphi, \psi \mid=\Delta$ wtw $\Gamma, \varphi \wedge \psi \models \Delta$

- $(\vee) \Gamma \models \Delta, \varphi, \psi$ wtw $\Gamma \models \Delta, \varphi \vee \psi$

- $(\rightarrow) \Gamma, \varphi \mid=\Delta, \psi$ wtw $\Gamma \models \Delta, \varphi \rightarrow \psi$

Oczywiście spójniki te można zdefiniować za pomocą innych równoważności:

- $\left(\wedge^{\prime}\right) \Gamma \models \Delta, \varphi$ i $\Gamma \models \Delta, \psi$ wtw $\Gamma \models \Delta, \varphi \wedge \psi$

- $\left(\vee^{\prime}\right) \varphi, \Gamma \models \Delta$ i $\psi, \Gamma \models \Delta$ wtw $\varphi \vee \psi, \Gamma \models \Delta$

- $\left(\rightarrow^{\prime}\right) \Gamma \models \Delta, \varphi$ i $\psi, \Gamma \models \Delta$ wtw $\varphi \rightarrow \psi, \Gamma \models \Delta$

Obie charakterystyki są równoważne ${ }^{4}$. Dla przykładu wykażemy to dla koniunkcji.

$(\wedge)$ implikuje $\left(\wedge^{\prime}\right)$ :

$\Longrightarrow$ Załóżmy, że $\Gamma \models \Delta, \varphi$ i $\Gamma \models \Delta, \psi$. Z $\varphi \wedge \psi \models \varphi \wedge \psi$, które jest instancją (ZWR) wynika, przez $(\wedge), \varphi, \psi \models \varphi \wedge \psi$. To ostatnie przez dwa użycia (TR) (i (MON)) do założeń daje $\Gamma \models \Delta, \varphi \wedge \psi$.

\footnotetext{
${ }^{4}$ Oczywiście przy założeniu (ZWR), (MON), (TR); por. uwaga 2.3
} 
$\Longleftarrow$ Załóżmy, że $\Gamma \models \Delta, \varphi \wedge \psi$. Ponieważ (ZWR) i (MON) daje $\varphi, \psi, \Gamma \models$ $\Delta, \varphi$, skąd, przez $(\wedge)$, mamy $\varphi \wedge \psi, \Gamma \models \Delta$, $\varphi$, więc przez (TR) otrzymujemy $\Gamma \models \Delta, \varphi$. W analogiczny sposób otrzymujemy $\Gamma \models \Delta, \psi$.

$\left(\wedge^{\prime}\right)$ implikuje $(\wedge)$ :

$\Longrightarrow$ Załóżmy, że $\Gamma, \varphi, \psi \models \Delta . \mathrm{Z} \varphi \wedge \psi \models \varphi \wedge \psi$ otrzymujemy przez $\left(\wedge^{\prime}\right)$ zarówno $\varphi \wedge \psi \models \varphi$ jak i $\varphi \wedge \psi \models \psi$. Dwa zastosowania (TR) i (MON) do założenia prowadzą do $\Gamma, \varphi \wedge \psi \models \Delta$.

$\Longleftarrow \varphi, \psi, \Gamma \models \Delta, \varphi$ i $\varphi, \psi, \Gamma \models \Delta, \psi$, które uzyskujemy przez (ZWR) i $(\mathrm{MON})$ prowadzą, przez $\left(\wedge^{\prime}\right)$ do $\varphi, \psi, \Gamma \models \Delta, \varphi \wedge \psi$. Stąd i z założenia $\Gamma, \varphi \wedge \psi \models \Delta$ przez (TR) otrzymujemy $\Gamma, \varphi, \psi=\Delta$.

Scott analizując stosunek swojej teorii do teorii Tarskiego odnotował, że związek wyznaczony wzorem:

$$
\Gamma \vdash \varphi \text { wtw } \varphi \in C n(\Gamma)
$$

nie musi być wzajemnie jednoznaczny. Wprawdzie każda konsekwencja Scotta jednoznacznie definiuje konsekwencję w sensie Tarskiego, ale konwers w ogólności nie zachodzi, tzn. każda operacja $C n$ wyznacza pewną klasę relacji konsekwencji $\vdash$. Dokładniej rzecz ujmując mamy co następuje:

1. Każda relacja $\vdash \subseteq \mathcal{P}(F O R) \times \mathcal{P}(F O R)$ spełniająca warunki (ZWR), $(\mathrm{MON}),(\mathrm{TR})$ wyznacza operację konsekwencji $C n_{\vdash}(\Gamma)=\{\varphi: \Delta \vdash \varphi\}$, gdzie $\Delta$ to dowolny skończony podzbiór $\Gamma$.

2. Dla danej operacji $C n$ zdefiniujemy dwie relacje:

$$
\begin{aligned}
& \Gamma \vdash_{\text {min }} \Delta \text { wtw } C n(\Gamma) \cap \Delta \neq \varnothing \quad \text { oraz } \\
& \Gamma \vdash_{\text {max }} \Delta \text { wtw } \bigcap_{\varphi \in \Delta} C n\left(\Gamma^{\prime} \cup\{\varphi\}\right) \subseteq C n\left(\Gamma^{\prime}\right) \text {, dla dowolnego } \Gamma^{\prime} \supseteq \Gamma .
\end{aligned}
$$

Obie są relacjami konsekwencji w sensie Scotta a ponadto wyznaczają klase relacji konsekwencji $C$ taką, że dla każdej $\vdash \in C$ :

- $\vdash_{\min } \subseteq \vdash \subseteq \vdash_{\max }$

- $C n=C n_{\vdash}$ wtw $\vdash_{\min } \subseteq \vdash \subseteq \vdash_{\max }$

Wynik ten pokazuje, że aparat teorii relacji Scotta może być bardziej subtelnym narzędziem badawczym. Wprawdzie w przypadku zbiorów skończonych oba podejścia są wzajemnie definiowalne: w bezpośredni sposób, gdy $\mathrm{w}$ języku dysponujemy alternatywą i w trochę bardziej złożony w przypadku 
jej braku ${ }^{5}$. Jednak w przypadku zbiorów nieskończonych sytuacja jest inna. Rozważmy zbiór $H_{\vdash}$ dopuszczalnych waluacji, które spełniają pewną (Tarskiego lub Scotta) $\vdash$ (tzn. $h \in H_{\vdash}$ wtw dla żadnego $\Gamma \vdash \Delta$ nie zachodzi, że $h \Gamma \subseteq\{1\}$ i $h \Delta \subseteq\{0\})$.

Naturalnie, ponieważ każda semantyka generuje relację konsekwencji możemy rozważać relację generowaną przez $H_{\vdash}$, tzn. $\vdash_{H_{\vdash}}$ jak również $H_{\vdash_{H}}$, tzn., zbiór dopuszczalnych waluacji, które spełniają $\vdash_{H}$. łatwo można dowieść, że zachodzą następujące własności Galois:

1. $\vdash_{1} \subseteq \vdash_{2}$ implikuje $H_{\vdash_{2}} \subseteq H_{\vdash_{1}}$

2. $H_{1} \subseteq H_{2}$ implikuje $\vdash_{H_{2}} \subseteq \vdash_{H_{1}}$

3. $H \subseteq H_{\vdash_{H}}$

4. $\vdash \subseteq \vdash_{H_{\vdash}}$

Dowody punktów 1 i 2 można znaleźć np. w Wójcicki [150] dla konsekwencji Tarskiego i łatwo uogólnić na przypadek relacji Scotta. Dowód pominiemy, gdyż bardziej interesujące są przypadki 3 i 4.

Punkt 4 można wzmocnić do równości dzięki abstrakcyjnej wersji twierdzenia Lindenbauma. Wynik ten zachodzi też dla relacji Scotta, ale wymaga innej konstrukcji, nazywanej atlasem Scotta przez Dunna i Hardegree [36]. Ważna różnica między konsekwencją w sensie Tarskiego i Scotta leży w punkcie 3. W przypadku konsekwencji Tarskiego każda relacja determinuje semantykę, ale niekoniecznie jedną. Z drugiej strony, dla konsekwencji Scotta własność 3 może być wzmocniona do równości co znaczy, że każda taka relacja determinuje dokładnie jedną taką semantykę. Zauważmy, że jest to własność dualna do pełności; Dunn i Hardegree [36] nazywają tę własność absolutnością i podkreślają jej ważność, wskazując, że jest ona analogiczna do własności kategoryczności teorii.

Jak wspomnieliśmy w poprzednim podrozdziale, okazuje się, że gdy zbiory zastąpimy multizbiorami, to znacznie wzrośnie ilość logik, które można scharakteryzować. Avron [9] przedstawia następującą klasyfikację relacji konsekwencji:

- Dowolna relacja $\vdash$ na skończonych multizbiorach formuł spełniająca warunki (ZWR) i (TR) (zwrotna i przechodnia) jest prostą relacja konsekwencji.

${ }^{5}$ Szczegóły konstrukcji oraz dowód podanego wyżej rezultatu można znaleźć w Wójcicki [150]. 
- Prosta relacja konsekwencji spełniająca warunek (C) (kontrakcji) i jego konwers (czyli zdefinowana na zbiorach) jest regularną relacją konsekwencji.

- Regularna relacja konsekwencji spełniająca warunek (MON) (monotoniczności) jest relacją konsekwencji w sensie Scotta.

- Regularna relacja konsekwencji spełniająca warunek (MON) (monotoniczności) typu many-one jest relacją konsekwencji w sensie Tarskiego.

W przypadku prostych relacji konsekwencji, nawet tych, które dodatkowo spełniają warunek (MON) uzyskujemy możliwość generowania wielu logik, których nie zdefiniujemy nawet na gruncie teorii konsekwencji Scotta. Wspominaliśmy już wcześniej (uwaga 2.3) o przypadku logik podstrukturalnych dokonując rozróżnienia między spójnikami addytywnymi i multiplikatywnymi. Użyte przez nas wyżej warunki $(\wedge),(\vee),(\rightarrow)$ definiowały spójniki multiplikatywne, natomiast warunki $\left(\wedge^{\prime}\right),\left(\vee^{\prime}\right),\left(\rightarrow^{\prime}\right)$ definiowały spójniki addytywne. Jeżeli oba zestawy warunków porównamy z podanymi w paragrafie 2.2.1 regułami dla koniunkcji, to łatwo zauważymy, że $\left(\mathrm{d}^{\prime}\right)$ otrzymujemy bezpośrednio z warunku $(\wedge)$, a $\left(c^{\prime \prime}\right) \mathrm{z}\left(\wedge^{\prime}\right)$. Wyprowadzenie reguły $\left(\mathrm{c}^{\prime}\right) \mathrm{z}(\wedge)$ oraz reguł $\left(d^{\prime \prime} 1\right)$ i $\left(d^{\prime \prime} 2\right)$ z $\left(\wedge^{\prime}\right)$ wymaga trochę więcej wysiłku - zachęcamy do jego podjęcia, ewentualnie do skorzystania z lematu 4.13.

Na koniec wspomnijmy, że można też rozważać konsekwencje generowane nie przez sekwenty, ale przez reguły sekwentowe. $\mathrm{W}$ tym przypadku $\vdash$ nie odpowiada $\Rightarrow$, ale linii oddzielającej przesłanki od konkluzji w regułach, czyli $\vdash \subseteq \mathcal{P}(S e k) \times S e k$. Takie podejście było rozwinięte przez hiszpańskich logików skupionych wokół ośrodka w Barcelonie (Font, Jansana). Ściśle rzecz biorąc ograniczyli oni swoje rozważania do konsekwencji definiowanych na sekwentach typu intuicjonistycznego, ale podejście to można uogólnić na inne rodzaje sekwentów. Wprowadzenie do tak rozumianych relacji konsekwencji zawiera Font [44]. 


\section{Rozdział 3}

\section{LK Gentzena dla KRZ}

W tym rozdziale zaprezentujemy zdaniową część oryginalnego systemu Gentzena LK. Sposób prezentacji i wprowadzona terminologia odbiega jednak od oryginalnego ujęcia Gentzena, a zgodna jest ze sposobami prezentacji we współczesnych opracowaniach. Wprowadzona poniżej terminologia będzie miała charakter uniwersalny w tym sensie, że zdefiniowane pojęcia stosują się nie tylko do LK ale również do innych wersji RS wprowadzonych w kolejnych rozdziałach. Ograniczymy się zasadniczo do prezentacji czysto syntaktycznych aspektów RS. Omówimy reguły LK, konstrukcję dowodów i pewne własności dowolnego RS (3.1) oraz wykażemy adekwatność LK przez dowód równoważności z H-systemem z rozdziału 1 (3.2). W ostatnim podrozdziale wyjdziemy poza syntaktyczne aspekty - poszerzymy semantykę KRZ na sekwenty i udowodnimy semantyczne przystosowanie LK.

\subsection{Rachunek sekwentów LK Gentzena}

Definicja 3.1 (Sekwent LK) Sekwent to para uporzadkowana skończonych ciagów (list) formut rozdzielonych symbolem $\Rightarrow$. Dowolny sekwent jest więc obiektem o postaci $\varphi_{1}, \ldots, \varphi_{k} \Rightarrow \psi_{1}, \ldots, \psi_{n}, z k \geq 0, n \geq 0$, gdzie lewy ciag to poprzednik, a prawy to następnik sekwentu. Sekwenty, które zawieraja tylko zmienne zdaniowe będziemy nazywali sekwentami atomowymi.

Ponieważ dla oznaczenia dowolnych ciągów formuł używać będziemy liter $\Gamma, \Delta, \Theta, \Lambda, \Xi, \Pi, \Sigma$, więc często sekwenty zapisywać będziemy $\Gamma \Rightarrow \Delta, \Pi \Rightarrow \Sigma$ itp. Podając przykłady konkretnych sekwentów nie będziemy używali ostrych nawiasów dla zaznaczania ciągów formuł z poprzednika i następnika. Przykładowo, sekwent z $\Gamma:=\langle p, q \vee r, \neg r\rangle, \Delta:=\langle p \rightarrow \neg q, s \wedge r\rangle$ zapiszemy następująco: $p, q \vee r, \neg r \Rightarrow p \rightarrow \neg q, s \wedge r$. 
Zapis postaci $\Gamma, \Pi \Rightarrow \Delta, \varphi$ oznaczać będzie sekwent, którego poprzednik stanowi konkatenację ciągów $\Gamma$ i $\Pi$, a następnik to konkatenacja ciągu $\Delta$ i jednoelementowego ciagu $\langle\varphi\rangle$.

Uwaga 3.1: Rezygnacja z użycia standardowych teoriomnogościowych oznaczeń sprzyja nie tylko uproszczeniu zapisu ale i jego większej uniwersalności, gdyż w wielu rozważanych dalej wariantach $\Gamma$ i $\Delta$ nie będą oznaczały ciągów formul, ale multizbiory (zbiory z powtórzeniami) lub zwykłe zbiory formuł. W każdym przypadku będziemy stosować tę samą formę zapisu sekwentu zaznaczając jedynie jakiego typu obiektami są składniki sekwentów. I tak, w przypadku gdy sekwenty będą zwykłymi zbiorami zapis postaci $\Gamma, \Pi \Rightarrow \Delta, \varphi$ oznaczać będzie sekwent, którego poprzednik to suma zbiorów $\Gamma$ i $\Pi$, a następnik to suma zbioru $\Delta$ i jednoelementowego zbioru $\{\varphi\}$. Na początek przyjrzymy się jednak oryginalnej postaci rachunku pochodzącej od Gentzena.

Uwaga 3.2: Definicja dopuszcza sytuację, że zarówno poprzednik, jak i następnik sekwentu mogą być ciągami pustymi. Zauważmy, że dopuszczenie pustych ciągów jako składników sekwentu powoduje, że za sekwenty należy uznać nie tylko obiekty o postaci $p, q \vee r, \neg r \Rightarrow$, czy $\Rightarrow p \rightarrow \neg q, s \wedge r$, ale nawet $\Rightarrow$. Sekwent z pustym poprzednikiem i następnikiem pełnił będzie zresztą - jak się przekonamy - ważną funkcję. Będziemy też stosowali zapis $\Gamma \Rightarrow \mathrm{i} \Rightarrow \Delta \mathrm{w}$ przypadku schematów sekwentów z pustym następnikiem lub poprzednikiem.

\subsubsection{Reguły}

Definicja 3.2 (Rachunek sekwentów LK) Rachunek sktada się z jednego schematu sekwentu aksjomatycznego oraz zbioru regut pozwalajacych na dedukcję nowego sekwentu (sekwentu-wniosku) z pary sekwentów lub pojedynczego sekwentu (sekwenty-przestanki).

Lista reguł podanych przez Gentzena, dająca adekwatną formalizację KRZ:

\section{Reguły strukturalne}

$$
\begin{array}{ll}
(A X) \varphi \Rightarrow \varphi & \\
(C u t) \frac{\Gamma \Rightarrow \Delta, \varphi \quad \varphi, \Pi \Rightarrow \Sigma}{\Gamma, \Pi \Rightarrow \Delta, \Sigma} & \\
(W \Rightarrow) \frac{\Gamma \Rightarrow \Delta}{\varphi, \Gamma \Rightarrow \Delta} & (\Rightarrow W) \frac{\Gamma \Rightarrow \Delta}{\Gamma \Rightarrow \Delta, \varphi}
\end{array}
$$




$$
\begin{array}{ll}
(C \Rightarrow) \frac{\varphi, \varphi, \Gamma \Rightarrow \Delta}{\varphi, \Gamma \Rightarrow \Delta} & (\Rightarrow C) \frac{\Gamma \Rightarrow \Delta, \varphi, \varphi}{\Gamma \Rightarrow \Delta, \varphi} \\
(P \Rightarrow) \frac{\Pi, \varphi, \psi, \Gamma \Rightarrow \Delta}{\Pi, \psi, \varphi, \Gamma \Rightarrow \Delta} & (\Rightarrow P) \frac{\Gamma \Rightarrow \Delta, \psi, \varphi, \Pi}{\Gamma \Rightarrow \Delta, \varphi, \psi, \Pi}
\end{array}
$$

\section{Reguły logiczne}

$$
\begin{array}{ll}
(\neg \Rightarrow) \frac{\Gamma \Rightarrow \Delta, \varphi}{\neg \varphi, \Gamma \Rightarrow \Delta} & (\Rightarrow \neg) \frac{\varphi, \Gamma \Rightarrow \Delta}{\Gamma \Rightarrow \Delta, \neg \varphi} \\
(\wedge \Rightarrow) \frac{\varphi, \Gamma \Rightarrow \Delta}{\varphi \wedge \psi, \Gamma \Rightarrow \Delta} & (\wedge \Rightarrow) \frac{\psi, \Gamma \Rightarrow \Delta}{\varphi \wedge \psi, \Gamma \Rightarrow \Delta} \\
(\Rightarrow \wedge) \frac{\Gamma \Rightarrow \Delta, \varphi \quad \Gamma \Rightarrow \Delta, \psi}{\Gamma \Rightarrow \Delta, \varphi \wedge \psi} & (\vee \Rightarrow) \frac{\varphi, \Gamma \Rightarrow \Delta \quad \psi, \Gamma \Rightarrow \Delta}{\varphi \vee \psi, \Gamma \Rightarrow \Delta} \\
(\Rightarrow \vee) \frac{\Gamma \Rightarrow \Delta, \varphi}{\Gamma \Rightarrow \Delta, \varphi \vee \psi} & (\Rightarrow \vee) \frac{\Gamma \Rightarrow \Delta, \psi}{\Gamma \Rightarrow \Delta, \varphi \vee \psi} \\
(\rightarrow \Rightarrow) \frac{\Gamma \Rightarrow \Delta, \varphi \quad \psi, \Pi \Rightarrow \Sigma}{\varphi \rightarrow \psi, \Gamma, \Pi \Rightarrow \Delta, \Sigma} & (\Rightarrow \rightarrow) \frac{\varphi, \Gamma \Rightarrow \Delta, \psi}{\Gamma \Rightarrow \Delta, \varphi \rightarrow \psi}
\end{array}
$$

Reguły strukturalne dotyczą jedynie najogólniejszych operacji dokonywanych na elementach sekwentów, które są niezależne od kształtu formuł. Inaczej można powiedzieć, że reguły strukturalne tworzą teorię $\Rightarrow$. Reguły logiczne podają warunki wprowadzania stałych logicznych, a dokładniej formuły z taką stałą do sekwentu. W pewnym sensie tworzą one teorię rozważanych stałych logicznych (por. uwagi na temat inferencjalizmu w podrozdziale 4.5 i paragrafie 6.1.1).

Dla każdej stałej reguły logiczne pozwalają na jej wprowadzenie zarówno do poprzednika jak i do następnika sekwentu. Nazwy reguł logicznych odzwierciedlają tę ich funkcję. W regułach strukturalnych W oznacza osłabianie (weakening), $\mathrm{C}$ - kontrakcję, a $\mathrm{P}$ - permutację; (Cut) pochodzi stąd, że formuła $\varphi$ występująca w obu przesłankach ulega niejako wycięciu w sekwenciewniosku. Nazwa "osłabianie" może brzmieć dosyć zagadkowo, wyjaśnimy jej sens później. W dalszym ciągu mówiąc po prostu o zastosowaniach reguł strukturalnych bez precyzowania czy chodzi o reguły z następnika czy z poprzednika sekwentu, będziemy używali oznaczeń typu $(W),(C),(P)$ lub określeń "osłabianie", itp.

Przykład 3.1.

$$
\frac{p \wedge q, q \rightarrow r \Rightarrow \neg q, p \rightarrow r \quad p \wedge q, q \rightarrow r \Rightarrow \neg q, \neg s}{p \wedge q, q \rightarrow r \Rightarrow \neg q,(p \rightarrow r) \wedge \neg s}
$$


daje nam ilustrację zastosowania $(\Rightarrow \wedge)$, natomiast

$$
\frac{p \wedge q, q \rightarrow r \Rightarrow \neg q, p \rightarrow r, \neg r \quad p \vee q, q \rightarrow r, q \wedge r \Rightarrow \neg(p \vee r), \neg s}{\neg r \rightarrow p \vee q, p \wedge q, q \rightarrow r, q \rightarrow r, q \wedge r \Rightarrow \neg q, p \rightarrow r, \neg(p \vee r), \neg s}
$$

daje przykład zastosowania $(\rightarrow \Rightarrow)$. Zauważmy, że w przypadku $(\Rightarrow \wedge)$ mamy takie same ciągi $\Gamma:=p \wedge q, q \rightarrow r$ i $\Delta:=\neg q \mathrm{w}$ obu przesłankach i we wniosku. Dla odmiany w przykładzie dla $(\rightarrow \Rightarrow)$ mamy różne ciągi w przesłankach, natomiast we wniosku pojawia się konkatenacja tych ciągów, stąd np. $q \rightarrow r$, które jest ostatnim elementem $\Gamma$ i pierwszym elementem $\Pi$ we wniosku występuje dwukrotnie. Wynika to stąd, że w LK $(\Rightarrow \wedge)$ jest regułą $\mathrm{k}$-jednolitą, a $(\rightarrow \Rightarrow)$ regułą k-niezależną (por. paragraf 2.2.1).

Uwaga 3.3: Godne uwagi, że sekwentową formalizację intuicjonizmu osiągnął Gentzen za pomocą bardzo prostego zabiegu. Rachunek LI dla INT składa się $\mathrm{z}$ tych samych reguł jedynie na sekwenty nałożone jest ograniczenie: w następniku może występować co najwyżej jedna formuła. Z tego powodu, w poprzednim rozdziale sekwenty tego typu nazwaliśmy intuicjonistycznymi (int-sekwentami). Faktycznie ograniczenie tego typu nie jest konieczne dla wszystkich reguł, por. Kleene [83].

Dla precyzyjnej analizy dowodów w RS przydatne jest wyróżnienie pewnych elementów w zastosowaniu reguł.

Definicja 3.3 (Elementy reguł sekwentowych) • Formuła, która powstaje w wyniku zastosowania danej reguły logicznej to formuła zasadnicza tego sekwentu ( $w$ regułach strukturalnych wszystkie wyróżnione $w$ schematach regut formuty $\varphi, \psi$ to formuly zasadnicze $w$ zastosowaniu tych regut).

- Formuła, bądź formuły, które posłużyły do jej uzyskania, to formuły poboczne sekwentów-przesłanek.

- Wszystkie pozostate elementy zbiorów $\Gamma i \Delta$, to formuły parametryczne (krótko parametry) w zastosowaniu danej reguty.

Przykładowo: w podanym przykładzie zastosowania $(\rightarrow \Rightarrow) \neg r$ i $p \vee q$ to formuły poboczne przesłanek, a $\neg r \rightarrow p \vee q$ to formuła zasadnicza wniosku; pozostałe formuły to parametry. 


\subsubsection{Dowody}

Zorganizowane zastosowania reguł RS pozwalają budować dowody sekwentów. Intuicyjnie, dowodem sekwentu $w R S$ jest drzewo binarne, którego każdy liść jest sekwentem aksjomatycznym, korzeń jest dowodzonym sekwentem, a poszczególne węzły są uzyskane w wyniku zastosowania wymienionych wyżej reguł. Precyzyjną definicję sformułujemy następująco:

Definicja 3.4 (Dowód sekwentu) 1. Każde jednoelementowe drzewo, którego węzet jest sekwentem aksjomatycznym $S$ jest dowodem sekwentu $S$.

2. Jeżeli $\mathcal{D}$ jest dowodem sekwentu $S$, to drzewo uzyskane przez dopisanie sekwentu S' poniziej sekwentu $S$ jest dowodem sekwentu $S$ ', pod warunkiem, że $S$ jest podstawieniem przestanki a $S^{\prime}$ jest podstawieniem wniosku jednej z regut jednoprzesłankowych.

3. Jeżeli $\mathcal{D}$ jest dowodem sekwentu $S$ a $\mathcal{D}^{\prime}$ jest dowodem $S$ ', to drzewo uzyskane przez dopisanie sekwentu $S^{\prime \prime}$ poniżej sekwentów $S$ i $S^{\prime}$ jest dowodem sekwentu S", pod warunkiem, że S jest podstawieniem lewej przestanki, S' jest podstawieniem prawej przestanki, a $S$ " jest podstawieniem wniosku jednej z regut dwuprzestankowych.

4. Nic więcej nie jest dowodem sekwentu w RS.

To, że sekwent $\Gamma \Rightarrow \Delta$ ma dowód będziemy zaznaczać pisząc $\vdash \Gamma \Rightarrow \Delta$. W szczególności dowód sekwentu $\Rightarrow \varphi$ (pusty poprzednik, jednoelementowy następnik) oznacza, że formuła $\varphi$ ma dowód, czyli jest tezą.

Podana definicja dowodu jest indukcyjna. Ma to ważne konsekwencje, gdyż do dowodów w LK czy innych wariantach RS można będzie stosować dowody przez indukcje po rozmiarach dowodu. Rozmiary dowodu można rozmaicie definiować, poniżej wprowadzimy trzy najczęściej stosowane miary.

- długość dowodu

- wysokość dowodu (height)

- wielkość dowodu

Jako pierwszą miarę wprowadzimy pojęcie długości dowodu, które definiujemy następująco: 
Definicja 3.5 (długość dowodu) • Dowód aksjomatu ma długość 0

- jeżeli $S$ został wydedukowany z $S^{\prime}$ za pomoca reguły jedno-przesłankowej, to jeżeli dowód $S^{\prime}$ ma długość $n$, to dowód $S$ ma długość $n+1$

- jeżeli $S$ został wydedukowany z S' i $S^{\prime \prime}$ za pomoca reguty dwu-przesłankowej, to jeżeli dowód S' ma dtugość n, a dowód $S " m a$ dtugość $m$, to dowód $S$ ma długość $\max (n, m)+1$

Jeżeli $\mathcal{D}$ oznacza dowód, to długość dowodu oznaczymy przez $|\mathcal{D}|$.

Czasem wygodnie będzie w obliczaniu wielkości abstrachować od zastosowania reguł strukturalnych, za wyjątkiem (Cut). Wprowadzimy osobną miarę - wysokość dowodu (por. Negri, von Plato [101]):

Definicja 3.6 (wysokość dowodu) • Dowód aksjomatu ma wysokość 0

- jeżeli $S$ zostat wydedukowany z $S^{\prime}$ za pomoca logicznej reguty jednoprzesłankowej, to jeżeli dowód $S^{\prime}$ ma wysokość n, to dowód $S$ ma wysokość $n+1$

- jeżeli $S$ zostat wydedukowany z S' i $S^{\prime \prime}$ za pomoca reguty dwu-przestankowej, to jeżeli dowód $S^{\prime}$ ma wysokość n, a dowód $S$ " ma wysokość $m$, to dowód $S$ ma wysokość $\max (n, m)+1$

Jeżeli $\Gamma \Rightarrow \Delta$ ma dowód wysokości $n$, to będziemy to czasami zaznaczać pisząc $\Gamma \Rightarrow_{n} \Delta$ lub $\vdash_{n} \Gamma \Rightarrow \Delta$.

Pokrewną miarą do wysokości jest pojęcie wielkości dowodu (por. Buss [20]), w którym też abstrachujemy od reguł strukturalnych (z wyjątkiem (Cut)) ale pod uwagę bierzemy absolutną ilość wystąpień reguł logicznych w dowodzie (sumujemy wielkości gałęzi w przypadku reguły dwu-przesłankowej zamiast wybierać większą). Formalnie:

Definicja 3.7 (wielkość dowodu) • Dowód aksjomatu ma wielkość 0

- jeżeli $S$ zostat wydedukowany z $S^{\prime}$ za pomoca logicznej reguły jednoprzestankowej, to jeżeli dowód $S^{\prime}$ ma wielkość n, to dowód $S$ ma wielkość $n+1$

- jeżeli $S$ zostat wydedukowany z $S^{\prime}$ i $S^{\prime \prime}$ za pomoca reguty dwu-przestankowej, to jeżeli dowód S' ma wielkość n, a dowód S" ma wielkość m, to dowód $S$ ma wielkość $n+m+1$ 
Jeżeli $\mathcal{D}$ oznacza dowód, to wielkość dowodu oznaczymy przez $\|\mathcal{D}\|$. W rozdziale 5 uwzględnimy jeszcze sposób mierzenia rozmiaru dowodu przez Gentzena w jego oryginalnym dowodzie eliminacji cięcia, nazwany przez nas głębokością.

Zazwyczaj zapisuje się dowody w RS jako drzewa z korzeniem na dole, co oddaje strukturę zależności logicznych (procesu inferencji) od aksjomatów w dół do sekwentu dowodzonego. Konstruując dowód postępuje się zazwyczaj odwrotnie, tzn. zaczyna od sekwentu dowodzonego i dopisuje kolejno przesłanki zastosowanych reguł. Rzecz jasna ze względu na występowanie (Cut), oraz inne własności pewnych reguł Gentzena, takie postępowanie nie musi zakończyć się sukcesem. Do kwestii warunków gwarantujących sukces w poszukiwaniu dowodu, a nawet automatyzację tego procesu, powrócimy w rozdziale 6.

Przykład 3.2: Zaprezentujemy dowód tzw. sylogizmu Fregego, często występującego w roli jednego z aksjomatów KRZ w systemie H z rozdziału 1.

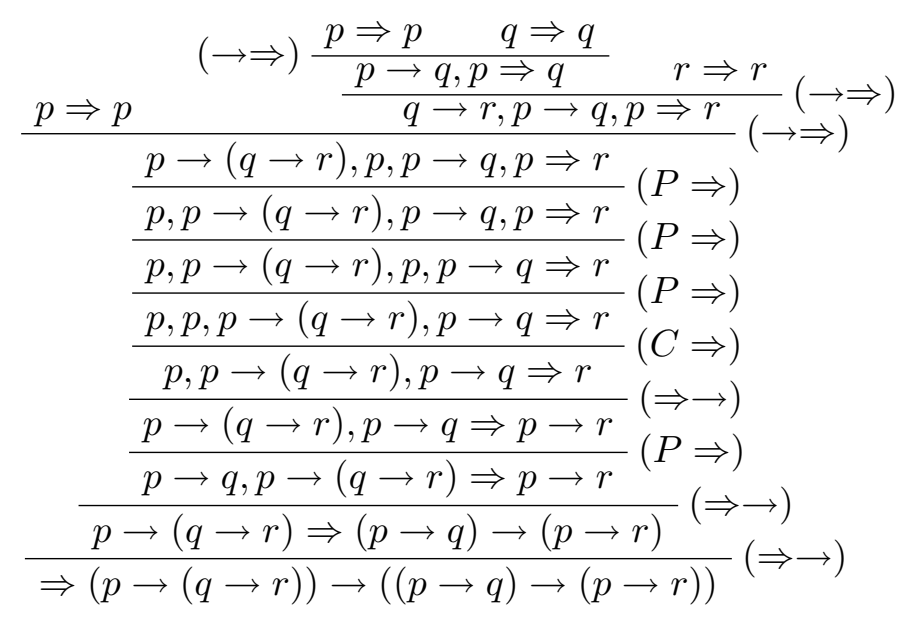

W przedstawionym dowodzie zwraca uwagę duża ilość zastosowań reguł strukturalnych. Jego długość wynosi 11, choć wysokość jedynie 6 (równa wielkości w tym przypadku). W dalszym ciągu zazwyczaj takie "oczywiste" kroki w dowodzie będziemy pomijać zaznaczając miejsce ich występowania za pomocą podwójnej kreski. Powyższy dowód w takiej skondensowanej formie, która oddaje jedynie jego wysokość i wielkość, będzie więc wyglądał następująco: 


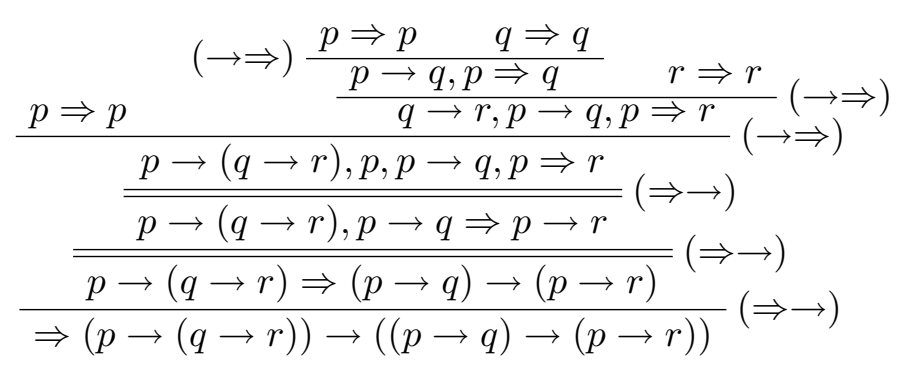

Poniższy lemat pozwala zauważyć pewne zależności między formułami w poprzedniku i następniku dowiedlnego sekwentu i uświadomić sobie pewne intuicje związane $\mathrm{z}$ pojęciem sekwentu. Zarazem podaje formalne podstawy dla trzech interpretacji sekwentu omówionych w poprzednim rozdziale.

Lemat 3.1 Dla dowolnego sekwentu $\varphi_{1}, \ldots, \varphi_{i} \Rightarrow \psi_{1}, \ldots, \psi_{k},(i, k>0)$ podane niżej cztery formy są równoważne:

$$
\begin{aligned}
& \text { 1. } \vdash \varphi_{1}, \ldots, \varphi_{i} \Rightarrow \psi_{1}, \ldots, \psi_{k} \\
& \text { 2. } \vdash \varphi_{1}, \ldots, \varphi_{i}, \neg \psi_{1}, \ldots, \neg \psi_{k} \Rightarrow \\
& \text { 3. } \vdash \Rightarrow \neg \varphi_{1}, \ldots, \neg \varphi_{i}, \psi_{1}, \ldots, \psi_{k} \\
& \text { 4. } \vdash \varphi_{1} \wedge \ldots \wedge \varphi_{i} \Rightarrow \psi_{1} \vee \ldots \vee \psi_{k}
\end{aligned}
$$

DowóD:

1. $\Longrightarrow 2$. Z 1. otrzymujemy $\vdash \neg \psi_{1}, \ldots, \neg \psi_{k}, \varphi_{1}, \ldots, \varphi_{i}, \Rightarrow$ przez $k$ zastosowań $(\neg \Rightarrow)$, skąd przez wielokrotną permutację mamy 2 .

2 . $\Longrightarrow 1$. Po pierwsze zauważmy, że dla każdego $i \leq k$ przez obie reguły dla $\neg$ otrzymujemy $\vdash \neg \neg \psi_{i} \Rightarrow \psi_{i}$. Z 2 . przez wielokrotną permutację mamy $\vdash \neg \psi_{1}, \ldots, \neg \psi_{k}, \varphi_{1}, \ldots, \varphi_{i}, \Rightarrow$, skąd przez $(\Rightarrow \neg)$ otrzymujemy $\vdash \neg \psi_{2}, \ldots, \neg \psi_{k}, \varphi_{1}, \ldots, \varphi_{i}, \Rightarrow \neg \neg \psi_{1}$. Stosując $(C u t)$ na $\vdash \neg \neg \psi_{1} \Rightarrow \psi_{1}$ otrzymujemy $\vdash \neg \psi_{2}, \ldots, \neg \psi_{k}, \varphi_{1}, \ldots, \varphi_{i}, \Rightarrow \psi_{1}$. Powtarzamy tę dedukcję $k-1$ razy aż do otrzymania 1.

1. $\Longleftrightarrow 3$. analogicznie

1. $\Longrightarrow$ 4. Wykonujemy następującą dedukcję:

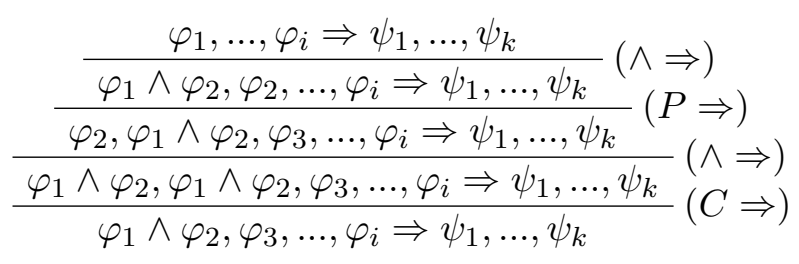


Powtarzamy tę dedukcję tak długo aż otrzymamy $\varphi_{1} \wedge, \ldots, \wedge \varphi_{i} \Rightarrow \psi_{1}, \ldots, \psi_{k}$, następnie przeprowadzamy analogiczną dedukcję z wykorzystaniem $(\Rightarrow \vee),(\Rightarrow$ $P)$ i $(\Rightarrow C)$ na następniku aż otrzymamy 4 .

4. $\Longrightarrow 1$. Odnotujmy wpierw, że dla $k \geq 2$ zachodzi $\vdash \psi_{1} \vee \ldots \vee \psi_{k} \Rightarrow$ $\psi_{1}, \ldots, \psi_{k}$, oto poczatek dowodu:

$$
\left.\begin{array}{l}
(\Rightarrow W) \frac{\psi_{1} \Rightarrow \psi_{1}}{\psi_{1} \Rightarrow \psi_{1}, \psi_{2}} \quad \frac{\psi_{2} \Rightarrow \psi_{2}}{\frac{\psi_{2} \Rightarrow \psi_{1}, \psi_{2}}{2}}(\Rightarrow W),(\Rightarrow P) \\
\quad(\vee \Rightarrow) \frac{\psi_{3} \Rightarrow \psi_{3}}{\overline{\psi_{3} \Rightarrow \psi_{1}, \psi_{2}, \psi_{3}}}
\end{array} \quad(\Rightarrow W),(\Rightarrow P)\right)
$$

Analogicznie, dla $i \geq 2$ udowadniamy, że zachodzi $\vdash \varphi_{1}, \ldots ., \varphi_{i} \Rightarrow \varphi_{1} \wedge$ $\ldots . \wedge \varphi_{i}$. stosując dwa razy $(C u t)$ do 4 . i do otrzymanych sekwentów otrzymujemy 1.

Ograniczenie się do sekwentów z jednoelementowym następnikiem pozwala dodatkowo ujawnić związek $\Rightarrow \mathrm{z}$ implikacją, co oddaje poniższy:

Lemat 3.2 Dla dowolnego sekwentu $\varphi_{1}, \ldots, \varphi_{i} \Rightarrow \psi(i>0)$, podane niżej trzy formy są równoważne:

$$
\begin{aligned}
& \text { 1. } \vdash \varphi_{1}, \ldots, \varphi_{i} \Rightarrow \psi \\
& \text { 2. } \vdash \Rightarrow \varphi_{1} \rightarrow\left(\varphi_{2} \rightarrow \ldots,\left(\varphi_{i} \rightarrow \psi\right) \ldots\right) \\
& \text { 3. } \vdash \Rightarrow \varphi_{1} \wedge \ldots \wedge \varphi_{i} \rightarrow \psi
\end{aligned}
$$

DowóD:

1. $\Longrightarrow 2$. Z 1. za pomocą $(P \Rightarrow)$ otrzymujemy $\vdash \varphi_{i}, \ldots, \varphi_{1} \Rightarrow \psi$, skąd przez $i$-krotne zastosowanie $(\Rightarrow \rightarrow)$ otrzymujemy 2 .

2. $\Longrightarrow 1$. Zauważ, że dla dowolnych $\varphi, \psi$ zachodzi $\vdash \varphi \rightarrow \psi, \varphi \Rightarrow \psi, \mathrm{w}$ szczególności $\vdash \varphi_{1} \rightarrow\left(\varphi_{2} \rightarrow \ldots,\left(\varphi_{i} \rightarrow \psi\right) \ldots\right), \varphi_{1} \Rightarrow \varphi_{2} \rightarrow\left(\varphi_{3} \rightarrow \ldots,\left(\varphi_{i} \rightarrow\right.\right.$ $\psi) \ldots)$. Stąd przez 2. i (Cut) otrzymujemy $\vdash \varphi_{1} \Rightarrow \varphi_{2} \rightarrow\left(\varphi_{3} \rightarrow \ldots,\left(\varphi_{i} \rightarrow\right.\right.$ $\psi)$...). Powtarzamy tę dedukcję $i-1$ razy (z kolejnymi podstawieniami $\vdash$ $\left.\varphi_{k} \rightarrow \chi, \varphi_{k} \Rightarrow \chi, k \leq i\right)$ aż uzyskamy 1 .

1. $\Longrightarrow$ 3. Przez lemat 3.1, 1. $\Longrightarrow 4$. i $(\Rightarrow \rightarrow)$

3. $\Longrightarrow 1$. Ponieważ $\vdash \varphi_{1} \wedge \ldots \wedge \varphi_{i} \rightarrow \psi, \varphi_{1} \wedge \ldots \wedge \varphi_{i} \Rightarrow \psi$, więc przez (Cut) na 3. mamy $\vdash \varphi_{1} \wedge \ldots . \wedge \varphi_{i} \Rightarrow \psi$, skąd przez lemat 3.1 mamy 1 .

Oczywiście z obu lematów wynika, że jeżeli jakiś sekwent podpadający pod jeden ze schematów jest niedowiedlny, to jego równoważniki również. 
Dla dalszych rozważań nad dowodami w LK (lub innych wariantach RS) wygodnie jest wprowadzić dodatkową terminologię.

Definicja $3.8 \quad$ 1. Ciag sekwentów tworzy gałąź w dowodzie $S$ wtw jego pierwszym elementem jest sekwent aksjomatyczny, a ostatnim jest $S$ oraz każdy sekwent w tym ciagu oprócz ostatniego jest (jedna) przesłanka pewnej reguły, której wnioskiem jest kolejny sekwent z tego ciagu.

2. Sekwent $S_{1}$ jest nad sekwentem $S_{2}$ lub poprzedza $S_{2}$ (a $S_{2}$ jest pod $S_{1}$ lub następuje po $S_{1}$ ) w dowodzie wtw istnieje gałaź $w$ tym dowodzie, która zawiera $S_{1}$ jako wcześniejszy a $S_{2}$ jako późniejszy element. Jeżeli między $S_{1}$ a $S_{2}$ nie ma żadnego innego sekwentu, to mówimy o bezpośrednim poprzedzaniu (następowaniu po).

3. Zastosowanie reguły $R$ poprzedza lub jest nad zastosowaniem reguty $R$ ' ( $R$ ' następuje po $R$ lub jest pod $R$ ) $w$ dowodzie wtw wniosek $R$ jest nad wnioskiem $R$ '. Jeżeli dodatkowo wniosek $R$ jest przestanka zastosowania $R$ ' to mamy bezpośrednie poprzedzanie (następowanie po).

4. Jeżeli $S$ występuje w dowodzie $\mathcal{D}$, to zbiór zawierajacy $S$ oraz wszystkie sekwenty, które sa nad $S w \mathcal{D}$ jest poddowodem $\mathcal{D}$ (i dowodem $S$ ). Jeżeli $\mathcal{D}^{\prime}$ jest poddowodem $\mathcal{D}$, to $\mathcal{D}$ jest jego dowodem nadrzędnym (naddowodem).

5. Jeżeli $S_{1}$ bezpośrednio poprzedza $S_{2}$, to $\varphi \in S_{2}$ jest bezpośrednim potomkiem (jedynym) $\psi$ wtw (a) $\psi$ jest formuta parametryczna $w S_{1}$, a $\varphi:=\psi$ i występuje $w$ tej samej pozycji $w S_{2}$ co $\psi w S_{1}$, albo (b) $\psi$ jest formuła poboczna $w S_{1}$, a $\varphi$ formuta zasadnicza $S_{2} \cdot \varphi$ jest potomkiem $\psi$ wtw istnieje ciag 0 lub więcej bezpośrednich potomków od $\psi$ do $\varphi$ (relacja potomstwa jest zwrotnym, tranzytywnym domknięciem relacji bezpośredniego potomstwa).

6. $\varphi$ jest bezpośrednim przodkiem (niekoniecznie jedynym) $\psi$ wtw $\psi$ jest bezpośrednim potomkiem $\varphi . \varphi$ jest przodkiem $\psi$ wtw $\psi$ jest potomkiem $\varphi$.

Warto odnotować, że:

Fakt 3.1 1. Formuła zasadnicza (Cut) oraz wszystkie formuły sekwentu dowodzonego nie maja bezpośredniego potomka.

2. Formuły w (AX) oraz formuły zasadnicze (W) nie maja bezpośrednich przodków. 
3. W przypadku (P) bezpośrednimi przodkami (potomkami) formut zasadniczych sa ich przestawione wystapienia w bezpośrednio sasiadujacym sekwencie.

Wprowadzimy też pewne ważne uogólnienie pojęcia dowodu sekwentu $S$.

Definicja 3.9 (Dedukcja) Drzewo, w którym niekoniecznie każdy liść jest sekwentem aksjomatycznym, ale które spełnia pozostałe dwa warunki definicji dowodu, to dedukcja sekwentu $S$. Niech $\mathcal{D}$ będzie dedukcja $S$, a X oznacza zbiór wszystkich liści drzewa $\mathcal{D}$, które nie sa sekwentami aksjomatycznymi, wtedy $\mathcal{D}$ jest dedukcją $\mathrm{S}$ z $X$. Jeżeli istnieje dedukcja $S z X$, to $S$ jest dedukowalne z $X$, co zaznaczamy $X \vdash S$.

W szczególności dedukcja z pustym $X$ jest dowodem $S$. Z punktu widzenia zastosowania RS jako metody rozstrzygalnej szczególne znaczenie będą miały dedukcje z (nieaksjomatycznych) sekwentów atomowych i sposoby ich konstruowania. Oczywiście terminologia z poprzedniej definicji stosuje się też do dedukcji, z tym, że gałąź w dedukcji nie musi się zaczynać od sekwentu aksjomatycznego. W przypadku dedukcji mówimy też o poddedukcji, chociaż w szczególnych wypadkach poddedukcja może być poddowodem nawet jeżeli nadrzędna dedukcja nie jest dowodem.

Uwaga 3.4: Zauważmy, że powyżej użyliśmy $\vdash$ jeszcze w jednej funkcji, dla zaznaczenia relacji dedukowalności między zbiorami sekwentów a sekwentami. Jest to naturalne uogólnienie symbolu $\vdash$ w funkcji dowiedlności $S$, tak jak relacja dedukowalności między zbiorami formuł i formułami jest naturalnym uogólnieniem $\vdash \mathrm{w}$ funkcji asercji tezy. Natomiast zauważmy, że nie należy mylić zdefiniowanej wyżej sekwentowej relacji dedukowalności z relacją zachodzącą między poprzednikiem a następnikiem sekwentu, którą też czasem oznaczamy przez $\vdash$ zamiast $\Rightarrow$ (por. podrozdział 2.4).

Definicja 3.10 (Podsekwenty, złożenie sekwentów) $\quad \Gamma \Rightarrow \Delta$ jest podsekwentem $\Pi \Rightarrow \Sigma$ wtw $\Gamma \subseteq \Pi i \Delta \subseteq \Sigma$; relacje " $S$ jest podsekwentem $S^{\prime \prime}$ zaznaczymy przez $S \sqsubseteq S^{\prime}$

- Dla $\Gamma \Rightarrow \Delta i \Pi \Rightarrow \Sigma$ ich złożeniem jest $\Gamma, \Pi \Rightarrow \Delta, \Sigma$ oraz dowolna permutacja jego elementów; dla $S$ i $S^{\prime}$ ich złożenie oznaczymy przez $S \circ S^{\prime}$.

Odnotujmy: 
Fakt 3.2 1. Jeżeli $S \sqsubseteq S^{\prime}$, to $S \vdash S^{\prime}$.

2. $S_{i} \vdash S_{1} \circ S_{2}$, dla $i=1,2$.

3. Jeżeli $S=S_{1} \circ S_{2}$, to $S_{i} \sqsubseteq S$, dla $i=1,2$.

4. $S \sqsubseteq S^{\prime}$ wtw dla pewnego $S^{\prime \prime}, S \circ S^{\prime \prime}=S^{\prime}$.

\subsection{Adekwatność LK}

Skąd wiemy, że przedstawiony zestaw reguł daje nam adekwatną formalizację klasycznego rachunku zdań? Gentzen udowodnił adekwatność LK wykazując jego równoważność z aksjomatycznym ujęciem KRZ, udowodnił zatem twierdzenie: $^{1}$

Twierdzenie 3.1 (Równoważność LK z H-KRZ) $\vdash_{H} \varphi w t w \vdash_{L K} \Rightarrow \varphi$

Udowodnimy teraz jedną z implikacji składających się na powyższe twierdzenie:

Lemat 3.3 Jeżeli $\vdash_{H} \varphi$, to $_{L K} \Rightarrow \varphi$

DowóD: lematu wymaga skonstruowania w LK schematów dowodów wszystkich aksjomatów oraz wykazania, że każde zastosowanie MP w dowodzie w H daje się odtworzyć w LK. Dowody większości aksjomatów są łatwe i zachęcamy do ich samodzielnej konstrukcji. Dowód dla konkretnego podstawienia aksjomatu 2. podaliśmy w poprzednim paragrafie - wystarczy w nim zamienić każde wystąpienie $p$ na $\varphi, q$ na $\psi$ a $r$ na $\chi$ i otrzymamy ogólny schemat dowodu każdej instancji tego aksjomatu.

Pokażemy teraz schemat dowodu dla aksjomatu 8.

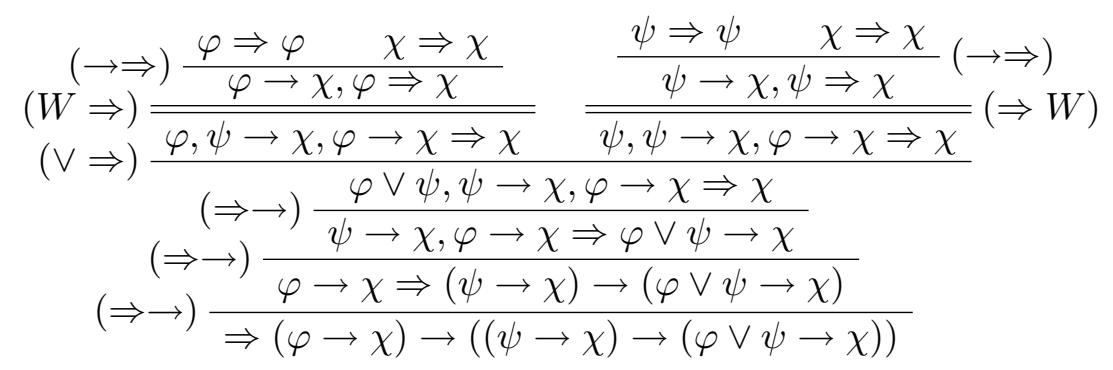

\footnotetext{
${ }^{1}$ Gentzen faktycznie udowodnił równoważność 3 systemów: LK, H i NK, czyli systemu dedukcji naturalnej, i to dla KRK. Udowodnił też równoważność takich samych systemów dla logiki intuicjonistycznej pierwszego rzędu.
} 
Jeżeli chodzi o zastosowania MP, to w LK odpowiada im następująca figura dowodowa:

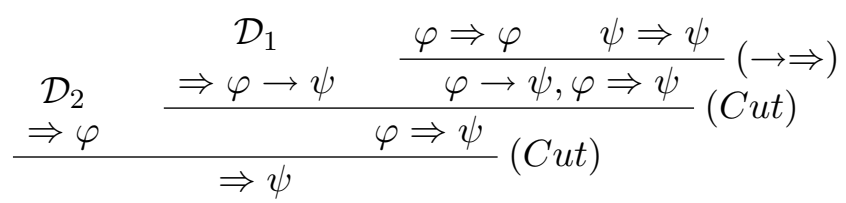

gdzie $\mathcal{D}_{1}$ i $\mathcal{D}_{2}$ to symulacje (w LK) dowodów w $\mathrm{H}$ obu tez stanowiących przesłanki zastosowania MP.

Aby udowodnić implikację w drugą stronę musiał jednak Gentzen dokonać jakiejś formy przekładu sekwentów na uboższy język aksjomatycznej formalizacji. Dowolny sekwent o postaci $\varphi_{1}, \ldots, \varphi_{i} \Rightarrow \psi_{1}, \ldots, \psi_{k} \mathrm{z} i>0, k>0$ należy zinterpretować jako formułę postaci $\varphi_{1} \wedge \ldots \wedge \varphi_{i} \rightarrow \psi_{1} \vee \ldots \vee \psi_{k}$. W przypadku $i=1$ lub $k=1$ mamy do czynienia ze zredukowaną (jednoelementową) koniunkcją lub alternatywą. Łatwo zauważyć zbieżność tej interpretacji z wynikami podanymi w lematach 3.1 i 3.2. Pozostaje kwestia interpretacji sekwentów z pustym poprzednikiem lub następnikiem. Pusty poprzednik sekwentu interpretujemy jako $T$ natomiast pusty następnik jako $\perp$, zatem sekwent $\Rightarrow \psi_{1}, \ldots, \psi_{k}$ interpretujemy jako $\top \rightarrow \psi_{1} \vee \ldots \vee \psi_{k}$, lub prościej - jako $\psi_{1} \vee \ldots \vee \psi_{k}$, natomiast $\varphi_{1}, \ldots, \varphi_{i} \Rightarrow$ jako $\varphi_{1} \wedge \ldots \wedge \varphi_{i} \rightarrow \perp$ lub $-\mathrm{w}$ myśl definicji negacji - jako $\neg\left(\varphi_{1} \wedge \ldots \wedge \varphi_{i}\right)$. Sekwent z pustym poprzednikiem i następnikiem oznacza po prostu $\perp$, gdyż $\top \rightarrow \perp \leftrightarrow \neg \top \vee \perp \leftrightarrow \perp \vee \perp \leftrightarrow \perp$.

Dla wykazania, że $\vdash_{L K} \Rightarrow \varphi$ implikuje $\vdash_{H} \varphi$ Gentzen udowodnił, że przekład każdej reguły LK daje nam regułę wyprowadzalną w systemie aksjomatycznym. Pominiemy syntaktyczny dowód Gentzena, gdyż jest to dość żmudne ćwiczenie $\mathrm{w}$ dowodzeniu $\mathrm{w}$ systemie aksjomatycznym, co nie jest przedmiotem tej pracy. Zaprezentujemy alternatywny dowód Kleene'go [83], który jest znacznie prostszy. Opiera się on na intepretacji $\Rightarrow$ jako relacji dowiedlności w systemie $\mathrm{H}$.

Lemat 3.4 Jeżeli $\vdash_{L K} \Gamma \Rightarrow \Delta$, to $\Gamma, \neg \Delta \vdash_{H} \perp$

DowóD: Przez indukcję po długości dowodu w LK. Wystarczy odwołać się do własności $\vdash$ podanych w lemacie 1.1. Dowód bazy jest trywialny gdyż z lematu 1.1. własność 1 mamy $\varphi \vdash \varphi$, skąd przez własność 9 tegoż lematu mamy $\varphi, \neg \varphi \vdash \perp$.

W założeniu indukcyjnym przyjmujemy, że lemat zachodzi dla dowolnego dowodu długości $<n$ i wykazujemy, że zachodzi dla $n$ rozważając wszystkie przypadki zastosowania reguł. Przeanalizujmy jeden przypadek: 
$(\Rightarrow \wedge): \Gamma \Rightarrow_{n} \Delta:=\Gamma \Rightarrow_{n} \Delta^{\prime}, \varphi \wedge \psi$. Obie przesłanki mają dowody krótsze zatem podpadaja pod założenie indukcyjne, czyli $\Gamma, \neg \Delta^{\prime}, \neg \varphi \vdash_{H} \perp$ i $\Gamma, \neg \Delta^{\prime}, \neg \psi \vdash_{H} \perp$. Z lematu 1.1, własność 9, mamy $\Gamma, \neg \Delta^{\prime} \vdash_{H} \varphi$ i $\Gamma, \neg \Delta^{\prime} \vdash_{H}$ $\psi$. Z aksjomatu 5 przez własność 6 lematu 1.1 mamy $\varphi, \psi \vdash_{H} \varphi \wedge \psi$, co po dwukrotnym zastosowaniu własności 4 daje $\Gamma, \neg \Delta^{\prime} \vdash_{H} \varphi \wedge \psi$, czyli (przez własność 9) $\Gamma, \neg \Delta^{\prime}, \neg(\varphi \wedge \psi) \vdash_{H} \perp$.

Z lematu 3.4 przy $\Gamma$ pustym i $\Delta:=\varphi$ otrzymujemy przez lemat 1.1 konwers lematu 3.3, a to daje dowód twierdzenia 3.1.

\subsection{Semantyczna interpretacja}

Dla rozważań przeprowadzonych w następnym rozdziale wygodnie będzie już teraz wprowadzić semantyczne ujęcie LK, a w zasadzie dowolnego wariantu RS. Niezależnie od podanego wyżej dowodu udowodnimy też semantyczny lemat o przystosowaniu LK, co wymaga z kolei uprzedniego zdefiniowania sposobu semantycznej interpretacji sekwentów. Można oczywiście odwołać się do podanego wyżej sposobu przekładu sekwentów na formuły, wygodniej jest jednak zrobić to bezpośrednio, wzmacniając semantykę przez podanie dodatkowego warunku prawdziwości (spełniania) sekwentów o postaci:

$\mathfrak{M} \vDash \Gamma \Rightarrow \Delta$ wtw przynajmniej jedna formuła $\mathrm{w}$ poprzedniku jest fałszywa lub przynajmniej jedna w następniku jest prawdziwa.

Falsyfikację sekwentu definiujemy następująco:

$\mathfrak{M} \not \models \Gamma \Rightarrow \Delta$ wtw każda formuła $\mathrm{w}$ poprzedniku jest prawdziwa, a każda $\mathrm{w}$ następniku jest fałszywa.

W oczywisty sposób na sekwenty poszerza się inne ważne pojęcia semantyczne; tutaj ograniczymy się do tautologiczności. To, że sekwent jest tautologiczny będziemy zaznaczać w taki sam sposób jak w przypadku formuł poprzez użycie $\models$.

$$
\vDash \Gamma \Rightarrow \Delta \text { wtw } \forall_{\mathfrak{M}}, \mathfrak{M} \vDash \Gamma \Rightarrow \Delta
$$

Łatwo wykazać, że taki sposób semantycznej interpretacji sekwentu jest zgodny z syntaktyczną interpretacją zaproponowaną przez Gentzena. Ujmuje to poniższy fakt, którego dowód pominiemy:

Fakt 3.3 $\mathfrak{M} \vDash \varphi_{1}, \ldots \varphi_{i} \Rightarrow \psi_{1}, \ldots \psi_{k}$ wtw $\mathfrak{M} \vDash \varphi_{1} \wedge \ldots \wedge \varphi_{i} \rightarrow \psi_{1} \vee \ldots \vee \psi_{k}$

Przy zadanej wyżej interpretacji możemy wykazać: 
Lemat 3.5 Każda reguła LK jest niezawodna

DowóD: Należy pokazać, że jeżeli przesłanki reguły są tautologiczne, to wniosek też.

Przypadek $(\rightarrow \Rightarrow)$ : Załóżmy, że $\models \Gamma \Rightarrow \Delta, \varphi \mathrm{i} \models \psi, \Pi \Rightarrow \Sigma$ ale $\not \models \varphi \rightarrow$ $\psi, \Gamma, \Pi \Rightarrow \Delta, \Sigma$. Zatem w pewnym modelu $\mathfrak{M}$ zarówno $\varphi \rightarrow \psi$ jak i wszystkie elementy $\Gamma$ i $\Pi$ są spełnione natomiast wszystkie elementy $\Delta$ i $\Sigma$ są tam fałszywe. Skoro $\mathfrak{M} \vDash \varphi \rightarrow \psi$, to $\mathfrak{M} \not \models \varphi$ lub $\mathfrak{M} \vDash \psi$. Oba przypadki prowadzą do sprzeczności; przy pierwszym lewa, a przy drugim prawa przesłanka byłaby sfalsyfikowana w $\mathfrak{M}$.

Lemat 3.6 (Przystosowanie) Jeżeli $\vdash \Gamma \Rightarrow \Delta$, to $\models \Gamma \Rightarrow \Delta$

DowóD: Przez indukcję po długości dowodu $\Gamma \Rightarrow \Delta$. Dowód bazy jest oczywisty, gdyż każdy jednoelementowy dowód to sekwent aksjomatyczny, który jest tautologią. Pokazujemy, że dowód sekwentu $\Gamma \Rightarrow \Delta$ o długości $n$ jest dowodem tautologii przy założeniu, że każdy dowód krótszy spełnia ten warunek. Ponieważ dowód każdej z przesłanek sekwentu $\Gamma \Rightarrow \Delta$ ma długość mniejszą od $n$, więc przesłanki podpadają pod założenie indukcyjne i są sekwentami tautologicznymi. Zgodnie z poprzednim lematem każda reguła LK jest niezawodna, więc wydedukowany sekwent też jest tautologiczny.

Ponieważ przedstawiona przez nas w rozdziale 1 aksjomatyka KRZ jest pełna, więc lemat 3.3 implikuje (słabą) pełność LK, a to wraz z ostatnim lematem daje adekwatność LK względem semantycznie scharakteryzowanego KRZ. Niezależne od uzyskanego tutaj wyniku w dalszym ciągu podamy też bezpośrednie dowody pełności dla LK i innych wariantów RS, które zaprezentujemy w rozdziale 7 . 


\section{Rozdział 4}

\section{Warianty standardowego RS dla KRZ}

Istnieje wiele wariantów RS, które są równoważne rachunkowi LK w sensie posiadania dokładnie takiego samego zbioru sekwentów dowiedlnych. Zatem dają one również adekwatną formalizację KRZ, a ponadto, podobnie jak LK, można je modyfikować tak by dostarczyły charakteryzacji innych logik. Pomimo równoważności tych rachunków wybór takiej lub innej wersji ma wpływ na posiadanie lub brak wielu istotnych własności, które będziemy w dalszym ciągu rozważać. Dlatego w tym rozdziale zbiorczo omówimy kilka najważniejszych sposobów modyfikacji i ich bezpośrednich konsekwencji. Zaczniemy od omówienia podstawowych wariantów reguł: Gentzena i Ketonena oraz k-jednolitych i k-niezależnych. W podrozdziale 4.2 skupimy się na problemie odwracalności reguł i wprowadzimy system LK-K. Następny podrozdział będzie poświęcony omówieniu systemu ARS, w którym nie występują żadne reguły strukturalne, włączając w to (Cut). W kolejnych podrozdziałach udowodnimy rezultat pozwalający na łatwe generowanie rozmaitych wariantów reguł i udowadnianie ich równoważności (4.4), oraz omówimy istotne własności reguł RS (4.5). Na koniec (4.6) omówimy sposoby budowania RS dla KRZ na int-sekwentach.

\subsection{Warianty reguł}

Aby wykazać równoważność dwóch systemów RS i RS' musimy pokazać, że każda reguła pierwotna RS jest regułą wtórną RS' i odwrotnie. Wprowadzony w kontekście rachunków aksjomatycznych podział reguł wtórnych na wyprowadzalne i dopuszczalne przeniesiemy obecnie na RS. 


\section{Definicja 4.1}

Reguta $\frac{S_{1}, \ldots, S_{n}}{S}$ jest wyprowadzalna $w R S$ wtedy, gdy w RS mamy dedukcję $S z S_{1}, \ldots, S_{n}$.

Reguła $\frac{S_{1}, \ldots, S_{n}}{S}$ jest dopuszczalna $w R S$ wtedy, gdy jeżeli w RS mamy dowody sekwentów $S_{1}, \ldots, S_{n}$, to mamy też dowód $S$.

Oczywiście każda reguła wyprowadzalna jest regułą dopuszczalną, gdyż jeżeli do dedukcji $S$ z $S_{1}, \ldots, S_{n}$ możemy dodać dowód każdej z przesłanek (tj. dopisać go nad odpowiednim sekwentem $S_{i}$ ), to uzyskujemy w ten sposób dowód $S$. Zależność w drugą stronę nie zachodzi ${ }^{1}$.

Wykazywanie wyprowadzalności reguł jest zadaniem stosunkowo prostym - wymaga skonstruowania schematu dedukcji sekwentu wniosku z przesłanek przy użyciu reguł pierwotnych. Zabiegu takiego już wyżej dokonaliśmy (w dowodzie lematu 3.3) pokazując, że reguła MP postaci: $\Rightarrow \varphi, \Rightarrow \varphi \rightarrow \psi / \Rightarrow \psi$ jest w LK wyprowadzalna. W tym rozdziale rozważymy wiele takich wariantów reguł LK, które są w nim wyprowadzalne, ale prowadzą do uzyskania interesujących wariantów RS.

Dla odmiany, wykazywanie w sposób syntaktyczny dopuszczalności reguły, która nie jest w danym systemie wyprowadzalna wymaga często sporo wysiłku i pomysłowości. Zazwyczaj sprowadza się to do wykazania, że każde zastosowanie takiej reguły $\mathrm{w}$ danym systemie można $\mathrm{z}$ dowodu wyeliminować, stąd często zamiast o dopuszczalności mówi się o eliminowalności takiej reguły z danego rachunku. W rozdziale 5 zaprezentujemy takie dowody dla (Cut), ale już w tym rozdziale przeprowadzimy dowody dopuszczalności rozmaitych reguł strukturalnych w pewnych wariantach RS. Zauważmy też, że choć syntaktyczne dowody dopuszczalności reguł są nietrywialne, to mamy proste kryterium semantyczne ich identyfikacji, które wyraża poniższy lemat.

Lemat 4.1 Jeżeli $R S$ jest adekwatne względem semantyki SEM i reguła (r) jest niezawodna w SEM, to jest dopuszczalna $w R S$.

DowóD: Załóżmy, że każda przesłanka (r) ma dowód w RS. Z racji przystosowania RS do SEM są one tautologiczne, a ponieważ (r) jest niezawodna w SEM, to wniosek (r) też jest tautologiczny. Z racji pełności RS wniosek ten musi mieć dowód $\mathrm{w}$ RS.

\footnotetext{
${ }^{1}$ Pomijając przypadek strukturalnej zupełności pewnych aksjomatycznych formalizacji KRZ - por. uwaga 1.9 .
} 
Lemat ten pozwala w prosty sposób wykazywać dopuszczalność reguł w danym RS, gdyż sprawdzenie ich niezawodności zazwyczaj nie sprawia kłopotu. Niestety często aby wykazać adekwatność RS względem danej semantyki potrzebujemy właśnie tych reguł, których dopuszczalność mamy wykazać, a w takiej sytuacji powyższe kryterium jest bezużyteczne.

\subsubsection{Aksjomaty uogólnione}

W sformułowaniu reguł wielu wariantów RS wymaga się, aby każde podstawienie $(A X)$ było sekwentem atomowym. Przy okazji dowodu wielu twierdzeń pokażemy potrzebę takiego obostrzenia, natomiast teraz wykażemy, że takie ograniczenie w stosunku do sekwentów aksjomatycznych nie powoduje osłabienia RS.

Lemat 4.2 Jeżeli $w$ RS jedyne sekwenty aksjomatyczne sa sekwentami atomowymi, to $\vdash \varphi \Rightarrow \varphi$ dla dowolnego $\varphi$

DowóD przeprowadzimy przez indukcję po długości $\varphi$. Wystarczy zbudować schematy dowodów pokazujace, że $\varphi \Rightarrow \varphi$ dla $\varphi$ o dowolnej strukturze można wydedukować z sekwentów $\psi \Rightarrow \psi$, gdzie $\psi$ jest formułą krótszą od $\varphi$. Jeżeli $\varphi:=\varphi \wedge \psi$, to można zbudować następujaccy schemat dowodu:

$$
(\wedge \Rightarrow) \frac{\varphi \Rightarrow \varphi}{\frac{\varphi \wedge \psi \Rightarrow \varphi}{\varphi \wedge \psi \Rightarrow \varphi \wedge \psi} \frac{\psi \Rightarrow \psi}{\varphi \wedge \psi \Rightarrow \psi}(\wedge \Rightarrow)}(\Rightarrow \wedge)
$$

Z drugiej strony dla ułatwienia dowodu wielu twierdzeń wygodne jest dysponowanie uogólnioną wersją aksjomatów, w której na miejscu $\varphi$ może występować dowolna formuła. Przykładowo korzystaliśmy z tego faktu w dowodzie lematu 3.1, gdyby aksjomaty w LK były ograniczone do atomowych, to wcześniej musielibyśmy i tak dowieść poprzedni lemat.

Zauważmy, że dopuszczalną postać aksjomatów można uogólnić jeszcze bardziej poprzez zastosowanie do sekwentów aksjomatycznych reguł osłabiania i permutacji. Odnotujmy to jako

Lemat 4.3 Jeżeli ciagi $\Gamma$ is maja przynajmniej po jednym wystapieniu takiej samej formuty, to $\vdash \Gamma \Rightarrow \Delta$

Rozróżnijmy dla wygody możliwe formy aksjomatów: oryginalna forma Gentzena to $\left(A X_{n}\right)$, czyli sekwent nieatomowy, ale dwuelementowy. Jego 
ograniczenie do formuł atomowych, to $\left(A X_{a}\right)$, czyli sekwent dwuelementowy atomowy. Wersja uogólniona z podanego wyżej lematu, to $\left(U A X_{n}\right)$. W szczególności możemy też ograniczyć się do takiej wersji uogólnionej, gdzie sekwent aksjomatyczny $\Gamma \Rightarrow \Delta$ zawiera w poprzedniku i następniku wspólną formułę atomową; oznaczmy ją jako $\left(U A X_{a}\right)$. Jest ona dowiedlna bezpośrednio z $\left(A X_{a}\right)$ przez osłabianie i permutację. Jeżeli w grę będzie wchodziła dowolna postać aksjomatu, to będziemy po prostu używać skrótu $(A X)$. Ponieważ $\left(A X_{a}\right)$ jest szczególnym przypadkiem wszystkich pozostałych wersji, a one z niego dadzą się wydedukować, więc możemy stwierdzić:

Twierdzenie 4.1 Wersje $R S$ z następującymi formami sekwentów aksjomatycznych sa równoważne:

1. $\varphi \Rightarrow \varphi$, dla dowolnej zmiennej $\varphi$

2. $\varphi \Rightarrow \varphi$, dla dowolnej formuty $\varphi$

3. $\Gamma, \varphi, \Pi \Rightarrow \Sigma, \varphi, \Delta$, dla dowolnej zmiennej $\varphi$

4. $\Gamma, \varphi, \Pi \Rightarrow \Sigma, \varphi, \Delta$, dla dowolnej formuły $\varphi$

\subsubsection{Warianty reguł dwuprzesłankowych}

Daleko ważniejsza różnica $\mathrm{w}$ konstrukcji przyjmowanych reguł dotyczy roli parametrów, czyli kontekstu danej reguły. Zauważmy, że w oryginalnym systemie Gentzena występuje istotna asymetria pomiędzy regułami $(\Rightarrow \wedge)$ i $(\vee \Rightarrow)$ z jednej strony, a $(C u t)$ i $(\rightarrow \Rightarrow)$ z drugiej. W regułach dla $\wedge \mathrm{i} \vee$ obie przesłanki mają takie same listy parametrów jak wniosek; w pozostałych regułach 2-przesłankowych listy parametrów we wniosku to konkatenacja różnych list występujących w przesłankach. Reguły pierwszego typu, które wymagają dla swojego zastosowania jednolitego kontekstu w obu przesłankach, określiliśmy w rozdziale 2 jako $k$-jednolite (context-sharing), a reguły drugiego typu jako k-niezależne (niezależne od kontekstu, context-free, context-independent). Łatwo zauważyć, że LK Gentzena można zmodyfikować na dwa różne sposoby dokonując ujednolicenia kształtu reguł. Obie reguły dla $\wedge \mathrm{i} \vee$ można zastąpić przez warianty k-niezależne stosowalne bez konieczności uzgodnienia list parametrów w przesłankach:

$$
(\Rightarrow \wedge) \frac{\Gamma \Rightarrow \Delta, \varphi \quad \Pi \Rightarrow \Sigma, \psi}{\Gamma, \Pi \Rightarrow \Delta, \Sigma, \varphi \wedge \psi} \quad(\vee \Rightarrow) \frac{\varphi, \Gamma \Rightarrow \Delta \quad \psi, \Pi \Rightarrow \Sigma}{\varphi \vee \psi, \Gamma, \Pi \Rightarrow \Delta, \Sigma}
$$

$\mathrm{Z}$ drugiej strony możemy $(C u t)$ i $(\rightarrow \Rightarrow)$ zastąpić przez warianty k-jednolite, w których listy parametrów w obu przesłankach są identyczne jak we wniosku. Obie reguły wyglądają wtedy następująco: 


$$
\text { (Cut) } \frac{\Gamma \Rightarrow \Delta, \varphi \quad \varphi, \Gamma \Rightarrow \Delta}{\Gamma \Rightarrow \Delta} \quad(\rightarrow \Rightarrow) \frac{\Gamma \Rightarrow \Delta, \varphi \quad \psi, \Gamma \Rightarrow \Delta}{\varphi \rightarrow \psi, \Gamma \Rightarrow \Delta}
$$

Łatwo wykazać, że reguły k-niezależne są wyprowadzalne z reguł k-jednolitych, przy użyciu osłabiania i permutacji do przesłanek. Natomiast reguły k-jednolite są wyprowadzalne z reguł k-niezależnych przy użyciu kontrakcji na wniosku. To, że w systemie Gentzena występują oba rodzaje reguł wiązało się głównie z tym, że dokonał on równocześnie formalizacji logiki intuicjonistycznej (por. uwaga 3.3). Poniżej pokażemy, że wybór któregoś rodzaju reguł ma istotne znaczenie, najpierw jednak rozważymy jeszcze jeden wariant reguł sekwentowych.

\subsubsection{Reguły Ketonena}

Występowanie dwóch reguł $(\Rightarrow \vee)$ i $(\wedge \Rightarrow)$ również wiązało się z kwestią formalizacji logiki intuicjonistycznej i w przypadku RS dla KRZ ujawnia pewne trudności:

- w wielu dowodach nie można uniknąć zastosowań kontrakcji;

- prowadzi do komplikacji w przypadku zastosowań LK jako procedury rozstrzygalnej;

- reguły te nie są odwracalne.

Co do pierwszego punktu, to najlepiej zilustruje go poniższy

Przykład 4.1.

$$
\begin{gathered}
\frac{p \Rightarrow p}{q, p \Rightarrow p}(W \Rightarrow) \\
\left.\frac{p \Rightarrow q \rightarrow p}{p \Rightarrow \rightarrow}\right) \\
\frac{\frac{p \Rightarrow(p \rightarrow q) \vee(q \rightarrow p)}{p \Rightarrow(p \rightarrow q) \vee(q \rightarrow p), q}}{\frac{p}{\Rightarrow(p \rightarrow q) \vee(q \rightarrow p), p \rightarrow q}(\Rightarrow W)} \\
\frac{\Rightarrow(p \rightarrow q) \vee(q \rightarrow p),(p \rightarrow q) \vee(q \rightarrow p)}{\Rightarrow(p \rightarrow q) \vee(q \rightarrow p)}(\Rightarrow \vee
\end{gathered}
$$

Taka konstrukcja reguł okazuje się jeszcze bardziej kłopotliwa w przypadku zastosowań RS jako procedury rozstrzygalnej, co omówimy dokładnie w rozdziale 6 . Z drugiej strony łatwo zauważyć, że sposób interpretacji poprzednika jako koniunkcji, a następnika jako alternatywy elementów pozwala 
uniknąć tych problemów i wprowadzić pojedyncze reguły, tak jak w przypadku implikacji. Reguły takie o postaci:

$$
(\wedge \Rightarrow) \frac{\varphi, \psi, \Gamma \Rightarrow \Delta}{\varphi \wedge \psi, \Gamma \Rightarrow \Delta} \quad(\Rightarrow \vee) \frac{\Gamma \Rightarrow \Delta, \varphi, \psi}{\Gamma \Rightarrow \Delta, \varphi \vee \psi}
$$

jako pierwszy wprowadził Ketonen [82]. Łatwo dowieść:

Lemat 4.4 $W$ dowolnym systemie $R S$ z kontrakcja $i$ osłabianiem reguły Gentzena $i$ Ketonena sa równoważne.

DowóD: Aby dowieść wyprowadzalność wariantu Ketonena wystarczy do przesłanki dwukrotnie zastosować wariant Gentzena, a następnie kontrakcję. Aby dowieść wyprowadzalność wariantu Gentzena wystarczy do przesłanki zastosować osłabianie by uzyskać brakującą formułę poboczną, a następnie użyć reguły Ketonena.

Dowód powyższego sekwentu z użyciem wariantu Ketonena wygląda następująco:

Przykład 4.2.

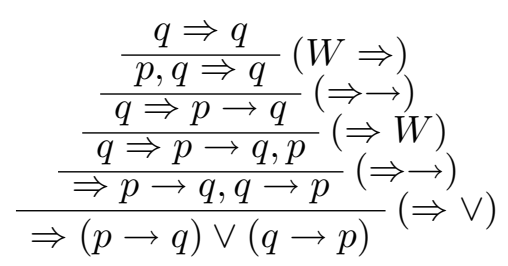

Wprowadzając warianty Ketonena na miejsce reguł Gentzena uzyskujemy nie tylko uproszczenie w repertuarze reguł (tylko jedna zamiast dwóch) i prostsze dowody, ale także ważną własność zwaną odwracalnością, której omówieniu poświęcimy następny podrozdział.

\subsection{Odwracalność reguł}

Rozróżnienie pomiędzy regułami k-jednolitymi i k-niezależnymi w przypadku reguł dwuprzesłankowych, oraz wariantami Gentzena i Ketonena dla reguł jednoprzesłankowych ma niebagatelne znaczenie. Po pierwsze, w rozdziale 2 wspominaliśmy, że dwuprzesłankowe reguły k-jednolite wraz z podwójnymi regułami jednoprzesłankowymi (tylko jedna formuła poboczna w przesłance) definiują w zasadzie inne stałe logiczne (addytywne) niż dwuprzesłankowe 
reguły k-niezależne wraz z jednoprzesłankowymi regułami Ketonena (multiplikatywne). Toteż $\mathrm{w}$ LK $\vee \mathrm{i} \wedge$ są addytywne a $\rightarrow$ jest multiplikatywna. Zauważmy przy okazji, że dla addytywnej wersji $\rightarrow$ oprócz k-jednolitej reguły dwuprzesłankowej musielibyśmy użyć też dwóch reguł jednoprzesłankowych, mianowicie:

$$
\left(\Rightarrow \rightarrow_{1}\right) \frac{\varphi, \Gamma \Rightarrow \Delta}{\Gamma \Rightarrow \Delta, \varphi \rightarrow \psi} \quad\left(\Rightarrow \rightarrow_{2}\right) \frac{\Gamma \Rightarrow \Delta, \psi}{\Gamma \Rightarrow \Delta, \varphi \rightarrow \psi}
$$

Jak widać moglibyśmy na podstawie tego rozróżnienia wprowadzić dwa warianty LK: LK-M (multiplikatywny) i LK-A (addytywny). Oba charakteryzowałyby jednak KRZ, gdyż jak pokazaliśmy wyżej, przy użyciu reguł strukturalnych są one wzajemnie wyprowadzalne.

Uwaga 4.1: Należy pamiętać, że reguły te definiują różne stałe logiczne dopiero w systemach RS o zubożonym zestawie reguł strukturalnych. W ten sposób można uzyskać sekwentowe formalizacje bardzo wielu logik nieklasycznych słabszych od logiki klasycznej, zwanych zbiorczo logikami podstrukturalnymi, właśnie ze względu na to, że ich formalizacje uzyskuje się na drodze zubożenia zestawu reguł strukturalnych. Dokładniej o logikach podstrukturalnych informowaliśmy w uwadze 2.3.

W tym miejscu bardziej interesujacy jest dla nas inny wariant - z regułami Ketonena i k-jednolitymi. Oznaczmy go jako LK-K. Zawiera następujące reguły:

$$
\begin{aligned}
& (A X) \varphi \Rightarrow \varphi \\
& \text { (Cut) } \frac{\Gamma \Rightarrow \Delta, \varphi \quad \varphi, \Gamma \Rightarrow \Delta}{\Gamma \Rightarrow \Delta} \\
& (W \Rightarrow) \frac{\Gamma \Rightarrow \Delta}{\varphi, \Gamma \Rightarrow \Delta} \\
& (\Rightarrow W) \quad \frac{\Gamma \Rightarrow \Delta}{\Gamma \Rightarrow \Delta, \varphi} \\
& (C \Rightarrow) \frac{\varphi, \varphi, \Gamma \Rightarrow \Delta}{\varphi, \Gamma \Rightarrow \Delta} \\
& (\Rightarrow C) \frac{\Gamma \Rightarrow \Delta, \varphi, \varphi}{\Gamma \Rightarrow \Delta, \varphi} \\
& (P \Rightarrow) \quad \frac{\Pi, \varphi, \psi, \Gamma \Rightarrow \Delta}{\Pi, \psi, \varphi, \Gamma \Rightarrow \Delta} \\
& (\Rightarrow P) \quad \begin{array}{l}
\Gamma \Rightarrow \Delta, \psi, \varphi, \Pi \\
\Gamma \Rightarrow \Delta, \varphi, \psi, \Pi
\end{array} \\
& (\neg \Rightarrow) \frac{\Gamma \Rightarrow \Delta, \varphi}{\neg \varphi, \Gamma \Rightarrow \Delta} \\
& (\Rightarrow \neg) \frac{\varphi, \Gamma \Rightarrow \Delta}{\Gamma \Rightarrow \Delta, \neg \varphi} \\
& (\wedge \Rightarrow) \frac{\varphi, \psi, \Gamma \Rightarrow \Delta}{\varphi \wedge \psi, \Gamma \Rightarrow \Delta} \quad(\Rightarrow \wedge) \frac{\Gamma \Rightarrow \Delta, \varphi \quad \Gamma \Rightarrow \Delta, \psi}{\Gamma \Rightarrow \Delta, \varphi \wedge \psi} \\
& (\Rightarrow \vee) \frac{\Gamma \Rightarrow \Delta, \varphi, \psi}{\Gamma \Rightarrow \Delta, \varphi \vee \psi} \quad(\vee \Rightarrow) \frac{\varphi, \Gamma \Rightarrow \Delta \quad \psi, \Gamma \Rightarrow \Delta}{\varphi \vee \psi, \Gamma \Rightarrow \Delta}
\end{aligned}
$$




$$
(\Rightarrow \rightarrow) \frac{\varphi, \Gamma \Rightarrow \Delta, \psi}{\Gamma \Rightarrow \Delta, \varphi \rightarrow \psi} \quad(\rightarrow \Rightarrow) \frac{\Gamma \Rightarrow \Delta, \varphi \quad \psi, \Gamma \Rightarrow \Delta}{\varphi \rightarrow \psi, \Gamma \Rightarrow \Delta}
$$

W stosunku do LK różnice są następujące: (Cut) jest w wersji k-jednolitej, reguły $(\Rightarrow \vee)$ i $(\wedge \Rightarrow)$ są w wersji Ketonena, a $(\rightarrow \Rightarrow)$ w wersji k-jednolitej.

Wykazaliśmy wyżej, że wszystkie reguły LK-K są wyprowadzalne w LK i odwrotnie, zatem LK-K jest równoważny LK w sensie posiadania takiego samego zbioru sekwentów dowiedlnych. Zatem LK-K też jest adekwatną formalizacją KRZ. Dla reguł LK-K (z wyjątkiem (W)) zachodzi jednak pewna ważna własność, która nie zachodzi dla wielu reguł LK. Określimy ją jako odwracalność (lub inwersję) i zdefiniujemy w dwóch wersjach:

Definicja 4.2 (Odwracalność reguły) - W wersji semantycznej: jeżeli wniosek jest tautologiczny, to przesłanki też sa tautologiczne (reguła odwrotna jest niezawodna)

- W wersji syntaktycznej: przesłanki sa dedukowalne z wniosku reguły.

Oczywiście w przypadku adekwatności rachunku względem semantyki, na gruncie której definiujemy niezawodność reguł, obie własności są równoważne, co łatwo wykazać:

Lemat 4.5 Jeżeli RS jest adekwatne względem semantyki SEM, to reguła (r) jest semantycznie odwracalna wtw jest syntaktycznie odwracalna.

DowóD: Jeżeli reguła (r) nie jest syntaktycznie odwracalna, to dla pewnej przesłanki $S_{1}$ i wniosku $S_{2}$ mamy $S_{2} \nvdash S_{1}$. Z racji pełności $S_{2} \not \models S_{1}$, zatem istnieje model spełniający $S_{2}$ i falsyfikujący $S_{1}$ co oznacza, że (r) nie jest semantycznie odwracalna. Jeżeli (r) jest syntaktycznie odwracalna, to $S_{2} \vdash$ $S_{i}$, dla każdej przesłanki $S_{i}$. Zatem, z racji przystosowania $S_{2} \models S_{i}$, więc gdy $\models S_{2}$, to $\models S_{i}$, co oznacza, że (r) jest semantycznie odwracalna.

Ze względu na podany wyżej lemat i adekwatność LK i LK-K będziemy w dalszym ciągu mówić po prostu o odwracalności. Oczywiście znacznie łatwiej wykazać odwracalność danej reguły semantycznie niż syntaktycznie jednak poniżej zrobimy to dla obu wersji niezależnie. Na początek, korzystając z semantycznej interpretacji sekwentów z rozdziału poprzedniego, pokażemy czemu osłabianie, reguły k-niezależne i Gentzenowskie reguły jednoprzesłankowe nie są odwracalne.

Lemat 4.6 W LK własność odwracalności nie zachodzi dla następujących regut: $(C u t),(W \Rightarrow),(\Rightarrow W),(\rightarrow \Rightarrow),(\wedge \Rightarrow),(\Rightarrow \vee)$ 
DowóD: Podamy dwa przypadki.

Przypadek $(\wedge \Rightarrow)$ : Aby pokazać, że choć $=\varphi \wedge \psi, \Gamma \Rightarrow \Delta$, to $\not \models \varphi, \Gamma \Rightarrow \Delta$, wystarczy rozważyć $\mathfrak{M}$ falsyfikujaccy $\varphi, \Gamma \Rightarrow \Delta$ i przyjąć, że $\mathfrak{M} \not \models \psi$, wtedy $\mathfrak{M} \not \models \varphi \wedge \psi$ i $\mathfrak{M} \vDash \varphi \wedge \varphi, \Gamma \Rightarrow \Delta$. Analogicznie dla $\psi, \Gamma \Rightarrow \Delta$.

Przypadek $(\rightarrow \Rightarrow)$ : Podobnie, niech $\mathfrak{M} \not \models \Gamma \Rightarrow \Delta, \varphi$, czyli $\mathfrak{M} \vDash \Gamma$ i $\mathfrak{M} \not \models$ $\Delta, \varphi$. Wystarczy przyjaćc, że jakiś element $\Pi$ jest $\mathrm{w} \mathfrak{M}$ fałszywy lub jakiś element $\Sigma$ prawdziwy aby $\mathfrak{M} \vDash \varphi \rightarrow \psi, \Gamma, \Pi \Rightarrow \Delta, \Sigma$. Analogicznie dla drugiej przesłanki $\psi, \Pi \Rightarrow \Sigma$.

Ponieważ odwracalność zachodzi dla wszystkich reguł pozostałych (włączając w to (Cut) w wersji k-jednolitej) więc sformułujemy to jako specyficzną własność LK-K.

Lemat 4.7 (o odwracalności (semantycznej) reguł w LK-K) $W L K$ $K$ dla każdej reguły oprócz osłabiania, jeżeli wniosek jest tautologiczny, to przesłanki też.

DowóD: Podamy dla porównania dwa przypadki reguł, które zastąpiły w LK-K analizowane powyżej reguły Gentzena.

Przypadek $(\wedge \Rightarrow)$ w wersji Ketonena: Załóżmy, że $\models \varphi \wedge \psi, \Gamma \Rightarrow \Delta$, ale $\not=\varphi, \psi, \Gamma \Rightarrow \Delta$. Wtedy istnieje $\mathfrak{M}$ falsyfikujący $\varphi, \psi, \Gamma \Rightarrow \Delta$, ale falsyfikuje on również $\varphi \wedge \psi, \Gamma \Rightarrow \Delta$ gdyż $\mathfrak{M} \vDash \varphi \wedge \psi$, skoro $\mathfrak{M} \vDash \varphi$ i $\mathfrak{M} \vDash \psi$. Sprzeczność.

Przypadek $(\rightarrow \Rightarrow)$ w wersji k-jednolitej: Załóżmy, że $=\varphi \rightarrow \psi, \Gamma \Rightarrow \Delta$ ale $\not \models \Gamma \Rightarrow \Delta, \varphi$ lub $\not \models \psi, \Gamma \Rightarrow \Delta$. W pierwszym przypadku pewien $\mathfrak{M} \vDash \Gamma \mathrm{i}$ $\mathfrak{M} \not \models \Delta, \varphi$. Wtedy jednak $\mathfrak{M} \vDash \varphi \rightarrow \psi$, a to powoduje, że $\mathfrak{M} \not \models \varphi \rightarrow \psi, \Gamma \Rightarrow \Delta$ - sprzeczność. Analogicznie dla drugiej przesłanki $\psi, \Gamma \Rightarrow \Delta$.

Lemat 4.8 (o odwracalności (syntaktycznej) reguł w LK-K) W LK$K$ dla każdej reguły oprócz osłabiania, jeżeli wniosek ma dowód, to przesłanki té

DowóD: Pokażemy dowód dla (Cut) oraz obu reguł z $\wedge$ :

Przypadek (Cut): Każda z przesłanek da się wydedukować przez zastosowanie (W) do wniosku. Oczywiście dotyczy to tylko (Cut) w wersji kjednolitej.

Przypadek $(\wedge \Rightarrow)$

$$
(\Rightarrow \wedge) \frac{\frac{\varphi \Rightarrow \varphi \quad \psi \Rightarrow \psi}{\varphi, \psi \Rightarrow \varphi \wedge \psi}}{\frac{\frac{\varphi \wedge \psi, \Gamma \Rightarrow \Delta}{\varphi, \psi, \Gamma \Rightarrow \Delta, \varphi \wedge \psi}}{\varphi(\varphi \wedge \psi, \varphi, \psi, \Gamma \Rightarrow \Delta}} \text { (Cut) }
$$


Przypadek $(\Rightarrow \wedge)$

$$
\begin{gathered}
(\Rightarrow W) \frac{\frac{\varphi \Rightarrow \varphi}{\psi, \varphi \Rightarrow \varphi}(W \Rightarrow)}{\Gamma \Rightarrow \Delta, \varphi \wedge \psi}(P \Rightarrow) \\
(\Rightarrow P) \frac{\frac{\frac{\varphi}{\varphi, \psi \Rightarrow \varphi}}{\Gamma \Rightarrow \Delta, \varphi \wedge \psi, \varphi}}{\frac{\varphi \wedge \psi \Rightarrow \varphi}{\Gamma \Rightarrow \Delta, \varphi, \varphi \wedge \psi}} \quad \frac{\frac{\varphi)}{\varphi \wedge \psi, \Gamma \Rightarrow \Delta, \varphi}}{\Gamma \Rightarrow \Delta, \varphi}(C u t)
\end{gathered}
$$

Analogicznie dla drugiej przesłanki $(\Gamma \Rightarrow \Delta, \psi) \mathrm{w}(\Rightarrow \wedge)$. Dla innych reguł w podobny sposób.

Zauważmy, że w LK-K tylko osłabianie jest nieodwracalne. Jeżeli się go pozbędziemy wprowadzając aksjomaty uogólnione postaci $\Gamma, \varphi \Rightarrow \Delta, \varphi$, to syntaktyczny dowód odwracalności wielu reguł w takiej postaci w jakiej podaliśmy go wyżej, tj. z użyciem (W), stanie się problematyczny. W szczególności, jak pokazaliśmy, syntaktyczny dowód odwracalności (Cut) bazował wyłącznie na użyciu (W). Jak pokażemy jednak w następnym podrozdziale jest możliwe uzyskanie wariantu RS z uogólnionymi aksjomatami i bez osłabiania oraz bez (Cut), który będzie systemem w pełni odwracalnym.

Uwaga 4.2: Odnotujmy, że syntaktyczny dowód odwracalności reguł przeprowadzony przy użyciu (Cut) sprowadza się do wykazania, że konwersy odwracalnych reguł są wyprowadzalne w LK-K. Warto porównać to z dowodem przedstawionym w podrozdziale 4.3 , gdzie wrócimy do problemu odwracalności reguł, ale w sytuacji braku reguły (Cut) jako pierwotnej.

Warto odnotować przy okazji dowodu poprzedniego lematu, dowiedlność kilku sekwentów, które będziemy dalej wykorzystywać. Pojawiają się one jako sekwenty wyprowadzalne z aksjomatów, a nie z przesłanek.

Fakt 4.1 W LK dowiedlne sa następujace sekwenty:

- $\varphi \Rightarrow \neg \neg \varphi$

- $\neg \neg \varphi \Rightarrow \varphi$

- $\varphi \wedge \psi \Rightarrow \varphi$

- $\varphi \wedge \psi \Rightarrow \psi$

- $\varphi, \psi \Rightarrow \varphi \wedge \psi$ 
- $\varphi \Rightarrow \varphi \vee \psi$

- $\psi \Rightarrow \varphi \vee \psi$

- $\varphi \vee \psi \Rightarrow \varphi, \psi$

- $\varphi \rightarrow \psi, \varphi \Rightarrow \psi$

- $\neg \psi, \varphi \rightarrow \psi \Rightarrow \neg \varphi$

- $\Rightarrow \varphi, \varphi \rightarrow \psi$

- $\psi \Rightarrow \varphi \rightarrow \psi$

Uważny czytelnik, który dowiódł wszystkie aksjomaty w lemacie 3.3 z pewnością mógł odnotować dowiedlność tych sekwentów już wtedy.

\subsection{Eliminacja reguł strukturalnych}

Jak widać w przypadku samego LK, który jest przykładem c-systemu można przez modyfikację reguł otrzymać wiele wariantów, oprócz LK-K również M-wariant (multiplikatywny) lub A-wariant (addytywny). W każdej wersji można też przyjąc którąś z czterech form aksjomatów, choć - ze względu na obecność (W) - niezbędne są tylko formy proste. Nie chodzi nam jednak tylko o kombinatoryczne wytwarzanie coraz to nowych systemów. Racja wprowadzenia nowych wersji RS musi być ich przydatność do pełnienia pewnych funkcji. Np. jedne wersje lepiej się nadają do tego, żeby udowadniać dla nich pewne metalogiczne wyniki, inne jako praktyczne systemy poszukiwania dowodów itd. Stąd też wyodrębnimy tylko takie warianty, które znajdą później zastosowania.

Wszystkie wymienione wyżej wersje LK są równoważne i stanowią odmiany wariantu ogólnego, czyli takiego, w którym mamy obecność zarówno reguł strukturalnych jak i logicznych. W paragrafie 2.2 .2 wspominaliśmy o wariantach logicznym i strukturalnym RS. Wariant strukturalny scharakteryzujemy w rozdziale 10, gdzie omówimy pozostałe typy RS. Teraz bardziej interesujący będzie dla nas wariant logiczny, w którym udział reguł strukturalnych jest wyeliminowany. $\mathrm{W}$ tym celu przejdziemy do innych alternatyw RS jakimi sa m-systemy i z-systemy (sekwenty definiowane na multizbiorach/zbiorach). Zauważmy, że zmiana ciągów na multizbiory automatycznie prowadzi do eliminacji reguł permutacji, a na zbiory dodatkowo eliminuje kontrakcję. W tej ostatniej alternatywie, jeżeli przyjmiemy aksjomaty uogólnione, to dodatkowo możemy wyeliminować (W), a ponieważ (Cut) też jest 
eliminowalne, co wykażemy w rozdziale 5 , więc otrzymujemy wariant logiczny bez reguł strukturalnych. Dodatkowo, po przyjęciu wariantów reguł Ketonena mamy też pełną semantyczną odwracalność reguł, co czyni taki system bardzo przydatnym w praktyce. Wyprzedzając rozważania z rozdziału 6 nazwiemy ten system analitycznym RS (ARS). Oto jego reguły:

$$
\begin{array}{lr}
(U A X) \Gamma, \varphi \Rightarrow \varphi, \Delta & \\
(\neg \Rightarrow) \frac{\Gamma \Rightarrow \Delta, \varphi}{\neg \varphi, \Gamma \Rightarrow \Delta} & (\Rightarrow \neg) \frac{\varphi, \Gamma \Rightarrow \Delta}{\Gamma \Rightarrow \Delta, \neg \varphi} \\
(\wedge \Rightarrow) \frac{\varphi, \psi, \Gamma \Rightarrow \Delta}{\varphi \wedge \psi, \Gamma \Rightarrow \Delta} & (\Rightarrow \wedge) \frac{\Gamma \Rightarrow \Delta, \varphi \quad \Gamma \Rightarrow \Delta, \psi}{\Gamma \Rightarrow \Delta, \varphi \wedge \psi} \\
(\Rightarrow \vee) \frac{\Gamma \Rightarrow \Delta, \varphi, \psi}{\Gamma \Rightarrow \Delta, \varphi \vee \psi} & (\vee \Rightarrow) \frac{\varphi, \Gamma \Rightarrow \Delta \quad \psi, \Gamma \Rightarrow \Delta}{\varphi \vee \psi, \Gamma \Rightarrow \Delta} \\
(\Rightarrow \rightarrow) \frac{\varphi, \Gamma \Rightarrow \Delta, \psi}{\Gamma \Rightarrow \Delta, \varphi \rightarrow \psi} & (\rightarrow \Rightarrow) \frac{\Gamma \Rightarrow \Delta, \varphi \quad \psi, \Gamma \Rightarrow \Delta}{\varphi \rightarrow \psi, \Gamma \Rightarrow \Delta}
\end{array}
$$

Definicje dowodu, dedukcji itp. bez zmian, jak dla LK.

Uwaga 4.3: W ARS brak jest reguł strukturalnych (w tym (Cut)!), lecz teraz ;itery $\Gamma, \Delta$ oznaczają niekoniecznie zbiory. Jak pokażemy niżej, ten sam zestaw reguł, ale podany jako m-system, też jest adekwatną formalizacją KRZ. Ma to ważne konsekwencje, gdyż w wielu przypadkach multizbiory są wygodniejszym obiektem syntaktycznych operacji niż zbiory, a ponadto m-systemy pozwalają na formalizację wielu logik nieklasycznych, np. podstrukturalnych (por. uwaga 4.1), dla których z-systemy są niewystarczające. Tam gdzie w grę będzie wchodziło rozróżnienie obu alternatyw ARS będziemy pisać odpowiednio z-ARS lub m-ARS. Zauważmy jednak, że aby wykazać adekwatność m-ARS musimy udowodnić dopuszczalność kontrakcji, co zrobimy niżej.

Uwaga 4.4: Można skonstruować również wersję ARS, która jest c-systemem (np. system w Gallier [48]). Jest to o tyle istotne, że operowanie c-sekwentami bywa wygodniejsze w przypadku zastosowań RS na potrzeby automatycznej dedukcji, gdyż ciągi są z punktu widzenia implementacji wygodniejszymi strukturami danych do przetwarzania. W tym celu trzeba przeformułowć reguły tak by wykluczyć potrzebę stosowania (P). Aby osiągnąć taki efekt należy zarówno formuły poboczne jak i formułę główną umieścić w schemacie w neutralny sposób, a nie na skraju poprzednika czy następnika. Dla przykładu reguły dla $\neg \mathrm{i} \wedge$ wyglądają następująco:

$$
(\neg \Rightarrow) \frac{\Pi, \Gamma \Rightarrow \varphi, \Delta}{\Pi, \neg \varphi, \Gamma \Rightarrow \Delta} \quad(\Rightarrow \neg) \frac{\varphi, \Gamma \Rightarrow \Delta, \Sigma}{\Gamma \Rightarrow \Delta, \neg \varphi, \Sigma}
$$




$$
(\wedge \Rightarrow) \frac{\Pi, \varphi, \psi, \Gamma \Rightarrow \Delta}{\Pi, \varphi \wedge \psi, \Gamma \Rightarrow \Delta} \quad(\Rightarrow \wedge) \quad \frac{\Gamma \Rightarrow \Delta, \varphi, \Sigma \quad \Gamma \Rightarrow \Delta, \psi, \Sigma}{\Gamma \Rightarrow \Delta, \varphi \wedge \psi, \Sigma}
$$

Oczywiście, każdy z ciągów parametrów w schemacie może być pusty. Przy tak zdefiniowanych regułach, jeżeli zadamy pewien porządek stosowania reguł na formułach, np. od lewej do prawej, to mamy gwarancję, że do każdej złożonej formuły w pewnym momencie zostanie zastosowana reguła, a otrzymane formuły poboczne zostaną wzięte pod uwagę w następnej fazie procedury szukania dowodu (por. podrozdział 6.2).

Zauważmy też, że dowolne alternatywy ARS mogą występować z aksjomatem uogólnionym z $\varphi$ dowolnym (wersja lepsza dla praktycznych zastosowań) lub atomowym (wersja wygodniejsza dla dowodów dopuszczalności rozmaitych reguł, w tym (Cut)). W zależności od potrzeb będziemy wybierali w dalszym ciągu jedną z wersji. Ich równoważność wynika z twierdzenia 4.1 .

Ustalimy teraz szereg interesujących własności ARS.

Twierdzenie 4.2 (Adekwatność) $\vdash_{A R S} \Gamma \Rightarrow \Delta w t w \models \Gamma \Rightarrow \Delta$.

DowóD: Przystosowanie wynika z lematu 3.6. Co do pełności, to nie możemy odwołać się do lematu 3.3., gdyż w jego dowodzie wykorzystywaliśmy (Cut), które nie należy do zestawu reguł pierwotnych ARS. Wprawdzie w rozdziale 5 dowiedziemy twierdzenie o dopuszczalności (Cut) w ARS i w ten sposób pośrednio uzyskamy dowód twierdzenia o pełności, to jednak już tutaj wykażemy ten rezultat bezpośrednio w prosty sposób przez odwołanie się do semantycznej odwracalności wszystkich reguł ARS (lemat 4.7). W tym celu udowodnimy lemat, który dodatkowo ustala nam górne ograniczenia dla wielkości dowodów w ARS.

Lemat 4.9 (Pełność ARS) Jeżeli $\models \Gamma \Rightarrow \Delta i w \Gamma \Rightarrow \Delta$ jest $n$ wystapień stałych logicznych, to $\vdash \Gamma \Rightarrow \Delta$ i istnieje dowód $\mathcal{D}$ dla $\Gamma \Rightarrow \Delta$ taki, że $\|\mathcal{D}\|$ $<2^{n}$

Dowód: Przez indukcję po $n$.

Baza: $n=0$ oznacza, że $\Gamma \Rightarrow \Delta$ jest sekwentem atomowym, a skoro jest tautologia, to jest aksjomatem z dowodem o wielkości 0 .

Założenie indukcyjne mówi, że lemat zachodzi dla dowolnego $\Gamma^{\prime} \Rightarrow \Delta^{\prime}$ o ilości stałych $<n$. Pokazujemy, że zajdzie również dla sekwentu zawierającego $n$ stałych. Musimy rozważyć przypadki wszystkich formuł złożonych w $\Gamma \Rightarrow \Delta$. Rozważymy przypadek koniunkcji. 
$\varphi \wedge \psi$ w poprzedniku. Zatem $\Gamma \Rightarrow \Delta:=\varphi \wedge \psi, \Gamma^{\prime} \Rightarrow \Delta$. Z odwracalności mamy, że $=\varphi, \psi, \Gamma^{\prime} \Rightarrow \Delta$, a ponieważ sekwent ten ma $n-1$ stałych więc podpada pod założenie indukcyjne, zatem $\vdash \varphi, \psi, \Gamma^{\prime} \Rightarrow \Delta$ i $\|\mathcal{D}\|<2^{n-1}$. Dodajac do $\mathcal{D}, \varphi \wedge \psi, \Gamma^{\prime} \Rightarrow \Delta$ jako kolejny sekwent uzyskany przez $(\wedge \Rightarrow)$ otrzymujemy dowód $\mathcal{D}^{\prime}$ tegoż sekwentu taki, że $\left\|\mathcal{D}^{\prime}\right\|<2^{n-1}+1 \leq 2^{n}$.

$\varphi \wedge \psi$ w następniku. Zatem $\Gamma \Rightarrow \Delta:=\Gamma \Rightarrow \Delta^{\prime}, \varphi \wedge \psi$. Z odwracalności mamy, że zarówno $\models \Gamma \Rightarrow \Delta^{\prime}, \varphi$ jak i $\models \Gamma \Rightarrow \Delta^{\prime}, \psi$. a ponieważ każdy z tych sekwentów ma $n-1$ stałych, więc podpada pod założenie indukcyjne i ma dowód $\|\mathcal{D}\|<2^{n-1}$. Do obu dowodów dodajemy $\Gamma \Rightarrow \Delta^{\prime}, \varphi \wedge \psi$ uzyskany przez $(\Rightarrow \wedge)$ i otrzymujemy dowód $\mathcal{D}^{\prime}$ tegoż sekwentu taki, że $\left\|\mathcal{D}^{\prime}\right\|<2^{n}$, gdyż dla dowolnych $i, j<2^{n-1}, i+j+1<2^{n}$.

Dla dalszych zastosowań przydatne jest udowodnienie następującego lematu

Lemat 4.10 (Dopuszczalność osłabiania) Jeżeli $\vdash_{A R S} \Gamma^{\prime} \Rightarrow \Delta^{\prime}, t_{o} \vdash_{A R S}$ $\Gamma \Rightarrow \Delta$, dla $\Gamma^{\prime} \subseteq \Gamma, \Delta^{\prime} \subseteq \Delta$, ponadto długość dowodu nie jest większa.

DowóD indukcyjny po długości dowodu $\Gamma^{\prime} \Rightarrow \Delta^{\prime}$.

Baza: Dowód $\Gamma^{\prime} \Rightarrow \Delta^{\prime}$ ma długość 0 , zatem jest to aksjomat. Więc $\Gamma \Rightarrow \Delta$ też jest aksjomatem o dowodzie długości 0 .

Założenie indukcyjne mówi, że lemat zachodzi dla dowolnego dowodu $\Gamma^{\prime} \Rightarrow \Delta^{\prime}$ o długości $<n$. Pokazujemy, że zajdzie również, gdy dowód ma długość $n$.

Musimy rozważyć przypadki zastosowania wszystkich reguł do uzyskania $\Gamma^{\prime} \Rightarrow \Delta^{\prime}$. Rozważmy przypadek $(\wedge \Rightarrow)$.

Mamy zatem dowód $\mathcal{D}$ długości $n$ zakończony sekwentem $\varphi \wedge \psi, \Gamma^{\prime \prime} \Rightarrow$ $\Delta^{\prime}:=\Gamma^{\prime} \Rightarrow \Delta^{\prime}\left(\Gamma^{\prime}=\Gamma^{\prime \prime} \cup\{\varphi \wedge \psi\}\right)$. Przesłanka $\varphi, \psi, \Gamma^{\prime \prime} \Rightarrow \Delta^{\prime}$ ma dowód długości $n-1$ zatem podpada pod założenie indukcyjne, czyli $\varphi, \psi, \Gamma^{\prime \prime}, \Pi \Rightarrow$ $\Delta$, gdzie $\Pi=\Gamma-\Gamma^{\prime}$, ma dowód tej samej długości, tj. $n-1$. Przez $(\wedge \Rightarrow)$ otrzymujemy $\varphi \wedge \psi, \Gamma^{\prime \prime}, \Pi \Rightarrow \Delta:=\Gamma \Rightarrow \Delta$; dowód ma długość $n$.

Uwaga 4.5: Można przeprowadzić dowód dopuszczalności (W) w ARS w inny, bardziej bezpośredni sposób przez odwołanie się do pewnej własności reguł ARS, zwanej niezależnością kontekstową (por. podrozdział 4.5), a przez Avrona [7] 'czystością' reguł, a sprowadzającej się do tego, że żadna reguła nie wprowadza warunków ograniczających na kształt parametrów. Wobec tego, jeśli mamy dowód $\Gamma \Rightarrow \Delta$, to zawsze można go przerobić na dowód (tej samej długości) dla $\varphi, \Gamma \Rightarrow \Delta$ lub $\Gamma \Rightarrow \Delta, \varphi$ przez dopisanie $\varphi$ do każdego sekwentu $\mathrm{w}$ dowodzie w poprzedniku lub następniku. Niestety w RS dla innych logik, np. modalnych wiele reguł nie posiada tej własności. 
Dla dowiedzenia dopuszczalności kontrakcji w m-ARS potrzebujemy dowodu syntaktycznej odwracalności reguł logicznych. Oczywiście nie możemy skorzystać z lematu 4.8 o odwracalności reguł dla LK-K, gdyż tamten był dowiedziony przy użyciu (Cut), a w ARS jej nie posiadamy. Na szczęście można dowieść tego samego rezultatu bez użycia (Cut) dla wariantu z aksjomatami, w których formuła po obu stronach $\Rightarrow$ jest atomowa. Dowód podany niżej jest $\mathrm{w}$ istocie dowodem dopuszczalności konwersu każdej reguły pierwotnej ARS, w przeciwieństwie do dowodu lematu 4.8, w którym wykazaliśmy ich wyprowadzalność ale przy użyciu (Cut) (por. uwaga 4.2). Dowód dopuszczalności jest o wiele bardziej skomplikowany, ale przy okazji możemy też wykazać, że dowody przesłanek są nie dłuższe od dowodów wniosków. Dla odróżnienia od lematu 4.8 poniższy wynik określimy nazwą lematu o inwersji. Dla obu lematów (o inwersji i dopuszczalności kontrakcji) również przeprowadzimy dowód indukcyjny po długości dowodu.

Lemat 4.11 (o inwersji reguł ARS) Dla każdej reguły, jeżeli wniosek ma dowód (długości $n$ ), to przesłanki też maja dowody (długości $\leq n$ ).

DowóD: Przeprowadzimy dowód indukcyjny po długości dowodu sekwentuwniosku. Wymaga on rozpatrzenia każdej reguły z osobna. Rozważmy obie reguły dla $\wedge$.

Baza: Dowód wniosku ma długość 0, zatem jest to aksjomat. Niech to będzie np. $\varphi \wedge \psi, \Gamma \Rightarrow \Delta$, gdzie pewne $\chi \in \Gamma \cap \Delta . \chi \neq \varphi \wedge \psi$, gdyż jest formułą atomową, ale wtedy $\varphi, \psi, \Gamma \Rightarrow \Delta$ też jest aksjomatem. Podobnie gdy $\Gamma \Rightarrow \Delta, \varphi \wedge \psi$ ma dowód długości 0 , wtedy zarówno $\Gamma \Rightarrow \Delta, \varphi$ jak i $\Gamma \Rightarrow \Delta, \psi$ są dowiedlne, jako aksjomaty (analogicznie postępujemy w dowodzie bazy dla innych przypadków reguł).

Założenie indukcyjne mówi, że lemat zachodzi dla dowolnego dowodu wniosku o długości $<n$. Pokazujemy, że zajdzie również gdy dowód ma długość $n$.

Rozważmy przypadek $(\wedge \Rightarrow)$. Mamy zatem dowód $\mathcal{D}$ długości $n$ zakończony sekwentem $S:=\varphi \wedge \psi, \Gamma \Rightarrow \Delta$. Należy rozważyć 2 podprzypadki:

a. $\varphi \wedge \psi$ jest formułą zasadniczą $S$

b. $\varphi \wedge \psi$ nie jest formułą zasadniczą $S$

Jeżeli ostatnia reguła to $(\wedge \Rightarrow) \mathrm{z} \varphi \wedge \psi$ jako formułą zasadniczą, to po obcięciu ostatniego sekwentu z $\mathcal{D}$ mamy dowód $\varphi, \psi, \Gamma \Rightarrow \Delta$ (długości $n-1)$.

Rozważmy przypadek $(\wedge \Rightarrow)$, podprzypadek b. Jeżeli $\varphi \wedge \psi$ nie jest formułą zasadniczą $S$, to jest formułą parametryczną. Przykładowo, jeżeli ostatnio zastosowana reguła była 2-przesłankowa, to $\mathcal{D}$ kończy się następująco: 


$$
\frac{\varphi \wedge \psi, \Gamma^{\prime} \Rightarrow \Delta^{\prime} \quad \varphi \wedge \psi, \Gamma^{\prime \prime} \Rightarrow \Delta^{\prime \prime}}{\varphi \wedge \psi, \Gamma \Rightarrow \Delta}
$$

Ponieważ dowody obu przesłanek mają długość $<n$, to podpadają pod założenie indukcyjne. Zatem mamy dowody sekwentów $\varphi, \psi, \Gamma^{\prime} \Rightarrow \Delta^{\prime}$ i $\varphi, \psi, \Gamma^{\prime \prime} \Rightarrow$ $\Delta^{\prime \prime}$. Ale wtedy za pomocą tej samej reguły 2-przesłankowej, która kończyła $\mathcal{D}$ wydedukujemy z nich sekwent $\varphi, \psi, \Gamma \Rightarrow \Delta$.

Podobnie gdy $\Gamma \Rightarrow \Delta, \varphi \wedge \psi$ ma dowód długości $n$ oraz dla przypadków innych reguł.

Na koniec dowiedziemy (dla m-ARS)

Lemat 4.12 (Dopuszczalność kontrakcji) Jeżeli $\vdash_{A R S} \varphi, \varphi, \Gamma \Rightarrow \Delta$, to $\vdash_{A R S} \varphi, \Gamma \Rightarrow \Delta$, oraz jeżeli $\vdash_{A R S} \Gamma \Rightarrow \Delta, \varphi, \varphi$, to $\vdash_{A R S} \Gamma \Rightarrow \Delta, \varphi$, ponadto dtugość dowodu nie jest większa.

DowóD: Przeprowadzimy dowód indukcyjny po długości dowodu $\varphi, \varphi, \Gamma \Rightarrow$ $\Delta$ (dla $\Gamma \Rightarrow \Delta, \varphi, \varphi$ analogicznie)

Baza: $\varphi, \varphi, \Gamma \Rightarrow \Delta$ ma dowód długości 0 , zatem jest aksjomatem i bez względu na to czy $\psi \in(\Gamma \cup\{\varphi\}) \cap \Delta$ jest identyczne z $\varphi$ czy nie, to $\varphi, \Gamma \Rightarrow \Delta$ też jest aksjomatem.

Założenie indukcyjne mówi, że lemat zachodzi dla dowolnego dowodu wniosku o długości $<n$. Pokazujemy, że zajdzie również gdy dowód ma długość $n$. Należy rozważyć 2 podprzypadki:

a. $\varphi$ nie jest formułą zasadniczą

b. $\varphi$ jest formuła zasadniczą

Jeżeli $\varphi$ nie jest formułą zasadniczą w dowodzonym sekwencie, to $\varphi, \varphi, \Gamma \Rightarrow$ $\Delta$ został wydedukowany z $\varphi, \varphi, \Gamma^{\prime} \Rightarrow \Delta^{\prime}$ przez regułę jednoprzesłankową lub dodatkowo z $\varphi, \varphi, \Gamma^{\prime \prime} \Rightarrow \Delta^{\prime \prime}$ przez regułę dwuprzesłankową. W każdym przypadku przesłanki podpadają pod założenia indukcyjne, zatem $\varphi, \Gamma^{\prime} \Rightarrow \Delta^{\prime}$ (i $\varphi, \Gamma^{\prime \prime} \Rightarrow \Delta^{\prime \prime}$ ) mają dowody długości mniejszej od $n$ skąd przez zastosowanie tej samej reguły jedno (lub dwu) przesłankowej dostajemy dowód $\varphi, \Gamma \Rightarrow \Delta$ o długości co najwyżej $n$.

Jeżeli $\varphi$ jest formułą zasadniczą $\mathrm{w}$ dowodzonym sekwencie, to musimy rozważyć wszystkie przypadki formy $\varphi$. Niech $\varphi:=\psi \wedge \chi$. Wtedy rozważany sekwent ma postać $\psi \wedge \chi, \psi \wedge \chi, \Gamma \Rightarrow \Delta$, a przesłanka postać $\psi, \chi, \psi \wedge$ $\chi, \Gamma \Rightarrow \Delta$ i dowód długości $n-1$. Z lematu poprzedniego (o odwracalności) $\psi, \chi, \psi, \chi, \Gamma \Rightarrow \Delta$ też ma dowód o długości nie większej od $n-1$. Z założenia indukcyjnego zastosowanego dwukrotnie mamy dowód $\psi, \chi, \Gamma \Rightarrow \Delta$ 
o długości nie większej od $n-1$. Zatem przez $(\wedge \Rightarrow)$ otrzymujemy dowód $\psi \wedge \chi, \Gamma \Rightarrow \Delta$ o długości nie większej od $n$.

Analogicznie dla $\varphi$ postaci $\neg \psi, \psi \vee \chi, \psi \rightarrow \chi$.

Uwaga 4.6: Odnotujmy, że aby można było dowieść, że kontrakcja jest dopuszczalna $\mathrm{w}$ jakimś wariancie m-RS, to konieczne jest, aby wszystkie dwuprzesłankowe reguły były w nim k-jednolite. W każdym m-RS z regułami k-niezależnymi kontrakcja musi być regułą pierwotną.

\subsection{Równoważność reguł}

Wielokrotnie już udowadnialiśmy równoważność pewnych reguł. Co więcej, w rozdziale 10 zaprezentujemy dalsze warianty RS, które też będą wymagały wykazania ich adekwatności względem KRK, co w przypadku syntaktycznych dowodów równoważności wymaga wykazania wzajemnej wyprowadzalności reguł. Można postawić pytanie czy nie istnieją jakieś ogólne metody szybkiego sprawdzania takich własności opartego na ogólnej strukturze reguł. Poniżej udowodnimy dwa lematy, które dają częściową pozytywną odpowiedź na nasze pytanie, gdyż zestawiają równoważne schematy reguł sekwentowych i sekwentów. Pierwszy z nich ma charakter dość szczegółowy, gdyż dotyczy równoważników regułowych dla sekwentów postaci $\varphi \Rightarrow \psi, \varphi, \psi \Rightarrow \chi$ oraz $\varphi \Rightarrow \psi, \chi$. Biorąc pod uwagę, że większość rozważanych przez nas reguł nie wykracza poza schemat: jedna formuła zasadnicza i jedna lub dwie poboczne, to wynik ten w praktyce jest wystarczający dla naszych potrzeb i bardzo przydatny zarówno w szybkim uzyskiwaniu twierdzeń o równoważności dla różnych systemów RS, jak i w generowaniu nowych wariantów o określonych własnościach. Tym niemniej sformułujemy uogólnienie tego szczegółowego wyniku dla reguł równoważnych dowolnemu skończonemu sekwentowi. Dla uproszczenia dowodów przyjmujemy, że operujemy z-sekwentami, a reguły wieloprzesłankowe podajemy w wersji k-niezależnej. Jednakże te same rezultaty zachodzą dla reguł k-jednolitych oraz, przy nieznacznych modyfikacjach (użycie kontrakcji, osłabień), dla reguł zdefiniowanych na c- i m-sekwentach.

Lemat 4.13 Podane nizej w trzech grupach schematy sekwentów i reguł sekwentowych sa wzajemnie wyprowadzalne:

1. $\varphi \Rightarrow \psi$

2. $\psi, \Gamma \Rightarrow \Delta / \varphi, \Gamma \Rightarrow \Delta$ 
3. $\Gamma \Rightarrow \Delta, \varphi / \Gamma \Rightarrow \Delta, \psi$
4. $\Gamma \Rightarrow \Delta, \varphi ; \psi, \Gamma^{\prime} \Rightarrow \Delta^{\prime} / \Gamma, \Gamma^{\prime} \Rightarrow \Delta, \Delta^{\prime}$

$B$

1. $\varphi, \psi \Rightarrow \chi$

2. $\chi, \Gamma \Rightarrow \Delta / \varphi, \psi, \Gamma \Rightarrow \Delta$

3. $\Gamma \Rightarrow \Delta, \varphi / \psi, \Gamma \Rightarrow \Delta, \chi$

4. $\Gamma \Rightarrow \Delta, \psi / \varphi, \Gamma \Rightarrow \Delta, \chi$

5. $\Gamma \Rightarrow \Delta, \varphi ; \Gamma^{\prime} \Rightarrow \Delta^{\prime}, \psi / \Gamma, \Gamma^{\prime} \Rightarrow \Delta, \Delta^{\prime}, \chi$

6. $\Gamma \Rightarrow \Delta, \varphi ; \chi, \Gamma^{\prime} \Rightarrow \Delta^{\prime} / \psi, \Gamma, \Gamma^{\prime} \Rightarrow \Delta, \Delta^{\prime}$

7. $\Gamma \Rightarrow \Delta, \psi ; \chi, \Gamma^{\prime} \Rightarrow \Delta^{\prime} / \varphi, \Gamma, \Gamma^{\prime} \Rightarrow \Delta, \Delta^{\prime}$

8. $\Gamma \Rightarrow \Delta, \varphi ; \Gamma^{\prime} \Rightarrow \Delta^{\prime}, \psi ; \chi, \Pi \Rightarrow \Sigma / \Gamma, \Gamma^{\prime}, \Pi \Rightarrow \Delta, \Delta^{\prime}, \Sigma$

C

1. $\varphi \Rightarrow \psi, \chi$

2. $\Gamma \Rightarrow \Delta, \varphi / \Gamma \Rightarrow \Delta, \psi, \chi$

3. $\psi, \Gamma \Rightarrow \Delta / \varphi, \Gamma \Rightarrow \Delta, \chi$

4. $\chi, \Gamma \Rightarrow \Delta / \varphi, \Gamma \Rightarrow \Delta, \psi$

5. $\psi, \Gamma \Rightarrow \Delta ; \chi, \Gamma^{\prime} \Rightarrow \Delta^{\prime} / \varphi, \Gamma, \Gamma^{\prime} \Rightarrow \Delta, \Delta^{\prime}$

6. $\Gamma \Rightarrow \Delta, \varphi ; \chi, \Gamma^{\prime} \Rightarrow \Delta^{\prime} / \Gamma, \Gamma^{\prime} \Rightarrow \Delta, \Delta^{\prime}, \psi$

7. $\Gamma \Rightarrow \Delta, \varphi ; \psi, \Gamma^{\prime} \Rightarrow \Delta^{\prime} / \Gamma, \Gamma^{\prime} \Rightarrow \Delta, \Delta^{\prime}, \chi$

8. $\Gamma \Rightarrow \Delta, \varphi ; \psi, \Gamma^{\prime} \Rightarrow \Delta^{\prime} ; \chi, \Pi \Rightarrow \Sigma / \Gamma, \Gamma^{\prime}, \Pi \Rightarrow \Delta, \Delta^{\prime}, \Sigma$

Dowód: Dla A.

1. $\Longrightarrow 2 .:$ Wystarczy zastosować (Cut) do 1 i przesłanki w 2 , by dostać wniosek.

2. $\Longrightarrow 3 .: \mathrm{Z}$ aksjomatu $\psi \Rightarrow \psi$ przez 2 otrzymujemy $\varphi \Rightarrow \psi$, które przez (Cut) z przesłanką w 3 daje wniosek.

3 . $\Longrightarrow 4$.: wyprowadzalność demonstruje poniższy schemat dowodu: 


$$
\frac{\Gamma \Rightarrow \Delta, \varphi \quad \text { (3.) } \frac{\varphi \Rightarrow \varphi}{\varphi \Rightarrow \psi} \quad \psi, \Gamma^{\prime} \Rightarrow \Delta^{\prime}}{\varphi, \Gamma^{\prime} \Rightarrow \Delta^{\prime}}(C u t)
$$

4. $\Longrightarrow 1 .: \mathrm{Z} \varphi \Rightarrow \varphi$ i $\psi \Rightarrow \psi$ przez 4 otrzymujemy 1 .

Dla B.

1. $\Longrightarrow 2 .:$ Wystarczy zastosować (Cut) do 1 i przesłanki 2 by dostać wniosek.

2. $\Longrightarrow 3 .:$ Z aksjomatu $\chi \Rightarrow \chi$ przez 2 otrzymujemy $\varphi, \psi \Rightarrow \chi$, które przez (Cut) z przesłanką w 3 daje wniosek.

3. $\Longrightarrow 4$.: analogicznie do poprzedniego, z 3 zastosowanym do $\varphi \Rightarrow \varphi$.

4. $\Longrightarrow 5$.: analogicznie do poprzedniego, $\mathrm{z}$ tym, że 4 zamiast do aksjomatu stosujemy do przesłanki w 5 postaci $\Gamma^{\prime} \Rightarrow \Delta^{\prime}, \psi$ by przez (Cut) na drugiej przesłance dostać wniosek.

$5 . \Longrightarrow 6 .:$ wyprowadzalność demonstruje poniższy schemat dowodu:

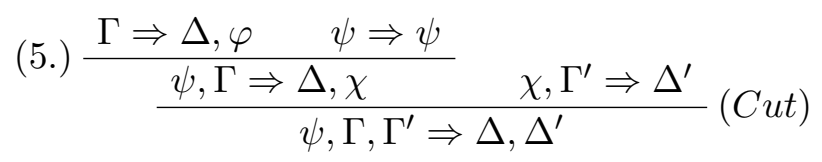

6. $\Longrightarrow 7 .:$ wyprowadzalność demonstruje poniższy schemat dowodu:

$$
\frac{\Gamma \Rightarrow \Delta, \psi \quad \frac{\varphi \Rightarrow \varphi \quad \chi, \Gamma^{\prime} \Rightarrow \Delta^{\prime}}{\psi, \varphi, \Gamma^{\prime} \Rightarrow \Delta^{\prime}}(C u t)}{\varphi, \Gamma, \Gamma^{\prime} \Rightarrow \Delta, \Delta^{\prime}}
$$

7. $\Longrightarrow 8 .:$ wyprowadzalność demonstruje poniższy schemat dowodu:

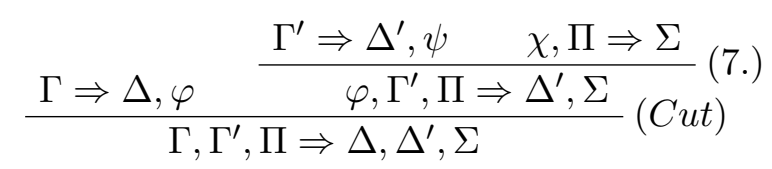

8. $\Longrightarrow 1 .: \mathrm{Z} \varphi \Rightarrow \varphi, \psi \Rightarrow \psi$ i $\chi \Rightarrow \chi$ przez 8 otrzymujemy 1 .

Dowód C dualnie do części B.

Zobaczmy na przykładzie $\vee$ jakie pożytki płyną z powyższego lematu. Jedna $\mathrm{z}$ reguł $(\Rightarrow \vee$ ) dla (addytywnej) alternatywy podpada pod schemat A.3., zatem równoważnie można użyć: 
A.1. $\varphi \Rightarrow \varphi \vee \psi$

A.2. $\varphi \vee \psi, \Gamma \Rightarrow \Delta / \varphi, \Gamma \Rightarrow \Delta$

lub

A.4. $\Gamma \Rightarrow \Delta, \varphi ; \varphi \vee \psi, \Gamma^{\prime} \Rightarrow \Delta^{\prime} / \Gamma, \Gamma^{\prime} \Rightarrow \Delta, \Delta^{\prime}$

Dla odmiany $(\vee \Rightarrow)$ podpada pod schemat C.5. $(\mathrm{z} \varphi:=\psi \vee \chi)$, co generuje następujące równoważniki:

C.1. $\psi \vee \chi \Rightarrow \psi, \chi$

C.2. $\Gamma \Rightarrow \Delta, \psi \vee \chi / \Gamma \Rightarrow \Delta, \psi, \chi$

C.3. $\psi, \Gamma \Rightarrow \Delta / \psi \vee \chi, \Gamma \Rightarrow \Delta, \chi$

C.4. $\chi, \Gamma \Rightarrow \Delta / \psi \vee \chi, \Gamma \Rightarrow \Delta, \psi$

C.6. $\Gamma \Rightarrow \Delta, \psi \vee \chi ; \chi, \Gamma^{\prime} \Rightarrow \Delta^{\prime} / \Gamma, \Gamma^{\prime} \Rightarrow \Delta, \Delta^{\prime}, \psi$

C.7. $\Gamma \Rightarrow \Delta, \psi \vee \chi ; \chi, \Gamma^{\prime} \Rightarrow \Delta^{\prime} / \Gamma, \Gamma^{\prime} \Rightarrow \Delta, \Delta^{\prime}, \chi$

C.8. $\Gamma \Rightarrow \Delta, \psi \vee \chi ; \psi, \Gamma^{\prime} \Rightarrow \Delta^{\prime} ; \chi, \Pi \Rightarrow \Sigma / \Gamma, \Gamma^{\prime}, \Pi \Rightarrow \Delta, \Delta^{\prime}, \Sigma$

Odwołując się do lematu 4.13 można np. wykazać równoważność podanych w paragrafie 1.2.1 trzech wersji MP, czy wyprowadzalność odpowiednich reguł Gentzena (por. paragraf 2.2.1) z równoważności charakteryzujacych koniunkcje podanych w podrozdziale 2.4 (odpowiednio B.2. i B.5. w przypadku koniunkcji multiplikatywnej, i A.1. z A.2. dla koniunkcji addytywnej.). Można też z podanego lematu łatwo otrzymać dowód, że dwie równoważnościowe charakterystyki spójników podane w podrozdziale 2.4. są sobie równoważne.

Podamy teraz uogólnienie wyniku z poprzedniego lematu.

Lemat 4.14 Dla dowolnego sekwentu postaci $\Gamma \Rightarrow \Delta$, gdzie $\Gamma=\left\{\varphi_{1}, \ldots, \varphi_{k}\right\}$ $a \Delta=\left\{\psi_{1}, \ldots, \psi_{n}\right\}, k \geq 0, n \geq 0$, istnieje $2^{k+n}-1$ równoważnych regut podpadajacych pod ogólny schemat:

$$
\frac{\Pi_{1}, \Rightarrow \Sigma_{1}, \varphi_{1}, \ldots, \Pi_{i} \Rightarrow \Sigma_{i}, \varphi_{i} \quad \psi_{1}, \Pi_{i+1} \Rightarrow \Sigma_{i+1}, \ldots, \psi_{j}, \Pi_{i+j} \Rightarrow \Sigma_{i+j}}{\Gamma^{-i}, \Pi_{1}, \ldots, \Pi_{i}, \Pi_{i+1}, \ldots, \Pi_{i+j} \Rightarrow \Sigma_{1}, \ldots, \Sigma_{i}, \Sigma_{i+1}, \ldots, \Sigma_{i+j} \Delta^{-j}}
$$

gdzie $\Gamma^{-i}=\Gamma-\left\{\varphi_{1}, \ldots, \varphi_{i}\right\}$ a $\Delta^{-j}=\Delta-\left\{\psi_{1}, \ldots, \psi_{j}\right\}$, dla $0 \leq i \leq k, 0 \leq$ $j \leq n$.

Dowód przebiega jak dla lematu poprzedniego. Wymaga jedynie rozważenia konkretnych wartości $k$ i $n$. Wykazaliśmy to dla $k=n=1$ oraz $k=2, n=1$ i $k=1, n=2$. Dla przypadków bazowych gdy $k=1, n=0$ lub $k=0, n=1$, czyli sekwentów postaci $\varphi \Rightarrow \mathrm{i} \Rightarrow \psi$, istnieje po jednym odpowiedniku regułowym, odpowiednio: $\Gamma \Rightarrow \Delta, \varphi / \Gamma \Rightarrow \Delta$, oraz 
$\psi, \Gamma \Rightarrow \Delta / \Gamma \Rightarrow \Delta$. Generalnie, reguły tworzymy ujmując dowolną ilość formuł z poprzednika lub następnika rozważanego sekwentu i dla każdej takiej formuły tworzac sekwent-przesłankę, gdzie element poprzednika $\left(\varphi_{i}\right)$ umieszczamy w następniku a element następnika $\left(\psi_{j}\right)$ w poprzedniku sekwentuprzesłanki; pozostałe formuły sekwentu wyjściowego tworza zbiory $\Gamma^{-i}$ i $\Delta^{-j}$ sekwentu-wniosku. Krańcowy przypadek, to $\Gamma^{-k}$ i $\Delta^{-n}$, czyli oba zbiory sac puste, reguła ma $k+n$ przesłanek, po jednej dla każdej formuły z wyjściowego sekwentu, a sekwent wniosek zawiera tylko sumy parametrów z przesłanek. Dla odmiany, jeżeli uwzględnimy sytuację, gdy zarazem $\Gamma^{-0}$ i $\Delta^{-0}$, to nasz schemat dotyczy również przypadku reguły z zerową ilością przesłanek, czyli wyjściowego sekwentu.

Dla lepszego zrozumienia sposobu generowania reguł proponujemy czytelnikowi samodzielne wypisanie piętnastu schematów reguł, które można wyprowadzić z sekwentu $\varphi_{1}, \varphi_{2} \Rightarrow \psi_{1}, \psi_{2}$

\subsection{Własności reguł}

Pomimo wprowadzenia kilku wariantów RS, które istotnie różnią się co do swych własności, można zaobserwować pewne cechy wspólne, zwłaszcza jeżeli chodzi o budowę reguł. Poprzedni podrozdział pokazywał jakie formy moga potencjalnie przyjmować reguły w systemach RS. Łatwo zauważyć, że reguły w standardowych RS typu Gentzenowskiego (tj. dokładniej w podtypie typu pierwszego wyróżnionego przez nas w paragrafie 2.2.2) podlegaja $\mathrm{w}$ tym względzie istotnym ograniczeniom $\mathrm{w}$ porównaniu do innych typów RS, które omówimy w rozdziale 10. Poniżej podamy listę kilkunastu ważnych cech, które posiada większość reguł w standardowych Gentzenowskich systemach RS.

Przypomnijmy, że typ 1 RS (w stylu Gentzena) charakteryzuje się tym, że ilość sekwentów bazowych jest ograniczona do minimum natomiast rachunek opiera się na regułach. Ponadto, sekwenty aksjomatyczne mają charakter strukturalny, a zawartość logiczna (charakterystyka stałych) zawarta jest w regułach. Dodatkowo, w ramach typu pierwszego, standardowe RS w stylu Gentzena spełnia warunek progresywności:

Każda reguła logiczna jest regułą wprowadzania stałej do dowodu.

Innymi słowy są to reguły podpadające pod schemat (c) i (d) z paragrafu 2.2.1. Warunek progresywności możemy uznać za wyróżnik standardowych systemów RS w obrębie typu pierwszego. Inne RS należące do tego typu, które nie spełniają warunku progresywności, np. sekwentowe DN, nazwiemy 
niestandardowymi. Omówimy je również w rozdziale 10, obok systemów reprezentujaccych typ drugi (w stylu Hertza) i trzeci (mieszany; por. paragraf 2.2.2). Pozostałe własności reguł podzielimy na trzy grupy: ogólne, logiczne i strukturalne.

Do najważniejszych własności ogólnych zaliczyć możemy:

1. Rozdzielność: każdy element reguły jest albo parametrem albo formułą poboczną, albo zasadniczą.

2. Własność podformuł: każda formuła występująca w przesłankach występuje też we wniosku jako podformuła (niekoniecznie właściwa).

3. Odwracalność: przesłanki są dedukowalne z wniosku.

Własność rozdzielności ma w zasadzie charakter definicyjny. Jak dotąd dużo uwagi poświęciliśmy własności odwracalności reguł. Jak wiemy, nie jest ona uniwersalna, gdyż nie spełniają jej np. $(W),(\rightarrow \Rightarrow)$ w LK. Własność podformuł jest jeszcze ważniejsza i łatwo zauważyć, że spełniają ją wszystkie reguły oprócz (Cut). Obu własnościom i ich konsekwencjom, w szczególności analityczności i zbieżności, poświęcimy wiele uwagi w rozdziale 6.

Własności logiczne to cechy reguł logicznych; najważniejsze z nich to:

1. Kumulatywność: formuła zasadnicza jest zawsze złożona.

2. Separowalność: schemat reguły logicznej dla danej stałej nie zawiera innych stałych.

3. Symetria słaba: każda stała ma reguły wprowadzania do następnika lub poprzednika sekwentu (i żadnych innych).

4. Symetria mocna: każda stała ma obie reguły wprowadzania (i żadnych innych).

5. Eksplicytność słaba: stała występuje tylko w sekwencie-wniosku.

6. Eksplicytność mocna: stała występuje tylko raz w sekwencie-wniosku.

7. Wyłączność: formuły poboczne występują tylko w sekwentach-przesłankach.

Warto zauważyć, że separowalność oznacza, iż reguła daje czysto strukturalne wyjaśnienie znaczenia stałej, bez odwoływania się do znaczenia innych stałych logicznych. Ta, i inne wyżej podane, własności reguł logicznych 
przyczyniły się do ufundowania antyrealistycznej teorii znaczenia stałych logicznych, tzw. inferencjalizmu, w której znaczenie stałej określa się poprzez warunki jej użycia ${ }^{2}$. Zauważmy też, że wszystkie reguły logiczne należące do LK, oraz do każdego z wariantów RS opisanych w tym rozdziale, spełniają wszystkie podane wyżej warunki. Nie jest to regułą w przypadku standardowych RS dla wielu logik nieklasycznych (a nawet dla KRK, jak zobaczymy w rozdziale 9 ).

Własności strukturalne dotyczą parametrów (ale we wszystkich regułach a nie jedynie strukturalnych):

1. Kongruencja: każdy parametr we wniosku ma dokładnie jednego bezpośredniego przodka w (każdej) przesłance.

2. Niezależność kontekstowa: poprawność danej reguły nie jest zakłócona przez zmiany dokonane na parametrach, w szczególności:

(a) dodanie dalszych parametrów do sekwentów-przesłanek i sekwentuwniosku;

(b) skasowanie tych samych parametrów w przesłankach i wniosku;

(c) zamianę danego parametru na inny w przesłankach i wniosku.

Kongruencja z dodatkiem w nawiasie jest kongruencją mocną, która zachodzi dla reguł k-jednolitych, ale niekoniecznie dla reguł k-niezależnych. Łatwo sprawdzić, że wszystkie reguły każdego wariantu spełniają całkowicie niezależność kontekstową, ale już w RS z int-sekwentami jest ona ograniczona tylko do poprzedników. Jak przekonamy się w rozdziale $9 \mathrm{w}$ regułach kwantyfikatorowych (konkretnie $(\Rightarrow \forall)$ i $(\exists \Rightarrow)$ ) z tej własności tylko kasowanie parametrów jest możliwe ${ }^{3}$.

Wymienione wyżej własności reguł mają wagę nie tylko dla pewnej filozofii znaczenia stałych logicznych. Jak pokażemy w następnym rozdziale, występowanie tych własności reguł, pozwala na przeprowadzenie pewnego typu dowodów eliminacji cięcia, które polegają na globalnych przekształceniach fragmentów dowodu, możliwych dzięki własnościom reguł.

\footnotetext{
${ }^{2}$ Literatura poświęcona tym zagadnieniom jest ogromna, z ważniejszych prac wymienić można m.in.: Dummett [35], Prawitz [113], Hacking [60], Sundholm [132]. Przystępne podsumowanie tych propozycji w polskiej literaturze znaleźć można np. w Maciaszek [97].

${ }^{3}$ Podobnie wygląda sytuacja w RS dla wielu logik nieklasycznych.
} 


\subsection{Klasyczny RS na int-sekwentach}

W rozdziale 2 wprowadziliśmy określenie "intuicjonistyczne sekwenty" (intsekwenty) na takie sekwenty, w których w następniku występuje co najwyżej jedna formuła. Jak wyjaśniliśmy w rozdziale 3 określenie to związane jest z faktem, że w taki sposób Gentzen zbudował sekwentową formalizację INT tzw. rachunek LJ (por. uwaga 3.2). Pełna symetria reguł w omawianych dotąd formalizacjach RS dla KRZ wynikająca z braku takiego ograniczenia na następnikach daje wiele korzyści, ale biorąc pod uwagę interpretację symbolu $\Rightarrow$ jako relacji konsekwencji możemy czasem potrzebować takich wariantów RS, które bezpośrednio odpowiadają pojmowaniu tej relacji w bardziej tradycyjny sposób. Poniżej omówimy krótko trzy sposoby budowania RS-KRZ na bazie RS-INT.

Jedna z możliwości to dołączenie do RS-INT dodatkowych sekwentów aksjomatycznych postaci: $\neg \neg \varphi \Rightarrow \varphi$. Łatwo zauważyć, że w LJ nie dowiedzie się sekwentów tej postaci, gdyż wymagałoby to pojawienia się dwóch formuł w następniku sekwentu. W taki sposób formalizuje KRZ np. Grandy [56]. W jego systemie wymaga się zresztą dodatkowo by następniki były niepuste, co stwarza pewien dodatkowy problem z regułami dla negacji. Można go rozwiązać wprowadzając zamiast reguł Gentzena następujące reguły:

$$
(\neg \Rightarrow) \frac{\Gamma \Rightarrow \varphi}{\neg \varphi, \Gamma \Rightarrow \psi} \quad(\Rightarrow \neg) \frac{\varphi, \Gamma \Rightarrow \psi \quad \varphi, \Gamma \Rightarrow \neg \psi}{\Gamma \Rightarrow \neg \varphi}
$$

Reguła $\mathrm{z}$ prawej jest tu w istocie słabą formą dowodu nie wprost. Można ją sprowadzić do jednoprzesłankowej postaci, gdy zamiast dowolnej formuły $\psi$ użyjemy stałej falsum $\perp$. Wtedy prawa przesłanka staje się zbędna jako aksjomatyczna.

Użycie aksjomatycznego sekwentu $\neg \neg \varphi \Rightarrow \varphi$ ma pewien mankament. Reguła cięcia nie jest eliminowalna, chociaż można ją sprowadzić do takich użyć, w których co najmniej jedna z przesłanek jest aksjomatem tego ty$\mathrm{pu}^{4}$. Zilustrujemy to dowodami prawa wyłączonego środka (LEM) i prawa Peirce'a:

\footnotetext{
${ }^{4}$ Wynika to z pewnego uogólnienia twierdzenia o eliminacji (Cut) (twierdzenie 9.5.), które omówimy w paragrafie 9.8.1.
} 


$$
\begin{aligned}
& \begin{array}{c}
(\Rightarrow \vee) \frac{p \Rightarrow p}{p \Rightarrow p \vee \neg p} \\
(\neg \Rightarrow) \frac{p(\neg(p \vee \neg p) \Rightarrow}{p(p \vee \neg p) \Rightarrow \neg p} \\
(\Rightarrow \neg) \frac{\neg(p \vee \neg p) \Rightarrow p \vee \neg p}{(\Rightarrow} \\
(\neg \Rightarrow) \frac{\neg(p \vee \neg p), \neg(p \vee \neg p) \Rightarrow}{(C \Rightarrow)} \\
(\Rightarrow \neg) \frac{\neg(p \vee \neg p) \Rightarrow}{\Rightarrow \neg \neg(p \vee \neg p)} \quad \Rightarrow p(p \vee \neg p) \Rightarrow p \vee \neg p \\
\end{array}
\end{aligned}
$$

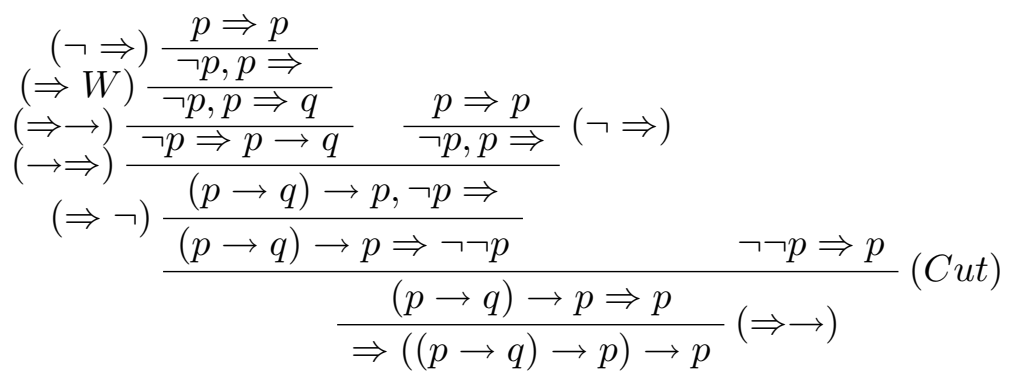

Zauważmy, że w pierwszym przypadku lewa gałąź jest poprawnym dowodem w RS-INT i pokazuje nam generalną strategię dowodzenia dla dowolnej tezy KRZ jej podwójnej negacji w RS-INT.

Inne rozwiązanie proponuje Curry [27], który w pierwszej kolejności uzyskuje formalizację KRZ bez negacji na Gentzenowskim LJ dołączając regułę Peirce'a postaci:

$$
(P e \Rightarrow) \frac{\Gamma, \varphi \rightarrow \psi \Rightarrow \varphi}{\Gamma \Rightarrow \varphi}
$$

Reguła ta umożliwia prosty dowód prawa Peirce'a; pozostawiamy to czytelnikowi.

Curry rozważa różne sposoby poszerzenia takiego rachunku o samą negację, o sam $\perp$ jako pierwotną stałą, lub o obie stałe. W pierwszym przypadku dodajemy zwyczajne dwie reguły dla $\neg$ (dopuszczające pusty następnik). W drugim mamy dodatkową regułę:

$$
(\Rightarrow \perp) \quad \frac{\Gamma \Rightarrow \perp}{\Gamma \Rightarrow \varphi}
$$

W przypadku gdy zarówno $\neg$ jak i $\perp$ są traktowane jako pierwotne stałe oprócz $(P e \Rightarrow)$ i $(\Rightarrow \perp)$ mamy lekko zmodyfikowane reguły dla negacji:

$$
(\Rightarrow \neg) \frac{\Gamma, \varphi \Rightarrow \perp}{\Gamma \Rightarrow \neg \varphi} \quad(\neg \Rightarrow) \frac{\Gamma \Rightarrow \varphi \quad \perp, \Gamma \Rightarrow \psi}{\neg \varphi, \Gamma \Rightarrow \psi}
$$


Uwaga 4.7: Reguły te można zdefiniować na zwykłych sekwentach z wieloma formułami w następniku dokładając w schematach kontekst $\Delta$. Otrzymamy w ten sposób jeszcze jeden wariant $\mathrm{LK} \mathrm{z} \perp \mathrm{i} \neg$ jako stałymi pierwotnymi, w którym $(\neg \Rightarrow)$ jest dwuprzesłankowa. Oczywiście w tym przypadku $(P e \Rightarrow)$ staje się regułą zbędną.

W tym ostatnim przypadku dowiedlne są dwa sekwenty $\neg \varphi \Rightarrow \varphi \rightarrow \perp \mathrm{i}$ $\varphi \rightarrow \perp \Rightarrow \neg \varphi$, które łącznie pozwalają zdefiniować $\neg \mathrm{w}$ terminach $\perp \mathrm{i} \rightarrow$. Poniżej dowód jednego z nich:

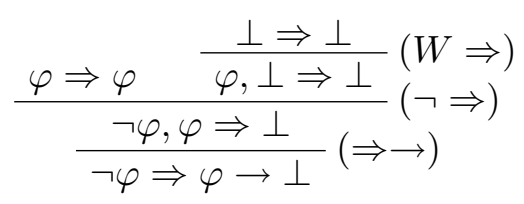

Pomimo, że reguła $(P e \Rightarrow)$ nie posiada wielu z własności rozważanych przez nas w poprzednim podrozdziale, to Curry udowadnia, że w takim systemie (Cut) też jest eliminowalne.

Negri, von Plato [101] rozważają wersję m-ARS dla INT, z dodaną regułą atomowego prawa wyłączonego środka (LEM):

$$
\text { (LEM-at) } \frac{\varphi, \Gamma \Rightarrow \psi \quad \neg \varphi, \Gamma \Rightarrow \psi}{\Gamma \Rightarrow \psi}
$$

gdzie $\varphi$ jest formułą atomową.

Dla systemu tego zachodzą udowodnione wyżej dla ARS twierdzenia dotyczące dopuszczalności reguł strukturalnych, włączając w to (Cut). Mimo to z praktycznego punktu widzenia reguła (LEM-at) wydaje się równie niewygodna jak (Cut), gdyż własność podformuł nie zachodzi dla tej reguły również. W systemie tym można też udowodnić, że ogólna reguła (LEM), w której porzucone jest ograniczenie $\varphi$ do atomów jest też dopuszczalna. Jednak z punktu widzenia strategii poszukiwania dowodu ważniejsze jest raczej, że zastosowania (LEM-at) można w dowodach zawęzić do tych atomów, które występują w następniku dowodzonego sekwentu. W ten sposób system wbrew pozorom okazuje się przydatny również w praktyce poszukiwania dowodów ${ }^{5}$.

Dla ilustracji podamy dowód twierdzenia Peirce'a (łatwe dowody prawa wyłączonego środka czy podwójnej negacji pozostawiamy czytelnikowi).

\footnotetext{
${ }^{5}$ Wynik ten jest analogiczny do tego, który zachodzi dla tablicowego systemu KE, gdzie zastosowania zbliżonej reguły PB (principle of bivalence) można ograniczyć do podformuł dowodzonej formuły.
} 


$$
\begin{gathered}
\frac{\frac{p \Rightarrow p, q}{\neg p, p \Rightarrow q}(\neg \Rightarrow)}{\frac{\neg p \Rightarrow p \rightarrow q}{\neg,(p \rightarrow q) \rightarrow p \Rightarrow p \quad}(\Rightarrow) \quad p, \neg p \Rightarrow p} \\
\frac{(p \rightarrow q) \rightarrow p \Rightarrow p}{\Rightarrow((p \rightarrow q) \rightarrow p) \rightarrow p}(\rightarrow \rightarrow)
\end{gathered}(\rightarrow)
$$

Na koniec zauważmy jeszcze, że na potrzeby rozważań teoriodowodowych systemy RS bardzo często formułowane są bez negacji, a za to $\mathrm{z} \perp$ jako pierwotną stałą. Tak jest choćby w przypadku rozważanych przez Negri i von Plato [101] form ARS. Jednak jest ona zazwyczaj wprowadzana nie za pomocą reguły Curry'ego $(\Rightarrow \perp)$, ale za pomoca aksjomatu:

$$
(\perp) \quad \perp, \Gamma \Rightarrow \Delta
$$

W RS z $\perp$ łatwo dowieść obu reguł dla negacji, którą definiujemy następująco: $\neg \varphi:=\varphi \rightarrow \perp$. Z kolei w RS, w którym $\perp$ zdefiniujemy: $\perp:=\neg(\varphi \rightarrow \varphi)$ łatwo dowodzimy $(\perp)$. Pokazują to poniższe schematy:

$$
\begin{aligned}
& \frac{\Gamma \Rightarrow \Delta, \varphi \quad \perp, \Gamma \Rightarrow \Delta}{\varphi \rightarrow \perp, \Gamma \Rightarrow \Delta}(\rightarrow \Rightarrow) \\
& \frac{\frac{\varphi, \Gamma \Rightarrow \Delta}{\varphi, \Gamma \Rightarrow \Delta, \perp}(\Rightarrow W)}{\Gamma \Rightarrow \Delta, \varphi \rightarrow \perp}(\Rightarrow \rightarrow) \\
& \frac{\frac{\varphi, \Gamma \Rightarrow \Delta, \varphi}{\Gamma \Rightarrow \Delta, \varphi \rightarrow \varphi}}{\neg(\varphi \rightarrow \varphi), \Gamma \Rightarrow \Delta}(\neg \Rightarrow)
\end{aligned}
$$




\section{Rozdział 5}

\section{Dowody twierdzenia o eliminacji cięcia}

Najważniejszym wynikiem strukturalnej teorii dowodu opartej na sekwentowych formalizacjach logiki jest twierdzenie o eliminacji cięcia, które przez samego Gentzena określane było jako twierdzenie zasadnicze (Hauptsatz) jego teorii ${ }^{1}$. Przekonanie o fundamentalnym charakterze tego twierdzenia nadal się utrzymuje mimo rozmaitych zastrzeżeń wysuwanych zwłaszcza z punktu widzenia badań nad automatyczną dedukcją i złożonością dowodów² ${ }^{2}$.

Współcześnie częściej dowodzi się twierdzenia o dopuszczalności (Cut) w systemach takich jak ARS. Dlatego na początku wyjaśnimy różnice między dowodami eliminowalności a dopuszczalności (Cut) oraz nieformalnie omówimy typową lokalną strategię konstruowania dowodów nie zawierających zastosowań (Cut), którą w podrozdziale 5.2 zademonstrujemy dokładnie na przykładzie oryginalnego dowodu Gentzena. W podrozdziale 5.3 przedstawimy trzy dowody dopuszczalności (Cut) w ARS pochodzące od Dragalina, Smullyana i Schüttego. Wszystkie realizują strategię lokalną, ale są prostsze od dowodu Gentzena i zostały uszeregowane wg. stopnia podobieństwa do tego dowodu. Następnie (5.4) omówimy dowody Curry'ego i Bussa, które bazują na globalnych przekształceniach dowodu. Dodatkowo Buss także dowodzi eliminowalności (Cut) z dowodu, ale wykorzystuje ogólną strategię organizacji dowodu pochodzącą od Taita, która istotnie różni się od podejścia Gentzena, a ponadto pozwala dokonać oszacowania wielkości otrzymanego dowodu. Na koniec (5.5) dokonamy porównania prezentowanych dowodów.

\footnotetext{
${ }^{1}$ Zwane też jest krócej jako twierdzenie o eliminacji, np. Curry [26], lub jako twierdzenie o normalnej formie (dowodu), np. Kleene [83].

${ }^{2}$ Por. zwłaszcza D’Agostino [1], Buss [20], Fitting [43], Indrzejczak [74].
} 


\section{$5.1 \quad$ Uwagi wprowadzające}

Dlaczego należy eliminować (Cut)? Z jednej strony reguła ta zdaje się być niezwykle ważna. Przy interpretacji sekwentów jako twierdzeń o relacji konsekwencji cięcie wyraża jedną z najważniejszych i niekwestionowanych własności takich relacji, czyli przechodniość. Ponadto szczególne przypadki (Cut) reprezentują w kontekście RS wiele ważnych reguł np.

- Modus Ponens: $\Rightarrow \varphi ; \varphi \Rightarrow \psi / \Rightarrow \psi$

- Sylogizm Hipotetyczny: $\chi \Rightarrow \varphi ; \varphi \Rightarrow \psi / \chi \Rightarrow \psi$

Nie odwołując się do żadnych konkretnych schematów reguł można zauważyć, że (Cut) po prostu wyraża przechodniość $\Rightarrow$, czy też relacji konsekwencji wyrażanej przez $\Rightarrow$, jeżeli przyjmiemy interpretację 4 (por. podrozdział 2.3). Stosując dla odmiany interpretację 2. i czytając, zgodnie z nią, reguły od wniosku do przesłanek, zauważyć można, że (Cut) wyraża zasadę dwuwartościowości, tzn, że dowolna formuła może być dodana do sekwentu jako prawdziwa (w poprzedniku) lub fałszywa (w następniku $)^{3}$. Taka interpretacja jest m.in. podstawą systemu KE Mondadoriego i D'Agostino [1]. Z punktu widzenia techniki dowodzenia, zastosowanie (Cut) w dowodzie odpowiada zastosowaniom wcześniej dowiedzionych wyników (lematów) w celu szybszego uzyskania wyniku. Jest to charakterystyczne dla tzw. syntetycznych dowodów tez, w przeciwieństwie do dowodów analitycznych, które odwołują się jedynie do tego co można wydedukować z pierwotnych założeń lub przesłanek dowodu. W formacie RS takie analityczne dowody nie korzystają z (Cut). Więcej na temat dowodów analitycznych powiemy w następnym rozdziale ${ }^{4}$.

Niezależnie od wielkiej wagi reguły (Cut) możliwość jej eliminacji z repertuaru pierwotnych reguł systemu przynosi tyle korzyści, że ważność samego twierdzenia nie budzi żadnych wątpliwości. Wybrane konsekwencje tego twierdzenia omówimy później, natomiast w tym rozdziale skupimy się na samej technice jego dowodzenia.

${ }^{3}$ Biorąc pod uwagę, że (Cut) występuje też w formalizacjach wielu logik nieklasycznych, które nie są charakteryzowalne przez dwuwartościowe matryce, lepsze jest odczytanie następujące: dowolna formuła może być uznana lub odrzucona. Można w tym kontekście rozważyć związek (Cut) z tzw. tezą Suszki [138].

${ }^{4}$ Powyższe uwagi nie wyczerpuja listy możliwych interpretacji (Cut); więcej na ten temat, np. o korespondencji między użyciem (Cut) w RS a dowodów nie wprost w DN, znajdzie czytelnik w Indrzejczak [74]. 
Poniżej zaprezentujemy sześć różnych dowodów, kolejno: Gentzena [50], Dragalina [32], Smullyana [131], Schütte'go [123], Curry'ego [27] i BussaTaita [20]. Podstawą rozróżnienia będzie strategia transformacji dowodu; lokalna w przypadku czterech pierwszych i globalna w pozostałych dwóch. Dowód Gentzena zostanie omówiony bardzo detalicznie, w pozostałych przypadkach koncentrować się będziemy na elementach dowodu istotnie różnych.

\subsubsection{Eliminacja czy dopuszczalność}

W literaturze przedmiotu twierdzenie o eliminacji cięcia występuje często jako twierdzenie o dopuszczalności cięcia. Różnica polega na tym, że w pierwszym przypadku (Cut) występuje jako reguła pierwotna systemu (wtedy wykazujemy jego eliminację z dowodów), a w drugim nie (wtedy wykazujemy, że (Cut) jest regułą dopuszczalną). W zasadzie można powiedzieć, że różnica nie jest istotna, gdyż dopuszczalność jest konwersem eliminowalności, w tym sensie, że jeżeli RS oznacza dowolny system z (Cut) jako regułą pierwotną, a $\mathrm{RS}^{\prime}$ ten sam system bez reguły cięcia, to (Cut) jest eliminowalne w RS wtw (Cut) jest dopuszczalne w RS'. Mimo to zachodzą dwie dość istotne różnice pomiędzy dowodami twierdzeń o eliminacji i dopuszczalności:

1. w obu przypadkach inaczej formułuje się samo twierdzenie;

2. dowód twierdzenie o dopuszczalności ma prostszą strukturę ogólną.

Typowe sformułowania obu twierdzeń wyglądają następująco:

Twierdzenie o eliminacji: Jeżeli $\vdash_{R S} S$, to $\vdash_{R S^{\prime}} S$

Twierdzenie o dopuszczalności: Jeżeli $\vdash_{R S^{\prime}} \Gamma \Rightarrow \Delta, \varphi \mathrm{i} \vdash_{R S^{\prime}} \varphi, \Pi \Rightarrow \Sigma$, to $\vdash_{R S^{\prime}} \Gamma, \Pi \Rightarrow \Delta, \Sigma$

Warto podkreślić, że drugie sformułowanie w pewien sposób ukonkretnia w jakim sensie (Cut) jest regułą wtórną. Pierwsze sformułowanie zachodzi również wtedy gdy (Cut) jest regułą dowiedlną w $\mathrm{RS}^{\prime}$. Zauważmy jednak, że ani $\mathrm{w} \mathrm{LK}^{\prime}$ ani w innych, pokrewnych mu, standardowych systemach $\mathrm{RS}^{\prime}$ nie można wykazać, że (Cut) jest regułą dowiedlną ${ }^{5}$. Zatem nie jest możliwe zastąpienie dowolnego użycia (Cut) w jednolity sposób przez sekwencję zastosowań innych reguł w dowodzie. To że (Cut) nie jest regułą dowiedlną, a jedynie dopuszczalną prowadzi do znacznej komplikacji dowodu twierdzenia

\footnotetext{
${ }^{5}$ Dowiedlność cięcia można jednak wykazać w innych systemach sekwentowych, które omówimy w rozdziale 10 .
} 
o eliminacji i wymaga rozważenia wielu konkretnych przypadków zastosowania (Cut).

Druga różnica bierze się stąd, że przy dowodzeniu eliminowalności (Cut) z dowodu musimy się liczyć z tym, że w dowodach przesłanek tė̇ zastosowano cięcie, gdyż jest ono regułą pierwotną, natomiast w dowodzie dopuszczalności, z założenia dowody przesłanek go nie zawierają. Istnieją dwie strategie radzenia sobie $\mathrm{z}$ wielością zastosowań (Cut) w przypadku dowodu eliminowalnści:

1. Indukcja po ilości wystąpień (Cut) w dowodzie - rozwiązanie Gentzena (lemat 5.3).

2. Indukcja (zstępująca) po długości cut-formuł - zastosowana m.in. przez Taita [140] i Bussa [20] (lemat 5.5).

W pierwszym przypadku eliminujemy wystąpienia (Cut) po kolei idąc od góry. W drugim najpierw eliminujemy tzw. maksymalne zastosowania (Cut), tzn. z najdłuższymi cut-formułami. Druga strategia ma tę przewagę nad pierwszą, że pozwala przy okazji oszacować wielkość uzyskanego dowodu, w którym (Cut) nie występuje. Dowody dopuszczalności (Cut) nie wymagają takiej nadrzędnej indukcji.

Mimo tych różnic większość z omawianych dowodów oparta jest na podobnej idei, którą nieformalnie tu zarysujemy zanim przedstawimy szczegółowe rozwiązania.

\subsubsection{Ogólna strategia dowodu}

Załóżmy, że mamy dowód $\mathcal{D}$ sekwentu S, w którym zastosowano (Cut). Staramy się zmodyfikować $\mathcal{D}$ tak by wszystkie zastosowania (Cut) zostały zastąpione przez kombinacje innych reguł. Robimy to poprzez:

1. bezpośrednią eliminację danego zastosowania (Cut);

2. przez wykonanie odpowiednich kroków redukcyjnych, które zamieniaja dane wystąpienie (Cut) na inne, w zdefiniowanym sensie "prostsze".

Kroki redukcyjne wprawdzie nie eliminują zastosowań (Cut), ale ich systematyczne wykonywanie w efekcie końcowym pozwala całkiem pozbyć się (Cut) z dowodu, poprzez sprowadzenie do tych przypadków, które podpadają pod 1 . 
Na początek rozważmy, które szczególne zastosowania (Cut) są eliminowalne całkowicie z dowodu. Dadzą się tu wyróżnić dwa przypadki.

a) Jeżeli przynajmiej jedna przesłanka (Cut) jest aksjomatyczna, to eliminacja tego zastosowania jest trywialna gdyż fragment dowodu:

$$
(C u t) \frac{\varphi \Rightarrow \varphi \quad \varphi, \Gamma \Rightarrow \Delta}{\varphi, \Gamma \Rightarrow \Delta}
$$

zamieniamy po prostu na dowód $\varphi, \Gamma \Rightarrow \Delta$. Analogicznie, gdy aksjomatem jest prawa przesłanka (Cut).

Powyższa sytuacja da się uogólnić na dowolne zastosowanie (Cut), w którym jedna z przesłanek zawiera pewną formułę zarówno w poprzedniku jak i w następniku (jest aksjomatem uogólnionym). Zachodzą tu dwie możliwości:

(i) cut-formuła występuje po obu stronach (jest formułą aksjomatyczną);

(ii) cut-formuła nie występuje po obu stronach (nie jest formułą aksjomatyczną).

Pierwszy przypadek jest ściśle analogiczny do zilustrowanego wyżej tyle tylko, że do drugiej przesłanki należy dołączyć brakujące formuły z drugiej przez osłabianie (i ew. permutację w LK). W przypadku (ii) mamy:

$$
(C u t) \frac{\psi, \Gamma \Rightarrow \Delta, \psi, \varphi \quad \varphi, \Pi \Rightarrow \Sigma}{\psi, \Gamma, \Pi \Rightarrow \Delta, \psi, \Sigma}
$$

Zatem wniosek jest też aksjomatem uogólnionym $\psi, \Gamma, \Pi \Rightarrow \Delta, \psi, \Sigma$, który bądź zaczyna dowód (np. w ARS) bądź daje się wydedukować przez osłabianie $\mathrm{z}$ aksjomatu $\psi \Rightarrow \psi$. Analogicznie, gdy aksjomatem uogólnionym jest prawa przesłanka (Cut).

b) Jeżeli w przynajmniej jednej przesłance cut-formuła jest uzyskana przez osłabianie sytuacja jest podobna. Fragment dowodu:

$$
\begin{aligned}
(\Rightarrow W) & \frac{\Gamma \Rightarrow \Delta}{\Gamma \Rightarrow \Delta, \varphi} \quad \varphi, \Pi \Rightarrow \Sigma \\
(C u t) & \frac{\Gamma, \Pi \Rightarrow \Delta, \Sigma}{\Gamma, \Pi \Rightarrow \Delta}
\end{aligned}
$$

zamieniamy na:

$$
(W)(P) \frac{\Gamma \Rightarrow \Delta}{\overline{\Gamma, \Pi \Rightarrow \Delta, \Sigma}}
$$


gdzie $(W)(P)$ oznacza wielokrotne zastosowanie osłabiania i permutacji po obu stronach. Analogicznie, gdy przez osłabianie uzyskana jest cut-formuła w prawej przesłance. Podsumujmy powyższe jako:

Fakt 5.1 (Cut), którego jedna z przesłanek jest aksjomatem (uogólnionym) lub zawiera cut-formułe uzyskana przez zastosowanie ostabiania jest całkowicie eliminowalny.

Niestety w pozostałych wypadkach (Cut) nie daje się wyeliminować tak prosto i zazwyczaj wymaga zastępowania jednych zastosowań (Cut) przez inne, w pewnym sensie prostsze. Generalnie sprowadza się do wykonywania w systematyczny sposób dwóch typów kroków redukcyjnych:

1. zastępujemy złożone cut-formuły przez prostsze (ich podformuły);

2. przesuwamy "do góry" zastosowania (Cut) w dowodzie .

Zilustrujmy te dwa rodzaje redukcji:

Przykład 5.1. Rozważmy następujące zastosowanie (Cut) z cut-formułą $\varphi \vee \psi$. Fragment dowodu o postaci:

$$
(\Rightarrow \vee) \frac{\frac{\Gamma \Rightarrow \Delta, \varphi}{\Gamma \Rightarrow \Delta, \varphi \vee \psi} \quad \frac{\varphi, \Pi \Rightarrow \Sigma \quad \psi, \Pi \Rightarrow \Sigma}{\varphi \vee \psi, \Pi \Rightarrow \Sigma}(\vee \Rightarrow)}{\Gamma, \Pi \Rightarrow \Delta, \Sigma}(\vee)
$$

zostaje zastąpiony przez następujący, w którym (Cut) jest zastosowane na podformule $\varphi$ poprzedniej cut-formuły, co więcej jedna z gałęzi dowodu staje się zbędna:

$$
\frac{\Gamma \Rightarrow \Delta, \varphi \quad \varphi, \Pi \Rightarrow \Sigma}{\Gamma, \Pi \Rightarrow \Delta, \Sigma}(C u t)
$$

Zauważmy, że w analizowanym wyżej fragmencie dowodu cut-formuła $\varphi \vee \psi \mathrm{w}$ obu przesłankach (Cut) pojawiła się po raz pierwszy w wyniku zastosowania odpowiednich reguł dla $\vee$.

Przykład 5.2. Rozważmy następujące zastosowanie (Cut) na $\varphi$. Fragment dowodu o postaci:

$$
(C u t) \frac{\Gamma \Rightarrow \Delta, \varphi \quad \frac{\varphi, \Pi \Rightarrow \Sigma, \psi}{\varphi, \Pi \Rightarrow \Sigma, \psi \vee \chi}}{\Gamma, \Pi \Rightarrow \Delta, \Sigma, \psi \vee \chi}(\Rightarrow \vee)
$$


zostaje zastąpiony przez:

$$
(\Rightarrow \vee) \frac{\Gamma \Rightarrow \Delta, \varphi \quad \varphi, \Pi \Rightarrow \Sigma, \psi}{\Gamma, \Pi \Rightarrow \Delta, \Sigma, \psi \vee \chi}(C u t)
$$

Tym razem cut-formuła nie uległa zmianie, ale zmniejszył się rozmiar tego fragmentu dowodu, który kończył się zastosowaniem cięcia. Rozważane zastosowanie (Cut) zostało "podciągnięte" do góry poprzez permutację (Cut) i $(\Rightarrow \vee)$.

Systematyczne przesuwanie zastosowania (Cut) w górę musi prowadzić do uzyskania takich dowodów, w których cut-formuła pojawia się w obu przesłankach (Cut) po raz pierwszy. Jeżeli któreś z tych pojawień to aksjomat lub zastosowanie osłabiania, to wyżej pokazaliśmy, że można się go pozbyć całkowicie (fakt 5.1). Jeżeli zaś oba pojawienia się cut-formuły zawdzięczamy zastosowaniu odpowiedniej reguły logicznej, to można wymienić je na zastosowania (Cut) na prostszych formułach (jak w przykładzie 5.1). W ten sposób można wykazać, że w wyniku szeregu transformacji wykonanych na $\mathcal{D}$ poprzez naprzemienne przesuwanie (Cut) w górę lub redukowanie rozmiaru cut-formuły osiągniemy cel jakim jest dowód $\mathcal{D}^{\prime}$ tegoż samego sekwentu $S$ ale bez zastosowań (Cut). Formalnie poprawne ujęcie tego procesu redukcji wymaga zastosowania co najmniej podwójnej indukcji: po rozmiarze cut-formuły i po rozmiarze dowodów przesłanek danego zastosowania (Cut). Wstępnie przyjmijmy, że rozmiar dowodu każdej przesłanki utożsamimy z wysokością lub długością dowodu, zdefiniowaną w paragrafie 3.1.2. Co do rozmiaru cut-formuły to w zasadzie nie ma różnicy czy utożsamimy go z jej długością czy złożonością względnie czy przeprowadzamy tzw. indukcję strukturalną (por. dodatek).

\subsection{Dowód Gentzena}

Zaczniemy od przedstawienia oryginalnego dowodu Gentzena; którego dobrą ekspozycję można też znaleźć w Kleene [83] oraz w Takeuti [143]. Poniższa prezentacja różni się od tamtych tym, że zamiast pewnych ogólnych schematów grupujących podobne transformacje wielu reguł podajemy bardziej konkretne schematy przekształceń w kontekście wybranych reguł pozostawiajac podobne transformacje w kontekście innych reguł do przeprowadzenia czytelnikowi. Taki sposób podejścia jest bardziej detaliczny i przez to 
może bardziej nużący w czytaniu, ale naszym zdaniem pozwala nie tylko dowód Gentzena lepiej prześledzić, ale i lepiej zrozumieć a, co najważniejsze, nauczyć się samodzielnie takie dowody przeprowadzać.

\subsubsection{Kroki wstępne}

Dowód twierdzenia o eliminacji cięcia będzie przeprowadzony dla oryginalnej wersji LK, jednak sam Gentzen wprowadził dwie zmiany w stosunku do ogólnej idei dowodu zarysowanej we wstępie. Po pierwsze, ze względu na obecność kontrakcji w systemie zastąpił (Cut) przez jego uogólnioną wersję - regułę (Mix), określaną także jako (Multicut):

$$
\text { (Mix) } \frac{\Gamma \Rightarrow \Delta[\varphi] \quad \Pi[\varphi] \Rightarrow \Sigma}{\Gamma, \Pi_{\varphi} \Rightarrow \Delta_{\varphi}, \Sigma}
$$

gdzie $\Pi[\varphi]$ oznacza, że $\varphi$ przynajmniej raz występuje $\mathrm{w} \Pi$, a $\Pi_{\varphi}$ oznacza, że z $\Pi$ usunięto wszystkie wystąpienia $\varphi$. W tych schematach kroków redukcyjnych, w których pewne wystąpienia formuły eliminowanej będą zaznaczone explicite, zapis $\Pi_{\varphi}$ oznaczać będzie, że ze zbioru parametrów $\Pi$ usunięto ewentualne wystąpienia $\varphi$.

Oto przykład zastosowania (Mix):

$$
(M i x) \frac{r \wedge t, q \Rightarrow p, q \vee r, \neg s, t \quad \neg s, q \rightarrow r, \neg s, \neg s \Rightarrow \neg q, t}{r \wedge t, q, q \rightarrow r \Rightarrow p, q \vee r, t, \neg q, t}
$$

Dlaczego (Cut) zostaje wymienione na (Mix)? Źródłem kłopotów, jak wspomnieliśmy, jest kontrakcja, gdyż w jej przypadku nie pracuje redukcja po rozmiarze dowodu przesłanki. Rozważmy następujące zastosowanie (Cut):

$$
(C u t) \frac{\Gamma \Rightarrow \Delta, \varphi \quad \frac{\varphi, \varphi, \Pi \Rightarrow \Sigma}{\varphi, \Pi \Rightarrow \Sigma}}{\Gamma, \Pi \Rightarrow \Delta, \Sigma}(C \Rightarrow)
$$

Po zastosowaniu redukcji po długości dowodu prawej przesłanki otrzymujemy:

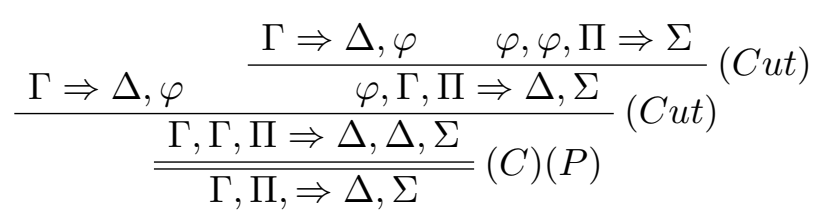


Fakt, że jedno wystąpienie (Cut) zostało zastąpione przez dwa sam w sobie nie jest kłopotliwy ${ }^{6}$. Zauważmy jednak, że chociaż pierwsze od góry zastosowanie (Cut) ma mniejszą wysokość, to drugie ma taką samą jak (Cut) w dowodzie wyjściowym, co oznacza, że nie udało nam się dokonać redukcji. Oczywiście po zastąpieniu (Cut) przez (Mix) problem znika gdyż dokonujemy następującej transformacji:

$$
(M i x) \frac{\Gamma \Rightarrow \Delta, \varphi \quad \varphi, \varphi, \Pi \Rightarrow \Sigma}{\Gamma, \Pi \Rightarrow \Delta, \Sigma}
$$

w której wysokość dowodu prawej przesłanki (Mix) uległa zmniejszeniu.

Teraz musimy pokażać, że system z (Mix) (roboczo nazwijmy go $\mathrm{LK}_{M i x}$ ) jest równoważny systemowi z (Cut).

Lemat $5.1 \vdash_{L K} S w t w \vdash_{L K_{M i x}} S$.

DowóD: Wystarczy pokazać, że (Cut) jest wyprowadzalne w $\mathrm{LK}_{M i x}$ a (Mix) w LK. Dowolne zastosowanie (Cut) postaci:

$$
\frac{\Gamma \Rightarrow \Delta, \varphi \quad \varphi, \Pi \Rightarrow \Sigma}{\Gamma, \Pi \Rightarrow \Delta, \Sigma}(C u t)
$$

zastępujemy przez:

$$
\frac{\Gamma \Rightarrow \Delta, \varphi \quad \varphi, \Pi \Rightarrow \Sigma}{(W)(P) \frac{\Gamma, \Pi_{\varphi} \Rightarrow \Delta_{\varphi}, \Sigma}{\Gamma, \Pi \Rightarrow \Delta, \Sigma}}(\text { Mix })
$$

Odwrotnie, dowolne zastosowanie (Mix) postaci:

$$
\frac{\Gamma \Rightarrow \Delta[\varphi] \quad \Pi[\varphi] \Rightarrow \Sigma}{\Gamma, \Pi_{\varphi} \Rightarrow \Delta_{\varphi}, \Sigma}(\operatorname{Mix})
$$

zastępujemy przez:

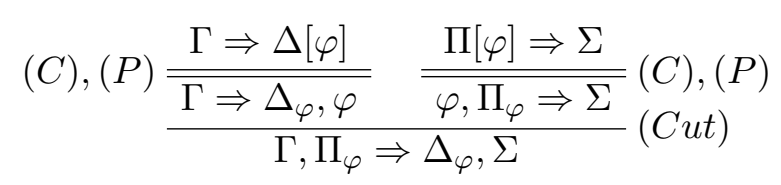

\footnotetext{
${ }^{6}$ Przynajmniej jeżeli chodzi o procedurę samego eliminowania cięcia, gdyż ma z pewnością negatywny wpływ na wzrastanie złożoności transformowanego dowodu.
} 
Niestety zamiana (Cut) na (Mix) zmusza nas do rezygnacji z tak prostej i naturalnej miary wielkości dowodów przesłanek jaką jest ich długość lub wysokość. Aby zrozumieć dlaczego przeanalizujmy następujące zastosowanie (Mix):

$$
(\text { Mix }) \frac{\frac{\varphi, \psi \Rightarrow \Sigma}{\varphi \wedge \psi, \psi \Rightarrow \Sigma}(\wedge \Rightarrow)}{\frac{\Gamma \wedge \varphi \wedge \psi \quad}{\varphi \wedge \psi, \varphi \wedge \psi \Rightarrow \Sigma}}(P \Rightarrow)(\wedge \Rightarrow)
$$

Po przeprowadzeniu standardowej transformacji otrzymujemy:

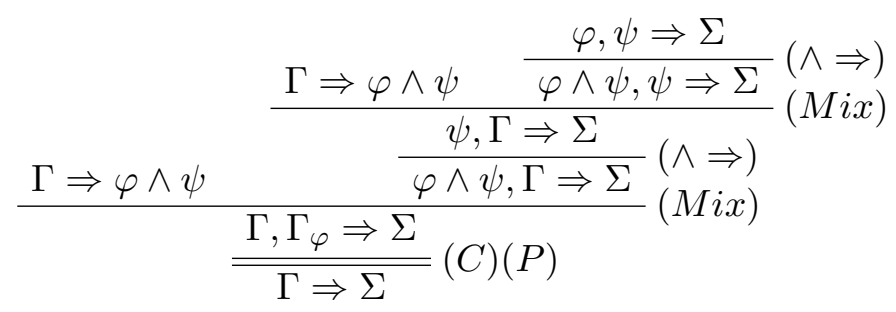

Jak łatwo zauważyć wysokość dowodu prawej przesłanki drugiego zastosowania (Mix) nawet wzrosła, zatem nie otrzymaliśmy oczekiwanej redukcji. $\mathrm{Z}$ drugiej strony cut-formuła (a raczej mix-formuła; w dalszym ciągu będziemy używać raczej pierwszej nazwy nawet przy zastosowaniu (Mix)) występuje nad każdym zastosowaniem (Mix) tylko raz z prawej strony, podczas gdy w wyjściowym schemacie występowała w dwóch sekwentach.

Problemy tego typu doprowadziły Gentzena do wprowadzenia innej miary rozmiaru dowodów przesłanek (Mix) niż wysokość ich dowodu. Zamiast tego rozważał ilość sekwentów zawierających mix-formułę i występujących jeden nad drugim w jednej gałęzi nad sekwentem przesłanką danego zastosowania (Mix). Oczywiście takich gałęzi, które kończą się przesłanką (Mix) może być wiele i mogą różnić się ilością sekwentów, w których występuje mix-formuła. Wybieramy wartość najwyższą, a nie sumę ilości wystąpień na wszystkich gałęziach i określamy ją jako głębokość lewej (prawej) przesłanki (w skrócie L-rank i R-rank). Natomiast suma takich miar dla obu przesłanek danego zastosowania (Mix) to głębokość (rank) (Mix). Precyzyjna definicja wygląda tak:

Definicja 5.1 (Głębokość (Mix)) Niech $\varphi$ będzie mix-formuła, a $\mathcal{B}$ dowolna gałęzia, która kończy się lewa (prawa) przesłanka (Mix). Rank(B) to ilość węztów w tej gatęzi, w których występuje $\varphi$ w następniku (w poprzedniku) i które sa nad wnioskiem (Mix). 
- L-rank $(\varphi)$ to maksymalna wartość rank $(\mathcal{B})$, gdzie $\mathcal{B}$ to dowolna z gatęzi zawierajacych lewa przestanka (Mix).

- $R$-rank $(\varphi)$ definiujemy analogicznie, ale dla prawej przesłanki (Mix) $i$ $z \varphi$ w poprzedniku.

- $\operatorname{Rank}(\varphi)=L-\operatorname{rank}(\varphi)+R-\operatorname{rank}(\varphi)$.

- Gtębokość danego zastosowania (Mix) to rank jego mix-formuty.

Odnotujmy, że minimalna głębokość danego zastosowania (Mix) wynosi 2; jest tak wtedy, gdy w obu przesłankach mix-formuła pojawiła się po raz pierwszy jako formuła zasadnicza tego sekwentu.

\subsubsection{Dowód}

Udowodnimy teraz:

Twierdzenie 5.1 (Hauptsatz) Każdy dowód w LK Mix z użyciem (Mix) można przeksztatcić $w$ dowód bez użycia tej reguły.

Dokładnie rzecz ujmując klasyczna wersja dowodu tego twierdzenia, przedstawiona przez Gentzena [50], zawiera potrójną indukcję: po ilości wystąpień cięcia w dowodzie, po długości cut-formuły i po głębokości (Mix).

Ponieważ cały dowód jest potrójną indukcją, więc warto przeanalizować jego ogólną strukturę, aby ilość detali nie przesłoniła nam jego sensu. Nadrzędna indukcja przebiega po ilości wystąpień (Mix) w dowodzie. Oczywiście w bazie udowadniamy nietrywialny przypadek, że (Mix) jest eliminowalny z każdego dowodu, w którym występuje jeden raz jako ostatnia reguła. Następnie wykazujemy, że (Mix) jest eliminowalny z dowodu, w którym występuje $n>1$, przy założeniu, że jest eliminowalny z każdego dowodu o mniejszej ilości wystąpień (Mix). Cała reszta dowodu przebiega w obrębie dowodu bazy tej pierwszej indukcji. Z tego względu, i ponieważ dowód kroku indukcyjnego jest - jak zobaczymy - dość trywialny, eliminacja cięcia jest w literaturze często prezentowana jako indukcja podwójna zastosowana do każdego dowodu, w którym (Mix) występuje tylko raz.

Nadrzędna indukcja przebiega tutaj po długości cut-formuły - w bazie wykazujemy, że jeśli jest to zmienna, to z dowodu można wyeliminować to (jedyne) wystąpienie (Mix). W kroku indukcyjnym zakładamy, że (Mix) jest eliminowalne w każdym przypadku, gdy długość cut-formuły jest mniejsza od $n>1$ i wykazujemy, że dowód z (Mix) na cut-formule o długości $n$ można zastąpić przez dowód, w którym każdy (Mix) jest na cut-formule krótszej (a 
zatem eliminowalny na mocy założenia indukcyjnego). Zarówno dowód bazy jak i kroku indukcyjnego indukcji po długości cut-formuły wymaga przeprowadzenia kolejnej indukcji - po głębokości (Mix). W bazie tej indukcji dowodzimy, że ilekroć głębokość wynosi 2 (w obu przesłankach cut-formuła pojawiła się po raz pierwszy), to można albo ten (Mix) całkowicie wyeliminować (tak dowodzimy dla bazy indukcji po długości cut-formuły), albo ten dowód zastąpić przez dowody z cut-formułami o mniejszej długości (a te są eliminowalne z założenia indukcyjnego indukcji po długości cut-formuły). Dowód kroku indukcyjnego indukcji po głębokości sprowadza się do wykazania, że (Mix), w którym (lewy lub prawy) rank > 1, można zastąpić przez (Mix) o miniejszej głębokości, który - z założenia indukcyjnego indukcji po głębokości - jest redukowalny. Oto schemat dowodu:

\section{Indukcja po ilości (Mix).}

1.1. Baza: W dowodzie zawierającym jedno zastosowanie (Mix), jest on eliminowalny.

II. Indukcja po długości cut-formuły.

2.1. Baza: (Mix) na formule atomowej jest eliminowalny.

\section{Indukcja po głębokości cut-formuły.}

3.1. Baza: (Mix) na cut-formule długości 0 i rank=2 jest eliminowalny.

3.2. Krok indukcyjny: Jeżeli (Mix) na cut-formule o długości 0 ma rank $>2$, to można go zastąpić przez (Mix) o mniejszej głębokości.

Wniosek z 3.1., 3.2: (Mix) o dowolnej głębokości na cut-formule o długości 0 można wyeliminować.

2.2. Krok indukcyjny: Jeżeli (Mix) na cut-formule o długości $k<n$ jest eliminowalny, to jest też eliminowalny na cut-formule o długości

$n$.

\section{Indukcja po głębokości cut-formuły.}

4.1. Baza: (Mix) na cut-formule o długości $n$ i o rank=2 jest zastępowalny przez (Mix) na cut-formułach o długości $k<n$.

4.2. Krok indukcyjny: Jeżeli (Mix) na cut-formule o długości $n$ ma rank $>2$, to można go zastąpić przez (Mix) o mniejszej głębokości.

Wniosek z 4.1., 4.2: (Mix) o dowolnej głębokości na cut-formule o długości $n$ można zastąpić przez zastosowania (Mix) na cut-formułach o długości mniejszej. 
Wniosek z 2.1., 2.2: (Mix) na cut-formule o dowolnej długości jest eliminowalny z dowodu, w którym występuje raz.

1.2. Krok indukcyjny: Jeżeli (Mix) jest eliminowalny w dowodzie, w którym występuje $k<n$ razy, to jest eliminowalny w dowodzie, w którym występuje $n$ razy.

Wniosek z 1.1., 1.2: (Mix) jest eliminowalne w każdym dowodzie.

Na początek udowodnijmy krok indukcyjny 1.2, aby pokazać, że dla dowodu twierdzenia o eliminacji, wystarczy dowiedzenie bazy indukcji I (czyli krok $1.1 \mathrm{w}$ powyższym schemacie). Sformułujemy je jako osobne lematy:

Lemat 5.2 Dowód, w którym (Mix) wystęuje tylko raz jako jego ostatnia reguła można przekształcić $w$ dowód nie zawierajacy żadnego zastosowania (Mix).

Lemat 5.3 Jeżeli (Mix) jest eliminowalny w dowodzie, w którym wystęuje $k<n$ razy, to jest eliminowalny $w$ dowodzie, $w$ którym wystęuje $n$ razy.

DowóD: W dowolnym dowodzie z wieloma zastosowaniami (Mix) $(n \geq 2)$ wybieramy takie, nad którym nie występuje inne zastosowanie tej reguły (może być ich kilka). Poddowód, który kończy się tym zastosowaniem (Mix) spełnia warunki lematu 5.2, zatem można go w rozważanym dowodzie wymienić na taki poddowód, który już żadnego zastosowania (Mix) nie posiada. Ilość zastosowań (Mix) w nowym dowodzie wynosi $n-1$ zatem podpada pod założenia indukcyjne kroku 1.2.

Zatem możemy skupić się na dowodzie Lematu 5.2. W schemacie indukcja po głębokości (Mix) występuje dwukrotnie (punkty 3.1 i 3.2 a potem 4.1 i 4.2) jednak rozdzielanie ich $\mathrm{w}$ ten sposób jest niecelowe. Dlatego omówimy indukcję III (tj. po głębokości (Mix)) łącznie, ale wskazując jaką rolę odgrywa dla obu przesłanek indukcji II (po długości cut-formuły).

DowóD Lematu 5.2: Baza indukcji III (punkt 3.1, 4.1): Głębokość (Mix)=2.

Punkt 3.1. W tej części dowodu, która przebiega na potrzeby dowodu bazy indukcji II (punkt 2.1) przyjmujemy, że cut-formuła jest zmienną. Dowód punktu 3.1 jest trywialny, gdyż przy głębokości 2 eliminowana zmienna mogła być wprowadzona albo przez osłabianie albo w sekwencie aksjomatycznym, a oba przypadki (Mix) są eliminowalne zgodnie z faktem 5.1.

Punkt 4.1. Rozważając formuły nieatomowe, w przypadku gdy jedna z przesłanek jest aksjomatem, lub otrzymana przez $(W)$, (Mix) jest eliminowalny całkowicie, analogicznie jak w punkcie 3.1 przez odwołanie do faktu 
5.1. Kontrakcja i permutacja nie wchodzą w grę skoro głębokość $(\mathrm{Mix})=$ 2 , gdyż wtedy L-rank lub R-rank $>1$. Zostają zatem przypadki, w których cut-formuła jest otrzymana przez regułę logiczną w obu przesłankach. Wykazujemy w każdym przypadku, że (Mix) na formule o długości $n$ jest zastępowalny przez zastosowania (Mix) na formułach krótszych.

1. Przypadek, gdy cut-formuła $:=\varphi \wedge \psi$. Fragment dowodu o postaci:

$$
(\Rightarrow \wedge) \frac{\Gamma \Rightarrow \Delta, \varphi \quad \Gamma \Rightarrow \Delta, \psi}{(M i x) \frac{\Gamma \Rightarrow \Delta, \varphi \wedge \psi}{\Gamma, \Pi \Rightarrow \Delta, \Sigma}} \frac{\varphi, \Pi \Rightarrow \Sigma}{\varphi \wedge \psi, \Pi \Rightarrow \Sigma}(\wedge \Rightarrow)
$$

zostaje zastąpiony przez:

$$
\frac{\Gamma \Rightarrow \Delta, \varphi \quad \varphi, \Pi \Rightarrow \Sigma}{(W)(P) \frac{\Gamma, \Pi_{\varphi} \Rightarrow \Delta_{\varphi}, \Sigma}{\Gamma, \Pi \Rightarrow \Delta, \Sigma}}(\text { Mix })
$$

Zauważmy, że zgodnie z założeniem $\varphi \wedge \psi$ nie występuje ani $\mathrm{w} \Delta$ ani $\mathrm{w} \Pi$. Analogicznie dla $(\wedge \Rightarrow)$ na $\psi$.

2. i 3. Analogicznie dla $\vee \mathrm{i} \neg$.

4. Przypadek gdy cut-formuła $:=\varphi \rightarrow \psi$. Fragment dowodu o postaci:

$$
(\Rightarrow \rightarrow) \frac{\varphi, \Gamma \Rightarrow \Delta, \psi}{\frac{\Gamma \Rightarrow \Delta, \varphi \rightarrow \psi}{\Gamma, \Pi, \Lambda \Rightarrow \Delta, \Sigma, \Xi} \quad \frac{\Pi \Rightarrow \Sigma, \varphi \quad \psi, \Lambda \Rightarrow \Xi}{\varphi \rightarrow \psi, \Pi, \Lambda \Rightarrow \Sigma, \Xi}(\rightarrow \Rightarrow)}(\text { Mix })
$$

zostaje zastąpiony przez:

$$
\frac{\Pi \Rightarrow \Sigma, \varphi \quad \frac{\varphi, \Gamma \Rightarrow \Delta, \psi \quad \psi, \Lambda \Rightarrow \Xi}{\varphi, \Gamma, \Lambda_{\psi} \Rightarrow \Delta_{\psi}, \Xi}(\text { Mix })}{\frac{\Pi, \Gamma_{\varphi}, \Lambda_{\psi, \varphi} \Rightarrow \Sigma_{\varphi}, \Delta_{\psi}, \Xi}{\Gamma, \Pi, \Lambda \Rightarrow \Delta, \Sigma, \Xi}(W)(P)}
$$

gdzie $\Lambda_{\psi, \varphi}$ oznacza $\Lambda$ bez wystąpień $\psi$ i $\varphi$.

Zauważmy, że w wyniku otrzymanej transformacji mamy dwa wystąpienia (Mix), a przecież dowodzimy faktycznie lematu, zgodnie z którym eliminowalne jest (Mix), które ma jedno wystąpienie jako ostatnia reguła w dowodzie. Oba zastosowania (Mix) są na cut-formule o mniejszej długości. To, 
które występuje wyżej jest zatem eliminowalne, gdyż spełnia założenie indukcyjne indukcji II (po długości - punkt 2.2.). Zatem dowód $\varphi, \Gamma, \Lambda_{\psi} \Rightarrow \Delta_{\psi}, \Xi$ możemy zastąpić dowodem bez (Mix), a wtedy drugie wystąpienie (Mix) staje się jedynym i też podpada pod założenie indukcyjne indukcji II, a zatem też jest eliminowalne.

Krok indukcyjny indukcji III (po głębokości (Mix) - punkt 3.2 i 4.2).

Przeprowadzenie tej części dowodu wymaga znacznie więcej pracy i rozważenia wielu przypadków.

Punkt. 3.2. Krok indukcyjny po głębokości (Mix). Założenie indukcyjne: Przyjmijmy, że (Mix) o głębokości $<n$ jest eliminowalny. Dowodzimy, że każdy (Mix) o głębokości $=n$ można zastąpić zastosowaniami (Mix) na tej samej formule (długość nie ulega zmianie) o mniejszej głębokości. Dowód ma dwie części:

A. Zakładamy, że R-rank> 1 i rozważamy różne przypadki, które doprowadziły do dedukcji prawej przesłanki (Mix).

B. Zakładamy, że L-rank> 1 i rozważamy różne przypadki, które doprowadziły do dedukcji lewej przesłanki (Mix).

W każdej części należy rozważyć sytuacje gdy cut-formuła jest:

1. parametryczna;

2. przesłankowa (zastosowanej reguły);

3. zasadnicza.

Przy czym dla dowodu bazy indukcji II (punkt 3.2) znaczenie mają tylko przypadki 2 i 3, gdyż tylko wtedy cut-formuła może być zmienną. Natomiast dla dowodu kroku indukcyjnego tej indukcji (punkt 4.2) ważne są wszystkie przypadki. Rozważając poszczególne sytuacje trzeba dodatkowo wziąć pod uwagę wszystkie możliwe reguły strukturalne i logiczne. Poniżej dowiedziemy części A, zostawiając dowód części B, jako symetryczny do A, czytelnikowi. W dowodzie części A. rozważymy wszystkie przypadki różniące się istotnie od siebie pozostawiając czytelnikowi przerobienie pozostałych, podobnych przekształceń.

A. Zakładamy, że R-rank> 1

A1. Przypadki gdy cut-formuła jest parametrem. 
A11. Gdy prawa przesłanka jest otrzymana przez regułę działającą tylko na następniku:

A111. Jednoprzesłankowe reguły:

A1111. Przypadek $(\Rightarrow \vee)$. Fragment dowodu o postaci:

$$
\left.(M i x) \frac{\Gamma \Rightarrow \Delta[\varphi] \quad \frac{\Pi[\varphi] \Rightarrow \Sigma, \psi}{\Pi[\varphi] \Rightarrow \Sigma, \psi \vee \chi}}{\Gamma, \Pi_{\varphi} \Rightarrow \Delta_{\varphi}, \Sigma, \psi \vee \chi} \Rightarrow \vee\right)
$$

zostaje zastąpiony przez:

$$
(\Rightarrow \vee) \frac{\Gamma \Rightarrow \Delta[\varphi] \quad \Pi[\varphi] \Rightarrow \Sigma, \psi}{\Gamma, \Pi_{\varphi} \Rightarrow \Delta_{\varphi}, \Sigma, \psi}(\text { Mix })
$$

A1112-A1114. Analogicznie dla $(\Rightarrow W),(\Rightarrow C),(\Rightarrow P)$.

A112. Dwuprzesłankowe reguły - tylko $(\Rightarrow \wedge)$. Fragment dowodu o postaci:

$$
\frac{\Gamma \Rightarrow \Delta[\varphi] \quad \frac{\Pi[\varphi] \Rightarrow \Sigma, \psi \quad \Pi[\varphi] \Rightarrow \Sigma, \chi}{\Pi[\varphi] \Rightarrow \Sigma, \psi \wedge \chi}(\text { Mix })}{\Gamma, \Pi_{\varphi} \Rightarrow \Delta_{\varphi}, \Sigma, \psi \wedge \chi}(\Rightarrow \wedge)
$$

zostaje zastąpiony przez:

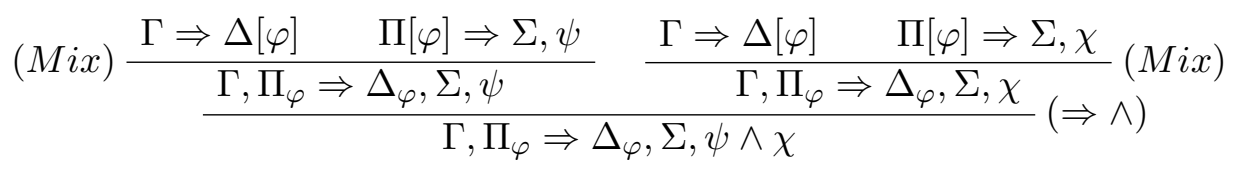

gdzie oba zastosowania (Mix) mają mniejszą głębokość, są zatem eliminowalne z założenia indukcyjnego.

A12. Przypadki gdy cut-formuła jest parametrem a prawa przesłanka jest otrzymana przez regułę działającą tylko na poprzedniku.

A121. Jednoprzesłankowe reguły.

A1211. Przypadek $(\wedge \Rightarrow)$. Fragment dowodu o postaci:

$$
(\operatorname{Mix}) \frac{\Gamma \Rightarrow \Delta[\varphi] \quad \frac{\psi, \Pi[\varphi] \Rightarrow \Sigma}{\psi \wedge \chi, \Pi[\varphi] \Rightarrow \Sigma}}{\Gamma, \psi \wedge \chi, \Pi_{\varphi} \Rightarrow \Delta_{\varphi}, \Sigma}(\wedge \Rightarrow)
$$


zostaje zastąpiony przez:

$$
(\wedge \Rightarrow)(P \Rightarrow) \frac{\Gamma \Rightarrow \Delta[\varphi] \quad \psi, \Pi[\varphi] \Rightarrow \Sigma}{\frac{\Gamma, \psi, \Pi_{\varphi} \Rightarrow \Delta_{\varphi}, \Sigma}{\Gamma, \psi \wedge \chi, \Pi_{\varphi} \Rightarrow \Delta_{\varphi}, \Sigma}} \text { (Mix) }
$$

A1212-A1214. Analogicznie dla $(W \Rightarrow),(C \Rightarrow),(P \Rightarrow)$.

A122. Dwuprzesłankowe reguły - tylko $(\vee \Rightarrow)$ dowód analogicznie do A112, czyli $(\Rightarrow \wedge)$.

A13. Przypadki gdy cut-formuła jest parametrem a prawa przesłanka jest otrzymana przez regułę działającą na obu stronach sekwentu.

A131. Jednoprzesłankowe reguły.

A1311. Przypadek $(\Rightarrow \rightarrow)$. Fragment dowodu o postaci:

$$
(M i x) \frac{\Gamma \Rightarrow \Delta[\varphi] \quad \frac{\psi, \Pi[\varphi] \Rightarrow \Sigma, \chi}{\Pi[\varphi] \Rightarrow \Sigma, \psi \rightarrow \chi}}{\Gamma, \Pi_{\varphi} \Rightarrow \Delta_{\varphi}, \Sigma, \psi \rightarrow \chi}(\Rightarrow \rightarrow)
$$

zostaje zastąpiony przez:

$$
(\Rightarrow \rightarrow)(P \Rightarrow) \frac{\Gamma \Rightarrow \Delta[\varphi] \quad \psi, \Pi[\varphi] \Rightarrow \Sigma, \chi}{\Gamma, \psi, \Pi_{\varphi} \Rightarrow \Delta_{\varphi}, \Sigma, \chi}(\text { Mix })
$$

A1312-A1313. Analogicznie dla $(\neg \Rightarrow),(\Rightarrow \neg)$.

A132. Dwuprzesłankowe reguły - tylko $(\rightarrow \Rightarrow)$. Fragment dowodu o postaci:

$$
\frac{\Pi[\varphi] \Rightarrow \Sigma, \psi \quad \chi, \Lambda[\varphi] \Rightarrow \Xi}{\Gamma \Rightarrow \Delta[\varphi] \quad \frac{(\rightarrow \Rightarrow)}{\psi \rightarrow \chi, \Pi[\varphi], \Lambda[\varphi] \Rightarrow \Sigma, \Xi}(\text { Mix })}
$$

zostaje zastąpiony przez:

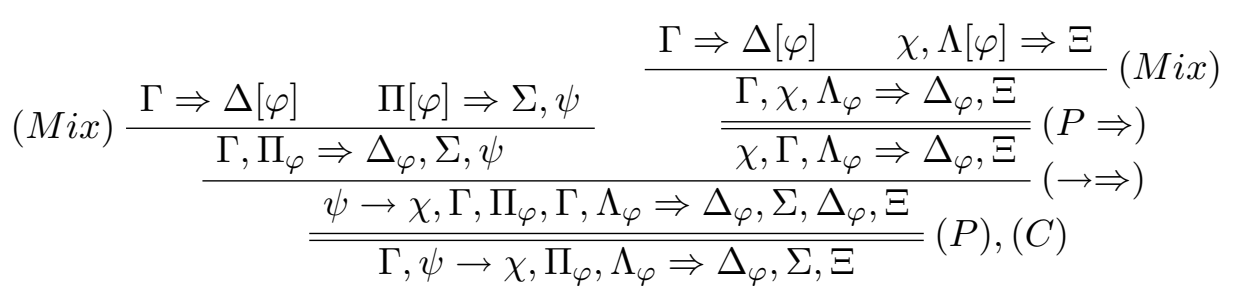


gdzie oba zastosowania (Mix) mają mniejszą głębokość, są zatem eliminowalne z założenia indukcyjnego.

A2. Przypadki gdy cut-formuła jest formuła przesłankową reguły zastosowanej do prawego sekwentu-przesłanki.

A21. Jednoprzesłankowe reguły.

A211. Przypadek $(\Rightarrow \rightarrow)$. Fragment dowodu o postaci:

$$
(\operatorname{Mix}) \frac{\Gamma \Rightarrow \Delta[\varphi] \quad \frac{\varphi, \Pi[\varphi] \Rightarrow \Sigma, \psi}{\Pi[\varphi] \Rightarrow \Sigma, \varphi \rightarrow \psi}}{\Gamma, \Pi_{\varphi} \Rightarrow \Delta_{\varphi}, \Sigma, \varphi \rightarrow \psi}(\Rightarrow \rightarrow)
$$

zostaje zastąpiony przez:

$$
\begin{aligned}
& \frac{\Gamma \Rightarrow \Delta[\varphi] \quad \varphi, \Pi[\varphi] \Rightarrow \Sigma, \psi}{\Gamma, \Pi_{\varphi} \Rightarrow \Delta_{\varphi}, \Sigma, \psi} \\
& (W \Rightarrow) \frac{\text { Mix })}{\varphi, \Gamma, \Pi_{\varphi} \Rightarrow \Delta_{\varphi}, \Sigma, \psi} \\
& (\Rightarrow \rightarrow) \frac{\Gamma, \Pi_{\varphi} \Rightarrow \Delta_{\varphi}, \Sigma, \varphi \rightarrow \psi}{\Gamma, \varphi}
\end{aligned}
$$

A212-A213. Analogicznie dla pozostałych reguł jednoprzesłankowych: $(\neg \Rightarrow)$ i $(\wedge \Rightarrow)$.

A22. Dwuprzesłankowe reguły.

A221. Przypadek $(\rightarrow \Rightarrow)$. Fragment dowodu o postaci:

$$
\frac{\Gamma \Rightarrow \Sigma, \psi \quad \varphi, \Lambda \Rightarrow \Xi}{\Gamma \Rightarrow \Delta] \quad \frac{\Pi \Rightarrow)}{\psi \rightarrow \varphi, \Pi, \Lambda \Rightarrow \Sigma, \Xi}(M i x)}
$$

Tym razem mamy dwie możliwości:

A221a. jeżeli $\varphi$ nie jest $\mathrm{w} \Pi\left(\Pi_{\varphi}=\Pi\right)$, to zostaje zastąpiony przez:

$$
\begin{gathered}
\frac{\Gamma \Rightarrow \Delta[\varphi] \quad \varphi, \Lambda \Rightarrow \Xi}{\Gamma, \Lambda_{\varphi} \Rightarrow \Delta_{\varphi}, \Xi}(\text { Mix }) \\
\frac{\frac{\Pi \Rightarrow \Sigma, \psi \quad}{\varphi, \Gamma, \Lambda_{\varphi}, \Rightarrow \Delta_{\varphi}, \Xi}}{(W)}(\rightarrow) \\
\frac{\psi \rightarrow \varphi, \Pi, \Gamma, \Lambda_{\varphi} \Rightarrow \Sigma, \Delta_{\varphi}, \Xi}{\Gamma, \psi \rightarrow \varphi, \Pi_{\varphi}, \Lambda_{\varphi} \Rightarrow \Delta_{\varphi}, \Sigma, \Xi}(P)
\end{gathered}
$$

A221b. jeżeli $\varphi$ jest $\mathrm{w} \Pi$, to zostaje zastąpiony przez: 


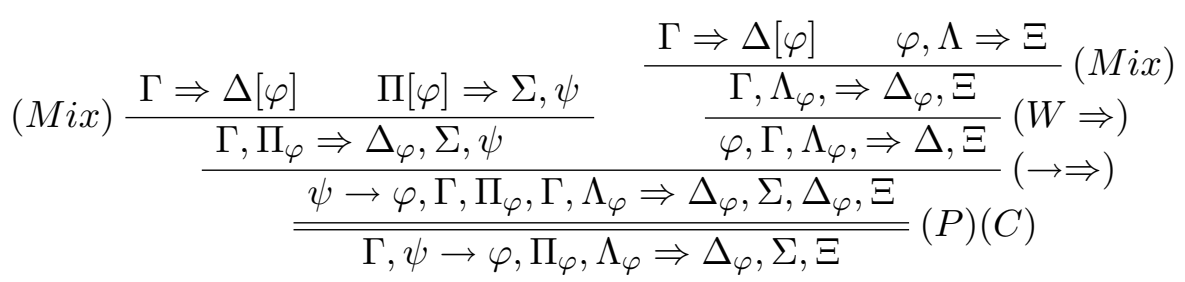

A222. Przypadek $(\vee \Rightarrow)$ jest analogiczny.

A3 Przypadki gdy cut-formuła jest formułą zasadniczą reguły zastosowanej do prawego sekwentu-przesłanki (zauważmy, że wtedy cut-formuła musi tė̇, z założenia o R-rank, występować w zbiorze parametrów).

A31. Gdy zastosowana reguła jest jednoprzesłankowa.

A311. Przypadek $(\wedge \Rightarrow)$. Fragment dowodu o postaci:

$$
(\operatorname{Mix}) \frac{\Gamma \Rightarrow \Delta[\varphi \wedge \psi] \quad \frac{\varphi, \Pi[\varphi \wedge \psi] \Rightarrow \Sigma}{\varphi \wedge \psi, \Pi[\varphi \wedge \psi] \Rightarrow \Sigma}}{\Gamma, \Pi_{\varphi \wedge \psi} \Rightarrow \Delta_{\varphi \wedge \psi}, \Sigma}(\wedge \Rightarrow)
$$

zostaje zastąpiony przez:

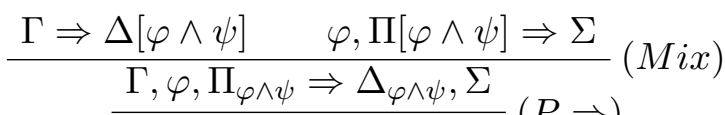

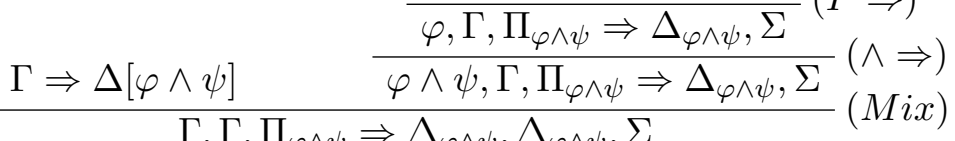

$$
\begin{aligned}
& \frac{\Gamma, \Gamma, \Pi_{\varphi \wedge \psi} \Rightarrow \Delta_{\varphi \wedge \psi}, \Delta_{\varphi \wedge \psi}, \Sigma}{\Gamma, \Pi_{\varphi \wedge \psi} \Rightarrow \Delta_{\varphi \wedge \psi}, \Sigma}(P),(C)
\end{aligned}
$$

Zauważmy, że drugie zastosowanie (Mix) ma R-rank=1, gdyż cut-formuła pojawia się po raz pierwszy w prawej przesłance; wystąpienia cut-formuły powyżej się nie liczą gdyż tamten (Mix) podlega najpierw eliminacji z racji podpadania pod założenie indukcyjne. Analogiczna uwaga dotyczy każdego najniżej występującego zastosowania (Mix) w przekształceniach uzyskanych dla kolejnego przypadku.

A312. Analogicznie dla pozostałych reguł jednoprzesłankowych, czyli dla $(\neg \Rightarrow)$.

A32. Reguły dwuprzesłankowe.

A321. Przypadek $(\rightarrow \Rightarrow)$. Mamy fragment dowodu o postaci: 


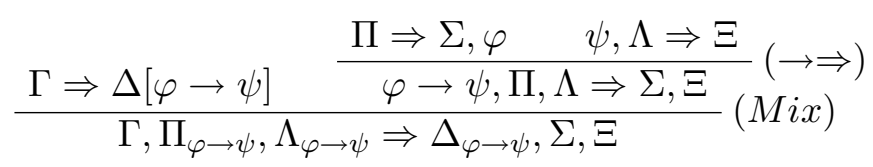

Zauważmy, że nie wiemy czy jakieś wystąpienia $\varphi \rightarrow \psi$ są w obu zbiorach parametrów $\Pi$ i $\Lambda$ zatem musimy rozważyć trzy przypadki:

A321a $\varphi \rightarrow \psi$ jest zarówno w $\Pi$ jak i w $\Lambda$. Dowód wyjściowy zostaje zastąpiony przez:

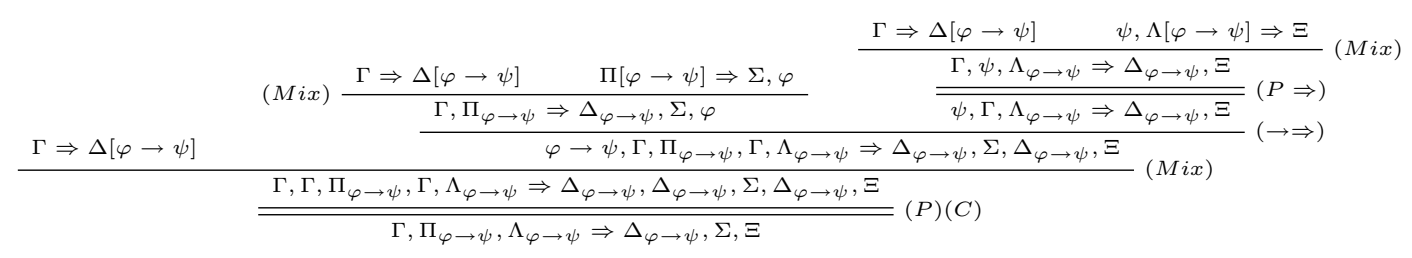

A321b $\varphi \rightarrow \psi$ jest $\mathrm{w} \Pi$ ale nie $\mathrm{w} \Lambda$. Dowód wyjściowy zostaje zastąpiony przez:

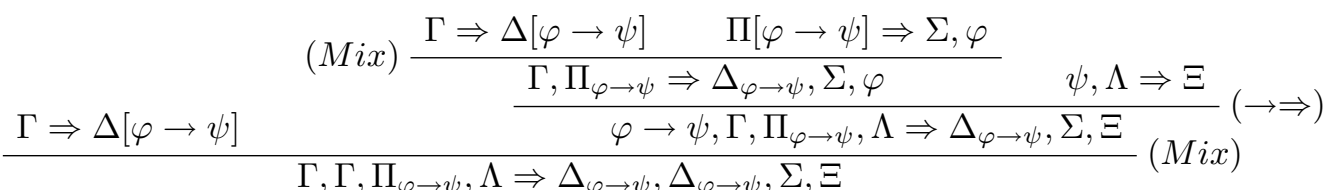

$$
\begin{aligned}
& \Gamma, \Pi_{\varphi \rightarrow \psi}, \Lambda \Rightarrow \Delta_{\varphi \rightarrow \psi}, \Sigma, \Xi
\end{aligned}
$$

A321c $\varphi \rightarrow \psi$ jest $\mathrm{w} \Lambda$ ale nie $\mathrm{w} \Pi$. Dowód wyjściowy zostaje zastąpiony przez:

$$
\begin{gathered}
\frac{\Gamma \Rightarrow \Delta[\varphi \rightarrow \psi] \quad \psi, \Lambda[\varphi \rightarrow \psi] \Rightarrow \Xi}{\Gamma, \psi, \Lambda_{\varphi \rightarrow \psi} \Rightarrow \Delta_{\varphi \rightarrow \psi}, \Xi} \\
\frac{\Gamma \Rightarrow \Delta[\varphi \rightarrow \psi]}{\overline{\psi, \Gamma, \Lambda_{\varphi \rightarrow \psi} \Rightarrow \Delta_{\varphi \rightarrow \psi}, \Xi}}(\text { Mix }) \\
\frac{\Pi \Rightarrow \Sigma, \varphi}{\varphi \rightarrow \psi, \Pi, \Gamma, \Lambda_{\varphi \rightarrow \psi} \Rightarrow \Sigma, \Delta_{\varphi \rightarrow \psi}, \Xi} \\
\frac{\Gamma, \Pi, \Gamma, \Lambda_{\varphi \rightarrow \psi} \Rightarrow \Delta_{\varphi \rightarrow \psi}, \Sigma, \Delta_{\varphi \rightarrow \psi}, \Xi}{\Gamma, \Pi, \Lambda_{\varphi \rightarrow \psi} \Rightarrow \Delta_{\varphi \rightarrow \psi}, \Sigma, \Xi}(P)(C)
\end{gathered}
$$

A322. Analogiczny dowód dla $(\vee \Rightarrow)$ choć bez rozważania podprzypadków.

B. Analogicznie jak w części A. Dowodzimy redukcji głębokości (Mix) przy założeniu, że L-rank> 1 . 
Odnotujmy, że przystosowanie oryginalnego dowodu Gentzena do LK jako m-systemu nie nastręcza żadnych trudności, gdyż reguły (P) nie odgrywają w nim żadnej istotnej roli.

\subsection{Dowody oparte na lokalnych przekształceniach}

Poniżej zaprezentujemy trzy dowody dopuszczalności (Cut), które też są oparte na lokalnych przekształceniach analizowanego dowodu i w tym sensie przypominają dowód Gentzena. Natomiast podstawowe różnice z dowodem Gentzena są następujące:

1. są to dowody dopuszczalności (Cut) - pokazują nie jak eliminować (Cut) z dowodu ale, że jego dołączenie nie wzmacnia systemu;

2. indukcja po dwóch parametrach (nie po trzech);

3. dla ARS z aksjomatami atomowymi (za wyjątkiem dowodu Smullyana, który nie nakłada ograniczeń na aksjomaty);

4. bezpośrednio dla (Cut), a nie dla (Mix);

5. indukcja nie po głębokości, ale po długości/wysokości dowodu przesłanek (Cut).

Punkt 2 jest, jak wyżej odnotowaliśmy (por.paragraf 5.1.1) konsekwencją punktu 1. Nadrzędna indukcja po ilości zastosowań (Cut) staje się zbędna, gdyż nie rozważamy dowodów systemu, w którym (Cut) jest regułą pierwotną - obie przesłanki analizowanego zastosowania (Cut) są z założenia pozbawione użycia tej reguły. Punkty 4 i 5 są konsekwencją 3, czyli przyjęcia systemu ARS, w szczególności udowodnionej dla m-ARS dopuszczalności kontrakcji. Dodatkowo zakładamy dla wszystkich dowodów omawianych w tym podrozdziale (oprócz dowodu Smullyana), że aksjomaty mają postać $\varphi, \Gamma \Rightarrow \Delta, \varphi$, gdzie $\varphi \in Z Z$ (p. 3). Oczywiście nie osłabia to systemu, gdyż twierdzenie 4.1 zachodzi dla ARS, a przez dopuszczalność (W) $\vdash \Gamma \Rightarrow \Delta$, dla dowolnego $\Gamma \cap \Delta \neq \varnothing$. Założenie to jedynie upraszcza dowód. Ponieważ w ARS nie mamy pierwotnych reguł strukturalnych, więc pojęcie długości i wysokości dowodu się pokrywają.

Uwaga 5.1: Przypomnijmy, że długość zastosowania (Cut) określamy jako sumę długości dowodów obu przesłanek. Ponieważ generalnie długość dowodu sekwentu jest określana nie jako suma długości dowodów przesłanek ale jako maksymalna długość gałęzi tego dowodu +1 (por. definicję w rozdziale 
3) niesie to pewne konsekwencje, na które trzeba uważać podczas kroków redukcyjnych. Otóż w ogólności długość (Cut) nie jest monotoniczna, tzn. jeżeli w dowodzie mamy dwa zastosowania (Cut) - nazwijmy je cut1 i cut2 (gdzie cut2 jest niżej w dowodzie) - to długość cut2 nie musi być większa niż długość cut1. Np. niech długość cut1 $=k+j$, a długość dowodu tej przesłanki cut2, nad którą znajduje sice cut1 wynosi $m$ a drugiej $n$. Wprawdzie $m>k$ i $m>j$ ale może być tak, że $m+n<k+j$.

\subsubsection{Dowód Dragalina}

Poniżej zaprezentujemy dowód, który został zaprezentowany w zarysie przez Dragalina [32] dla logicznej wersji m-systemu RS dla INT. Detaliczną prezentację tego dowodu zawiera Dyckhoff [37], a jego zastosowanie do m-ARS dla KRZ znaleźć można np. w Schwichtenberg, Troelstra [145], czy Negri, von Plato [101]. Popularność tego dowodu wynika stąd, że zachowując zasadnicze idee dowodu Gentzena prowadzi jednak do dużego uproszczenia całej jego struktury i mniejszej ilości detali z powodu braku reguł strukturalnych. Wykazujemy dla m-ARS z aksjomatami atomowymi, że jeżeli $\vdash \Gamma \Rightarrow \Delta, \varphi$ i $\vdash \varphi, \Pi \Rightarrow \Sigma$, to $\vdash \Gamma, \Pi \Rightarrow \Delta, \Sigma$.

Dowód rozbity jest na 3 części:

1. co najmniej jedna przesłanka aksjomatyczna;

2. cut-formuła nie jest zasadnicza w co najmniej jednej przesłance;

3. cut-formuła jest zasadnicza w obu przesłankach.

DowóD: W każdym przypadku rozważamy podprzypadki zastosowania różnych reguł do rozważanej przesłanki (Cut). W pierwszej części pokazujemy, że (Cut) jest całkowicie eliminowalne. Wynika to z faktu 5.1.

W punkcie 2 wykazujemy, że można zredukować długość dowodu jednej przesłanki (Cut). Nie ma potrzeby detalicznie rozważać wszystkich przypadków, gdyż zasadniczo pokrywają się one z transformacjami omówionymi dla dowodu Gentzena w punktach A1 oraz (zostawionym czytelnikowi) B1. Całkowicie odpada rozważanie przypadków zgrupowanych w punkcie A2 i A3 (oraz B2 i B3), gdyż zachodzą one dla systemu z (pierwotną) kontrakcją i z (Mix) zamiast (Cut), co uzasadnimy poniżej (uwaga 5.2).

Przyjmujemy, przykładowo, że cut-formuła nie jest zasadnicza w lewej przesłance (Cut) zatem przy niezmienionej przesłance prawej pokazujemy, że długość dowodu lewej przesłanki można zmniejszyć. Rozważamy wszystkie 
osiem przypadków zastosowania reguł logicznych do uzyskania lewej przesłanki. Dla przykładu pokażemy $(\rightarrow \Rightarrow)$ :

$$
(\rightarrow \Rightarrow) \frac{\Gamma \Rightarrow \Delta, \varphi, \chi \quad \psi, \Gamma \Rightarrow \Delta, \chi}{\frac{\varphi \rightarrow \psi, \Gamma \Rightarrow \Delta, \chi}{\varphi \rightarrow \psi, \Gamma, \Pi \Rightarrow \Delta, \Sigma} \quad \chi, \Pi \Rightarrow \Sigma}(C u t)
$$

zostaje zastąpiony przez:

$$
(C u t) \frac{\Gamma \Rightarrow \Delta, \varphi, \chi \quad \chi, \Pi \Rightarrow \Sigma}{\frac{\Gamma, \Pi \Rightarrow \Delta, \Sigma, \varphi}{\varphi \rightarrow \psi, \Gamma, \Pi \Rightarrow \Delta, \Sigma}} \quad \frac{\psi, \Gamma \Rightarrow \Delta, \chi \quad \chi, \Pi \Rightarrow \Sigma}{\psi, \Gamma, \Pi \Rightarrow \Delta, \Sigma}(\text { Cut })
$$

gdzie oba zastosowania (Cut) mają mniejszą długość, są zatem eliminowalne z założenia indukcyjnego.

Jak widać kroki przeprowadzane w punkcie 2 odpowiadają transformacjom z punktu B1 w dowodzie Gentzena, który pozostawiliśmy czytelnikowi. Analogiczne transformacje przeprowadzamy jeżeli założymy, że cut-formuła jest parametryczna w prawej przesłance. Znów rozważamy osiem przypadków zastosowania reguł logicznych, tym razem do prawej przesłanki. Pokrywają się one z punktem A1 w dowodzie Gentzena tylko są prostsze gdyż nie wymagają uwzględniania zastosowań reguł strukturalnych.

W punkcie 3. dowodzimy, że można zredukować długość cut-formuły. Ponieważ zmienne nie moga być formułami zasadniczymi, więc w konsekwencji prowadzi to do całkowitej eliminacji (Cut). Dowód w tym punkcie nie różni się od dowodu punktu $4.1 \mathrm{w}$ dowodzie Gentzena, choć tu dla odmiany transformacje dla cut-formuł o postaci koniunkcji i alternatywy są bardziej skomplikowane dla wariantów Ketonena. Dla przykładu podamy przypadek koniunkcji:

$$
(\Rightarrow \wedge) \frac{\Gamma \Rightarrow \Delta, \varphi \quad \Gamma \Rightarrow \Delta, \psi}{(C u t) \frac{\Gamma \Rightarrow \Delta, \varphi \wedge \psi}{\Gamma, \Pi \Rightarrow \Delta, \Sigma}} \frac{\varphi, \psi, \Pi \Rightarrow \Sigma}{\varphi \wedge \psi, \Pi \Rightarrow \Sigma}(\wedge \Rightarrow)
$$

zostaje zastąpiony przez:

$$
\frac{\Gamma \Rightarrow \Delta, \psi \quad \frac{\Gamma \Rightarrow \Delta, \varphi \quad \varphi, \psi, \Pi \Rightarrow \Sigma}{\psi, \Gamma, \Pi \Rightarrow \Delta, \Sigma}(C u t)}{\frac{\Gamma, \Gamma, \Pi \Rightarrow \Delta, \Delta, \Sigma}{\Gamma, \Pi \Rightarrow \Delta, \Sigma}(C)}(C u t)
$$


Jak widać w porównaniu do stosownej transformacji dla reguł Gentzena zmuszeni jesteśmy zastosować (Cut) dwukrotnie. Co więcej, wysokość drugiego zastosowania (Cut) może być większa, ale oba zastosowania są na mniejszych cut-formułach. Zatem cel redukcji jest w tym punkcie osiągnięty. Niezbędne jest też użycie kontrakcji, ale - jak dowiedliśmy w podrozdziale 4.3 - jest ona dopuszczalna w m-ARS.

Uwaga 5.2: Zauważmy, że przypadki rozważane przez nas w dowodzie Gentzena w punkcie A2 i B2 (cut-formuła jako formuła przesłankowa) podpadaja (jako szczególne przypadki) pod transformacje przeprowadzane w dowodzie Dragalina w punkcie drugim, gdyż z dwóch wystąpień cut-formuły w prawej przesłance (Cut) tylko jedna jest eliminowana po przesunięciu danego zastosowania (Cut) do góry; druga nadal może być wykorzystana poniżej jako formuła poboczna zastosowania odpowiedniej reguły. Z kolei przypadki podpadające w dowodzie Gentzena pod punkt A3 i B3 (cut-formuła jako formuła zasadnicza) nie znajdują zastosowania, gdyż (Cut) wycina tylko jedno wystąpienie cut-formuły, a nie wszystkie jak (Mix).

Uwaga 5.3: Podział dowodu na trzy części istotnie wyczerpuje wszystkie przypadki opierając się na dwustopniowej klasyfikacji. Pierwsze kryterium dotyczy długości dowodu; dychotomicznie oddzielamy dwa przypadki: 1 . przynajmniej jeden z dowodów przesłanek (Cut) ma długość 0 (część 1) 2. żaden nie ma (tzn. oba mają długość większą - część 2 i 3). Drugie kryterium dotyczy charakteru cut-formuły: 2.1. przynajmniej jedna jest parametryczna (część 2) 2.2. żadna nie jest (tj. obie są zasadnicze - część 3). Taki sam podział zastosowany jest eksplicite w dowodzie Smullyana [131] omawianym w następnym paragrafie. Prezentacja dowodu w Negri, von Plato [101] zawiera dodatkowy podział części drugiej na dwa przypadki: (a) cut-formuła nie jest zasadnicza w lewej (ewentualnie prawej) przesłance; (b) cut-formuła jest zasadnicza tylko w lewej (ewentualnie prawej) przesłance. Nie zmienia to jednak niczego w samym dowodzie, a tylko w jego zewnętrznej organizacji.

Zauważmy jednak, że można punkty (a) i (b) (wyróżnione w wersji dowodu z Negri, von Plato [101]) potraktować, obok części pierwszej, jako kompletny podział dowodu dopuszczalności (Cut) w ARS. Przeprowadzamy wtedy indukcję tylko po długości dowodu jednej z przesłanek (Cut) (np. lewej) oraz korzystamy z tego, że wszystkie reguły są odwracalne (lemat 4.11). Otóż, analizując przypadek (b) nie musimy rozważać czy cut-formuła w prawej przesłance jest zasadnicza czy nie, gdyż możemy odwołać się do lematu o inwersji (tzn. lemat 4.11). I tak, w przykładzie analizowanym wyżej dowód przesłanki $\varphi \wedge \psi, \Pi \Rightarrow \Sigma$ możemy zastąpić dowodem $\varphi, \psi, \Pi \Rightarrow \Sigma$, 
na mocy lematu o inwersji. Reszta przekształceń bez zmian. W ten sposób można dowód Dragalina jeszcze bardziej uprościć sprowadzając krok 3 do 2. W dowodzie Schüttego, omawianym dalej, lemat o inwersji reguł będzie podstawowym środkiem dowodzenia dopuszczalności (Cut), ale organizacja dowodu jest inna.

\subsubsection{Dowód Smullyana}

Smullyan [131] podaje elegancki wariant dowodu dopuszczalności cięcia dla systemu tablicowego. Poniżej przedstawimy go w wersji dostosowanej do zsystemu ARS z addytywnym (Cut) (tj. w wersji k-jednolitej). Organizacja dowodu jest w zasadzie taka sama jak dowodu Dragalina (por. uwaga 5.3), ale użycie z-systemu i innej wersji (Cut) wprowadza pewne różnice, dlatego warto go przytoczyć. Aksjomaty nie muszą być atomowe, nie korzysta się też z odwracalności reguł czy dopuszczalności kontrakcji (gdyż to z-system!), ale dowód w istotny sposób opiera się na lemacie o dopuszczalności (W).

Wprowadzimy, za Smullyanem, następujące oznaczenia i terminologię:

$\vdash \Gamma \Rightarrow_{k}^{\varphi} \Delta$ oznacza, że $\Gamma \Rightarrow \Delta$ ma dowód o długości $k$, w którym ostatnia zastosowana reguła była na formule $\varphi \in \Gamma \cup \Delta$, tzn. $\varphi$ jest formułą zasadniczą $\mathrm{w} \Gamma \Rightarrow \Delta$.

Zauważmy, że $\vdash \Gamma \Rightarrow_{k} \Delta$ wtw $k=0$ (aksjomat) lub $k>0$ i istnieje $\varphi$ takie, że $\vdash \Gamma \Rightarrow_{k}^{\varphi} \Delta$. Oczywiście $\vdash \Gamma \Rightarrow \Delta$ oznacza, że $\exists k$ takie, że $\vdash \Gamma \Rightarrow_{k} \Delta$.

$\varphi$ jest $k$-eliminowalne wtw jest cut-formuła takiego zastosowania (Cut), w którym suma długości dowodów obu przesłanek wynosi $k$.

$\varphi$ jest eliminowalne wtw $\varphi$ jest $k$-eliminowalne dla dowolnego $k$.

W dowodzie korzystamy też z twierdzenia o dopuszczalności (W) z zachowaniem długości dowodu (lemat 4.10). Za jego pomocą wstępnie dowodzimy następującego faktu:

Lemat 5.4 Dla dowolnego $i, j<k$,

1. jeżeli $\vdash \Gamma \Rightarrow_{k}^{\natural \varphi} \Delta, \neg \varphi$, to $\vdash \Gamma, \varphi \Rightarrow_{i} \Delta, \neg \varphi$

2. jeżeli $\vdash \Gamma, \neg \varphi \Rightarrow_{k}^{\neg \varphi} \Delta$, to $\vdash \Gamma, \neg \varphi \Rightarrow_{i} \Delta, \varphi$

3. jeżeli $\vdash \Gamma \Rightarrow_{k}^{\varphi \wedge \psi} \Delta, \varphi \wedge \psi$, to $\vdash \Gamma \Rightarrow_{i} \Delta, \varphi, \varphi \wedge \psi$ oraz $\vdash \Gamma \Rightarrow_{j} \Delta, \psi, \varphi \wedge \psi$

4. jeżeli $\vdash \Gamma, \varphi \wedge \psi \Rightarrow_{k}^{\varphi \wedge \psi} \Delta$, to $\vdash \Gamma, \varphi, \psi, \varphi \wedge \psi \Rightarrow_{i} \Delta$

5. jézeli $\vdash \Gamma \Rightarrow_{k}^{\varphi \vee \psi} \Delta, \varphi \vee \psi$, to $\vdash \Gamma \Rightarrow_{i} \Delta, \varphi, \psi, \varphi \vee \psi$ 
6. jeżeli $\vdash \Gamma, \varphi \vee \psi \Rightarrow_{k}^{\varphi \vee \psi} \Delta$, to $\vdash \Gamma, \varphi, \varphi \vee \psi \Rightarrow_{i} \Delta$ oraz $\vdash \Gamma, \psi, \varphi \vee \psi \Rightarrow_{j} \Delta$

7. jeżeli $\vdash \Gamma \Rightarrow_{k}^{\varphi \rightarrow \psi} \Delta, \varphi \rightarrow \psi$, to $\vdash \Gamma, \varphi \Rightarrow_{i} \Delta, \psi, \varphi \rightarrow \psi$

8. jeżeli $\vdash \Gamma, \varphi \rightarrow \psi \Rightarrow_{k}^{\varphi \rightarrow \psi} \Delta$, to $\vdash \Gamma, \psi, \varphi \rightarrow \psi \Rightarrow_{i} \Delta$ oraz $\vdash \Gamma, \varphi \rightarrow$ $\psi \Rightarrow_{j} \Delta, \varphi$

DowóD: Zauważmy, że lemat ten jest osłabioną wersją lematu o inwersji, niezbędną dla udowodnienia wyniku zasadniczego. Dowód jest trywialny. Rozważmy przypadek 3. Jeżeli $\vdash \Gamma \Rightarrow_{k}^{\varphi \wedge \psi} \Delta, \varphi \wedge \psi$, to w dowodzie bezpośrednio poprzedzają go sekwenty $\Gamma \Rightarrow \Delta, \varphi$ oraz $\Gamma \Rightarrow \Delta, \psi$, których dowody są krótsze od $k$. Przez dopuszczalność (W) otrzymujemy dowody $\Gamma \Rightarrow \Delta, \varphi, \varphi \wedge \psi$ oraz $\Gamma \Rightarrow \Delta, \psi, \varphi \wedge \psi \mathrm{z}$ tą samą długością. Dla innych przypadków analogicznie.

Aby dowieść twierdzenia, które mówi, że każde $\varphi$ jest eliminowalne Smullyan dowodzi twierdzenia pomocniczego:

Twierdzenie 5.2 Dla dowolnych $n, k$, dowolne $\varphi$ długości $n$ jest $k$-eliminowalne, jeżeli spetnione sa warunki:

c1) dowolne $\psi$ dtugości mniejszej od n jest eliminowalne

c2) dowolne $\psi$ długości $n$ jest $k^{\prime}$-eliminowalne, dla $k^{\prime}<k$

Z twierdzenia tego wynika twierdzenie o eliminacji (Cut), które w wersji Smullyana brzmi:

Twierdzenie 5.3 (O eliminacji) Każde $\varphi$ jest eliminowalne.

Aby uzasadnić, że twierdzenie o eliminacji wynika z twierdzenia pomocniczego 5.2, załóżmy nie wprost, że pewne $\varphi$ nie jest eliminowalne. Wybierzmy najmniejsze takie nieeliminowalne $\varphi$ i niech długość $\varphi=n$. Oznacza to, że wszystkie formuły o mniejszej od $n$ długości są eliminowalne (warunek c1). Skoro $\varphi$ nie jest eliminowalne, to istnieje najmniejsze $k$ takie, że $\varphi$ nie jest $k$-eliminowalne, czyli jest $k^{\prime}$-eliminowalne dla każdego $k^{\prime}<k$ (warunek $\mathrm{c} 2$ ). Ale oba warunki implikują, że $\varphi$ jest $k$-eliminowalne; sprzeczność.

Przejdźmy zatem do dowodu twierdzenia pomocniczego gdyż daje ono warunki wystarczające dopuszczalności (Cut).

DowóD: Załóżmy, że spełnione są podane wyżej warunki c1 i c2. Dowodzimy, że $\varphi$ długości $n$ jest $k$-eliminowalne, tzn. przy założeniu, że (1) $\vdash \Gamma \Rightarrow_{k 1} \Delta, \varphi$ i (2) $\vdash \varphi, \Gamma \Rightarrow_{k 2} \Delta$, gdzie $k=k 1+k 2$ dowodzimy, że $\vdash \Gamma \Rightarrow \Delta$ 
Zauważmy, że zachodzi alternatywa: A1 $k 1=0$ lub $k 2=0$, albo A2 $k 1 \geq 1$ i $k 2 \geq 1$.

Rozważmy A1 i przyjmijmy, że $k 1=0$, zatem $\Gamma \Rightarrow \Delta, \varphi$ jest aksjomatem i istnieje $\psi$ takie, że $\psi \in \Gamma \cap \Delta \cup\{\varphi\} . \psi=\varphi$ lub nie, jeżeli to drugie, to $\psi \in$ $\Gamma \cup \Delta \mathrm{i} \vdash \Gamma \Rightarrow \Delta$. Jeżeli $\psi=\varphi$, to $\Gamma \Rightarrow \Delta:=\varphi, \Gamma^{\prime} \Rightarrow \Delta$, ale z założenia (2) taki sekwent jest dowiedlny, gdyż $\varphi, \Gamma^{\prime} \Rightarrow \Delta:=\varphi, \varphi, \Gamma^{\prime} \Rightarrow \Delta:=\varphi, \Gamma \Rightarrow \Delta$. Dla $k 2=0$ dowód analogiczny.

A2: Załóżmy, że $k 1 \geq 1$ i $k 2 \geq 1$, wtedy $\left(1^{\prime}\right) \vdash \Gamma \Rightarrow_{k 1}^{\psi} \Delta, \varphi$ i (2') $\vdash \varphi, \Gamma \Rightarrow_{k 2}^{\chi} \Delta$, dla pewnych $\psi, \chi$.

Zauważmy, że zachodzi alternatywa: B1 $\varphi \neq \psi \operatorname{lub} \varphi \neq \chi$, albo B2 $\varphi=\psi$ i $\varphi=\chi$.

Rozważmy B1 i załóżmy $\varphi \neq \psi$. Musimy rozważyć przypadki $\psi$.

B11. $\psi=\chi \vee \delta$ i należy do $\Delta$ czyli (1') wygląda następująco $\vdash \Gamma \Rightarrow_{k 1}^{\chi \vee \delta}$ $\Delta^{\prime}, \chi \vee \delta, \varphi$. Przez lemat 5.4. $\vdash \Gamma \Rightarrow_{i} \Delta^{\prime}, \chi, \delta, \chi \vee \delta, \varphi$ dla $i<k 1$. Z założenia $\left(2^{\prime}\right) \vdash \varphi, \Gamma \Rightarrow_{k 2} \Delta^{\prime}, \chi \vee \delta$, zatem przez dopuszczalność (W) $\vdash \varphi, \Gamma \Rightarrow_{k 2}$ $\Delta^{\prime}, \chi, \delta, \chi \vee \delta$. Zatem mamy $\vdash \Gamma \Rightarrow_{i} \Delta, \chi, \delta, \varphi \mathrm{i} \vdash \varphi, \Gamma \Rightarrow_{k 2} \Delta, \chi, \delta$, gdzie $i+k 2<k$, więc przez warunek c2 $\varphi$ jest $i+k 2$-eliminowalne, czyli $\vdash \Gamma \Rightarrow$ $\Delta, \chi, \delta$, skąd przez $(\Rightarrow \vee)$ mamy $\vdash \Gamma \Rightarrow \Delta$.

B12. $\psi=\chi \wedge \delta$ i należy do $\Delta$ czyli (1') wygląda następująco $\vdash \Gamma \Rightarrow_{k 1}^{\chi \wedge \delta}$ $\Delta^{\prime}, \chi \wedge \delta, \varphi$. Przez lemat 5.4 mamy (i) $\vdash \Gamma \Rightarrow_{i} \Delta^{\prime}, \chi, \chi \wedge \delta, \varphi$ oraz (ii) $\vdash$ $\Gamma \Rightarrow_{j} \Delta^{\prime}, \delta, \chi \wedge \delta, \varphi$ dla $i, j<k 1$. Z założenia $\left(2^{\prime}\right) \vdash \varphi, \Gamma \Rightarrow_{k 2} \Delta^{\prime}, \chi \wedge \delta$, zatem przez dopuszczalność (W) mamy (iii) $\vdash \varphi, \Gamma \Rightarrow_{k 2} \Delta^{\prime}, \chi, \chi \wedge \delta$ oraz (iv) $\vdash \varphi, \Gamma \Rightarrow_{k 2} \Delta^{\prime}, \delta, \chi \wedge \delta$. Zatem z (i) i (iii) mamy $\vdash \Gamma \Rightarrow_{i} \Delta, \chi, \varphi$ i $\vdash \varphi, \Gamma \Rightarrow_{k 2} \Delta$, $\chi$, gdzie $i+k 2<k$, więc przez warunek c2 $\varphi$ jest $i+k 2$ eliminowalne, czyli mamy (v) $\vdash \Gamma \Rightarrow \Delta$, $\chi$. Podobnie z (ii) i (iv) przez c2 otrzymujemy, że $\varphi$ jest $i+k 2$-eliminowalne gdyż $j+k 2<k$, czyli (vi) $\vdash \Gamma \Rightarrow \Delta, \chi . \mathrm{Z}(\mathrm{v})$ i (vi) przez $(\Rightarrow \wedge)$ i fakt, że $\chi \wedge \delta \in \Delta$ mamy $\vdash \Gamma \Rightarrow \Delta$.

Dowód dla pozostałych przypadków oraz przy założeniu, że $\varphi \neq \chi$ analogiczny.

Załóżmy teraz B2 $\varphi=\psi$ i $\varphi=\chi$, zatem $\left(1^{\prime}\right) \vdash \Gamma \Rightarrow_{k 1}^{\varphi} \Delta, \varphi$ i (2') $\vdash \varphi, \Gamma \Rightarrow_{k 2}^{\varphi} \Delta$. Ponownie musimy rozważyć różne przypadki dla $\varphi$.

B21. $\varphi=\chi \wedge \delta$ : wtedy, przez lemat 5.4, mamy (i) $\vdash \Gamma \Rightarrow_{i} \Delta^{\prime}, \chi, \chi \wedge \delta$ oraz (ii) $\vdash \Gamma \Rightarrow_{j} \Delta^{\prime}, \delta, \chi \wedge \delta$ dla $i, j<k 1$. Z założenia (2'), przez dopuszczalność (W), mamy (iii) $\vdash \varphi, \Gamma \Rightarrow_{k 2} \Delta$, $\chi$ oraz (iv) $\vdash \varphi, \Gamma \Rightarrow_{k 2} \Delta, \delta$. Z (i) i (iii) przez c2 mamy (v) $\vdash \Gamma \Rightarrow_{i+k 2} \Delta$, $\chi$ a z (ii) i (iv) przez c2 mamy (vi) $\vdash \Gamma \Rightarrow_{j+k 2} \Delta, \delta$ 
gdyż $i+k 2<k$ i $j+k 2<k$, więc $\varphi$ jest odpowiednio $i+k 2$-eliminowalne i $j+k 2$-eliminowalne. Ponadto z (2') i lematu 5.4 mamy (vii) $\vdash \varphi, \chi, \delta, \Gamma \Rightarrow_{k 2-1}^{\varphi}$ $\Delta$, a z (1'), przez dopuszczalność (W), mamy (viii) $\vdash \Gamma, \chi, \delta, \Rightarrow_{k 1}^{\varphi} \Delta, \varphi$, co znów przez c2 daje (ix) $\vdash \Gamma, \chi, \delta \Rightarrow_{k 1+k 2-1} \Delta$. Teraz korzystamy z warunku $\mathrm{c} 2$, najpierw z (v) i (ix) dostajemy $(\mathrm{x}) \vdash \Gamma, \delta \Rightarrow \Delta$, gdyż $\chi$ jest eliminowalne jako krótsze od $\varphi$. Następnie z (vi) i (x) w analogiczny sposób otrzymujemy $\vdash \Gamma \Rightarrow \Delta$.

Pozostałe przypadki dowodzimy analogicznie.

\subsubsection{Dowód metodą Schüttego}

Jest to oryginalna forma dowodu w istotny sposób odbiegająca od dowodu Dragalina czy Smullyana, które są bliższe dowodowi Gentzena.

Pierwotne dowód ten był przeprowadzony dla systemu, który właściwie wogóle nie jest systemem sekwentowym sensu stricto. Schütte [123] symulował jednak na formułach własności sekwentów z pomocą definicji pozytywnych i negatywnych wystąpień podformuł. Nie będziemy tu dokładniej omawiać jego systemu - dla nas istotne jest, że można jego strategię dowodu dopuszczalności (Cut) przenieść na standardowe z-ARS lub m-ARS. W tym wypadku zaprezentujemy dowód dla z-ARS. Różnice z dowodem Gentzena są takie same jak w poprzednich dwóch przypadkach. Ponadto, dowód poniższy w istotny sposób bazuje na lemacie o inwersji reguł i dopuszczalności (W). Ponownie dowodzimy, że jeżeli $\vdash \Gamma \Rightarrow \Delta, \varphi \mathrm{i} \vdash \varphi, \Pi \Rightarrow \Sigma$, to również $\vdash \Gamma, \Pi \Rightarrow \Delta, \Sigma$.

Uwaga 5.4: $\mathrm{W}$ literaturze przedmiotu często mówi się o dowodzie metodą Schüttego-Taita. Mimo pewnych podobieństw uważamy, że nie należy ich jednak utożsamiać. Po pierwsze, oba dowody są przeprowadzone dla innego typu systemów. W przypadku Taita [140] jest to RS z sekwentami jednostronnymi opartymi na interpretacji trzeciej z podrozdziału 2.3 (tzn. są to skończone zbiory formuł lub alternatywy - Tait rozważał zreszta zbiory nieskończone), ponadto formuły sprowadzone są do negacyjnej postaci normalnej, tzn. z negacjami tylko przed atomami. Po drugie, u Taita mamy dowód eliminacji, a nie dopuszczalności, co rzutuje na jego strukturę ogólną. Odbiega ona od Gentzenowskiej, gdyż indukcja nadrzędna jest przeprowadzona nie po ilości wystąpień (Cut), ale po długości cut-formuł. Podrzędne indukcje są przeprowadzone w zasadzie tak samo jak w dowodzie Dragalina. Wprawdzie mamy tam też do czynienia z wykorzystaniem odwracalności reguł (por. prezentacja dowodu w Schwichtenberg [124]), ale w zasadzie jest to zbędne. Ogólna strategia dowodu Taita będzie omówiona w paragrafie 5.4.2. 
Dowód Schüttego jest zorganizowany inaczej niż dowód Dragalina i Smullyana omawiane wyżej; nadrzędne kryterium to długość cut-formuły. Zatem przeprowadzamy indukcję po długości $\varphi$, a w jej obrębie dodatkowo indukcję po długości dowodu jednej z przesłanek (Cut). Jednak w przeciwieństwie do dowodu Gentzena, ta druga indukcja jest przeprowadzona tylko w obrębie bazy indukcji nadrzędnej i dotyczy jedynie długości jednej przesłanki ${ }^{7}$. Dowód kroku indukcyjnego indukcji po długości $\varphi$ przeprowadzamy odwołując się do lematu o inwersji reguł ARS, co pozwala zrezygnować z ponownej indukcji po długości dowodu, a w szczególności z osobnego rozważania przypadku gdy w obu przesłankach cut-formuła została wprowadzona po raz pierwszy przez regułę logiczną (punkt $4.1 \mathrm{w}$ dowodzie Gentzena, część $3 \mathrm{w}$ dowodzie Dragalina). Poniższy schemat pozwala na lepsze porównanie ze strukturą dowodu Gentzena:

\section{Indukcja po długości cut-formuły.}

1.1. Baza: (Cut) na cut-formule o długości 0 jest dopuszczalny.

\section{Indukcja po długości dowodu (lewej) przesłanki (Cut).}

2.1. Baza: (Cut) z lewą przesłanką o dowodzie długości 0 jest dopuszczalny.

2.2. Krok indukcyjny: Jeżeli (Cut) z lewą przesłanką o dowodzie długości $<n$ jest dopuszczalny, to w dowodzie długości $n$ też jest dopuszczalny.

Wniosek z 2.1., 2.2: (Cut) na cut-formule o długości 0 jest dopuszczalny bez względu na długość dowodu lewej przesłanki.

1.2. Krok indukcyjny: Jeżeli (Cut) na cut-formule o długości $<n$ jest dopuszczalny, to dla cut-formuły o długości $n$ też jest dopuszczalny.

Wniosek z 1.1., 1.2: (Cut) na dowolnej formule jest dopuszczalny.

DowóD: Punkt. 1.1. Zakładamy, że $\varphi$ jest zmienną i (punkt 2.1) zakładamy, że dowód lewej przesłanki (Cut) $\Gamma \Rightarrow \Delta, \varphi$ jest długości 0 , tzn. jest aksjomatem. Eliminowalność (Cut) wynika z faktu 5.1. Przypomnijmy, że mamy do rozważenia dwa przypadki:

a) $\Gamma \cap \Delta \neq \varnothing(\varphi \notin \Gamma)$ wtedy $\Gamma, \Pi \Rightarrow \Delta, \Sigma$ też jest aksjomatem.

\footnotetext{
${ }^{7}$ Indukcję po długości drugiej przesłanki musielibyśmy przeprowadzać tylko w przypadku, gdy któraś z reguł jest nieodwracalna. Wtedy trzeba dodatkowo analizować w jaki sposób dana formuła została wprowadzona do dowodu.
} 
b) $\Gamma \cap \Delta=\varnothing\left(\right.$ tzn. $\varphi$ jest formułą zasadniczą i $\left.\Gamma=\Gamma^{\prime}, \varphi\right)$ ponieważ prawa przesłanka $\varphi, \Pi \Rightarrow \Sigma$ ma dowód, więc, przez dopuszczalność (W), $\Gamma^{\prime}, \varphi, \Pi \Rightarrow \Delta, \Sigma$ też ma dowód.

Punkt 1.1, 2.2, założenie indukcyjne: (Cut) na zmiennej $\varphi$ z lewą przesłanką o dowodzie długości $<n$ jest dopuszczalny. Dowodzimy, że (Cut) na zmiennej $\varphi$ z lewą przesłanką o dowodzie długości $n$ też jest dopuszczalny. Dowód przez rozważenie wszystkich przypadków, które doprowadziły do dedukcji $\Gamma \Rightarrow \Delta, \varphi$. Ponieważ $\varphi$ jest zmienną, więc $\mathrm{w}$ grę wchodzą tylko takie przekształcenia gdzie była formułą parametryczną. Przekształcenia są analogiczne do rozważanych w punkcie B1. dowodu Gentzena ale ponieważ dowód części B pozostawiliśmy czytelnikowi więc poniżej zademonstrujemy dwa przypadki. Przedstawimy je tym razem nie w postaci przekształcanych figur dowodowych, ale w bardziej konwencjonalnej postaci, podobnie jak w dowodzie Smullyana.

Przypadek $(\Rightarrow \neg) . \Gamma \Rightarrow \Delta, \varphi:=\Gamma \Rightarrow \Delta^{\prime}, \neg \psi, \varphi$ i wydedukowana z $\psi, \Gamma \Rightarrow$ $\Delta^{\prime}, \varphi$. Sekwent-przesłanka ma dowód długości $n-1$ zatem podpada pod założenie indukcyjne, tzn. jeżeli $\vdash \psi, \Gamma \Rightarrow \Delta^{\prime}, \varphi$ i $\vdash \varphi, \Pi \Rightarrow \Sigma(\mathrm{tj}$. prawa przesłanka), to również dowiedlne jest $\psi, \Gamma, \Pi \Rightarrow \Delta^{\prime}, \Sigma$, skąd przez $(\Rightarrow \neg)$ mamy $\Gamma, \Pi \Rightarrow \Delta^{\prime}, \neg \psi, \Sigma:=\Gamma, \Pi \Rightarrow \Delta, \Sigma$.

Przypadek $(\Rightarrow \wedge) . \Gamma \Rightarrow \Delta, \varphi:=\Gamma \Rightarrow \Delta^{\prime}, \psi \wedge \chi, \varphi$ i wydedukowana z $\Gamma \Rightarrow$ $\Delta^{\prime}, \psi, \varphi$ oraz $\Gamma \Rightarrow \Delta^{\prime}, \chi, \varphi$. Oba sekwenty-przesłanki mają dowody długości $<n$ zatem podpadaja pod założenie indukcyjne, tzn., że (w połączeniu z prawą przesłanką) dowiedlne jest zarówno $\Gamma, \Pi \Rightarrow \Delta^{\prime}, \Sigma, \psi$, jak i $\Gamma, \Pi \Rightarrow$ $\Delta^{\prime}, \Sigma, \chi$, skąd przez $(\Rightarrow \wedge)$ mamy $\Gamma, \Pi \Rightarrow \Delta^{\prime}, \psi \wedge \chi, \Sigma:=\Gamma, \Pi \Rightarrow \Delta, \Sigma$.

Pozostałe przypadki analogicznie.

Dowiedliśmy (przez indukcję po długości dowodu lewej przesłanki), że dla dowolnej zmiennej $\varphi$ jeżeli $\vdash \Gamma \Rightarrow \Delta, \varphi$ i $\vdash \varphi, \Pi \Rightarrow \Sigma$, to również $\vdash$ $\Gamma, \Pi \Rightarrow \Delta, \Sigma$.

Punkt 1.2. założenie indukcyjne: (Cut) na $\varphi$ o długości $<n$ jest dopuszczalny. Dowodzimy, że (Cut) na $\varphi$ o długości $n$ też jest dopuszczalny. Dowód przez rozważenie wszystkich przypadków $\varphi$.

Przypadek $\varphi:=\neg \psi$. Obie przesłanki (Cut) maja postać $\Gamma \Rightarrow \Delta, \neg \psi$ i $\neg \psi, \Pi \Rightarrow \Sigma$. Z lematu o inwersji dowód mają też ich przesłanki, tj. $\vdash \psi, \Gamma \Rightarrow$ $\Delta \mathrm{i} \vdash \Pi \Rightarrow \Sigma$, zatem z założenia indukcyjnego (gdyż $\psi$ ma długość $n-1$ ) dowiedlne jest $\Gamma, \Pi \Rightarrow \Delta, \Sigma$.

Przypadek $\varphi:=\psi \wedge \chi$. Obie przesłanki (Cut) mają postać $\Gamma \Rightarrow \Delta, \psi \wedge \chi \mathrm{i}$ $\psi \wedge \chi, \Pi \Rightarrow \Sigma$. Z lematu o inwersji dowód mają też ich przesłanki, tj. (i) $\vdash \Gamma \Rightarrow$ 
$\Delta, \psi$, (ii) $\vdash \Gamma \Rightarrow \Delta, \chi$ i (iii) $\vdash \psi, \chi, \Pi \Rightarrow \Sigma$, zatem z założenia indukcyjnego (gdyż $\psi$ i $\chi$ mają długość $<n$ ), (i) i (iii) dowiedlne jest $\chi, \Gamma, \Pi \Rightarrow \Delta$, $\Sigma$, skąd, przez (ii) i założenie indukcyjne, mamy dowód $\Gamma, \Pi \Rightarrow \Delta, \Sigma$.

Pozostałe przypadki analogicznie.

Dowiedliśmy w ten sposób (przez indukcję po długości cut-formuły), że dla dowolnej $\varphi$, jeżeli $\vdash \Gamma \Rightarrow \Delta, \varphi$ i $\vdash \varphi, \Pi \Rightarrow \Sigma$, to również $\vdash \Gamma, \Pi \Rightarrow \Delta, \Sigma$. Wskazane jest dla lepszego zrozumienia tej strategii dowodowej przeprowadzenie dowodu dopuszczalności (Cut) symetrycznie, tzn. dokonując w P. 2.1, 2.2 indukcji po długości dowodu prawej przesłanki (Cut).

\subsection{Dowody oparte na globalnych transformacjach dowodu}

Chociaż najbardziej rozpowszechnione sposoby dowodzenia eliminacji lub dopuszczalności (Cut) oparte są na stosowaniu lokalnych przekształceń, to własności reguł omawiane $\mathrm{w}$ podrozdziale 4.5 pozwalają na wykonywanie bardziej globalnych transformacji na całych fragmentach dowodów. Co więcej, taki sposób prowadzenia dowodu pozwala na jego znaczną ekonomizację. Przedstawimy poniżej dwa takie dowody. Starszy, pochodzący od Curry'ego [27], stał się póżniej podstawą bardzo ogólnych strategii dowodu eliminacji cięcia wypracowanych dla tzw. display logic (por Belnap [12]), które jest uogólnioną wersją RS. Drugi dowód pochodzi od Bussa [20], ale ogólna struktura zapożyczona jest od Taita [140].

\subsubsection{Dowód Curry'ego}

Dowód Curry'ego przeprowadzony jest dla dowolnej wersji LK, której reguły spełniają sprecyzowane wcześniej warunki. Dla naszych potrzeb (tj. oryginalne LK Gentzena dla KRZ) nie musimy go podawać w tak ogólnej postaci jak u Curry'ego co prowadzi do wielu uproszczeń. Różnice z dowodem Gentzena są następujące:

1. pokazuje nie jak eliminować (Cut) z dowodu ale, że jego dołączenie nie wzmacnia systemu;

2. bezpośrednio dla (Cut) a nie dla (Mix);

3. indukcja po dwóch parametrach (nie po trzech);

4. indukcja nie po głębokości, ale po długości dowodu przesłanki (Cut); 
5. dowód rozbity na trzy niezależne etapy;

6. dowód dwóch etapów oparty jest na globalnych przekształceniach dowodu.

Jak widać w punktach 1-4 dowód Curry'ego zbieżny jest z dowodem Dragalina, choć poprowadzony jest dla LK z kontrakcjac jako regułą pierwotną. Na tym jednak kończą się podobieństwa zarówno z dowodem Gentzena, jak i Dragalina. Odnośnie punktu 5, konstrukcja trzech etapów zapewnia odseparowanie od siebie indukcji po długości cut-formuły od indukcji po długości jednej z przesłanek zastosowania (Cut). Curry trafnie odnotował, że w dowodzie indukcji po głębokości u Gentzena rozważamy tylko dowód jednej przesłanki, a dowód drugiej ma charakter stałego parametru, toteż zamiast zagnieżdżać jedną indukcję $\mathrm{w}$ drugiej potraktował ich dowody oddzielnie. Podobnie jest w omawianym wyżej dowodzie Schüttego, ale tam analiza jednej przesłanki jest wystarczająca dzięki wykorzystaniu odwracalności reguł. Omówimy dokładnie oba te punkty.

Niech $\varphi^{(1)}$ oznacza, że cut-formuła $\varphi$ występuje po raz pierwszy $\mathrm{w}$ sekwencie.

Dowód Curry'ego jest podzielony na trzy etapy:

Etap 1:

Założenia:

$\mathrm{E} 11 \vdash \Gamma \Rightarrow \Delta, \varphi$

E12 jeżeli $\vdash \varphi^{(1)}, \Pi \Rightarrow \Sigma$, to $\vdash \Gamma, \Pi \Rightarrow \Delta, \Sigma$

Dowodzimy, że $\vdash \Gamma, \Pi \Rightarrow \Delta, \Sigma$ przez indukcję po długości dowodu prawej przesłanki (Cut).

Etap 2:

Założenia:

$\mathrm{E} 21 \vdash \varphi, \Pi \Rightarrow \Sigma$

E22 jeżeli $\vdash \Gamma \Rightarrow \Delta, \varphi^{(1)}$, to $\vdash \Gamma, \Pi \Rightarrow \Delta, \Sigma$

Dowodzimy, że $\vdash \Gamma, \Pi \Rightarrow \Delta, \Sigma$ przez indukcję po długości dowodu lewej przesłanki (Cut). 
Etap 3:

Założenia:

E31 (Cut) jest dopuszczalne dla każdej podformuły $\varphi$

$\mathrm{E} 32 \vdash \Gamma \Rightarrow \Delta, \varphi^{(1)}$

$\mathrm{E} 33 \vdash \varphi^{(1)}, \Pi \Rightarrow \Sigma$

Dowodzimy $\vdash \Gamma, \Pi \Rightarrow \Delta, \Sigma$ przez indukcję po długości cut-formuły.

Przedstawimy poniżej, w postaci dowodu w systemie dedukcji naturalnej, w jaki sposób łącznie trzy etapy prowadzą do udowodnienia dopuszczalności (Cut). Podobnie prezentowany jest, wzorowany na Currym, dowód dopuszczalności (Cut) dla systemu display logic u Belnapa [12], choć nasza rekonstrukcja istotnie odbiega od tam podanej. Sam Curry formułuje swój dowód słownie, ale, jak podkreśla Belnap, każda proza jedynie zaciera strukturę tego dowodu. Poniższa dedukcja jest elementem dowodu przez mocną indukcję po długości cut-formuły, konkretnie daje dowód kroku indukcyjnego postaci:

Jeżeli (Cut) na podformułach cut-formuly $\varphi$ jest dopuszczalny, to na $\varphi$ też jest dopuszczalny.

I. Indukcja (mocna) po długości cut-formuły

1. (Cut) na podformułach cut-formuly $\varphi$ jest dopuszczalny (E31) [zał ind.]

2. $\vdash \Gamma \Rightarrow \Delta, \varphi(\mathrm{E} 11)$

3. $\vdash \varphi, \Pi \Rightarrow \Sigma(\mathrm{E} 21)$

3.1. $\vdash \varphi^{(1)}, \Pi \Rightarrow \Sigma(\mathrm{E} 33)$

3.1.1. $\vdash \Gamma \Rightarrow \Delta, \varphi^{(1)}(\mathrm{E} 32)$

3.1.2. $\vdash \Gamma, \Pi \Rightarrow \Delta, \Sigma \quad$ 1., 3.1., 3.1.1., Etap 3

3.2. jeżeli $\vdash \Gamma \Rightarrow \Delta, \varphi^{(1)}$, to $\vdash \Gamma, \Pi \Rightarrow \Delta, \Sigma$ 3.1.1.- 3.1.2.

3.3. $\vdash \Gamma, \Pi \Rightarrow \Delta, \Sigma$ 3., 3.2., Etap 2

4. jeżeli $\vdash \varphi^{(1)}, \Pi \Rightarrow \Sigma$, to $\vdash \Gamma, \Pi \Rightarrow \Delta, \Sigma \quad 3.1$. -3.3 .

5. $\vdash \Gamma, \Pi \Rightarrow \Delta, \Sigma \quad 2 ., 4$., Etap 1

Odnośnie dowodów poszczególnych etapów, to dowód etapu 3 wygląda dokładnie tak samo jak dowód kroku indukcyjnego po długości formuły przy założonej głębokości $2 \mathrm{w}$ dowodzie Gentzena (punkt 4.1 i punkt 3 u Dragalina). Etapy 1 i 2 są dowodzone niezależnie i każdy z nich może być udowodniony tak jak u Gentzena (punkty A i B), za pomocą lokalnych transformacji 
redukujących długość dowodu jednej z przesłanek. Jednak u Curry'ego występuje inny dowód polegający na globalnych przekształceniach dowodu odpowiedniej przesłanki. Dowód ten odwołuje się do ustalonych w podrozdziale 4.5. własności reguł LK. Poniżej przeprowadzimy dowód etapu 1.

DowóD: Niech $\mathcal{D}$ będzie dowodem prawej przesłanki (Cut), tj. $\varphi, \Pi \Rightarrow \Sigma$, a $S_{1}, \ldots, S_{n}$ enumeracją występujących w nim sekwentów zachowującą porządek inferencji, tzn. sekwenty przesłanki danego zastosowania reguły występują zawsze przed wnioskami; oczywiście $S_{n}:=\varphi, \Pi \Rightarrow \Sigma$. Zdefiniujmy indukcyjnie $S_{k}:=\Phi_{k}, \Pi_{k} \Rightarrow \Sigma_{k}$ dla $k \leq n$, postępując od korzenia czyli $S_{n}$ :

1. $\Phi_{n}:=\varphi, \Pi_{n}=\Pi, \Sigma_{n}=\Sigma$

2. Jeżeli $S_{k}$ jest przesłanką dla $S_{m}$, to:

(a) wszystkie parametry z $\Phi_{m}$, które są w $S_{k}$ znajdują się w $\Phi_{k}$

(b) jeżeli zasadnicza formuła zastosowania $(C \Rightarrow)$ lub $(W \Rightarrow)$ jest $\mathrm{w}$ $\Phi_{m}$, to w pierwszym przypadku oba wystąpienia tej formuły też sac w $\Phi_{k}$, a w drugim $\Phi_{k}$ jest pozbawione tej formuły.

Oczywiście $\Phi_{k}$ jest zdefiniowane dla każdego $k$ i jest multizbiorem (możliwe, że pustym) wystąpień $\varphi$. Niech $D_{1}$ będzie ciągiem tych sekwentów z $\mathcal{D}$, w których $\Phi_{k}$ jest puste, a $D_{2}$ tych, w których jest niepuste. Zauważmy, że wszystkie przesłanki dla elementów $D_{1}$, też do niego należą, z definicji $\Phi_{k}$ (warunek 2).

Dla każdego $S_{k}$ zdefiniujmy $S_{k}^{\prime}:=(\Gamma), \Pi_{k} \Rightarrow(\Delta), \Sigma_{k}$ następująco:

- $(\Gamma)$ to $n$ powtórzeń ciągu $\Gamma$ wstawionych do poprzednika $S_{k}$ zamiast $n$ wystąpień $\varphi$.

- $(\Delta)$ to $n$ powtórzeń ciągu $\Delta$ dołączonych do następnika $S_{k}$

Zauważmy, że jeżeli $S_{k}$ należy do $D_{1}$, to $S_{k}=S_{k}^{\prime}$ oraz, że $S_{n}^{\prime}$ jest wnioskiem naszego zastosowania (Cut), tzn. $S_{n}^{\prime}:=\Gamma, \Pi \Rightarrow \Delta, \Sigma$.

Wykazujemy przez indukcję po $k$, że jeżeli zachodzi założenie E12, to każde $S_{k}^{\prime}$ jest dowiedlne, zatem w szczególności $S_{n}^{\prime}$, czyli wniosek etapu 1. Mamy 5 przypadków do rozważenia:

1. $S_{k}$ należy do $D_{1}$, zatem $S_{k}^{\prime}:=S_{k}$ i jest dowiedlne.

2. $S_{k}$ jest aksjomatem i należy do $D_{2}$, zatem - skoro $\Phi_{k}$ nie jest puste ma postać $\varphi \Rightarrow \varphi$. Wtedy $S_{k}^{\prime}:=\Gamma \Rightarrow \Delta, \varphi$, ale to jest lewa przesłanka (Cut), która jest dowiedlna z założenia. 
3. $S_{k}$ należy do $D_{2}$ i jest wyprowadzona z $S_{i}$ (i $S_{j}$ w przypadku reguł dwuprzesłankowych) za pomoca takiej instancji reguły, w której wszystkie elementy $\Phi_{k}$ są parametrami. Z założenia indukcyjnego $S_{i}^{\prime}$ (i ew. $S_{j}^{\prime}$ ) jest dowiedlne. Ponieważ wszystkie reguły spełniają warunek niezależności kontekstowej (por. podrozdział 4.5), więc $S_{k}^{\prime}$ jest dedukowalne z $S_{i}^{\prime}\left(\mathrm{i}\right.$ ew. $S_{j}^{\prime}$ ) za pomocą tej samej reguły.

4. $S_{k}$ należy do $D_{2}$, formuła zasadnicza jest w $\Phi_{k}$ i $S_{k}$ jest wyprowadzona z $S_{i}$ za pomocą $(C \Rightarrow)$ lub $(W \Rightarrow)$. Z założenia indukcyjnego $S_{i}^{\prime}$ jest dowiedlne. W przypadku zastosowania $(C \Rightarrow) S_{k}^{\prime}$ różni się od $S_{i}^{\prime}$ tylko tym, że zawiera o jedno wystąpienie $\Gamma$ (i ewentualnie $\Delta$ jeśli jest niepuste) mniej, zatem jest dedukowalne z $S_{i}^{\prime}$ przez wielokrotne zastosowanie $(C)$. W przypadku zastosowania $(W \Rightarrow), \Phi_{k}$ w $S_{k}$ zawiera o jedno więcej $\varphi$ niż $\Phi_{i}$, zatem $S_{k}^{\prime}$ będzie dedukowalne z $S_{i}^{\prime}$ przez wielokrotne zastosowanie $(W)$ do uzyskania $\Gamma \mathrm{w}$ poprzedniku i ewentualnie $\Delta$ (jeśli jest niepusta) w następniku.

5. $S_{k}$ należy do $D_{2}$, formuła zasadnicza jest w $\Phi_{k}$ i $S_{k}$ jest wyprowadzona z $S_{i}$ (i ewentualnie $S_{j}$ ) za pomocą reguły logicznej. Niech $S_{k}^{\prime \prime}$ oznacza $S_{k}$, w którym wszystkie parametry z $\Phi_{k}$ (czyli inne wystąpienia $\varphi$ wydedukowane wcześniej - jeśli takie są) zostały zastąpione przez wystąpienia $\Gamma$ i tyleż wystąpień $\Delta$ dodano w następniku. Wtedy $S_{k}^{\prime \prime}$ jest dedukowalne z $S_{i}^{\prime}$ w taki sposób jak w przypadku 3 . Ponadto w $S_{k}^{\prime \prime} \varphi$ występuje po raz pierwszy, zatem $S_{k}^{\prime \prime}$ podpada pod założenie E12 a zatem $S_{k}^{\prime}$ jest z niego dedukowalne.

Dowód etapu 2 jest dualny; pozostawiamy go czytelnikowi. Jak widać Curry [27] w dowodzie obu etapów dokonuje globalnego przekształcenia całego dowodu przesłanki (Cut) i opiera się w nim na ustalonych wcześniej własnościach reguł, w tym wypadku na ich kontekstowej niezależności. Curry zauważa też, że dowód etapów 1 i 2 można przeprowadzić przez odwołanie się do odwracalności reguł.

\subsubsection{Dowód metodą Taita-Bussa}

Inny dowód eliminacji (Cut) oparty na globalnych przekształceniach dowodu podaje Buss [20]. Jego dowód co do ogólnej strategii oparty jest na dowodzie Taita [140], który nie wykorzystuje indukcji po ilości zastosowań (Cut) (jak w dowodzie Gentzena), ale opiera się jedynie na indukcji po długości cut-formuły. Jest to eleganckie rozwiązanie, które pozwala przy okazji podać oszacowanie wielkości zbudowanego w wyniku dokonanych transformacji nowego dowodu. W przeciwieństwie do Taita w swoim dowodzie Buss nie używa jednak lokalnych przekształceń, ale stosuje globalne transformacje.

Buss używa systemu LK-K z atomowymi aksjomatami i addytywnym 
(Cut). Pierwsze ograniczenie jest istotne dla zachowania poprawności dokonywanych transformacji. Drugie nie jest ważne toteż zaprezentujemy tu jego dowód eliminacji, ale dostosowany do multiplikatywnej wersji (Cut), dla łatwiejszego porównania z poprzednimi dowodami (za wyjątkiem dowodu Smullyana, który też dotyczy addytywnej wersji).

Jak wyżej wspomnieliśmy, charakterystyczne dla ogólnej struktury dowodu jest też to że, w przeciwieństwie do dowodu Gentzena, nie eliminujemy po kolei najwyższych wystąpień (Cut), ale eliminujemy kolejno maksymalne (co do długości cut-formuły) zastosowania (Cut).

Podstawą dowodu jest poniższy:

Lemat 5.5 Jeżeli D jest dowodem zakończonym (Cut), w którym cut-formuła $\varphi$ ma długość n, a każda inna cut-formuła ma długość mniejsza, to można go zamienić na dowód $\mathcal{D}^{\prime}$, w którym każda cut-formuła ma długość mniejsza od $n$.

DowóD: Niech $\mathcal{D}_{l}$ oznacza dowód lewej przesłanki ostatniego (Cut), a $\mathcal{D}_{r}$ prawej. Jeżeli któryś z nich nie zawiera zastosowania logicznych reguł, to mamy do czynienia z uogólnionym aksjomatem i zgodnie z faktem 5.1. to zastosowanie (Cut) jest eliminowalne. Zatem przy rozważaniu dalszych przypadków zakładamy, że $\left\|\mathcal{D}_{l}\right\|$ i $\left\|\mathcal{D}_{r}\right\|$ są większe od 0 . Dowód wymaga rozważenia wszystkich przypadków $\varphi$.

$\varphi$ jest zmienną. W tym przypadku przekształcamy $\mathcal{D}_{l}$ na $\mathcal{D}_{l}^{\prime}$ w następujący sposób: Każdy sekwent $\Lambda \Rightarrow \Theta \mathrm{w} \mathcal{D}_{l}$ zamieniamy na $\Gamma, \Pi, \Lambda \Rightarrow \Delta, \Sigma, \Theta_{\varphi}$, gdzie $\Theta_{\varphi}$ oznacza wyrzucenie z $\Theta$ wszystkich wystąpień $\varphi$. W szczególności każdy liść $\psi \Rightarrow \psi \mathrm{w} \mathcal{D}_{l}$ stał się $\mathrm{w} \mathcal{D}_{l}^{\prime}$ sekwentem postaci $\Gamma, \Pi, \psi \Rightarrow \Delta, \Sigma, \psi$ gdy $\psi$ jest różne od $\varphi$ lub $\Gamma, \Pi, \psi \Rightarrow \Delta, \Sigma$, gdy $\psi=\varphi$. Dzięki kontekstowej niezależności reguł (por. podrozdział 4.5), ani dodanie nowych parametrów ani eliminacja parametru $\varphi$ nie wpływa na poprawność zastosowanych reguł zatem $\mathcal{D}_{l}^{\prime}$ jest drzewem dowodowym, które kończy się sekwentem $\Gamma, \Pi, \Gamma \Rightarrow \Delta, \Sigma, \Delta$. Następnie tworzymy z $\mathcal{D}_{l}^{\prime}$ dowód $\mathcal{D}^{\prime}$ dla $\Gamma, \Pi \Rightarrow \Delta, \Sigma$ w następujący sposób: (a) Sekwent końcowy otrzymujemy z sekwentu końcowego $\mathcal{D}_{l}^{\prime}$ przez kontrakcję i permutację. (b) Dla każdego liścia postaci $\Gamma, \Pi, \psi \Rightarrow \Delta, \Sigma, \psi$ dodajemy u góry dowód z $\psi \Rightarrow \psi$ za pomocą $(W)$ i $(P)$. (c) Dla każdego liścia postaci $\Gamma, \Pi, \varphi \Rightarrow \Delta, \Sigma$ dodajemy u góry dowód prawej przesłanki (Cut), czyli $\varphi, \Pi \Rightarrow \Sigma$ z dołączoną dedukcją $\Gamma, \Pi, \varphi \Rightarrow \Delta, \Sigma$ za pomocą $(W)$ i $(P)$.

Uwaga 5.5: Dowód tego przypadku pokazuje alternatywny (i prostszy) do dowodu Schüttego - sposób eliminacji atomowych (Cut). Zauważmy, że przeprowadzona transformacja nie wprowadza innych (Cut) na miejsce eli- 
minowanego natomiast w $\mathcal{D}$ z założenia nie ma powyżej innych zastosowań (Cut), gdyż $n=0$ (atom jako cut-formuła).

Przypadek $\varphi:=\neg \psi$. W tym przypadku przekształcamy oba dowody $\mathcal{D}_{l}$ i $\mathcal{D}_{r}$ na dowody $\mathcal{D}_{l}^{\prime}$ i $\mathcal{D}_{r}^{\prime}$ sekwentów $\psi, \Gamma \Rightarrow \Delta$ i $\Pi \Rightarrow \Sigma, \psi$ odpowiednio. Na obu można wykonać (Cut) na $\psi$. Zatem w rezultacie otrzymujemy dowód $\mathcal{D}^{\prime}$ dla $\Gamma, \Pi \Rightarrow \Delta, \Sigma$, w którym żadna cut-formuła nie ma długości większej od $n-1$. Szczegóły transformacji są następujące: każdy sekwent $\Lambda \Rightarrow \Theta$ ${ }_{\mathrm{w}} \mathcal{D}_{l}$ zastępujemy przez $\psi, \Lambda \Rightarrow \Theta_{\varphi}$ a w $\mathcal{D}_{r}$ przez $\Lambda_{\varphi} \Rightarrow \Theta, \psi$. Ponownie dzięki kontekstowej niezależności reguł ani dodanie nowych parametrów $\psi$ ani eliminacja parametru $\varphi$ nie wpływa na poprawność zastosowanych reguł. W szczególności żaden liść nie ma postaci $\varphi \Rightarrow \varphi$, z racji ograniczenia do atomów, zatem nie możemy otrzymać liści postaci $\psi, \varphi \Rightarrow \operatorname{lub} \Rightarrow \varphi, \psi \cdot \varphi$ musiało być zatem wprowadzone przez $(W)$, a wtedy po prostu zostanie wykasowane, lub wprowadzone reguła dla $\neg$. W tym drugim wypadku fragment dowodu $\mathcal{D}_{l}$ postaci $\frac{\psi, \Lambda \Rightarrow \Theta}{\Lambda \Rightarrow \Theta, \neg \psi}$ zostanie zastąpiony przez $\frac{\psi, \psi, \Lambda \Rightarrow \Theta_{\varphi}}{\psi, \Lambda \Rightarrow \Theta_{\varphi}}$ który jest poprawny dzięki kontrakcji; analogicznie w $\mathcal{D}_{r}$. Zatem $\mathcal{D}_{l}^{\prime}$ i $\mathcal{D}_{r}^{\prime}$ to drzewa dowodowe, które zaczynają się od liści postaci $\psi, \chi \Rightarrow \chi$ lub $\chi \Rightarrow \chi, \psi$ $\mathrm{z} \chi$ atomowym. Wystarczy dopisać nad każdym liściem tej postaci aksjomat $\chi \Rightarrow \chi$, aby otrzymać dowód $\mathcal{D}^{\prime}$ dla $\Gamma, \Pi \Rightarrow \Delta, \Sigma$.

Przypadek $\varphi:=\psi \wedge \chi$. W tym przypadku na bazie $\mathcal{D}_{r}$ konstruujemy $\mathcal{D}_{r}^{\prime}$ dla $\psi, \chi, \Pi \Rightarrow \Sigma$, w którym każdy sekwent $\Lambda \Rightarrow \Theta$ zastępujemy przez $\psi, \chi, \Lambda_{\varphi} \Rightarrow \Theta$. Znów, wszystkie inferencje zachowują poprawność dzięki kontekstowej niezależności. W szczególności, jeżeli $\varphi$ było otrzymane w $\mathcal{D}_{r}$ przez $(\wedge \Rightarrow)$, to po przekształceniu na $\mathcal{D}_{r}^{\prime}$ musimy dodać dwa zastosowania kontrakcji, aby mieć poprawne przejście od $\psi, \chi, \psi, \chi, \Lambda_{\varphi} \Rightarrow \Theta$ do $\psi, \chi, \Lambda_{\varphi} \Rightarrow \Theta$. By otrzymać dowód $\psi, \chi, \Pi \Rightarrow \Sigma$ nad każdym liściem postaci $\psi, \chi, \gamma \Rightarrow \gamma$ dodajemy aksjomat $\gamma \Rightarrow \gamma$ i dwa zastosowania $(W \Rightarrow)$.

W przypadku $\mathcal{D}_{l}$ konstruujemy w analogiczny sposób dwa dowody: $\mathcal{D}_{\psi}^{\prime}$ dla $\Gamma \Rightarrow \Delta, \psi$ i $\mathcal{D}_{\chi}^{\prime}$ dla $\Gamma \Rightarrow \Delta, \chi$. W pierwszej transformacji każdy sekwent $\Lambda \Rightarrow \Theta$ zastępujemy przez $\Lambda \Rightarrow \Theta_{\varphi}, \psi$, a w drugiej przez $\Lambda \Rightarrow \Theta_{\varphi}, \chi$ Tym razem jeśli $\varphi \mathrm{w} \mathcal{D}_{l}$ było wprowadzone przez $(\Rightarrow \wedge)$, to po transformacji na $\mathcal{D}_{\psi}^{\prime}$ otrzymujemy:

$$
\frac{\Lambda \Rightarrow \Theta_{\varphi}, \psi, \psi \quad \Lambda \Rightarrow \Theta_{\varphi}, \chi, \psi}{\Lambda \Rightarrow \Theta_{\varphi}, \psi}
$$

z którego można wyrzucić całą prawą przesłankę i prowadzący do niej dowód gdyż wniosek jest wyprowadzalny z lewej przez $(\Rightarrow C)$. Analogicznie 
postępujemy w $\mathcal{D}_{\chi}^{\prime}$, ponadto w liściach obu drzew dowodowych dodajemy aksjomaty - tak jak w poprzednich przypadkach - otrzymując dowody $\mathcal{D}_{\psi}^{\prime}$ i $\mathcal{D}_{\chi}^{\prime}$. Na koniec, budujemy z tych trzech dowodów nowy dowód $\mathcal{D}^{\prime}$ w następujący sposób.

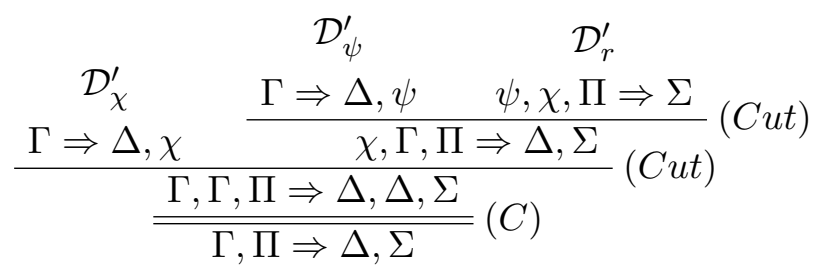

Oba zastosowania (Cut) są na cut-formułach o długości mniejszej od $n$.

Analogicznie dla innych rodzajów formuł.

Uwaga 5.6: Warto zwrócić uwagę, że transformacja dowodu u Bussa przebiega inaczej niż u Curry'ego; można wskazać przynajmniej dwie istotne różnice:

1. U Curry'ego mamy do czynienia ze wstawianiem parametrów z drugiej przesłanki, a tu tylko z zastępowaniem cut-formuły jej podformułami. Bierze się to stąd, że cel transformacji jest zasadniczo inny - u Curry'ego jest to elimnacja (Cut), a u Bussa zmniejszenie długości cut-formuły. Tylko w przypadku formuły atomowej u Bussa występuje podobna transformacja.

2. U Curry'ego tylko te sekwenty są zmieniane, w których występują poprzedniki cut-formuły. U Bussa zasadniczo wszystkie sekwenty ulegają zmianie. Faktycznie w dowodzie Bussa w przypadku konstrukcji odpowiadającej dwuprzesłankowym regułom wprowadzającym cut-formułę mamy do czynienia z dodaniem $\psi$ lub $\chi$ nie do każdego sekwentu, a tylko do tych gdzie wykasowaliśmy poprzedniki $\varphi$ - odpowiada to konstrukcji $\Phi$ u Curry'ego. Cały dowód Bussa można w ten sposób przerobić.

Kolejny krok to dowód następującego rezultatu:

Lemat 5.6 Każdy dowód $\mathcal{D}$, w którym każda cut-formuła ma dtugość nie większa od $n$ można przeksztatcić na dowód $\mathcal{D}^{\prime}$, w którym każda cut-formuła ma długość mniejsza od $n$.

DowóD: Po ilości wystąpień takich maksymalnych (Cut). Każdy poddowód $\mathcal{D}$ (idąc od góry) kończący się zastosowaniem (Cut) na cut-formule długości $n$ można - zgodnie z lematem 5.5 - zastąpić takiem dowodem, który ma tylko krótsze cut-formuły. Powtarzając tę operację otrzymujemy w końcu dowód z cut-formułami tylko o mniejszej długości. 
Twierdzenie o eliminacji (Cut) wynika z obu lematów. Po pierwsze stosując tę konstrukcję kolejno na coraz mniejszych wartościach $n$ otrzymujemy w końcu dowód, w którym wszystkie cut-formuły są atomowe. Ale dowód tego przypadku, zanurzony dowodzie lematu 5.5, pokazywał, że eliminacja atomowych cut-formuł prowadzi do konstrukcji dowodu nie zawierającego wogóle (Cut).

\subsection{Porównanie}

Spróbujmy na koniec dokonać pewnego zestawienia podstawowych technik dowodzenia eliminacji/dopuszczalności cięcia, cząstkowych rezultatów i możliwych sposobów ich łączenia. Omówimy kolejno:

1. sposoby redukcji ilości zastosowań (Cut);

2. przypadki całkowitej eliminacji (Cut);

3. redukowalność atomowych cut-formuł;

4. redukowalność złożonych cut-formuł;

5. ogólną organizację dowodu.

Pierwszy punkt dotyczy tylko dowodów eliminowalności (Cut). Wyróżniliśmy tu dwie strategie: Gentzena i Taita. Ponieważ różnice w obu podejściach omawialiśmy już w kilku miejscach (5.1.1 i 5.4.2), więc ograniczymy się tylko do krótkich uwag. W pierwszym przypadku indukcja po ilości zastosowań (Cut) w dowodzie to dodatkowa nadrzędna rama, która staje się zbędna gdy przeprowadzamy dowód dopuszczalności. W metodzie Taita mimo, iż dowodzimy eliminowalności nie wprowadzamy tej dodatkowej indukcji gdyż wykorzystana jest długość cut-formuły jako podstawa nadrzędnej indukcji.

Również drugi punkt nie wymaga długich rozważań. Fakt 5.1 zestawia wszystkie przypadki (Cut), które są bezpośrednio eliminowalne. Każdy dowód wykorzystuje w jakiejś postaci ten rezultat.

Punkt 3 dotyczy problemu transformacji tych zastosowań (Cut), które działają na formułach atomowych. Możemy go ująć jako osobny:

Lemat 5.7 (redukcja atomowych (Cut)) (Cut) na formule atomowej jest eliminowalny/dopuszczalny. 
W takiej postaci zresztą występuje w ekspozycji niektórych wersji dowodu dopuszczalności cięcia ${ }^{8}$. Nie eksponowaliśmy dotąd tego wyniku w taki sposób, ale można zauważyć, że jest to istotny i samodzielny element przynajmniej dwóch prezentowanych dowodów: Schüttego i Bussa. W pierwszym przypadku dowód przebiega przez indukcję po długości dowodu przesłanki (Cut) z wykorzystaniem faktu $5.1 \mathrm{w}$ bazie. W dowodzie Bussa jest oparty na globalnej transformacji i nie wymaga dowodu indukcyjnego (por. uwaga $5.5)$.

W punkcie 4 chodzi nam o inny cząstkowy wynik, który odgrywa decydującą rolę w indukcji po długości cut-formuły. Ujmijmy go jako:

Lemat 5.8 (zastępowalnść nieatomowych (Cut)) (Cut) na formule złożonej $\varphi$ jest zastępowalny przez (Cut) na podformułach $\varphi$.

Wynik ten występuje w dwóch postaciach: jako zastępowalność (Cut) na formułach zasadniczych obu przesłanek (Cut) i bez tego ograniczenia. Pierwsza postać eksplicite występuje jako etap 3 dowodu Curry'ego, ale wyróżniana jest też w dowodzie Gentzena (punkt 4.1), Dragalina (punkt 3) czy Smullyana. W drugim wariancie nie wymaga się by złożona cut-formuła była zasadnicza, gdyż dowód odwołuje się do lematu o inwersji reguł (Schütte) lub bazuje na globalnych przekształceniach dowodów obu przesłanek (Buss). W uwadze 5.3 wspominaliśmy, że w przypadku odwołania się do lematu o inwersji możliwa jest jeszcze inna droga, gdy w dowodzie dzielimy przypadki według statusu jednej z cut-formuł: parametryczna a zasadnicza. Przy takim podejściu lemat o inwersji wykorzystujemy nie do obu przesłanek (jak w dowodzie Schüttego), ale tylko do jednej - w drugiej korzystamy z założenia, że cut-formuła jest zasadnicza. Podejście takie jest pośrednim rozwiązaniem między dowodzeniem zastępowalności (Cut) na formułach zasadniczych, które nie wymaga odwracalności reguł, a podejściem Schüttego. W podrozdziale 5.4.1 wspomnieliśmy, że Curry takie podejście rozważał jako alternatywny sposób dowodzenia etapu 1 i 2.

Co do ogólnej organizacji dowodu, która pozwala w ekonomiczny sposób uwzględnić wszystkie przypadki, to zauważmy, że oryginalny dowód Gentzena jest dość redundatny w tym względzie. W uwadze 5.3 i dalej wskazaliśmy, że:

${ }^{8}$ Np. w dowodzie Bella i Machovera [11], który jest wersją dowodu Schüttego, ale dostosowaną do systemu tablicowego. 
- Dowody Dragalina i Smullyana dzielą przypadki według: 1. długości dowodu przesłanek (1.1. co najmniej jedna $0 ; 1.2$. obie $>0$ ), 2. statusu cut-formuły (2.1. obie zasadnicze; 2.2. przynajmniej jedna parametryczna - zastosowane do punktu 1.2). Możliwy wariant tego rozwiązania to analiza tylko jednej przesłanki (Cut).

- Dowód Schüttego dzieli przypadki według: 1. długości cut-formuły (1.1. zmienna; 1.2. złożona), 2. długości dowodu jednej przesłanki (2.1. długość 0 , a 2.2. >0 - zastosowane do punktu 1.1)

- Dowód Curry'ego w zasadzie dzieli przypadki tylko według statusu cut-formuły (2.1. obie zasadnicze - etap 3; 2.2. przynajmniej jedna parametryczna - etap 1 i 2 )

- Dowód Bussa dzieli przypadki tylko według długości cut-formuły.

Biorąc pod uwage powyższe ustalenia można zapytać czy istnieją jakieś stałe elementy każdego dowodu eliminacji/dopuszczalności cięcia. W niektórych pracach analizuje się warunki wystarczające zachodzenia tego rezultatu, np. Ciabattoni i Terui [25] stwierdzają, że dla dowolnego RS na intsekwentach wystarczy, aby reguły były:

1. reduktywne, tzn. pozwalały na zastąpienie (Cut) na formułach złożonych przez (Cut) na podformułach;

2. substytutywne, tzn. pozwalały na zastąpienie dowolnej formuły w danej instancji reguły przez dowolny multizbiór formuł bez utraty poprawności.

Powyższe zestawienie i analiza różnych dowodów pokazują, że nie są to jednak warunki konieczne, aby zachodziło twierdzenie o eliminacji (Cut). Zauważmy, że można np. zbudować dowód dopuszczalności (Cut), który nie potrzebuje ani lematu 5.8, ani indukcji po długości dowodu przesłanki. Jedna możliwość to dowód według strategii Schüttego, ale w którym lemat 5.7 dowiedziemy metodą Bussa, która nie wymaga takiej indukcji. Oczywiście, sam dowód Bussa też jest przykładem dowodu eliminowalności (Cut) bez wykorzystania obu rezultatów cząstkowych. 


\section{Rozdział 6}

\section{Konsekwencje eliminacji cięcia}

Postaramy się obecnie wyjaśnić dlaczego eliminacja cięcia jest tak ważna. Wykazanie że RS bez tej reguły jest systemem równie silnym niesie zarówno dla KRZ jak i dla innych logik, dla których to twierdzenie zachodzi, szereg interesujących konsekwencji. Do najważniejszych należą m.in. dowody: niesprzeczności, rozstrzygalności, konserwatywności, separowalności oraz interpolacji. Sam Gentzen [34] w oparciu o swój Hauptsatz podał:

- dowód rozstrzygalności rachunku zdań w wersji klasycznej i intuicjonistycznej;

- dowód niesprzeczności logiki klasycznej i intuicjonistycznej;

- dowód niesprzeczności arytmetyki bez reguły indukcji.

W rozdziale tym skupimy się tylko na wybranych konsekwencjach eliminacji cięcia. Zresztą bliższa analiza pokazuje, że większość wymienionych przez nas konsekwencji eliminacji cięcia jest pochodną tzw. własności podformut, którą posiadają wszystkie rozważane przez nas reguły RS oprócz (Cut). Własność ta powoduje, że RS (bez (Cut)) jest systemem analitycznym. Ponieważ określenia te są używane w różnych znaczeniach, toteż dokładniej wyjaśnimy ich sens w podrozdziale 6.1 . W 6.2 zajmiemy się problemem dowodzenia roztrzygalności KRZ na gruncie RS oraz związanym z tym problemem strategii szukania dowodów i przydatnej dla tego celu własności zbieżności. W ostatnim podrozdziale udowodnimy twierdzenie Maehary, z którego wynika własność interpolacji dla KRZ. 


\subsection{Analityczność}

Jeden z ważnych wyników Gentzena, który otrzymujemy natychmiast jako wniosek z Hauptsatz to:

Twierdzenie 6.1 (Twierdzenie o niesprzeczności LK i LJ:) Sekwent $\Rightarrow$ nie jest dowiedlny $w L K(L J)$.

DowóD jest natychmiastowy. (Cut) jest jedyną regułą, która powoduje, że w dowodzie moga "ubywać" formuły przy przechodzeniu od przesłanek do wniosków. Ale skoro wszystko da się w LK (i w LJ, czyli RS dla intuicjonizmu) dowieść bez użycia (Cut), to niemożliwe jest otrzymanie dowodu sekwentu $\Rightarrow$, który wyraża sprzeczność.

Chwila zastanowienia wystarcza, żeby uświadomić sobie, że odpowiada za ten fakt tak zwana własność podformuł, którą krótko omówiliśmy w podrozdziale 4.5. Warto poświęcić jej więcej uwagi.

\subsubsection{Własność podformuł}

Określenie własność podformuł jest zazwyczaj używane w odniesieniu do systemów tablicowych, w których wnioski reguł składają się z podformuł przesłanek, względnie z podformuł i ich negacji. W RS mamy niejako odwrotność takiej charakterystyki; reguła posiada tę własność wtedy, gdy w sekwentachprzesłankach występują tylko podformuły formuł z sekwentu-wniosku. Łatwo zauważyć, że w rozważanych dotąd wariantach RS wszystkie reguły oprócz (Cut) posiadają tę własność, wobec tego powiemy, że cały system (tj. RS bez (Cut)) posiada własność podformuł. Na koniec przyjmijmy, że dowód sekwentu $S$ posiada własność podformuł wtedy, gdy wszystkie sekwenty w nim występujące składają się tylko z podformuł $S^{1}$. Dowód taki jest kumulatywny w tym sensie, że sekwent końcowy jest systematycznie budowany ze składników sekwentów poprzedzających. Żadna formuła nie ulega skróceniu ani nie znika z dowodu (mogą jedynie zmniejszać się ilości jej wystąpień w wyniku kontrakcji), co najwyżej staje się składnikiem innej formuły. Dowody takie nie są pośrednie w tym sensie, że nie dochodzą do wyniku okrężną drogą z użyciem wcześniej dowiedzionych wyników. Korzystają one tylko z elementów, które są zawarte w końcowym rezultacie.

Jak widać własność podformuł można orzekać o regułach, o systemie lub o dowodach. Zauważmy, że jeżeli każda reguła systemu ma tę własność

\footnotetext{
${ }^{1}$ Tak zresztą, tj. jako cechę tzw. cut-free dowodów a nie reguł czy systemu, definiuje własność podformuł Gentzen [50].
} 
to i system ją posiada, a jeżeli system RS ma własność podformuł, to i każdy dowód w tym systemie ją posiada. Zależność odwrotna jednak nie musi zachodzić - wyjaśnimy to poniżej.

Jedną z bezpośrednich i ważnych konsekwencji własności podformuł jest własność separacji ${ }^{2}$.

Definicja 6.1 (Separacja stałych) System RS ma wtasność separacji wtw każdy dowiedlny sekwent, w którym nie występuje stała $\star$ ma dowód, w którym nie sa użyte reguty dla $\star$.

Zależność separacji od własności podformuł podaje poniższy:

Lemat 6.1 (O separacji) Jeżeli $R S$ ma własność podformut, to ma téz własność separacji.

DowóD: Załóżmy, że $\star$ nie występuje w sekwencie $S$, ale w jego dowodzie została użyta reguła wprowadzająca $\star$. Lecz w systemie z własnością podformuł każda wprowadzona przez regułę logiczną formuła złożona pozostaje jako podformuła w sekwencie końcowym; sprzeczność.

Inna ważna własność systemu, związana z własnością podformuł, to konserwatywność. Własność ta, wraz z własnością eliminowalności, zostały pierwotnie sformułowane przez S. Leśniewskiego [91] jako warunki, które musi spełniać poprawna definicja. W przypadku tej pierwszej nieformalnie można ją wysłowić następująco: definicja nowego terminu jest konserwatywna wtw nie zmienia wartości logicznej zdań nie zawierających tego terminu. W kontekście rozważań nad antyrealistycznymi teoriami znaczenia, w szczególności nad definiowalnością stałych logicznych za pomocą reguł, warunki te zostały przeformułowane w syntaktyczny sposób ${ }^{3}$. Reguły definiujące nowa stałą są konserwatywne wtw pozwalają tylko na dowodzenie "nowych" tez, czyli zawierających nową stałą. Sformułowanie to odnosi się wprawdzie do reguł, ale właściwego sensu nabiera w kontekście systemu, dlatego nie omawialiśmy go w podrozdziale 4.5. Ścisła definicja w odniesieniu do systemu wygląda następująco:

Definicja 6.2 (Konserwatywność systemu) Niech $L \star$ oznacza język $L z$ dołaczona stała $\star$ a $R S \star$ oznacza system $R S$ z dodanymi regułami dla . Powiemy, że:

$R S \star$ konserwatywnie poszerza $R S$ wtw dla każdego sekwentu $S$ w języku L: jeżeli $\nvdash_{R S} S$, to $\nvdash_{R S \star} S$.

\footnotetext{
${ }^{2}$ Należy odróżnić ją od własności separowalności dla reguł.

${ }^{3}$ Szczegółowe rozważania na ten temat w Poggiolesi [108].
} 
Zależność konserwatywności od własności podformuł podaje poniższy:

Lemat 6.2 (O konserwatywnych poszerzeniach) Jeżeli $R S \star m a$ wtasność podformut, to jest konserwatywnym poszerzeniem $R S$.

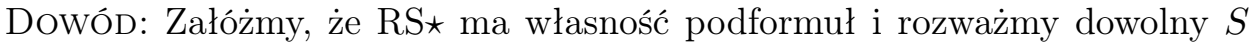
nie zawierający $\star$. Jeżeli $\vdash_{R S \star} S$, to reguły dla $\star$ nie mogły być użyte w dowodzie, gdyż wtedy, ze względu na własność podformuł, ^ wystąpiłoby w $S$. Zatem dowód ten jest też dowodem w RS.

Jest mocno dyskutowaną kwestią jakie warunki muszą spełniać reguły RS by uznać je za rodzaj definicji stałej logicznej, ale łatwo zauważyć, że własność konserwatywności odgrywa tu ważną rolę. Jeden z najstarszych i najbardziej znanych ataków na inferencjalizm (por. podrozdział 4.5) pochodzacy od Priora [112] polegał na zaproponowaniu pary reguł dla pewnej stałej (Prior nazwał ją "tonk"), która prowadziła do trywializacji systemu. Prior sformułował je jako reguły wprowadzania i eliminacji dla systemu DN; w wydaniu dla RS reguły Priora wyglądają następująco:

$$
\begin{aligned}
& \Gamma \Rightarrow \Delta, \varphi / \Gamma \Rightarrow \Delta, \varphi \text { tonk } \psi \\
& \Gamma \Rightarrow \Delta, \varphi \text { tonk } \psi / \Gamma \Rightarrow \Delta, \psi
\end{aligned}
$$

Czytelnik łatwo może się przekonać, że nie są one konserwatywne, gdyż prowadzą do dowodu sekwentu $\varphi \Rightarrow \psi$, w którym $\varphi$ i $\psi$ mogą być dowolnymi formułami, zatem również nie zawierającymi tonk (oczywiście nie spełniają też własności podformuł).

W opini obrońców inferencjalizmu Prior pokazał jedynie, że nie każda para reguł nadaje się na definicję stałej logicznej, co otworzyło trwającą do dziś dyskusję na temat warunków, które poprawne reguły muszą spełniać. Własność konserwatywności jest przez niektórych zwolenników inferencjalizmu, np. Dummetta [35], podawana jako warunek konieczny ${ }^{4}$.

\subsubsection{Własność podformuł a analityczność}

Własność podformuł ma również ścisły związek z pojęciem analityczności, które ma bardzo stary rodowód. Jednak to ostatnie pojęcie ma różne znaczenia, które warto tu wymienić:

\footnotetext{
${ }^{4}$ Por. Poggiolesi [108].
} 
1. Euklidesowe - dowód przez równoważnościowe przekształcenia.

2. Kartezjańskie - rozwiązanie problemu sprowadzalne do rozwiązania podproblemów.

3. Teoriodowodowe - dowód jest prowadzony od tyłu (od twierdzenia do aksjomatów).

4. Metodologiczne (w RS) - reguła cięcia jest eliminowalna.

5. Metodologiczne (w RS, w systemach tablicowych) - wszystkie reguły systemu mają własność podformuł.

6. Metodologiczne (w systemach tablicowych) - wszystkie reguły są regułami eliminacji stałych.

7. Metodologiczne (w RS, DN) - stosowalność reguł jest ograniczona do wyznaczonego zbioru formuł (np. zbioru podformuł dowodzonej formuły) lub sekwentu.

Podane wyżej znaczenia nadawane terminowi "analityczny" są ze sobą ściśle powiązane, ale z pewnością nie identyczne. Zauważmy, że w badaniach nad systemami dowodzenia twierdzeń w jednym ze znaczeń tego terminu (6) przeciwstawia się systemy analityczne jako te, w których reguły pozwalają tylko rozbijać formuły na ich części składowe, systemom syntetycznym, w których reguły przeciwnie, pozwalają składać formuły z podformuł. Z tego punktu widzenia systemy tablicowe byłyby systemami analitycznymi, natomiast RS bez (Cut) byłby systemem syntetycznym. Jednak jeżeli za podstawę kwalifikacji systemów przyjąć nie definicję reguł i dowodu w RS, ale sam fakt posiadania własności podformuł (7), to RS bez (Cut) jest również systemem analitycznym. Jest to uzasadnione zarówno odwracalnością reguł (1) jak i powszechną praktyką konstruowania dowodów w RS (3). Otóż, jak już wspominaliśmy w rozdziale 3 , w praktyce dowód najczęściej konstruuje się "od dołu" zaczynając od sekwentu dowodzonego i systematycznie poszukując dla niego możliwych przesłanek. System RS, który posiada własność podformuł (analityczny w sensie 5) będziemy określać jako ściśle analityczny.

Na marginesie warto zauważyć, że często w pracach dotyczących sekwentowych formalizacji, utożsamia się analityczność w tym sensie (5), z zachodzeniem twierdzenia o eliminacji cięcia (4). Nie jest to uzasadnione, gdyż jest wiele systemów dla logik nieklasycznych, w których wprawdzie cięcie jest eliminowalne, ale nie są one analityczne $\mathrm{w}$ tym znaczeniu. Jest tak dlatego, że nieusuwalne są inne reguły tych systemów, które własności podformuł 
nie spełniają ${ }^{5}$. Może to sugerować, że eliminowalność (Cut) jest warunkiem koniecznym, ale nie wystarczającym analityczności (przynajmniej w sensie 5). Z drugiej strony, analityczność można rozumieć szerzej (7), tak że ani własność podformuł ani nawet eliminacja cięcia nie jest wymagana (czyli nie jest nawet warunkiem koniecznym). Wystarczy, że wszystkie dowody konstruowane w systemie mają własność podformuł. Generalnie, analityczność w tym najsłabszym znaczeniu (7) oznacza po prostu eliminację indeterminizmu w poszukiwaniu kolejnych kroków konstrukcji dowodu. System ściśle analityczny dobrze spełnia tę rolę, ale nie jest niezbędny; wybory ograniczone do podformuł tego sekwentu, którego dowód usiłujemy skonstruować tė̇ gwarantują ograniczenie przestrzeni poszukiwań. Zauważmy, że nawet (Cut) można ograniczyć do takich zastosowań; nazwiemy je analitycznymi ${ }^{6}$.

Każde zastosowanie reguły, w którym przesłanki zawierają tylko podformuły dowodzonego sekwentu określać będziemy jako analityczne zastosowanie tej reguły, natomiast system, w którym każda reguła jest stosowana analitycznie (czyli każdy dowód spełnia własność podformuł) określimy jako system analityczny. Oczywiście każdy system ściśle analityczny jest systemem analitycznym, ale nie odwrotnie. Dowolny system analityczny, ale nie ściśle analityczny, określać będziemy jako system słabo analityczny. Przyjmijmy następujące definicje:

Definicja 6.3 1. System $R S$, w którym stosowalność regut $w$ dowodzie jest ograniczona do wyznaczonego zbioru formut (np. zbioru podformut dowodzonego sekwentu lub jakiegoś dobrze zdefiniowanego ich nadzbioru) jest (słabo) analityczny.

2. System RS, który posiada wtasność podformut będziemy określać jako ściśle analityczny.

\subsection{Rozstrzygalność KRZ}

Rozważania nad (silną) analitycznością RS bez (Cut) w naturalny sposób prowadzą do problematyki rozstrzygalności (por. podrozdział 1.7). Przy okazji udowadniania rozstrzygalności dla KRZ przy użyciu RS pokażemy, że z

\footnotetext{
${ }^{5}$ Dobrym przykładem może być tzw. Display Calculus Belnapa [12] - bardzo ogólna forma RS, czy RS Mintsa [99] dla modalnej logiki S5

${ }^{6}$ Można wprowadzić jeszcze mocniejsze pojęcie analitycznego cięcia, w którym cutformuła należy do zbioru podformuł sekwentu-wniosku danego zastosowania (Cut); tak np. definiuje się analityczny (Cut) w Wansing [148]. Dla naszych potrzeb elastyczniejsze pojęcie, przy którym dopuszczalna jest każda podformuła sekwentu końcowego dowodu, jest jednak wygodniejsze.
} 
punktu widzenia automatyzacji procesu dowodzenia i jego efektywności nie jest sprawą obojętną jakiej wersji RS użyjemy. Dlatego najpierw zademonstrujemy procedurę dla LK bez (Cut), a potem pokażemy, jakie korzyści można uzyskać przy zastąpieniu LK przez inne wersje RS.

Niezależnie od stosowanej wersji RS zasadniczy schemat pozostaje ten sam. Dlatego zanim formalnie zdefiniujemy procedury rozstrzygalne dla KRZ oparte na różnych wersjach RS i skupimy się na szczegółach, opiszmy krótko jej istotę. Zaczynamy od dowodzonego sekwentu i konstruujemy drzewo dowodowe stosując reguły w porządku odwrotnym, od sekwentu-wniosku do sekwentów-przesłanek. Ponieważ na każdym kroku ilość wyborów jest ograniczona (skończona ilość formuł złożonych w sekwencie-wniosku), więc mamy tutaj do czynienia z ograniczonym niezdeterminowaniem procedury, który łatwo przekształcić w algorytm deterministyczny, np. narzucając porządek wyboru zawsze od lewej ku prawej. Zauważmy, że jeżeli taki sposób postępowania chcemy zautomatyzować, to najlepsze okazują się c-systemy w typie RS Galliera [48] (por. uwaga 4.4).

Pokażemy, że w KRZ, przy spełnieniu pewnych warunków, taka procedura daje zawsze drzewo skończone, które jest bądź dowodem (każda gałąź zakończona liściem, który jest sekwentem aksjomatycznym) bądź umożliwia falsyfikację sprawdzanego sekwentu (co najmniej jedna gałąź zakończona sekwentem atomowym, ale nie aksjomatycznym).

Powyżej użyliśmy określenia "drzewo dowodowe", gdyż efekt stosowania takiej procedury nie musi dać dowodu. Dla potrzeb stosowania RS jako procedury rozstrzygalnej warto wprowadzić formalnie pojęcie drzewa dowodowego sekwentu $S$, które ułatwi precyzyjne ujęcie etapów poszukiwania dowodu dla sekwentu $S$ oraz wykazywanie odpowiednich własności procedury. Definicja ta zgodna jest z tym, że w praktyce dowód najczęściej konstruuje się "od dołu" zaczynając od sekwentu dowodzonego i systematycznie poszukując dla niego możliwych przesłanek.

Definicja 6.4 (Drzewo dowodowe sekwentu S) 1. Każde drzewo jednoelementowe, którego węzeł jest sekwentem $S$ jest drzewem dowodowym sekwentu $S$.

2. Jeżeli $S$ ' jest nieatomowym liściem w drzewie dowodowym sekwentu $S$, to drzewo uzyskane przez dopisanie sekwentu $T$ powyżej sekwentu $S^{\prime}$ jest drzewem dowodowym sekwentu $S$, pod warunkiem, że T jest podstawieniem przestanki, a $S^{\prime}$ jest podstawieniem wniosku jednej z regut jednoprzesłankowych. 
3. Jeżeli $S$ ' jest nieatomowym liściem $w$ drzewie dowodowym sekwentu $S$, to drzewo uzyskane przez dopisanie sekwentów $T$ i T' powyżej sekwentu $S$ ' jest drzewem dowodowym sekwentu $S$, pod warunkiem, że T jest podstawieniem lewej przesłanki, T' jest podstawieniem prawej przestanki, a $S^{\prime}$ jest podstawieniem wniosku jednej z reguł dwuprzesłankowych.

4. Nic więcej nie jest drzewem dowodowym sekwentu $S$.

Warto porównać tę definicję z definicją dowodu (i dedukcji) sekwentu podanymi w podrozdziale 3.1. Przypomnijmy, że drzewo, w którym niekoniecznie każdy liść jest sekwentem aksjomatycznym, ale które spełnia pozostałe dwa warunki definicji dowodu, to dedukcja sekwentu $S$. $X \vdash S$ oznacza, że istnieje dedukcją $S$ z $X$, gdzie $X$ oznacza zbiór wszystkich liści, które nie są sekwentami aksjomatycznymi. W szczególności, dedukcja z pustym $X$ jest dowodem $S$.

Zarówno definicja dowodu/dedukcji podane w podrozdziale 3.1, jak i definicja drzewa dowodowego są indukcyjnymi definicjami szczególnego rodzaju drzew, jednak budowanymi w różny sposób. Definicja dowodu zaczyna się od liści i pokazuje jak dojść do korzenia, natomiast definicja drzewa dowodowego zaczyna od korzenia i pokazuje jak dojść do liści. Definicja taka jest przydatniejsza jako podstawa dla stosowania indukcji wstępującej po gałęziach konstruowanego drzewa. Zależność między dwoma ujęciami oddaje poniższy:

Fakt 6.1 D jest dedukcja $S$ z $X$ wtw $\mathcal{D}$ jest drzewem dowodowym sekwentu $S$, w którym $X$ jest podzbiorem zbioru liści.

DowóD przez porównanie warunków indukcyjnych; w obu wypadkach przejścia między węzłami regulują te same reguły.

Szczególnie ważne są takie drzewa dowodowe, których już nie da się poszerzyć, nazwijmy je kompletnymi.

Definicja 6.5 (drzewo dowodowe kompletne) Jest to drzewo dowodowe, w którym każdy liść jest sekwentem atomowym.

Dla drzew dowodowych zachodzi ważny:

Lemat 6.3 Każde drzewo dowodowe sekwentu $S$ można poszerzyć do drzewa kompletnego.

DowóD: Rozważmy pewne niekompletne drzewo $\mathcal{D}$. Z racji niekompletności musi mieć ono przynajmniej jeden nieatomowy sekwent-liść. Wybieramy 
pierwszy od lewej nieatomowy sekwent-liść $S$ i stosujemy do niego logiczną regułę (po ewentualnych permutacjach) do wybranej nieatomowej formuły. Powtarzamy tę operację tak długo aż skrajna lewa gałąź otrzymana z S zakończy się sekwentem atomowym. Przechodzimy na prawo do następnego nieatomowego sekwentu-liścia i powtarzamy powyższą procedurę. Własność podformuł zapewnia skończoność takiej procedury.

Prostą konsekwencją powyższego lematu jest:

Lemat 6.4 Każde kompletne drzewo dowodowe sekwentu $S$ jest dowodem $S$ albo dedukcja $S$ z niepustego zbioru nieaksjomatycznych atomowych sekwentów $X$.

Zastanówmy się teraz czy każde kompletne drzewo dowodowe dla $S$, które nie jest dowodem tylko dedukcją $S$ z pewnej liczby atomowych sekwentów nieaksjomatycznych daje gwarancję, że $S$ jest niedowiedlne. Zależy to od rodzaju RS. Prosty przykład pokazuje, że w przypadku LK musimy na to pytanie udzielić odpowiedzi negatywnej. Porównajmy dwa drzewa dowodowe $\frac{\Rightarrow p \rightarrow p}{\Rightarrow(p \rightarrow p) \vee p}$ i $\frac{\Rightarrow p}{\Rightarrow(p \rightarrow p) \vee p}$. Do pierwszego można zastosować $(\Rightarrow \rightarrow)$ i otrzymać dowód $\Rightarrow(p \rightarrow p) \vee p$ podczas, gdy drugie jest już drzewem kompletnym, ale nie dowodem. W naszkicowanej w dowodzie lematu 6.3 procedurze nie jesteśmy zdeterminowani ani co do tego, którą formułę złożoną wybieramy w ramach rozważanego sekwentu, aby zastosować do niej regułę, ani co do tego, którą regułę zastosujemy, jeżeli są dwie (tak jak w rozważanym przykładzie). Co więcej, w przypadku reguł k-niezależnych ten indeterminizm wzrasta z powodu różnych możliwości rozpisania parametrów w przesłankach.

Zatem w LK nie każde kompletne drzewo dowodowe rozstrzyga kwestię dowiedlności. Jeżeli w wyniku zastosowania powyższego algorytmu otrzymamy dowód, to wiemy że testowany sekwent jest dowiedlny. Jeżeli jednak otrzymamy dedukcję z niepustego zbioru sekwentów atomowych, ale nieaksjomatycznych, to wcale nie przesądza to o niedowiedlności testowanego sekwentu. Nie oznacza to, że LK (bez (Cut)) nie umożliwia otrzymania procedury rozstrzygalnej dla KRZ, nie jest jednak w tym względzie narzędziem optymalnym. O tym, że dany sekwent jest niedowiedlny możemy przesądzić dopiero wtedy, gdy skonstruujemy wszystkie możliwe kompletne drzewa dowodowe i żadne z nich nie okaże się dowodem tegoż sekwentu. Na szczęście inne warianty RS zachowują się lepiej w tym względzie. 


\subsubsection{Zbieżność}

Aby lepiej wyjaśnić o co chodzi wprowadzimy pojęcie zbieżności (ang. confluency) systemu. Ma ono sens tylko na gruncie takich formalizacji, które pozwalają na definiowanie algorytmów poszukiwania dowodu. Dla RS można tę własność zdefinować następująco:

Definicja 6.6 System RS jest zbieżny wtw jeżeli sekwent jest dowiedlny, to dowolne poszerzenie każdego niekompletnego drzewa dowodowego $z$ tym sekwentem jako korzeniem daje dowód tego sekwentu.

Innymi słowy, bez względu na to, w jakiej kolejności zastosujemy reguły, próbując konstrukcji dowodu od końca, to i tak w rezultacie otrzymamy dowód, o ile sprawdzany sekwent jest dowiedlny. Systemy zbieżne są wygodne z punktu widzenia automatycznego dowodzenia twierdzeń, gdyż nie zmuszają do uwzględniania możliwości powrotu (backtracking) do wcześniejszych etapów konstrukcji, jeżeli dokonaliśmy po drodze "złych" wyborów, zatem mniej obciążaja pamięć programu. Z punktu widzenia rezultatu w systemach zbieżnych nie ma złych wyborów, choć takie a nie inne wybory moga mieć niebanalny wpływ na rozmiary otrzymanego dowodu.

Łatwo zauważyć, że w procesie poszukiwania dowodu dla LK możemy być zmuszeni do wielokrotnych powrotów i zaczynania poszukiwań dowodu od nowa nawet, gdy nie musimy używać (Cut). Przyczyną braku zbieżności LK jest występowanie kontrakcji, osłabiania, Gentzenowskich reguł $(\Rightarrow \vee)$ i $(\wedge \Rightarrow)$ oraz k-niezależnej reguły $(\rightarrow \Rightarrow)$. Jak wyżej pokazaliśmy, w LK, w rezultacie braku zbieżności, mimo iż $S$ jest dowiedlne, to można otrzymać jego drzewo dowodowe, które nie jest dowodem $S$. Obie Gentzenowskie reguły $(\Rightarrow \vee)$ i $(\wedge \Rightarrow)$ nie są najgorsze, gdyż zostawiają tylko dwie możliwości. W przypadku kontrakcji i osłabiania mamy tyle możliwości ile formuł w sekwencie, a w przypadku k-niezależnej $(\rightarrow \Rightarrow$ ) tyle ile możliwych rozkładów formuł parametrycznych we wniosku między dwa sekwenty przesłanki. Problemów takich możemy uniknąć, jeżeli procedurę oprzemy na ARS. Można wtedy dowieść:

Lemat 6.5 (zbieżność ARS) Jeżeli S jest dowiedlne w ARS, to każde drzewo dowodowe sekwentu $S$ można poszerzyć do dowodu $S$ w ARS.

DowóD: Załóżmy, że mimo dowiedlności $S$ otrzymaliśmy w wyniku procedury naszkicowanej w dowodzie lematu 6.3 kompletne drzewo dowodowe, które nie jest jego dowodem. Rozważmy gałąź, która zaczyna się od nieaksjomatycznego atomowego liścia $S^{\prime}$. Model, w którym wszystkie elementy 
poprzednika $S^{\prime}$ są prawdziwe, a wszystkie elementy następnika fałszywe, falsyfikuje nie tylko ten sekwent, ale również każdy inny sekwent na tej gałęzi, gdyż wszystkie reguły ARS są odwracalne. Zatem również $S$ byłby sfalsyfikowany, co - z racji adekwatności ARS - przeczy założeniu o jego dowiedlności.

Uwaga 6.1: Analogiczny rezultat możemy uzyskać, gdy procedurę szukania dowodu oprzemy na LK-K, czyli wariancie LK z regułami Ketonena i kjednolitymi. Musimy wtedy jednak zrezygnować ze stosowania kontrakcji, a (W) stosujemy dopiero w ostatniej fazie, do sekwentów, które są już wprawdzie atomowymi aksjomatami uogólnionymi, ale nie są aksjomatami w sensie LK-K.

Zauważmy - na podstawie podanego wyżej dowodu - że jeżeli zawęzimy nasze rozważania do takich wersji RS, które używają uogólnionych aksjomatów, co automatycznie czyni (W) zbędnym, to brak zbieżności związany jest z występowaniem reguł nieodwracalnych. Oddaje to poniższe twierdzenie.

Twierdzenie 6.2 RS jest zbieżny wtw wszystkie reguły sa odwracalne.

DowóD: Załóżmy, że RS jest zbieżne, ale pewna reguła $r$ jest nieodwracalna. Rozważmy dowiedlny sekwent $S$, dla którego budujemy drzewo dowodowe, w którym na pewnej gałęzi użyliśmy $r$; niech to będzie instancja $S_{1} / S_{2}$ tej reguły i niech to będzie pierwsze, idąc od korzenia, użycie reguły nieodwracalnej na tej gałęzi. Ponieważ wszystkie reguły użyte na gałęzi poniżej $S_{2}$ są odwracalne, więc $\vdash S_{2}$, ale to znaczy, że z racji zbieżności, dowolne drzewo dowodowe $\frac{S_{1}}{S_{2}}$ można poszerzyć do dowodu $S_{2}$. Ale wtedy również $\vdash S_{1}$, gdyż każda gałąź, która prowadzi do $S_{1}$ w otrzymanym finalnie drzewie dowodowym zaczyna się od aksjomatu. Zatem $r$ też jest odwracalna.

Z kolei załóżmy, że wszystkie reguły są odwracalne, ale RS jest niezbieżny. Zatem dla pewnego $\vdash S_{1}$ istnieje kompletne drzewo dowodowe, którego przynajmiej jeden liść, np. $S_{2}$ nie jest aksjomatem. Ale skoro każda reguła jest odwracalna, to każdy sekwent poprzedzający $S_{1}$ na gałązi zaczynającej się od $S_{2}$ musi być dowiedlny - sprzeczność.

Konsekwencją powyższych jest:

Twierdzenie 6.3 (O rozstrzygalności dla KRZ:) Dla dowolnego $S$ w skończony sposób można wykazać, że jest dowiedlne lub dowodu nie posiada.

DowóD: Jest to wzmocnienie lematu 6.4. Stosujemy do ARS podaną w dowodzie lematu 6.3 procedurę uzyskując w skończonej ilości kroków drzewo 
kompletne. Jednak tym razem drzewo, które nie jest dowodem, musi falsyfikować $S$ z racji zachodzenia lematu 6.5.

Uwaga 6.2: Oczywiście przy pomocy LK też można dowieść rozstrzygalności KRZ, ale wymaga to uwzględnienia konieczności "backtrackingu" - powracania do pewnych etapów budowy drzewa i kolejnego rozważania innych możliwych poszerzeń danego drzewa dowodowego. Tym niemniej uwzględnianie takich wersji RS nie jest bez znaczenia, gdyż dla wielu roztrzygalnych logik nieklasycznych, np. modalnych, nie istnieją zbieżne systemy RS.

\subsubsection{Algorytmy}

W dowodach dotychczasowych rezultatów wykorzystywaliśmy nieformalnie pewną procedurę budowy drzew dowodowych. W książce tej nie zamierzamy się zajmować kwestiami automatyzacji dowodzenia ani, tym bardziej, implementacji takich programów, czy strategiami optymalizacji. Pomijamy też całkowicie kwestie efektywności związane z obliczaniem przestrzeni poszukiwania dowodu. Tym niemniej pewne elementarne uwagi mogą okazać się przydatne choćby w przypadku sięgnięcia do bardziej zaawansowanej literatury (np. Fitting [43], Gallier [48].)

Poniżej w pseudokodzie, który w zasadzie wystarcza do rozwinięcia w dowolnym języku programowania, podamy zapis algorytmu, który wykorzystaliśmy w dowodach lematów i twierdzeń z poprzednich paragrafów. Sekwenty aksjomatyczne będziemy zaznaczać jako zamknięte, aby nie rozważać ich podczas następnego etapu.

Wejście: sekwent $S$

Wyjście: potwierdzenie albo zaprzeczenie dowiedlności $S$

0 . Start Wpisz $S$ jako korzeń drzewa.

1. Select skrajny lewy niezamknięty liść $S^{\prime}$.

2. If $S^{\prime}$ nie jest aksjomatyczny, then

\subsection{If $S^{\prime}$ jest atomowy, then} stop: $\nvdash S$

else zastosuj regułę do wybranej formuły goto 1 . else zamknij $S^{\prime}$.

3. If $S^{\prime}$ jest skrajnym prawym liściem, then stop: $\vdash S$

else

3.1. przejdź do następnego liścia $S^{\prime \prime}$

3.2. $S^{\prime \prime}:=S^{\prime}$ goto 2 . 
Oto kilka cech podanego algorytmu szukania dowodu:

1. drzewo budowane według strategii DEPTH-FIRST;

2. wczesne zastosowanie testu zamykania gałęzi;

3. ograniczony niedeterminizm;

4. brak strategii preferencji.

Co do pierwszej własności, to istnieją różne typy algorytmów budujących lub przeszukujących drzewa. Do najpopularniejszych strategii należą budujące (przeszukujące) wszerz (breadth-first) i w głąb (depth-first). Przykłady algorytmów pierwszego typu dla ARS można znaleźć np. w Gallier [48], Buss [20], Kleene [84]; są one bardziej przydatne dla nierozstrzygalnych logik, toteż rozwiązanie tego typu zastosujemy w rozdziale 9 do KRK.

Podany przez nas tutaj algorytm należy do drugiej grupy, gdyż po każdym zastosowaniu reguły wracamy do kroku 1, czyli cały czas rozbudowujemy skrajną lewą gałąź aż do skutku i dopiero wtedy przechodzimy do następnej gałęzi. Tym skutkiem może być sekwent atomowy nieaksjomatyczny, co skutkuje zakończeniem bez rozwijania innych gałęzi (to też charakterystyczne dla strategii depth-first), albo aksjomatyczny, który nie musi być atomowy. To, że na każdym etapie w kroku 2 sprawdzamy czy sekwent jest aksjomatyczny zanim podejmiemy dalsze działania, to druga cecha naszego algorytmu. Alternatywnie moglibyśmy rozwijać każdą gałąź aż do atomowego liścia i dopiero wtedy sprawdzać czy jest to aksjomat.

Ograniczony niedeterminizm sprowadza się do tego, że w przypadku sekwentu nieatomowego wybieramy formułę, do której stosujemy regułę. Zatem procedura nie jest $\mathrm{w}$ pełni deterministyczna, gdyż jakiś wybór musi być dokonany, ale jest to niedeterminizm ograniczony tylko do wyboru pewnej formuły w danym sekwencie. Mamy tu dwie możliwości, niedeterminizm procedury może być wyeliminowany całkowicie przez narzucenie kolejności rozważania formuł np. od lewej ku prawej ${ }^{7}$. Z drugiej strony, można wykorzystać niedeterminizm i przy okazji zastosować pewne strategie optymalizacji, np. stosować najpierw reguły, które nie rozgałęziają, a dopiero potem rozgałęziające, aby ograniczyć wielkość drzewa dowodowego. W ten sposób wprowadzilibyśmy do algorytmu pewnę strategię preferencji.

\footnotetext{
${ }^{7} \mathrm{~W}$ tym przypadku lepsze jest używanie c-systemów (por. uwaga 4.4 o ARS Galliera).
} 


\subsection{Twierdzenie o interpolacji}

Jedno z bardziej interesujących zastosowań twierdzenia o eliminacji cięcia to dowód twierdzenie o interpolacji Craiga, a raczej pewnego bardziej ogólnego twierdzenia, które implikuje twierdzenie $\mathrm{Craiga}^{8}$. W dowodzie zastosujemy metodę Maehary, która jest dość ogólna, gdyż z jej pomocą wykazano interpolację dla wielu logik nieklasycznych w formalizacji RS. Co więcej, dowody te są konstruktywne gdyż, w przeciwieństwie do innych, semantycznych dowodów (np. oryginalny dowód Craiga), pokazują dla konkretnych przypadków, w jaki sposób skonstruować formułę interpolacyjną. Prezentację metody Maehary i jej poszerzenie na inne logiki można znaleźć m.in. w opracowaniach Takeutiego [143] i Ono [104]. Przykład innego konstruktywnego dowodu tego twierdzenia można znaleźć w Kleene [84].

Na potrzeby dowodu twierdzenia Maehary wprowadzimy do języka stałe $\top \mathrm{i} \perp$ oraz wzbogacimy LK o aksjomaty postaci $\Rightarrow \top \mathrm{i} \perp \Rightarrow$. Twierdzenie o eliminacji cięcia nadal zachodzi dla takiej formy LK, gdyż jest to konserwatywne poszerzenie LK. Zakładamy też dla uproszczenia, że sekwenty składają się z multizbiorów, $\sqcup$ oznacza sumę multizbiorów (por. dodatek), ale $Z Z(\Gamma)$ oznacza zbiór atomów występujących w multizbiorze $\Gamma$, wliczając w to stałe $\top \mathrm{i} \perp$. Dla dowolnego sekwentu $\Gamma \Rightarrow \Delta$ wprowadzimy pojęcie jego partycji.

Definicja 6.7 Niech $\Gamma_{1} \sqcup \Gamma_{2}=\Gamma, a \Delta_{1} \sqcup \Delta_{2}=\Delta$. Wtedy $\left(\left(\Gamma_{1}, \Delta_{1}\right),\left(\Gamma_{2}, \Delta_{2}\right)\right)$ jest partycja $\Gamma \Rightarrow \Delta$.

Zauważmy, że w partycji dopuszczalne są też multizbiory puste, np. $(\Gamma, \varnothing),(\varnothing, \Delta)$ też jest partycją $\Gamma \Rightarrow \Delta$.

Twierdzenie 6.4 Jeżeli $\vdash \Gamma \Rightarrow \Delta$, to dla dowolnej partycji $\left(\left(\Gamma_{1}, \Delta_{1}\right),\left(\Gamma_{2}, \Delta_{2}\right)\right)$ istnieje takie $\varphi$, że:

1. $\vdash \Gamma_{1} \Rightarrow \Delta_{1}, \varphi$

2. $\vdash \varphi, \Gamma_{2} \Rightarrow \Delta_{2}$

3. $Z Z(\varphi) \subseteq Z Z\left(\Gamma_{1} \sqcup \Delta_{1}\right) \cap Z Z\left(\Gamma_{2} \sqcup \Delta_{2}\right)$

${ }^{8}$ Właściwie dowód tego twierdzenia wynika raczej z własności podformuł; np. można tym sposobem udowodnić twierdzenie interpolacji dla modalnej logiki S5, która nie posiada RS formalizacji bez (Cut) ale zastosowania (Cut) są tam ograniczone do analitycznych por. np. Ono [104]. 
DowóD: Przez indukcję po długości $k$ dowodu $\Gamma \Rightarrow \Delta$ w LK bez (Cut).

Przypadek $k=0$ zatem $\Gamma \Rightarrow \Delta$ jest aksjomatem. Niech będzie postaci $\varphi \Rightarrow \varphi$. Wtedy mamy do rozważenia 4 partycje:

$((\varphi, \varphi),(\varnothing, \varnothing)),((\varnothing, \varnothing),(\varphi, \varphi)),((\varphi, \varnothing),(\varnothing, \varphi)),((\varnothing, \varphi),(\varphi, \varnothing))$.

$\mathrm{W}$ pierwszym przypadku interpolantem jest $\perp$, gdyż mamy $\vdash \varphi \Rightarrow \varphi, \perp$ $\mathrm{i} \vdash \perp \Rightarrow$. W drugim $\top$, gdyż $\vdash \Rightarrow \top \mathrm{i} \vdash \top, \varphi \Rightarrow \varphi$. W trzecim jest to $\varphi$, a w czwartym $\neg \varphi$, gdyż $\vdash \Rightarrow \varphi, \neg \varphi$ i $\vdash \neg \varphi, \varphi \Rightarrow$. Dla aksjomatu postaci $\Rightarrow \top$ mamy dwie partycje $((\varnothing, \top),(\varnothing, \varnothing))$ i $((\varnothing, \varnothing),(\varnothing, \top)$. W pierwszym przypadku interpolantem jest $\perp$, gdyż $\vdash \Rightarrow T, \perp$ i $\vdash \perp \Rightarrow$, w drugim $T$. Dla aksjomatu postaci $\perp \Rightarrow$ dualnie do poprzedniego przypadku.

W przypadku $k>0$, rozważamy kolejno ostatnią zastosowaną w dowodzie regułę. Dla przykładu dokładnie przeanalizujemy obie reguły dla $\wedge$.

$(\wedge \Rightarrow)$ : wtedy $\Gamma \Rightarrow \Delta:=\psi \wedge \chi, \Gamma^{\prime} \Rightarrow \Delta$, a poprzedni sekwent ma postać $\psi, \Gamma^{\prime} \Rightarrow \Delta$ lub $\chi, \Gamma^{\prime} \Rightarrow \Delta$; weźmy pierwszy z nich (dla drugiego dowód jest analogiczny). Nie musimy rozważać wszystkich partycji $\Gamma \Rightarrow \Delta$, a nawet nie jesteśmy w stanie tego zrobić, gdyż mamy tylko schemat sekwentu a nie konkretny sekwent z określonymi formułami. Zatem musimy rozważyć dwie sytuacje: dowolna partycja, w której $\psi \wedge \chi \in \Gamma_{1}$ i taka, w której $\psi \wedge \chi \in \Gamma_{2}$.

Rozważmy dowolną partycję taką, że $\psi \wedge \chi \in \Gamma_{1}$ (inaczej $\Gamma_{1}:=\psi \wedge \chi, \Gamma_{1}^{\prime}$ ) i dla sekwentu przesłanki rozważmy odpowiadająca jej partycję z $\psi \in \Gamma_{1}$ (inaczej $\Gamma_{1}:=\psi, \Gamma_{1}^{\prime}$ ). Ponieważ $\psi, \Gamma^{\prime} \Rightarrow \Delta$ ma dowód długości $k-1$ więc, z założenia indukcyjnego istnieje $\varphi$ takie, że:

1. $\vdash \Gamma_{1}^{\prime}, \psi \Rightarrow \Delta_{1}, \varphi$

2. $\vdash \varphi, \Gamma_{2} \Rightarrow \Delta_{2}$

3. $Z Z(\varphi) \subseteq Z Z\left(\Gamma_{1}^{\prime} \sqcup\{\psi\} \sqcup \Delta_{1}\right) \cap Z Z\left(\Gamma_{2} \sqcup \Delta_{2}\right)$

Wtedy z 1 . mamy $\psi \wedge \chi, \Gamma_{1}^{\prime} \Rightarrow \Delta_{1}, \varphi$, a skoro zachodzi 2., a ponadto $Z Z(\varphi) \subseteq Z Z\left(\Gamma_{1}^{\prime} \sqcup\{\psi \wedge \chi\} \sqcup \Delta_{1}\right) \cap Z Z\left(\Gamma_{2} \sqcup \Delta_{2}\right)$, więc $\varphi$ jest również interpolantem dla $\psi \wedge \chi, \Gamma^{\prime} \Rightarrow \Delta$.

Rozważmy teraz dowolną partycję taką, że $\psi \wedge \chi \in \Gamma_{2}$ (inaczej $\Gamma_{2}:=$ $\left.\psi \wedge \chi, \Gamma_{2}^{\prime}\right)$ i dla przesłanki rozważmy odpowiadająca jej partycję z $\psi \in \Gamma_{2}$ (inaczej $\Gamma_{2}:=\psi, \Gamma_{2}^{\prime}$ ). Znów z założenia indukcyjnego istnieje $\varphi$ takie, że:

1. $\vdash \Gamma_{1} \Rightarrow \Delta_{1}, \varphi$

2. $\vdash \varphi, \Gamma_{2}^{\prime}, \psi \Rightarrow \Delta_{2}$

3. $Z Z(\varphi) \subseteq Z Z\left(\Gamma_{1} \sqcup \Delta_{1}\right) \cap Z Z\left(\Gamma_{2}^{\prime} \sqcup\{\psi\} \sqcup \Delta_{2}\right)$ 
Wtedy z 2. mamy $\psi \wedge \chi, \varphi, \Gamma_{2}^{\prime} \Rightarrow \Delta_{2}$, a skoro zachodzi 1 ., a ponadto $Z Z(\varphi) \subseteq Z Z\left(\Gamma_{1} \sqcup \Delta_{1}\right) \cap Z Z\left(\Gamma_{2}^{\prime} \sqcup\{\psi \wedge \chi\} \sqcup \Delta_{2}\right)$, więc $\varphi$ jest również wtedy interpolantem dla $\psi \wedge \chi, \Gamma^{\prime} \Rightarrow \Delta$.

$(\Rightarrow \wedge)$ : wtedy $\Gamma \Rightarrow \Delta:=\Gamma \Rightarrow \Delta^{\prime}, \psi \wedge \chi$, a oba sekwenty-przesłanki maja postać $\Gamma \Rightarrow \Delta^{\prime}, \psi$ i $\Gamma \Rightarrow \Delta^{\prime}, \chi$. Rozważmy dowolną partycję taką, że $\psi \wedge \chi \in \Delta_{1}$ (inaczej $\Delta_{1}:=\Delta_{1}^{\prime}, \psi \wedge \chi$ ) i dla sekwentów przesłanek rozważmy odpowiadające im partycję z $\psi \in \Delta_{1}$ i $\chi \in \Delta_{1}$ (inaczej $\Delta_{1}:=\Delta_{1}^{\prime}, \psi$ i $\left.\Delta_{1}:=\Delta_{1}^{\prime}, \chi\right)$. Z założenia indukcyjnego dla obu przesłanek mamy odpowiednio interpolanty $\varphi_{1}, \varphi_{2}$ takie, że:

1. $\vdash \Gamma_{1} \Rightarrow \Delta_{1}^{\prime}, \psi, \varphi_{1}$

2. $\vdash \varphi_{1}, \Gamma_{2} \Rightarrow \Delta_{2}$

3. $Z Z\left(\varphi_{1}\right) \subseteq Z Z\left(\Gamma_{1} \sqcup \Delta_{1}^{\prime} \sqcup\{\psi\}\right) \cap Z Z\left(\Gamma_{2} \sqcup \Delta_{2}\right)$

4. $\vdash \Gamma_{1} \Rightarrow \Delta_{1}^{\prime}, \chi, \varphi_{2}$

5. $\vdash \varphi_{2}, \Gamma_{2} \Rightarrow \Delta_{2}$

6. $Z Z\left(\varphi_{2}\right) \subseteq Z Z\left(\Gamma_{1} \sqcup \Delta_{1}^{\prime} \sqcup\{\chi\}\right) \cap Z Z\left(\Gamma_{2} \sqcup \Delta_{2}\right)$

Wtedy z 1. i 4. wydedukujemy z pomoca $(\Rightarrow \vee)$ i $(\Rightarrow \wedge) \Gamma_{1} \Rightarrow \Delta_{1}^{\prime}, \psi \wedge$ $\chi, \varphi_{1} \vee \varphi_{2}$, a z 2. i 5. wydedukujemy $\varphi_{1} \vee \varphi_{2}, \Gamma_{2} \Rightarrow \Delta_{2}$ przez $(\vee \Rightarrow)$. Zatem $\varphi_{1} \vee \varphi_{2}$ jest poszukiwanym interpolantem dla $\Gamma \Rightarrow \Delta^{\prime}, \psi \wedge \chi \operatorname{gdyz} Z Z\left(\varphi_{1} \vee\right.$ $\left.\varphi_{2}\right) \subseteq Z Z\left(\Gamma_{1} \sqcup \Delta_{1}^{\prime} \sqcup\{\psi \wedge \chi\}\right) \cap Z Z\left(\Gamma_{2} \sqcup \Delta_{2}\right)$.

Rozważmy teraz dowolną partycję taką, że $\psi \wedge \chi \in \Delta_{2}$ (inaczej $\Delta_{2}:=$ $\left.\Delta_{2}^{\prime}, \psi \wedge \chi\right)$ i dla sekwentów przesłanek rozważmy odpowiadające im partycję z $\psi \in \Delta_{2}$ i $\chi \in \Delta_{2}$ (inaczej $\Delta_{2}:=\Delta_{2}^{\prime}, \psi$ i $\Delta_{2}:=\Delta_{2}^{\prime}, \chi$ ). Z założenia indukcyjnego dla obu przesłanek mamy odpowiednio interpolanty $\varphi_{1}, \varphi_{2}$ takie, że:

1. $\vdash \Gamma_{1} \Rightarrow \Delta_{1}, \varphi_{1}$

2. $\vdash \varphi_{1}, \Gamma_{2} \Rightarrow \Delta_{2}^{\prime}, \psi$

3. $Z Z\left(\varphi_{1}\right) \subseteq Z Z\left(\Gamma_{1} \sqcup \Delta_{1}\right) \cap Z Z\left(\Gamma_{2} \sqcup \Delta_{2}^{\prime} \sqcup\{\psi\}\right)$

4. $\vdash \Gamma_{1} \Rightarrow \Delta_{1}, \varphi_{2}$

5. $\vdash \varphi_{2}, \Gamma_{2} \Rightarrow \Delta_{2}^{\prime}, \chi$

6. $Z Z\left(\varphi_{2}\right) \subseteq Z Z\left(\Gamma_{1} \sqcup \Delta_{1}\right) \cap Z Z\left(\Gamma_{2} \sqcup \Delta_{2}^{\prime} \sqcup\{\chi\}\right)$ 
Wtedy z 1. i 4 . wydedukujemy z pomocą $(\Rightarrow \wedge) \Gamma_{1} \Rightarrow \Delta_{1}, \varphi_{1} \wedge \varphi_{2}$, a z 2. i 5. za pomoca $(\wedge \Rightarrow)$ i $(\Rightarrow \wedge)$ wydedukujemy $\varphi_{1} \wedge \varphi_{2}, \Gamma_{2} \Rightarrow \Delta_{2}^{\prime}, \psi \wedge \chi$. Zatem $\varphi_{1} \wedge \varphi_{2}$ jest poszukiwanym interpolantem dla $\Gamma \Rightarrow \Delta^{\prime}, \psi \wedge \chi$, gdyż $Z Z\left(\varphi_{1} \wedge \varphi_{2}\right) \subseteq Z Z\left(\Gamma_{1} \sqcup \Delta_{1}\right) \cap Z Z\left(\Gamma_{2} \sqcup \Delta_{2}^{\prime} \sqcup\{\psi \wedge \chi\}\right)$.

Pozostałe przypadki dowodzimy w podobny sposób.

Zauważmy, że w dowodzie nie musieliśmy rozważać przypadku, gdy $\Gamma \Rightarrow$ $\Delta$ jest wydedukowane z pomocą (Cut). Do tego przypadku nie dałoby się zastosować metody dowodu przedstawionej wyżej, chyba, że zastosowania (Cut) miałyby charakter analityczny (por. paragraf 6.1.2 i przypis 6).

$\mathrm{Z}$ udowodnionego twierdzenia wynika oryginalne twierdzenie Craiga jako szczególny przypadek. Załóżmy, że $\models \varphi \rightarrow \psi$ i $Z Z(\varphi) \cap Z Z(\psi) \neq \varnothing$, z adekwatności LK i lematu o inwersji mamy $\vdash \varphi \Rightarrow \psi$. Zatem, przy partycji $\Gamma_{1}:=\varphi, \Delta_{2}:=\psi, \Gamma_{2}=\Delta_{1}=\varnothing \mathrm{z}$ twierdzenia 6.4. mamy interpolant $\chi$, taki, $\dot{\mathrm{z} e} \vdash \varphi \Rightarrow \chi \mathrm{i} \vdash \chi \Rightarrow \psi$. 


\section{Rozdział 7}

\section{Metody semantyczne w RS}

Wprawdzie RS jest traktowane głównie jako narzędzie badań teoriodowodowych jednak można z powodzeniem stosować je do prezentacji klasycznych wyników metalogicznych zamiast rozpowszechnionego formalizmu aksjomatycznego. Co więcej, w wielu przypadkach ujęcie tych rezultatów na gruncie RS sprzyja większej prostocie i przejrzystości dowodów. Pokażemy obecnie jak RS można przystosować do tego, aby semantycznie dowodzić rozmaite ważne metalogiczne własności. Skoncentrujemy się zwłaszcza na pokazaniu jak można wykazać twierdzenie o pełności dla RS za pomocą rozmaitych technik. Dowody przedstawimy dla systemu ARS, czyli analitycznego wariantu RS omówionego w rozdziale 4, ale odpowiednie fragmenty dowodów łatwo zmienić tak, aby pasowały do dowolnego innego wariantu RS. Zademonstrujemy w tym rozdziale trzy rodzaje dowodów pełności ARS:

- niekonstruktywny - oparty na technice Lindenbauma-Henkina, czyli wykorzystujący zbiory maksymalnie niesprzeczne;

- konstruktywny - oparty na konstrukcji zbiorów nasyconych Hintikki;

- pośredni - wykorzystujący zbiory niesprzeczne maksymalne relatywnie do pewnego zbioru skończonego.

Poza ostatnim przypadkiem pozostałe strategie były krótko omówione w rozdziale $1 \mathrm{w}$ kontekście H-KRZ. Przeniesienie tych technik na grunt RS wymaga zazwyczaj pewnych uogólnień pojęć i konstrukcji wykorzystywanych dla systemów aksjomatycznych. W rezultacie otrzymujemy przejrzyste i eleganckie warianty dowodów klasycznych rezultatów. Zastosowanie klasycznej techniki dowodu Lindenbauma-Henkina, którą uogólnimy dla potrzeb sekwentowej formalizacji w podrozdziale 7.1 , wymaga użycia (Cut). W prze- 
ciwieństwie do tego dowód metodą Hintikki. jest zarazem alternatywnym (semantycznym) sposobem wykazania twierdzenia o eliminowalności (Cut), gdyż dowodzimy pełności ARS bez tej reguły. W każdym przypadku omówimy pewne warianty obu metod. W podrozdziale 7.3 pokażemy dowód pełności o pośrednim charakterze, w którym korzystamy z analitycznej wersji (Cut). Na koniec, w charakterze suplementu pokażemy, w jaki sposób ARS może być użyte $\mathrm{w}$ dowodzie słabej pełności metodą Posta.

\subsection{Pełność ARS z (Cut) metodą Henkina}

Pokażemy obecnie jak można dla RS z (Cut) wykazać dowód o pełności korzystając ze standardowej metody Henkina opartej o wykorzystanie lematu Lindenbauma o maksymalizacji. Formalizm RS umożliwia eleganckie uogólnienie tej metody. Na początek potrzebujemy parę ważnych definicji:

Definicja 7.1 (Niesprzeczność par zbiorów formuł) $1 . \Gamma \vdash \Delta w t w$ $\vdash \Gamma^{\prime} \Rightarrow \Delta^{\prime}$ dla pewnego skończonego $\Gamma^{\prime} \subseteq \Gamma i \Delta^{\prime} \subseteq \Delta$.

2. $\Gamma \nvdash \Delta$ wtw $\nvdash \Gamma^{\prime} \Rightarrow \Delta^{\prime}$ dla kazddego skończonego $\Gamma^{\prime} \subseteq \Gamma i \Delta^{\prime} \subseteq \Delta$.

3. $(\Gamma, \Delta)$ jest niesprzeczna wtw $\Gamma \nvdash \Delta$.

4. $(\Gamma, \Delta)$ jest sprzeczna wtw $\Gamma \vdash \Delta$.

Domyślnie $\vdash$ oznacza tu dowiedlność w ARS dla KRZ i do niej zrelatywizowane jest pojęcie (nie)sprzeczności par zbiorów, ale definicje te mają walor ogólny - dla dowolnej wersji RS i dowolnej logiki.

Uwaga 7.1: Powyższe definicje oparte są na omawianej w podrozdziale 2.3 interpretacji $\Rightarrow$ jako relacji konsekwencji i poszerzają nam dowiedlność sekwentów na przypadki nieskończonych zbiorów formuł. Podana definicja (nie)sprzeczności pary zbiorów może w pierwszym odruchu budzić zastanowienie. Jest jednak bardzo naturalnym uogólnieniem pojęcia sprzeczności zbioru zdefiniowanym $\mathrm{w}$ rozdziale 1 za pomoca relacji dowiedlności w $\mathrm{H}-$ systemie. Zauważmy, że dowolne $\Gamma$ jest sprzeczne wtw $\Gamma^{\prime} \vdash_{H} \perp$ dla pewnego skończonego $\Gamma^{\prime} \subseteq \Gamma$, ale na mocy równoważności $\vdash_{H}$ i $\vdash_{R S}$ (lematy 3.3. i 3.4.) mamy $\vdash_{R S} \Gamma^{\prime} \Rightarrow$, czyli $(\Gamma, \varnothing)$ jest sprzeczna. Zauważmy też, że gdy $(\Gamma, \Delta)$ jest sprzeczna, to do $\Delta$ możemy dołączyć przez $(\Rightarrow W)$ dowolną formułę co zgodne jest ze standardową charakterystyką sprzeczności $\Gamma$ podaną w lemacie 1.3, zgodnie z którą $C n(\Gamma)=F O R$.

Oto kilka prostych wniosków z podanej wyżej definicji. 
Lemat 7.1 Jeżeli $(\Gamma, \Delta)$ jest niesprzeczna, to:

- $\Gamma \cap \Delta=\varnothing$

- $\left(\Gamma^{\prime}, \Delta^{\prime}\right)$ jest niesprzeczna, dla dowolnego $\Gamma^{\prime} \subseteq \Gamma i \Delta^{\prime} \subseteq \Delta$

DowóD: W pierwszym wypadku gdyby $\Gamma \cap \Delta \neq \varnothing$, to $\vdash \varphi \Rightarrow \varphi$ dla pewnego $\varphi \in \Gamma \cap \Delta$, zatem istnieje skończone $\Gamma^{\prime} \subseteq \Gamma, \Delta^{\prime} \subseteq \Delta$ takie, że $\vdash \Gamma^{\prime} \Rightarrow \Delta^{\prime}$ co prowadzi do sprzeczności z założeniem.

Podobnie w drugim przypadku, gdyby jakieś $\left(\Gamma^{\prime}, \Delta^{\prime}\right)$ było sprzeczne, to wtedy, z racji dopuszczalności (W) mamy $\vdash \Gamma \Rightarrow \Delta$, co prowadzi do sprzeczności z założeniem.

Lemat 7.2 Jeżeli $(\Gamma, \Delta)$ jest niesprzeczna, to:

1. jeżeli $\varphi \in \Gamma$, to $\varphi \notin \Delta$

2. jeżeli $\varphi \in \Delta$, to $\varphi \notin \Gamma$

3. jeżeli $\neg \varphi \in \Gamma$, to $\varphi \notin \Gamma$

4. je żeli $\neg \varphi \in \Delta$, to $\varphi \notin \Delta$

5. jeżeli $\varphi \wedge \psi \in \Gamma$, to $\varphi \notin \Delta i \psi \notin \Delta$

6. jeżeli $\varphi \wedge \psi \in \Delta$, to $\varphi \notin \Gamma$ lub $\psi \notin \Gamma$

7. jeżeli $\varphi \vee \psi \in \Gamma$, to $\varphi \notin \Delta$ lub $\psi \notin \Delta$

8. jeżeli $\varphi \vee \psi \in \Delta$, to $\varphi \notin \Gamma i \psi \notin \Gamma$

9. jeżeli $\varphi \rightarrow \psi \in \Gamma$, to $\varphi \notin \Gamma$ lub $\psi \notin \Delta$

10. jézeli $\varphi \rightarrow \psi \in \Delta$, to $\varphi \notin \Delta i \psi \notin \Gamma$

DowóD: Pierwsze dwa przypadki, to bezpośrednia konsekwencja poprzedniego lematu. Dla ilustracji udowodnimy punkt 9 i 10.

Dla 9. Załóżmy nie wprost, że $\varphi \rightarrow \psi \in \Gamma$ ale $\varphi \in \Gamma$ i $\psi \in \Delta$. Jednak $\vdash \varphi \rightarrow \psi, \varphi \Rightarrow \psi$, więc mamy $\Gamma \vdash \Delta$, co jest sprzeczne z założeniem lematu.

Dla 10. Zakładamy nie wprost, że $\varphi \in \Delta$ lub $\psi \in \Gamma$, chociaż $\varphi \rightarrow \psi \in \Delta$. Zauważmy jednak, że zarówno $\Rightarrow \varphi \rightarrow \psi, \varphi$ jak i $\psi \Rightarrow \varphi \rightarrow \psi$ są dowiedlne (por. fakt 4.1.), więc w każdym wypadku mamy $\Gamma \vdash \Delta$, co przeczy założeniu lematu. 
Jak już wspomnieliśmy zastosowanie techniki Lindenbauma-Henkina wymaga użycia (Cut) zatem skorzystamy z twierdzenia o dopuszczalności (Cut) w ARS, aby udowodnić:

Lemat 7.3 Jeżeli $(\Gamma, \Delta)$ jest niesprzeczna, to $(\Gamma \cup\{\varphi\}, \Delta)$ jest niesprzeczna lub $(\Gamma, \Delta \cup\{\varphi\})$ jest niesprzeczna, dla dowolnej formuly $\varphi$.

DowóD: Załóżmy nie wprost, że oba zbiory są sprzeczne, wtedy zarówno $\vdash \Gamma^{\prime}, \varphi \Rightarrow \Delta^{\prime}$ jak i $\vdash \Gamma^{\prime} \Rightarrow \Delta^{\prime}, \varphi$, dla pewnych skończonych $\Gamma^{\prime} \subseteq \Gamma$ i $\Delta^{\prime} \subseteq \Delta$. Przez (Cut) otrzymamy $\vdash \Gamma^{\prime} \Rightarrow \Delta^{\prime}$, co przeczy założeniu.

Aby dowieść pełności metodą Henkina-Lindenbauma musimy też uogólnić pojęcie zbioru maksymalnego na pary zbiorów formuł.

Definicja 7.2 (Maksymalność par zbiorów formuł) ( $\Gamma, \Delta)$ jest maksymalna wtw $\Gamma \cup \Delta=F O R$.

Oczywiste konsekwencje definicji maksymalności dla par niesprzecznych podaje poniższy lemat. Jak łatwo zauważyć są to konwersy pierwszych czterech warunków z lematu 7.2 charakteryzującego pary niesprzeczne.

Lemat 7.4 Jeżeli $(\Gamma, \Delta)$ jest niesprzeczna i maksymalna, to:

1. jeżeli $\varphi \notin \Gamma$, to $\varphi \in \Delta$

2. jezeli $\varphi \notin \Delta$, to $\varphi \in \Gamma$

3. jeżeli $\neg \varphi \notin \Gamma$, to $\varphi \in \Gamma$

4. jeżeli $\neg \varphi \notin \Delta$, to $\varphi \in \Delta$

DowóD: Dla 3. Gdyby zarówno $\neg \varphi \notin \Gamma$ jak i $\varphi \notin \Gamma$, to $-\mathrm{z}$ racji maksymalności $-\{\neg \varphi, \varphi\} \subseteq \Delta$. Ale $\vdash \Rightarrow \neg \varphi, \varphi$, co przeczy niesprzeczności $(\Gamma, \Delta)$.

Kolejny lemat to odpowiednik lematu Lindenbauma dla par zbiorów formuł. Przedstawimy go tutaj w większym skrócie w porównaniu do wersji standardowej z rozdziału 1.

Lemat 7.5 (Lindenbaum) Jeżeli $(\Gamma, \Delta)$ jest niesprzeczna, to istnieje maksymalna i niesprzeczna $\left(\Gamma^{\prime}, \Delta^{\prime}\right)$ taka, ze $\Gamma \subseteq \Gamma^{\prime} i \Delta \subseteq \Delta^{\prime}$. 
DowóD: Z racji przeliczalności FOR możemy uporządkować liniowo ten zbiór i kolejno dodawać każdą formułę do $\Gamma$ lub $\Delta$. Dokładniej, niech $\varphi_{1}, \varphi_{2}, \ldots$. będzie nieskończoną listą wszystkich formuł . Definiujemy nieskończony ciąg sekwentów $\Gamma_{0} \Rightarrow \Delta_{0}, \Gamma_{2} \Rightarrow \Delta_{2}, \ldots$ taki, że $\Gamma_{0} \Rightarrow \Delta_{0}:=\Gamma \Rightarrow \Delta$, a dla każdego $i \geq 0, \Gamma_{i+1} \Rightarrow \Delta_{i+1}:=\Gamma_{i} \Rightarrow \Delta_{i}, \varphi_{i+1}$, jeżeli $\left(\Gamma_{i}, \Delta_{i} \cup\left\{\varphi_{i+1}\right\}\right)$ jest niesprzeczna; w przeciwnym wypadku $\Gamma_{i+1} \Rightarrow \Delta_{i+1}:=\Gamma_{i}, \varphi_{i+1} \Rightarrow \Delta_{i}$.

Z lematu 7.3 i konstrukcji ciągu wynika, że na każdym etapie przynajmniej jedna z rozważanej pary sekwentów jest niesprzeczna, zatem każdy kolejny element ciągu sekwentów jest niesprzeczny.

Niech $\Gamma^{\prime}=\bigcup \Gamma_{i}$, a $\Delta^{\prime}=\bigcup \Delta_{i}$, dla $i<\omega$. Jest oczywiste, że $\Gamma^{\prime} \cup \Delta^{\prime}=$ FOR, $\left(\Gamma^{\prime}, \Delta^{\prime}\right)$ jest zatem maksymalna. Załóżmy nie wprost, że $\left(\Gamma^{\prime}, \Delta^{\prime}\right)$ jest sprzeczna. Ponieważ każdy dowód jest skończony oznacza to, że istnieje skończona para $(\Pi, \Sigma)$, taka, że $\Pi \subseteq \Gamma^{\prime}, \Sigma \subseteq \Delta^{\prime}$ oraz $\Pi \Rightarrow \Sigma$ ma dowód. Z racji skończoności $(\Pi, \Sigma)$ istnieje $\mathrm{w}$ konstrukcji ciągu sekwentów taki etap $i$, że $\Pi \subseteq \Gamma_{i}$ i $\Sigma \subseteq \Delta_{i}$, ale to oznacza, że $\Gamma_{i} \Rightarrow \Delta_{i}$ jest sprzeczna, wbrew temu, co dowiedliśmy wyżej. Z definicji konstrukcji ciągu mamy też, że $\Gamma \subseteq \Gamma^{\prime}$ i $\Delta \subseteq \Delta^{\prime}$. Zatem $(\Gamma, \Delta)$ można poszerzyć do niesprzecznej pary maksymalnej.

Lemat 7.6 (lemat prawdziwościowy) Jeżeli $(\Gamma, \Delta)$ jest maksymalna, to istnieje model $\mathfrak{M}$, taki, że: dla każdego $\varphi, \varphi \in \Gamma$ wtw $\mathfrak{M} \vDash \varphi$.

DowóD: Definujemy model przyjmując, że $\mathfrak{M}=Z Z(\Gamma)$ i dowodzimy, że spełnia warunki przez indukcję po długości formuł. Baza wynika z definicji.

a. Niech $\varphi:=\neg \psi$ :

Jeżeli $\neg \psi \in \Gamma$, to - przez lemat 7.2, punkt $3-\psi \notin \Gamma$, a przez lemat 7.4, punkt $1-\psi \in \Delta$. Z założenia indukcyjnego $\mathfrak{M} \not \models \psi$, zatem $\mathfrak{M} \vDash \neg \psi$.

Podobnie w drugą stronę, gdy $\mathfrak{M} \vDash \neg \psi$, czyli $\mathfrak{M} \not \models \psi$, to z założenia indukcyjnego $\psi \in \Delta$. Przez lemat 7.2, punkt $4, \neg \psi \notin \Delta$, zatem przez lemat 7.4, punkt $2, \neg \psi \in \Gamma$.

b. Niech $\varphi:=\psi \wedge \chi$ :

Jeżeli $\varphi \in \Gamma$, to $\psi \notin \Delta$ i $\chi \notin \Delta$ (lemat 7.2, punkt 5). Zatem, przez lemat 7.4, punkt $2, \psi \in \Gamma$ i $\chi \in \Gamma$. Z założenia indukcyjnego $\mathfrak{M} \vDash \psi$ i $\mathfrak{M} \vDash \chi$, zatem $\mathfrak{M} \vDash \varphi$.

Jeżeli $\varphi \notin \Gamma$, to przez lemat 7.4, punkt $1, \varphi \in \Delta$, więc przez lematy 7.2 i $7.4, \psi \notin \Gamma$ lub $\chi \notin \Gamma$ czyli $\psi \in \Delta$ lub $\chi \in \Delta$. Z założenia indukcyjnego $\mathfrak{M} \not \models \psi$ lub $\mathfrak{M} \not \models \chi$; bez względu na to, który przypadek zachodzi mamy $\mathfrak{M} \not \models \varphi$. 
Twierdzenie 7.1 (Pełność) Jeżeli $=\Gamma \Rightarrow \Delta$, to $\vdash \Gamma \Rightarrow \Delta$.

DowóD: Załóżmy, że $\nvdash \Gamma \Rightarrow \Delta$, co znaczy, że $(\Gamma, \Delta)$ jest niesprzeczna. Zgodnie z lematem 7.5 istnieje jej maksymalne poszerzenie $\left(\Gamma^{\prime}, \Delta^{\prime}\right)$, a zgodnie z lematem 7.6 istnieje dla tej pary model, taki, że wszystkie elementy $\Gamma^{\prime}$ (a zatem i $\Gamma$ ) są w nim spełnione, a wszystkie elementy $\Delta^{\prime}$ (a zatem i $\Delta$ ) sa tam fałszywe. Ale wtedy nie jest prawdą, że $=\Gamma \Rightarrow \Delta$.

\subsubsection{Alternatywne dowody}

Dowód metodą Lindenbauma-Henkina można też przeprowadzić w trochę inny sposób. Wskażemy krótko dwie podobne alternatywny. Przy pierwszym sposobie zachowujemy definicję maksymalnej (i niesprzecznej) pary zbiorów, ale zamiast osobno dowodzić lemat 7.2 dla niesprzecznych par, a potem lemat 7.4, który dołącza istotne własności maksymalnych par, można od razu udowodnić lemat o własnościach par niesprzecznych i maksymalnych:

Lemat 7.7 Jeżeli $(\Gamma, \Delta)$ jest niesprzeczna i maksymalna, to ma następujace własności:
1. $\neg \varphi \in \Gamma w t w \varphi \in \Delta$
2. $\neg \varphi \in \Delta w t w \varphi \in \Gamma$
3. $\varphi \wedge \psi \in \Gamma w t w \varphi \in \Gamma i \psi \in \Gamma$
4. $\varphi \wedge \psi \in \Delta w t w \varphi \in \Delta l u b \psi \in \Delta$
5. $\varphi \vee \psi \in \Gamma w t w \varphi \in \Gamma l u b \psi \in \Gamma$
6. $\varphi \vee \psi \in \Delta w t w \varphi \in \Delta i \psi \in \Delta$
7. $\varphi \rightarrow \psi \in \Gamma w t w \varphi \in \Delta l u b \psi \in \Gamma$
8. $\varphi \rightarrow \psi \in \Delta w t w \varphi \in \Gamma i \psi \in \Delta$

DowóD: Rozważmy przypadek 1. i 7.

Jeżeli $\neg \varphi \in \Gamma$, to z racji niesprzeczności $(\Gamma, \Delta), \varphi \notin \Gamma$, gdyż $\vdash \varphi, \neg \varphi \Rightarrow$ co daje $\Gamma \vdash \Delta$. Z racji maksymalności $\varphi \in \Delta$, gdyż $\varphi \in \Gamma \cup \Delta$. Analogicznie $\mathrm{w}$ drugą stronę.

Jeżeli $\varphi \rightarrow \psi \in \Gamma$, to oczywiście $\varphi \notin \Gamma$ lub $\psi \notin \Delta$, gdyż w przeciwnym razie $\Gamma \vdash \Delta$, skoro $\vdash \varphi \rightarrow \psi, \varphi \Rightarrow \psi$. Zatem, z racji maksymalności $\varphi \in \Delta$ lub $\psi \in \Gamma$. Załóżmy, że $\varphi \in \Delta$ lub $\psi \in \Gamma$, oraz że $\varphi \rightarrow \psi \notin \Gamma$. Zatem 
$\varphi \rightarrow \psi \in \Delta$ z racji maksymalności. W obu przypadkach prowadzi to jednak do uznania, że $\Gamma \vdash \Delta$, gdyż w pierwszym przypadku $\vdash \varphi \rightarrow \psi$, $\varphi$, a w drugim $\vdash \psi \Rightarrow \varphi \rightarrow \psi$.

Udowodniony lemat pozwala jeszcze prościej udowodnić lemat prawdziwościowy, gdyż podane w nim warunki pokrywają się z warunkami spełniania formuł. Np. dowód dla $\varphi \wedge \psi$ wygląda następująco:

$\varphi \wedge \psi \in \Gamma$ wtw (przez lemat 7.7.) $\varphi \in \Gamma$ i $\psi \in \Gamma$ wtw (przez założenie indukcyjne) $\mathfrak{M} \vDash \varphi$ i $\mathfrak{M} \vDash \psi$ wtw $\mathfrak{M} \vDash \varphi \wedge \psi$.

Jest możliwe jeszcze inne podejście. Mianowicie można sformułować definicję maksymalnej pary zbiorów jako pary spełniającej podane w lemacie 7.7 warunki. Nie musimy ich wtedy udowadniać, ale przy tym podejściu zmienia się dowód lematu 7.5. Konstrukcję stosujemy taką samą, ale musimy udowodnić, że uzyskana para jest maksymalna, tzn., że spełnia podane w lemacie osiem warunków. Pozostawiamy to zadanie czytelnikom.

\subsection{Dowód analityczny pełności}

Zaprezentowana w poprzednim rozdziale procedura szukania dowodu, która została tam wprowadzona dla udowodnienia rozstrzygalności, pokazuje, że do problemu adekwatności RS bez (Cut) można podejść w sposób bezpośredni, tzn. zbudować konstruktywny dowód pełności. W przeciwieństwie do dowodu metodą Lindenbauma-Henkina otrzymujemy dla każdego przypadku sekwentu nietautologicznego konkretny przepis na model falsyfikujący.

Dla potrzeb wykazania pełności ARS wprost (tj. bez odwoływania się do twierdzenia o pełności dla wersji z (Cut) i do faktu jej eliminowalności), potrzebujemy nowego pojęcia, które jest osłabieniem pojęcia maksymalności. Chodzi o pojęcie nasycania w dół, albo saturacji, wprowadzone przez Hintikkę (por. paragraf 1.4.3). Obecnie dostosujemy je do ujęcia sekwentowego, tzn. zdefiniujemy dla par zbiorów formuł, a nie dla pojedynczych zbiorów.

Oczywiście można w przypadku KRZ obyć się bez całego aparatu, który dalej wprowadzimy, biorąc pod uwagę prosty dowód pełności dla ARS oparty na semantycznej odwracalności reguł i przedstawiony przez nas w rozdziale 4. Jednak konstrukcje przedstawione poniżej są bardziej ogólne i można je zastosować do dowodzenia pełności wielu innych logik, w tym takich, których sekwentowe formalizacje zawierają reguły nieodwracalne. Kluczowe pojęcie pary zbiorów nasyconych można wprowadzić na co najmniej dwa sposoby: 
a. bezpośrednio definiując pojęcie nasyconej pary zbiorów formuł;

b. pośrednio (np. Goré [54]) sprowadzając nasycanie do pojęcie domknięcia na zastosowanie reguły.

\subsubsection{Metoda bezpośrednia}

Zacznijmy od pierwszej metody, przy której pojęcie pary zbiorów nasyconych wprowadza się definicyjnie.

Definicja $7.3(\Gamma, \Delta)$ jest (w dót) nasycona wtw spełnia warunki:

1. jeżeli $\neg \varphi \in \Gamma$, to $\varphi \in \Delta$

2. jeżeli $\neg \varphi \in \Delta$, to $\varphi \in \Gamma$

3. jeżeli $\varphi \wedge \psi \in \Gamma$, to $\varphi \in \Gamma$ i $\psi \in \Gamma$

4. jeżeli $\varphi \wedge \psi \in \Delta$, to $\varphi \in \Delta$ lub $\psi \in \Delta$

5. jeżeli $\varphi \vee \psi \in \Gamma$, to $\varphi \in \Gamma$ lub $\psi \in \Gamma$

6. jeżeli $\varphi \vee \psi \in \Delta$, to $\varphi \in \Delta$ i $\psi \in \Delta$

7. jeżeli $\varphi \rightarrow \psi \in \Gamma$, to $\varphi \in \Delta$ lub $\psi \in \Gamma$

8. jeżeli $\varphi \rightarrow \psi \in \Delta$, to $\varphi \in \Gamma$ i $\psi \in \Delta$

Uwaga 7.2: Niektórzy dodają warunek niesprzeczności do definicji saturacji. Ma to wpływ na prostsze sformułowanie twierdzeń o istnieniu modelu, ale w przypadku, gdy chcemy definiować algorytmy szukania dowodu poprzez saturację, to lepiej tego nie przesądzać, gdyż przecież nie wiemy z góry, czy sprawdzany sekwent jest dowiedlny czy nie, tzn. czy odpowiadająca mu para zbiorów jest niesprzeczna. Porównując podaną tu definicję z własnościami maksymalnych par wyrażonymi w lemacie 7.7 widzimy, że zamiast równoważności mamy implikacje. Związek tych warunków z regułami ARS czytanymi od wniosku do przesłanek jest oczywisty. Zauważmy, że dowolna para zbiorów zmiennych (nawet pusta) będzie parą Hintikki.

Kluczowy lemat prawdziwościowy wygląda teraz następująco: 
Lemat 7.8 (lemat prawdziwościowy - wersja analityczna) Jézeli $(\Gamma, \Delta)$ jest nasycona i niesprzeczna, to istnieje model $\mathfrak{M}$, taki, że:

- jeżeli $\varphi \in \Gamma$, to $\mathfrak{M} \vDash \varphi$;

- jeżeli $\varphi \in \Delta$, to $\mathfrak{M} \not \models \varphi$.

DowóD: Definiujemy model przyjmując, że $\mathfrak{M}=\mathrm{ZZ}(\Gamma)$ i dowodzimy, że spełnia warunki przez indukcję po długości formuł. Baza wynika z definicji. Niech $\varphi:=\neg \psi$ :

Jeżeli $\neg \psi \in \Gamma$, to - przez warunek 1. definicji $-\psi \in \Delta$. Z założenia indukcyjnego $\mathfrak{M} \not \models \psi$ ale wtedy $\mathfrak{M} \vDash \neg \psi$. Przypadek gdy $\neg \psi \in \Delta$ dowodzimy symetrycznie.

Analogicznie pozostałe przypadki.

Musimy wykazać, że dla dowolnego sekwentu niedowiedlnego istnieje nasycona para, która jest jego niesprzecznym poszerzeniem.

Lemat 7.9 (Saturacja) Jeżeli $\nvdash \Gamma \Rightarrow \Delta$, to istnieje nasycona $(\Pi, \Sigma)$, taka, $\dot{z} e$ :

(a) $\Pi \cup \Sigma \subseteq S F(\Gamma \cup \Delta)$;

(b) $\Pi \nvdash \Sigma($ tzn. $(\Pi, \Sigma)$ jest niesprzeczna).

Przypomnijmy, że $S F(\Gamma \cup \Delta)$ oznacza zbiór wszystkich podformuł występujących w formułach z $\Gamma \cup \Delta$.

DowóD: jest prosty gdyż możemy się odwołać do istnienia procedury szukania dowodu zdefiniowanej $\mathrm{w}$ rozdziale 6 . Jeżeli $\nvdash \Gamma \Rightarrow \Delta$, to $\mathrm{w}$ kompletnym drzewie dowodowym istnieje co najmniej jedna gałąź, której liść jest nieaksjomatyczny i atomowy. Jest ona skończonym ciągiem sekwentów: $\Gamma \Rightarrow \Delta, \ldots, \Gamma_{n} \Rightarrow \Delta_{n}$

Zdefiniujmy: $\Pi=\bigcup \Gamma_{i}, \Sigma=\bigcup \Delta_{i}$, gdzie $i \leq n$ (tzn. $\Gamma_{i} \Rightarrow \Delta_{i}$ to dowolny sekwent występujący na tej gałęzi) Należy wykazać, że $(\Pi, \Sigma)$ jest nasycona oraz spełnia warunki (a) i (b).

Nasycenie wynika z faktu, że warunki definiujące parę nasyconą odpowiadają regułom zastosowanym w konstrukcji rozważanej gałęzi.

(a) jest konsekwencją własności podformuł;

(b) jest spełniony z definicji (otwarta gałąź). 
Twierdzenie 7.2 (Pełność:) Jeżeli $\models \Gamma \Rightarrow \Delta$, to $\vdash \Gamma \Rightarrow \Delta$.

DowóD:

1. $\nvdash \Gamma \Rightarrow \Delta$ (założenie),

2. istnieje nasycone i niesprzeczne $(\Pi, \Sigma)$ (Lemat 7.9. o saturacji),

3. istnieje model falsyfikujacy dla $(\Pi, \Sigma)$ (Lemat 7.8. prawdziwościowy),

4. istnieje model falsyfikujacy dla $(\Gamma, \Delta)$ bo $\Gamma \subseteq \Pi$ a $\Delta \subseteq \Sigma$,

5. $\forall \Gamma \Rightarrow \Delta$.

W łatwy sposób można dodatkowo przeprowadzić dowód konwersu lematu prawdziwościowego.

Lemat 7.10 Jeżeli $\Gamma \Rightarrow \Delta$ ma model falsyfikujacy, to może być poszerzony do (niesprzecznego) nasyconego sekwentu $\Pi \Rightarrow \Sigma$.

DowóD: Niech $\mathfrak{M}$ będzie modelem falsyfikującym $\Gamma \Rightarrow \Delta$. Przyjmijmy, że $\Pi=\{\varphi: \mathfrak{M} \vDash \varphi\}$, a $\Sigma=\{\varphi: \mathfrak{M} \not \models \varphi\}$. Jest oczywiste, że $\Pi \cap \Sigma=\varnothing$, oraz że $\Gamma \subseteq \Pi$ i $\Delta \subseteq \Sigma$. Porównując warunki nasycenia z definicją relacji spełniania $\vDash$ widzimy, że $(\Pi, \Sigma)$ musi spełniać te warunki, zatem jest nasycony i niesprzeczny.

Zatem mamy twierdzenie:

Twierdzenie 7.3 $\Gamma \Rightarrow \Delta$ ma model falsyfikujacy wtw może być poszerzona do (niesprzecznego) nasyconego sekwentu.

\subsubsection{Dowód pośredni}

Alternatywny dowód konstruktywny pełności uzyskujemy pośrednio (np. Goré [54]) sprowadzając nasycanie do pojęcie domknięcia na zastosowanie reguły.

Definicja 7.4 Para $(\Gamma, \Delta)$ jest (w dół) nasycona wtw:

(i) jest niesprzeczna;

(ii) $\Gamma \Rightarrow \Delta$ jest domknięty na każda regułę.

Definicja taka jest prostsza, ale oczywiście najpierw trzeba zdefiniować pojęcie domknięcia sekwentu na daną regułę, np. w taki sposób: 
Definicja 7.5 $\Gamma \Rightarrow \Delta$ jest domknięty na regutę

a) jednoprzesłankowa wtw, jeżeli formuła zasadnicza tej reguły należy do sekwentu, to formuty poboczne tez należa;

b) dwuprzesłankowa wtw, jeżeli formuła zasadnicza tej reguły należy do sekwentu, to co najmniej jedna formuła poboczna też należy.

Uwaga 7.3: Nie tylko brak w definicji 7.4. definiujących warunków, ale wymagamy też niesprzeczności (w poprzedniej definicji nie było to wymagane para zbiorów nasyconych mogła być sprzeczna). W konsekwencji w sformułowaniu lematu prawdziwościowego wymagamy tylko aby para $(\Gamma, \Delta)$ była nasycona, a w sformułowaniu lematu o saturacji pomijamy warunek (b).

Dowód lematu prawdziwościowego przebiega w podobny sposób choć zamiast do warunków charakteryzujących pary zbiorów Hintikki odwołujemy się do pojęcia domknięcia na reguły. Pozostawiamy to czytelnikowi.

Dowodzacc lematu o saturacji tym razem definiujemy algorytm nasycania dla dowolnej niesprzecznej pary formuł (a nie szukania dowodu dla dowolnego sekwentu!). Natomiast wykazać należy, że otrzymana para spełnia warunek (i) i (ii) (tj. niesprzeczność i domknięcie na reguły). W dowodzie wykorzystujemy ponadto lemat 4.11 o odwracalności reguł w ARS. ${ }^{1}$ Przedstawimy poniżej alternatywny dowód lematu o nasycaniu.

DowóD: Definiujemy rekurencyjnie skończony ciąg sekwentów: $\Gamma_{0} \Rightarrow \Delta_{0}, \ldots$ , $\Gamma_{n} \Rightarrow \Delta_{n}$.

a) $\Gamma_{0} \Rightarrow \Delta_{0}:=\Gamma \Rightarrow \Delta$, jeżeli nie da się zastosować żadna reguła logiczna, to jest to poszukiwany przez nas sekwent nasycony.

b) Rozważmy przejście od $i$ do $i+1$. Niech $\Gamma_{i} \Rightarrow \Delta_{i}$ będzie sekwentem otrzymanym $\mathrm{w}$ etapie $i$, który jest niesprzeczny. Jeżeli nie da się zastosować żadna reguła logiczna, to jest to poszukiwany przez nas niesprzeczny sekwent nasycony. W przeciwnym wypadku wybierz formułę ze względu, na którą $\left(\Gamma_{i}, \Delta_{i}\right)$ nie jest domknięty. Należy rozważyć z osobna przypadek każdej formuły złożonej w $\Gamma_{i}$ i w $\Delta_{i}$.

Dla przykładu niech to będzie $\varphi \wedge \psi \in \Delta_{i}$.

Zatem $\Gamma_{i} \Rightarrow \Delta_{i}:=\Gamma_{i} \Rightarrow \Delta_{i}^{\prime}, \varphi \wedge \psi \mathrm{i}$ w grę wchodzi zastosowanie reguły $(\Rightarrow \wedge)$ z przesłanek $\Gamma_{i} \Rightarrow \Delta_{i}^{\prime}, \varphi$ i $\Gamma_{i} \Rightarrow \Delta_{i}^{\prime}, \psi$.

\footnotetext{
${ }^{1}$ Oczywiście nie możemy wykorzystać lematu 4.8 o odwracalności reguł podanego w podrozdziale 4.2, gdyż tamten dowód wykorzystywał (Cut), my natomiast chcemy się odwołać do faktu, że reguły rachunku bez (Cut) też tę własność posiadają.
} 
Co najmniej jedna z nich nie ma dowodu, gdyż inaczej, wbrew założeniu, dowiedlny jest $\Gamma_{i} \Rightarrow \Delta_{i}$. Wybierzmy tę przesłankę, która nie ma dowodu - niech to będzie, np. $\Gamma_{i} \Rightarrow \Delta_{i}^{\prime}, \varphi$ i zdefiniujmy $\Gamma_{i+1} \Rightarrow \Delta_{i+1}:=\Gamma_{i} \Rightarrow$ $\Delta_{i}^{\prime}, \varphi, \varphi \wedge \psi$.

Zauważmy, że $\Gamma_{i} \subseteq \Gamma_{i+1}$ i $\Delta_{i} \subseteq \Delta_{i+1}$, a ponadto $\Gamma_{i+1} \Rightarrow \Delta_{i+1}$ jest domknięta na jedną regułę więcej (dla $\varphi \wedge \psi)$ niż $\Gamma_{i} \Rightarrow \Delta_{i}^{\prime}$.

Należy jeszcze wykazać, że $\Gamma_{i+1} \Rightarrow \Delta_{i+1}$ też jest niesprzeczne. Załóżmy nie wprost, że $\Gamma_{i+1} \Rightarrow \Delta_{i+1}$ ma dowód, wtedy - przez lemat o inwersji dowód mają obie przesłanki tego sekwentu, ze względu na regułę $(\Rightarrow \wedge)$, czyli dowód ma $\Gamma_{i} \Rightarrow \Delta_{i}^{\prime}, \varphi, \varphi:=\Gamma_{i} \Rightarrow \Delta_{i}^{\prime}, \varphi$, wbrew założeniu o jego niesprzeczności.

Powtarzamy tę procedurę aż uzyskamy sekwent nasycony. Jest to proces skończony, gdyż każdy kolejny element ciągu zmniejsza ilość formuł, ze względu na które $\Gamma_{0} \Rightarrow \Delta_{0}$ jest niedomknięty. Warunek (ii) definicji nasycenia jest spełniony poprzez konstrukcję ciągu, a (i) jest spełniony, gdyż jak wykazaliśmy, każdy kolejny element ciągu dziedziczy niesprzeczność z elementu poprzedzającego.

\subsection{Pełność RS z analitycznym (Cut)}

W poprzednim rozdziale przy okazji rozważań nad (słabą) analitycznością wprowadziliśmy pojęcie analitycznego cięcia. Pokażemy, że można zbudować konstruktywny dowód pełności oparty na jego wykorzystaniu. Dowód taki łączy elementy konstrukcji Lindenbauma i Hintikki przez zbudowanie z dowolnej niesprzecznej pary zbiorów $(\Gamma, \Delta)$ skończonej pary relatywnie maksymalnej w zbiorze $S F(\Gamma \cup \Delta)$ (lemat 7.11) i udowodnienie, że jest nasycona (lemat 7.12). Dowód pełności przebiega analogicznie jak w przypadku twierdzenia 7.2, tj. w oparciu o lemat 7.8, zgodnie z którym z pary nasyconej budujemy model falsyfikujący dla $\Gamma \Rightarrow \Delta$. Poniższa definicja dostosowuje konstrukcję Lindenbauma do skończonych par zbiorów.

Definicja 7.6 (Relatywna maksymalność) Para zbiorów $(\Gamma, \Delta)$ jest relatywnie maksymalna $w$ zbiorze $\Pi \subseteq$ FOR wtw dla dowolnej $\varphi \in \Pi, \varphi \in \Gamma$ lub $\varphi \in \Delta$, inaczej $\Gamma \cup \Delta=\Pi$.

Następny lemat jest odpowiednikiem lematu Lindenbauma.

Lemat 7.11 Jeżeli $(\Gamma, \Delta)$ jest niesprzeczna, to istnieje niesprzeczna $i$ relatywnie maksymalna $w S F(\Gamma \cup \Delta)$ para $\left(\Gamma_{n}, \Delta_{n}\right)$ taka, ż $\Gamma \subseteq \Gamma_{n} i \Delta \subseteq \Delta_{n}$. 
DowóD: analogiczny do dowodu lematu Lindenbauma.

Załóżmy, że $\Gamma \Rightarrow \Delta$ jest niesprzeczna. Tworzymy skończoną listą wszystkich formuł z $S F(\Gamma \cup \Delta)$ :

$\varphi_{1}, \varphi_{2}, \ldots ., \varphi_{n}$

Następnie definiujemy ciąg sekwentów $\Gamma_{0} \Rightarrow \Delta_{0}, \ldots, \Gamma_{n} \Rightarrow \Delta_{n}$, taki, że $\Gamma_{0} \Rightarrow \Delta_{0}:=\Gamma \Rightarrow \Delta$, a dla każdego $n \geq i \geq 0$,

$\Gamma_{i+1} \Rightarrow \Delta_{i+1}:=\Gamma_{i} \Rightarrow \Delta_{i}, \varphi_{i+1}$, jeżeli $\left(\Gamma_{i}, \Delta_{i} \cup\left\{\varphi_{i+1}\right\}\right.$ jest niesprzeczna; w przeciwnym wypadku $\Gamma_{i+1} \Rightarrow \Delta_{i+1}:=\Gamma_{i}, \varphi_{i+1} \Rightarrow \Delta_{i}$.

Relatywna maksymalność $\left(\Gamma_{n}, \Delta_{n}\right)$ wynika z faktu, że każdy element $S F(\Gamma \cup \Delta)$ został na pewnym etapie konstrukcji dodany do jednego lub drugiego zbioru pary.

Z lematu 7.3 i konstrukcji ciągu wynika, że każdy jego element, a w szczególności $\Gamma_{n} \Rightarrow \Delta_{n}$ jest niesprzeczy.

Zauważmy, że wszystkie użycia (Cut) były analityczne w podanym wyżej dowodzie.

Wystarczy teraz wykazać, że sekwent otrzymany w wyniku procedury z dowodu poprzedniego lematu jest też nasycony, a wtedy - przez lemat 7.8 - mamy istnienie modelu falsyfikującego $\Gamma_{n} \Rightarrow \Delta_{n}$, a zarazem $\Gamma \Rightarrow \Delta$ co wystarcza dla dowodu pełności.

Lemat $7.12\left(\Gamma_{n}, \Delta_{n}\right)$ jest nasycona.

DowóD: Aby wykazać nasycenie $\Gamma_{n} \Rightarrow \Delta_{n}$ wystarczy odwołać się w dowodzie każdego warunku do faktu jego niesprzeczności i odpowiedniego warunku z lematu 7.2. Przykładowo:

a) załóżmy, że $\varphi \wedge \psi \in \Gamma_{n}$, wtedy - poprzez lemat 7.2, warunek 5 - mamy, że $\varphi \notin \Delta_{n}$ i $\psi \notin \Delta_{n}$, ale zarówno $\varphi$ jak i $\psi$ - jako podformuły $\Gamma \cup \Delta$ muszą się w $\Gamma_{n} \Rightarrow \Delta_{n}$ znajdować. Zatem obie należą do $\Gamma_{n}$.

Ponieważ powyższa konstrukcja jest skończona więc przy okazji pozwala na dowód rozstrzygalności. Oczywiście procedura rozstrzygalności dla KRZ oparta na powyższym dowodzie nie jest równie efektywna jak procedury zaprezentowane wcześniej i oparte na RS ściśle analitycznym. Istnieją jednak rozstrzygalne logiki nieklasyczne, dla których mamy tylko systemy słabo analityczne, a wtedy procedury oparte na analitycznych zastosowaniach (Cut) są konieczne dla dowiedzenia ich rozstrzygalności w konstruktywny sposób. 


\subsection{ARS a postacie normalne}

Na koniec pokażemy też, w jaki sposób można na gruncie ARS udowodnić słabą pełność KRZ metodą Posta, tzn. przez sprowadzenie do postaci normalnych koniunkcyjno-alternatywnych (KA) (por. definicję w podrozdziale 1.1, twierdzenie 1.1 i paragraf 1.4.1). Jest to możliwe dzięki odwracalności wszystkich reguł. Najpierw udowodnimy twierdzenie Posta z pomoca ARS:

Lemat 7.13 (Post) Dla dowolnej $\varphi$ istnieje $\varphi^{\prime} w$ postaci KA, takie, że:

- $\vdash \Rightarrow \varphi \varphi^{\prime} i$

- $\vdash \Rightarrow \varphi^{\prime} \rightarrow \varphi$.

DowóD: Zmodyfikujmy nieco procedurę poszukiwania dowodu sekwentu sformułowaną w rozdziale 6 przez wprowadzenie wymogu, aby każdą gałąź poszerzać tak długo aż otrzymamy atomowy liść. Innymi słowy, nie zatrzymujemy budowy gałęzi gdy pojawi się nieatomowy aksjomat i nie zatrzymujemy procedury gdy pojawi się atomowy liść nieaksjomatyczny. W rezultacie, dla każdego sekwentu $S$ otrzymujemy kompletne drzewo dowodowe z $n$ liśćmi atomowymi. Każdemu atomowemu liściowi $S_{i}:=p_{1}, \ldots, p_{k} \Rightarrow q_{1}, \ldots, q_{l}$ odpowiada alternatywa elementarna $\psi_{i}:=\neg p_{1} \vee \ldots \vee \neg p_{k} \vee q_{1} \vee \ldots \vee q_{l}$.

Rozważmy otrzymane $\mathrm{w}$ ten sposób drzewo dowodowe $\mathcal{D}$ dla $\Rightarrow \varphi \mathrm{z} n$ liśćmi atomowymi.

Zmodyfikujmy najpierw $\mathcal{D}$ dodając $\varphi$ do poprzednika każdego sekwentu. Ponieważ reguły ARS mają własność niezależności kontekstowej (por. podrozdział 4.5), więc dodanie nowego parametru w poprzedniku każdego sekwentu zachowuje poprawność reguł. Otrzymaliśmy w ten sposób drzewo dowodowe $\mathcal{D}^{\prime}$, którego korzeń to $\varphi \Rightarrow \varphi$, a każdy liść ma postać $S_{i}^{\prime}:=$ $\varphi, p_{1}, \ldots, p_{k} \Rightarrow q_{1}, \ldots, q_{l}$. Ponieważ reguły są odwracalne, a korzeń $\mathcal{D}^{\prime}$ aksjomatyczny, więc nawet dla tych $S_{i}$, które nie są aksjomatyczne mamy teraz $\vdash S_{i}^{\prime}$. Zatem również $\vdash \varphi \Rightarrow \psi_{i}$ przez zastosowanie do $S_{i}^{\prime}$ odpowiednią ilość razy $(\Rightarrow \neg)$ i $(\Rightarrow \vee)$. Przez $n$-krotne zastosowanie $(\Rightarrow \wedge)$ i $(\Rightarrow \rightarrow)$ otrzymujemy $\vdash \Rightarrow \varphi \rightarrow \psi_{1} \wedge \ldots \wedge \psi_{n}$, czyli $\vdash \Rightarrow \varphi \rightarrow \varphi^{\prime}$.

W druga stronę, należy w $\mathcal{D}$ do poprzednika każdego sekwentu dodać $\psi_{1}, \ldots, \psi_{n}$, gdzie każde $\psi_{i}, i \leq n$ odpowiada liściowi $S_{i}$. Otrzymujemy w ten sposób drzewo dowodowe $\mathcal{D}^{\prime}$ sekwentu $\psi_{1}, \ldots, \psi_{n} \Rightarrow \varphi$, które jest jego dowodem lub łatwo na dowód daje się przerobić. W przypadku, gdy wszystkie liście były już aksjomatami $\mathcal{D}^{\prime}$ jest dowodem tak jak i $\mathcal{D}$. W przeciwnym wypadku te liście, które były aksjomatami nadal nimi pozostaną natomiast każdy nieaksjomatyczny liść $S_{i}:=p_{1}, \ldots, p_{k} \Rightarrow q_{1}, \ldots, q_{l}$ zamienia sią na 
dowiedlny liść $S_{i}^{\prime}:=\psi_{1}, \ldots, \psi_{n}, p_{1}, \ldots, p_{k} \Rightarrow q_{1}, \ldots, q_{l}$. Jest tak dlatego, że $\psi_{1}, \ldots, \psi_{n} \Rightarrow \psi_{i}$ daje się wydedukować z $S_{i}^{\prime}$ przez $(\Rightarrow \neg)$ i $(\Rightarrow \vee)$, a ponieważ reguły są odwracalne więc $S_{i}^{\prime}$ jest dedukowalne z $\psi_{1}, \ldots, \psi_{n} \Rightarrow \psi_{i}$. Ten ostatni jest jednak aksjomatem a zatem otrzymujemy dowód $\mathcal{D}^{\prime \prime}$ sekwentu $\psi_{1}, \ldots, \psi_{n} \Rightarrow \varphi$ po dodaniu do każdego nieaksjomatycznego liścia $S_{i}^{\prime} \mathrm{w} \mathcal{D}^{\prime}$ jego dowodu z $\psi_{1}, \ldots, \psi_{n} \Rightarrow \psi_{i}$. Po zastosowaniu $(\wedge \Rightarrow)$ i $(\Rightarrow \rightarrow)$ otrzymujemy dowód $\Rightarrow \psi_{1} \wedge \ldots \wedge \psi_{n} \rightarrow \psi_{i}$.

Twierdzenie o pełności wynika z powyższego twierdzenia i łatwego do zaobserwowania faktu, że $\models \varphi$ wtw każda alternatywa elementarna $\mathrm{w} \varphi^{\prime}$ musi zawierać parę literałów komplementarnych (tj. dla pewnego $i \leq k \mathrm{i}$ $j \leq k, p_{i}=q_{j}$ ). Ale wtedy drzewo dowodowe dla $\varphi$ jest dowodem, gdyż każde $S_{i}$ jest aksjomatyczne.

Pokazany tu dowód jest dobrym przykładem adaptacji standardowych technik metalogicznych do formatu RS i pokazuje interesujący związek między RS a postaciami normalnymi, w tym wypadku koniunkcyjno-alternatywnymi. Do kwestii związków RS z postaciami normalnymi w ogólności powrócimy w ostatnim rozdziale. Tutaj trzeba podkreślić, że technika Posta nie ma waloru ogólnego i w przeciwieństwie do metody Hintikki (w której odwracalność reguł nie jest niezbędna) nie daje się przenieść na grunt RS-formalizacji dla innych logik. 


\section{Rozdział 8}

\section{Klasyczny Rachunek Kwantyfikatorów}

Ten rozdział, podobnie jak rozdział 1, ma charakter pomocniczy i należy go traktować jako kompendium informacji o klasycznym rachunku kwantyfikatorów (KRK) niezbędnych przy dalszej lekturze. Podrozdział 8.1 omawia języki pierwszego rzędu; szczególnie dużo uwagi poświęcono kwestii poprawnego podstawiania za zmienne wolne. Kolejny podrozdział wprowadza aksjomatyczne ujęcie rachunku kwantyfikatorów i przykładowych teorii pierwszego rzędu oraz kilka ważnych twierdzeń syntaktycznych. Semantyka teoriomodelowa omówiona jest w podrozdziale 8.3 gdzie pojawia się kilka ważnych wyników o charakterze technicznym. Podrozdział 8.4 poświęcony jest prezentacji dowodu twierdzenia o adekwatności dla logiki klasycznej, wraz z modyfikacjami niezbędnymi dla uwzględnienia identyczności. Na końcu podajemy krótkie informacje o semi-roztrzygalności i interpolacji KRK (8.5) oraz regułach dedukcji naturalnej (8.6).

\subsection{Zagadnienia syntaktyczne}

KRK jest naturalnym poszerzeniem KRZ, które powstaje przez analizę struktury wewnętrznej zdań prostych oraz uwzględnienie dodatkowych stałych logicznych - kwantyfikatorów: ogólnego ( $\forall$ - czytamy "dla każdego") i szczegółowego ( $\exists$ - czytamy "dla jakiegoś”). KRK zwana jest często logiką pierwszego rzędu ze względu na to, że kwantyfikacja dopuszczona jest jedynie dla zmiennych indywiduowych (lub nazwowych), czyli rzędu pierwszego (denotujących obiekty), a nie rozważa się kwantyfikacji po zmiennych predykatywnych (drugiego rzędu - denotujących zbiory obiektów). Logika taka jest siłą rzeczy w 
pewien sposób ograniczona co do swoich możliwości ekspresji ale, w zasadzie stanowi wystarczającą bazę dla formalizacji teorii matematycznych. Nie znaczy to, że logiki wyższych rzędów, czyli takie gdzie dopuszcza się kwantyfikację po zmiennych coraz wyższych rzędów (denotujących zbiory obiektów, zbiory zbiorów obiektów, zbiory zbiorów zbiorów obiektów,...) nie są przydatne i nie doczekały się analizy teoriodowodowej w rachunku sekwentów, ale uwzględnianie tutaj ich teorii wymagałoby znacznego poszerzenia rozmiarów książki ${ }^{1}$.

Natomiast uwzględnimy podstawowe poszerzenie KRK, które uzyskujemy przez dodanie predykatu identyczności jako kolejnej stałej, gdyż bez identyczności budowa teorii matematycznych w językach pierwszego rzędu jest problematyczna. To czy uwzględnianie identyczności daje nam mocniejszą logikę (KRKI) czy też teorię pierwszego rzędu (inaczej, teorię elementarną), tzn. czy identyczność jest stałą logiczną czy pozalogiczną, jest przedmiotem filozoficznej debaty (por. np. Quine [114]), której tu podejmować nie będziemy. Faktem jest, że z punktu widzenia kryteriów logiczności stałych, które wypracowano na gruncie teoriodowodowych analiz, identyczność nie wypada dobrze jako logiczna stała, gdyż nie pozwala się scharakteryzować za pomocą reguł spełniających odpowiednie syntaktyczne kryteria. Ponieważ $\mathrm{w}$ tym rozdziale prezentujemy podstawowe fakty niezbędne dla zrozumienia teoriodowodowych rozważań przeprowadzanych w dalszej części, więc dla uproszczenia potraktujemy tu KRKI jako logikę.

\subsubsection{Języki pierwszego rzędu}

Zaczniemy od przypomnienia podstawowych informacji dotyczacych budowy języków pierwszego rzędu. Mówimy o językach, gdyż na gruncie logiki rozważa się tylko ogólny schemat języka, w którym oprócz zmiennych indywiduowych, używamy schematycznych symboli oznaczających nazwy (termy) lub własności i relacje (predykaty). Konkretne języki uzyskujemy wprowadzając zamiast nieokreślonych symboli ( $w$ istocie zmiennych, choć nie poddawanych kwantyfikacji) konkretne stałe pozalogiczne.

\footnotetext{
${ }^{1}$ Podstawowe informacje o logikach wyższych rzędów, czy o teorii typów stanowiącej ich ogólne ujęcie, można znaleźć np. w Mostowski [100] lub Andrews [5], a wykorzystanie do nich RS w Takeuti [143].
} 
Definicja 8.1 (Słownik języka pierwszego rzędu) jest to suma rozłącznych zbiorów:

- $V A R=\{x, y, z, \ldots\}-$ przeliczalny zbiór zmiennych indywiduowych

- $C O N=\{a, b, c, \ldots\}$ - przeliczalny zbiór symboli nazw indywiduowych

- $F U N=\{f, g, h, \ldots\}$ - przeliczalny zbiór symboli funkcyjnych

- PRED $=\{A, B, C, \ldots\}$ - przeliczalny zbiór symboli predykatów

- $L O G=\{\neg, \wedge, \vee, \rightarrow, \leftrightarrow, \forall, \exists,=\}$

- $A U X=\{(),,[]$,

Uwaga 8.1: Zbiór $V A R$ jest stały we wszystkich językach, jego elementy mają za zadanie reprezentować nieokreślone obiekty oraz występować w powiązaniu z kwantyfikatorami. Niektórzy autorzy, w tym Gentzen, wprowadzają konwencję graficznego rozróżnienia między (meta)zmiennymi niezwiązanymi, a związanymi przez kwantyfikator. Dyskusję nad zaletami i wadami obu rozwiązań przeprowadzimy w rozdziale 9. Symboli ' $x$ ', ' $y$ ', (jak również 'a', 'f', 'A') będziemy też w dalszym ciągu, dla uproszczenia zapisu, używać jako metazmiennych $\mathrm{w}$ definicjach, zapisach schematów reguł itp. gdyż w rozważanych przez nas kontekstach nie prowadzi to do nieporozumień. Używać będziemy jedynie dodatkowych metazmiennych $\tau_{i}$ dla dowolnych termów (tak jak $\varphi, \psi$ dla dowolnych formul).

Uwaga 8.2: Kwantyfikatory zawsze występują w połączeniu z konkretnymi zmiennymi, np. $\forall x, \exists y$ (dla dowolnego $x$, dla jakiegoś $y$ ) oraz z formułami, w których takie zmienne winny się znajdować (choć nie jest to konieczne, dopuszczamy przypadek tzw. pustej kwantyfikacji). Toteż oba kwantyfikatory należą do grupy wyrażeń zwanych operatorami, których zadaniem jest "wiązanie" zmiennych w wyrażeniach.

Uwaga 8.3: W konkretnych językach zbiory CON, FUN, PRED są zazwyczaj skończone i mogą być puste - zawierają one stałe pozalogiczne (nazwy, operacje, relacje). Elementy $F U N$ i PRED mają określoną argumentowość (lub arność), którą często zaznacza się w górnym indeksie, np. $f^{2}, A^{1}$. Zazwyczaj będziemy te indeksy pomijać wtedy, gdy argumentowość symbolu jest jasna z kontekstu. Intuicyjnie argumentowość predykatu oznacza, że reprezentuje on relację zachodzącą między obiektami reprezentowanymi przez jego argumenty (predykaty dwu- i więcej argumentowe) lub własność obiektu (predykaty jednoargumentowe). Analogicznie dla symboli funkcyjnych. 
W szczególności, identyczność $=$ też jest predykatem dwuargumentowym. Zauważmy, że symbolu = będziemy dalej używać dwuznacznie zarówno dla reprezentowania stałej logicznej w rozważanych językach, jak i metajęzykowo - np. powyżej dla zaznaczenia, że pewien napis jest nazwą jakiegoś zbioru. Nie powinno to prowadzić do nieporozumień.

Uwaga 8.4: Zbiór $C O N$ można zredukować do zbioru $F U N$ traktując nazwy jako funkcje zero-argumentowe (analogicznie nie wyróżniamy jako osobnej kategorii symboli zdaniowych traktując je jako predykaty zero-argumentowe). Zostawiamy je jako osobną kategorię, gdyż wygodnie będzie je wykorzystać dla reprezentacji systemu Gentzena jako symboli zmiennych nie związanych przez kwantyfikatory - por. rozdział 9.

Uwaga 8.5: Symbole w $C O N, F U N, P R E D$ mają charakter parametryczny, gdyż nie oznaczają konkretnych pozalogicznych stałych odpowiednich kategorii. Operowanie nimi jest przydatne w ogólnych rozważaniach nad logiką pierwszego rzędu i dowolnymi językami. W konkretnych językach elementy zbiorów $C O N, F U N, P R E D$ będą oznaczane specjalnymi symbolami zamiast liter $a, b, f, P$ itp.

Przykłady słowników konkretnych języków:

Teoria grup: $C O N=\{1\}, F U N=\{\cdot\}$ (dwuargumentowy)

Teoria krat: $C O N=\{1\}, F U N=\{\times,+\}$ (oba dwuargumentowe)

Teoria mnogości: PRED $=\{\in\}$ (dwuargumentowy)

Arytmetyka: $C O N=\{0\}, F U N=\{s\}$ (jednoargumentowy)

Oczywiście, w praktyce tak oszczędne języki są niewygodne i wprowadza się definicyjnie kolejne stałe pozalogiczne. Np. w teorii mnogości stałe $\varnothing$, operacje $\cap, \cup,-, \mathcal{P}$ i predykaty $\subseteq, \subset$ itp., w arytmetyce stałe $1,2,3, \ldots$ operacje,$+ \times$, predykaty $\leq,<$ itd.

\section{Definicja 8.2 (zbioru termów (wyrażeń nazwowych) TERM)}

1. $V A R \cup C O N \subseteq T E R M$;

2. jeżeli $f^{n} \in F U N$, to $f^{n}\left(\tau_{1}, \ldots, \tau_{n}\right) \in T E R M$, gdzie $\tau_{i} \in T E R M$ dla dowolnego $i \leq n$ (przy czym termy $\tau_{1}, \ldots, \tau_{n}$ nie musza być różne);

3. nic więcej nie należy do zbioru termów.

Uwaga 8.6: W praktyce będziemy pomijali zarówno indeks górny charakteryzujący argumentowość $f$ jak i nawiasy, jeżeli nie będzie to prowadzić do 
nieporozumień - ale nie zawsze da się tego uniknąć np. fxgya jest dwuznaczne. Można jednoznacznie je zapisać jako $f x g(y a)$, gdy $f^{2}$ i $g^{2}$, lub $f x g(y) a$ gdy $f^{3}$, a $g^{1}$. Zauważmy tė̇, że zazwyczaj dla konkretnych języków stosuje się zapis infiksowy, a nie prefiksowy, tzn. zamiast $\times x y$ napiszemy $x \times y$. Przykłady termów w konkretnych językach:

$s x, s s O, s(x+s y)+s(s s 0+z)-\mathrm{w}$ arytmetyce

$x \cap(y \cup-z), \mathcal{P}(x \cap y)-\mathrm{w}$ teorii mnogości

\section{Definicja 8.3 (zbioru formuł FOR)}

1. jeżeli $P^{n} \in P R E D$, to $P^{n}\left(\tau_{1}, \ldots, \tau_{n}\right) \in F O R$, gdzie $\tau_{i} \in T E R M$ dla dowolnego $i \leq n$ (przy czym termy $\tau_{1}, \ldots, \tau_{n}$ nie musza być różne);

2. jeżeli $\tau_{1}, \tau_{2} \in T E R M$, to $\tau_{1}=\tau_{2} \in F O R$;

3. jeżeli $\varphi \in F O R$, to $\neg \varphi \in F O R$;

4. jeżeli $\varphi, \psi \in$ FOR, to $(\varphi \wedge \psi),(\varphi \vee \psi),(\varphi \rightarrow \psi) \in$ FOR;

5. jeżeli $\varphi \in F O R$, to dla dowolnej $x \in V A R, \forall x(\varphi), \exists x(\varphi) \in F O R$;

6. nic więcej nie należy do zbioru formut.

Formuła składająca się z predykatu i jego argumentów to formuła atomowa. Natomiast formuła $\varphi$ występująca w formule $\forall x(\varphi)$ to zasieg kwantyfikatora $\forall x$ (analogicznie dla $\exists x$ ).

Uwaga 8.7: W praktyce będziemy pomijali zarówno indeks górny charakteryzujący argumentowość $P$ jak i nawiasy, jeżeli nie będzie to prowadzić do nieporozumień, analogicznie jak w przypadku wyrażeń funkcyjnych (ale np. $P f x y$ jest dwuznaczne - $P f(x y)$ lub $P f(x) y)$. Konwencje pomijania nawiasów w formułach złożonych są takie same jak w języku KRZ, w szczególności kwantyfikatory traktujemy analogicznie jak negację, czyli zachowujemy nawias jeżeli zasięg kwantyfikatora jest formułą złożoną, a pomijamy jeżeli jest formułą atomową. Będziemy też stosować konwencję pomijania symboli takich samych kwantyfikatorów, jeżeli występują w bezpośrednim sąsiedztwie, tzn. zamiast $\forall x \forall y \forall z(\varphi)$ napiszemy $\forall x y z(\varphi)$.

Uwaga 8.8: W praktyce, dla konkretnych języków stosuje się zapis infiksowy, tzn. zamiast $\leq x y$ napiszemy $x \leq y$. Przykłady formuł:

$s x \leq s s O, x \leq s y \rightarrow y=x, \forall x y(x+s y \leq s x+s y)$ - w arytmetyce $x \in y, x \subseteq x \cap y, \exists x(x=y \cap \varnothing)-\mathrm{w}$ teorii mnogości 
Uwaga 8.9: Dla powyższej definicji języka można przyjąć prostą definicję podformuły, tzn. dla formuły $Q x \varphi$ jej jedyną właściwą bezpośrednią podformuła jest $\varphi$. Nie jest to jednak rozwiązanie wygodne dla naszych rozważań dlatego w następnym rozdziale zmodyfikujemy definicję podformuły dla formuł z kwantyfikatorami.

\subsubsection{Zmienne indywiduowe}

Okoliczność, że te same zmienne mogą być w tym samym wyrażeniu wolne lub związane przez któryś kwantyfikator zmusza do poczynienia dodatkowych ustaleń i rozróżnienia między zmienną a jej wystąpieniami. Wystąpienie zmiennej $x$ w zasięgu $\forall x$ lub $\exists x$ jest zwiazane, w przeciwnym wypad$\mathrm{ku}$ jest wolne. Zmienna jest związana (wolna) w formule, jeżeli ma w niej co najmniej jedno związane (wolne) wystąpienie. Jak widać dana zmienna może być w tej samej formule zarazem wolna i związana. Sporadycznie będziemy też używać zapisu $\varphi(x)$ dla oznaczenia formuły z wolną zmienną $x$ (zawierająca co najmniej jedno wolne wystąpienie $x$ ). Podane tu objaśnienia sprecyzujemy niżej za pomocą definicji indukcyjnych.

Definicja $8.4(\operatorname{Var}(\tau))$ Niech $\operatorname{Var}(\tau)$ oznacza zbiór wszystkich zmiennych wystęujacych w termie $\tau$; wtedy:

1. $\operatorname{Var}(x):=\{x\}$

2. $\operatorname{Var}(c):=\varnothing$

3. $\operatorname{Var}\left(f\left(\tau_{1}, \ldots, \tau_{n}\right)\right):=\operatorname{Var}\left(\tau_{1}\right) \cup \ldots \cup \operatorname{Var}\left(\tau_{n}\right)$

Uwaga 8.10: Formalnie rzecz ujmując Var jest funkcją, która przypisuje każdemu termowi zbiór zmiennych w nim występujących. Można ją poszerzyć na formuły i ich zbiory. Definicję indukcyjną $\operatorname{Var}(\varphi)$ zostawiamy czytelnikowi, $\operatorname{Var}(\Gamma)=\bigcup\{\operatorname{Var}(\varphi): \varphi \in \Gamma\}$.

Ponadto niech $V F(\varphi)(V F(\Gamma))$ oznacza zbiór wszystkich wolnych zmiennych w formule $\varphi$ (w zbiorze formuł $\Gamma$ ) a $V B(\varphi), V B(\Gamma)$ zbiór wszystkich zmiennych związanych w $\varphi, \Gamma$. Precyzyjna definicja indukcyjna dla $V F$ i $V B$ wygląda następująco:

\section{Definicja 8.5 (zmienne wolne)}

1. $\operatorname{VF}\left(P\left(\tau_{1}, \ldots, \tau_{n}\right)\right):=\operatorname{Var}\left(\tau_{1}\right) \cup \ldots \cup \operatorname{Var}\left(\tau_{n}\right)$

2. $\operatorname{VF}\left(\tau_{1}=\tau_{2}\right):=\operatorname{Var}\left(\tau_{1}\right) \cup \operatorname{Var}\left(\tau_{2}\right)$ 
3. $V F(\neg \varphi):=V F(\varphi)$

4. $V F(\varphi * \psi):=V F(\varphi) \cup V F(\psi)$, dla $* \in\{\wedge, \vee, \rightarrow\}$

5. $V F(Q x(\varphi)):=V F(\varphi)-\{x\}$, dla $Q \in\{\forall, \exists\}$

6. $V F(\Gamma):=\bigcup\{V F(\varphi): \varphi \in \Gamma\}$

\section{Definicja 8.6 (zmienne związane)}

1. $\operatorname{VB}\left(P\left(\tau_{1}, \ldots, \tau_{n}\right)\right):=\varnothing$

2. $V B\left(\tau_{1}=\tau_{2}\right):=\varnothing$

3. $V B(\neg \varphi):=V B(\varphi)$

4. $V B(\varphi * \psi):=V B(\varphi) \cup V B(\psi)$, dla $* \in\{\wedge, \vee, \rightarrow\}$

5. $V B(Q x(\varphi)):=V B(\varphi) \cup\{x\}$, dla $Q \in\{\forall, \exists\}$

6. $V B(\Gamma):=\bigcup\{V B(\varphi): \varphi \in \Gamma\}$

Jeżeli $\operatorname{VF}(\varphi)=\varnothing$, to $\varphi$ nazywamy zdaniem (lub domknięta formuła), w przeciwnym wypadku jest formuła otwarta. Generalnie $V F(\varphi) \cap V B(\varphi)$ może być niepuste (podobnie dla zbiorów formuł), jednak dla naszych rozważań w dalszych rozdziałach duże znaczenie ma fakt, że każda taka formuła jest równoważna formule $\varphi^{\prime}$ takiej, że $V F\left(\varphi^{\prime}\right) \cap V B\left(\varphi^{\prime}\right)=\varnothing$. Fakt ten udowodnimy w paragrafie 8.2.1. Odnotujmy też, że w przypadku stałych zdaniowych takich jak $\perp$, które incydentalnie wprowadzamy, $\operatorname{Var}(\perp)=V F(\perp)=V B(\perp)=\varnothing$.

Przykład 8.1:

Niech $\varphi:=\forall x(\forall y(A x \rightarrow R y z) \rightarrow B x \wedge \exists x S x y \vee C x)$, wtedy $\operatorname{Var}(\varphi)=$ $\{x, y, z\}, V F(\varphi)=\{y, z\}, V B(\varphi)=\{x, y\}$. Zauważmy, że $y \in V F(\varphi) \cap$ $V B(\varphi)$, a ponadto, że różne wystąpienia $x$ są związane przez różne kwantyfikatory (w $A x, B x$ i $C x$ przez ogólny, a w $S x y$ przez szczegółowy). Formułą równoważną $\varphi$, w której unikamy obu sytuacji jest, np. $\forall x(\forall v(A x \rightarrow R v z) \rightarrow$ $B x \wedge \exists w S w y \vee C x)$, gdzie związane wystąpienie $y$ zamieniliśmy na $v$, a powtórną kwantyfikację $x$ na kwantyfikację $w$. 


\subsubsection{Podstawianie i zastępowanie}

Dla poprawnego scharakteryzowania reguł dowolnego rachunku dla KRK niezbędne jest precyzyjne zdefiniowanie operacji podstawiania na zmiennych wolnych $\mathrm{w}$ formułach (termach). Podstawiamy dowolne termy ale tylko za zmienne wolne $\mathrm{w}$ danej formule czy termie. $\varphi[x / \tau]$ (ewentualnie $\tau_{1}\left[x / \tau_{2}\right]$ ) oznacza rezultat podstawiania termu $\tau$ za $x$ w formule $\varphi$ (ewentualnie termu $\tau_{2}$ za $x$ w termie $\tau_{1}$ ).

Intuicyjnie dość łatwo jest sformułować warunki właściwego podstawiania, tj. takiego, które z formuły prawdziwej w pewnej interpretacji nie uczyni formuły fałszywej. Są one następujące:

1. wszystkie wolne wystąpienia $x$ są zastąpione przez $\tau$;

2. jeżeli $\tau$ zawiera zmienne, to pozostają one wolne $\mathrm{w} \varphi$.

Oba warunki wiążą się z tym, że chcemy, aby operacja podstawiania zachowywała prawdziwość formuł w modelach, tzn. żeby wykluczona była sytuacja, że formuła prawdziwa zamieni się w fałszywą. Obostrzenie pierwsze wynika nie tylko stąd, że dziedziną operacji podstawiania są tylko zmienne wolne, ale również stąd, że wybiórcze potraktowanie wystąpień podstawianej zmiennej może prowadzić od formuły prawdziwej do fałszywej. Np. gdy w $x=$ $x$, które jest prawdziwe $\mathrm{w}$ dowolnej interpretacji podstawimy $a$ za tylko jedno wystąpienie $x$, to otrzymamy formułę fałszywą w dowolnej interpretacji, w której $x$ i $a$ mają inne desygnaty.

Obostrzenie drugie również jest niezbędne dla uniknięcie podobnych kłopotów. Zilustrujmy to intuicyjnie na prostym przykładzie; $\forall x \exists y, x<y$ jest prawdziwe w arytmetyce liczb naturalnych, ale $\exists y, x<y[x / y]:=\exists y, y<y$ jest fałszywe, choć $\exists y, x<y[x / \tau]$ będzie prawdziwe dla każdego $\tau$, które spełnia warunek $y \notin \operatorname{Var}(\tau)$.

Poniżej sformułujemy precyzyjnie zarówno definicję podstawiania jak i warunki jej poprawności.

\section{Definicja 8.7 (podstawianie - przypadek termów)}

1. $x[y / \tau]:=\tau, g d y x=y$

2. $x[y / \tau]:=x, g d y x \neq y$

3. $c[x / \tau]:=c$

4. $f\left(\tau_{1}, \ldots, \tau_{n}\right)[x / \tau]:=f\left(\tau_{1}[x / \tau], \ldots, \tau_{n}[x / \tau]\right)$ 


\section{Definicja 8.8 (podstawianie - przypadek formuł)}

1. $P\left(\tau_{1}, \ldots, \tau_{n}\right)[x / \tau]:=P\left(\tau_{1}[x / \tau], \ldots, \tau_{n}[x / \tau]\right)$

2. $\tau_{1}=\tau_{2}[x / \tau]:=\tau_{1}[x / \tau]=\tau_{2}[x / \tau]$

3. $\neg \varphi[x / \tau]:=\neg(\varphi[x / \tau])$

4. $\varphi * \psi[x / \tau]:=\varphi[x / \tau] * \psi[x / \tau], d l a * \in\{\wedge, \vee, \rightarrow\}$

5. $Q x(\varphi)[y / \tau]:=Q x(\varphi[y / \tau])$ pod warunkiem, że $x \neq y$ i $x \notin \operatorname{Var}(\tau), w$ przeciwnym wypadku (tj. jeżeli $x \in \operatorname{Var}(\tau)$ lub $x=y) Q x(\varphi)[y / \tau]:=$ $Q x(\varphi)$, dla $Q \in\{\forall, \exists\}$

W ostatnim warunku podane są wprawdzie minimalne warunki poprawności podstawiania, ale nie są one wystarczające dla uniknięcia błędnych przypadków podstawiania. Np. $\varphi:=\forall x(y=0 \rightarrow x=0) \rightarrow(y=0 \rightarrow \forall x x=$ $0)$ jest prawdziwa. $\varphi[y / x]$ jest wykonalne zgodnie z punktem 4 . definicji i da nam $\varphi^{\prime}:=\forall x(y=0 \rightarrow x=0) \rightarrow(x=0 \rightarrow \forall x x=0)$. Ale $\varphi^{\prime}[y / 1]$ daje fałszywą $\varphi^{\prime \prime}:=\forall x(1=0 \rightarrow x=0) \rightarrow(x=0 \rightarrow \forall x x=0)$. Aby uniknąć takich przypadków trzeba ściślej określić kiedy term $\tau$ jest poprawnie podstawialny za zmienną $x \mathrm{w} \varphi$. W tym celu wprowadzimy kolejne pojęcie:

Definicja 8.9 ( $\tau$ jest termem wolnym za $x$ w $\varphi) \quad(k r o ́ t k o \tau \in \operatorname{Free}(x, \varphi))$ wtw żadne wolne wystapienie $x w \varphi$ nie występuje $w$ obrębie podformuty po-

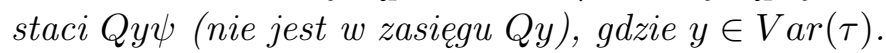

W dalszym ciągu będziemy używali zapisu $\varphi[x / \tau]$ tylko w przypadku poprawnych podstawień, tj. takich, że $\tau \in \operatorname{Free}(x, \varphi)$.

Uwaga 8.11: W ostatnim warunku definicji podstawiania określona jest sytuacja kiedy (poprawne) podstawianie termu nie jest wykonalne, gdyż albo $y$ nie jest wolne $\mathrm{w}$ formule, w której dokonujemy podstawienia albo występująca $\mathrm{w}$ podstawianym termie zmienna zostanie związana przez jakiś kwantyfikator (kolizja zmiennych). W podanym wyżej przykładzie 8.1 ze względu na pierwsze obostrzenie nie jest możliwe $[x / \tau]$ dla żadnego $\tau$, gdyż $x \notin V F(\varphi)$. Ze względu na drugie obostrzenie nie jest możliwe $[z / x],[z / y]$ i $[y / x]$. Każde takie podstawienie jest $\mathrm{w}$ tym sensie niewykonalne, że nie zmienią kształtu $\varphi$ (inaczej, jest pustym podstawieniem). Zauważmy jednak, że poprzez konsekwentne przemianowywanie zmiennych związanych zawsze można uniknąć kolizji zmiennych. 
Formuła, w której dokonano podstawienia, to instancja podstawieniowa formuły wyjściowej. Można wyróżnić dwa typy takich instancji: ścisłe i nieścisłe. O instancji podstawieniowej w sensie ścisłym powiemy, gdy podstawiany term występuje tylko w tych miejscach, gdzie występowała podstawiana zmienna, czyli wtedy, gdy podstawiany term jest nowy w formule. Przykładowo: $\operatorname{Rxyz}[y / a]:=\operatorname{Rxaz}$ jest instancją podstawieniową $\mathrm{w}$ sensie ścisłym, a $R x y z[y / z]:=R x z z$ nie. O operacji podstawiania, która prowadzi do ścisłej instancji powiemy pochodnie, że jest ścisłym podstawieniem.

Warto odnotować bez dowodu kilka prostych faktów dotyczących poprawnego podstawiania:

Fakt 8.1 1. $\varphi[x / x]:=\varphi$;

2. jeżeli $x \notin V F(\varphi)$, to $\varphi[x / \tau]:=\varphi$ dla dowolnego $\tau$;

3. $w$ przypadku ścistego podstawiania $(\varphi[x / y])[y / x]=\varphi$;

4. w przypadku ścisłego podstawiania $\left(\ldots\left(\varphi\left[x / y_{1}\right]\right) \ldots\right)\left[y_{n} / y_{n+1}\right]=\varphi\left[x / y_{n+1}\right]$.

Operacja podstawiania (w szczególności ścisłego) pozwala wprowadzić inne ważne pojęcie:

Definicja 8.10 (Formuły podobne) $\varphi(x) i \varphi(y)$ sa podobne wtw y $\notin V F(\varphi(x)$ $i \varphi(y):=\varphi(x)[x / y]$, tzn. wtedy, gdy każda $z$ nich jest ścistym podstawieniem drugiej.

Intuicyjnie: $\varphi(y)$ ma wolne wystapienia $y$ dokładnie w tych miejscach, gdzie $\varphi(x)$ ma wolne wystąpienia $x$. Łatwo zauważyć że relacja podobieństwa formuł jest relacją równoważnościową.

Definicja 8.11 (Alfabetyczne warianty) $\varphi^{\prime}$ jest alfabetycznym wariantem $\varphi$ wtw zamiast podformuły $Q x \psi(x)$ wystepujacej $w \varphi$ zawiera $Q y \psi(y)$ gdzie $x \neq y$ oraz $\psi(x)$ i $\psi(y)$ sa formułami podobnymi.

Oprócz podstawiania wyróżnimy zastępowanie. W przeciwieństwie do podstawiania nie zastępujemy tylko zmiennych, ale dowolne termy i nie musimy zastępować wszystkich ich wystąpień:

$\varphi\left[\tau_{1} / / \tau_{2}\right]$ (ewentualnie $\tau\left[\tau_{1} / / \tau_{2}\right]$ ) oznacza rezultat zastapienia termu $\tau_{1}$ przez $\tau_{2} \mathrm{w} \varphi$ (ewentualnie $\mathrm{w}$ termie $\tau$ ).

Zauważmy, że zastępowanie nie jest operacją w takim sensie jak podstawianie, tzn. nie przypisuje danej formule dokładnie jednej formuły będącej wynikiem podstawienia, ale zbiór formuł. Np. Pxx $[x / / y]$ daje trzy możliwe rezultaty: Pyy, Pxy, Pyx. 


\subsection{Teorie pierwszego rzędu}

Formalizacje teorii pierwszego rzędu (zwanych też elementarnymi) najczęściej prezentowane są w postaci aksjomatycznej czyli jako H-systemy - podajemy:

1. Aksjomaty dla logiki KRK.

2. Aksjomaty dla relacji identyczności (logika KRKI) (nie zawsze potrzebne).

3. Reguły logiczne.

4. Aksjomaty (i ewentualnie reguły) pozalogiczne.

\subsubsection{Aksjomatyzacja KRK}

Poniżej podamy jedną z popularnych aksjomatyzacji KRK, zawiera ona:

Dowolną aksjomatyzację KRZ (w szczególności tę z rozdziału 1) plus

$A \forall E \quad \forall x \varphi \rightarrow \varphi[x / \tau]$

$A \forall \quad \forall x(\varphi \rightarrow \psi) \rightarrow(\varphi \rightarrow \forall x \psi)$, pod warunkiem, że $x \notin V F(\varphi)$

$A \exists \quad \exists x \varphi \leftrightarrow \neg \forall x \neg \varphi$

Reguły pierwotne:

$M P \quad \varphi \rightarrow \psi, \varphi / \psi$

GEN $\varphi / \forall x \varphi$

Pojęcia dowodu, dowiedlności, tezy, zbioru (nie)sprzecznego definiujemy podobnie jak w przypadku KRZ.

Definicja 8.12 $\quad \Gamma \vdash \varphi$ wtw istnieje skończony ciag formut, $w$ którym ostatnim elementem jest $\varphi$ i gdzie każdy element jest:

1. podstawieniem aksjomatu lub

2. elementem zbioru $\Gamma$ (założeniem) lub

3. wynikiem zastosowania jednej z reguł pierwotnych (MP lub GEN) do poprzedzajacych wyrazów ciagu

- $\vdash \varphi w t w \varnothing \vdash \varphi$

- $\Gamma$ jest sprzeczna wtw $\Gamma \vdash \perp$, w przeciwnym wypadku jest niesprzeczna. 
Uwaga 8.12: Jak widać różnica dotyczy jedynie uwzględnienia poszerzonego zbioru aksjomatów i reguł pierwotnych. W rozdziale 1 wspomnieliśmy zresztą (uwaga 1.6), że można w inny sposób zdefiniować relację dowiedlności odwołując się do pojęcia tezy jako pojęcia pierwotnego:

$$
\Gamma \vdash_{2} \varphi \text { wtw } \vdash_{2} \psi_{1} \wedge \ldots \wedge \psi_{n} \rightarrow \varphi\left(\text { gdzie }\left\{\psi_{1}, \ldots, \psi_{n}\right\} \subseteq \Gamma\right)
$$

Chociaż w przypadku KRZ obie charakterystyki relacji dowiedlności są równoważne, to w przypadku podanego systemu dla KRK dają inny efekt, dlatego druga relacja została oznaczona dolnym indeksem 2. Dla przykładu, dla $\vdash_{2}$ zachodzi TD w postaci takiej samej jak dla KRZ, natomiast dla $\vdash$ mamy TD w postaci słabszej, niżej podanej. Gdyby TD nie było w jakiś sposób ograniczone dla $\vdash$, to otrzymalibyśmy $\vdash A x \rightarrow \forall x A x$, gdyż $A x \vdash$ $\forall x A x$ z warunku 2. i 3. podanej definicji. Dla odmiany $A x \nvdash_{2} \forall x A x$ gdyż $\nvdash_{2} A x \rightarrow \forall x A x$. Pojęcie tezy jest zresztą w obu przypadkach takie same, tzn. $\vdash \varphi$ wtw $\vdash_{2} \varphi$. Również gdy $V F(\Gamma \cup\{\varphi\})=\varnothing$ (czyli, gdy są to wyłącznie zdania), to $\Gamma \vdash \varphi$ wtw $\Gamma \vdash_{2} \varphi$. Generalnie między obiema relacjami zachodzi relacja inkluzji, tzn. $\vdash_{2} \subset \vdash$ co gwarantuje, że każda reguła dowiedlna dla $\vdash_{2}$ jest też dowiedlna dla $\vdash$, ale nie odwrotnie. Inkluzja taka nie zachodzi dla reguł dopuszczalnych.

Relację $\vdash_{2}$ można zdefiniować również w terminach dowodu z założeń, ale wtedy trzeba na zastosowanie GEN nałożyć warunek, że kwantyfikacji podlegają tylko takie zmienne, które nie są wolne w założeniach dowodu. Jest to naturalne ograniczenie, ale niestety wymusza dalsze komplikacje, gdyż do reguł pierwotnych trzeba dorzucić regułę pozwalającą na zmianę dowolnej formuły występującej w dowodzie na jej alfabetyczny wariant. Bez tego dodatku nie można dowieść warunku monotoniczności dla relacji dowiedlności (por. np. Church [24], Andrews [5]).

Dla $\vdash$ w KRK zachodzi słabsza wersja twierdzenia o dedukcji o postaci:

Twierdzenie 8.1 Jeżeli $\Gamma, \varphi \vdash \psi$ i $\varphi$ jest zdaniem, to $\Gamma \vdash \varphi \rightarrow \psi$

Dowód przez mocną indukcję po długości dowodu $\Gamma, \varphi \vdash \psi$ znajduje się w dodatku.

Odnotujmy bez dowodu:

Fakt 8.2 Nastęujace dwie reguty sa wyprowadzalne $w H$-KRK: ${ }^{2}$

$\forall I \quad \varphi \rightarrow \psi[x / c] / \varphi \rightarrow \forall x \psi$, gdzie stała c nie występuje $w \varphi, \psi$

$\exists E \quad \varphi[x / c] \rightarrow \psi / \exists x \varphi \rightarrow \psi$, gdzie stała c nie wystęuje $w \varphi, \psi$

\footnotetext{
${ }^{2} \mathrm{~W}$ wielu aksjomatyzacjach KRK są one przyjmowane jako pierwotne zamiast $G E N$; warto porównać je z odpowiednimi regułami RS w podrozdziale 9.2.
} 
Lemat 8.1 Jeżeli $\varphi(x) i \varphi(y)$ sa podobne, to:

$$
\begin{aligned}
& \text { 1. } \vdash \forall x \varphi(x) \leftrightarrow \forall y \varphi(y) \\
& \text { 2. } \vdash \exists x \varphi(x) \leftrightarrow \exists y \varphi(y)
\end{aligned}
$$

DowóD: Dla 1. $\forall x \varphi(x) \rightarrow \varphi(y)$ jest podstawieniem aksjomatu $A \forall E$, a $\forall y(\forall x \varphi(x) \rightarrow \varphi(y)) \rightarrow(\forall x \varphi(x) \rightarrow \forall y \varphi(y))$ jest podstawieniem aksjomatu $A \forall$, gdyż $y \notin V F(\forall x \varphi(x))$. Z pierwszego, przez GEN, mamy $\forall y(\forall x \varphi(x) \rightarrow$ $\varphi(y))$, co przez MP daje $\forall x \varphi(x) \rightarrow \forall y \varphi(y)$. Analogicznie w drugą stronę i dla 2. z wykorzystaniem $\forall \exists$.

Ponieważ reguła ekstensjonalności RE (por. rozdział 1) jest również dopuszczalna w H-KRK, więc z powyższego lematu za jej pomocą wyprowadzimy:

Lemat 8.2 $\vdash \varphi \leftrightarrow \varphi^{\prime}$, gdzie $\varphi^{\prime}$ jest dowolnym alfabetycznym wariantem $\varphi$.

Kolejnym ważnym pojęciem jest pojęcie formuły w postaci preneksowej.

Definicja 8.13 (Formuły preneksowe) Formuła jest w postaci preneksowej wtw ma postać $Q x_{1}, \ldots, Q x_{k} \varphi$, gdzie $\varphi$ nie zawiera żadnych kwantyfikatorów a $k \geq 0$ to liczba różnych zmiennych wolnych $w \varphi$. Ciag $Q x_{1}, \ldots, Q x_{k}$ to preneks (lub prefiks), a $\varphi$ to matryca.

Przypomnijmy, że:

Fakt 8.3 Następujące równoważności sa tezami KRK:

- $\forall x(\varphi \wedge \psi) \leftrightarrow \forall x \varphi \wedge \forall x \psi$

- $\exists x(\varphi \vee \psi) \leftrightarrow \exists x \varphi \vee \exists x \psi$

- $\forall x(\varphi \vee \psi) \leftrightarrow \varphi \vee \forall x \psi$, pod warunkiem, że $x \notin V F(\varphi)$

- $\exists x(\varphi \wedge \psi) \leftrightarrow \varphi \wedge \exists x \psi$, pod warunkiem, że $x \notin V F(\varphi)$

- $\exists x(\varphi \rightarrow \psi) \leftrightarrow \varphi \rightarrow \exists x \psi$, pod warunkiem, że $x \notin V F(\varphi)$

- $\exists x(\varphi \rightarrow \psi) \leftrightarrow \forall x \varphi \rightarrow \psi$, pod warunkiem, że $x \notin V F(\psi)$

- $\forall x(\varphi \rightarrow \psi) \leftrightarrow \varphi \rightarrow \forall x \psi$, pod warunkiem, że $x \notin V F(\varphi)$

- $\forall x(\varphi \rightarrow \psi) \leftrightarrow \exists x \varphi \rightarrow \psi$, pod warunkiem, że $x \notin V F(\psi)$ 
Równoważności te wraz z prawami De Morgana, RE i lematem 8.1. pozwalają na dowód:

Twierdzenie 8.2 Dla dowolnej formuły $\varphi$ istnieje równoważna jej formuła w postaci preneksowej.

DowóD: Ponieważ $\varphi$ może zawierać wiele wystąpień kwantyfikatorów wiążących taką samą zmienną, więc w etapie pierwszym dokonujemy zamiany na alfabetyczny wariant $\varphi^{\prime}$, w którym każdy kwantyfikator wiąże zmienną o innym kształcie. Następnie stosujemy RE i, wykorzystując podane wyżej równoważności, systematycznie przesuwamy kwantyfikatory na lewo. Zauważmy, że dana formuła może otrzymać wiele różnych preneksowych równoważników w zależności od kolejności przeprowadzanych operacji.

Odnotujmy, że korzystając z twierdzenia Posta można dodatkowo matrycę formuły preneksowej sprowadzić do postaci normalnej KA (koniunkcyjnoalternatywnej).

Na koniec dowiedziemy:

Lemat 8.3 Jeżeli $\Gamma$ jest niesprzeczny, to $\Gamma \cup\{\exists x \varphi \rightarrow \varphi[x / c]\}$, gdzie stała c nie występuje $w \Gamma i w \varphi$, też jest niesprzeczny.

DowóD: Załóżmy niewprost, że $\Gamma \cup\{\exists x \varphi \rightarrow \varphi[x / c]\}$ jest sprzeczny, wtedy:

$\begin{array}{lll}1 & \Gamma, \exists x \varphi \rightarrow \varphi[x / c] \vdash \perp & \\ 2 & \Gamma \vdash \neg(\exists x \varphi \rightarrow \varphi[x / c]) & 1 \\ 3 & \psi_{1}, \ldots, \psi_{n} \vdash \neg(\exists x \varphi \rightarrow \varphi[x / c]) & 2, \text { z def. } \vdash \\ 4 & \psi_{1} \wedge \ldots \wedge \psi_{n} \vdash \neg(\exists x \varphi \rightarrow \varphi[x / c]) & 3, \text { lem. 1.1, wł } 13 \\ 5 & \psi_{1} \wedge \ldots \wedge \psi_{n} \vdash \exists x \varphi & 4 \\ 6 & \psi_{1} \wedge \ldots \wedge \psi_{n} \vdash \neg \varphi[x / c] & 4 \\ 7 & \vdash \psi_{1} \wedge \ldots \wedge \psi_{n} \rightarrow \neg \varphi[x / c] & 6, \text { TD } \\ 8 & \vdash \psi_{1} \wedge \ldots \wedge \psi_{n} \rightarrow \forall x \neg \varphi & 7, \forall I \text { (fakt 8.2) } \\ 9 & \psi_{1} \wedge \ldots \wedge \psi_{n} \vdash \forall x \neg \varphi & 8, \text { konwers TD } \\ 10 & \Gamma \vdash \perp & 5,9\end{array}$

\subsubsection{Aksjomatyzacje teorii elementarnych}

Aby uzyskać aksjomatyzację KRKI wystarczy dodać aksjomaty dla identyczności:

ID $\forall x(x=x)$

$L L \quad \forall x, y(x=y \rightarrow(\varphi \rightarrow \varphi[x / / y]))$, gdzie $\varphi$ jest formułą atomową 
Aby zbudować na bazie KRK (KRKI) teorię pierwszego rzędu dodajemy odpowiednie aksjomaty (i ewentualnie reguły) charakteryzujące stałe pozalogiczne danej teorii. Oto kilka przykładów aksjomatów dla teorii elementarnych:

Teoria grup:

$$
\begin{array}{ll}
G 1 & \forall x, y, z(x \cdot(y \cdot z)=(x \cdot y) \cdot z) \\
G 2 & \forall x(1 \cdot x=x) \\
G 3 & \forall x \exists y(y \cdot x=1)
\end{array}
$$

Po dodaniu:

$G 4 \forall x, y(x \cdot y=y \cdot x)$

otrzymujemy aksjomatyzację teorii grup przemiennych (Abelowych).

Arytmetyka Peano:

$$
\begin{array}{ll}
A 1 & \forall x(s x \neq 0) \\
A 2 & \forall x, y(s x=s y \rightarrow x=y) \\
A 3 & \forall x(x+0=x) \\
A 4 & \forall x, y(x+s y=s(x+y) \\
A 5 & \varphi(0) \wedge \forall x(\varphi(x) \rightarrow \varphi[x / s x]) \rightarrow \forall x \varphi(x)
\end{array}
$$

A5 to schemat aksjomatu indukcji, czasem wprowadza się odpowiednią regułę (por. dodatek).

Teoria krat:

$$
\begin{array}{lll}
K 1 & \forall x(x \sqcap x=x) & \forall x(x \sqcup x=x) \\
K 2 & \forall x, y(x \sqcap y=y \sqcap x) & \forall x, y(x \sqcup y=y \sqcup x) \\
K 3 & \forall x, y, z(x \sqcap(y \sqcap z)= & \forall x, y, z(x \sqcup(y \sqcup z)= \\
& (x \sqcap y) \sqcap z) & (x \sqcup y) \sqcup z) \\
K 4 & \forall x, y(x \sqcap(x \sqcup y)=x) & \forall x, y(x \sqcup(x \sqcap y)=x)
\end{array}
$$

Teoria Algebr Boole'a:

Aksjomaty teorii krat plus:

$$
\begin{array}{lll}
B 1 & \forall x, y, z(x \sqcap(y \sqcup z)= & \forall x, y, z(x \sqcup(y \sqcap z)= \\
& (x \sqcap y) \sqcup(x \sqcap z)) & (x \sqcup y) \sqcap(x \sqcup z)) \\
B 2 & \forall x(0 \sqcup x=x) & \forall x(0 \sqcap x=0) \\
B 3 & \forall x(1 \sqcup x=1) & \forall x(1 \sqcap x=x) \\
B 4 & \forall x(x \sqcup-x=1) & \forall x(x \sqcap-x=0)
\end{array}
$$


Zauważmy, że zarówno aksjomatyzacja teorii identyczności, jak i teorii krat i algebr Boole'a ma pewną ważną własność. Są to teorie uniwersalne $\mathrm{w}$ tym sensie, że każdy aksjomat jest postaci preneksowej $\forall x_{1}, \ldots, x_{n} \varphi$ (bez wystąpień $\exists$ ). Szczególnym przypadkiem takich formuł są uniwersalne implikacje o postaci:

$$
\forall x_{1}, \ldots, x_{k}\left(\varphi_{1} \wedge \ldots \wedge \varphi_{n} \rightarrow \psi_{1} \vee \ldots \vee \psi_{m}\right),
$$

gdzie $k \geq 1, n, m \geq 0$, każde $\varphi_{i}$ i $\psi_{i}$ jest atomem ( $m=0$ jest interpretowane jako $\perp)$.

Teorie uniwersalne posiadają wiele interesujących własności, ale z punktu widzenia dalszych rozważań ważne jest, że poddają się szczególnej postaci formalizacji na gruncie RS, którą omówimy w podrozdziale 9.8 .

Odnotujmy następujący:

Fakt 8.4 Zbiór aksjomatów dowolnej teorii uniwersalnej można sprowadzić do zbioru uniwersalnych implikacji.

DowóD: Dla dowolnego uniwersalnego aksjomatu, który nie jest uniwersalną implikacją, sprowadzamy jego matrycę do postaci KA. Następnie stosujemy prawo dystrybucji $\forall$ względem koniunkcji i regułę eliminacji koniunkcji, co daje nam skończony zbiór uniwersalnych klauzul. Na koniec każdą klauzulę przekształcamy na równoważną jej implikację.

Węższą klasę uniwersalnych teorii uzyskujemy gdy ograniczymy się do aksjomatów o postaci klauzul Horna, czyli:

$$
\forall x_{1}, \ldots, x_{k}\left(\varphi_{1} \wedge \ldots \wedge \varphi_{n} \rightarrow \psi\right),
$$

gdzie $k \geq 1, n \geq 0$, i każde $\varphi_{i}$ i $\psi$ jest atomem.

Teorią Hornowską jest dowolny skończony zbiór klazuzul Horna. Ta klasa uniwersalnych teorii ma szczególnie interesujące własności obliczeniowe czego świadectwem jest choćby ogromna popularność na polu automatycznego dowodzenia twierdzeń (por. Hodges [69]). Oczywiście zasięg zastosowań teorii Hornowskich można znacząco zwiększyć, gdy za atomy uznamy $\perp$ i formuły identycznościowe. Klauzule Horna, zawierające tylko pozalogiczne atomy (predykaty z termami) to ścisłe klauzule Horna.

Najogólniejszą formą teorii elementarnych, które tu zdefiniujemy, jest klasa, tzw. geometrycznych teorii (por. Vickers [151]). Formuła pierwszego rzędu jest geometryczna, gdy jest zbudowana z atomów postaci $R x y$ lub $x=y$ z pomocą $\perp, \wedge, \vee$ i $\exists$. Geometryczną teorią jest skończony zbiór zdań postaci: 
$\forall x_{1}, \ldots, x_{k}(\varphi \rightarrow \psi)$, gdzie $\varphi$ i $\psi$ są geometrycznymi formułami.

Lepiej można zrozumieć pojęcie geometrycznej formuły i zauważyć, że uogólnia ona pojęcie uniwersalnej implikacji, gdy posłużymy się pojęciem bazowej geometrycznej formuły postaci:

$$
\forall x_{1}, \ldots, x_{k}\left(\varphi_{1} \wedge \ldots \wedge \varphi_{n} \rightarrow \exists y_{1}, \ldots, y_{l}\left(\psi_{1} \vee \ldots \vee \psi_{m}\right)\right),
$$

gdzie $k \geq 1, l, n, m \geq 0$, każde $\varphi_{i}$ jest atomem a każde $\psi_{i}$ jest atomem lub skończoną koniunkcją atomów.

Bazowa teoria geometryczna składa się ze skończonego zbioru aksjomatów o takiej postaci. Ograniczenie się do takich teorii nie osłabia zakresu zastosowań, gdyż Simpson [128] udowodnił, że każda geometryczna teoria jest równoważna bazowej teorii geometrycznej.

Teorie elementarne sformułowane w oszczędnym języku zazwyczaj rozbudowuje się wprowadzając dodatkowe stałe za pomocą definicji. Oczywiście definicje muszą spełniać odpowiednie warunki poprawności. Ogólne wymogi dla definicji wprowadzających nowe stałe pozalogiczne do teorii to: eliminowalność i nietwórczość, które określić można następująco:

Niech $T$ będzie teorią w języku $L, L^{*}$ niech oznacza $L$ wzbogacony o nową stałą pozalogiczną $*$, a $T^{*}=T+\operatorname{Def}(*)$. Wtedy $\operatorname{Def}(*)$ jest:

- eliminowalna wtw $\forall_{\varphi \in L^{*}} \exists_{\varphi^{\prime} \in L} T^{*} \vdash \varphi \leftrightarrow \varphi^{\prime}$

- nietwórcza wtw $\forall_{\varphi \in L}$ (jeżeli $T^{*} \vdash \varphi$, to $T \vdash \varphi$ ).

Spełnienie tych warunków jest zapewnione przez reguły definiowania, których nie będziemy tu omawiać (por. np. Batóg [10], Trzęsicki [146]).

\subsection{Semantyka}

Większa złożoność języka KRK powoduje, że i konstrukcja semantyki jest bardziej skomplikowana. Kolejno wprowadzimy:

1. pojęcie struktury interpretacyjnej (systemu);

2. definicję spełniania formuły w strukturze przez waluację (ciąg obiektów);

3. definicję prawdziwości/fałszywości i modelu;

4. pojęcia logicznej prawdziwości, wynikania, niesprzeczności. 


\subsubsection{Struktura Interpretacyjna - ogólne pojęcie:}

Definicja 8.14 Struktura interpretacyjna (system) dla teorii pierwszego rzędu ma postać $\mathfrak{M}=\langle D, V\rangle$, gdzie $D$ to niepusta dziedzina, a $V$ to funkcja interpretacji (denotacji, ekstensji) pozalogicznych statych, definiowana następujaco:

- $V(c) \in D$, dla dowolnej stałej nazwowej c;

- $V\left(f^{n}\right) \in D^{D^{n}}\left(V\left(f^{n}\right): D^{n} \longrightarrow D\right)$, dla dowolnej n-argumentowej operacji $f^{n}$;

- $V\left(P^{n}\right) \subseteq D^{n}$, dla dowolnego n-argumentowego predykatu $P^{n}$.

W przypadku konkretnych języków o określonej (skończonej) liczbie stałych zazwyczaj strukturę przedstawia się następująco:

$$
\mathfrak{M}=\left\langle D, R_{1}, \ldots, R_{j}, f_{1}, \ldots, f_{k}, c_{1}, \ldots, c_{n}\right\rangle,
$$

gdzie symbole $R_{i}, f_{i}, c_{i}$ oznaczają denotacje odpowiednich stałych z danego języka. Jeżeli $j=0$, to struktury są algebrami.

Termy interpretujemy w dwóch etapach. Podstawowe pojęcie to waluacja zmiennych, która jest funkcją postaci $v: V A R \longrightarrow D$. Różne waluacje będziemy oznaczać przez $v_{1}, v_{2}, \ldots$, ponadto $v_{o}^{x}$ oznacza tzw. $x$-wariant waluacji $v$, tzn. waluację taką samą jak $v$ za wyjątkiem ewentualnie wartości zmiennej $x$ (obiekt $o$ z $D$ jest tu określony jako wartość $x$ ).

Interpretacja $I_{v}$ termu $\tau$ w strukturze $\mathfrak{M}$ przy waluacji $v$ jest definiowana następująco:

$$
I_{v}(\tau):= \begin{cases}v(\tau) & \text { jeżeli } \tau \in V A R \\ V(\tau) & \text { jeżeli } \tau \in C O N \cup F U N\end{cases}
$$

W szczególności, jeżeli $\tau=f\left(\tau_{1}, \ldots, \tau_{n}\right)$, to:

$I_{v}\left(f\left(\tau_{1}, \ldots, \tau_{n}\right)\right):=V(f)\left\langle I_{v}\left(\tau_{1}\right), \ldots, I_{v}\left(\tau_{n}\right)\right\rangle$.

Warunki prawdziwości definiujemy rekurencyjnie: 
Definicja 8.15 Formuła jest spetniona (prawdziwa) w modelu $\mathfrak{M}$ przez waluacje v:

$\begin{array}{lll}\mathfrak{M}, v \vDash P^{n}\left(\tau_{1} \ldots \tau_{n}\right) & \text { wtw } & \left\langle I_{v}\left(\tau_{1}\right), \ldots, I_{v}\left(\tau_{n}\right)\right\rangle \in V\left(P^{n}\right) \\ \mathfrak{M}, v \vDash \neg \varphi & \text { wtw } & \mathfrak{M}, v \not \varphi \\ \mathfrak{M}, v \vDash \varphi \wedge \psi & \text { wtw } & \mathfrak{M}, v \vDash \varphi i \mathfrak{M}, v \vDash \psi \\ \mathfrak{M}, v \vDash \varphi \vee \psi & \text { wtw } & \mathfrak{M}, a \vDash \varphi l u b \mathfrak{M}, v \vDash \psi \\ \mathfrak{M}, v \vDash \varphi \rightarrow \psi & \text { wtw } & \mathfrak{M}, v \not \models \varphi l u b \mathfrak{M}, v \vDash \psi \\ \mathfrak{M}, v \vDash \tau_{1}=\tau_{2} & \text { wtw } & I_{v}\left(\tau_{1}\right)=I_{v}\left(\tau_{2}\right) \\ \mathfrak{M}, v \vDash \forall x \varphi & \text { wtw } & \mathfrak{M}, v_{o}^{x} \vDash \varphi \text { dla kazdego o } \in D \\ \mathfrak{M}, v \vDash \exists x \varphi & \text { wtw } & \mathfrak{M}, v_{o}^{x} \vDash \varphi \text { dla pewnego } o \in\end{array}$

$\mathfrak{M}, v \not \models \varphi$ znaczy, że $v$ nie spełnia formuły $\varphi$ w $\mathfrak{M}$.

\subsubsection{Ważne pojęcia semantyczne:}

Podobnie jak w przypadku KRZ wprowadzimy niżej kilka najważniejszych pojęć semantycznych. Warto porównać je z odpowiednikami dla KRZ z rozdziału 1.

- Dla zbiorów formuł zapis $\mathfrak{M}, v \vDash \Gamma$ znaczy, że $v$ spełnia $\mathrm{w} \mathfrak{M}$ wszystkie elementy $\Gamma\left(\mathfrak{M}, v \vDash \psi\right.$ dla $\left.\forall_{\psi \in \Gamma}\right)$.

- $\mathfrak{M}, v \not \models \Gamma$ znaczy, że co najmniej jeden element z $\Gamma$ jest niespełniony $\mathrm{w}$ $\mathfrak{M}$.

- $\varphi$ (względnie $\Gamma)$ jest spetnialna $w \mathfrak{M}$ wtw, $\exists v$, że $\mathfrak{M}, v \vDash \varphi(\mathfrak{M}, v \vDash \Gamma)$.

- $\varphi(\Gamma)$ jest spetnialna (spójna, semantycznie niesprzeczna) wtw $\exists_{\mathfrak{M}}, \exists v$ taki, że $\mathfrak{M}, v \vDash \varphi(\mathfrak{M}, v \vDash \Gamma)$.

- $\varphi$ jest prawdziwe $($ w $\mathfrak{M})(\mathfrak{M} \vDash \varphi)$ wtw, $\forall v, \mathfrak{M}, v \vDash \varphi$.

- $\varphi$ jest fatszywe $(\mathrm{w} \mathfrak{M})(\mathfrak{M} \not \models \varphi)$ wtw, $\forall v, \mathfrak{M}, v \not \models \varphi$.

- Zawartość struktury $E(\mathfrak{M})=\{\varphi: \mathfrak{M} \vDash \varphi\}$.

- $\mathfrak{M}$ jest modelem zbioru $\Gamma$ wtw $\Gamma \subseteq E(\mathfrak{M})$.

Tautologiczność i wynikanie definiujemy następująco:

$$
\vDash \varphi w t w \forall_{\mathfrak{M}}, \mathfrak{M} \vDash \varphi
$$

( $\not=\varphi$ oznacza formułę nietautologiczną) 


$$
\Gamma \models \varphi \text { wtw, } \forall_{\mathfrak{M}}, \mathfrak{M} \vDash \Gamma \text { implikuje } \mathfrak{M} \vDash \varphi
$$

inaczej

$$
\Gamma \models \varphi w t w, \operatorname{MOD}(\Gamma) \subseteq M O D(\varphi)
$$

gdzie: $\operatorname{MOD}(\Gamma)=\{\mathfrak{M}: \Gamma \subseteq E(\mathfrak{M})\}$, a $M O D(\varphi)=\operatorname{MOD}(\{\varphi\})$.

Uwaga 8.13: Podana wyżej definicja wynikania jest semantycznym odpowiednikiem $\vdash$. Można oczywiście zdefiniować wynikanie w taki sposób, aby korespondowało do $\vdash_{2}$. Stosowna definicja wygląda następująco:

$$
\Gamma, \models_{2} \varphi w t w \forall_{\mathfrak{M}}, \forall_{v}, \mathfrak{M}, v \vDash \Gamma \text { implikuje } \mathfrak{M}, v \vDash \varphi
$$

Lemat 8.4 Kilka konsekwencji powyższych definicji:

1. $\varphi$ jest fałszywa $w \mathfrak{M} w t w \neg \varphi$ jest prawdziwa $w \mathfrak{M} ; \varphi$ jest prawdziwa $w$ $\mathfrak{M} w t w \neg \varphi$ jest fatszywa $w \mathfrak{M}$.

2. Jeżeli $\varphi$ jest zdaniem, to dla dowolnego $\mathfrak{M}$ albo $\varphi$ albo $\neg \varphi$ jest prawdziwa $w \mathfrak{M}$.

3. Jeżeli $\varphi$ nie jest zdaniem, to $w$ danym $\mathfrak{M}$ może nie być ani prawdziwa ani fatszywa (tj. spetniona przez pewne waluacje a przez inne nie).

4. Jeżeli $\varphi$ jest zdaniem, to jest spełnialna wtw jest prawdziwa $w$ pewnym $\mathfrak{M}$.

5. $\mathfrak{M} \vDash \varphi w t w \mathfrak{M} \vDash \forall x \varphi$.

6. $=\varphi$ wtw $\neg \varphi$ nie jest spetnialna; $\varphi$ jest spetnialna $w t w \not \models \neg \varphi$.

7. $\Gamma \models \varphi$ wtw $\Gamma \cup\{\neg \varphi\}$ jest niespetnialna.

DowóD: Wykażemy punkt 5.

$\mathfrak{M} \vDash \varphi$ wtw $\mathfrak{M} \vDash \forall x \varphi$

$\Longrightarrow$ Załóżmy, że $\mathfrak{M} \vDash \varphi$, co oznacza, że każda waluacja $v$ spełnia $\varphi \mathrm{w} \mathfrak{M}$, w szczególności dowolny $x$-wariant dowolnej waluacji. Zatem $\mathfrak{M} \vDash \forall x \varphi$.

$\Longleftarrow$ Jeżeli $\mathfrak{M} \vDash \forall x \varphi$, to dla dowolnej $v, \mathfrak{M}, v \vDash \forall x \varphi$. Rozważmy konkretną taką $v$, wtedy $\mathfrak{M}, v^{\prime} \vDash \varphi$ dla dowolnego $x$-wariantu $v$, w szczególności dla $v$, które jest swoim własnym $x$-wariantem. Zachodzi to dla dowolnego $v$, zatem $\mathfrak{M}, v \vDash \varphi$. 
Ważną rolę w dalszych dowodach odgrywają dwa lematy techniczne, które nazwiemy twierdzeniami o koincydencji i o podstawianiu.

\section{Lemat 8.5 (Twierdzenie o koincydencji:)}

1. Jeżeli $v_{1}(x)=v_{2}(x)$ dla dowolnego $x \in \operatorname{Var}(\tau)$, to $I_{v_{1}}(\tau)=I_{v_{2}}(\tau)$;

2. Jeżeli $v_{1}(x)=v_{2}(x)$ dla dowolnego $x \in V F(\varphi)$, to $\mathfrak{M}, v_{1} \vDash \varphi$ wtw $\mathfrak{M}, v_{2} \vDash \varphi$.

DowóD: przez indukcję strukturalną po złożoności termu $\tau$.

Część 1. Baza zawiera dwa przypadki do rozpatrzenia: $\tau:=x$ lub $\tau:=c$. W pierwszym:

$$
I_{v_{1}}(x)=v_{1}(x)=v_{2}(x)=I_{v_{2}}(x)
$$

gdyż $v_{1}(x)=v_{2}(x)$. Podobnie $\mathrm{w}$ drugim:

$$
I_{v_{1}}(c)=V(c)=I_{v_{2}}(c)
$$

Krok indukcyjny: dowodzimy, że twierdzenie zachodzi dla termu $\tau$ := $f\left(\tau_{1}, \ldots, \tau_{n}\right)$ przy założeniu, że zachodzi dla jego składników.

Założenie indukcyjne: twierdzenie zachodzi dla dowolnego $i \leq n$, czyli:

$$
\begin{gathered}
I_{v_{1}}\left(\tau_{i}\right)=I_{v_{2}}\left(\tau_{i}\right) \\
I_{v_{1}}\left(f\left(\tau_{1}, \ldots, \tau_{n}\right)\right)=V(f)\left\langle I_{v_{1}}\left(\tau_{1}\right), \ldots, I_{v_{1}}\left(\tau_{n}\right)\right\rangle \\
=V(f)\left\langle I_{v_{2}}\left(\tau_{1}\right), \ldots, I_{v_{2}}\left(\tau_{n}\right)\right\rangle \\
=I_{v_{2}}\left(f\left(\tau_{1}, \ldots, \tau_{n}\right)\right)
\end{gathered}
$$

Dla drugiej części twierdzenia o koincydencji przeprowadzamy dowód przez indukcję strukturalną po złożoności formuły $\varphi$.

Baza: $\varphi:=P\left(\tau_{1}, \ldots, \tau_{n}\right)$

Zauważmy, że dla każdego $i \leq n, \operatorname{Var}\left(\tau_{i}\right) \subseteq V F(\varphi)$ zatem, na mocy założenia i pierwszej części twierdzenia mamy:

$$
\star I_{v_{1}}\left(\tau_{i}\right)=I_{v_{2}}\left(\tau_{i}\right)
$$


Zatem:

$$
\begin{aligned}
\mathfrak{M}, v_{1} \vDash P\left(\tau_{1}, \ldots, \tau_{n}\right) \quad & \text { wtw }\left\langle I_{v_{1}}\left(\tau_{1}\right), \ldots, I_{v_{1}}\left(\tau_{n}\right)\right\rangle \in V(P) \\
& \text { wtw }\left\langle I_{v_{2}}\left(\tau_{1}\right), \ldots, I_{v_{2}}\left(\tau_{n}\right)\right\rangle \in V(P) \quad \text { przez } \star \\
& \text { wtw } \mathfrak{M}, v_{2} \vDash P\left(\tau_{1}, \ldots, \tau_{n}\right)
\end{aligned}
$$

Krok indukcyjny: dowodzimy, że twierdzenie zachodzi dla każdej formuły złożonej przy założeniu, że zachodzi dla jej podformuł. Rozważymy 2 przypadki dla ilustracji.

Przypadek $\varphi:=\psi \wedge \chi$

Założenie indukcyjne: twierdzenie zachodzi dla podformuł $\varphi$, czyli

$$
\begin{aligned}
& \mathfrak{M}, v_{1} \vDash \psi \text { wtw } \mathfrak{M}, v_{2} \vDash \psi \\
& \mathfrak{M}, v_{1} \vDash \chi \text { wtw } \mathfrak{M}, v_{2} \vDash \chi
\end{aligned}
$$

Zatem:

$$
\begin{array}{lll}
\mathfrak{M}, v_{1} \vDash \psi \wedge \chi & \text { wtw } \mathfrak{M}, v_{1} \vDash \psi \text { i } \mathfrak{M}, v_{1} \vDash \chi & \\
& \text { wtw } \mathfrak{M}, v_{2} \vDash \psi \text { i } \mathfrak{M}, v_{2} \vDash \chi \quad \text { zał. ind. } \\
& \text { wtw } \mathfrak{M}, v_{2} \vDash \psi \wedge \chi
\end{array}
$$

Przypadek $\varphi:=\forall x \psi$

Założenie indukcyjne: twierdzenie zachodzi dla $\psi$, czyli

$$
\mathfrak{M}, v_{1} \vDash \psi \text { wtw } \mathfrak{M}, v_{2} \vDash \psi
$$

dla dowolnych $v_{1}, v_{2}$ takich, że dla każdego $y \in V F(\psi), v_{1}(y)=v_{2}(y)$.

Rozważmy teraz dowolne $v_{1}$ i $v_{2}$, które zgadzają się na wszystkich elementach $V F(\forall x \psi)$. Więc dla dowolnego $o \in D$ ich $x$-warianty $v_{1}^{\prime}$ i $v_{2}^{\prime}$, takie, że $v_{1}^{\prime}(x)=v_{2}^{\prime}(x)=o$ zgadzają się na wszystkich elementach $V F(\psi)=$ $V F(\forall x \psi) \cup\{x\}$. Zatem z założenia indukcyjnego mamy:

$$
\star \mathfrak{M}, v_{1}^{\prime} \vDash \psi \text { wtw } \mathfrak{M}, v_{2}^{\prime} \vDash \psi
$$

Zatem:

$\mathfrak{M}, v_{1} \vDash \forall x \psi \quad$ wtw $\mathfrak{M}, v_{1}^{\prime} \vDash \psi$ dla dowolnego $o \in D$ wtw $\mathfrak{M}, v_{2}^{\prime} \vDash \psi$ dla dowolnego $o \in D \quad$ przez $\star$ wtw $\mathfrak{M}, v_{2} \vDash \forall x \psi$

Dowód przypadków dla $\varphi:=\neg \psi, \varphi \vee \psi, \varphi \rightarrow \psi, \exists x \psi$ pozostawiamy czytelnikowi.

Odnotujmy dwa ważne wnioski z lematu o koincydencji: 
Fakt 8.5 1. Jeżeli $\varphi$ jest zdaniem, to $\mathfrak{M}, v_{1} \vDash \varphi$ wtw $\mathfrak{M}, v_{2} \vDash \varphi$, dla dowolnych $v_{1}, v_{2}$.

2. Jeżeli $\varphi$ jest zdaniem, to jest spetnione przez pewna waluację wtw jest spetnione przez każda waluację.

DowóD:

Ad 1: $\operatorname{VF}(\varphi)=\varnothing$, więc dowolne waluacje zgadzają się na $V F(\varphi)$.

Ad 2: przejście od 'pewnej' do 'każdej' wynika z poprzedniego wniosku.

\section{Lemat 8.6 (Twierdzenie o podstawianiu:)}

1. $I_{v}\left(\tau\left[x / \tau^{\prime}\right]\right)=I_{v_{I_{v}\left(\tau^{\prime}\right)}^{x}}(\tau)$;

2. $\mathfrak{M}, v \vDash \varphi[x / \tau]$ wtw $\mathfrak{M}, v_{I_{v}(\tau)}^{x} \vDash \varphi$.

Uwaga 8.14: Dla osób 'uczulonych' na piętrowe wzory można powyższe twierdzenie wyrazić alternatywnie np. w taki sposób:

1. Jeżeli $v^{\prime}(x)=I_{v}\left(\tau^{\prime}\right)$, to $I_{v}\left(\tau\left[x / \tau^{\prime}\right]\right)=I_{v^{\prime}}(\tau)$;

2. Jeżeli $v^{\prime}(x)=I_{v}(\tau)$, to $\mathfrak{M}, v \vDash \varphi[x / \tau]$ wtw $\mathfrak{M}, v^{\prime} \vDash \varphi$.

DowóD: Ma podobny charakter do dowodu twierdzenia o koincydencji. W części pierwszej przez indukcję strukturalną po złożoności termu $\tau$. Tym razem $\mathrm{w}$ bazie mamy trzy przypadki: $\tau:=c$ lub $\tau$ jest zmienną różną lub identyczną z $x$.

Niech $\tau:=c$, wtedy $c\left[x / \tau^{\prime}\right]=c$

Zatem:

$$
I_{v}\left(c\left[x / \tau^{\prime}\right]=I_{v}(c)=V(c)=I_{v}^{\prime}(c)\right.
$$

Niech $\tau:=y$, wtedy $y\left[x / \tau^{\prime}\right]=y$

Zatem:

$$
I_{v}\left(y\left[x / \tau^{\prime}\right]=I_{v}(y)=v(y)=v^{\prime}(y)=I_{v}^{\prime}(y)\right.
$$


Zauważmy, że $v(y)=v^{\prime}(y)$ bo $v^{\prime}$ jest $x$-wariantem $v$ zatem zgadza się z $v$ na pozostałych zmiennych.

Na koniec $\tau:=x$, wtedy $x\left[x / \tau^{\prime}\right]=\tau^{\prime}$

Zatem:

$$
I_{v}\left(x\left[x / \tau^{\prime}\right]=I_{v}\left(\tau^{\prime}\right)=v^{\prime}(x)=I_{v}^{\prime}(x)=I_{v}^{\prime}(\tau)\right.
$$

Krok indukcyjny: dowodzimy, że twierdzenie zachodzi dla termu $\tau:=$ $f\left(\tau_{1}, \ldots, \tau_{n}\right)$ przy założeniu, że zachodzi dla jego składników.

Założenie indukcyjne: twierdzenie zachodzi dla dowolnego $i \leq n$, czyli:

$$
I_{v}\left(\tau_{i}\left[x / \tau^{\prime}\right]\right)=I_{v^{\prime}}\left(\tau_{i}\right)
$$

Zatem:

$$
\begin{aligned}
I_{v}\left(f\left(\tau_{1}, \ldots, \tau_{n}\right)\left[x / \tau^{\prime}\right]\right) & =I_{v}\left(f\left(\tau_{1}\left[x / \tau^{\prime}\right], \ldots, \tau_{n}\left[x / \tau^{\prime}\right]\right)\right) \\
& =V(f)\left\langle I_{v}\left(\tau_{1}\left[x / \tau^{\prime}\right]\right), \ldots, I_{v}\left(\tau_{n}\left[x / \tau^{\prime}\right]\right)\right\rangle \\
& =V(f)\left\langle I_{v^{\prime}}\left(\tau_{1}\right), \ldots, I_{v^{\prime}}\left(\tau_{n}\right)\right\rangle \\
& =I_{v^{\prime}}\left(f\left(\tau_{1}, \ldots, \tau_{n}\right)\right)
\end{aligned}
$$

Dla części drugiej twierdzenia o podstawianiu przeprowadzamy dowód przez indukcję strukturalną po złożoności formuły $\varphi$.

Baza $-\varphi:=P\left(\tau_{1}, \ldots, \tau_{n}\right)$.

$\mathrm{Z}$ poprzedniego punktu twierdzenia o podstawianiu mamy dla dowolnego $i \leq n$ :

$$
\star \quad I_{v}\left(\tau_{i}[x / \tau]\right)=I_{v^{\prime}}\left(\tau_{i}\right)
$$

Zatem:

$$
\begin{aligned}
\mathfrak{M}, v \vDash P\left(\tau_{1}, \ldots, \tau_{n}\right)[x / \tau] & \text { wtw } \mathfrak{M}, v \vDash P\left(\tau_{1}[x / \tau], \ldots, \tau_{n}[x / \tau]\right) \\
& \text { wtw }\left\langle I_{v}\left(\tau_{1}[x / \tau]\right), \ldots, I_{v}\left(\tau_{n}[x / \tau]\right)\right\rangle \in V(P) \\
& \text { wtw }\left\langle I_{v^{\prime}}\left(\tau_{1}\right), \ldots, I_{v^{\prime}}\left(\tau_{n}\right)\right\rangle \in V(P) \\
& \text { wtw } \mathfrak{M}, v^{\prime} \vDash P\left(\tau_{1}, \ldots, \tau_{n}\right)
\end{aligned}
$$

Krok indukcyjny: dowodzimy, że twierdzenie zachodzi dla każdej formuły złożonej przy założeniu, że zachodzi dla jej podformuł. Podobnie jak poprzednio ograniczymy się do rozważenia dwóch przypadków. 
Przypadek $\varphi:=\psi \wedge \chi$. Założenie indukcyjne: twierdzenie zachodzi dla podformul $\varphi$, czyli

$$
\begin{aligned}
& \mathfrak{M}, v \vDash \psi[x / \tau] \text { wtw } \mathfrak{M}, v^{\prime} \vDash \psi \\
& \mathfrak{M}, v \vDash \chi[x / \tau] \text { wtw } \mathfrak{M}, v^{\prime} \vDash \chi
\end{aligned}
$$

\section{Zatem:}

$$
\begin{aligned}
\mathfrak{M}, v \vDash \psi \wedge \chi[x / \tau] & \text { wtw } \mathfrak{M}, v \vDash \psi[x / \tau] \wedge \chi[x / \tau] & \\
& \text { wtw } \mathfrak{M}, v \vDash \psi[x / \tau] \mathrm{i} \mathfrak{M}, v \vDash \chi[x / \tau] & \\
& \text { wtw } \mathfrak{M}, v^{\prime} \vDash \psi \text { i } \mathfrak{M}, v^{\prime} \vDash \chi & \text { zał. ind. } \\
& \text { wtw } \mathfrak{M}, v^{\prime} \vDash \psi \wedge \chi &
\end{aligned}
$$

Przypadek $\varphi:=\forall y \psi$. Założenie indukcyjne: twierdzenie zachodzi dla $\psi$, czyli

$$
\mathfrak{M}, v \vDash \psi[x / \tau] \text { wtw } \mathfrak{M}, v^{\prime} \vDash \psi
$$

dla dowolnego $v^{\prime}$ takiego, że $v^{\prime}(x)=I_{v}(\tau)$.

Rozważmy dwa przypadki: $x \notin V F(\forall y \psi)$ i $x \in V F(\forall y \psi)$.

Jeżeli $x \notin V F(\forall y \psi)$ wtedy $\forall y \psi[x / \tau]:=\forall y \psi$, czyli:

$\mathfrak{M}, v \vDash \forall y \psi[x / \tau]$ wtw $\mathfrak{M}, v \vDash \forall y \psi$ wtw $\mathfrak{M}, v^{\prime} \vDash \forall y \psi$

ostatnie przejście uzasadnione przez lemat 8.5 , gdyż $v$ i $v^{\prime}$ różnią się tylko na $x$ a nie różnią się na $V F(\forall y \psi)$.

Jeżeli $x \in V F(\forall y \psi)$, to $x \neq y$ i mamy (a) $\forall y \psi[x / \tau]:=\forall y(\psi[x / \tau])$.

Ponadto $y \notin \operatorname{Var}(\tau)$, skoro $\tau$ jest podstawialne $\mathrm{w} \forall y \psi$, zatem na mocy lematu 8.5 mamy (b) $I_{v}(\tau)=I_{v_{o}^{y}}(\tau)$, dla dowolnego $o \in D$. Zatem:

$$
\begin{array}{ll}
\mathfrak{M}, v \vDash \forall y \psi[x / \tau] \quad \text { wtw } \mathfrak{M}, v \vDash \forall y(\psi[x / \tau]) \\
& \text { wtw } \mathfrak{M}, v_{o}^{y} \vDash \psi[x / \tau] \text { dla dowolnego } o \in D \\
& \text { wtw } \mathfrak{M},\left(v_{o}^{y}\right)^{\prime} \vDash \psi \text { dla dowolnego } o \in D \\
& \text { wtw } \mathfrak{M}, v^{\prime} \vDash \forall y \psi
\end{array}
$$

Dowód przypadków dla $\varphi:=\neg \psi, \varphi \vee \psi, \varphi \rightarrow \psi, \exists x \psi$ pozostawiamy czytelnikowi.

Na koniec dowiedziemy: 
Lemat 8.7 Niech:

(i) $T$ będzie dowolnym zbiorem termów stałych $(\operatorname{Var}(T)=\varnothing)$

(ii) $\mathfrak{M}=\langle D, V\rangle$ spetnia warunek: $\forall_{o \in D} \exists_{\tau \in T} \forall v, I_{v}(\tau)=o$

wtedy jeżeli $\forall_{\tau \in T}, \mathfrak{M} \vDash \varphi[x / \tau]$, to $\mathfrak{M} \vDash \forall x \varphi$.

DowóD: załóżmy, że $\forall_{\tau \in T}, \mathfrak{M} \vDash \varphi[x / \tau]$ i rozważmy dowolne $v$ z $v(x)=o$. Zatem, przez (ii), $\exists \tau^{\prime} \in T, I_{v}\left(\tau^{\prime}\right)=o=v(x)$. Z twierdzenia o podstawianiu mamy, że:

$$
\mathfrak{M}, v \vDash \varphi\left[x / \tau^{\prime}\right] \text { wtw } \mathfrak{M}, v \vDash \varphi
$$

(gdyż $v=v^{\prime}=v_{I_{v}\left(\tau^{\prime}\right)}^{x}$ z założenia tego twierdzenia)

Ponieważ $v$ było dowolne więc mamy:

$$
\mathfrak{M} \vDash \varphi\left[x / \tau^{\prime}\right] \text { wtw } \mathfrak{M} \vDash \varphi
$$

Z założenia mamy $\mathfrak{M} \vDash \varphi\left[x / \tau^{\prime}\right]$, więc $\mathfrak{M} \vDash \varphi$ skąd wynika $\mathfrak{M} \vDash \forall x \varphi$ przez lemat 8.4, punkt 5 .

\subsection{Adekwatność H-KRK}

Ustalimy adekwatność (mocną) systemu aksjomatycznego względem semantyki teoriomodelowej. Przypomnijmy, że adekwatność mocna stwierdza, że $\Gamma \vdash \varphi$ wtw $\Gamma \models \varphi$. Równoważność ta to koniunkcja dwóch twierdzeń:

O przystosowaniu (zgodności, soundness): Jeżeli $\Gamma \vdash \varphi$, to $\Gamma \models \varphi$.

O pełności (completeness): Jeżeli $\Gamma \models \varphi$, to $\Gamma \vdash \varphi$.

\subsubsection{Przystosowanie}

Aby dowieść twierdzenie o przystosowaniu wstępnie należy wykazać dwa lematy:

Lemat 8.8 Każdy aksjomat jest tautologia.

Lemat 8.9 Każda reguła pierwotna jest reguła niezawodna. 
DowóD: Zauważmy, że każdy schemat aksjomatu KRZ jest tautologią KRK. MP jest regułą niezawodną, a niezwodność GEN wynika z lematu 8.4 (punkt 5). Pozostaje wykazać, że trzy aksjomaty kwantyfikatorowe są tautologiami. Rozważmy dwa przypadki:

1. Przypadek $A \forall E$ : należy wykażać, że $\models \forall x \varphi \rightarrow \varphi[x / \tau]$.

Rozważmy dowolny $\mathfrak{M}$ i $v$ takie, że $\mathfrak{M}, v \vDash \forall x \varphi$, zatem $\mathfrak{M}, v_{o}^{x} \vDash \varphi$ dla dowolnego $o \in D$. W szczególności zachodzi to dla $o=I_{v}(\tau)$, czyli $\mathfrak{M}, v_{I_{v}(\tau)}^{x} \vDash$ $\varphi$, co przez twierdzenie o podstawianiu jest równoważne $\mathfrak{M}, v \vDash \varphi[x / \tau]$.

2. Przypadek $A \forall$; dowodzimy, że $\models \forall x(\varphi \rightarrow \psi) \rightarrow(\varphi \rightarrow \forall x \psi)$, pod warunkiem, że $x \notin V F(\varphi)$.

Załóżmy nie wprost, że $A \forall$ nie jest schematem tautologii, czyli istnieje taka interpretacja, że $\mathfrak{M}, v \vDash \forall x(\varphi \rightarrow \psi)$ ale $\mathfrak{M}, v \not \models \varphi \rightarrow \forall x \psi$. Zatem $\mathfrak{M}, v \vDash \varphi$ i $\mathfrak{M}, v \not \models \forall x \psi$, czyli $\mathfrak{M}, v_{o}^{x} \not \models \psi$, dla pewnego $o \in D$. Ponieważ $x \notin V F(\varphi)$ i $x \notin V F(\forall x(\varphi \rightarrow \psi)$, więc, przez twierdzenie o koincydencji, $\mathfrak{M}, v_{o}^{x} \vDash \forall x(\varphi \rightarrow \psi)$ i $\mathfrak{M}, v_{o}^{x} \vDash \varphi$. Ponieważ $v_{o}^{x}$ jest swoim własnym $x$ wariantem, więc $\mathfrak{M}, v_{o}^{x} \vDash \varphi \rightarrow \psi$, co w rezultacie daje sprzeczność (przez $\mathrm{MP})$.

Oba lematy umożliwiają dowód twierdzenia o przystosowaniu przez indukcję po długości dowodu $\Gamma \vdash \varphi$.

\subsubsection{Pełność}

Przystępując do dowodu twierdzenia o pełności przypomnijmy, że mocna postać:

(a) Jeżeli $\Gamma \models \varphi$, to $\Gamma \vdash \varphi$.

jest równoważna z:

(b) Każdy zbiór niesprzeczny jest spełnialny (ma model).

Poniżej udowodnimy warunek (b). Ograniczymy się do prezentacji niekonstruktywnego dowodu w wersji Henkina.

Dowód przeprowadzamy w trzech etapach:

1. Dowód Henkina wykorzystuje lemat Lindenbauma (każdy zbiór niesprzeczny zawiera się w jakimś zbiorze MNSP, tj. maksymalnie niesprzecznym), który dowodzony jest tak samo jak dla KRZ, ale wymaga wzmocnienia o tzw. własność Henkina (WH). 
2. Struktura interpretacyjna dla zbioru MNSP z WH jest budowana z termów stałych, tj. nie zawierających zmiennych ${ }^{3}$.

3. Dla skonstruowanej struktury interpretacyjnej dowodzimy lemat prawdziwościowy (wykazujemy, że jest modelem dla zbioru MNSP z WH a zatem również dla jego podzbioru)

Etap 1:

W KRK sama konstrukcja Lindenbauma nie wystarcza (nie każdy zbiór MNSP ma model). Dodatkowo dla tego zbioru musi być spełniona tzw. własność Henkina (lub $\omega$-zupełność):

Definicja 8.16 WH: $\Gamma$ ma własność Henkina wtw jeżeli $\exists x \varphi \in \Gamma$, to istnieje stała c (tzw. świadek, witness) taka, że $\varphi[x / c] \in \Gamma$.

Uwaga 8.15: Najczęściej w roli 'świadków' wykorzystuje się przeliczalny zbiór nowych stałych pozalogicznych, wtedy w istocie poszerzamy język o dodatkowy zbiór $C O N^{\prime}$ rozłączny ze zbiorem $C O N$. Niżej prezentowany dowód również opiera się na tej strategii.

Lemat 8.10 (Lindenbauma-Henkina) Dla każdego niesprzecznego zbioru $\Delta$ istnieje taki $\Gamma \supseteq \Delta$, który jest MNSP $i$ spetnia $W H$.

DowóD: Wykorzystujemy - tak jak w KRZ - ustalone uporządkowanie formuł i dodatkowo uporządkowanie zbioru $C O N^{\prime}$.

Budujemy ciąg zbiorów formuł: $\Delta=\Delta_{0}, \Delta_{1}, \ldots$ wg. przepisu:

1. $\Delta_{n+1}=\Delta_{n}$, jeżeli $\Delta_{n} \cup\left\{\varphi_{n}\right\}$ jest sprzeczna.

2. $\Delta_{n+1}=\Delta_{n} \cup\left\{\varphi_{n}\right\}$, jeżeli $\Delta_{n} \cup\left\{\varphi_{n}\right\}$ jest niesprzeczna i $\varphi_{n}$ nie jest formuła egzystencjalną.

3. $\Delta_{n+1}=\Delta_{n} \cup\left\{\varphi_{n}, \varphi_{n} \rightarrow \psi[x / c]\right\}$, gdzie $c \in C O N^{\prime}$ nie występuje $\mathrm{w}$ $\Delta_{n} \cup\left\{\varphi_{n}\right\}$, jeżeli $\Delta_{n} \cup\left\{\varphi_{n}\right\}$ jest niesprzeczna i $\varphi_{n}:=\exists x \psi$.

Ponownie jako $\Gamma$ wykorzystujemy uogólnioną sumę wszystkich zbiorów konstruowanego ciągu. W stosunku do konstrukcji zastosowanej do KRZ (por. podrozdział 1.4) tylko trzeci punkt jest nowy. Stałą $c$ wybieramy z listy $C O N^{\prime}$ jako pierwszą dotąd niewykorzystaną. Należy wykazać, że trzeci punkt również dziedziczy niesprzeczność, ale to wynika z lematu 8.3. Ponadto

\footnotetext{
${ }^{3}$ U Gödla [55] model był zbudowany z liczb naturalnych.
} 
mamy gwarancję, że uzyskany zbiór $\Gamma$ jest nie tylko MNSP ale spełnia też WH.

Etap 2 (konstrukcja modelu).

Definicja 8.17 Definicja struktury interpretacyjnej $\mathfrak{M}_{\Gamma}$ dla zbioru $\Gamma$, który jest MNSP $i$ spetnia WH.

$D_{\Gamma}$ to zbiór wszystkich termów stałych $z \Gamma, V_{\Gamma}$ definiujemy następująco:

- $V_{\Gamma}(c)=c$, dla dowolnej stałej nazwowej c.

- $V_{\Gamma}\left(f^{n}\left(\tau_{1}, \ldots, \tau_{n}\right)\right)=f^{n}\left(\tau_{1}, \ldots, \tau_{n}\right)$, dla dowolnej $n$-argumentowej operacji $f^{n} i$ dowolnych $\tau_{1}, \ldots, \tau_{n} \in D_{\Gamma}$.

- $\left\langle\tau_{1}, \ldots, \tau_{n}\right\rangle \in V_{\Gamma}\left(P^{n}\right)$ wtw $P^{n}\left(\tau_{1}, \ldots, \tau_{n}\right) \in \Gamma$ dla dowolnego n-argumentowego predykatu $P^{n} i$ dowolnych $\tau_{1}, \ldots, \tau_{n} \in D_{\Gamma}$.

Fakt 8.6 Oto pewne konsekwencje definicji struktury interpretacyjnej:

1. Niech $I_{v}$ oznacza interpretację termów $w \mathfrak{M}_{\Gamma}$ dla dowolnej waluacji $v$, dla dowolnego termu stałego $\tau, I_{v}(\tau)=\tau$.

2. $\mathfrak{M}_{\Gamma}$ spetnia warunek: $\forall_{o \in D_{\Gamma}} \exists_{\tau} \forall v, I_{v}(\tau)=o$.

3. Jeżeli $\forall_{\tau \in D_{\Gamma}}, \mathfrak{M}_{\Gamma} \vDash \varphi[x / \tau]$, to $\mathfrak{M}_{\Gamma} \vDash \forall x \varphi$.

DowóD: Punkt 1 wynika z definicji $V_{\Gamma}$, punkt 2 wynika z punktu 1 , a 3 z 2 i z lematu 8.7.

Etap 3:

Musimy wykazać, że $\mathfrak{M}_{\Gamma}$ jest modelem dla zbioru $\Gamma$, tj., że $\Gamma \subseteq E\left(\mathfrak{M}_{\Gamma}\right)$. Wykażemy $\mathrm{w}$ istocie fakt mocniejszy $-\Gamma=E\left(\mathfrak{M}_{\Gamma}\right)$. Dowód jest oparty na zmodyfikowanym lemacie prawdziwościowym: 
Lemat 8.11 (lemat prawdziwościowy H:) Dla dowolnego zbioru MNSP $\Gamma$ z WH istnieje model $\mathfrak{M}_{\Gamma}$ taki, że dla dowolnego zdania $\varphi$ :

$$
\varphi \in \Gamma w t w \mathfrak{M}_{\Gamma} \vDash \varphi
$$

DowóD: Dowodzimy przez indukcję strukturalną po kształcie formuł, że zachodzi podana wyżej równoważność

$$
\begin{array}{rll}
\text { Baza: } P\left(\tau_{1}, \ldots, \tau_{n}\right) \in \Gamma \text { wtw } \mathfrak{M}_{\Gamma} \vDash P\left(\tau_{1}, \ldots, \tau_{n}\right) & \\
P\left(\tau_{1}, \ldots, \tau_{n}\right) \in \Gamma \text { wtw } & \left\langle\tau_{1}, \ldots, \tau_{n}\right\rangle \in V_{\Gamma}(P) & \\
\text { wtw } & \left\langle I_{v}\left(\tau_{1}\right), \ldots, I_{v}\left(\tau_{n}\right)\right\rangle \in V_{\Gamma}(P), & \text { def. } V_{\Gamma} \\
& \text { dla dowolnego } I_{v}, \\
\text { wtw } & \mathfrak{M}_{\Gamma}, v \vDash P\left(\tau_{1}, \ldots, \tau_{n}\right), & \text { fakt } 8.6, \text { punkt } 1 . \\
& \text { dla dowolnego } v & \\
\text { wtw } & \mathfrak{M}_{\Gamma} \vDash P\left(\tau_{1}, \ldots, \tau_{n}\right) & \text { z def. } \vDash .
\end{array}
$$

Dla dowodu kroku indukcyjnego zakładamy, że każda formuła krótsza od $\varphi$ spełnia dowodzoną równoważność i wykazujemy ją dla $\varphi$ :

Przypadek $\varphi:=\forall x \psi:$

$$
\begin{array}{rll}
\Longrightarrow & \\
\forall x \psi \in \Gamma \text { implikuje } & \psi[x / \tau] \in \Gamma \text {, dla dowolnego } \tau \in D_{\Gamma} & \text { własności MNSP } \\
\text { wtw } & \mathfrak{M}_{\Gamma} \vDash \psi[x / \tau] & \text { z zał. ind. } \\
\text { implikuje } & \mathfrak{M}_{\Gamma} \vDash \forall x \psi & \text { fakt 8.6, punkt 3. }
\end{array}
$$

Uzasadnienie dla pierwszej implikacji wynika stąd, że każdy zb. MNSP zawiera wszystkie tezy (więc i $A \forall E$ ) i jest domknięty na MP.

$\Longleftarrow$ : Załóżmy, że (1) $\mathfrak{M}_{\Gamma} \vDash \forall x \psi$ ale (2) $\forall x \psi \notin \Gamma$. Z (2) wynika, że $\neg \forall x \psi \in \Gamma$ (bo $\Gamma$ jest MNSP), zatem $\exists x \neg \psi \in \Gamma$, przez aksjomat $A \exists$. Stąd, przez WH, mamy $\neg \psi[x / c] \in \Gamma$ dla pewnego $c \in C O N^{\prime}$, ale (1) implikuje $\mathfrak{M}_{\Gamma} \vDash \psi[x / c]$, co przez założenie indukcyjne jest równoważne $\psi[x / c] \in \Gamma-$ sprzeczność.

Kilka konsekwencji twierdzenia o pełności:

- $\varphi$ jest niesprzeczne z $\Gamma$ wtw $\Gamma \cup\{\varphi\}$ ma model;

- $\varphi$ jest niezależne od $\Gamma$ wtw $\Gamma \cup\{\neg \varphi\}$ ma model;

- $\Gamma$ ma model wtw każdy skończony podzbiór $\Gamma$ ma model (twierdzenie o zwartości); 
- jeżeli $\Gamma$ jest niesprzeczna, to ma model przeliczalny (twierdzenie LöwenheimaSkolema).

Uwaga 8.16: Ostatni fakt jest czasem traktowany jako paradoksalny, np. teoria liczb rzeczywistych jest aksjomatyzowalna jako teoria elementarna, zatem teoria opisująca zbiór nieprzeliczalny jest semantycznie charakteryzowalna z pomocą zbioru przeliczalnego.

\subsubsection{Pełność KRKI}

Powyższy dowód twierdzenia o pełności można przystosować do H-KRKI. Podstawowa modyfikacja dotyczy etapu 2 (konstrukcja modelu) - naszkicujemy ją poniżej.

W $D_{\Gamma}$ musimy utożsamić te termy stałe $\tau_{1}, \tau_{2}$, dla których zachodzi identyczność $\mathrm{w} \Gamma$, w tym celu wprowadzamy relację $\sim$ definiowaną następująco:

$$
\tau_{1} \sim \tau_{2} \text { wtw } \tau_{1}=\tau_{2} \in \Gamma
$$

Relacja $\sim$ jest równoważnością na zbiorze wszystkich termów stałych, gdyż z racji maksymalności $\Gamma$ odpowiednie twierdzenia dla $=$ (zwrotność, symetria, przechodniość) należą do tego zbioru. Dla dowolnej relacji równoważności zachodzi zasada abstrakcji, zatem $\sim$ dzieli zbiór wszystkich termów stałych na klasy abstrakcji $[\tau]_{\sim}=\left\{\tau^{\prime}: \tau \sim \tau^{\prime}\right\}$. Przyjmujemy, że $D_{\Gamma}$ jest strukturą ilorazową $\mathrm{z} \sim$, tzn. zbiorem wszystkich klas abstrakcji, czyli:

$$
D_{\Gamma}=\left\{[\tau]_{\sim}: \tau \text { jest termem stałym }\right\}
$$

W definicji $V_{\Gamma}$ musimy dokonać odpowiednich zmian, gdyż denotacjami stałych pozalogicznych są obecnie relacje lub operacje na klasach abstrakcji indukowane z ich odpowiedników na termach, zatem:

- $V_{\Gamma}(c)=[c]_{\sim}$, dla dowolnej stałej nazwowej $c$;

- $V_{\Gamma}\left(f^{n}\left(\tau_{1}, \ldots, \tau_{n}\right)\right)=f^{n}\left(\left[\tau_{1}\right]_{\sim}, \ldots,\left[\tau_{n}\right]_{\sim}\right)$, dla dowolnej $n$-argumentowej operacji $f^{n}$ i dowolnych $\left[\tau_{1}\right]_{\sim}, \ldots,\left[\tau_{n}\right]_{\sim} \in D_{\Gamma}$;

- $\left\langle\left[\tau_{1}\right]_{\sim}, \ldots,\left[\tau_{n}\right]_{\sim}\right\rangle \in V_{\Gamma}\left(P^{n}\right)$ wtw $P^{n}\left(\tau_{1}, \ldots, \tau_{n}\right) \in \Gamma$ dla dowolnego predykatu $n$-argumentowego $P^{n}$ i dowolnych $\left[\tau_{1}\right]_{\sim}, \ldots,\left[\tau_{n}\right]_{\sim} \in D_{\Gamma}$.

Poprawność definicji jest zagwarantowana przez odpowiednie prawa dla $=$ należące, z racji maksymalności, do $\Gamma$. 


\subsection{Wybrane własności KRK}

KRK nie jest logiką rozstrzygalną ${ }^{4}$, ale jest logiką semi-rozstrzygalną. W bardziej formalnym ujęciu możemy powiedzieć, że jej zbiór tautologii nie jest rekurencyjny (jak w przypadku KRZ), ale jest rekurencyjnie przeliczalny. W praktyce znaczy to, że jeżeli sprawdzana formuła jest tautologią, to można w skończonym czasie to potwierdzić za pomocą mechanicznej procedury (jedna $\mathrm{z}$ nich zostanie przedstawiona $\mathrm{w}$ następnym rozdziale). Natomiast nie istnieja (i nie moga istnieć) żadne procedury, które dla dowolnej nietautologicznej formuły, w skończonym czasie ustalą, że nie jest ona tautologią.

Należy podkreślić, że fakt nierozstrzygalności w żaden sposób nie przekreśla możliwości automatyzacji procesu poszukiwania dowodu. Co więcej istnieją liczne fragmenty KRK, które są rozstrzygalne, a wiele z nich posiada bardzo wydajne procedury sprawdzania nawet przy braku rozstrzygalności (np. logika klauzul Horna). Jeden z najwcześniejszych i najważniejszych wyników na polu automatyzacji dowodzenia w KRK i logikach elementarnych to twierdzenie Herbranda, które pokazuje jak w pewien sposób dowodzenie w KRK sprowadzić do wykazywania tautologiczności w KRZ. Oryginalne twierdzenie Herbranda i jego dowód jest trudny do prześledzenia, a ponadto zawiera błąd, który został zidentyfikowany przez Drebena, Andrewsa i Aanderaa [33] oraz poprawiony w pracy Drebena i Dentona [34]. Z tego względu w literaturze pod nazwą twierdzenia Herbranda funkcjonuje zaskakująco wiele twierdzeń o różnym stopniu ogólności, które w jakiś sposób wiążą się z jego wynikiem. Ponieważ jeden z wyników Gentzena, który przedstawimy w podrozdziale 9.7, przez samego Gentzena był (zresztą błędnie) postrzegany jako uogólnienie wyniku Herbranda, więc przedstawimy tu w dużym skrócie idee tego twierdzenia. Dodatkowo, w podrozdziale 9.8 udowodnimy pewną specjalną postać twierdzenia Herbranda dla zilustrowania przydatności opisanego tam sposobu formalizowania teorii elementarnych.

Wynik Herbranda ma charakter czysto syntaktyczny (wbrew często występującym współcześnie semantycznym wariantom). W swojej dysertacji oprócz pewnej wersji systemu aksjomatycznego H, Herbrand przedstawił pewien specjalny system dedukcyjny HR dla KRK. Jego aksjomatami były wszystkie tautologie bez kwantyfikatorów, a zbiór reguł pierwotnych zawierał reguły dołączania kwantyfikatorów, zamiany na alfabetyczne warianty, przesuwania kwantyfikatorów do wewnątrz formuły (przeciwieństwo tworzenia formuł w postaci preneksowej) i upraszczania (kontrakcji) alternatyw

\footnotetext{
${ }^{4}$ Nieroztrzygalność KRK wynika z tezy Churcha-Turinga, zgodnie z którą zbiór funkcji obliczalnych pokrywa się ze zbiorem funkcji obliczalnych w sensie dowolnego matematycznego modelu obliczania, np. maszyn Turinga.
} 
zawierających więcej wystąpień tej samej formuły. System HR nie zawiera reguły MP, zatem jest w pewien sposób odpowiednikiem RS bez (Cut). Dodatkowo, z każdą formułą pierwszego rzędu $\varphi$ koreluje Herbrand nieskończony ciąg formuł $\psi_{1}, \psi_{2}, \ldots$, które nie zawierają kwantyfikatorów. Elementy tego ciągu są efektywnie otrzymywane z $\varphi$ przez dokonanie podstawień zdefiniowanych odpowiednio termów dla podformuł, które są w zasięgu kwantyfikatora ogólnego. Dowolna skończona alternatywa $\psi_{1} \vee \ldots \vee \psi_{n}$ to ekspansja $\varphi$.

Zasadniczy wynik to:

\section{Twierdzenie 8.3 (Herbrand) 1. Jeżeli $\vdash_{H R} \varphi, t_{H} \vdash_{H} \varphi$.}

2. Jeżeli $\vdash_{H} \varphi$, to pewna ekspansja $\varphi$ jest tautologiczna.

3. Jeżeli pewna ekspansja $\varphi$ jest tautologiczna, to $\vdash_{H R} \varphi$.

Intuicyjnie rzecz ujmując wynik Herbranda pokazuje jak problem dowiedlności w KRK sprowadzić do problemu dowiedlności w KRZ. Część druga pokazuje, że w oparciu o dowolny dowód $\varphi$ można obliczyć wielkość jego tautologicznej ekspansji (tzn. określić $n$ ). Część trzecia jest dla nas najbardziej interesująca, gdyż stanowi pewien analogon twierdzenia o eliminacji (Cut).

Twierdzenie o interpolacji zachodzi również dla KRK; można je przedstawić w następującej postaci:

Twierdzenie 8.4 Jeżeli $=\varphi \rightarrow \psi$ i $P(\varphi) \cap P(\psi) \neq \varnothing$, to istnieje $\chi$ takie, $\dot{z} e$ :

- $P(\chi) \subseteq P(\varphi) \cap P(\psi)$,

$\bullet \models \varphi \rightarrow \chi$

$\bullet \models \chi \rightarrow \psi$.

gdzie $P(\varphi)$ oznacza zbiór symboli pozalogicznych, które występują w $\varphi$ czyli termów i predykatów. Z twierdzenia tego wynikają w prosty sposób (a ściślej rzecz ujmując są równoważne) ważne twierdzenia: Betha o definiowalności i Robinsona o łącznej spójności modelowej $\vdash_{H R} \varphi$ (joint consistency theorem); por. np. Gallier [48]. 


\subsection{Dedukcja naturalna}

System DN Gentzena dla KRK zawiera dodatkowo dwie reguły inferencji i dwie reguły konstrukcji dowodu. Zamiast zmiennych wolnych używa Gentzen specjalnych symboli tzw. parametrów. Dyskusję nad zaletami i wadami tego rozwiązania przeprowadzimy w następnym rozdziale. Schematy reguł wyglądają następująco:

$(\forall E) \quad \forall x \varphi / \varphi[x / a]$, gdzie $a$ jest dowolnym parametrem.

$(\forall D) \quad$ Jeżeli $\Gamma \vdash_{D N} \varphi[x / a]$, to $\Gamma \vdash_{D N} \forall x \varphi$, gdzie $a$ jest parametrem nie występującym w aktywnych założeniach $\Gamma$.

$(\exists D) \quad \varphi[x / a] / \exists x \varphi$, gdzie $a$ jest dowolnym parametrem.

$(\exists E) \quad$ Jeżeli $\Gamma \vdash_{D N} \exists x \varphi$ i $\Delta, \varphi[x / a] \vdash_{D N} \psi$, to $\Gamma, \Delta \vdash_{D N} \psi$, pod warunkiem, że $a$ jest parametrem nie występującym w $\varphi, \psi$ i zbiorze aktywnych założeń $\Gamma, \Delta$.

Ostatnia reguła w zastosowaniu w drzewie dowodowym wygląda następująco:

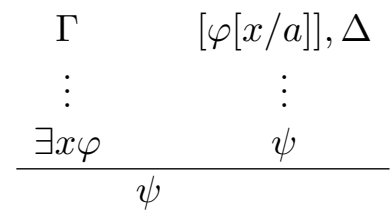

Powyższy zestaw reguł może być oczywiście zastosowany również na gruncie systemu DN z dowodami linearnymi czyli w stylu Jaśkowskiego ${ }^{5}$. Ostatnia reguła wymaga wtedy wprowadzania nowego poddowodu zaczynającego się od $\varphi[x / a]$ jako dodatkowego założenia. Zastosowanie $(\forall D) \mathrm{w}$ formacie Jaśkowskiego w zasadzie nie wymaga otwierania nowego poddowodu, a jedynie dopilnowania by warunki ograniczajace były spełnione. Stwarza to wrażenie, że - w przeciwieństwie do $(\exists E)-(\forall D)$ jest regułą inferencji. Jak widać zachowana jest strategia charakteryzowania każdej stałej z pomocą pary reguł, ale $(\forall D)$ i $(\exists E)$ ujawniają pewien brak symetrii, w przeciwieństwie do reguł RS, które omówimy w następnym rozdziale. Stosowane były zresztą później rozmaite rozwiązania, w których np. zarówno $(\forall D)$ jak i $(\exists E)$ były regułami inferencji (por. obszerną dyskusję w Indrzejczak [74]). Dotąd jednak można spotkać się z zarzutem, że istniejące systemy DN są w pewien sposób "nieeleganckie" a nawet nienaturalne.

\footnotetext{
${ }^{5}$ Jaśkowski [76] też zaproponował reguły dla kwantyfikatorów. Były one jednak - w zamierzeniu autora - słabsze od reguł dla kwantyfikatorów klasycznych i charakteryzowały pewien system logiki inkluzywnej czyli dopuszczającej modele z pustymi dziedzinami.
} 
Warto zauważyć, że relacja $\vdash_{D N}$ generowana przez powyższy zestaw reguł odpowiada $\vdash_{2}$ w systemie aksjomatycznym. Zachodzi następujące:

Twierdzenie 8.5 $\Gamma \vdash_{D N} \varphi$ wtw $\Gamma \vdash_{2} \varphi$ w systemie aksjomatycznym

Podobna sytuacja zachodzi w przypadku RS, jeżeli $\Rightarrow$ interpretujemy jako relację dowiedlności $\vdash$. 


\section{Rozdział 9}

\section{RS dla KRK i teorii elementarnych}

W rozdziale tym, w skondensowanej formie, poszerzymy na RS dla KRK i teorii pierwszego rzędu, podstawowe rezultaty uzyskane w rozdziałach 3-7 dla KRZ. Kondensacja polega przede wszystkim na tym, że uzupełniamy zazwyczaj tylko jeden z dowodów podanych dla wersji zdaniowych, pozostawiając wysiłek systematycznego poszerzenia innych podejść czytelnikowi. Natomiast dokładniej są traktowane kwestie charakterystyczne dla języka pierwszego rzędu. Po omówieniu kwestii językowych związanych z budową RS dla KRK, a związanych $\mathrm{z}$ dwiema strategiami w odniesieniu do traktowania zmiennych wolnych, wprowadzimy oryginalny rachunek Gentzena LK. W podrozdziale 9.3 zdefiniujemy ważną klasę tzw. PV-dowodów i opiszemy dwa sposoby jej charakteryzowania. Podrozdział 9.4 jest poświęcony dowodowi eliminacji cięcia dla LK, przy czym omówiony jest tylko dowód Gentzena. W dwóch kolejnych podrozdziałach charakteryzujemy ARS dla KRK i dowodzimy analogony najważniejszych twierdzeń, które przedstawiono wcześniej dla wersji zdaniowej. W szczególności, w 9.6 podany jest konstruktywny dowód pełności metodą Hintikki. W kolejnym podrozdziale przedstawiamy dowód wzmocnionego twierdzenia o eliminacji (Cut), który można uznać za pewną wersję twierdzenia Herbranda. Na koniec omawiamy różne sposoby formalizowania teorii elementarnych na gruncie RS, koncentrując się przede wszystkim na regułowym podejściu Negri i von Plato, które wydaje się oferować najwięcej korzyści. 


\subsection{Zagadnienia językowe}

W pracach z zakresu teorii dowodu czy badań nad automatycznym dowodzeniem twierdzeń można odnotować dwie zasadnicze strategie odnośnie konstrukcji języka:

- standardowa - te same symbole reprezentują zmienne indywiduowe zarówno związane jak i wolne;

- parametryczna - rozróżnia się notacyjnie pomiędzy zmiennymi związanymi a wolnymi; te ostatnie nazywając zazwyczaj parametrami.

Prezentując języki pierwszego rzędu w poprzednim rozdziale zastosowaliśmy konstrukcję standardową, w której te same symbole reprezentują zmienne zarówno związane jak i wolne. Oryginalny system Gentzena LK (i LJ) jest jednak zdefiniowany dla języków, w których używa się osobnych symboli dla zmiennych związanych i wolnych. Wydaje się, że u Gentzena wiązało się to jedynie z chęcia uproszczenia sposobu prezentacji swojego wyniku. Podobnie podchodziło do tego potem wielu innych autorów, np. Takeuti [143], stwierdzając, że jest to czysto techniczne rozwiązanie upraszczające dowody. Jednak w wielu pracach późniejszych autorów można znaleźć także intuicyjne uzasadnienia dla tego typu zabiegu; tak jest np. w pracach Smullyana [131], Fittinga [43] czy Fine'a [41]. W takim ujęciu zmienne to tylko termy związane przez kwantyfikatory, natomiast zamiast zmiennych wolnych używa się nie tylko osobnego rodzaju symboli, ale wprowadza się osobną kategorię wyrażeń nazwowych określanych zazwyczaj jako parametry.

Potrzeba wprowadzania nowego rodzaju termów związana jest zazwyczaj z faktem, że zmienne wolne są często domyślnie rozumiane jako kwantyfikowane ogólnie, natomiast parametry mają za zadanie wskazywać pewne nieokreślone obiekty. Są więc raczej bliższe stałym indywiduowym, z tym, że stałe wskazują określony obiekt (przy zadanej interpretacji), a parametry obiekt nieokreślony.

Sens parametru najlepiej uchwycić na przykładzie działania reguły odłącania $\exists \mathrm{w}$ dedukcji naturalnej czy systemach tablicowych. Oto mamy $\exists x \varphi$, wiemy zatem, że pewien obiekt spełnia warunek $\varphi$, choć nie wiemy jaki to obiekt. Chcąc dalej w dedukcji korzystać z $\varphi$ odłączamy $\exists$ wstawiając za $x$ parametr $a$. Jest to w pewnym sensie nazwa jakiegoś obiektu, ale o specyficznym statusie. Zewnętrznym i czysto syntaktycznym wyrazem różnicy między parametrami, a stałymi indywiduowymi jest to, że stała indywiduowa może występować $\mathrm{w}$ dowodzonej tezie podczas gdy parametr może wystąpić 
jedynie $\mathrm{w}$ obrębie dowodu jako jego tymczasowy, techniczny element ${ }^{1}$. W przypadku systemu DN Gentzena uzyskujemy to w ten sposób, że $\varphi[x / a]$ jest wprowadzone jako dodatkowe założenie dla dedukcji formuły nie zawierającej $a$ (por. schemat $(\exists E)$ podany pod koniec poprzedniego rozdziału).

Wybór strategii parametrycznej ma swoje zalety, wymieńmy tu trzy:

1. większa intuicyjność;

2. uproszczenie definicji poprawnego podstawiania;

3. twierdzenie o eliminacji (Cut) bez ograniczeń.

Co do pierwszego punktu to wyżej zaznaczyliśmy, że użycie parametrów już na poziomie syntaktycznym odzwierciedla intuicyjne różnice jakie zachodzą między zmienną związaną, która jest faktycznie tylko wskaźnikiem miejsca dla termu (tzw. placeholder), a jej nieokreślonym statusem po odjęciu kwantyfikatora. Odnośnie drugiej kwestii; jeżeli przyjmiemy, że symbole reprezentujące zmienne związane nie mogą występować jako wolne, to zbędny staje się wymóg, aby zmienne podstawianego termu nie stały się związane, gdyż z definicji jest to niemożliwe. Do trzeciego punktu wrócimy poniżej, po wprowadzeniu reguł dla kwantyfikatorów.

Modyfikacja języka przez wprowadzenie parametrów ma też pewne niekorzystne konsekwencje, gdyż przy standardowym podejściu mamy:

1. prostszy słownik;

2. prostszą definicję termu i formuły;

3. prostszą definicję podformuły.

Pierwszy punkt nie wymaga komentarza. W dalszym ciągu przedstawiając podejście Gentzena unikniemy zresztą rozbudowy słownika, gdyż nie będziemy w przykładach stosować osobnych symboli dla parametrów - użyjemy po prostu tych samych symboli, które schematycznie przyjęliśmy dla reprezentowania stałych nazwowych, tj. $a, b, c, \ldots{ }^{2}$. Różnica ze standardowym podejściem sprowadzi się tu tylko do tego, że wykluczymy możliwość wystąpienia symboli $x, y, .$. jako reprezentujących zmienne wolne.

${ }^{1}$ Podobna sytuacja występuje w dowodach pełności dla KRK, gdzie zbiór termów wzbogaca się o przeliczalny zbiór tzw. świadków, aby zagwarantować w modelu kanonicznym prawdziwość formuł egzystencjalnych; por. paragraf 8.4.2, uwaga 8.15.

2 Rozwiązanie takie stosuje wielu autorów w przypadku systemów tablicowych, np. Bell i Machover [11], czy DN, np. Garson [47]. 
Co do drugiego punktu, to zauważmy, że w wyniku przyjętego rozróżnienia wyrażenia typu $f(a x), A y$ nie są ściśle rzecz biorąc termami czy formułami. Żeby formalnie ująć różnicę syntaktyczną między obu rodzajami zmiennych należy albo (a) zmodyfikować definicję termu i formuły albo (b) oprócz termów i formuł wprowadzić dodatkowo pojęcie semi-termu (quasitermu) i semi-formuły (quasi-formuły).

Przy pierwszym podejściu (tj. (a)) w definicji termu wyrzucamy warunek, że $V A R \subseteq T E R M$. Wtedy w definicji formuły w warunku 1 nic nie musimy zmieniać, ale warunek 5 musimy zamienić na następujący:

5' jeżeli $\varphi(a) \in F O R$, to dla dowolnej $x \in V A R, \forall x(\varphi[a / x]), \exists x(\varphi[a / x]) \in$ FOR.

Uwaga 9.1: W sformułowaniu warunku 5' pozwoliliśmy sobie użyć notacji oznaczającej poprawne podstawiania termu za zmienną co może budzić pewne wątpliwości, gdyż formalna definicja tej operacji zakładała przecież wcześniejsze zdefiniowanie pojęcia formuly. Jest to jednak tylko dogodny skrót bo to co jest nam tu faktycznie potrzebne, czyli operacja zastąpienia wszystkich wystąpień $a$ przez $x$, może być tu podana w opisowy sposób, np.

5' jeżeli $\varphi \in F O R$, to dla dowolnej $x \in V A R, \forall x\left(\varphi^{\prime}\right), \exists x\left(\varphi^{\prime}\right) \in F O R$, gdzie $\varphi^{\prime}$ powstaje z $\varphi$ przez zastąpienie wszystkich wystąpień parametru $a$ przez zmienną $x$.

Uwaga 9.2: Takeuti [143] podaje ten warunek w jeszcze bardziej restryktywnej formie:

5" jeżeli $\varphi(a) \in F O R$, to dla dowolnej $x \in V A R$ takiej, że $x \notin V B(\varphi)$, $\forall x(\varphi[a / x]), \exists x(\varphi[a / x]) \in F O R$.

Zastrzeżenie dotyczące zmiennej $x$ od razu wymusza na języku efekt, jaki w rozdziale poprzednim można uzyskać przez odwołanie się do twierdzenia o alfabetycznych wariantach. Np. $\forall x(A x \wedge \exists x B x)$ nie jest formułą wg. takiej definicji, ale $\forall y(A y \wedge \exists x B x)$ już jest, podobnie formułą nie jest przy takim ujęciu przykład 8.1 analizowany przez nas w poprzednim rozdziale. Jak się przekonamy, z punktu widzenia dowodu eliminacji cięcia, takie ograniczenie języka na wejściu jest korzystne.

Przy drugim podejściu (tj. (b)) wprowadzamy ogólniejszą kategorię semitermu definiowaną tak jak w poprzednim rozdziale zdefiniowaliśmy termy, z tym, że z semi-termem lub semi-formułą mamy do czynienia, gdy przynajmniej jeden argument wyrażenia funkcyjnego lub predykatu jest symbolem zmiennej, ale nie związanym. 
Odnośnie trzeciego punktu, to rozwiązanie z parametrami generalnie prowadzi do tego, że zbiór podformuł dowolnej formuły zawierającej kwantyfikatory staje się nieskończony. Wprawdzie rozwiązanie z semi-termami i semiformułami umożliwia pozostawienie prostej definicji podformuły - $P x$ nadal jest jedyną bezpośrednią podformułą $\forall x P x$, z tym, że jest to semi-formuła, ale nie będziemy go tu przyjmowali. Może się wydawać, że konsekwencja w postaci nieskończonych zbiorów podformuł jest niekorzystna, ale zauważmy, że tylko przyjęcie takiego rozumienia podformuły pozwala dla reguł kwantyfikatorowych ocalić własność podformuł. Dlatego nawet dla standardowego rozumienia języka przyjmiemy taką definicję.

W ujęciu Gentzena $P x$ nie jest podformułą $\forall x P x$, ale jest nią dowolna $P[x / a]$, gdzie $a$ jest parametrem. Takie rozwiązanie automatycznie powoduje, że już zbiór bezpośrednich podformuł dowolnej formuły z kwantyfikatorem jest nieskończony.

Za Kleene'm zdefiniujemy pojęcie podformuły jeszcze ogólniej przyjmując, że bezpośrednią podformułą $Q x \varphi$ jest każde $\varphi[x / \tau]$ a zbiór podformuł obejmuje samo $Q x \varphi$ i wszystkie podformuły każdego $\varphi[x / \tau]$. Formalnie, wzbogacamy definicję $1.3 \mathrm{z}$ rozdziału 1 o następujący warunek:

- dla $\psi:=Q x \varphi$, gdzie $Q \in\{\forall, \exists\}, S F(\psi)=\{\psi\} \cup S F(\{\varphi[x / \tau]$ : gdzie $\varphi[x / \tau]$ jest instancja poprawnego podstawienia $\tau$ za $x \mathrm{w} \varphi\})$.

Ujęcie takie jest niezależne od tego czy przyjmujemy standardową czy parametryczną wersję języka, tzn. podstawianym $\tau$ może być zarówno zmienna (przy standardowym podejściu) jak i parametr, oraz dowolny term złożony. Przykładowo dla $\forall x \forall y(A x \wedge B y)$ bezpośrednia podformuła jest zarówno $\forall y(A a \wedge B y)$ jak i $\forall y(A z \wedge B y)$ czy nawet $\forall y(A f(a z) \wedge B y)$; ale nie $\forall y(A f(a y) \wedge B y)$, gdyż narusza warunki poprawnego podstawiania.

W dalszym ciągu postaramy się formułować reguły i wyniki dla RS w KRK w sposób możliwie neutralny względem przyjętej wersji językowej, zaznaczając różnice wtedy, gdy są istotne.

\subsection{LK dla logiki pierwszego rzędu.}

LK Gentzena [50] zawiera następujące reguły dla kwantyfikatorów:

$$
\begin{array}{ll}
(\forall \Rightarrow) \frac{\varphi[x / \tau], \Gamma \Rightarrow \Delta}{\forall x \varphi, \Gamma \Rightarrow \Delta} & (\Rightarrow \forall)^{1} \frac{\Gamma \Rightarrow \Delta, \varphi[x / a]}{\Gamma \Rightarrow \Delta, \forall x \varphi} \\
(\exists \Rightarrow)^{1} \frac{\varphi[x / a], \Gamma \Rightarrow \Delta}{\exists x \varphi, \Gamma \Rightarrow \Delta} & (\Rightarrow \exists) \frac{\Gamma \Rightarrow \Delta, \varphi[x / \tau]}{\Gamma \Rightarrow \Delta, \exists x \varphi}
\end{array}
$$


Warunki poprawności:

1. gdzie $a$ jest zmienną wolną (lub parametrem) nie występującą w $\Gamma, \Delta$ i $\varphi$. a jest zazwyczaj określone jako eigenvariable zastosowania danej reguły; termin ten będzie dalej również przez nas używany.

Uwaga 9.3: Faktycznie podana przez nas wersja jest nieco ogólniejsza; u Gentzena $\mathrm{w}(\forall \Rightarrow)$ i $(\Rightarrow \exists)$ za $x$ podstawialne są tylko parametry, a nie dowolne termy.

Uwaga 9.4: Dla LJ przyjmujemy, że w $(\Rightarrow \forall)$ i $(\Rightarrow \exists) \Delta$ jest pusta, a w $(\forall \Rightarrow)$ i $(\exists \Rightarrow)$ zawiera co najwyżej jedną formułę. W istocie oba ograniczenia są zbędne co wykazał Kleene [83] (por. uwaga 3.3).

Uwaga 9.5: Warto zauważyć, że w przypadku $(\exists \Rightarrow)$ i $(\Rightarrow \forall)$ formuła poboczna przesłanki jest zawsze instancją podstawieniową zasięgu formuły głównej w sensie ścisłym (por. uwaga 8.11) podczas gdy w przypadku $(\forall \Rightarrow)$ i $(\Rightarrow \exists)$ dopuszcza się dowolne instancje podstawieniowe. Przykładowo, jeżeli $\forall x(A x \rightarrow B a)$ jest w poprzedniku, to $A a \rightarrow B a$ jest dopuszczalnym podstawieniem, ale w następniku nie, gdyż podstawiany parametr ma być nowy.

Konsekwencją przyjętej przez nas definicji podformuły jest to, że dla LK (LJ) nadal zachodzi własność podformuł. Dla dalszych rozważań przytoczmy ją we wzmocnionej postaci:

Fakt 9.1 Jeżeli $w$ dowodzie $\Gamma \Rightarrow \Delta$ nie zastosowano (Cut), to dowód ma własność podformut; co więcej, jeżeli $w$ dowodzie nie zastosowano regut dla $\neg i \rightarrow$, to każda formuła występująca w poprzedniku (następniku) jakiegoś sekwentu tego dowodu jest podformuta pewnej formuły $z \Gamma(\Delta)$.

Konsekwencją zachodzenia własności podformuł dla LK-KRK jest odziedziczenie przez ten system wyników podanych w paragrafie 6.1.1 dla KRZ takich jak separowalność i konserwatywność, a przede wszystkim niesprzeczność. Dowody tych rezultatów są takie same. Z drugiej strony, jak pokażemy dalej, rozstrzygalności nie daje się utrzymać, gdyż zbiór podformuł jest nieskończony.

Udowodnimy teraz syntaktycznie, że LK jest adekwatną charakteryzacją KRK przez wykazanie równoważności z aksjomatyczną formalizacją KRK. 
Twierdzenie 9.1 (Adekwatność) $\vdash_{H} \varphi w t w \vdash_{L K} \Rightarrow \varphi$

DowóD przeprowadzimy tak samo jak w przypadku KRZ. Implikacja od lewej do prawej wymaga dowodu wszystkich aksjomatów i wykazania dowiedlności GEN w LK. Oto schemat dowodu dowolnej instancji $A \forall$ :

$$
\begin{gathered}
(\rightarrow \Rightarrow) \frac{\varphi \Rightarrow \varphi \quad \psi[x / a] \Rightarrow \psi[x / a]}{\varphi \rightarrow \psi[x / a], \varphi \Rightarrow \psi[x / a]} \\
\quad(\forall \Rightarrow) \frac{\varphi(\varphi \rightarrow \psi), \varphi \Rightarrow \psi[x / a]}{\forall x(\varphi \rightarrow \psi), \varphi \Rightarrow \forall x \psi} \\
\quad(\Rightarrow \forall) \frac{\forall x(\varphi \rightarrow \psi)}{\forall x(\varphi \rightarrow \psi) \Rightarrow \varphi \rightarrow \forall x \psi} \\
(\Rightarrow \rightarrow) \frac{\forall x(\varphi \rightarrow \psi) \rightarrow(\varphi \rightarrow \forall x \psi)}{\Rightarrow \forall x(\varphi \rightarrow \psi)\left({ }^{2}\right)}
\end{gathered}
$$

Zastosowanie $(\forall \Rightarrow)$ jest poprawne, gdyż z założenia poczynionego dla $A \forall$ mamy, że $x \notin V F(\varphi)$ zatem $(\varphi \rightarrow \psi)[x / a]:=\varphi \rightarrow \psi[x / a]$. Z tego powodu również zastosowanie $(\Rightarrow \forall)$ jest poprawne gdyż w przesłance $a$ występuje tylko w $\psi$. Proste dowody $A \forall E$ i $A \exists$ pozostawiamy czytelnikowi. Dowiedlność GEN wynika z faktu, że jeżeli $\Rightarrow \varphi$ ma dowód, to ma go również $\Rightarrow \varphi[x / a]$ (por. niżej lemat 9.5) z a spełniającym warunki poprawności dla $(\Rightarrow \forall)$, a zatem możemy z niego wydedukować $\Rightarrow \forall x \varphi$.

Dla dowodu implikacji w drugą stronę znów oprzemy się na mocniejszym wyniku, który opiera się na interpretacji $\Rightarrow$ jako relacji dowiedlności w systemie $\mathrm{H}$.

Lemat 9.1 Jeżeli $\vdash_{L K} \Gamma \Rightarrow \Delta$, to $\Gamma, \neg \Delta \vdash_{H} \perp$.

DowóD: Przez indukcję po długości dowodu w LK. Wystarczy odwołać się do własności $\vdash$ podanych w lemacie 1.1 oraz do faktu, że w $\mathrm{H}$ dopuszczalne są reguły wtórne $\forall I$ i $\exists E$. Dowód bazy i kroku indukcyjnego dla reguł zdaniowych pozostaje bez zmian wystarczy sprawdzić zastosowania czterech reguł kwantyfikatorowych. W założeniu indukcyjnym przyjmujemy, że lemat zachodzi dla dowolnego dowodu długości $<n$ i wykazujemy, że zachodzi dla $n$. Przeanalizujmy przypadek obu reguł dla $\forall$ :

$(\forall \Rightarrow)$ : Mamy $\forall x \varphi, \Gamma^{\prime} \Rightarrow_{n} \Delta$. Przesłanka $\varphi[x / \tau], \Gamma^{\prime} \Rightarrow_{n-1} \Delta$ ma dowód krótszy zatem podpada pod założenie indukcyjne, czyli $\varphi[x / \tau], \Gamma^{\prime}, \neg \Delta \vdash_{H} \perp$. $\mathrm{Z}$ aksjomatu $A \forall E$ i lematu 1.1, własność 6, mamy $\forall x \varphi \vdash_{H} \varphi[x / \tau]$, co przez lemat 1.1, własność 4 , daje $\forall x \varphi, \Gamma^{\prime}, \neg \Delta \vdash_{H} \perp$.

$(\Rightarrow \forall)$ : Przesłanka zastosowania reguły podpada pod założenie indukcyjne, zatem mamy $\Gamma, \neg \Delta^{\prime}, \neg \varphi[x / a] \vdash_{H} \perp$ skąd przez lemat 1.1, własność 9, mamy 
$\Gamma, \neg \Delta^{\prime} \vdash_{H} \varphi[x / a] . \Gamma$ i $\neg \Delta$ sa skończone, zatem wielokrotne zastosowanie lematu 1.1, wł. 13, daje nam $\wedge\left(\Gamma \cup \neg \Delta^{\prime}\right) \vdash_{H} \varphi[x / a]$ skąd przez własność 6

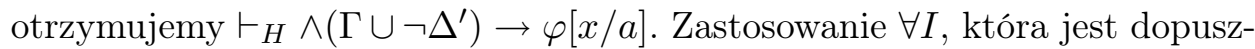
czalna w H-KRK, daje nam $\vdash_{H} \wedge\left(\Gamma \cup \neg \Delta^{\prime}\right) \rightarrow \forall x \varphi$.

\subsection{PV-dowody}

LK-KRK zachowuje wiele własności swego podsystemu dla KRZ, w tym eliminowalność cięcia. Jednak sformułowanie tego wyniku nie jest neutralne względem wyboru wersji językowej KRK. W tym momencie możemy pokazać dlaczego rozwiązanie Gentzena pozwala na prostsze sformułowanie twierdzenia o eliminacji (Cut) dla LK. Za Kleene'm [83] przytoczmy przykład dowodu $\mathrm{w}$ LK, ale w standardowej wersji języka:

Przykład 9.1:

$$
\begin{aligned}
& (\wedge \Rightarrow) \frac{A z \Rightarrow A z}{B y \wedge A z \Rightarrow A z} \\
& (\forall \Rightarrow) \frac{\forall y(B y \wedge A z) \Rightarrow A z}{\forall x} \\
& (\forall \Rightarrow) \frac{A y \Rightarrow A y}{\forall x \forall y(B y \wedge A x) \Rightarrow A z} \quad(\forall \Rightarrow) \\
& (C u t) \frac{\forall x \forall y(B y \wedge A x) \Rightarrow \forall x A x}{\forall x A x \Rightarrow A y}
\end{aligned}
$$

Dowodu tego nie można przekształcić na dowód bez użycia (Cut), co można łatwo wykazać przez odwołanie się do faktu 9.1. W $\forall x \forall y(B y \wedge A x) \Rightarrow$ Ay nie ma $\neg \mathrm{i} \rightarrow$ zatem w poszukiwanym dowodzie bez (Cut) reguły dla tych spójników nie będą użyte. Wtedy, zgodnie z faktem 9.1, każda podformuła $\forall x \forall y(B y \wedge A x)$ może wystąpić tylko w poprzednikach sekwentów z dowodu a (jedyna) podformuła $A y$ tylko w następnikach. Łatwo zauważyć, że $A y$ nie należy do zbioru podformuł $\forall x \forall y(B y \wedge A x)$ co uniemożliwia znalezienie aksjomatów, które zaczynałyby taki dowód.

Powyższy przykład (a można podobnych skonstruować dowolnie wiele) mógłby sugerować, że w przeciwieństwie do LK dla KRZ, (Cut) w LK-KRK nie jest eliminowalny. Zauważmy jednak, że w języku z parametrami dowiedziona teza nie jest wogóle formułą gdyż zawiera nieuprawnione (niezwiązane) wystąpienie zmiennej $y$. Jeżeli zastąpimy je przez parametr, to łatwo uzyskamy dowód bez użycia (Cut): 


$$
\begin{gathered}
(\wedge \Rightarrow) \frac{A a \Rightarrow A a}{B a \wedge A a \Rightarrow A a} \\
(\forall \Rightarrow) \frac{\forall y(B y \wedge A a) \Rightarrow A a}{\forall x \forall y(B y \wedge A x) \Rightarrow A a}
\end{gathered}
$$

Powyższy przykład sugeruje, że w wersji z parametrami można sformułować twierdzenie o eliminacji (Cut) bez ograniczeń, natomiast w języku standardowym musimy wyrazić je następująco: (Cut) jest eliminowalne w dowodzie dowolnego sekwentu, w którym żadna zmienna nie występuje równocześnie jako wolna i związana. Oczywiście tego typu ograniczenie jest pozorne, gdyż na mocy twierdzenia o alfabetycznych wariantach (lemat 8.2.) każdą formułę niespełniającą tego warunku możemy zamienić na równoważną jej formułę, która ten warunek spełnia. W istocie Gentzen nawet w dowodzie Hauptsatz dla swojej wersji LK (LJ) wprowadza jeszcze jeden warunek dla rozważanych dowodów, który również nie ogranicza tak naprawdę zasięgu jego twierdzenia.

\subsubsection{Podejście Kleene'go}

Zamiast rozwiązania Gentzena zaprezentujemy niżej sposób ujęcia tej problematyki przez Kleenego [83], który przeprowadza dowód dla wersji LK na języku standardowym. Kluczowe pojęcie wprowadza poniższa

Definicja 9.1 (Pure-variable Property) Dowód D jest $P V$-dowodem wtw:

(i) $V F(\mathcal{D}) \cap V B(\mathcal{D})=\varnothing$;

(ii) każda eigenvariable występuje tylko w sekwentach powyżej danego zastosowania $(\exists \Rightarrow) \operatorname{lub}(\Rightarrow \forall)$.

$V F(\mathcal{D})$ i $V B(\mathcal{D})$ oznaczają zbiory wszystkich zmiennych wolnych i związanych występujących $\mathrm{w}$ dowodzie. Warunek (i) dla wersji z parametrami jest spełniony z definicji natomiast (ii) wprowadza również Gentzen, aby ułatwić dowód twierdzenia o eliminacji (Cut). Takeuti [143], który też operuje na wersji parametrycznej, każdy dowód spełniający warunek (ii) nazywa regularnym. Może się wydawać w pierwszej chwili, że warunek (ii) nie wprowadza niczego więcej ponad to co narzuca samo sformułowanie reguł $(\exists \Rightarrow)$ i $(\Rightarrow \forall)$. Jednak jest to mylne wrażenie, gdyż w dowolnym dowodzie różne zastosowania tych reguł, ale na innych gałęziach mogą wprowadzić tę samą eigenvariable. Warunek (ii) wymusza by wszystkie zmienne tego typu w dowodzie były różne a nie tylko te, które znajdują się na tej samej gałęzi. 
Aby wykazać, że każdy dowód można przekształcić na PV-dowód odnotujmy za Kleene'm najpierw dwa fakty dotyczace operacji na regułach zachowujących ich poprawność:

Fakt 9.2 Jeżeli w danej instancji aksjomatu lub reguty dowolna zmienna w jej wszystkich wolnych wystapieniach (lub wszystkich zwiazanych wystapieniach) zastapimy inna zmienna, która nie występuje w tej instancji (ani jako wolna ani zwiazana), to otrzymamy nadal poprawna instancje aksjomatu lub reguty.

Fakt 9.3 Jeżeli w danej instancji aksjomatu lub reguły za wszystkie wolne wystapienia zmiennej dokonamy poprawnego podstawienia pewnego termu, to otrzymamy nadal poprawna instancje aksjomatu lub reguty pod warunkiem, $\dot{z}$ e w przypadku $(\exists \Rightarrow) i(\Rightarrow \forall)$ dodatkowo spetnimy następujace warunki:

(i) term podstawiany nie zawiera eigenvariable tej instancji reguły,

(ii) zmienna, za która podstawiamy nie jest eigenvariable tej instancji reguty.

Dowód tych faktów jest oczywisty przez analizę reguł. W Fakcie 9.3 dwa warunki ograniczające zapewniają, że restrykcje dotyczące obu reguł nie zostaną przypadkowo pogwałcone. Gentzen dowodzi słabszego faktu, że instancja danej reguły pozostaje poprawna, gdy parametr zastąpimy innym parametrem, ale pod warunkiem, że ani zastępowany ani zastępujący parametr to nie eigenvariable. Jest to odpowiednik faktu 9.2, wystarczający dla LK w wersji z parametrami. Odpowiednika faktu 9.3 Gentzen nie potrzebuje z racji ograniczenia wszystkich reguł do podstawiania tylko parametrów za zmienne (por. uwaga 9.3).

Na bazie powyższych obserwacji Kleene dowodzi dwóch lematów dotyczących transformacji dowolnego dowodu w PV-dowód.

Lemat 9.2 Dowolny dowód D sekwentu $S$ takiego, że $V F(S) \cap V B(S)=\varnothing$ można przekształcić na dowód $\mathcal{D}^{\prime}$ tego sekwentu, taki, że $V F\left(\mathcal{D}^{\prime}\right) \cap V B\left(\mathcal{D}^{\prime}\right)=$ $\varnothing$.

DowóD: Niech $x_{1}, \ldots, x_{i} \in V F(S)$ ale $x_{1}, \ldots, x_{i} \in V B(\mathcal{D})$ a $y_{1}, \ldots, y_{j}=$ $V F(\mathcal{D}) \cap V B(\mathcal{D})$. Niech $z_{1}, \ldots, z_{i}, v_{1}, \ldots, v_{j}$ nie występują wogóle w $\mathcal{D}$. Wymieniamy wszystkie (i tylko) związane wystąpienia $x_{1}, \ldots, x_{i}$ na $z_{1}, \ldots, z_{i}$ a wszystkie wolne wystąpienia $y_{1}, \ldots, y_{j}$ na $v_{1}, \ldots, v_{j}$. Sekwent dowodzony zostaje nie zmieniony, a z faktu 9.2 wynika, że otrzymane drzewo nadal jest jego dowodem. 
Lemat pokazuje jak dowolny dowód przekształcić na taki, który spełnia warunek (i) definicji PV-dowodu. Dla LK na języku z parametrami wynik ten jest spełniony z definicji. Natomiast kolejny lemat pojawia się też u Gentzena w preliminariach do dowodu Hauptsatz.

Lemat 9.3 Dowolny dowód $\mathcal{D}$ taki, że $V F(\mathcal{D}) \cap V B(\mathcal{D})=\varnothing$ można przeksztatcić na $P V$-dowód tego samego sekwentu.

DowóD: Niech $\mathcal{D}$ będzie takim dowodem, w którym jest $k$ zastosowań $(\exists \Rightarrow$ ), $(\Rightarrow \forall)$. Ponieważ nie mamy gwarancji, że wszystkie $k$ przypadków eigenvariable to różne zmienne więc bierzemy $x_{1}, \ldots, x_{k}$, które wogóle nie występują w $\mathcal{D}$ i zamieniamy po kolei, zaczynając od najwyższego zastosowania takiej reguły, wszystkie wystąpienia danej eigenvariable w sekwentach powyżej tego zastosowania danej reguły, na nową zmienną. Z faktu 9.2 wynika, że nowo uzyskana część dowodu jest również dowodem. Powtarzamy tę operację do $k$ razy. Uzyskany dowód jest PV-dowodem tego samego sekwentu gdyż wszystkie zmiany dotyczyły tylko sekwentów wyżej położonych.

\subsubsection{Alternatywne podejście}

Uzasadnienie dla odpowiednich transformacji niezbędnych $\mathrm{w}$ dowodzie eliminacji (Cut) można też uzyskać przez odwołanie się do twierdzenia o alfabetycznych wariantach i twierdzenia o podstawianiu dla dowiedlnych sekwentów. Takie podejście reprezentuje np. Takeuti [143], Negri, von Plato [101].

W oczywisty sposób poszerzamy pojęcie podstawiania z formuł na sekwenty.

Definicja 9.2 Dla zbioru (multizbioru, ciagu) $\Gamma:=\varphi_{1}, \ldots, \varphi_{n}$ :

- $\Gamma[x / \tau]:=\varphi_{1}[x / \tau], \ldots, \varphi_{n}[x / \tau]$

- $(\Gamma \Rightarrow \Delta)[x / \tau]:=\Gamma[x / \tau] \Rightarrow \Delta[x / \tau]$.

Niezależnie od twierdzenia o alfabetycznych wariantach z poprzedniego rozdziału warto udowodnić ten rezultat syntaktycznie w wersji dla RS na standardowym języku.

Lemat 9.4 (Alfabetyczne warianty) Każdy dowód D sekwentu $S$ można przeksztatcić na dowód $D^{\prime}$ sekwentu $S^{\prime}$ o tej samej dtugości, w którym pewna formuła $z S$ została zastapiona alfabetycznym wariantem. 
DowóD: Przez indukcję po długości dowodu. Jeżeli $k=0$, to $\varphi \Rightarrow \varphi$ po dokonaniu przemianowania w nim dowolnej zmiennej związanej (jeżeli taka jest) nadal jest aksjomatem. Niech $k>0$, zakładamy, że lemat zachodzi dla dowolnego dowodu krótszego od $k$ i musimy rozważyć jaka reguła została zastosowana $\mathrm{w}$ dedukcji ostatniego. Jeżeli jest to reguła zdaniowa, to wynik przenosi się trywialnie z przesłanek na wniosek, tak jak w przypadku aksjomatu, ale przez odwołanie się do założenia indukcyjnego. Rozważmy przypadek $(\forall \Rightarrow)$ z przesłanką $\varphi[x / \tau], \Gamma \Rightarrow \Delta$ i wnioskiem $\forall x \varphi, \Gamma \Rightarrow \Delta$. Jeżeli przemianowywana zmienna jest różna od $x$, to mamy taką samą sytuację jak dla reguł zdaniowych, jeżeli jest to $x$, które chcemy zamienić na $y$, to zauważmy, że $\forall y(\varphi[x / y]), \Gamma \Rightarrow \Delta$ jest również poprawnie dedukowalne $\mathrm{z} \varphi[x / \tau], \Gamma \Rightarrow \Delta$ inaczej $\tau$ musiałoby mieć jakieś zmienne, które stałyby się związane $\mathrm{w} \varphi[x / y]$, ale to jest niemożliwe, gdyż wtedy wyjściowa dedukcja też byłaby niepoprawna. Przypadek $(\Rightarrow \forall)$ podobnie.

Na mocy tego lematu każdy sekwent, w którym jakaś zmienna występuje zarazem jako zmienna wolna i związana można zastąpić takim, w którym dokonamy przemianowania zmiennych związanych na takie, które nie występują jako wolne, czyli na taki, który spełnia warunek (i) PV-dowodów. Np. dowód sekwentu $\forall x \forall y(B y \wedge A x) \Rightarrow A y$ zastąpimy dowodem sekwentu $\forall x \forall z(B z \wedge A x) \Rightarrow A y$, a dla tego ostatniego uzyskamy dowód bez użycia (Cut).

Przyjęcie założenia o rozłączności zbioru zmiennych wolnych i związanych w dowodzonych sekwentach upraszcza też dowód kolejnego lematu:

Lemat 9.5 (Podstawianie) Jeżeli $\vdash_{k} \Gamma \Rightarrow \Delta$, to $\vdash_{k}(\Gamma \Rightarrow \Delta)[x / \tau]$.

DowóD: Przez indukcję po długości dowodu. Jeżeli $k=0$, to $(\varphi \Rightarrow \varphi)[x / \tau]$ też jest aksjomatem. Niech $k>0$, zakładamy, że lemat zachodzi dla dowolnego dowodu krótszego od $k$ i musimy rozważyć jaka reguła została zastosowana $\mathrm{w}$ dedukcji ostatniego. Jeżeli jest to reguła zdaniowa, to wynik przenosi się trywialnie z przesłanek na wniosek, tak jak w przypadku aksjomatu, ale przez odwołanie się do założenia indukcyjnego. Rozważmy dla przykładu przypadek $(\Rightarrow \wedge)$. Niech $\Gamma \Rightarrow \Delta:=\Gamma \Rightarrow \Delta^{\prime}, \varphi \wedge \psi$. Dowody przesłanek podpadaja pod założenie indukcyjne zatem mamy $\vdash\left(\Gamma \Rightarrow \Delta^{\prime}, \varphi\right)[x / \tau] \mathrm{i} \vdash(\Gamma \Rightarrow$ $\left.\Delta^{\prime}, \psi\right)[x / \tau]$ czyli $\vdash \Gamma[x / \tau] \Rightarrow \Delta^{\prime}[x / \tau], \varphi[x / \tau] \mathrm{i} \vdash \Gamma[x / \tau] \Rightarrow \Delta^{\prime}[x / \tau], \psi[x / \tau]$. Przez $(\Rightarrow \wedge)$ otrzymujemy $\vdash \Gamma[x / \tau] \Rightarrow \Delta^{\prime}[x / \tau], \varphi[x / \tau] \wedge \psi[x / \tau]$, co na mocy definicji podstawiania oznacza $\vdash \Gamma[x / \tau] \Rightarrow \Delta^{\prime}[x / \tau],(\varphi \wedge \psi)[x / \tau]$ czyli $\vdash\left(\Gamma \Rightarrow \Delta^{\prime}, \varphi \wedge \psi\right)[x / \tau]$.

Rozważmy przypadek $(\forall \Rightarrow)$, z racji założenia o rozłączności zbioru zmiennych wolnych i związanych $\mathrm{w}$ dowodzie odpada nam przypadek, gdy $x$ 
jest kwantyfikowaną zmienną, czyli przesłanka ma kształt $\varphi\left[y / \tau^{\prime}\right], \Gamma^{\prime} \Rightarrow \Delta$, a wniosek $\forall y \varphi, \Gamma \Rightarrow \Delta \mathrm{z} x \neq y$. Z założenia indukcyjnego otrzymujemy $\vdash_{k-1}$ $\left(\varphi\left[y / \tau^{\prime}\right]\right)[x / \tau], \Gamma^{\prime}[x / \tau] \Rightarrow \Delta[x / \tau]$, a mamy dowieść, że $\forall y \varphi[x / \tau], \Gamma[x / \tau] \Rightarrow$ $\Delta[x / \tau]$. Zauważmy, że $\left(\varphi\left[y / \tau^{\prime}\right]\right)[x / \tau]:=(\varphi[x / \tau])\left[y / \tau^{\prime}[x / \tau]\right]$, zatem $\vdash_{k-1}$ $(\varphi[x / \tau])\left[y / \tau^{\prime}[x / \tau]\right], \Gamma^{\prime}[x / \tau] \Rightarrow \Delta[x / \tau]$ skąd przez $(\forall \Rightarrow)$ otrzymamy $\vdash_{k}$ $\forall y(\varphi[x / \tau]), \Gamma^{\prime}[x / \tau] \Rightarrow \Delta[x / \tau]$. Z definicji podstawiania mamy $\forall y \varphi[x / \tau]:=$ $\forall y(\varphi[x / \tau])$, więc $\vdash_{k} \forall y \varphi[x / \tau], \Gamma^{\prime}[x / \tau] \Rightarrow \Delta[x / \tau] \operatorname{czyli}_{k}\left(\forall y \varphi, \Gamma^{\prime} \Rightarrow \Delta\right)[x / \tau]$.

Rozważmy przypadek $(\Rightarrow \forall)$. Podobnie jak poprzednio, z racji założenia o rozłączności zbioru zmiennych wolnych i związanych w dowodzie odpada nam przypadek, gdy $x$ jest kwantyfikowaną zmienną, czyli mamy $\vdash_{k-1} \Gamma \Rightarrow \Delta^{\prime}, \varphi[y / v]$, gdzie $v \notin V F\left(\Gamma, \Delta^{\prime}, \varphi\right)$. Ponieważ nie mamy gwarancji, że $v \neq x$ lub $v \notin \operatorname{Var}(\tau)$ zatem weźmy $w$ takie, że $w \notin V F\left(\Gamma, \Delta^{\prime}, \varphi\right)$ a ponadto $w \neq x$ i $w \notin \operatorname{Var}(\tau)$. Z założenia indukcyjnego $\vdash_{k-1} \Gamma[v / w] \Rightarrow$ $\Delta^{\prime}[v / w],(\varphi[y / v])[v / w]$, ale to daje $\vdash_{k-1} \Gamma \Rightarrow \Delta^{\prime}, \varphi[y / w]$, gdyż $\Gamma[v / w]=$ $\Gamma, \Delta^{\prime}[v / w]=\Delta^{\prime}$ skoro $v \notin V F\left(\Gamma, \Delta^{\prime}\right)$, a ponadto $(\varphi[y / v])[v / w]:=\varphi[y / w]$ na mocy punktu 4 faktu 8.1, gdyż są to instancje ścisłego podstawiania. $\mathrm{Z}$ założenia indukcyjnego zastosowanego ponownie mamy $\vdash_{k-1} \Gamma[x / \tau] \Rightarrow$ $\Delta^{\prime}[x / \tau],(\varphi[y / w])[x / \tau]$. Ze względu na dobór $w$ mamy, że $(\varphi[y / w])[x / \tau]:=$ $(\varphi[x / \tau])[y / w]$, zatem $\vdash_{k-1} \Gamma[x / \tau] \Rightarrow \Delta^{\prime}[x / \tau],(\varphi[x / \tau])[y / w]$, skąd przez zastosowanie $(\Rightarrow \forall)$ mamy $\vdash_{k} \Gamma[x / \tau] \Rightarrow \Delta^{\prime}[x / \tau], \forall y(\varphi[x / \tau])$. Z definicji podstawiania $\vdash_{k} \Gamma[x / \tau] \Rightarrow \Delta^{\prime}[x / \tau],(\forall y \varphi)[x / \tau]$ czyli $\vdash_{k}\left(\Gamma \Rightarrow \Delta^{\prime}, \forall y \varphi\right)[x / \tau]$.

\subsection{Eliminacja cięcia w LK}

Dowód twierdzenia o eliminacji (Cut) w RS dla KRK nie nastręcza większych trudności. Przeprowadzimy go tutaj ponownie dla LK Gentzena, gdyż ten dowód zawiera najwięcej detali, a potem pokażemy jak przebiega dowód Dragalina dla ARS. Nie będziemy omawiać osobno jak należy uzupełnić inne dowody podane przez nas w rozdziale 5 , gdyż nie wymagają one zasadniczo innych rozwiązań. Uważny czytelnik powinien sam uzupełnić je w oparciu o podane niżej transformacje.

Twierdzenie 9.2 (Eliminacja (Cut)) Każdy PV-dowód można przeksztatcić na PV-dowód nie zawierajacy zastosowań (Mix)

DowóD: Zachowując numerację przypadków z dowodu podanego w rozdziale 5 uzupełnimy przypadki transformacji, w których występują zastosowania reguł kwantyfikatorowych. 
W punkcie 4.1, gdy głębokość (Mix) $=2$ rozważmy przypadek, gdy cutformuła : $=\forall x \varphi$

$$
\underset{(M i x)}{(\Rightarrow \forall) \frac{\Gamma \Rightarrow \Delta, \varphi[x / a]}{\Gamma \Rightarrow \Delta, \forall x \varphi} \quad \frac{\varphi[x / \tau], \Pi \Rightarrow \Sigma}{\forall x \varphi, \Pi \Rightarrow \Sigma}}(\forall \Rightarrow)
$$

Tym razem nie możemy po prostu podnieść zastosowania (Mix) wyżej gdyż $a$ nie jest identyczne z $\tau$. Ponieważ jest to PV-dowód $\Gamma, \Pi \Rightarrow \Delta, \Sigma$ więc żadna zmienna $\mathrm{w} \tau$ nie jest identyczna z jakąś eigenvariable $\mathrm{w}$ dowodzie $\Gamma \Rightarrow \Delta, \varphi[x / a]$, wliczając w to $a$. Również $a$ musi być różne od innych zmiennych występujacych jako eigenvariable $\mathrm{w}$ dowodzie lewej przesłanki (warunek (ii)). Z kolei z własności (i) PV-dowodów wynika, że $\tau$ jest podstawialne za $a$ (inaczej jakieś zmienne wolne $\mathrm{w} \tau$ musiałyby być związane $\mathrm{w}$ innym miejscu dowodu). Zatem przez fakt 9.3 możemy w dowodzie lewej przesłanki podstawić $\tau$ za wszystkie wystąpienia $a$ uzyskując dowód $\Gamma \Rightarrow \Delta, \varphi[x / \tau]$. Odwołanie się tutaj do faktu 9.3 może wymagać komentarza, gdyż warunek (ii) mówi, że nie można podstawić $\tau$ za eigenvariable, a przecież $a$ jest właśnie taką zmienną (ew. parametrem). Ale w dowodzie $\Gamma \Rightarrow \Delta, \varphi[x / a], a$ nie jest już eigenvariable instancji żadnej z zastosowanych tam reguł, więc warunek (ii) nie znajduje tu zastosowania.

Alternatywnie uzasadniamy tę operację odwołując się do lematu 9.5, z którego wynika, że dowód $\Gamma \Rightarrow \Delta, \varphi[x / a]$ możemy zastąpić dowodem $\Gamma \Rightarrow$ $\Delta, \varphi[x / \tau]$ tej samej długości, gdyż $\tau$ jest podstawialne za $x \mathrm{w} \varphi$. W rezultacie otrzymujemy:

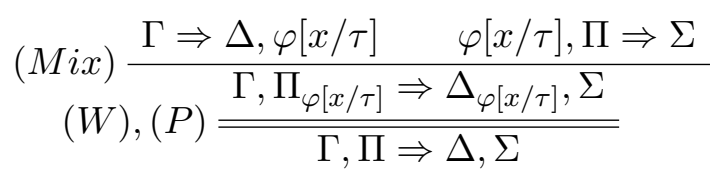

Dla cut-formuła $:=\exists x \varphi$ mamy analogiczne przekształcenia.

W dowodzie kroku indukcyjnego indukcji III (punkty 3.2 i 4.2), w części A dowodu, przy założeniu, że R-rank $>1$ i że cut-formuła jest parametrem mamy dwa dodatkowe przypadki w A111, tzn. tam gdzie prawa przesłanka (Mix) jest uzyskana przez $(\Rightarrow \forall)$ lub $(\Rightarrow \exists)$. Rozważmy pierwszy z nich.

$$
(M i x) \frac{\Gamma \Rightarrow \Delta[\varphi] \quad \frac{\Pi[\varphi] \Rightarrow \Sigma, \psi[x / a]}{\Pi[\varphi] \Rightarrow \Sigma, \forall x \psi}}{\Gamma, \Pi_{\varphi} \Rightarrow \Delta_{\varphi}, \Sigma, \forall x \psi}(\Rightarrow \forall)
$$


przekształcamy go następująco:

$$
\begin{gathered}
(\operatorname{Mix}) \frac{\Gamma \Rightarrow \Delta[\varphi] \quad \Pi[\varphi] \Rightarrow \Sigma, \psi[x / a]}{\Gamma, \Pi_{\varphi} \Rightarrow \Delta_{\varphi}, \Sigma, \psi[x / a]} \\
(\Rightarrow \forall) \frac{\Pi_{\varphi} \Rightarrow \Delta_{\varphi}, \Sigma, \forall x \psi}{\Gamma, \forall}
\end{gathered}
$$

Warunek (ii) definicji PV-dowodów gwarantuje nam, że $a$ nie występuje $\mathrm{w} \Gamma, \Delta$ zatem zastosowanie $(\Rightarrow \forall)$ jest poprawne. Zresztą nawet gdyby tak nie było, to przez lemat 9.5 , moglibyśmy dowód $\Pi[\varphi] \Rightarrow \Sigma, \psi[x / a]$ zastąpić dowodem $\Pi[\varphi] \Rightarrow \Sigma, \psi[x / b]$ tej samej długości, ale z $b$ nie występującą $\mathrm{w}$ $\Gamma, \Delta$.

Przypadek $(\Rightarrow \exists)$ jest podobny. Analogiczna sytuacja występuje też w punkcie A1211, tzn. gdy cut-formuła jest parametrem, ale mamy do czynienia z zastosowaniem $(\forall \Rightarrow)$ lub $(\exists \Rightarrow)$ w prawej przesłance.

W części A2, gdzie cut-formuła jest formułą poboczną reguły zastosowanej do prawego sekwentu-przesłanki, rozważyć musimy jedynie przypadek $(\forall \Rightarrow)$, gdyż $(\exists \Rightarrow)$ nie wchodzi w grę z racji warunku nałożonego na eigenvariable. W przypadku $(\forall \Rightarrow)$ wystarczy jedynie podnieść zastosowanie (Mix) na prawej przesłance o jeden wiersz w górę. Otrzymane zastosowanie (Mix) ma zredukowany rank o 1, więc podpada pod założenie indukcyjne. Wynik nowego (Mix) wymaga jedynie zastosowania $(W \Rightarrow)$, aby dołączyć brakującą formułę $\forall x \varphi$ do poprzednika.

W części A3 rozważamy przypadki, gdy cut-formuła jest formułą zasadniczą reguły zastosowanej do prawego sekwentu-przesłanki. Mamy tu ponownie do rozważenia dodatkowe przypadki $(\forall \Rightarrow)$ i $(\exists \Rightarrow)$. Rozważmy pierwszy z nich. Fragment dowodu o postaci:

$$
(M i x) \frac{\Gamma \Rightarrow \Delta[\forall x \varphi] \quad \frac{\varphi[x / \tau], \Pi[\forall x \varphi] \Rightarrow \Sigma}{\forall x \varphi, \Pi[\forall x \varphi] \Rightarrow \Sigma}}{\Gamma, \Pi_{\forall x \varphi} \Rightarrow \Delta_{\forall x \varphi}, \Sigma}(\forall \Rightarrow)
$$

zostaje zastąpiony przez:

$$
\begin{gathered}
\frac{\Gamma \Rightarrow \Delta[\forall x \varphi] \quad \varphi[x / \tau], \Pi[\forall x \varphi] \Rightarrow \Sigma}{\Gamma, \varphi[x / \tau], \Pi_{\forall x \varphi} \Rightarrow \Delta_{\forall x \varphi}, \Sigma}(\text { Mix }) \\
\frac{\Gamma \Rightarrow)}{\frac{\varphi[x / \tau], \Gamma, \Pi_{\forall x \varphi} \Rightarrow \Delta_{\forall x \varphi}, \Sigma}{\forall x \varphi, \Gamma, \Pi_{\forall x \varphi} \Rightarrow \Delta_{\forall x \varphi}, \Sigma}}(P \Rightarrow) \\
\frac{\Pi_{\forall x \varphi} \Rightarrow \Delta_{\forall x \varphi}, \Delta_{\forall x \varphi}, \Sigma}{\Gamma, \Pi_{\forall x \varphi} \Rightarrow \Delta_{\forall x \varphi}, \Sigma}(P),(C)
\end{gathered}
$$


Zauważmy, że drugie zastosowanie (Mix) ma R-rank=1, gdyż cut-formuła pojawia się po raz pierwszy $\mathrm{w}$ prawej przesłance; wystąpienia cut-formuły powyżej się nie liczą, gdyż tamten (Mix) podlega najpierw eliminacji z racji podpadania pod założenie indukcyjne. Analogicznie wygląda przypadek $(\exists \Rightarrow)$; warunki dla eigenvariable są nadal spełnione po transformacji, ponieważ mamy do czynienia z PV-dowodem, zatem $a$ nie występuje w lewej przesłance (Mix).

Dowody dla części B są symetryczne i pozostawiamy je czytelnikom.

\subsection{ARS dla KRK}

Choć, jak pokazaliśmy w poprzednim podrozdziale, dowód eliminacji (Cut) nie nastręcza poważnych trudności, to niestety nie implikuje rozstrzygalności KRK. Co więcej, Hauptsatz dla LK-KRK zachowuje też własność podformuł. Mimo to proces budowy drzewa dowodowego może okazać się nieskończony gdyż własność podformuł w KRK dopuszcza nieskończoną ilość podstawień dla formuł kwantyfikatorowych.

Rozważmy dla przykładu formułę $\neg \forall x \exists y R x y$. Pozornie wydaje się, że łatwo zbudować skończone drzewo, które pozwoli sfalsyfikować tę formułę:

Przykład 9.2:

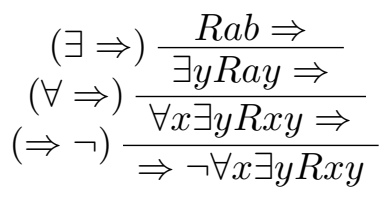

Jednak dwuelementowy model, w którym $R a b$ jest spełnione nie gwarantuje, że $\forall x \exists y R x y$ będzie spełnione. Do $V(R)$ musiałaby też należeć jakaś para uporządkowana z $V(b)$ na pierwszym miejscu, a żeby tak było, to w poprzedniku sekwentu musiałaby się znaleźć np. formuła $R b b$ (lub $R b a$ ). Wydaje się, że można temu zaradzić wykorzystując regułę kontrakcji: 
Przykład 9.3:

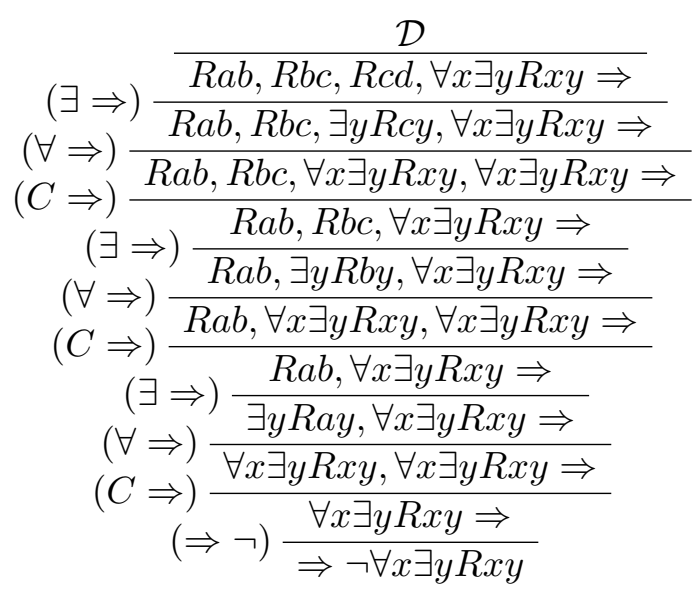

Jednak tym razem otrzymujemy drzewo nieskończone. Podany przez nas przykład pokazuje jedynie pewną wadliwość RS jako rachunku, z punktu widzenia efektywnego szukania kontrprzykładów, nie jest natomiast dobrym przykładem dla pokazania nieroztrzygalności KRK jako takiego. Wprawdzie istnieje "naturalny" model falsyfikujący dla tej formuły, który jest nieskończony; wystarczy jako dziedzinę wziąć zbiór liczb naturalnych, a jako $V(R)$ wziąć <. Ale ten przykład można przecież sfalsyfikować również w modelu z dziedziną jednoelementową, w którym $V(a)=V(b)$. Istnieje jednak nieskończenie wiele przykładów formuł i schematów rozumowań w języku pierwszego rzędu, które można sfalsyfikować tylko w modelach nieskończonych. Np. wystarczy, że do podanego w przykładzie sekwentu dodamy w poprzedniku dwie formuły: $\forall x \neg R x x, \forall x y z(R x y \wedge R y z \rightarrow R x z)$. Przy podanej wyżej interpretacji podane formuły są prawdziwe (stwierdzają przeciwzwrotność i przechodniość <) natomiast $\neg \forall x \exists y R x y$ jest oczywiście fałszywa, gdyż dla każdej liczby naturalnej istnieje liczba od niej większa. Jednak w żadnym modelu skończonym nie można takiego sekwentu sfalsyfikować.

Niezależnie od braku rozstrzygalności warto jednak pomyśleć o takiej wersji RS dla KRK, która lepiej będzie się zachowywać z punktu widzenia automatyzacji procedur poszukiwania dowodu. Jak pamiętamy z paragrafu 6.2.1 ma to istotny związek z odwracalnością reguł. W podanej wyżej postaci tylko $(\Rightarrow \forall)$ i $(\exists \Rightarrow)$ są odwracalne, co wykażemy niżej. Aby uzyskać dla KRK odpowiednik ARS zamienimy pozostałe dwie reguły na następujące:

$$
(\forall \Rightarrow) \frac{\varphi[x / \tau], \forall x \varphi, \Gamma \Rightarrow \Delta}{\forall x \varphi, \Gamma \Rightarrow \Delta} \quad(\Rightarrow \exists) \frac{\Gamma \Rightarrow \Delta, \exists x \varphi, \varphi[x / \tau]}{\Gamma \Rightarrow \Delta, \exists x \varphi}
$$


W LK kontrakcja jest regułą nieeliminowalną, gdyż - niezależnie od kniezależnej $(\rightarrow \Rightarrow)$ (por. uwaga 4.6) - niezbędna jest do powielania $\forall$-formuł w poprzedniku i $\exists$-formuł w następniku na wypadek, gdy będą niezbędne dla kolejnych zastosowań $(\forall \Rightarrow)$ i $(\Rightarrow \exists)$ w procesie poszukiwania dowodu (por. przykład 9.3). W przypadku podanych wyżej wariantów tych reguł efekt kontrakcji mamy wtopiony w odpowiednie reguły logiczne.

Dla ARS-KRK zachodzą wyniki dowiedzione przez nas w podrozdziale 4.3 dla ARS-KRZ, czyli twierdzenia o dopuszczalności osłabiania, odwracalności reguł i dopuszczalności kontrakcji dla m-ARS oraz dopuszczalności (Cut), jednak dowody trzeba poszerzyć o uwzględnienie przypadków reguł kwantyfikatorowych. Dopuszczalność kontrakcji jest nam potrzebna jedynie dla dowodu dopuszczalności (Cut) metodą Dragalina dla m-ARS, gdyż jedyne przypadki kontrakcji istotne dla pełności systemu są zapewnione przez kształt nowych reguł $(\forall \Rightarrow)$ i $(\Rightarrow \exists)$.

Dowiedziemy najpierw

Lemat 9.6 (Dopuszczalność osłabiania) Jeżeli $\vdash_{A R S} \Gamma \Rightarrow \Delta$, to $\vdash_{A R S}$ $\Gamma \Rightarrow \Delta, \psi i \vdash_{A R S} \psi, \Gamma \Rightarrow \Delta$, ponadto dtugość dowodu nie jest większa.

DowóD: Tak jak w przypadku ARS-KRZ przez indukcję po długości dowodu. Rozważmy przypadek, gdy $\vdash_{k} \Gamma \Rightarrow \Delta$ jest dowiedziona przez zastosowanie $(\forall \Rightarrow)$, zatem ma postać $\vdash_{k} \forall x \varphi, \Gamma^{\prime} \Rightarrow \Delta$, a przesłanka $\vdash_{k-1} \varphi[x / \tau], \Gamma^{\prime} \Rightarrow$ $\Delta$. Z założenia indukcyjnego $\vdash_{k-1} \varphi[x / \tau], \Gamma^{\prime} \Rightarrow \Delta, \psi$ skąd przez $(\forall \Rightarrow)$ mamy $\vdash_{k} \forall x \varphi, \Gamma^{\prime} \Rightarrow \Delta, \psi$. Analogicznie dla $\psi$ w poprzedniku.

Gdy $\vdash_{k} \Gamma \Rightarrow \Delta$ jest dowiedziona przez zastosowanie $(\Rightarrow \forall)$, wtedy ma postać $\vdash_{k} \Gamma \Rightarrow \Delta^{\prime}, \forall x \varphi$, a przesłanka $\vdash_{k-1} \Gamma \Rightarrow \Delta^{\prime}, \varphi[x / a]$. Wprawdzie $a$ nie występuje $\mathrm{w} V F\left(\Gamma, \Delta^{\prime}, \varphi\right)$, ale nie mamy gwarancji czy nie występuje w $V F(\psi)$. Zatem wybierzmy $b$, która spełnia ten warunek. Na podstawie lematu 9.5 mamy $\vdash_{k-1}\left(\Gamma \Rightarrow \Delta^{\prime}, \varphi[x / a]\right)[a / b]$ co $\mathrm{w}$ istocie daje $\vdash_{k-1} \Gamma \Rightarrow \Delta^{\prime},(\varphi[x / a])[a / b]$, gdyż $b \notin V F\left(\Gamma, \Delta^{\prime}\right)$. Ponieważ sac to podstawienia ścisłe, więc na mocy faktu 8.1, punkt $4,(\varphi[x / a])[a / b]:=\varphi[x / b]$. Zatem $\vdash_{k-1} \Gamma \Rightarrow \Delta^{\prime}, \varphi[x / b]$. Na bazie założenia indukcyjnego otrzymujemy $\vdash_{k-1} \Gamma \Rightarrow \Delta^{\prime}, \varphi[x / b], \psi$, a ponieważ $b \notin V F\left(\Gamma, \Delta^{\prime}, \varphi, \psi\right)$, więc przez $(\Rightarrow \forall)$ mamy $\vdash_{k} \Gamma \Rightarrow \Delta^{\prime}, \forall x \varphi, \psi$. Analogicznie dla $\psi$ w poprzedniku.

Dowód dla reguł dla $\exists$ przeprowadzamy dualnie.

Możemy teraz dowieść

Lemat 9.7 (Odwracalność reguł) Dla każdej reguły, jeżeli wniosek ma dowód (długości $n$ ), to przesłanki też maja dowody (długości $\leq n$ ). 
DowóD: Dla $(\forall \Rightarrow)$ i $(\Rightarrow \exists)$ w obecnej postaci odwracalność zachodzi przez dopuszczalność osłabiania. Dla pozostałych reguł dowód przez indukcję po długości dowodu wniosku reguły, tak jak dla KRZ w podrozdziale 4.3 (lemat 4.11) Dowiedziemy odwracalności $(\exists \Rightarrow)$, tzn. wykażemy, że:

$$
\text { jeżeli } \vdash_{n} \exists x \varphi, \Gamma \Rightarrow \Delta \text {, to } \vdash_{n} \varphi[x / a], \Gamma \Rightarrow \Delta
$$

Dowód dla $(\Rightarrow \forall)$ przeprowadzamy analogicznie.

Baza: Załóżmy, że $\vdash_{n} \exists x \varphi, \Gamma \Rightarrow \Delta$. Jeżeli $n=0$, to $\Gamma \cap \Delta \neq \varnothing$, ale wtedy $\varphi[x / a], \Gamma \Rightarrow \Delta$ też jest aksjomatem. Przypomnijmy, że bierzemy tu pod uwagę wersję ARS z uogólnionymi aksjomatami atomowymi, więc $\exists x \varphi$ nie jest formułą, ze względu na którą $\exists x \varphi, \Gamma \Rightarrow \Delta$ jest aksjomatem.

Założenie indukcyjne mówi, że lemat zachodzi dla dowolnego dowodu wniosku o długości $<n$. Pokazujemy, że zajdzie również gdy dowód ma długość $n$. Mamy zatem dowód $\mathcal{D}$ długości $n$ zakończony sekwentem $S:=$ $\exists x \varphi, \Gamma \Rightarrow \Delta$.

Należy rozważyć dwa podprzypadki:

a. $\exists x \varphi$ jest formułą zasadniczą $S$;

b. $\exists x \varphi$ nie jest formułą zasadniczą $S$.

Jeżeli ostatnia reguła to $(\exists \Rightarrow)$ z $\exists x \varphi$ jako formułą zasadniczą, to wtedy po obcięciu ostatniego sekwentu z $\mathcal{D}$ mamy dowód $\varphi[x / a], \Gamma \Rightarrow \Delta$ (długości $n-1)$.

Rozważmy podprzypadek b.

Jeżeli $\exists x \varphi$ nie jest formułą zasadniczą $S$, to jest formułą parametryczną. Jeżeli zastosowana reguła jest zdaniowa, to dowód wygląda tak samo jak w przypadku ARS-KRZ. Przykładowo, jeżeli ostatnio zastosowana reguła była dwuprzesłankowa, to $\mathcal{D}$ kończy się następująco:

$$
\frac{\exists x \varphi, \Gamma^{\prime} \Rightarrow \Delta^{\prime} \quad \exists x \varphi, \Gamma^{\prime \prime} \Rightarrow \Delta^{\prime \prime}}{\exists x \varphi, \Gamma \Rightarrow \Delta}
$$

Ponieważ dowody obu przesłanek mają długość $<n$, to podpadają pod założenie indukcyjne. Zatem mamy dowody sekwentów $\varphi[x / a], \Gamma^{\prime} \Rightarrow \Delta^{\prime} \mathrm{i}$ $\varphi[x / a], \Gamma^{\prime \prime} \Rightarrow \Delta^{\prime \prime} \mathrm{z}$ a nie występującym w żadnym z rozważanych sekwentów. Ale wtedy za pomocą tej samej reguły dwuprzesłankowej, która kończyła $\mathcal{D}$ wydedukujemy z nich sekwent $\varphi[x / a], \Gamma \Rightarrow \Delta$. 
Natomiast w przypadku, gdy reguła była kwantyfikatorowa wskazana jest ostrożność w celu uniknięcia kolizji zmiennych. Przykładowo, niech $\vdash_{n}$ $\exists x \varphi, \Gamma \Rightarrow \Delta$ zostało wydedukowane przez $(\Rightarrow \forall)\left(\Delta:=\Delta^{\prime}, \forall y \psi\right)$ z przesłanki $\vdash_{n-1} \exists x \varphi, \Gamma \Rightarrow \Delta^{\prime}, \psi[y / a]$. Wtedy musimy odwołać się do lematu o podstawianiu i zastąpić dowód przesłanki przez dowód sekwentu $\vdash_{n-1} \exists x \varphi, \Gamma \Rightarrow$ $\Delta^{\prime}, \psi[y / b]$ z $b$ spełniającym również warunki poprawności ale różnym od $a$. $\mathrm{Z}$ założenia indukcyjnego mamy $\vdash_{n-1} \varphi[x / a], \Gamma \Rightarrow \Delta^{\prime}, \psi[y / b]$. Skąd przez $(\Rightarrow \forall) \vdash_{n} \varphi[x / a], \Gamma \Rightarrow \Delta^{\prime}, \forall y \psi$. Podobnie postępujemy gdy w grę wchodzi $(\forall \Rightarrow)$ lub $(\Rightarrow \exists)$ i $\tau$ zawiera lub jest identyczne z $a$.

Wydawać się może, że dowód twierdzenia o odwracalności jest w ten sposób zakończony, zauważmy jednak, że dowodzenie odwracalności reguł zdaniowych w rozdziale 4 nie uwzględniało w przypadku b., że zastosowana reguła jest regułą kwantyfikatorową. Zatem, aby być pewnym, że reguły zdaniowe w ARS-KRK nadal są odwracalne trzeba również uzupełnić podany tam dowód odwracalności dla reguł zdaniowych przez rozważenie przypadku zastosowania reguł dla kwantyfikatorów ${ }^{3}$.

Na przykładzie $(\Rightarrow \wedge)$ pokażemy, że dowód odwracalności reguł zdaniowych pozostaje poprawny w ARS-KRK, tzn. że zastosowanie reguł kwantyfikatorowych nie wpływa na dowód kroku indukcyjnego dla reguł zdaniowych. Niech $\vdash_{n} \Gamma \Rightarrow \Delta, \varphi \wedge \psi$ będzie wydedukowane za pomocą $(\exists \Rightarrow)$. Wtedy $\Gamma:=\exists x \chi, \Gamma^{\prime}$, a przesłanka ma postać $\chi[x / a], \Gamma^{\prime} \Rightarrow \Delta, \varphi \wedge \psi$. Z założenia indukcyjnego $\vdash \chi[x / a], \Gamma^{\prime} \Rightarrow \Delta, \varphi \mathrm{i} \vdash \chi[x / a], \Gamma^{\prime} \Rightarrow \Delta, \psi$ (z dowodami długości nie większej od $n-1)$, a zatem przez $(\exists \Rightarrow) \vdash \exists x \chi, \Gamma^{\prime} \Rightarrow \Delta, \varphi$ i $\vdash \exists x \chi, \Gamma^{\prime} \Rightarrow \Delta, \psi$ (z dowodami długości nie większej od $n$ ), gdyż warunki poprawności dla $a$ nie są zakłócone.

Podobnie postępujemy, gdy w grę wchodzą inne reguły kwantyfikatorowe i inne reguły zdaniowe.

Na koniec dowiedziemy (dla m-ARS)

Lemat 9.8 (Dopuszczalność kontrakcji) Jeżeli $\vdash_{A R S} \varphi, \varphi, \Gamma \Rightarrow \Delta$, to $\vdash_{A R S} \varphi, \Gamma \Rightarrow \Delta$, oraz jeżeli $\vdash_{A R S} \Gamma \Rightarrow \Delta, \varphi, \varphi, t_{A} \vdash_{A R S} \Gamma \Rightarrow \Delta, \varphi$. Ponadto długość dowodu nie jest większa.

DowóD: Musimy uzupełnić dowód lematu 4.12 uwzględniając zastosowanie reguł kwantyfikatorowych. Ponownie konstrułujemy dowód indukcyjny po długości dowodu $\varphi, \varphi, \Gamma \Rightarrow \Delta$ (względnie $\Gamma \Rightarrow \Delta, \varphi, \varphi$ ). Dowód bazy się nie

\footnotetext{
${ }^{3}$ Szczegół ten zdaje się umykać wielu autorom prac zawierających wyniki dla RS, np., w znakomitym skądinąd opracowaniu Negri, von Plato [101].
} 
zmienia. Również w dowodzie kroku indukcyjnego rozważanie przypadku, gdy $\varphi$ nie jest formułą zasadniczą nie ulega zmianie po dodaniu kwantyfikatorów. Pozostaje nam rozważenie przypadku, gdy $\varphi$ jest formułą zasadniczą. Założenie indukcyjne mówi, że lemat zachodzi dla dowolnego dowodu wniosku o długości $<n$. Pokazujemy, że zajdzie też gdy dowód ma długość $n$.

Niech $\varphi:=\exists x \psi$, wtedy rozważany sekwent ma postać $\exists x \psi, \exists x \psi, \Gamma \Rightarrow \Delta$, a przesłanka postać $\psi[x / a], \exists x \psi, \Gamma \Rightarrow \Delta$ i posiada dowód długości $n-1$. Z lematu o odwracalności $\psi[x / a], \psi[x / a], \Gamma \Rightarrow_{n-1} \Delta$, skąd przez założenie indukcyjne mamy $\psi[x / a], \Gamma \Rightarrow_{n-1} \Delta$, a przez $(\exists \Rightarrow) \exists x \psi, \Gamma \Rightarrow_{n} \Delta$.

Niech $\varphi:=\forall x \psi$. Wtedy rozważany sekwent ma postać $\forall x \psi, \forall x \psi, \Gamma \Rightarrow \Delta$, a przesłanka postać $\psi[x / \tau], \forall x \psi, \forall x \psi, \Gamma \Rightarrow \Delta$ i dowód o długości $n-1$. Tutaj nie musimy się nawet odwoływać do lematu o odwracalności, gdyż z założenia indukcyjnego z przesłanki dostajemy $\psi[x / \tau], \forall x \psi, \Gamma \Rightarrow_{n-1} \Delta$. Skąd przez $(\forall \Rightarrow)$ mamy $\forall x \psi, \Gamma \Rightarrow_{n} \Delta$.

Analogicznie dla eliminacji kontrakcji w następniku, gdy uwzględnić musimy przypadek $(\Rightarrow \forall)$ i $(\Rightarrow \exists)$.

Dla ARS-KRK możemy dowieść dopuszczalności cięcia metodą Dragalina.

\section{Twierdzenie 9.3 (Dopuszczalność (Cut) w ARS)}

DowóD przebiega tak jak u Gentzena. Zmienia się nieco przypadek $4 \mathrm{w}$ stosunku do A1 w dowodzie Gentzena, gdyż mamy reguły z powtórzeniem formuły zasadniczej $\mathrm{w}$ przesłance. Przypadek dla cut-formuły $:=\forall x \varphi$ wygląda następująco:

$$
(\Rightarrow \forall) \frac{\Gamma \Rightarrow \Delta, \varphi[x / a]}{\Gamma \Rightarrow \Delta, \forall x \varphi} \quad \frac{\varphi[x / \tau], \forall x \varphi, \Pi \Rightarrow \Sigma}{\forall x \varphi, \Pi \Rightarrow \Sigma}(\forall \Rightarrow)
$$

Zastępujemy go przez:

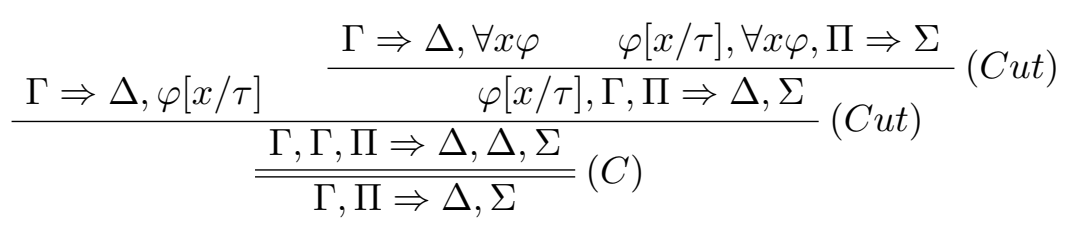

gdzie znów odwołaliśmy się do lematu 9.5 dla uzasadnienia zamiany dowodu $\Gamma \Rightarrow \Delta, \varphi[x / a]$ na dowód $\Gamma \Rightarrow \Delta, \varphi[x / \tau]$ i gdzie pierwsze zastosowanie (Cut) mimo tej samej cut-formuły ma mniejszą o 1 długość. 


\subsection{Metody semantyczne w ARS}

Cała dotychczasowa prezentacja wyników dla LK i ARS miała charakter czysto syntaktyczny. Obecnie pokażemy, w jaki sposób można na grunt dowolnego RS dla logiki pierwszego rzędu przenosić rezultaty semantyczne. Ograniczymy się, podobnie jak w przypadku KRZ, do dowodu twierdzenia o adekwatności dla ARS.

\subsubsection{Dowód adekwatności ARS}

Wykażemy najpierw, że:

Lemat 9.9 Kazda reguła ARS jest niezawodna.

DowóD: Wykorzystujemy semantyczną interpretację sekwentu wprowadzoną w podrozdziale 3.3, dostosowując ją do semantyki teoriomodelowej. Uzasadnienie reguł zdaniowych pozostaje bez zmian, wystarczy wykazać niezawodność reguł kwantyfikatorowych. Wykażemy niezawodność dwóch reguł wprowadzających formuły kwantyfikatorowe do poprzednika. Dowody dla reguł działających na następniku są symetryczne.

1. $(\forall \Rightarrow)$ : Załóżmy, że $\models \forall x \varphi, \varphi[x / \tau], \Gamma \Rightarrow \Delta$ ale $\not \models \forall x \varphi, \Gamma \Rightarrow \Delta$. Wtedy istnieje model $\mathfrak{M}$ i waluacja $v$ taka, że $\mathfrak{M}, v \vDash \forall x \varphi, \Gamma$ i $\mathfrak{M}, v \not \models \Delta$, co implikuje $\mathfrak{M}, v \not \models \varphi[x / \tau]$. Przez twierdzenie o podstawianiu (lemat 8.6) $\mathfrak{M}, v_{I_{v}(\tau)}^{x} \not \models \varphi$. Ale $\mathfrak{M}, v_{o}^{x} \vDash \varphi$ dla wszystkich $o \in D$, w szczególności dla $o=I_{v}(\tau)$, co prowadzi do sprzeczności ${ }^{4}$.

2. $(\exists \Rightarrow)$ : Załóżmy, że $\models \varphi[x / a], \Gamma \Rightarrow \Delta$ i rozważmy dowolny model $\mathfrak{M}$ i waluację $v$ taką, że $\mathfrak{M}, v \vDash \exists x \varphi, \Gamma$. Musimy dowieść, że $\mathfrak{M}, v \vDash \Delta$. Z założenia mamy, że $\mathfrak{M}, v_{o}^{x} \vDash \varphi$ dla pewnego $o \in D$. Z twierdzenia o koincydencji (lemat 8.5) mamy, że również $\mathfrak{M},\left(v_{o}^{a}\right)_{o}^{x} \vDash \varphi$, gdyż $a \notin V F(\varphi)$, więc $v$ i $v_{o}^{a}$ zgadzają się na zmiennych wolnych (parametrach) $\varphi$. Ponieważ $v_{o}^{a}(a)=o=I_{v_{o}^{a}}(a)$, więc to ostatnie możemy przepisać jako $\mathfrak{M},\left(v_{o}^{a}\right)_{I_{v_{o}^{a}(a)}}^{x} \vDash \varphi$. Przez twierdzenie o podstawianiu (lemat 8.6) otrzymujemy $\mathfrak{M}, v_{o}^{a} \vDash \varphi[x / a]$, a ponieważ $a \notin$ $V F(\Gamma)$, więc również $\mathfrak{M}, v_{o}^{a} \vDash \Gamma$ przez twierdzenie o koincydencji (lemat 8.5). Z założenia otrzymujemy, że również $\mathfrak{M}, v_{o}^{a} \vDash \Delta$ co - ponownie przez twierdzenie o koincydencji - daje $\mathfrak{M}, v \vDash \Delta$ gdyż $a \notin V F(\Delta)$.

Powyższy lemat wystarczy do udowodnienia przystosowania. Dowód jest identyczny jak dla KRZ (por. lemat 3.6).

\footnotetext{
${ }^{4}$ Zauważmy, że podany argument uzasadnia również zwykłą (nieodwracalną) formę tej reguły podaną dla LK.
} 
W rozdziale 7 pokazaliśmy kilka dowodów twierdzenia o pełności dla ARS-KRZ. Oprócz ostatniego (metodą Posta) każdy z nich można wykorzystać dla konstrukcji analogicznego dowodu dla KRK. I tak, mając udowodnioną dopuszczalność (Cut) w ARS można wykorzystać ten fakt do udowodnienia pełności tego rachunku metodą Henkina, w taki sposób jak zrobiliśmy to w rozdziale 7 dla ARS-KRZ. Zachęcamy czytelnika by dokonał stosownej adaptacji dowodu podanego w rozdziale 8 dla systemu aksjomatycznego ${ }^{5}$. Jednak nawet nie dysponując twierdzeniem o dopuszczalności (Cut) możemy przeprowadzić bezpośrednio analityczny dowód pełności dla ARS jedną z metod wprowadzonych w rozdziale 7 . Ograniczymy się do dowodu zaprezentowanego w paragrafie 7.2.1, zachęcając czytalnika do adaptacji innych metod. W celu poszerzenia podanej tam metody dowodu na KRK musimy:

- wzbogacić pojęcie pary zbiorów nasyconych;

- zmodyfikować definicję modelu i waluacji niezbędną dla dowodu lematu prawdziwościowego;

- wykazać, że dla każdego niedowiedlnego sekwentu również da się zbudować parę zbiorów nasyconych.

Dwa pierwsze punkty mają charakter semantyczny, a ostatni czysto syntaktyczny.

\subsubsection{Istnienie modelu}

Definiując pojęcie pary zbiorów nasyconych w KRK i indukowanego przez nią modelu musimy chwilę uwagi poświęcić zbiorowi termów, który posłuży jako dziedzina modelu. Może się zdarzyć, że model wystarczający do falsyfikacji niedowiedlnego sekwentu będzie skończony, ale generalnie musimy liczyć się z dziedzinami nieskończonymi. Najwygodniejszym rozwiązaniem jest przyjęcie podejścia parametrycznego względem zmiennych wolnych, tzn. potraktowanie ich jako stałych, i posłużenie się pojęciem uniwersum Herbranda dla danego zbioru formuł. Jest to popularne rozwiązanie stosowane $\mathrm{w}$ wielu opracowaniach przede wszystkim dla metod tablicowych (np. Fitting [43], Keisler i Robbin [81], Letz [92] ), ale również dla RS (np. Gallier [48])

\footnotetext{
${ }^{5}$ Zwróćmy uwagę, że dowód tam podany wykorzystywał wzbogacenie zbioru termów o przeliczalny zbiór tzw. świadków $C O N^{\prime}$. Adaptując go do RS najprościej jest zastosować strategię językową, w której zamiast zmiennych wolnych używamy parametrów interpretowanych semantycznie (tzn. przy konstrukcji modelu kanonicznego) jako stałe.
} 
Rozważmy dowolny zbiór formuł $\Gamma$. Niech $\Gamma_{C}$ oznacza zbiór wszystkich stałych nazwowych (parametrów) w $\Gamma$ a $\Gamma_{F}$ wszystkich wyrażeń funkcyjnych w $\Gamma$. Oczywiście oba zbiory moga być puste.

Definicja 9.3 (Uniwersum Herbranda) Uniwersum Herbranda $H$ dla zbioru $\Gamma$ to algebra termów zdefiniowana następujaco:

- $\Gamma_{C} \subseteq H$; jeżeli $\Gamma_{C}=\varnothing$, to $a \in H$, dla arbitralnie wybranego parametru;

- jeżeli $\tau_{1}, \ldots, \tau_{n} \in H i f^{n} \in \Gamma_{F}$, to $f^{n}\left(\tau_{1}, \ldots, \tau_{n}\right) \in H$, gdzie $\tau_{1}, \ldots, \tau_{n}$ nie musza być różne.

Uwaga 9.6: $\mathrm{W}$ przypadku $\Gamma_{C}$ pustego musimy arbitralnie wprowadzić przynajmniej jeden element, gdyż modele dla logiki klasycznej są niepuste. Gdy $\Gamma_{F}$ jest niepuste, np. zawiera $f^{1}$, to $H$ automatycznie staje się nieskończone, gdyż zawiera $f a, f f a, f f f a, \ldots$. Natomiast pustość $\Gamma_{F}$ nie gwarantuje skończoności $H$ - por. przykład 9.3. Tym niemniej ograniczenie się do modeli falsyfikujacych budowanych na uniwersach Herbranda pozwala w wielu przypadkach, gdy $\Gamma_{F}$ jest puste uzyskiwać modele skończone. Zależy to jednak w dużej mierze od tego jak zdefiniujemy procedurę nasycania gałęzi.

Definicja $9.4(\Gamma, \Delta)$ jest (w dót) nasycony względem $H$ wtw spetnia warunki dla KRZ i dodatkowo:

1. jeżeli $\forall x \varphi \in \Gamma$, to $\varphi[x / \tau] \in \Gamma$, dla dowolnego $\tau \in H$;

2. jeżeli $\forall x \varphi \in \Delta$, to $\varphi[x / a] \in \Delta$, dla pewnego $a \in H$;

3. jeżeli $\exists x \varphi \in \Gamma$, to $\varphi[x / a] \in \Gamma$, dla pewnego $a \in H$;

4. jeżeli $\forall x \varphi \in \Delta$, to $\varphi[x / \tau] \in \Delta$, dla dowolnego $\tau \in H$;

gdzie $H$ jest uniwersum Herbranda dla $\Gamma \cup \Delta$.

Uwaga 9.7: Pozbywanie się zmiennych wolnych nie jest konieczne dla zastosowania prezentowanych rozwiązań, ale upraszcza dowody. Jeżeli uwzględniamy zmienne wolne, to musimy wzbogacić zarówno definicję pary nasyconej jak i indukowanego modelu (por. np. Bell, Machover [11]). W pierwszym przypadku musimy dodać warunek:

jeżeli $x \in V F(\Gamma \cup \Delta)$, to $x \in H$; 
Natomiast jako valuację stowarzyszoną z modelem bierzemy dowolne $v$, które jest funkcją identycznościową na dowolnej $x \in H$.

Łatwo dowieść, że para nasycona względem $H$ ma model falsyfikujący zwany modelem Herbranda.

Definicja 9.5 (Struktura interpretacyjna $\mathfrak{M}_{H}$ dla pary $\left.(\Gamma, \Delta)\right) D_{H}=$ $H$ (zbiór wszystkich termów stałych $z \Gamma \cup \Delta$ )

$V_{H}$ definiujemy następujaco:

- $V_{H}(c)=c$, dla dowolnej statej nazwowej c;

- $V_{H}\left(f^{n}\left(\tau_{1}, \ldots, \tau_{n}\right)\right)=f^{n}\left(\tau_{1}, \ldots, \tau_{n}\right)$, dla dowolnej n-argumentowej operacji $f^{n} i$ dowolnych $\tau_{1}, \ldots, \tau_{n} \in D_{H}$;

- $\left\langle\tau_{1}, \ldots, \tau_{n}\right\rangle \in V_{H}\left(P^{n}\right)$ wtw $P^{n}\left(\tau_{1}, \ldots, \tau_{n}\right) \in \Gamma$ dla dowolnego n-argumentowego predykatu $P^{n} i$ dowolnych $\tau_{1}, \ldots, \tau_{n} \in D_{H}$.

Musimy wykazać, że $\mathfrak{M}_{H}$ jest modelem dla pary zbiorów nasyconych $\Gamma, \Delta$.

Lemat 9.10 (lemat prawdziwościowy - wersja analityczna)

- Jézeli $\varphi \in \Gamma$, to $\mathfrak{M}_{H} \vDash \varphi$;

- jeżeli $\varphi \in \Delta$, to $\mathfrak{M}_{H} \not \models \varphi$.

DowóD: Dowodzimy przez indukcję strukturalną po kształcie formuł, że zachodzą oba warunki. Baza jest oczywista, gdyż $P\left(\tau_{1}, \ldots, \tau_{n}\right) \in \Gamma$ wtw $\left\langle\tau_{1}, \ldots, \tau_{n}\right\rangle \in V_{H}\left(P^{n}\right)\left(\right.$ z definicji $\left.V_{H}\right)$ wtw $\mathfrak{M}_{H} \vDash P\left(\tau_{1}, \ldots, \tau_{n}\right)$.

Dla dowodu kroku indukcyjnego zakładamy, że każda formuła krótsza od $\varphi$ spełnia dowodzoną równoważność i wykazujemy ją dla $\varphi$. Rozważymy przypadek $\varphi:=\forall x \psi$.

A. $\varphi \in \Gamma$

$\forall x \psi \in \Gamma$ implikuje $\quad \psi[x / \tau] \in \Gamma$, def. pary Hintikki dla dowolnego $\tau \in D_{H}$ implikuje $\quad \mathfrak{M}_{H} \vDash \psi[x / \tau]$ $\mathrm{z}$ zał. ind. implikuje $\quad \mathfrak{M}_{H} \vDash \forall x \psi$ fakt 8.6, punkt 3 .

B. $\varphi \in \Delta$

$\forall x \psi \in \Delta$ implikuje, że $\psi[x / \tau] \in \Delta$, dla pewnego $\tau \in D_{H}$ (z definicji pary Hintikki), co z kolei implikuje, że $\mathfrak{M}_{H} \vDash \psi[x / \tau]$ z założenia indukcyjnego. Załóżmy niewprost, że $\mathfrak{M}_{H} \vDash \forall x \psi$ czyli dla dowolnego $v, \mathfrak{M}_{H}, v \vDash \forall x \psi$, a zatem 
$\mathfrak{M}_{H}, v_{o}^{x} \vDash \psi$ dla dowolnego termu $o \in D_{H}$. W szczególności $\mathfrak{M}_{H}, v_{I_{v}(\tau)}^{x} \vDash \psi$, co - przez twierdzenie o podstawianiu (lemat 8.6) - daje $\mathfrak{M}_{H}, v \vDash \psi[x / \tau]$. Ponieważ $v$ było dowolne, więc otrzymujemy sprzeczność.

Uwaga 9.8: Operowanie modelami Herbranda nie jest konieczne. Np. dowód Kleene'go [84], Bussa [20] dla RS czy Bella i Machovera [11] dla systemu tablicowego wykorzystuje modele budowane na bazie listy wszystkich termów. Przy takich podejściach nie zakłada się, że uzyskany model będzie skończony nawet dla tych przypadków, gdzie byłoby to możliwe.

\subsubsection{Saturacja}

Pozostaje wykazać, że dla każdego niedowiedlnego sekwentu (= niesprzecznej pary zbiorów) istnieje nasycone niesprzeczne poszerzenie. Tym razem generowane drzewo dowodowe może być nieskończone dlatego w dowodzie musimy wykorzystać dwa wyniki podane w dodatku: lemat Königa i twierdzenie o enumeracji zbiorów przeliczalnych. Pierwszy wynik gwarantuje nam, że jeżeli drzewo jest nieskończone, to (ponieważ jest skończenie generowane) istnieje w nim nieskończona gałąź. Drugi gwarantuje nam, że zbiór wszystkich formuł i termów możemy uporządkować liniowo ${ }^{6}$.

$\mathrm{W}$ istocie rozważamy nie tyle uporządkowanie zbioru wszystkich formuł i termów, co raczej tych, które budowane są w oparciu o dane uniwersum Herbranda dla rozważanego sekwentu. Innymi słowy, dla każdego sekwentu rozważamy taki język pierwszego rzędu, który jest generowany przez predykaty i termy występujące w sekwencie. Oczywiście dla sekwentu nie zawierającego żadnego parametru nazwowego deklarujemy arbitralnie przynajmniej jeden (por. uwaga 9.6). Ze względu na warunek poprawności nałożony na reguły $(\exists \Rightarrow)$ i $(\Rightarrow \forall)$ wygodnie jest wydzielić osobną nieskończoną listę parametrów $P$, które niezależnie od tego występują na liście wszystkich termów. W przypadku, gdy sekwent nie ma żadnego wyrażenia funkcyjnego lista parametrów $P$ jest wystarczająca dla naszych celów. Poniżej przedstawimy dowód dla tego przypadku, a następnie uogólnimy go dla przypadku z dowolnymi termami.

\footnotetext{
${ }^{6}$ Nie będziemy tutaj omawiać żadnego konkretnego uporządkowania zbioru termów; nieformalne omówienie problemu można znaleźć np. w Kleene [84], a formalny algorytm w Gallier [48].
} 
Lemat 9.11 (Saturacja) Jeżeli $\nvdash \Gamma \Rightarrow \Delta$, to istnieje nasycone $(\Pi, \Sigma)$ takie, $\dot{z} e$ :

(a) $\Pi \cup \Sigma \subseteq S F(\Gamma \cup \Delta)$;

(b) $(\Pi, \Sigma)$ jest niesprzeczny;

gdzie $S F(\Gamma \cup \Delta)$ oznacza zbiór wszystkich podformuł wystęujacych w formułach $z \Gamma \cup \Delta$.

DowóD: Konstruując $(\Pi, \Sigma)$ dla KRK możemy się ponownie odwołać do procedury szukania dowodu zdefiniowanej w rozdziale 6 . Tym razem jednak wygodniejsze jest użycie algorytmów typu breadth-first (budujących wszerz), gdyż poprzednia strategia może prowadzić do rozwijania nieskończonej gałęzi (i nieskończonego modelu falsyfikującego) w przypadkach gdzie eksploatacja innej gałęzi może dać efekt skończony. Ponadto przy algorytmach typu breadth-first proces przeszukiwania listy termów jest prowadzony równolegle dla wszystkich liści drzewa na danym etapie. Na etapie pierwszym oczywiście wypisujemy sekwent, dla którego szukamy dowodu. Każdy etap $n+1$ budujemy na bazie drzewa uzyskanego w etapie $n$ w następujący sposób:

Jeżeli każdy liść jest aksjomatyczny, otrzymujemy dowód, w przeciwnym wypadku:

1. Stosujemy wszystkie możliwe reguły zdaniowe oraz $(\Rightarrow \forall)$ i $(\exists \Rightarrow)$ do każdego liścia nieatomowego i nieaksjomatycznego. W przypadku dwóch ostatnich reguł wybieramy kolejne parametry z listy $P$, które nie zostały dotąd użyte na danej gałęzi.

2. Stosujemy $(\Rightarrow \exists)$ i $(\forall \Rightarrow)$ do wszystkich nieużytych dotąd na drzewie, ale relewantnych termów. Dokładniej, gdy wybieramy $\forall x \varphi \mathrm{z}$ poprzednika (podobnie gdy stosujemy $(\Rightarrow \exists$ )), to dopisujemy do niego zbiór instancji $\varphi\left[x / \tau_{1}\right], \ldots, \varphi\left[x / \tau_{n}\right]$ dla wszystkich $\tau_{i}, i \leq n$ takich, że:

a. $\tau_{n}$ jest parametrem o najwyższym indeksie na liście $P$, który został użyty w tym etapie jako eigenvariable na tej gałęzi.

b. każde $\tau_{i}, 1 \leq i<n$ to term, który na liście $P$ poprzedza $\tau_{n}$, ale nie został użyty wcześniej jako instancja dla $\varphi$ na tej gałęzi.

Nazwijmy sekwent quasi-atomowym, jeżeli oprócz formuł atomowych zawiera $\forall$-formuły w poprzedniku lub $\exists$-formuły w następniku, ale brak jest relewantnych termów dla zastosowania $(\forall \Rightarrow)$ lub $(\Rightarrow \exists)$ (tzn. wszystkie parametry z listy $P$ do $n$ włącznie zostały już użyte). 
Jeżeli przynajmniej jeden liść uzyskany w etapie $n+1$ jest nieaksjomatyczny, ale atomowy lub quasi-atomowy, to $\nvdash \Gamma \Rightarrow \Delta$. W przeciwnym wypadku przechodzimy do kolejnego etapu i powtarzamy opisaną wyżej pętlę.

Jak widać, jeżeli $\nvdash \Gamma \Rightarrow \Delta$, to w kompletnym drzewie dowodowym istnieje co najmniej jedna skończona gałąź, której liść jest nieaksjomatyczny i atomowy (quasi-atomowy) lub gałąź nieskończona. Istnienie takiej nieskończonej gałęzi gwarantuje nam lemat Königa. Gałąź taka jest przeliczalnym ciągiem sekwentów: $\Gamma \Rightarrow \Delta, \Gamma_{1} \Rightarrow \Delta_{1}, \ldots$

Zdefiniujmy: $\Pi=\bigcup \Gamma_{i}, \Sigma=\bigcup \Delta_{i}$, gdzie $i \leq \aleph$ (tzn. $\Gamma_{i} \Rightarrow \Delta_{i}$ to dowolny sekwent występujący na tej gałęzi).

Należy wykazać, że $(\Pi, \Sigma)$ jest nasycony oraz spełnia warunki (a) i (b).

Nasycenie wynika z faktu, że warunki definiujące parę nasyconą odpowiadają regułom zastosowanym w konstrukcji rozważanej gałęzi. W szczególności, sposób potraktowania formuł kwantyfikatorowych gwarantuje, że wszystkie wymagane podstawienia pojawiły się na gałęzi. Natomiast (a) jest konsekwencją własności podformuł, a (b) jest spełniony z definicji (otwarta gałąź).

Dowód twierdzenia o pełności w oparciu o podane wyżej rezultaty nie różni się od dowodu dla KRZ.

Uwaga 9.9: Łatwo zauważyć, że w podanym w dowodzie przepisie na budowę drzewa dowodowego nie przestrzegamy warunku (ii) charakteryzującego PV-dowody, tzn. ten sam parametr może się pojawiać na różnych gałęziach jako eigenvariable. $\mathrm{Z}$ jednej strony wprowadza to pewną komplikację, gdyż zamiast jednej listy $P$ musimy rozważać dla każdej gałęzi $B$ jej kopię $P_{B}$, na której osobno odnotowujemy, które parametry zostały wykorzystane na danym etapie. Z drugiej strony, w praktyce, pozwala to w tych przypadkach, w których sekwent jest falsyfikowalny z pomocą skończonego modelu znacznie ograniczyć długość otwartych gałęzi (i liczebność dziedzin modeli) gdyż nie musimy stosować $(\forall \Rightarrow)$ i $(\Rightarrow \exists)$ do żadnego parametru, który nie został tam wprowadzony jako eigenvariable lub nie znajdował się w sekwencie wyjściowym.

Uogólnienie podanego wyniku na sekwenty zawierające wyrażenia funkcyjne prowadzi generalnie do rezygnacji z uzyskania modeli skończonych. Oczywiście incydentalnie moga pojawić się liście atomowe, które pozwolą na uzyskanie skończonego modelu falsyfikującego na danym etapie. Generalnie jednak musimy przyjąć, że konstrukcja algorytmu powinna po prostu pozwolić na to, by prędzej czy później każdy term z listy wszystkich termów z 
danego uniwersum Herbranda (lub po prostu wszystkich termów - por. uwaga 9.8) został użyty przy zastosowaniu reguł $(\forall \Rightarrow)$ i $(\Rightarrow \exists)$. Nieformalny opis algorytmu tego typu dla RS można znaleźć np. w Buss [20], natomiast Gallier [48] zawiera bardzo szczegółowe i formalne potraktowanie takiej procedury.

\subsection{Wzmocnienie twierdzenia o eliminacji (Cut)}

Gentzen [50] zaprezentował też mocniejszą postać twierdzenia o eliminacji cięcia, którą określimy mianem twierdzenia o sekwencie pośredniczącym ${ }^{7}$. Sam Gentzen uznał je za wzmocnienie twierdzenia Herbranda, W istocie jest to tylko jego szczególny przypadek. Nieporozumienie wynikało stąd, że wynik Herbranda w oryginalnej postaci sformułowany był w dość zawiły sposób, a jego dowód zawierał błędy. Wątpliwości odnośnie faktycznego zasiegu rezultatu Herbranda zostały rozproszone dopiero w pracach [33] i [34]. Choć wynik Gentzena jest w istocie mniej ogólny od twierdzenia Herbranda, to jednak sformułowany i dowiedziony w przejrzysty sposób, a [50] zawiera jego interesujące zastosowanie $\mathrm{w}$ dowodzie niesprzeczności arytmetyki liczb naturalnych bez zasady indukcji.

Dla prostszego wysłowienia twierdzenia o sekwencie pośredniczącym, czyli mocnego twierdzenia o eliminacji (Cut), zdefiniujmy (kontekstowo) występujące w nim pojęcie.

Definicja $9.6 \mathcal{D}$ jest dowodem z sekwentem pośredniczacym wtw wszystkie reguły dla spójników zastosowane sa powyżej reguł dla kwantyfikatorów.

Zatem dowód o tej własności rozpada się na dwie części: od korzenia do sekwentu pośredniczącego jest część kwantyfikatorowa, powyżej część zdaniowa. Rozgałęzienia występują oczywiście tylko w części zdaniowej.

Przed dowodem twierdzenia o sekwencie pośredniczącym dowiedziemy następujący:

Lemat 9.12 Każdy dowód LK, w którym pewne aksjomaty zawieraja kwantyfikatory, możemy zamienić na dowód, w którym żaden aksjomat nie zawiera kwantyfikatorów.

DowóD: Jako krok wstępny odnotujmy, że dowolny aksjomat postaci $Q x \varphi \Rightarrow$ $Q x \varphi$ może być zastąpiony przez aksjomat postaci $\varphi[x / a] \Rightarrow \varphi[x / a]$. Np. dla $Q:=\forall$ mamy:

${ }^{7}$ Funkcjonuje ono w literaturze pod nazwami sharpened hauptsatz lub mid-sequent theorem. 


$$
\begin{gathered}
(\forall \Rightarrow) \frac{\varphi[x / a] \Rightarrow \varphi[x / a]}{\forall x \varphi \Rightarrow \varphi[x / a]} \\
(\Rightarrow \forall) \frac{\forall x \varphi}{\forall x \varphi \Rightarrow \forall x \varphi}
\end{gathered}
$$

Oczywiście $a$ musi spełniać warunek nienależenia do $\varphi$. Jeżeli $\varphi[x / a]:=$ $Q x \psi$ to procedurę powtarzamy aż otrzymamy aksjomaty, których formuły nie zaczynają się od kwantyfikatorów. Jeżeli uzyskane w ten sposób aksjomaty składają się z formuł nieatomowych, których składniki zawieraja kwantyfikatory, to odwołujemy się do twierdzenia 4.1, które uzasadniało dla LK-KRZ możliwość zastąpienia dowolnych aksjomatów przez atomowe, a dla uzyskanych w ten sposób aksjomatów złożonych z formuł kwantyfikatorowych ponownie stosujemy podaną wyżej redukcję. W ten sposób systematycznie zastępując każdy aksjomat zawierający kwantyfikatory przez odpowiedni dowód z aksjomatów zbudowanych z podformuł uzyskujemy stosowny dowód tego samego sekwentu.

Zauważmy, że nie jest niezbędne wymaganie, żeby wszystkie aksjomaty były atomowe.

Przystępując do dowodu twierdzenia o sekwencie pośredniczącym możemy na mocy lematu 9.12 ograniczyć się do dowodów z aksjomatami bez kwantyfikatorów. Ponadto rozważać będziemy tylko PV-dowody. Wstępnie zdefiniujmy pojęcie rzędu dowodu:

Definicja 9.7 • Ilość zastosowań regut zdaniowych występujacych w dowodzie ponizej zastosowania reguty kwantyfikatorowej nazywamy rzędem tej reguty kwantyfikatorowej.

- Suma rzędów wszystkich regut kwantyfikatorowych zastosowanych w dowodzie to rzad tego dowodu.

Jak widać każdy dowód z sekwentem pośredniczącym ma rząd 0. Przystąpimy teraz do dowodu zasadniczego twierdzenia.

Twierdzenie 9.4 (O sekwencie pośredniczącym) Dowolny PV-dowód bez (Cut) sekwentu, który zawiera tylko formuty preneksowe można przekształcić na PV-dowód bez (Cut) z sekwentem pośredniczacym.

DowóD: Przez indukcję po rzędzie dowodu.

Baza: jeżeli rząd dowodu $=0$, a formuły z kwantyfikatorami nie występują w aksjomatach, to musi istnieć sekwent $S$, w którym albo kwantyfikatory wogóle nie występują albo jedynie przed formułami (z założenia, że sekwent 
końcowy zawiera tylko formuły preneksowe). W pierwszym przypadku jest to nasz sekwent pośredniczący. $\mathrm{W}$ drugim przypadku, skoro rząd dowodu $=$ 0 , to formuły kwantyfikatorowe mogły być wprowadzone jedynie przez (W). Kasujemy wszystkie takie formuły, a otrzymany sekwent $S^{\prime}$ jest sekwentem pośredniczącym. Operacja wykasowania tych formuł z dowodu $S$ nie wpływa na dowiedlność sekwentu $S^{\prime}$, gdyż wykasowane formuły były jedynie formułami parametrycznymi w zastosowaniach reguł zdaniowych. Następnie do dowodu sekwentu pośredniczącego $S^{\prime}$ stosujemy (W) i (P) aż ponownie uzyskamy $S$. Podsumowując, dowód rzędu 0 albo już ma wymaganą postać albo uzyskuje ją przez dokonanie permutacji tych zastosowań (W), które wprowadziły formuły kwantyfikatorowe, względem występujących poniżej reguł zdaniowych.

Następnie dowodzimy kroku indukcyjnego zakładając, że twierdzenie zachodzi dla dowodu o rzędzie $n$. W dowodzie o rzędzie $n+1$ znajdujemy takie zastosowanie reguły kwantyfikatorowej, pod którym bezpośrednio występuje zastosowanie reguły zdaniowej i dokonujemy ich permutacji tak aby reguła zdaniowa występowała wyżej na gałęzi. Tak przeprowadzona transformacja zmniejsza rząd dowodu o 1, zatem nowy dowód podpada pod założenie indukcyjne. Dowód kroku indukcyjnego wymaga zatem pokazania jak można dokonać permutacji dowolnej reguły kwantyfikatorowej z regułą zdaniową na dowolnej gałęzi. Rozważmy najpierw przypadki, gdy jakaś reguła zdaniowa jednoprzesłankowa występuje pod regułą kwantyfikatorową, np. $(\Rightarrow \rightarrow)$ pod $(\Rightarrow \forall)$. Fragment dowodu postaci:

$$
\begin{gathered}
(\Rightarrow \forall) \frac{\psi, \Gamma \Rightarrow \Delta, \chi, \varphi[x / a]}{\psi, \Gamma \Rightarrow \Delta, \chi, \forall x \varphi} \\
(\Rightarrow P) \frac{\psi, \Gamma \Rightarrow \Delta, \forall x \varphi, \chi}{\psi, \Gamma \Rightarrow} \\
(\Rightarrow \rightarrow) \frac{1 \Rightarrow \Delta, \forall x \varphi, \psi \rightarrow \chi}{\Gamma \Rightarrow \Delta}
\end{gathered}
$$

zamieniamy na:

$$
\begin{aligned}
& (\Rightarrow P) \frac{\psi, \Gamma \Rightarrow \Delta, \chi, \varphi[x / a]}{\psi, \Gamma \Rightarrow \Delta, \varphi[x / a], \chi} \\
& (\Rightarrow \rightarrow) \frac{\Gamma \Rightarrow \Delta, \varphi[x / a], \psi \rightarrow \chi}{\Gamma \Rightarrow \chi} \\
& (\Rightarrow P) \frac{\Gamma, \varphi[x / a]}{\Gamma \Rightarrow \Delta, \psi \rightarrow \chi} \\
& (\Rightarrow \forall) \frac{\Gamma \Rightarrow \Delta, \psi \rightarrow \chi, \forall x \varphi}{\Gamma \Rightarrow \Delta, \forall x \varphi, \psi \rightarrow \chi}
\end{aligned}
$$


Wykonane operacje nie mają wpływu na poprawność zastosowania $(\Rightarrow \forall)$. Analogicznie dokonujemy permutacji innych reguł zdaniowych jednoprzesłankowych względem dowolnej reguły kwantyfikatorowej, która znajduje się nad nią. Zauważmy, że w sytuacji gdy formuła jest wydedukowana za pomoca reguły kwantyfikatorowej, to nie może być ona formułą poboczną zastosowanej niżej reguły zdaniowej. Jest to wykluczone przez założenie, że sekwent końcowy zawiera jedynie formuły preneksowe - formuła kwantyfikatorowa może być formułą poboczną jedynie dla zastosowania reguły kwantyfikatorowej.

Rozważmy przypadek, gdy występująca niżej reguła zdaniowa jest dwuprzesłankowa, np. $(\Rightarrow \wedge)$ występuje pod $(\Rightarrow \forall)$.

$$
\begin{aligned}
& (\Rightarrow \forall) \frac{\Gamma \Rightarrow \Delta, \psi, \varphi[x / a]}{\Gamma \Rightarrow \Delta, \psi, \forall x \varphi} \\
& (\Rightarrow P) \frac{\Gamma \Rightarrow \Delta, \forall x \varphi, \psi}{\Gamma \Rightarrow \Delta, \forall x \varphi, \chi} \\
& (\Rightarrow \wedge) \frac{\Gamma \Rightarrow \Delta, \forall x \varphi, \psi \wedge \chi}{\Gamma \Rightarrow \Delta}
\end{aligned}
$$

Zastępujemy przez:

$$
\begin{aligned}
& (\Rightarrow P)(\Rightarrow W) \frac{\Gamma \Rightarrow \Delta, \psi, \varphi[x / a]}{\frac{\Gamma \Rightarrow \Delta, \varphi[x / a], \forall x \varphi, \psi}{\Gamma \Rightarrow \Delta, \varphi[x / a], \forall x \varphi, \chi}} \quad \frac{\Gamma \Rightarrow \Delta, \forall x \varphi, \chi}{\overline{\Gamma \Rightarrow \Delta}}(\Rightarrow \wedge)(\Rightarrow W) \\
& \begin{array}{l}
(\Rightarrow P) \frac{\Gamma \Rightarrow \Delta, \varphi[x / a], \forall x \varphi, \psi \wedge \chi}{\Gamma \Rightarrow \Delta, \psi \wedge \chi, \forall x \varphi, \varphi[x / a]} \\
(\Rightarrow \forall) \frac{\Gamma \Rightarrow \Delta, \psi \wedge \chi, \forall x \varphi, \forall x \varphi}{}
\end{array} \\
& \begin{aligned}
(\Rightarrow \forall) & \frac{\Gamma \Rightarrow \Delta, \psi \wedge \chi, \forall x \varphi, \forall x \varphi}{\Gamma \Rightarrow \Delta, \forall x \varphi, \psi \wedge \chi}
\end{aligned}
\end{aligned}
$$

W analogiczny sposób dokonujemy innych permutacji systematycznie redukując rząd dowodu.

Uwaga 9.10: Uogólnienia rezultatu dotyczącego permutacji reguł dokonał Kleene [85]. Ograniczenia w odniesieniu do RS dla logiki intuicjonistycznej omówione są w [147].

\subsection{Teorie elementarne}

Jak pokazaliśmy w rozdziale $8 \mathrm{w}$ standardowym podejściu Hilbertowskim istnieje właściwie tylko jeden sposób budowy teorii elementarnej w oparciu o system aksjomatyczny. Dla odmiany, za pomocą RS można w różny sposób 
formalizować teorie aksjomatyczne. Ponadto rozmaite rozwiązania mają inne własności teoretyczne; np. rozmaicie zachowują się w kwestii problemu dopuszczalności reguł strukturalnych, w tym (Cut). Za Negri i von Plato [101] wyróżnimy cztery zasadnicze sposoby budowy teorii na bazie RS. Dysponując ustalonym systemem RS dla KRK budujemy teorię elementarną RS-T w jeden z następujących sposobów:

1. Dodając do zbioru sekwentów aksjomatycznych sekwent $\Rightarrow \varphi$ dla każdego aksjomatu $\varphi$ teorii $\mathrm{T}$.

2. Dodając odpowiednie sekwenty (bazowe) odpowiadające aksjomatom danej teorii do RS (Gentzen [52]).

3. Traktując zbiór aksjomatów $\Gamma$ jako kontekst dowodzonych twierdzeń; dowodzimy wtedy sekwentów postaci $\Gamma \Rightarrow \varphi$, gdzie $\varphi$ jest tezą teorii $\Gamma$ (Gentzen [50]).

4. Dodając do RS odpowiednie reguły, np. dla aksjomatu o postaci $\varphi \rightarrow \psi$ regułę postaci $\psi \Rightarrow \Delta / \varphi \Rightarrow \Delta$, a dla aksjomatu postaci $\varphi$ regułę postaci $\varphi \Rightarrow \Delta / \Rightarrow \Delta$.

Pierwsze trzy rozwiązania były wprowadzone przez Gentzena, natomiast ostatnie zyskało na popularności znacznie później. W szczególności Negri i von Plato rozwinęli interesująca metodologię konstruowania regułowych wzmocnień RS, która pozwala na wykorzystanie wielu metod strukturalnej analizy dowodu wykorzystywanych w RS dla KRK. Te cztery podejścia do kwestii formalizowania teorii na bazie RS są równoważne w tym sensie, że zbiór sekwentów dowiedlnych (w przypadku podejścia trzeciego z dodanym poprzednikiem $\Gamma$ ) jest taki sam w przypadku dowolnej teorii T. Jednak poszczególne rozwiązania rozmaicie zachowują się z punktu widzenia kwestii eliminowalności cięcia i procedur szukania dowodu W szczególności, dwa ostatnie pozwalają na dowód dopuszczalności (Cut) dla teorii tak sformalizowanej. Omówimy je kolejno.

\subsubsection{Systemy RS z dodanymi aksjomatami}

Pierwsza metoda budowania teorii elementarnych na gruncie RS jest prostym przeniesieniem na grunt RS metodologii zaczerpniętej z Hilbertowskiej teorii dowodu. Dodanie do zbioru sekwentów pierwotnych przeliczalnej ilości schematów aksjomatów postaci $\Rightarrow \varphi$ lub skończonej ilości takich aksjomatów, ale domkniętych na podstawianie, jest rozwiązaniem prostym, ale niezbyt zadowalającym. Przede wszystkim (Cut) nie jest eliminowalne w RS-T. Wyraźnie 
widać to na schemacie dowodu lematu 3.3. w podrozdziale 3.2, użytego do demonstracji wyprowadzalności MP. Wystarczy w nim skasować schematy $\mathcal{D}$ wiodace do dedukcji $\Rightarrow \varphi \mathrm{i} \Rightarrow \varphi \rightarrow \psi$ i uznać, że mamy do czynienia z aksjomatami tej postaci, a $\Rightarrow \psi$ nie ma dowodu bez użycia (Cut).

Pierwsze rozwiązanie można przekształcić trywialnie na rozwiązanie drugie dopuszczając oczywiste transformacje typu użycie $\varphi \Rightarrow \psi$ zamiast $\Rightarrow \varphi \rightarrow$ $\psi$, po ewentualnym wcześniejszym usunięciu kwantyfikatorów uniwersalnych jeżeli takie występują przed implikacją. Gentzen [52] rozważa węższą klasę takich teorii, które można zaksjomatyzować przez użycie tzw. bazowych sekwentów, czyli składających się z formuł atomowych.

Dla RS-teorii tego typu można dowieść tzw. mocnego twierdzenia o eliminacji (Cut), które de facto jest jednak w pewnym sensie słabszym wynikiem ${ }^{8}$. Można je sformułować następująco:

Twierdzenie 9.5 Jeżeli $S \vdash \Gamma \Rightarrow \Delta$, gdzie $S$ jest zbiorem sekwentów domkniętym na podstawianie, to można go przeksztatcić na dowód, w którym każde zastosowanie (Cut) ma przynajmniej jedna przestankę z $S$.

DowóD: Szczegółowy dowód pomijamy, gdyż nie wnosi nic nowego do repertuaru technik dowodowych. Jedyna różnica polega na tym, że standardowe redukcje wykorzystywane we wcześniejszych dowodach prowadzą do sytuacji, gdy jedna z przesłanek (Cut) należy do $S$ i wtedy (Cut) nie daje się całkowicie wyeliminować. Warunek domknięcia $S$ na podstawianie jest niezbędny, gdyż, jak pamiętamy, kroki redukcyjne związane z kwantyfikatorami wymagają zastosowania tej reguły do wszystkich sekwentów będących powyżej włączając w to liście, a te mogą należeć do $S$.

W przypadku podejścia trzeciego wykorzystanego przez Gentzena w [50] aksjomaty dodaje się nie w formie dodatkowych sekwentów aksjomatycznych, ale jako dodatkowe elementy poprzednika. Przykładowo, jeżeli chcemy udowodnić sekwent $\Gamma \Rightarrow \Delta$ na gruncie teorii zawierającej schematy aksjomatów $\varphi_{1}, \ldots, \varphi_{n}$, to dowodzimy sekwentu $\Pi, \Gamma \Rightarrow \Delta$, gdzie $\Pi$ jest skończonym zbiorem podstawien schematów aksjomatów wybranych ze zbioru $\varphi_{1}, \ldots, \varphi_{n}$. Takie rozwiązanie ma jedną zaletę - dowód twierdzenia o eliminacji (Cut) przenosi się automatycznie na tak formalizowane teorie. Jednak z punktu widzenia stosowalności RS jako narzędzia poszukiwania dowodu metoda ta wprowadza dużą dozę indeterminizmu, gdyż nawet jeśli wiemy, że dany se-

\footnotetext{
${ }^{8}$ Buss [20] używa określenia "eliminacja wolnych cięć", które ma charakter neutralny; określenia "mocne twierdzenie o eliminacji (Cut)" używa np. Girard [53] czy Avron [7].
} 
kwent jest dowiedlny $\mathrm{w}$ teorii, to nie wiadomo z góry, jakie podstawienia i których aksjomatów mogą być przydatne do znalezienia dowodu.

Równoważność tych trzech podejść do formalizowania teorii łatwo się dowodzi w oparciu o lemat 4.17. Inny dowód można znaleźć w [101].

\subsubsection{RS z dodatkowymi regułami}

Wynik podany w podrozdziale 4.4 umożliwia też rozmaite formalizacje regułowe dla teorii elementarnych na bazie RS, ale nie wszystkie mają interesujące własności teoriodowodowe. Poniżej omówimy dwa podejścia: jedno rozwinięte przez Negri, von Plato [101] dla teorii uniwersalnych i drugie rozwinięte przez Braünera [19] dla teorii geometrycznych.

Formalizacja teorii uniwersalnych przez reguły zaproponowana przez Negri, von Plato wykorzystuje jako bazę m-ARS dla $\mathrm{KRK}^{9}$ i oparta jest na następujących zasadach:

1. następnik sekwentu jest dowolnym i stałym kontekstem we wszystkich przesłankach i wniosku;

2. formuły poboczne i zasadnicze występują tylko w poprzednikach sekwentów;

3. formuły poboczne i zasadnicze są atomowe;

4. formuły zasadnicze występują również w poprzednikach przesłanek.

Łatwo sprawdzić, że dwa pierwsze warunki dają nam jedną z form reguł generowaną z wyjściowego sekwentu, którą rozważaliśmy w podrozdziale 4.4. Mianowicie dla sekwentu postaci $\varphi_{1}, \ldots, \varphi_{k} \Rightarrow \psi_{1}, \ldots, \psi_{n}, k, n \geq 0$ otrzymujemy schemat reguły $R$ postaci:

$$
R \frac{\psi_{1}, \Gamma \Rightarrow \Delta, \ldots, \psi_{n}, \Gamma \Rightarrow \Delta}{\varphi_{1}, \ldots, \varphi_{k}, \Gamma \Rightarrow \Delta}
$$

Jedyna różnica dotyczy tego, że w podrozdziale 4.4 rozważaliśmy reguły k-niezależne, a Negri i von Plato potrzebują reguł k-jednolitych. Warunek 3 prowadzi do dalszego uszczegółowienia, gdyż $\varphi_{i}, \psi_{j}$ mają być atomowe.

\footnotetext{
${ }^{9}$ Faktycznie Negri i von Plato rozważają ogólniejszy i bardziej skomplikowany przypadek regułowych odpowiedników uniwersalnych teorii budowanych na bazie RS dla logiki intuicjonistycznej.
} 
Ponieważ aksjomaty teorii uniwersalnych nawet po pozbyciu się kwantyfikatorów nie muszą natychmiast dawać nam schematów reguł spełniających ten warunek (chociaż dadzą nam regułę o podanej wyżej postaci z dowolnymi formułami $\varphi_{i}, \psi_{j}$ ), to musimy poddać je wstępnej transformacji. Niech $\forall x_{1}, \ldots, x_{n} \varphi$ będzie aksjomatem uniwersalnej teorii, wtedy dla sekwentu $\Rightarrow \varphi$ budujemy skończone drzewo dowodowe metodą zastosowaną w podrozdziale $7.4 \mathrm{w}$ dowodzie lematu 7.13. Z otrzymanego drzewa odrzucamy liście aksjomatyczne, natomiast pozostałe liście są atomowe zatem każdy z nich poddaje się transformacji w regułę. Ponieważ wszystkie reguły są odwracalne więc $\varphi$ jest równoważne koniunkcji wszystkich nieaksjomatycznych liści tego drzewa (a właściwie klauzul z niego utworzonych - por. lemat 7.13). W ten sposób dla każdego uniwersalnego aksjomatu otrzymujemy skończony zbiór reguł, które są mu dedukcyjne równoważne.

Warunek 4 zmienia dodatkowo postać reguły na następującą:

$$
R^{\star} \frac{\psi_{1}, \varphi_{1}, \ldots, \varphi_{k}, \Gamma \Rightarrow \Delta, \ldots, \psi_{n}, \varphi_{1}, \ldots, \varphi_{k}, \Gamma \Rightarrow \Delta}{\varphi_{1}, \ldots, \varphi_{k}, \Gamma \Rightarrow \Delta}
$$

Zmiana ta wynika stąd, że Negri, von Plato używają m-ARS i chcą żeby ustalona dla niego dopuszczalność kontrakcji zachodziła również dla regułowego wzmocnienia. $\mathrm{W}$ istocie, aby wynik ten zachodził, niezbędne jest domknięcie zbioru reguł na następujący warunek:

Jeżeli zbiór reguł zawiera schemat, którego podstawienie daje regułę postaci:

$$
R \frac{\psi_{1}, \varphi_{1}, \ldots, \varphi_{i}, \varphi_{i}, \ldots, \varphi_{k}, \Gamma \Rightarrow \Delta, \ldots, \psi_{n}, \varphi_{1}, \ldots, \varphi_{i}, \varphi_{i}, \ldots, \varphi_{k}, \Gamma \Rightarrow \Delta}{\varphi_{1}, \ldots, \varphi_{i}, \varphi_{i}, \ldots, \varphi_{k}, \Gamma \Rightarrow \Delta}
$$

to musi zawierać też regułę postaci:

$$
R^{\prime} \frac{\psi_{1}, \varphi_{1}, \ldots, \varphi_{i}, \ldots, \varphi_{k}, \Gamma \Rightarrow \Delta, \ldots, \psi_{n}, \varphi_{1}, \ldots, \varphi_{i}, \ldots, \varphi_{k}, \Gamma \Rightarrow \Delta}{\varphi_{1}, \ldots, \varphi_{i}, \ldots, \varphi_{k}, \Gamma \Rightarrow \Delta}
$$

Warunek ten jest łatwy do spełnienia, gdyż ilość reguł, które trzeba dodać do systemu jest ograniczona. Przykładowo, w teorii ścisłego porządku mamy aksjomat $\forall x y(x<y \rightarrow \neg y<x)$, z którego przez eliminację $\forall$ możemy uzyskać $x<x \rightarrow \neg x<x$, który implikuje $\neg x<x$. W ujęciu regułowym odpowiednikiem tego aksjomatu będzie schemat reguły bezprzesłankowej $x<y, y<x, \Gamma \Rightarrow \Delta$, który w wyniku podstawienia daje 
$x<x, x<x, \Gamma \Rightarrow \Delta$, zatem powyższy warunek wymaga, by do zbioru reguł dodać też schemat $x<x, \Gamma \Rightarrow \Delta$.

Dla ARS-T, w którym powyższe warunki są spełnione, tzn. T składa się jedynie z reguł spełniających cztery warunki definicyjne i warunek domknięcia, zachodzą twierdzenia o dopuszczalności osłabiania, kontrakcji i (Cut) jak dla ARS. Ponadto dowody nie wykorzystujące (Cut) posiadają następującą uogólnioną własność podformuł wyrażoną w poniższym:

Lemat 9.13 Jeżeli $\vdash \Gamma \Rightarrow \Delta w A R S$ - T, to wszystkie formuły użyte $w$ dowodzie sa podformułami $\Gamma \cup \Delta$ lub atomami.

DowóD: Własność ta wynika stąd, że przy braku (Cut) jedynie reguły pozalogiczne pozwalają by formuła, która była w przesłankach nie występowała we wniosku, a formuły te mogą być jedynie atomowe.

Podana własność, choć słabsza od zwykłej własności podformuł, pozwala jednak na uzyskanie szeregu ciekawych i ważnych wyników na drodze strukturalnej analizy dowodów. Zaliczyć do nich można:

1. prosty dowód niesprzeczności wielu teorii;

2. syntaktyczne dowody niezależności aksjomatów;

3. dowody konserwatywności rozszerzeń;

4. prosty dowód wersji twierdzenia Herbranda dla uniwersalnych teorii;

5. proste procedury poszukiwania dowodu.

Dla ilustracji omówimy punkt pierwszy i czwarty, natomiast punkt trzeci i piąty zilustrujemy w podrozdziale o identyczności. Odnośnie dowodów niezależności ogólna procedura sprowadza się do tego, że jeżeli aksjomat, którego niezależność chcemy dowieść wyraża atomowy sekwent $S$, to po odłączeniu odpowiadającej mu reguły z systemu możemy łatwo sprawdzić, że nie jest on dowiedlny. Piękną ilustrację takiej procedury zawiera Negri, von Plato [101], gdzie podana jest regułowa formalizacja geometrii Euklidesowej wraz z syntaktycznym dowodem niezależności 5 aksjomatu.

Modyfikacja własności podformuł powoduje, że dowód niesprzeczności (czyli niededukowalności $\Rightarrow$ ) nie może być przeniesiony na ARS z regułami dla teorii uniwersalnych. Tym niemniej, kształt tych reguł pozwala dowieść ogólny wynik o niesprzeczności dla wielu systemów, w których nie występują reguły pewnego rodzaju, mianowicie: 
(i) $\varnothing / \varphi_{1}, \ldots, \varphi_{n}, \Gamma \Rightarrow \Delta$

(ii) $\varphi_{1}, \Gamma \Rightarrow \Delta, \ldots, \varphi_{n}, \Gamma \Rightarrow \Delta / \Gamma \Rightarrow \Delta$

Twierdzenie 9.6 (Niesprzeczność) Jeżeli ARS-T nie zawiera regut typu (i) lub (ii), to jest niesprzeczny.

DowóD: Przez analizę struktury możliwego dowodu $\Rightarrow$. Z poprzedniego lematu wynika, że dowód taki nie może zawierać zastosowania żadnej reguły logicznej. Z faktu, że reguły pozalogiczne działają tylko na poprzednikach wynika, że wszystkie sekwenty w takim dowodzie mają pusty następnik. Zatem żaden liść nie może być aksjomatem logicznym, musi być więc postaci $\varphi_{1}, \ldots, \varphi_{n} \Rightarrow$, czyli być podstawieniem pozalogicznej zeroprzesłankowej reguły typu (i). Z kolei ostatni krok takiego dowodu musi mieć postać $\stackrel{\varphi_{1} \Rightarrow, \ldots, \varphi_{n} \Rightarrow}{\Rightarrow}$ czyli jest podstawieniem reguły typu (ii). Zatem jeżeli w systemie nie występuje ani jedna reguła postaci (i) lub (ii), to dowód $\Rightarrow$ jest niemożliwy.

Zauważmy, że reguły typu (i) odpowiadają sekwentom atomowym postaci $\varphi_{1}, \ldots, \varphi_{n} \Rightarrow$, a typu (ii) sekwentom $\Rightarrow \varphi_{1}, \ldots, \varphi_{n}$. Zatem warunkiem wystarczającym, aby uniwersalna teoria była niesprzeczna jest to, by w zbiorze klauzul wszystkich matryc w postaci KA dla każdego aksjomatu nie było klauzul czysto pozytywnych i czysto negatywnych. Oczywiście występowanie takich klauzul nie oznacza, że teoria jest sprzeczna, a jedynie, że nie możemy udowodnić jej niesprzeczności w podany wyżej sposób.

Negri, von Plato podają też prosty dowód dla pewnej wersji twierdzenia Herbranda ${ }^{10}$. Rozważmy RS-T utworzony w opisany wyżej sposób dla pewnej uniwersalnej teorii T. Niech $\varphi$ będzie dowolną $\Pi_{2}$-konsekwencją takiej teorii, tzn. formuła preneksową postaci $\forall x_{1}, \ldots, x_{l}, \exists y_{1}, \ldots, y_{k} \psi$. Zachodzi:

Twierdzenie 9.7 (Herbrand) Jeżeli $T \vdash \Rightarrow \varphi$, to istnieje skonczona sekwencja termów $\tau_{i, j}, i \leq r, j \leq k$, taka że $T \vdash \Rightarrow \psi_{1}^{\prime}, \ldots, \psi_{r}^{\prime}$, gdzie

$$
\begin{aligned}
\psi_{1}^{\prime} & :=\psi\left[x_{1} / a_{1}, \ldots, x_{l} / a_{l}, y_{1} / \tau_{1,1}, \ldots, y_{k} / \tau_{1, k}\right], \ldots, \\
\psi_{r}^{\prime} & :=\psi\left[x_{1} / a_{1}, \ldots, x_{l} / a_{l}, y_{1} / \tau_{r, 1}, \ldots, y_{k} / \tau_{r, k}\right]
\end{aligned}
$$

DowóD: Dla uproszczenia przyjmijmy, że $l=k=1$, wtedy ostatnie wiersze dowodu maja postać:

\footnotetext{
10 Por. też Kleene [84] i Buss [20], gdzie znaleźć można bardziej ogólne wersje tego twierdzenia dowiedzione za pomocą RS.
} 


$$
(\Rightarrow \exists) \frac{\Rightarrow \psi\left[x / a, y / \tau_{1,1}\right], \exists y \psi[x / a]}{(\Rightarrow \forall) \frac{\Rightarrow \exists y \psi[x / a]}{\Rightarrow \forall x \exists y \psi}}
$$

Konstrukcja dowodu może dalej przebiegać bądź przez zastosowanie reguł zdaniowych do $\psi\left[x / a, y / \tau_{1,1}\right.$, bądź przez dalsze stosowanie $(\Rightarrow \exists)$. W pierwszym przypadku otrzymujemy $\Gamma_{1} \Rightarrow \Delta_{1}, \exists y \psi[x / a]$ (i ewentualnie $\Gamma_{2} \Rightarrow$ $\Delta_{2}, \exists y \psi[x / a]$, jeżeli reguła była dwuprzesłankowa), gdzie $\Gamma_{1}, \Delta_{1}$ (ewentualnie $\left.\Gamma_{2}, \Delta_{2}\right)$ składają się z podformuł $\psi\left[x / a, y / \tau_{1,1}\right]$. W drugim przypadku otrzymujemy $\Rightarrow \psi\left[x / a, y / \tau_{1,1}\right], \psi\left[x / a, y / \tau_{2,1}\right], \exists y \psi[x / a]$. Proces ten może być powtarzany wielokrotnie, ale ponieważ $\varphi$ jest tezą $\mathrm{T}$, więc $\mathrm{w}$ pewnym momencie otrzymujemy drzewo skończone, które jest dowodem. Co więcej, każdy sekwent występujący jako węzeł ma postać: $\Gamma \Rightarrow \Delta, \psi_{1}^{\prime}, \ldots, \psi_{n}^{\prime}, \exists y \psi[x / a]$, dla $n \leq r$, z $\Gamma, \Delta$ składających się z podformuł instancji $\psi_{i}^{\prime}, i \leq n$. Dowolny liść, który jest aksjomatem pozostanie nim po skreśleniu $\exists y \psi[x / a]$, podobnie $\mathrm{w}$ przypadku zero-przesłankowych reguł teorii $\mathrm{T}$. Jeżeli do tak zmodyfikowanych liści zastosujemy ponownie wszystkie reguły logiczne i pozalogiczne, które były wcześniej użyte, oraz kontrakcję, to otrzymamy dowód $\Rightarrow \psi_{1}^{\prime}, \ldots, \psi_{r}^{\prime}$. Dla większych wartości $k$ i $l$ dowód przebiega tak samo.

Powyższa wersja twierdzenia Herbranda ma ograniczone zastosowanie z racji zawężenia do tez teorii $T$, które posiadają specjalną postać. Naszym celem w tym przypadku jest jedynie pokazanie, w jaki sposób użycie RS pozwala prosto otrzymywać i przejrzyście reprezentować znane wyniki metalogiczne.

Na koniec krótko scharakteryzujemy rozwiązanie zaproponowane przez Braünera [19]. Jego wynik sformułowany jest wprawdzie dla modalnych logik hybrydowych i to sformalizowanych w postaci systemów DN, ale można łatwo przenieść go na teorie elementarne (a konkretnie geometryczne) sformalizowane jako RS. W obu przypadkach korzystamy z reguł translacji, których tu nie będziemy omawiać; zainteresowanego czytelnika odsyłamy do Indrzejczak [74]. Przypomnijmy, że teorie geometryczne możemy zaksjomatyzować za pomoca formuł o postaci:

$$
\forall x_{1}, \ldots, x_{k}\left(\varphi_{1} \wedge \ldots \wedge \varphi_{n} \rightarrow \exists y_{1}, \ldots, y_{l}\left(\psi_{1} \vee \ldots \vee \psi_{m}\right)\right),
$$

gdzie $k \geq 1, l, n, m \geq 0$, każde $\varphi_{i}$ jest atomem, a każde $\psi_{i}$ atomem lub skończoną koniunkcją atomów.

Każdemu sekwentowi otrzymanemu w wyniku eliminacji $\forall$ i zastosowaniu $\Rightarrow \rightarrow$ odpowiada na mocy wyniku $\mathrm{z}$ podrozdziału 4.4. (tutaj $\mathrm{w}$ wersji $\mathrm{k}$ jednolitej) reguła postaci: 


$$
\frac{\Gamma \Rightarrow \Delta, \varphi_{1} \quad \ldots \quad \Gamma \Rightarrow \Delta, \varphi_{n} \quad \Psi_{1}, \Gamma \Rightarrow \Delta \quad \ldots \quad \Psi_{m}, \Gamma \Rightarrow \Delta}{\Gamma \Rightarrow \Delta}
$$

gdzie $k \geq 1, l, n, m \geq 0$, i każde $\Psi_{i}$ jest zbiorem instancji atomów, które tworzą koniunkcję $\psi_{i}$ przy czym żaden parametr, który został podstawiony za $y_{i}$ nie występuje w $\Gamma, \Delta, \varphi_{1}, \ldots, \varphi_{n}$.

Braüner udowodnił dla swoich systemów DN twierdzenie o normalizacji, któremu odpowiada twierdzenie o eliminacji (Cut) w przełożeniu na formalizację RS zbudowaną przy użyciu reguł tego typu.

\subsubsection{RS-KRKI}

Prześledzimy powyższe rozwiązania na przykładzie teorii identyczności. Dla uproszczenia rozważymy język bez termów złożonych. Standardowo formalizuje się taką teorię identyczności dodając do zestawu sekwentów aksjomatycznych dwa dodatkowe:

$$
\Rightarrow \tau=\tau \text { i } \tau_{1}=\tau_{2}, \varphi\left[x / \tau_{1}\right] \Rightarrow \varphi\left[x / \tau_{2}\right], \mathrm{z} \varphi \in A T
$$

Jest to rozwiązanie typu 2, gdzie oba dodatkowe sekwenty są bazowe $\mathrm{w}$ sensie Gentzena. Jak wiemy, zastosowania (Cut) w takim systemie nie moga być eliminowalne ale mogą być zredukowane do takich, w których co najmniej jedna przesłanka jest pozalogicznym aksjomatem. Dowód symetrii $=$ może posłużyć jako przykład; $a=b \Rightarrow b=a$ można $\mathrm{w}$ takim systemie wydedukować jedynie przez (Cut) na $\Rightarrow a=a$ i $a=b, a=a \Rightarrow b=a$, gdzie drugi sekwent jest podstawieniem drugiego aksjomatu z $\tau_{1}:=a, \tau_{2}:=b \mathrm{i}$ $\varphi:=x=a$.

Lepszym rozwiązaniem jest formalizacja typu 4, która w wersji Negri, von Plato polega na przyjęciu pary reguł postaci:

$$
(=E) \frac{\tau=\tau, \Gamma \Rightarrow \Delta}{\Gamma \Rightarrow \Delta} \quad(=\Rightarrow) \frac{\varphi\left[x / \tau_{1}\right], \tau_{1}=\tau_{2}, \varphi\left[x / \tau_{2}\right], \Gamma \Rightarrow \Delta}{\tau_{1}=\tau_{2}, \varphi\left[x / \tau_{2}\right], \Gamma \Rightarrow \Delta}
$$

gdzie $\varphi$ jest formułą atomową.

Druga z reguł stwarza możliwość powtórzenia tej samej formuły w poprzedniku, gdyż jej instancją jest np.

$$
\frac{b=b, a=b, a=b, \Gamma \Rightarrow \Delta}{a=b, a=b, \Gamma \Rightarrow \Delta}
$$

Jednak nie musimy dodawać specjalnej reguły, aby warunek domknięcia był spełniony, gdyż powyższy schemat po dokonaniu kontrakcji (oczywiście przed również) stanowi instancję zastosowania $(=E)$. Faktycznie, Negri, von Plato taką specjalną regułę postaci: 
$(\operatorname{Rep}) \frac{b=b, a=b, \Gamma \Rightarrow \Delta}{a=b, \Gamma \Rightarrow \Delta}$

dodają do swojego systemu gdyż jest ona niezbędna dla udowodnienia jego konserwatywności. System z taką dodatkową regułą jest redundantny, gdyż można wykazać, że jej zastosowanie pozwala wyeliminować z każdego dowodu użycie $(=E)$. Natomiast dowód twierdzenia o konserwatywności opiera się właśnie na eliminacji każdego wystąpienia $(=E)$ z dowodu. W rezultacie otrzymujemy adekwatny system dla KRKI z użyciem $(=\Rightarrow)$ i $(R e p)$ dla którego zachodzi:

Lemat 9.14 (konserwatywność) Jeżeli $\Gamma \Rightarrow \Delta$ nie zawiera $=i$ jest dowiedlne $w$ ARS-KRK $+(=\Rightarrow)+($ Rep $)$, to jest dowiedlne $w$ ARS-KRK.

DowóD wynika z kształtu reguł i własności podformuł. Użycie którejkolwiek pozostawia w dowodzie formułę identycznościową, którą jedynie $(=E)$ mogłoby usunąć.

Łatwo zauważyć, że dowody w tym systemie (i każdym innym, który zawiera tylko reguły tego kształtu) można sprowadzić do pewnej postaci normalnej. Dowód dowolnego sekwentu można rozbić na dwie części: 1) linearne dedukcje atomowych sekwentów z wyłącznym użyciem reguł pozalogicznych 2) dowód sekwentu końcowego zawierający jako liście aksjomaty lub sekwenty otrzymane w 1) i zbudowany wyłącznie z zastosowaniem reguł logicznych. Dyktuje to pewną procedurę poszukiwania dowodu dowolnego sekwentu. Najpierw stosujemy wyłącznie reguły logiczne, a następnie do każdego uzyskanego sekwentu atomowego dodajemy atomy do poprzednika za pomocą pozalogicznych reguł aż uzyskamy sekwent aksjomatyczny.

Stosując formalizację Braünera musimy zastąpić $(=\Rightarrow$ ) przez następującą regułę:

$$
(=) \frac{\Gamma \Rightarrow \Delta, \varphi\left[x / \tau_{1}\right] \quad \Gamma \Rightarrow \Delta, \tau_{1}=\tau_{2} \quad \varphi\left[x / \tau_{2}\right], \Gamma \Rightarrow \Delta}{\Gamma \Rightarrow \Delta}
$$

Adekwatność i dopuszczalność (Cut) dla takiej formalizacji KRKI wynikają z ogólnego rezultatu Braünera. 


\section{Rozdział 10}

\section{Niestandardowe typy RS}

W rozdziale 2 wyróżniliśmy trzy zasadnicze typy $\mathrm{RS}$ związane ze standardowym pojęciem sekwentu, a wydzielone ze względu na proporcje ilości sekwentów aksjomatycznych do reguł sekwentowych w systemie. Były to:

1. RS w stylu Gentzena, oparty na użyciu reguł dla charakteryzacji stałych logicznych;

2. RS w stylu Hertza, oparty na użyciu sekwentów dla charakteryzacji stałych logicznych;

3. typ mieszany, wykorzystujący zarówno sekwenty jak i reguły.

Dotąd ograniczyliśmy się do eksploatacji różnych wariantów standardowego RS Gentzena, który należy do typu pierwszego i dodatkowo spełnia warunek progresywności dla reguł logicznych (por. podrozdział 4.5). Pominęliśmy takie systemy należące do typu pierwszego, w których dopuszczamy inne rodzaje reguł niż reguły wprowadzania stałych do argumentów sekwentu. Koncentracja wyłacznie na tej odmianie pierwszego typu RS była uzasadniona, gdyż odegrał on największą rolę w badaniach teoriodowodowych. Pozostałe propozycje nie doczekały się jak dotąd omówienia w literaturze przedmiotu choć, przynajmniej niektóre z nich, wydają się zasługiwać na szersze rozpropagowanie.

W tym rozdziale uzupełnimy prezentację systemów RS o najciekawsze propozycje należące do trzech wyróżnionych typów. Zaczniemy od omówienia innych rodzajów RS należących do typu pierwszego, w tym system Gentzena z [51], który także należy do typu pierwszego, ale jest przykładem sekwentowego systemu DN. Następnie krótko omówimy kilka systemów RS należących do pozostałych dwóch typów. Szczególną uwagę poświęcimy omówieniu 
rachunku Suszki, który reprezentuje typ drugi (10.2). Na koniec (10.4) omówimy skrótowo relację RS do innych rodzajów systemów dedukcyjnych.

\subsection{Regułowe systemy RS}

W obrębie typu pierwszego występują systemy RS, w których rola sekwentów aksjomatycznych jest zredukowana do minimum. Oprócz standardowego RS, w którym reguły dodatkowo spełniają warunek progresywności, należą do niego m.in:

1. sekwentowy system DN Gentzena [51];

2. systemy logików rosyjskich (Ershow, Palyutin [39], Ławrow, Maksimowa $[96])$;

3. system Andrewsa [5];

4. DN Suppesa [133] i Lemmona [90];

5. RS Hermesa [64] oraz Ebbinghausa, Fluma i Thomasa [38];

6. system Leblanca [88, 89];

7. system Dos̆ena [30].

Omówimy je w kolejności podyktowanej stopniem podobieństwa do systemu sekwentowego DN Gentzena z [51].

\subsubsection{Sekwentowy DN Gentzena i jego warianty}

W [51] Gentzen użył w dowodzie niesprzeczności arytmetyki Peano takiej formalizacji KRK, która stanowi rodzaj kompromisu między LK a jego systemem dedukcji naturalnej NK. Jest to c-system z sekwentami intuicjonistycznymi, w którym mamy reguły wprowadzania stałych do następnika, ale zamiast reguł wprowadzania stałych do poprzednika mamy reguły eliminacji tychże w następniku. System jest zatem oparty na interpretacji 4 (por. podrozdział 2.3), gdzie poprzednik reprezentuje ciąg aktywnych założeń, a następnik formułę od nich dedukcyjnie zależną. Aktualna dedukcja odbywa się zasadniczo na następnikach, za wyjątkiem $(\Rightarrow \exists E)$.

Faktycznie Gentzen implicite wprowadził taki system już w [50] w dowodzie adekwatności NK. Gentzen wykazuje tam jego równoważność z aksjomatyczną formalizacją KRK przy pomocy LK. Jedna z części dowodu pokazuje 
jak dokonać transformacji każdego dowodu NK w dowód LK. W tym celu każda reguła inferencji NK zostaje przepisana z dodaniem listy wszystkich aktywnych założeń dla przesłanek i wniosku. W efekcie otrzymujemy, niejako przy okazji, system sekwentowy, który w [51] jest już zdefiniowany eksplicite.

Jako sekwentów pierwotnych Gentzen używa jedynie $\varphi \Rightarrow \varphi$ a ponadto reguły strukturalne $(\mathrm{W}),(\mathrm{P}),(\mathrm{C})$ na poprzedniku. Reguły logiczne sa następujące:

$$
\begin{array}{lc}
\begin{array}{l}
\Rightarrow \neg) \frac{\Gamma, \varphi \Rightarrow \psi \quad \Delta, \varphi \Rightarrow \neg \psi}{\Gamma, \Delta \Rightarrow \neg \varphi} \\
(\Rightarrow \wedge E 1) \frac{\Gamma \Rightarrow \varphi \wedge \psi}{\Gamma \Rightarrow \varphi}
\end{array} & (\Rightarrow \neg E) \frac{\Gamma \Rightarrow \neg \neg \varphi}{\Gamma \Rightarrow \varphi} \\
(\Rightarrow \wedge) \frac{\Gamma \Rightarrow \varphi \Delta \Rightarrow \psi}{\Gamma, \Delta \Rightarrow \varphi \wedge \psi} & (\Rightarrow \vee E) \frac{\Gamma, \varphi \Rightarrow \chi \quad \Delta, \psi \Rightarrow \chi \quad \Pi \Rightarrow \varphi \vee \psi}{\Gamma \Rightarrow \nu, \Pi \Rightarrow \chi} \\
(\Rightarrow \vee) \frac{\Gamma \Rightarrow \varphi}{\Gamma \Rightarrow \varphi \vee \psi} & (\Rightarrow \vee) \frac{\Gamma \Rightarrow \psi}{\Gamma \Rightarrow \varphi \vee \psi} \\
(\Rightarrow \rightarrow E) \frac{\Gamma \Rightarrow \varphi \quad \Delta \Rightarrow \varphi \rightarrow \psi}{\Gamma, \Delta \Rightarrow \psi} & (\Rightarrow \rightarrow) \frac{\Gamma, \varphi \Rightarrow \psi}{\Gamma \Rightarrow \varphi \rightarrow \psi} \\
(\Rightarrow \forall E) \frac{\Gamma \Rightarrow \forall x \varphi}{\Gamma \Rightarrow \varphi[x / \tau]} & (\Rightarrow \forall)^{1} \frac{\Gamma \Rightarrow \varphi[x / a]}{\Gamma \Rightarrow \forall x \varphi} \\
(\Rightarrow \exists) \frac{\Gamma \Rightarrow \varphi[x / \tau]}{\Gamma \Rightarrow \exists x \varphi} & (\Rightarrow \exists E)^{2} \frac{\Gamma \Rightarrow \exists x \varphi \quad \varphi[x / a], \Delta \Rightarrow \psi}{\Gamma, \Delta \Rightarrow \psi}
\end{array}
$$

Ograniczenia:

1. pod warunkiem, że $a$ nie jest wolne $\mathrm{w} \Gamma$.

2. pod warunkiem, że $a$ nie jest wolne $\mathrm{w} \Gamma, \Delta$ i w $\psi$.

Łatwo zauważyć, że (Cut) w sekwentowym systemie DN jest regułą wyprowadzalną dzięki zastosowaniu $(\Rightarrow \rightarrow)$ i $(\Rightarrow \rightarrow E)$.

Sekwentowy system Gentzena podporządkowany jest sztywnej koncepcji rachunku DN opartego o pary reguł logicznych działających wyłącznie na następnikach sekwentów. Jedyne operacje na poprzednikach mają charakter strukturalny. Wyjątek wydaje się stanowić $(\Rightarrow \exists E$ ), jednak jest to po prostu analogon reguły $(\Rightarrow \vee E)$, naturalny przy rozumieniu $\exists$ jako alternatywy $\mathrm{w}$ skończonej dziedzinie.

Trzeba przyznać, że w perspektywie późniejszego rozwoju, sekwentowy DN Gentzena okazał się bardzo popularnym rozwiązaniem na gruncie praktycznych formalizacji logiki, rywalizując skutecznie z ujęciem DN pochodzącym od Jaśkowskiego. Po wojnie powstało szereg systemów dedukcyjnych, 
które wzorowane były na omówionym wyżej sekwentowym DN Gentzena. Niektóre różniły się minimalnie - zazwyczaj doborem reguł, ale przy zachowaniu tzw. schematu int-elim, czyli pary reguł dołączanie-eliminacja. Pojawiły się też jednak rozwiązania, przez ich autorów zaliczane wprawdzie do systemów DN, ale które w doborze reguł wykazywały znacznie większą elastyczność dopuszczając również reguły logiczne działające na poprzednikach. Popularność takich systemów DN wiąże się z dwiema własnościami:

1. reguły logiczne na następnikach sekwentów są takie same jak w standardowych systemach DN na formułach (por. podrozdziały 1.6 oraz 8.6.);

2. każda formuła ma (w poprzedniku) listę wszystkich aktywnych założeń.

W szczególności, druga własność umożliwiła zastąpienie niewygodnego w praktyce formatu T-dowodu (czyli dowodu w postaci drzewa) przez dowód linearny nie wymuszając wprowadzania dodatkowych technicznych środków do zaznaczania zależności od założeń, jak to ma miejsce w systemach w stylu Jaśkowskiego (por. podrozdział 1.6). Co więcej, bierny charakter poprzedników sekwentów w regułach umożliwił rezygnację z przepisywania formuł parametrycznych - możliwość wykorzystana w pełni przez Suppesa [133].

\subsubsection{Systemy DN logików rosyjskich}

W Rosji sekwentowy DN Gentzena jest popularną formą podręcznikowej prezentacji logiki klasycznej. Pojawia się np. w Ershow, Palyutin [39], czy w Ławrow, Maksimowa [96]. W tej drugiej propozycji w postaci niemal identycznej jak w DN Gentzena dla KRZ; w pierwszej z regułami dwuprzesłankowymi k-jednolitymi. Co do reguł logicznych w obu systemach inaczej charakteryzowana jest $\neg$ :

$(\neg E \Rightarrow) \frac{\Gamma, \neg \varphi \Rightarrow}{\Gamma \Rightarrow \varphi} \quad(\Rightarrow \neg E) \frac{\Gamma \Rightarrow \varphi \quad \Gamma \Rightarrow \neg \varphi}{\Gamma \Rightarrow}$

W rozszerzeniu dla KRK Ershow, Palyutin [39] wykorzystują jednak reguły ze standardowego RS Gentzena (czyli wprowadzające formuły kwantyfikatorowe do poprzedników); dowodzą też rozmaitych reguł wtórnych, które wprowadzaja operacje logiczne w poprzednikach. W Ławrow, Maksimowa [96] $\exists$ jest scharakteryzowany jak w standardowym RS, a $\forall$ jak w DN, tzn. przez regułę dołączania i eliminacji w następniku. W obu przypadkach zachowany jest Gentzenowski format dowodów jako drzew. 


\subsubsection{DN Andrewsa}

Jest to c-system na sekwentach intuicjonistycznych, który różni się jednak istotnie doborem reguł od innych propozycji. Wszystkie reguły wieloprzesłankowe są k-jednolite. W systemie tym dowód zdefiniowany jest jako ciąg sekwentów. Dobór reguł jest następujący:

1. W grupie reguł strukturalnych jedyny sekwent aksjomatyczny ma postać $\Gamma \Rightarrow \varphi$, gdzie $\varphi \in \Gamma$. Dodatkowo występuje jedna zbiorcza reguła strukturalna odpowiadająca kontrakcji, permutacji i osłabianiu na poprzedniku dowolnego sekwentu.

2. Spójniki są scharakteryzowane tylko 3 regułami, które odpowiadają regułom konstrukcji dowodu w systemie DN na formułach. Są to: $(\Rightarrow \rightarrow),(\Rightarrow$ $\vee E)$ (w wersji k-jednolitej) oraz dla $\neg$

$$
(\neg E \Rightarrow) \frac{\Gamma, \neg \varphi \Rightarrow \perp}{\Gamma \Rightarrow \varphi}
$$

Zamiast osobnych reguł, które są sekwentowymi odpowiednikami reguł inferencji ze standardowego DN, Andrews wprowadza zbiorczą regułę:

(Taut) $\frac{\Gamma \Rightarrow \varphi_{1}, \ldots, \Gamma \Rightarrow \varphi_{n}}{\Gamma \Rightarrow \psi}$

gdzie $\varphi_{1} \wedge \ldots \wedge \varphi_{n} \rightarrow \psi$ jest tautologią $\mathrm{KRZ}^{1}$.

3. W charakterystyce kwantyfikatorów reguły eliminacji są takie jak $\mathrm{u}$ Gentzena (z tym, że $(\Rightarrow \exists E)$ jest regułą k-jednolitą). Reguły dołączania mają postać uogólnioną:

$$
(\Rightarrow \forall U) \frac{\Gamma \Rightarrow \psi \vee \varphi[x / a] \vee \chi}{\Gamma \Rightarrow \psi \vee \forall x \varphi \vee \chi} \quad(\Rightarrow \exists U) \frac{\Gamma \Rightarrow \psi \vee \varphi[x / \tau] \vee \chi}{\Gamma \Rightarrow \psi \vee \exists x \vee \chi}
$$

Oczywiście $(\Rightarrow \forall U)$ musi spełniać warunek nowości dla $a$ oraz w obu regułach dopuszcza się, że $\psi$ lub $\chi$ nie występuje. Ponadto w zestawie reguł pierwotnych jest jedna reguła zbiorcza pokrywająca efekt działania czterech reguł De Morgana dla kwantyfikatorów i reguła zamiany następnika dowolnego sekwentu na jego alfabetyczny wariant.

Łatwo zauważyć, że system Andrewsa jest redundantny, ponadto - przynajmniej w części zdaniowej - schemat int-elim dla reguł jest zarzucony. Jako osobne reguły dla spójników wyróżnione są tylko takie, których nie da się ująć jako sekwentów, gdyż w standardowym DN są regułami konstrukcji dowodu.

\footnotetext{
${ }^{1}$ Podobne rozwiązania stosują też niektórzy autorzy standardowych systemów DN, np. Quine [115].
} 


\subsubsection{Systemy DN Suppesa i Lemmona}

Jak wyżej wspomnieliśmy sekwentowy DN Gentzena otwiera duże możliwości jeżeli chodzi o jego uproszczenie i dostosowanie do praktyki dowodowej. Zostały one w pełni wykorzystane przez Suppesa [133] w jego podręcznikowej wersji DN spopularyzowanej potem w wielu podręcznikach logiki, np. w Lemmon [90], Forbes [45]. Uproszczenie sprowadza się do dwóch kroków:

1. Zamiast T-dowodów (tj. drzew) można w takim systemie używać dowodów linearnych (takie rozwiązanie jest też u Andrewsa), ale bez stosowania dodatkowych technik zaznaczających zasięg aktywnych założeń, gdyż każda dedukowana formuła (następnik sekwentu) niesie ze sobą całą potrzebną informację $\mathrm{w}$ poprzedniku. Takie rozwiązanie z praktycznego punktu widzenia ma przewagę zarówno nad standardowym DN w stylu Gentzena z [50] (z dowodami drzewami), jak i nad DN w stylu Jaśkowskiego (z dowodami linearnymi). W pierwszym przypadku unikamy wielokrotnego przepisywania partii dowodu w sytuacji, gdy to samo założenie służy do dedukcji wielu formuł. W drugim przypadku uzyskujemy większą elastyczność w konstrukcji dowodu, gdyż jako bezpośrednio sąsiadujące wiersze mogą występować formuły zależne od różnych założeń, co w DN Jaśkowskiego jest niemożliwe (por. podrozdział 1.6.).

2. Bierny charakter poprzedników umożliwia uniknięcie przepisywania formuł; zamiast tego można skorzystać z numerów wierszy, w których zostało wprowadzone odpowiednie założenie. Pomysł ten pojawił się po raz pierwszy u Feysa i Ladriere'a [40] w ich tłumaczeniu Gentzena [50] na francuski. Rozwiązanie takie powoduje, że otrzymujemy pozornie system DN zdefiniowany na formułach.

Oczywiście, aby w ten sposób "przerobić" system Gentzena należy w zestawie reguł wyeliminować takie, w których na elementach poprzednika dokonuje się logicznych operacji, w szczególności $(\Rightarrow \exists E)$. U Suppesa występuje reguła postaci:

$$
\Gamma \Rightarrow \exists x \varphi / \Gamma \Rightarrow \varphi\left[x / a_{y_{1}, \ldots, y_{n}}\right],
$$

gdzie mamy do czynienia z bezpośrednią eliminacją $\exists$, ale w rezultacie dokonujemy skolemizacji, gdyż $a$ jest nowym parametrem indeksowanym przez zmienne wolne w $\varphi$. Dodatkowo taka reguła wymusza znaczące komplikacje $\mathrm{w}$ sformułowaniu poprawnej reguły wprowadzania $\forall$. Toteż lepszym rozwiązaniem jest reguła Lemmona postaci: 


$$
\Gamma \Rightarrow \exists x \varphi ; \varphi[x / a] \Rightarrow \varphi[x / a] ; \Delta, \varphi[x / a] \Rightarrow \psi / \Gamma, \Delta \Rightarrow \psi,
$$

gdzie $a$ jest parametrem nowym dla $\Gamma, \Delta, \varphi, \psi$.

Przykład dowodu w DN Suppesa:

$\begin{array}{ccll}1 & \{1\} & p \rightarrow q & \mathrm{z} \\ 2 & \{2\} & q \rightarrow r & \mathrm{z} \\ 3 & \{3\} & p & \mathrm{z} \\ 4 & \{1,3\} & q & 1,3,(\rightarrow E) \\ 5 & \{1,2,3\} & r & 2,4,(\rightarrow E) \\ 6 & \{1,2\} & p \rightarrow r & 5,(\rightarrow D) \\ 7 & \{1\} & (q \rightarrow r) \rightarrow(p \rightarrow r) & 6,(\rightarrow D) \\ 8 & \varnothing & (p \rightarrow q) \rightarrow((q \rightarrow r) \rightarrow(p \rightarrow r)) & 7,(\rightarrow D)\end{array}$

\subsubsection{Systemy Hermesa i Ebbinhgausa, Fluma, Thomasa}

Hermes [64] zaprezentował system dla KRKI, który przez niego samego określany jest jako system DN, ale który odbiega pod wieloma względami od sekwentowego DN Gentzena czy jego transformacji w systemie Suppesa. Przede wszystkim dlatego, że swobodnie wykorzystuje reguły dołączania i eliminacji zrówno w następniku jak i w poprzedniku. Oczywiście uniemożliwia to zastosowanie rozwiązania Suppesa z numerami zastępującymi formuły w poprzednikach, ale pozwala na dużą elastyczność w konstruowaniu dowodów. Rachunek jest również c-systemem zdefiniowanym na sekwentach intuicjonistycznych. Jako sekwentów pierwotnych Hermes używa jedynie: $\varphi \Rightarrow \varphi$ oraz $\Rightarrow \tau=\tau$. Reguły logiczne są następujące:

$$
\begin{array}{lr}
(\neg E \Rightarrow) \frac{\Gamma, \varphi \Rightarrow \psi \quad \Delta, \neg \varphi \Rightarrow \psi}{\Gamma, \Delta \Rightarrow \psi} & (\Rightarrow \neg E) \frac{\Gamma \Rightarrow \varphi \quad \Delta \Rightarrow \neg \varphi}{\Gamma, \Delta \Rightarrow \psi} \\
(\Rightarrow \wedge E 1) \frac{\Gamma \Rightarrow \varphi \wedge \psi}{\Gamma \Rightarrow \varphi} & (\Rightarrow \wedge E 2) \frac{\Gamma \Rightarrow \varphi \wedge \psi}{\Gamma \Rightarrow \psi} \\
(\Rightarrow \wedge) \frac{\Gamma \Rightarrow \varphi \quad \Delta \Rightarrow \psi}{\Gamma, \Delta \Rightarrow \varphi \wedge \psi} & (\vee \Rightarrow) \frac{\Gamma, \varphi \Rightarrow \chi \quad \Delta, \psi \Rightarrow \chi}{\Gamma, \Delta, \varphi \vee \psi \Rightarrow \chi} \\
(\Rightarrow \vee) \frac{\Gamma \Rightarrow \varphi}{\Gamma \Rightarrow \varphi \vee \psi} & (\Rightarrow \vee) \frac{\Gamma \Rightarrow \psi}{\Gamma \Rightarrow \varphi \vee \psi} \\
(\rightarrow \Rightarrow) \frac{\Gamma, \neg \varphi \Rightarrow \chi \quad \Delta, \psi \Rightarrow \chi}{\Gamma, \Delta, \varphi \rightarrow \psi \Rightarrow \chi} & (\Rightarrow \rightarrow) \frac{\Gamma, \varphi \Rightarrow \psi}{\Gamma \Rightarrow \varphi \rightarrow \psi} \\
(\Rightarrow \forall E) \frac{\Gamma \Rightarrow \forall x \varphi}{\Gamma \Rightarrow \varphi} & (\Rightarrow \forall)^{1} \frac{\Gamma \Rightarrow \varphi}{\Gamma \Rightarrow \forall x \varphi}
\end{array}
$$




$$
\begin{aligned}
& (\Rightarrow \exists) \frac{\Gamma \Rightarrow \varphi}{\Gamma \Rightarrow \exists x \varphi} \quad(\exists \Rightarrow)^{2} \frac{\Gamma, \varphi \Rightarrow \psi}{\Gamma, \exists x \varphi \Rightarrow \psi} \\
& \left.(\Rightarrow=) \frac{\Gamma \Rightarrow \varphi}{\Gamma, x=\tau \Rightarrow \varphi[x / \tau]} \quad \text { (Subst) }\right)^{3} \frac{\Gamma \Rightarrow \varphi}{\Gamma^{\prime} \Rightarrow \varphi^{\prime}}
\end{aligned}
$$

Ograniczenia:

1. pod warunkiem, że $x$ nie jest wolne $\mathrm{w} \Gamma$.

2. pod warunkiem, że $x$ nie jest wolne w $\Gamma$ i w $\psi$.

3. gdzie $\Gamma^{\prime}, \varphi^{\prime}$ są uzyskane przez podstawienie z $\Gamma, \varphi$.

Dowód w systemie Hermesa jest definiowany liniowo, ale niżej użyjemy jednak reprezentacji drzewnej przy prezentacji przykładów.

Co do reguł to odnotujmy co następuje: $\vee$ i $\exists$ jest scharakteryzowane jak w standardowym RS Gentzena, a $\wedge \mathrm{i} \forall$ jak w sekwentowym DN, z tym, że przy regułach kwantyfikatorowych nie stosuje się podstawiania, które występuje jako osobna reguła pierwotna. $\rightarrow$ jest scharakteryzowane prawie jak w RS Gentzena, ale $(\rightarrow \Rightarrow)$ nie jest reguła separowalną (por. podrozdział 4.5), gdyż zawiera $\mathrm{w}$ jednej z przesłanek $\neg$. Sama $\neg$ jest scharakteryzowana $\mathrm{w}$ zupełnie niestandardowy sposób; $(\neg E \Rightarrow)$ to wariant dowodu rozgałęzionego (przez przypadki), a $(\Rightarrow \neg E$ ) to wariant reguły Dunsa Szkota.

Bardzo nietypową cechą systemu Hermesa jest brak reguł strukturalnych, mimo iż jest to c-system. Reguły te są jednak wyprowadzalne. Wyprowadzalność (P) wynika ze sposobu, w jaki Hermes definiuje podstawialność i z reguły (Subst). Wyprowadzalność (W) demonstruje poniższy schemat:

$$
\frac{\Gamma \Rightarrow \varphi \quad \psi \Rightarrow \psi}{\frac{\Gamma, \psi \Rightarrow \varphi \wedge \psi}{\Gamma, \psi \Rightarrow \varphi}(\Rightarrow \wedge \wedge)}
$$

Mimo, że MP nie występuje jako pierwotna reguła, to w systemie Hermesa (Cut) jest również regułą wyprowadzalną, co pokazuje poniższy schemat:

$$
(\neg E \Rightarrow) \frac{\Delta, \varphi \Rightarrow \psi \quad \frac{\Gamma \Rightarrow \varphi \quad \neg \varphi \Rightarrow \neg \varphi}{\Gamma, \neg \varphi \Rightarrow \psi}}{\Gamma, \Delta \Rightarrow \psi}(\Rightarrow \neg E)
$$

Jak widać obie reguły dla $\neg$ są bardzo silne dedukcyjnie i w zasadzie obejmują mechanizm cięcia; umożliwiają też dowód MP jako reguły wtórnej. Hermes chcąc zwiększyć łatwość dowodzenia w swoim systemie wykazuje wyprowadzalność jeszcze wielu innych reguł w tym również takich, które dokonują operacji logicznych na poprzednikach, np. dla $\wedge$ wprowadza: 


$$
(\wedge \Rightarrow) \frac{\Gamma, \varphi, \psi \Rightarrow \chi}{\Gamma, \varphi \wedge \psi \Rightarrow \chi} \quad(\wedge E \Rightarrow) \frac{\Gamma, \varphi \wedge \psi \Rightarrow \chi}{\Gamma, \varphi, \psi \Rightarrow \chi}
$$

Bardzo podobny system dla KRKI w języku z $\neg, \vee, \exists$ i dowodami liniowymi zawiera [38]. Różnice są następujące:

1. Wszystkie reguły dwuprzesłankowe są k-jednolite.

2. Wymusza to dodanie reguły (W) jako pierwotnej, gdyż nie jest ona dłużej wyprowadzalna (por. podany wyżej dowód Hermesa, gdzie korzystamy z reguły k-niezależnej dla $\wedge$ ), a jest niezbędna dla ujednolicania poprzedników w sekwentach, do których chcemy zastosować reguły dwuprzesłankowe. W systemie Ebbinhausa, Fluma i Thomasa jest jedna reguła strukturalna, która umożliwia na poprzedniku zarówno kontrakcję jak i permutację i osłabianie. Dodatkowo sekwent aksjomatyczny występuje w postaci $\Gamma \Rightarrow \varphi$, gdzie $\varphi \in \Gamma$

3. Dla negacji mamy zbliżoną parę reguł, którą podajemy niżej. $(\neg E \Rightarrow)$ (zwane regułą dowodu przez przypadki) jest takie samo jak u Hermesa (choć $\mathrm{w}$ wersji k-jednolitej) natomiast $(\Rightarrow \neg E$ ) (zwana regułą sprzeczności) ma nieco inną postać:

$$
(\neg E \Rightarrow) \frac{\Gamma, \varphi \Rightarrow \psi \quad \Gamma, \neg \varphi \Rightarrow \psi}{\Gamma \Rightarrow \psi} \quad(\Rightarrow \neg E) \frac{\Gamma, \neg \psi \Rightarrow \varphi \quad \Gamma, \neg \psi \Rightarrow \neg \varphi}{\Gamma \Rightarrow \psi}
$$

Reguła ( $\Rightarrow \neg E$ ) Hermesa (w wersji k-jednolitej) jest wyprowadzalna jako druga reguła sprzeczności, podobnie reguła (Cut) zwana regułą łańcuchową. W dowodzie schematu pierwszej wystarczy do obu przesłanek zastosować osłabianie wprowadzające $\neg \psi$, a potem zastosować pierwotną $(\Rightarrow \neg E)$; dowód wyprowadzalności (Cut) jak u Hermesa.

4. Pozostałe reguły (dla $\vee, \exists \mathrm{i}=$ ) jak u Hermesa z tą różnicą, że brak jest osobnej reguły podstawiania. Za to efekt podstawiania wtopiony jest $\mathrm{w}$ same reguły - tak jak u Gentzena.

\subsubsection{System Leblanca}

Leblanc w pracach $[88,89]$ zaprezentował pewien wariant LK na int-sekwentach, który ma charakter sekwentowego DN, ale z uogólnionymi regułami eliminacji. Różnice w stosunku do sekwentowego DN Gentzena są następujące:

1. Wszystkie reguły wieloprzesłankowe są k-jednolite.

2. W regułach $(\Rightarrow \forall)$ i $(\Rightarrow \exists E)$ nie ma podstawiania parametru (nowego) $a$ za $x$, ale $x$ musi spełniać warunek nie występowania jako wolna zmienna w $\Gamma(\mathrm{i} \psi \mathrm{w}(\Rightarrow \exists E))$. Obie reguły mają więc następujący kształt: 
$(\Rightarrow \forall) \frac{\Gamma \Rightarrow \varphi}{\Gamma \Rightarrow \forall x \varphi} \quad(\Rightarrow \exists E) \frac{\Gamma \Rightarrow \exists x \varphi \quad \Gamma, \varphi \Rightarrow \psi}{\Gamma \Rightarrow \psi}$

3. Reguły dla $\neg \mathrm{i} \vee$ są takie same jak u Gentzena (pomijajacc to, że $(\Rightarrow \neg) \mathrm{i}(\Rightarrow \vee E)$ są $\mathrm{k}$-jedolite), natomiast w pozostałych przypadkach mamy następujące reguły eliminacji:

$$
\begin{aligned}
& (\Rightarrow \forall E) \frac{\Gamma \Rightarrow \forall x \varphi \quad \Gamma, \varphi[x / y] \Rightarrow \psi}{\Gamma \Rightarrow \psi} \quad(\Rightarrow \wedge E) \frac{\Gamma \Rightarrow \varphi \wedge \psi \quad \Gamma, \varphi, \psi \Rightarrow \chi}{\Gamma \Rightarrow \chi} \\
& (\Rightarrow \rightarrow E) \frac{\Gamma \Rightarrow \varphi \rightarrow \psi \quad \Gamma \Rightarrow(\varphi \rightarrow \chi) \rightarrow \varphi}{\Gamma \Rightarrow \psi}
\end{aligned}
$$

Specyficzna forma reguł eliminacji dla $\rightarrow, \wedge$ i $\forall$ jest oparta na schemacie reguł eliminacji dla $\vee$ i $\exists$. Wprowadzenie takich reguł pozwala Leblancowi udowodnić interesującą własność, która jest osłabieniem własności podformuł. Dla każdego dowiedlnego w KRZ sekwentu $S$ można zbudować dowód, w którym każda stała występująca w dowolnym sekwencie tego dowodu występuje również w $S$. Wynik ten nie zachodzi dla KRK. Zauważmy, że mimo iż w systemie Leblanca fukcję reguły eliminacji dla $\neg$ pełni reguła eliminacji podwójnej negacji, to nie wystarcza to by w takim zestawie reguł otrzymać charakterystykę klasycznej implikacji za pomocą MP (tak jak w systemie Gentzena). W systemie Leblanca zastąpienie podanej wyżej reguły $(\Rightarrow \rightarrow E)$ przez MP daje implikację intuicjonistyczną. Oczywiście, aby otrzymać generalnie system dla INT trzeba też osłabić regułę eliminacji dla $\neg$, czyli zamiast reguły Gentzena (tj. eliminacji podwójnej negacji) użyć:

$(\Rightarrow \neg E) \frac{\Gamma \Rightarrow \varphi \quad \Gamma \Rightarrow \neg \varphi}{\Gamma \Rightarrow \psi}$

Interesujące zastosowanie dla tego typu reguł eliminacji, ale na gruncie standardowego systemu DN znalazła Negri i von Plato [101]. Zauważmy, że w tym kontekście każda reguła eliminacji staje się regułą konstrukcji dowodu, gdyż nie rozbijamy złożonej formuły bezpośrednio, ale za pomocą poddowodu, w którym dedukujemy konsekwencje jej składników aby przenieść je do dowodu nadrzędnego. Jak pokazał von Plato takie rozwiązanie pozwala na uzyskanie prostszego dowodu twierdzenia o normalizacji dowodów w DN.

\subsubsection{Strukturalny system Došena}

Došen [30] zaproponował tzw. strukturalną wersję LK w języku bez negacji, ale $\mathrm{z} \perp$, w której pierwotny (i nieeliminowalny) jest zestaw reguł strukturalnych natomiast każda stała logiczna jest scharakteryzowana za pomocą jednej, ale obustronnej reguły: 


$$
(\rightarrow) \frac{\varphi, \Gamma \Rightarrow \Delta, \psi}{\Gamma \Rightarrow \Delta, \varphi \rightarrow \psi} \quad(\wedge) \frac{\Gamma \Rightarrow \Delta, \varphi \quad \Gamma \Rightarrow \Delta, \psi}{\Gamma \Rightarrow \Delta, \varphi \wedge \psi}
$$

( $\frac{\varphi, \Gamma \Rightarrow \Delta \quad \psi, \Gamma \Rightarrow \Delta}{\varphi \vee \psi, \Gamma \Rightarrow \Delta}$

W każdym przypadku mamy oprócz reguły wprowadzania również reguły eliminacji danej stałej (czytajacc schemat od dołu). Łatwo też wykazać, wykorzystując lemat 4.13, że brakujące reguły wprowadzania stałych z RS Gentzena są regułami wyprowadzalnymi w systemie Došena (przy użyciu (Cut)). Czytelnik z pewnością zauważy, że reguły te odpowiadają podanym za pomocą równoważności w podrozdziale 2.4 charakterystykom spójników na gruncie relacji konsekwencji Scotta. Można oczywiście użyć dla każdego ze spójników reguł modelowanych na drugiej z podanych tam równoważności. Gdyby patrzeć na tego typu system jako narzędzie konstruowania dowodu, to oczywiście przyjęcie samych reguł jednoprzesłankowych (w jedną stronę) może wydawać się rozwiązaniem korzystniejszym. Dla Došena taki motyw był nieistotny, gdyż zaproponowany przez niego system miał służyć osiągnięciu pewnych celów teoretycznych, które krótko scharakteryzujemy.

System Došena służy ilustracji jego przekonań odnośnie kryteriów logiczności, a dokładniej próby ustalenia co to jest stała logiczna. Punktem wyjścia analizy stałych logicznych jest dla Došena przekonanie, że logika jest nauką o formalnych dowodach. W jego ujęciu dowód formalny to inaczej dowód strukturalny, czyli taki dowód w RS, w którym zastosowano jedynie reguły strukturalne ${ }^{2}$. Wyrażenie jest wg. Došena logiczne wtw poddaje się analizie czysto strukturalnej. Obustronne reguły logiczne w jego systemie są w tym sensie wyrazem takiej analizy, że po jednej stronie kreski mamy sekwenty czysto strukturalne tj. nie zawierające wystąpienia żadnej stałej logicznej. Zdaniem Došena aby jakieś wyrażenie można było uznać za stałą logiczną konieczne jest znalezienie obustronnych reguł tego typu, które po dołączeniu do zestawu reguł strukturalnych pozwalają uzyskać pełną charakterystykę danej stałej. Warto zauważyć, że tego kryterium logiczności nie spełnia wiele wyrażeń, np. funktorów modalnych, które powszechnie są traktowane jako stałe logiczne. Jednak przy przejściu do uogólnionych postaci RS można znaleźć bardziej zadowalające zestawy reguł (por. np. Wansing [148] czy Poggiolesi [108].)

Warto wspomnieć, że podobna idea wystąpiła znacznie wcześniej w serii prac Poppera (np. w $[110,111])$, gdzie była jednak słabo wyartykułowana

\footnotetext{
${ }^{2}$ Jest to w pewnym sensie rozwinięcie programu Hertza, o którym więcej powiemy w następnym podrozdziale.
} 
i związana z wadliwą próbą zbudowania teoriodowodowej semantyki. Projekt Poppera został poddany krytyce przez wielu logików, m.in. Kleene'ego i Curry'ego, ze względu na jego niespójność. Tym niemniej, jak przekonująco pokazał Schroeder-Heister [122], prace Poppera zawierały interesującą propozycję określenia kryteriów bycia stałą logiczną. Popper próbował scharakteryzować stałe za pomocą tzw. inferencyjnych definicji, z których można wyprowadzić obustronne reguły charakterystyczne dla stałych o postaci:
$(\rightarrow) \frac{\varphi, \chi \Rightarrow \psi}{\chi \Rightarrow \varphi \rightarrow \psi}$
$(\wedge) \frac{\varphi, \psi \Rightarrow \chi}{\varphi \wedge \psi \Rightarrow \chi}$
( $) \frac{\varphi \Rightarrow \chi \psi \psi \Rightarrow \chi}{\varphi \vee \psi \Rightarrow \chi}$
$(\neg) \frac{\varphi, \psi \Rightarrow \chi}{\neg \chi, \psi \Rightarrow \neg \varphi}$

\subsection{Typ strukturalny RS Hertza}

Systemy pierwszego typu, na których koncentrowaliśmy się dotąd, reprezentują skrajny typ RS, w którym mamy tylko jeden względnie dwa schematy aksjomatyczne natomiast stałe logiczne charakteryzowane są z pomocą reguł sekwentowych. Przeciwny biegun reprezentuje typ RS, który określiliśmy mianem typu Hertza lub strukturalnego. W tym podejściu reguły mają wyłącznie charakter strukturalny natomiast charakterystyka stałych logicznych jest zawarta $\mathrm{w}$ sekwentach pierwotnych. Z tego powodu typ ten można określić jako czysto strukturalny $\mathrm{RS}^{3}$.

Związek z Hertzem ma charakter historyczny. W [65] P. Hertz wprowadził m.in. pojęcie sekwentu (typu intuicjonistycznego), reguły sekwentowej, dowodu w postaci drzewa i zapoczątkował program rozwinięty póżniej przez Gentzena. Należy podkreślić, że Hertz nie przedstawił konkretnego systemu, który dawałby formalizację jakiejś logiki. Jego podejście było czysto abstrakcyjne; przedstawił raczej schemat systemu, w którym jedyne reguły inferencji mają charakter czysto strukturalny. Poza regułami kontrakcji, permutacji i osłabiania w poprzedniku Hertz używał następującej reguły sylogizmu, która jest rodzajem równoczesnego cięcia:

$$
\frac{\Gamma_{1} \Rightarrow \varphi_{1} \ldots . \Gamma_{n} \Rightarrow \varphi_{n}, \quad \varphi_{1}, \ldots, \varphi_{n}, \Delta \Rightarrow \psi}{\Gamma_{1}, \ldots, \Gamma_{n}, \Delta \Rightarrow \psi}
$$

Gentzen w swojej wczesnej pracy [49] wniósł pewien wkład do rozbudowy teorii Hertza. W szczególności przedstawił czysto strukturalne kryteria, które musi spełniać dowolny RS tego typu, aby jego zestaw sekwentów aksjo-

\footnotetext{
${ }^{3}$ Należy odróżnić to rozumienie od sensu strukturalności, który wystąpił w poprzednim podrozdziale w odniesieniu do systemu Došena.
} 
matycznych był niezależny. Gentzen zastąpił w [49] regułę sylogizmu Hertza przez (Cut), który jest szczególnym przypadkiem tej reguły dla $n=1$.

Podejście Hertza jako sposób charakteryzacji logiki nie znalazło zastosowania poza jednym znaczącym przypadkiem, który obecnie omówimy. Przyjęło się natomiast jako sposób formalizowania teorii na bazie danego (regułowego) systemu RS dla ustalonej logiki (sposoby 1 i 2 omówione w podrozdziale 9.8).

\subsubsection{System Suszki}

Wydaje się, że jedyny konsekwentny system typu Hertza dla konkretnych logik rozwinął Roman Suszko. W latach 40-tych zaproponował w swoim doktoracie [136] (por. też [135]) interesującą alternatywę dla systemu Gentzena, ale również Herbranda i Jaśkowskiego. Chociaż Suszko nie wspomina Hertza, to jego system stanowi przykład konkretnej realizacji programu Hertza, opartego na dodatkowych założeniach zaczerpniętych od Ajdukiewicza. Problem, który sobie postawił, określił jako problem logiki bez aksjomatóws. Można go wyrazić następująco: czy jest możliwe zbudowanie rachunku dla logiki klasycznej bez aksjomatów, a opartego wyłącznie na właściwych regułach inferencji? Tezy logiki mają być z pomoca tych reguł wydedukowanie z dowolnych formuł. Jest to formalny sposób wyrażenia idei, że analityczne zdania (= logiczne tezy) sa implikowane przez dowolne zdanie.

Zdaniem Suszki wszystkie nieaksjomatyczne systemy zaproponowane wcześniej były wadliwe w tym sensie, że zawierały pewne reguły niewłaściwe. Ale co to są reguły właściwe? W ujęciu Suszki są to reguły, w których zarówno schematy przesłanek, jak i wniosku są formułami kontyngentnymi. Łatwo zauważyć, że np. reguły konstrukcji dowodu oparte na twierdzeniu o dedukcji nie są właściwe w sensie Suszki, gdyż konkluzja ich zastosowania jest tezą implikacyjną. To samo odnosi się do innych reguł tego typu, jak dowód nie wprost czy dowód przez przypadki. Suszko opierał się w swoim poglądzie na pomyśle Ajdukiewicza [3] i traktował takie reguły jak przykłady aksjomatycznych postulatów. Wydaje się jednak, że obiekcje Suszki wobec takich reguł są przesadzone, gdyż ich schematy nie zawierają schematów konkretnych tez w konkluzji, co więcej, nie wszystkie zastosowania tych reguł w dowodach prowadzą do dedukcji tez (np. wtedy, gdy nie wszystkie założenia są zamknięte). Bez względu na słuszność przyjętych założeń Suszko odrzucił tego typu reguły, w rezultacie budując specyficzny rodzaj RS.

Suszko nazwał swój system LS i przedstawił go w dwóch wersjach: 
S1 - formalizacja KRZ w języku implikacyjno-negacyjnym

S2 - system LS dla logiki pierwszego rzędu z identycznością i deskrypcjami określonymi ${ }^{4}$

Obiekty rozważane przez Suszkę jako formalne reprezentacje reguł określał jako logistyczne sekwensy i prezentował za pomocą następujących schematów:

$$
\left.\begin{array}{l}
\varphi_{1} \\
\vdots \\
\varphi_{n}
\end{array}\right\} \longrightarrow \psi
$$

Nieformalnie, $\longrightarrow$ wyraża relację dedukowalności generowaną przez system aksjomatyczny. Dalej będziemy je prezentować jako sekwenty intuicjonistyczne.

W [135] Suszko zaprezentował jedynie adekwatną formalizację KRZ w języku implikacyjno-negacyjnym, składającą się z następujących siedem sekwentów:

1.1.1.

1.1.2. $\quad(\varphi \rightarrow \psi) \rightarrow \chi \Rightarrow \psi \rightarrow \chi$

1.1.3. $\varphi \rightarrow(\psi \rightarrow \chi) \Rightarrow(\varphi \rightarrow \psi) \rightarrow(\varphi \rightarrow \chi)$

1.1.4. $\varphi \rightarrow \psi \quad \Rightarrow \quad(\chi \rightarrow \varphi) \rightarrow((\psi \rightarrow \gamma) \rightarrow(\chi \rightarrow \psi))$

1.1.5. $\varphi, \varphi \rightarrow \psi \Rightarrow \psi$

1.1.6. $\quad(\varphi \rightarrow \psi) \rightarrow \chi \quad \Rightarrow \quad \neg \varphi \rightarrow \chi$

1.1.7. $\varphi \rightarrow \psi, \neg \varphi \rightarrow \psi \Rightarrow \psi$

W [136] pojawia się reszta reguł. Dla innych zdaniowych stałych mamy następujące sekwenty:

1.2 .2 .

$$
\varphi \rightarrow \psi \Rightarrow \varphi \wedge \chi \rightarrow \psi
$$

1.2.3.

1.3.1.

1.3.2.

1.3.3.

$$
\varphi \rightarrow \psi \quad \Rightarrow \quad \chi \wedge \varphi \rightarrow \psi
$$

1.4.3.

$$
\begin{aligned}
\varphi \rightarrow(\psi \rightarrow \chi), \gamma \rightarrow(\psi \rightarrow \delta) & \Rightarrow \varphi \rightarrow(\gamma \rightarrow(\psi \rightarrow \chi \wedge \delta)) \\
(\varphi \rightarrow \psi) \rightarrow \chi & \Rightarrow(\varphi \leftrightarrow \psi) \rightarrow \chi \\
(\varphi \rightarrow \psi) \rightarrow \chi & \Rightarrow(\psi \leftrightarrow \varphi) \rightarrow \chi \\
\varphi \rightarrow(\psi \rightarrow \chi), \gamma \rightarrow(\chi \rightarrow \psi) & \Rightarrow \varphi \rightarrow(\gamma \rightarrow(\psi \leftrightarrow \chi)) \\
\varphi \rightarrow \psi & \Rightarrow \varphi \rightarrow \psi \vee \chi \\
\varphi \rightarrow \psi & \Rightarrow \varphi \rightarrow \chi \vee \psi \\
\varphi \rightarrow(\psi \rightarrow \chi), \gamma \rightarrow(\delta \rightarrow \chi) & \Rightarrow \varphi \rightarrow(\gamma \rightarrow(\psi \vee \delta \rightarrow \chi))
\end{aligned}
$$

${ }^{4}$ Prezentację reguł dla deskrypcji, które stanowią formalizację teorii Hiberta i Bernaysa, pomijamy. Pełne omówienie systemu można znaleźć w Indrzejczak [73]. 
Alternatywnie, zamiast sekwentów 1.2.1. - 1.4.3., Suszko rozważa zbiór ośmiu sekwentów, które także wystarczają do wyrażenia znaczenia $\wedge, \vee, \leftrightarrow$ :

$$
\begin{array}{lrl}
1.2 .1^{\prime} . & \varphi \rightarrow(\psi \rightarrow \chi) & \Rightarrow \varphi \wedge \psi \rightarrow \chi \\
1.2 .2^{\prime} . & \varphi \wedge \psi \rightarrow \chi & \Rightarrow \varphi \rightarrow(\psi \rightarrow \chi) \\
1.3 .1^{\prime} . & \varphi \rightarrow(\psi \rightarrow \chi), \varphi \rightarrow(\chi \rightarrow \psi) & \Rightarrow \varphi \rightarrow(\psi \leftrightarrow \chi) \\
1.3 .2^{\prime} . & \varphi \rightarrow(\psi \leftrightarrow \chi) & \Rightarrow \varphi \rightarrow(\psi \rightarrow \chi) \\
1.3 .3^{\prime} . & \varphi \rightarrow(\psi \leftrightarrow \chi) & \Rightarrow \varphi \rightarrow(\chi \rightarrow \psi) \\
1.4 .1^{\prime} . & \varphi \rightarrow \psi, \chi \rightarrow \psi & \Rightarrow \varphi \vee \chi \rightarrow \psi \\
1.4 .2^{\prime} . & \varphi \vee \psi \rightarrow \chi & \Rightarrow \varphi \rightarrow \chi \\
1.4 .3^{\prime} . & \varphi \vee \psi \rightarrow \chi & \Rightarrow \psi \rightarrow \chi
\end{array}
$$

Dla kwantyfikatorów mamy następujące reguły:

2.1. $\varphi[x / a] \Rightarrow \forall x \varphi$

2.2.1. $\forall x(\varphi \rightarrow \psi) \Rightarrow \varphi \rightarrow \forall x \psi$

2.2.2. $\forall x(\psi \rightarrow \varphi) \quad \Rightarrow \quad \exists x \psi \rightarrow \varphi$

2.3.1. $\varphi \rightarrow \forall x \psi \Rightarrow \varphi \rightarrow \psi[x / \tau]$

2.3.2. $\quad \exists x \varphi \rightarrow \psi \quad \Rightarrow \quad \varphi[x / \tau] \rightarrow \psi$

Oczywiście w schematach 2.2.1. i 2.2.2. $\mathrm{w} \varphi$ nie ma wystąpienia $x$. Schemat 2.1. jasno pokazuje, że $\Rightarrow$ u Suszki odpowiada relacji $\vdash$, a nie $\vdash_{2}$ jak $\Rightarrow$ w RS Gentzena.

Dla identyczności mamy dwa sekwenty:

3.1. $\varphi \Rightarrow \exists x(x=a)$

3.2. $\varphi \Rightarrow \tau_{1}=\tau_{2} \rightarrow \varphi\left[\tau_{1} / / \tau_{2}\right]$

gdzie $\tau_{i}$ reprezentuje dowolny term, a $\varphi \mathrm{w}$ 3.1. jest dowolną formułą.

Aby wydedukować inne sekwenty z sekwentów pierwotnych Suszko używa różnych form (dokładnie sześciu) reguły podstawiania z rachunku aksjomatycznego ale stosowanych do całych sekwentów oraz cztery reguły strukturalne znane z RS Gentzena, czyli reguły osłabiania, permutacji i kontrakcji (w poprzedniku) oraz (Cut). Reguły te są explicite podane w [136]; w [135] są jedynie implicite stosowane.

Suszko nie zwracał uwagi na formę reprezentacji dowodów w swoim systemie. W [135] podaje jedynie nieformalne (choć dokładne) opisy dowodów trzech aksjomatów systemu Łukasiewicza dla KRZ. W [136] podanych jest ponad 100 dowiedlnych sekwentów ze wskazówkami dotyczącymi ich uzasadnienia, ale bez formalnych dowodów. Choć Suszko nie definiuje formalnie pojęcia dowodu, to można to zrobić na co najmniej dwa sposoby: 
- traktując LS jako rachunek sekwentów w stylu Gentzena, gdzie każda reguła inferencji jest sekwentem aksjomatycznym (elementami dowodu są sekwenty);

- traktując LS jako formę dedukcji naturalnej, w której reguły inferencji podane przez Suszkę pozwalają na wyprowadzanie nowych formuł w dowodzie (elementami dowodu są formuły).

Pierwsze rozwiązanie wydaje się bardzo naturalne; traktujemy jego system jako rodzaj RS i definiujemy dowody jako drzewa binarne z liśćmi etykietowanymi przez sekwenty pierwotne. Oczywiście każdy dowiedziony sekwent może być też użyty jako sekwent startowy w dalszych dowodach.

Przykład 10.2:

$$
\frac{\text { 1.1.3. } p \rightarrow(q \rightarrow r) \Rightarrow(p \rightarrow q) \rightarrow(p \rightarrow r) \quad(p \rightarrow q) \rightarrow(p \rightarrow r) \Rightarrow q \rightarrow(p \rightarrow r) \text { 1.1.2. }}{p \rightarrow(q \rightarrow r) \Rightarrow q \rightarrow(p \rightarrow r) \text { cut }}
$$

Ten prosty dowód daje uzasadnienie dla schematu reguły komutacji:

$$
\varphi \rightarrow(\psi \rightarrow \chi) \Rightarrow \psi \rightarrow(\varphi \rightarrow \chi)
$$

W dalszym ciągu będziemy jednak przezentować dowody w formacie linearnym, gdyż - w przeciwieństwie do dowodów w RS Gentzena - drzewa w systemie Suszki zawierają zawyczaj dość długie sekwenty już jako liście i trudno je zmieścić na stronie.

Interesującą cechą tego systemu jest to, że jedynie sekwenty z niepustym poprzednikiem mogą być wydedukowane z sekwentów pierwotnych za pomocą reguł strukturalnych. Takie sekwenty naturalnie reprezentują reguły inferencji, ale w jaki sposób wydedukować tezy? Przecież system Suszki nie jest formalizacją jakiejś czysto inferencyjnej logiki, w rodzaju logiki Kleene'go K3. Tezy logiki klasycznej są tu dedukowalne w postaci tzw. sekwentów absolutnych o postaci $\varphi \Rightarrow \psi$, gdzie $\varphi$ jest formułą atomową nie występującą jako podformuła $\psi$. Oto przykład dowodu tezy: 

1. $\quad p \rightarrow p \Rightarrow(p \rightarrow p) \rightarrow((p \rightarrow q) \rightarrow(p \rightarrow q))$ 1.1.4.
2. $\quad p \rightarrow p,(p \rightarrow p) \rightarrow((p \rightarrow q) \rightarrow(p \rightarrow q)) \quad$ 1.1.5.
$\Rightarrow(p \rightarrow q) \rightarrow(p \rightarrow q)$
3. $\quad p \rightarrow p, p \rightarrow p \Rightarrow(p \rightarrow q) \rightarrow(p \rightarrow q) \quad 1,2,($ Cut $)$
4. $\quad p \rightarrow p \Rightarrow(p \rightarrow q) \rightarrow(p \rightarrow q)$
3, kontrakcja
5. $\quad p \Rightarrow p \rightarrow p$
1.1.1
6. $\quad p \Rightarrow(p \rightarrow q) \rightarrow(p \rightarrow q)$
$4,5,(C u t)$
7. $(p \rightarrow q) \rightarrow(p \rightarrow q) \Rightarrow p \rightarrow((p \rightarrow q) \rightarrow q) \quad$ komutacja
8. $\quad p \Rightarrow p \rightarrow((p \rightarrow q) \rightarrow q)$
$6,7,($ Cut $)$
9. $\quad p, p \rightarrow((p \rightarrow q) \rightarrow q) \Rightarrow(p \rightarrow q) \rightarrow q$
1.1.5.
10. $p, p \Rightarrow(p \rightarrow q) \rightarrow q$
$8,9,($ Cut $)$
11. $p \Rightarrow(p \rightarrow q) \rightarrow q$
10, kontrakcja
12. $(p \rightarrow q) \rightarrow q \Rightarrow q \rightarrow q$
13. $p \Rightarrow q \rightarrow q$
$11,12,($ Cut $)$

Zauważmy, że dowód $q \Rightarrow q$ jest łatwy w systemie Suszki (jedno zastosowanie (Cut) na 1.1.1. i 1.1.5.), ale nie możemy zastosować twierdzenia o dedukcji, aby otrzymać absolutny sekwent z wiersza 13 powyżej.

W praktyce, jeżeli potraktujemy LS jako rodzaj rachunku sekwentowego to napotkamy szereg trudności przy zapisie dowodów. Częściowo można je obejść, gdy zastosujemy linearny zapis dowodu, ale ciągle dowody są zazwyczaj długie i operują długimi sekwentami. Większe uproszczenie uzyskamy gdy zdefiniujemy dowód w LS nie jako ciąg sekwentów, ale ciąg formuł, w którym pierwsze wiersze zawierają elementy poprzednika dowodzonego sekwentu a ostatni wiersz zawiera następnik. W tym ujęciu sekwenty pierwotne nie są jednostkami dowodu ale raczej opisami pierwotnych reguł inferencji na formułach. Dowód $p \Rightarrow q \rightarrow q$ można wtedy przepisać w bardziej zwartej i czytelnej formie:
1. $p$
poprzednik
2. $p \rightarrow p$
1,1.1.1.
3. $(p \rightarrow p) \rightarrow((p \rightarrow q) \rightarrow(p \rightarrow q))$
$2,1.1 .4$.
4. $(p \rightarrow q) \rightarrow(p \rightarrow q)$
$2,3,1.1 .5$.
5. $\quad p \rightarrow((p \rightarrow q) \rightarrow q)$
4, komutacja
6. $(p \rightarrow q) \rightarrow q$
1, 5, 1.1.5.
7. $q \rightarrow q$
6,1.1.2.

W kolumnie uzasadnienia odwołujemy się jedynie do numeru pierwotnego sekwentu lub nazwy dowiedlnego i wierszy, w których wystąpiły ich 
poprzedniki. Zastosowania (Cut), kontrakcji itp. występują implicite. Taka forma reprezentacji dowodu czyni LS bardziej praktycznym (krótsze dowody zrobione z krótszych formuł), a otrzymany system wydaje się bliższy dedukcji naturalnej. Zachodzi jednak istotna różnica między LS a systemami DN. W LS nie ma poddowodów, ani reguł zamykania dodatkowych założeń. Taki wariant LS jest za to podobny do systemu linearnego wnioskowania występującego u Herbranda.

Podsumowując: LS potraktowane jako RS typu Hertza ujawnia podstawową praktyczną wadę takich systemów - dowody w postaci drzew są nadmiernie rozwlekłe choć strukturalnie proste. Dla odmiany LS potraktowane jako forma dedukcji naturalnej zdradza następujące podobieństwa do standardowego DN:

- sekwenty jako reprezentacje schematów reguł inferencji;

- dowód sekwentu jako ciąg formuł wiodący od jego poprzedników do następnika.

Jednak w gruncie rzeczy jest to system innego rodzaju, gdyż:

- brak w nim poddowodów;

- brak reguł zamykania dodatkowych założeń.

Suszko przedstawił syntaktyczny dowód adekwatności swego systemu. Jeżeli chodzi o S1, to w jedną stronę wystarczy odnotować, że reguły inferencji wyrażone przez sekwenty 1.1.1.-1.1.7. są dowiedlne w systemie aksjomatycznym Łukasiewicza dla KRZ w języku implikacyjno-negacyjnym. W drugą stronę, Suszko zaprezentował detaliczny opis jak dowieść w swoim systemie następujące trzy absolutne sekwenty:

$$
\begin{aligned}
& 1 . \quad s \Rightarrow(p \rightarrow q) \rightarrow((q \rightarrow r) \rightarrow(p \rightarrow r)) \\
& 2 . \quad s \Rightarrow p \rightarrow(\neg p \rightarrow q) \\
& 3 . \quad s \Rightarrow(\neg p \rightarrow p) \rightarrow p
\end{aligned}
$$

które są odpowiednikami 3 aksjomatów Łukasiewicza; reguła Modus Ponens jest już obecna jako sekwent 1.1.5. W [136] adekwatność całego systemu LS jest dowiedziona przez demonstrację równoważności z aksjomatycznym systemem LF, który jest formalizacją Hilberta i Ackermanna dla logiki pierwszego rzędu z deskrypcjami określonymi. Suszko dowodzi:

Twierdzenie 10.1 $\vdash_{L F} \varphi$ wtw $\vdash_{L S} \psi \Rightarrow \varphi$, dla dowolnego absolutnego sekwentu $\psi \Rightarrow \varphi$. 
Dowód tego twierdzenia pomijamy. Pod koniec [136] Suszko poczynił też uwagi odnośnie formalizacji pewnych zdaniowych logik nieklasycznych.

1. System składający się jedynie z sekwentów 1.1.1. - 1.1.5. daje formalizację PRZ (Pozytywnego Rachunku Zdań).

2. Dodanie:

$$
(\varphi \rightarrow \psi) \rightarrow \varphi \Rightarrow \varphi
$$

do LS-PRZ daje implikacyjny KRZ.

3. Zastąpienie 1.1.7. w zdaniowej części (1.1.1.-1.4.3.) przez dowolne z poniższych:

$$
\begin{aligned}
\neg \varphi \rightarrow \neg \psi & \Rightarrow \quad(\varphi \rightarrow \neg \psi) \rightarrow \neg \psi \\
\varphi \rightarrow \psi & \Rightarrow \quad(\varphi \rightarrow \neg \psi) \rightarrow \neg \varphi
\end{aligned}
$$

daje formalizację INT.

4. Na koniec, jeżeli w LS-INT zastąpimy także 1.1.6. przez:

$$
(\varphi \rightarrow \neg \psi) \rightarrow \chi \Rightarrow \neg \varphi \rightarrow \chi
$$

to otrzymamy formalizację MRZ (Minimalny Rachunek Zdań) Kolmogorova, Johanssona.

Suszko nie był całkiem zadowolony z LS ponieważ projekt totalnej eliminacji aksjomatów na rzecz właściwych reguł inferencji nie został w pełni zrealizowany. Sekwent 3.1. jest absolutnym sekwentem wyrażającym kryptoaksjomatyczną regułę. Toteż choć dla LS zachodzi twierdzenie, że jeżeli zdanie jest dedukowalne $\mathrm{z}$ dowolnego zdania, to jest analityczne (tzn. jest tezą), to konwers nie zachodzi, przynajmniej jeżeli uwzględnimy identyczność. Ale Suszko się mylił, gdyż identyczność też można scharakteryzować z pomocą reguł właściwych; można np. użyć sekwentów odpowiadających regułom dla identyczności, które zastosowali w swoim systemie DN Kalish/Montague [78]:

$$
\begin{aligned}
\forall x(x=\tau \rightarrow \varphi(x)) & \Rightarrow \varphi(\tau) \\
\varphi(\tau) & \Rightarrow \forall x(x=\tau \rightarrow \varphi(x))
\end{aligned}
$$

Te sekwenty wyrażają reguły właściwe w sensie Suszki i wystarczają dla adekwatnej charakterystyki logiki pierwszego rzędu z identycznością. Zatem dla LS z powyższymi regułami zamiast 3.1. i 3.2. również zachodzi prawidłowość, że jeżeli zdanie jest analityczne, to jest dedukowalne z dowolnego zdania. 


\subsection{Typ mieszany}

Pośredniego rozwiązania dostarczają takie systemy RS, w których logiczne stałe są częściowo charakteryzowane przez sekwenty pierwotne, a częściowo przez reguły sekwentowe. Jest tu możliwa duża ilość kombinacji, które dadzą adekwatną charakterystykę logiki klasycznej. Rozważania na ten temat można znaleźć np. u Bernaysa [13], Poppera [110] i wielu innych autorów. Poniżej zilustrujemy ten typ RS za pomocą kilku przykładów.

Faktycznie pierwsze rozwiązanie tego typu pojawia się już u Gentzena w [50], gdzie zauważa, że wiele reguł sekwentowych LK można zastąpić bazowymi sekwentami:

$\bullet \varphi, \neg \varphi$

- $\neg \varphi, \varphi \Rightarrow$

- $\varphi \wedge \psi \Rightarrow \varphi$

- $\varphi \wedge \psi \Rightarrow \psi$

- $\varphi, \psi \Rightarrow \varphi \wedge \psi$

- $\varphi \Rightarrow \varphi \vee \psi$

- $\psi \Rightarrow \varphi \vee \psi$

- $\varphi \vee \psi \Rightarrow \varphi, \psi$

- $\varphi \rightarrow \psi, \varphi \Rightarrow \psi$

- $\forall x \varphi \Rightarrow \varphi[x / a]$

- $\varphi[x / a] \Rightarrow \exists x \varphi$

Jak widać daje to podstawę do całkowitej eliminacji reguł dla $\neg, \wedge, \vee$; pozostają jedynie trzy logiczne reguły sekwentowe: $(\Rightarrow \rightarrow),(\Rightarrow \forall)$ i $(\exists \Rightarrow)$. Reguły strukturalne i sekwent aksjomatyczny pozostają bez zmian.

Niech LK* oznacza LK, w którym wymieniono wszystkie reguły logiczne, oprócz trzech wyżej wspomnianych, na podane sekwenty, zachodzi: 
Twierdzenie $10.2 \vdash_{L K} \Gamma \Rightarrow \Delta w t w \vdash_{L K^{*}} \Gamma \Rightarrow \Delta$.

DowóD:

$\Longleftarrow$ Wystarczy w LK dowieść podane sekwenty. Dowód dla wszystkich oprócz dwóch pierwszych i dwóch ostatnich mamy z faktu $4.1 \mathrm{w}$ rozdziale 4; dla pozostałych dowód oczywisty.

$\Longrightarrow$ Trzeba pokazać, że wykluczone reguły są dowiedlne w LK*. Wystarczy w tym celu odwołać się do lematu $4.13 \mathrm{z}$ podrozdziału 4.4 .

Oczywiście (Cut) nie jest eliminowalne w LK* gdyż MP występuje tu w wersji inferencyjnej (sekwent), a nie jako reguła sekwentowa jak w sekwentowym DN Gentzena (por. 10.1.).

\subsubsection{Kleene i sekwentowe DN}

W znanym podręczniku [83] (również [84]) Kleene wprowadza wprawdzie system aksjomatyczny jako podstawowy, ale szybko na jego bazie udowadnia szereg wtórnych reguł dołączania i eliminacji, które faktycznie tworzą adekwatną formalizację KRK. W przeciwieństwie do Gentzena, Kleene używa z-sekwentów z jednym następnikiem, w rezultacie $\wedge \mathrm{i} \rightarrow$ charakteryzuje tak samo jak w LK* ${ }^{*}$, za pomocą odpowiednio, trzech sekwentów dla $\wedge$ oraz sekwentu wyrażajaccego inferencyjny MP oraz reguły wyrażajaccej TD. Dla wprowadzania alternatywy używa też dwóch sekwentów, ale eliminacji nie może wyrazić przez sekwent $\varphi \vee \psi \Rightarrow \psi, \chi$, więc używa reguły $(\vee \Rightarrow) \mathrm{w}$ wersji k-jednolitej (oczywiście z następnikiem jednoelementowym). Dla negacji stosuje dwa sekwenty: $\varphi, \neg \varphi \Rightarrow \psi, \neg \neg \varphi \Rightarrow \varphi$, oraz regułę sekwentową $\Gamma, \varphi \Rightarrow \psi ; \Gamma, \varphi \Rightarrow \neg \psi / \Gamma \Rightarrow \neg \varphi$. Dla kwantyfikatorów używa dwóch sekwentów i dwóch reguł (oczywiście na sekwentach intuicjonistycznych) jak w $\mathrm{LK}^{*}$ Gentzena.

Łatwo dowieść, w oparciu o lemat 4.13., że zestaw reguł Kleene'go jest adekwatny względem KRK, ale pod warunkiem, że dołączymy jeszcze sekwenty aksjomatyczne $\varphi \Rightarrow \varphi$ oraz osłabianie dla poprzednika i (Cut) jako reguły pierwotne. Permutacja i kontrakcja jest zbędna, gdyż używamy zsekwentów; (Cut) jest nieeliminowalne gdyż, podobnie jak w LK*, używamy inferencyjnej formy MP (sekwent, a nie reguła).

System, który można oprzeć na zestawie reguł Kleene'go jest bardzo bliski standardowemu systemowi DN zaprezentowanemu w podrozdziałach 1.6 i 8.6. Różnica dotyczy tego, że w standardowym DN z pomocą reguł inferencyjnych przetwarzamy formuły natomiast u Kleene'go przetwarzamy bezpośrednio sekwenty reprezentujące reguły inferencji. Jest to więc wersja 
sekwentowego DN, ale różniąca się od sekwentowego DN Gentzena i jego wariantów opisanych w podrozdziale 10.1 tym, że stałe logiczne są charakteryzowane zarówno sekwentami jak i regułami sekwentowymi, a nie wyłącznie regułami. Korespondencja między systemem Kleene'go a standardowym DN jest taka, że regułom inferencji z DN odpowiadają sekwenty a regułom konstrukcji dowodu - reguły sekwentowe. Ta korespondencja jest pełna, jeżeli chodzi o charakterystykę $\wedge, \vee \mathrm{i} \rightarrow$ (pomijając fakt, że u Kleene'go $(\vee \Rightarrow)$ jest k-jednolita, a w DN ( $\vee E)$ jest k-niezależna). Jeżeli chcemy uzyskać system w stylu Kleene'go, w którym mamy dokładne odpowiedniki reguł DN, to musimy dokonać następujących zmian:

1. W przypadku negacji użyć sekwentów: $\varphi, \neg \varphi \Rightarrow \perp$ oraz $\perp \Rightarrow \varphi$ zamiast $\varphi, \neg \varphi \Rightarrow \psi$, pozostawiając $\neg \neg \varphi \Rightarrow \varphi$, aby utrzymać logikę klasyczną. Zamiast reguły Kleene'go użyć reguły $\Gamma, \varphi \Rightarrow \perp / \Gamma \Rightarrow \neg \varphi$. Zmiany te wynikają stąd, że Kleene nie używa $\perp$. Można też użyć reguły sekwentowej odpowiadającej regule $(\neg E)$, co czyni sekwent $\neg \neg \varphi \Rightarrow \varphi$ zbędnym (por. 1.6).

2. W przypadku kwantyfikatorów zamiast $(\exists \Rightarrow)$ należy użyć odpowiednika $(\exists E)$ o postaci $\Gamma \Rightarrow \exists x \varphi ; \Delta, \varphi[x / a] \Rightarrow \psi / \Gamma, \Delta \Rightarrow \psi$ z warunkiem ograniczającym, że $a$ jest parametrem nie występującym $\mathrm{w} \varphi, \psi$ i zbiorach $\Gamma, \Delta$. Co do $(\forall D)$ to w DN jest to wprawdzie reguła inferencji, ale obciążona globalnym warunkiem dotyczącym aktywnych założeń, więc trzeba ją wyrazić z pomocą reguły $(\Rightarrow \forall)$. Regułom $(\forall E)$ i $(\exists D)$ odpowiadają sekwenty z $\mathrm{LK}^{*}$.

\subsubsection{System Hasenjaegera}

Hasenjaeger [61] zawiera RS zdefiniowany na intuicjonistycznych (ale bez dopuszczania sekwentów z pustym następnikiem) c-sekwentach dla KRZ ${ }^{5}$, w którym oprócz reguł strukturalnych (na poprzednikach) i (Cut) mamy tylko dwie reguły dla $\rightarrow$, konkretnie: $(\Rightarrow \rightarrow$ ) i jej konwers zamiast $(\rightarrow \Rightarrow)$; jak wiemy (por. paragraf 10.1.7. o wariancie strukturalnym Došena) daje to adekwatną charakterystykę (intuicjonistycznej) implikacji, która wzmocniona przez klasyczną negację daje implikację klasyczną.

Pozostałe spójniki są scharakteryzowane przez sekwenty pierwotne; $\wedge$ jak w LK*, podobnie dla $\vee \mathrm{w}$ następniku. Sekwent charakteryzujący $\vee \mathrm{w}$ poprzedniku musi być inny z tej racji, że w następniku nie dopuszczamy więcej niż jedną formułę; mamy więc:

\footnotetext{
${ }^{5}$ Dla KRK przedstawia inny system, którego reguły operują na formułach, a nie sekwentach.
} 


$$
\varphi \rightarrow \chi, \psi \rightarrow \chi, \varphi \vee \psi \Rightarrow \chi
$$

Dla negacji jest również inna charakterystyka:

- $\varphi, \neg \varphi \Rightarrow \psi$

$$
\text { - } \varphi \rightarrow \psi, \neg \varphi \rightarrow \psi \Rightarrow \psi
$$

Pierwszy sekwent jest taki sam jak w LK* Gentzena, z tym, że $\psi$ jest dodane do następnika, gdyż nie może być on pusty. Drugi sekwent zastępuje $\Rightarrow \varphi, \neg \varphi$ z powodu niedopuszczalności większej ilości formuł w następniku.

W systemie tym mamy jeszcze większą redukcję reguł sekwentowych na rzecz sekwentów pierwotnych, niż w przypadku systemów opisanych w poprzednim paragrafie, które dość ściśle odpowiadały standardowym systemom DN w oparciu o korespondencję: reguła inferencji $\longrightarrow$ sekwent bazowy, reguła konstrukcji dowodu $\longrightarrow$ reguła sekwentowa. W istocie rzeczy można w systemie Hasenjaegera zostawić tylko jedną regułę odpowiadającą TD, a zamiast jej konwersu użyć inferencyjnej wersji MP (czyli też sekwentu) por. podrozdział 4.4. Takie rozwiązanie pojawia się np. u Surmy [134], choć dobór sekwentów aksjomatycznych jest nieco inny.

Aby wykazać adekwatność systemu Hasenjaegera dla KRZ wystarczy wykazać jego równoważność z systemem LK*. W tym ostatnim łatwo można dowieść obu sekwentów dla $\neg \mathrm{i} \vee$, które zastępują sekwenty Gentzena z dwiema formułami w następniku. To daje formalizację wystarczającą dla INT (z racji strukturalnego ograniczenia na sekwentach dla INT przy identyczności reguł). Następnie wystarczy dowieść prawa wyłączonego środka, aby pokazać, że system Hasenjaegera, mimo ograniczenia na sekwentach, daje formalizację KRZ. Oto dowód:

$$
(\Rightarrow \rightarrow) \frac{\frac{\neg \varphi \Rightarrow \varphi \vee \neg \varphi}{\Rightarrow \neg \varphi \rightarrow \varphi \vee \neg \varphi}}{\Rightarrow} \quad(\Rightarrow \rightarrow) \frac{\frac{\varphi \Rightarrow \varphi \vee \neg \varphi}{\Rightarrow \varphi \rightarrow \varphi \vee \neg \varphi} \quad \varphi \rightarrow \varphi \vee \neg \varphi, \neg \varphi \rightarrow \varphi \vee \neg \varphi \Rightarrow \varphi \vee \neg \varphi}{\text { (Cut) }}
$$

\subsubsection{System Riegera}

Oryginalny system sekwentowy zdefiniowany na sekwentach typu 1-1 (jedna formuła zarówno w poprzedniku jak i w następniku) zawiera praca Riegera [119]. Zestaw sekwentów pierwotnych składa się z następujących: 
- $\varphi \Rightarrow \varphi$

- $\varphi \Rightarrow \varphi \vee \psi$

- $\varphi \Rightarrow \psi \vee \varphi$

- $\varphi \wedge \psi \Rightarrow \varphi$

- $\psi \wedge \varphi \Rightarrow \varphi$

- $\varphi \wedge(\psi \vee \chi) \Rightarrow \varphi \wedge \psi \vee \varphi \wedge \chi$

- $(\varphi \vee \psi) \wedge(\varphi \vee \chi) \Rightarrow \varphi \vee \psi \wedge \chi$

- $\neg \varphi \wedge \varphi \Rightarrow \psi$

- $\psi \Rightarrow \varphi \vee \neg \varphi$

- $\neg \varphi \vee \psi \Rightarrow \varphi \rightarrow \psi$

- $\varphi \rightarrow \psi \Rightarrow \neg \varphi \vee \psi$

- $\forall x \varphi \Rightarrow \varphi[x / a]$

- $\varphi[x / a] \Rightarrow \exists x \varphi$

Dodatkowo mamy następujące reguły pierwotne:

$(T R) \frac{\varphi \Rightarrow \psi \quad \psi \Rightarrow \chi}{\varphi \Rightarrow \chi}$

$$
\begin{array}{cr}
(\Rightarrow \wedge) \frac{\chi \Rightarrow \varphi \quad \chi \Rightarrow \psi}{\chi \Rightarrow \varphi \wedge \psi} & (\vee \Rightarrow) \frac{\varphi \Rightarrow \chi \psi \Rightarrow \chi}{\varphi \vee \psi \Rightarrow \chi} \\
(\Rightarrow \forall)^{1} \frac{\psi \Rightarrow \varphi}{\psi \Rightarrow \forall x \varphi} & (\exists \Rightarrow)^{1} \frac{\varphi \Rightarrow \psi}{\exists x \varphi \Rightarrow \psi}
\end{array}
$$

Ograniczenia:

1. pod warunkiem, że $x$ nie jest wolne w $\psi$.

Dowód definiuje Rieger jako ciąg sekwentów. Podobnie jak w przypadku systemu Suszki nie jest tutaj możliwa dedukcja sekwentu z pustym poprzednikiem. Ponieważ Rieger jest zainteresowany dowodami tez w zaksjomatyzowanych teoriach elementarnych przyjmuje, że tezą teorii $\mathrm{T}$ jest zdanie $\varphi$ wtw dowód ma sekwent $A \Rightarrow \varphi$, gdzie $A$ jest koniunkcją (podstawień) aksjomatów teorii T. W przeciwieństwie do systemu Suszki, Rieger udowadnia dla swojego systemu twierdzenie o dedukcji postaci: $\varphi \Rightarrow \psi$ wtw $\chi \Rightarrow \varphi \rightarrow \psi$, gdzie $\chi$ jest dowolnym zdaniem. 
Wybór takiej formy sekwentów przez Riegera w pewien sposób komplikuje zarówno dowody, jak i sposób ujęcia pewnych własności stałych logicznych w regułach. Przykładowo, Rieger potrzebuje osobnych sekwentów wyrażających prawa dystrybucji (konwersy są dowiedlne) dla uzyskania pełności. Inną konsekwencją użycia sekwentów typu 1-1 jest to, że niektóre sekwenty aksjomatyczne nie są separowalne (por. podrozdział 4.5). Jednak wybór takiego typu sekwentów nie jest przypadkowy, a wynika stąd, że praca Riegera dotyczy algebraicznych aspektów KRK i zarówno sekwenty, jak i reguły tego typu lepiej wyrażają algebraiczne własności logiki ${ }^{6}$. Rieger wprowadza zresztą sekwenty postaci $\varphi \Leftrightarrow \psi$, które bezpośrednio odpowiadają równościom w odpowiednich strukturach algebraicznych.

\subsection{RS a inne systemy dedukcyjne}

Wielokrotnie w tej pracy wspominaliśmy o związkach RS z DN, a użycie RS jako punktu odniesienia pozwoliło nam na podzielenie systemów DN na cztery klasy. Pierwszym kryterium jest charakter obiektów, które występują jako wiersze dowodu (węzły drzewa dowodowego). Są to formuły lub sekwenty $^{7}$. W zależności od tego możemy wyróżnić standardowe systemy DN (podrozdział 1.6 i 8.6) i sekwentowe systemy DN (podrozdział 10.1 i 10.3). W ramach pierwszej grupy istotnym kryterium dalszego podziału jest format dowodu: linearny (Jaśkowskiego), który zmusza do zastosowania dodatkowych środków wydzielania poddowodów, i drzewny (Gentzena), który tego nie wymaga. W ramach drugiej grupy stosowanie dowodów linearnych, czy $\mathrm{w}$ postaci drzew ma znaczenie tylko praktyczne, toteż istotnym kryterium podziału jest to czy dany sekwentowy system DN należy do typu pierwszego czy trzeciego w typologii systemów $\mathrm{RS}^{8}$.

Potraktowanie RS jako ogólnej ramy teoretycznej pozwala na wydefiniowanie również innych klas systemów dedukcyjnych. Dla ilustracji naszkicujemy związek RS z systemami tablicowymi, rezolucji i koneksji.

Zauważmy, że podane w podrozdziale 2.3 interpretacje sekwentów prowadzą do dwóch możliwych uproszczeń RS traktowanych jako praktyczne metody szukania dowodu; możemy:

${ }^{6}$ Podobnie w Dunn i Hardegree [36], gdzie rozważa się takie sekwentowe formalizacje dla logik równoważnościowych.

7 Można oczywiście wyróżnić jeszcze systemy, w których reguły operują na innego typu obiektach, np. formułach etykietowanych. Obszerne omówienie takich systemów w Indrzejczak [74].

8 System Suszki lub jemu podobne, należący do typu drugiego, z trudnością można uznać za system DN, jak zauważyliśmy w podrozdziale 10.2. 
- zastąpić sekwenty zbiorami formul;

- odwrócić kierunek dowodzenia (sprawdzania), budując odwrócone drzewa z korzeniem u góry.

Po takiej przeróbce interpretacja druga (w terminach falsyfikowalności) prowadzi do konstrukcji systemu tablicowego Hintikki [66], natomiast interpretacja trzecia (w terminach weryfikowalności) do konstrukcji systemu Rasiowej/Sikorskiego [117]. Konkretnie:

Każdej regule RS dla $\wedge, \vee, \rightarrow$ odpowiada reguła Hintikki według wzorca:

$$
\begin{array}{ll}
\frac{\Gamma \Rightarrow \Delta}{\Gamma^{\prime} \Rightarrow \Delta^{\prime}} \quad \Longleftrightarrow \quad & \frac{\Gamma^{\prime}, \neg \Delta^{\prime}}{\Gamma, \neg \Delta} \\
\frac{\Gamma \Rightarrow \Delta \quad \Gamma^{\prime} \Rightarrow \Delta^{\prime}}{\Gamma^{\prime \prime} \Rightarrow \Delta^{\prime \prime}} & \Longleftrightarrow \quad \frac{\Gamma^{\prime \prime}, \neg \Delta^{\prime \prime}}{\Gamma, \neg \Delta \mid \Gamma^{\prime}, \neg \Delta^{\prime}}
\end{array}
$$

W systemie Rasiowej/Sikorskiego mamy odpowiedniki dualne. Oprócz tego w obu systemach mamy regułę eliminacji podwójnej negacji: $\Gamma, \neg \neg \varphi / \Gamma, \varphi$

Reguły dla kwantyfikatorów otrzymujemy w oparciu o odpowiednie reguły dla ARS:

$\frac{\Gamma, \forall x \varphi}{\Gamma, \forall x \varphi, \varphi[x / a]} \quad \frac{\Gamma, \neg \forall x \varphi^{1}}{\Gamma, \neg \varphi[x / a]} \quad{\frac{\Gamma, \exists x \varphi^{1}}{\Gamma, \varphi[x / a]}}^{1} \quad \frac{\Gamma, \neg \exists x \varphi}{\Gamma, \neg \exists x \varphi, \neg \varphi[x / a]}$

1. gdzie $a$ jest zmienną wolną nie występującą $\mathrm{w} \Gamma \mathrm{i} \varphi$.

Ponownie, w systemie Rasiowej/Sikorskiego mamy odpowiedniki dualne.

Dowiedlność $\Gamma \vdash \varphi$ w systemie tablicowym sprowadza się do istnienia (odwróconego) drzewa, którego każdy liść to zbiór formuł zawierający parę wyrażeń sprzecznych a korzeń to zbiór $\Gamma, \neg \varphi$ (w systemie Hintikki) lub $\neg \Gamma, \varphi$ (w systemie Rasiowej/Sikorskiego).

Dalsza ewolucja systemów tablicowych prowadziła do kolejnych praktycznych uproszczeń mających na celu wyeliminowanie kłopotliwego przepisywania formuł parametrycznych. W rezultacie powstały systemy, w których reguły nie przetwarzają zbiorów, ale pojedyncze formuły. W szczególności, można tu wyróżnić:

- diagramy Betha [14], czyli dwukolumnowe tablice, w których jedna kolumna odpowiada formułom prawdziwym a druga fałszywym;

- systemy Lisa [93], Smullyana [131], w których formuły występują z prefiksami oznaczającymi ich status. 
Łatwo odnotować związek obu rozwiązań z postaciami normalnymi dla KRZ:

- system Hintikki odpowiada sprowadzeniu $\neg \varphi$ do postaci alternatywnokoniunkcyjnej, w tym sensie, że w uzyskanym drzewie atomowym każdy liść odpowiada koniunkcji literałów;

- system Rasiowej/Sikorskiego odpowiada metodzie Posta (sprowadzeniu $\varphi$ do jej koniunkcyjno-alternatywnej postaci) gdyż każdy liść odpowiada klauzuli.

Możliwe są oczywiście jeszcze dwa inne sposoby:

- sprowadzenie $\neg \varphi$ do jej koniunkcyjno-alternatywnej postaci;

- sprowadzenie $\varphi$ do jej alternatywno-koniunkcyjnej postaci.

Pierwsze rozwiązanie odpowiada najpopularniejszej w automatycznym dowodzeniu twierdzeń metodzie rezolucji wprowadzonej przez Robinsona [120]. Sama reguła rezolucji jest zresztą szczególną postacią (Cut), w której z dwóch klauzul zawierających sprzeczne literały dedukujemy klauzulę bez tych literałów. Drugie rozwiązanie prowadzi do konstrukcji metody koneksji wprowadzonej przez Bibela [15].

Powyższe uwagi ujmują kwestię związków między RS a innymi typami systemów dedukcyjnych w bardzo upraszczający sposób, który właściwie da się utrzymać w takiej postaci jedynie na gruncie rozważań nad formalizacjami KRZ. Rozwój badań nad każdym ze wspomnianych rodzajów systemów dedukcyjnych doprowadził do powstania wielu form systemów, dla których trudno wskazać tak proste reguły transformacji z RS jak wyżej podane ${ }^{9}$; można też relacje między tymi klasami systemów ujmować w inny sposób (por. np. Avron [7]). Wydaje się jednak, że z rozmaitych względów, systemy RS zajmują pozycję centralną w niezwykle bogatym spektrum systemów dedukcyjnych.

\footnotetext{
9 Jeżeli chodzi o systemy tablicowe w sensie Hintikki, to dobry przegląd rozmaitych rozwiązań zawiera [59]; dla systemów Rasiowej/Sikorskiego podobną rolę pełnić może Orłowska i Golińska-Pilarek [105].
} 


\section{Rozdział 11}

\section{Dodatek}

W dodatku zebrane są podstawowe fakty z zakresu teorii mnogości oraz dowodów indukcyjnych, które wykorzystywane są w tej pracy. Czytelnik może zaglądać tu w razie potrzeby, np. w przypadku wątpliwości notacyjnych.

\subsection{Zbiory, relacje, funkcje}

Przypomnijmy, że dowolny zbiór można scharakteryzować przez wyliczenie jego elementów, np. $\{a, b, c, d\}$ lub za pomocą operatora abstrakcji:

$\{x: \varphi(x)\}$ - zbiór tych $x$, które spełniają warunek $\varphi$

Ten ostatni sposób charakteryzacji jest bardzo przydatny przy definiowaniu konkretnych zbiorów, np. powstałych przy pomocy zastosowania odpowiednich operacji - oto lista używanych w książce:

Zbiór pusty: $\varnothing=\{x: x \neq x\}$

Iloczyn (przekrój) dwóch zbiorów: $A \cap B=\{x: x \in A \wedge x \in B\}$

Suma dwóch zbiorów: $A \cup B=\{x: x \in A \vee x \in B\}$

Różnica dwóch zbiorów: $A-B=\{x: x \in A \wedge x \notin B\}$

Zbiór potęgowy: $\mathcal{P}(A)=\{B: B \subseteq A\}$

W ostatnim przypadku w definiensie użyty jest predykat inkluzji $\subseteq$ dopuszczający identyczność obu zbiorów. Dla inkluzji ostrej (wykluczającej identyczność) używamy symbolu $\subset$.

Pojęcie iloczynu i sumy można uogólnić na dowolną (również nieskończoną) ilość zbiorów. Wygodnie jest wtedy operować pojęciem rodziny (zbioru) zbiorów, których przekrój lub sumę budujemy. Niech $\mathcal{A}$ oznacza taką niepustą rodzinę wtedy: 
Iloczyn rodziny zbiorów: $\bigcap \mathcal{A}=\{x: \forall A(A \in \mathcal{A} \rightarrow x \in A)\}=\{x: \forall A \in$ $\mathcal{A}, x \in A\}$.

Suma rodziny zbiorów: $\bigcup \mathcal{A}=\{x: \exists A(A \in \mathcal{A} \wedge x \in A\}=\{x: \exists A \in$ $\mathcal{A}, x \in A\}$.

W terminach zbioru można sukcesywnie zdefiniować następujące pojęcia:

para uporządkowana: $\langle a, b\rangle:=\{\{a\},\{a, b\}\}$;

trójka uporządkowana: $\langle a, b, c\rangle:=\langle\langle a, b\rangle, c\rangle$;

ogólnie - $n$-ka uporządkowana (lub ciąg): $\left\langle a_{1}, \ldots, a_{n}\right\rangle:=\left\langle\left\langle a_{1}, \ldots, a_{n-1}\right\rangle, a_{n}\right\rangle$;

W przypadku zbiorów zarówno kolejność elementów jak i ilość ich powtórzeń nie odgrywa roli, tzn: $\{a, b, c\}=\{b, c, a\}=\{a, b, c, a, c, c\}$, gdzie $a, b$ i $c$ to dowolne różne od siebie obiekty.

Ale w przypadku ciągów zarówno ilość jak i kolejność są ważne, tzn.: $\langle a, b\rangle \neq\langle b, a\rangle \neq\langle a, a, b\rangle$.

Pośredniego typu strukturą są multizbiory czyli zbiory z powtórzeniami oznaczane zazwyczaj za pomocą [,]. Nie rozróżniają one kolejności, ale rozróżniają ilość powtórzeń danego elementu. Znaczy to, że:

$$
[a, b, c] \neq[a, b, a, c] \text { ale }[a, b, b, c]=[b, c, a, b] .
$$

Formalnie multizbiory można potraktować jako pary $\left\langle A, f_{A}\right\rangle$, gdzie $A$ jest zbiorem, a $f_{A}$ funkcją, która każdemu elementowi $A$ przypisuje liczbę naturalną (ilość wystąpień). Wtedy operacje iloczynu i sumy można zdefiniować na multizbiorach następująco:

$$
\begin{aligned}
& A \sqcap B:=\left\langle A \cap B, f_{A, B}\right\rangle, \text { gdzie } f_{A, B}(x)=\min \left(f_{A}(x), f_{B}(x)\right) . \\
& A \sqcup B:=\left\langle A \cup B, f_{A, B}\right\rangle, \text { gdzie } f_{A, B}(x)=\max \left(f_{A}(x), f_{B}(x)\right) .
\end{aligned}
$$

Operowanie $n$-kami uporządkowanymi pozwala wprowadzić pojęcia relacji i funkcji w oparciu o operację iloczynu kartezjańskiego, w szczególności:

iloczyn kartezjański 2-giego stopnia: $A \times B=\{\langle x, y\rangle: x \in A \wedge y \in B\}$;

lloczyn kartezjański $n$-tego stopnia: $A_{1} \times \ldots \times A_{n}=\left\{\left\langle x_{1}, \ldots, x_{n}\right\rangle: x_{1} \in\right.$ $\left.A_{1} \wedge \ldots \wedge x_{n} \in A_{n}\right\}$.

Jeżeli $A_{1}=\ldots=A_{n}$, to piszemy zwykle $A^{n}$, w szczególności $A^{2}$ zamiast $A \times A$.

$R$ jest relacją 2-argumentową (binarną) na zbiorach $A, B$ wtw $R \subseteq A \times B$. $R$ jest relacją $n$-argumentową na zbiorach $A_{1}, \ldots, A_{n}$ wtw $R \subseteq A_{1} \times \ldots \times A_{n}$. 
Jeżeli $R \subseteq A \times B$, to:

- dziedzina $R: D_{l}(R)=\{x \in A: \exists y \in B,\langle x, y\rangle \in R\}$,

- przeciwdziedzina $R: D_{r}(R)=\{x \in B: \exists y \in A,\langle y, x\rangle \in R\}$.

Zamiast pisać $\langle x, y\rangle \in R$ zazwyczaj będziemy pisać $R(x y)$ lub $R x y$.

Niech $R \subseteq A^{2}$ a $x, y, z$ oznaczają dowolne elementy $A$, poniższa tabela podaje kilka ważnych własności relacji:

\begin{tabular}{|l|l|}
\hline nazwa & warunek \\
\hline serialność & $\forall x \exists y R x y$ \\
funkcyjność & $\forall x y z(R x y \wedge R x z \rightarrow y=z)$ \\
zwrotność & $\forall x R x x$ \\
przeciwzwrotność & $\forall x \neg R x x$ \\
przechodniość & $\forall x y z(R x y \wedge R y z \rightarrow R x z)$ \\
symetria & $\forall x y(R x y \rightarrow R y x)$ \\
asymetria mocna & $\forall x y(R x y \rightarrow \neg R y x)$ \\
asymetria słaba & $\forall x y(R x y \wedge x \neq y \rightarrow \neg R y x)$ \\
euklidesowość & $\forall x y z(R x y \wedge R x z \rightarrow R y z)$ \\
spójność & $\forall x y(R x y \vee R y x)$ \\
spójność słaba & $\forall x y(R x y \vee R y x \vee x=y)$ \\
\hline
\end{tabular}

Dwuargumentowa relacja $R \subseteq A^{2}$ jest równoważnością wtw spełnia warunki zwrotności, symetrii i przechodniości. Niech $R$ będzie równoważnością na $A$ wtedy:

1. $[x]_{R}=\{y: R x y\}$ jest klasą abstrakcji $x$-a względem $R$;

2. $A_{/ R}=\left\{[x]_{R}: x \in A\right\}$ jest strukturą ilorazową (zbiorem wszystkich klas abstrakcji).

Dla relacji równoważnościowych zachodzi tzw. Zasada Abstrakcji: Jeżeli $R$ jest relacją równoważności na $A$, to $A_{/ R}$ jest podziałem logicznym $A$, tzn. spełnia warunki:

- adekwatności: $A=\bigcup A_{/ R}$;

- rozłączności: $\forall x, y \in A\left([x]_{R} \neq[y]_{R} \rightarrow[x]_{R} \cap[y]_{R}=\varnothing\right)$;

- niepustości: $\forall x \in A,[x]_{R} \neq \varnothing$. 
A oto wybrane rodzaje relacji porządkujących:

- $R$ jest quasi-porządkiem wtw jest zwrotna i przechodnia;

- $R$ jest częściowym porządkiem wtw jest quasi-porządkiem słabo asymetrycznym;

- $R$ jest liniowym porządkiem wtw jest częściowym porządkiem mocno spójnym;

- $R$ jest ścisłym częściowym porządkiem wtw jest przechodnia i mocno asymetryczna;

- $R$ jest ścisłym liniowym porządkiem wtw jest ścisłym częściowym porządkiem słabo spójnym.

Zarówno relacje jak i funkcje są zbiorami. Można więc na nich przeprowadzać zwykłe operacje określone wyżej dla dowolnych zbiorów. Oprócz nich wyróżnimy kilka ważnych operacji specyficznych dla relacji:

- tranzytywne domknięcie $R \subseteq A^{2}$ to najmniejsza przechodnia relacja $R^{+} \subseteq A^{2}$ taka, że $R \subseteq R^{+}$.

- tranzytywne zwrotne domknięcie $R \subseteq A^{2}$ to najmniejsza przechodnia i zwrotna relacja $R^{*} \subseteq A^{2}$ taka, że $R \subseteq R^{*}$.

- konwers relacji $R \subseteq A \times B: \breve{R} x y$ wtw $R y x(\breve{R} \subseteq B \times A)$

- złożenie (iloczyn względny, superpozycja) relacji $R \subseteq A \times B$ i $S \subseteq$ $B \times C$ :

$R \circ S x y$ wtw $\exists z \in B(R x z \wedge S z y)(R \circ S \subseteq A \times C)$

Pojęcie drzewa jest charakteryzowane na różne sposoby. W terminach operacji wprowadzonych wyżej można tę strukturę zdefiniować następująco:

$\mathcal{T}=\langle T, R\rangle,, R \subseteq T^{2}$ jest drzewem wtw:

1. istnieje jedyny element $r \in T$ zwany korzeniem drzewa taki, że $\forall t \in$ $T, R^{*} r t$

2. każdy $t \in T$ różny od $r$ ma dokładnie jednego poprzednika, tzn. istnieje dokładnie jeden $t^{\prime} \in T$ taki, że $R t^{\prime} t$;

3. $R$ jest acykliczna, tzn. $\forall t \in T$ nie zachodzi $R^{+} t t$. 
Elementy $T$ są zwane węzłami drzewa $\mathcal{T}$. Jeżeli $R t t^{\prime}$, to $t$ jest rodzicem, a $t^{\prime}$ dzieckiem; jeżeli $R^{+} t t^{\prime}$, to $t$ jest przodkiem a $t^{\prime}$ potomkiem. węzeł, który nie ma dzieci to liść. $N$-ka $\left\langle t_{1}, \ldots, t_{n}\right\rangle$ gdzie dla każdego $i<n R t_{i} t_{i+1}$ jest gałęzią. Ilość dzieci danego węzła to jego czynnik rozgałęziający a czynnik rozgałęiający drzewa to maksymalna wartość czynników rozgałęziających jego węzłów. W szczególności drzewa binarne mają czynnik rozgałęziający $=2$. Drzewa skończenie generowane to takie, których czynnik rozgałęziający jest pewną liczbą naturalną (tzn. każdy węzeł ma skończenie wiele dzieci). Dla drzew tego typu zachodzi ważne

Twierdzenie 11.1 (König) Każde skończenie generowane, ale nieskończone drzewo ma przynajmniej jedna nieskończona gałaź.

Przypomnijmy, że $n$-argumentowa funkcja (odwzorowanie, przyporządkowanie) o dziedzinie (zbiorze argumentów) $A^{n}$ i przeciwdziedzinie (zbiorze wartości) w $B$ (oznaczana $f: A^{n} \longrightarrow B$ ), to $n+1$-argumentowa relacja $f \subseteq A^{n} \times B$ spełniająca warunki:

1. $\forall_{x_{1}, \ldots, x_{n} \in A} \exists_{y \in B}\left\langle x_{1}, \ldots, x_{n}, y\right\rangle \in f$

2. $\forall_{x_{1}, \ldots, x_{n} \in A} \forall_{y, z \in B}\left(\left\langle x_{1}, \ldots, x_{n}, y\right\rangle \in f \wedge\left\langle x_{1}, \ldots, x_{n}, z\right\rangle \in f \rightarrow y=z\right.$

Jeżeli $B=A$, to $f$ jest $n$-argumentową operacją (działaniem) w $A$. Warunek 2 umożliwia wprowadzenie notacji funkcyjnej zamiast relacyjnej, tzn. zamiast pisać $\left\langle x_{1}, \ldots, x_{n}, y\right\rangle \in f$ piszemy $f\left(x_{1}, \ldots, x_{n}\right)=y$. W szczególności, jednoargumentowa funkcja (odwzorowanie, przyporządkowanie) o dziedzinie (zbiorze argumentów) $A$ i przeciwdziedzinie (zbiorze wartości) w $B$ (oznaczana $f: A \longrightarrow B$ ), to dwuargumentowa relacja $f \subseteq A \times B$ spełniająca warunki serialności i funkcyjności:

1. $\forall_{x \in A} \exists_{y \in B}\langle x, y\rangle \in f$

2. $\forall_{x \in A} \forall y, z \in B(\langle x, y\rangle \in f \wedge\langle x, z\rangle \in f \rightarrow y=z)$

Rodzaje funkcji:

Niech $f: A^{n} \longrightarrow B$, to $f$ jest:

- injekcją (f. różnowartościową, f. 1-1) wtw $\forall_{x_{1}, \ldots, x_{n}, y_{1}, \ldots, y_{n} \in A}\left(f\left(x_{1}, \ldots, x_{n}\right)=\right.$ $\left.f\left(y_{1}, \ldots, y_{n}\right) \rightarrow\left\langle x_{1}, \ldots, x_{n}\right\rangle=\left\langle y_{1}, \ldots, y_{n}\right\rangle\right)$

- $\operatorname{surjekcją~(f.~na)~wtw~} B$ jest przeciwdziedziną $f$ wtw $\forall_{y \in B} \exists_{x_{1}, \ldots, x_{n} \in A} y=$ $f\left(x_{1}, \ldots, x_{n}\right)$ 
- bijekcją wtw jest zarazem injekcją i surjekcją

Na koniec przypomnijmy, że dwa zbiory, dla których istnieje jednoargumentowa bijekcja (której jeden z nich jest dziedziną a drugi preciwdziedziną) są zbiorami równolicznymi. Zbiory skończone lub równoliczne ze zbiorem liczb naturalnych to zbiory przeliczalne. Moc (czyli liczność) zbioru nieskończonego, ale przeliczalnego jest oznaczana symbolem $\aleph_{0}$. Dla zbiorów tej mocy zachodzi:

Twierdzenie 11.2 (o enumeracji zbiorów przeliczalnych) Każdy zbiór przeliczalny daje się uporzadkować liniowo.

Fakt ten wykorzystywaliśmy wielokrotnie w dowodach twierdzeń o pełności, odwołując się do przeliczalności zbiorów formuł, termów itp.

\subsection{Indukcja matematyczna}

Czytelnik zapewne zetknął się już wielokrotnie z dowodami przez indukcję matematyczną, tym niemniej ze względu na wszechobecność tego typu dowodów w przypadku ważnych twierdzeń dotyczących własności rachunków sekwentowych, warto poświęcić im trochę więcej uwagi.

Rozumowania przez indukcję matematyczną były stosowane już w XVII w. przez Pascala i Fermata. Termin i definicja pochodzą od De Morgana. Jako aksjomat arytmetyki pojawia się u Fregego i Peano. Przypadek paradygmatyczny indukcji matematycznej to arytmetyka liczb naturalnych. Przytoczmy kilka różnych sformułowań zasady indukcji matematycznej w arytmetyce. Rozróżniamy zasadą indukcji słabej i mocnej. Niech $N$ oznacza zbiór liczb naturalnych, a $s x$ następnik liczby $x$, tzw. indukcja słaba jest wyrażana za pomocą następujących zasad:

$$
\begin{aligned}
& \varphi(0) \wedge \forall_{x \in N}(\varphi(x) \rightarrow \varphi(s x)) \rightarrow \forall_{x \in N} \varphi(x) \\
& \varphi(0) \wedge \forall_{x \in N}(\varphi(x) \rightarrow \varphi(x+1)) \rightarrow \forall_{x \in N} \varphi(x) \\
& 0 \in A \wedge \forall_{x \in N}(x \in A \rightarrow s x \in A) \rightarrow A=N
\end{aligned}
$$

Indukcja mocna podawana jest m.in. w takiej postaci:

$$
\begin{aligned}
& \varphi(0) \wedge \forall_{x \in N}\left(\forall_{y \in N}(0 \leq y<x \rightarrow \varphi(y)) \rightarrow \varphi(x)\right) \rightarrow \forall_{x \in N} \varphi(x) \\
& 0 \in A \wedge \forall_{x \in N}\left(\forall_{y \in N}(0 \leq y<x \rightarrow y \in A) \rightarrow x \in A\right) \rightarrow A=N \\
& \forall_{x \in N}\left(\forall_{y \in N}(0 \leq y<x \rightarrow \varphi(y)) \rightarrow \varphi(x)\right) \rightarrow \forall_{x \in N} \varphi(x) \\
& \forall_{x \in N}\left(\forall_{y \in N}(0 \leq y<x \rightarrow y \in A) \rightarrow x \in A\right) \rightarrow A=N
\end{aligned}
$$


Określenie mocna i słaba indukcja matematyczna jest mylące - obie zasady są równoważne (zamiast mocna czasem mówi się zupełna).

Dowody przez indukcję matematyczną opierają się na powyższych zasadach i zawierają dwie części:

a. baza indukcyjna - dowodzimy, że 0 spełnia dany warunek $\varphi$

b. krok indukcyjny (teza indukcyjna) - zakładamy, że liczba $x$ spełnia warunek $\varphi$ (założenie indukcyjne) i na podstawie tego założenie i ewentualnie bazy indukcyjnej dowodzimy, że $s x$ również spełnia $\varphi$.

a. i b. przez zasadę indukcji implikują, że dowolna liczba spełnia $\varphi$.

Przykład dowodu indukcyjnego w arytmetyce:

Dowodzimy, że: $\forall_{x \in N} \neg(s x=x)$ przez indukcję po $x$

a. baza: $\varphi(0):=\neg(s 0=0)$

1. $\forall x \in N \neg(s x=0)$ aksjomat

2. $\neg(s 0=0) \quad$ 1., $\forall O, x / 0$

b. teza: $\varphi(x) \rightarrow \varphi(s x):=\neg(s x=x) \rightarrow \neg(s s x=s x)$

1. $\neg(s x=x) \quad$ zał. ind.

2. $\quad \forall x, y \in N(s x=s y \rightarrow x=y) \quad$ aksjomat

3. $s s x=s x \rightarrow s x=x \quad 2 ., \forall O, x / s x, y / x$

4. $\neg(s s x=s x) \quad$ 1., 3. MT

Należy postawić sobie pytanie dlaczego indukcja matematyczna jest poprawnym sposobem wnioskowania. Najprostsza odpowiedź brzmi: bo zbiór liczb naturalnych jest zbiorem indukcyjnym (rekurencyjnym). Co więcej, zbiór liczb naturalnych nie jest jedynym takim zbiorem. Dlatego ogólniej powiedzmy, że dowody indukcyjne można stosować do dowolnych twierdzeń postaci:

$$
\forall_{x}(x \in A \rightarrow x \in B)\left(\operatorname{lub}_{x}(\varphi(x) \rightarrow \psi(x))\right)
$$

pod warunkiem, że $A$ jest zbiorem indukcyjnym ( $\varphi$ jest własnością zdefiniowaną rekurencyjnie).

Zbiory indukcyjne to dowolne zbiory, które zdefiniowane są za pomoą definicji indukcyjnych. Każda definicja indukcyjna zawiera trzy części:

1. bazowa - wymienia elementy wyjściowe, które bezwarunkowo zawierają się $\mathrm{w}$ definiowanym zbiorze 
2. indukcyjna - określa jak nowe elementy definiowanego zbioru powstają z elementów już do niego należących (podaje reguły konstrukcji zbioru indukcyjnego)

3. końcowa - stwierdza, że nic innego poza obiektami uzyskanymi przez odwołanie się do 1. lub 2. nie należy do definiowanego zbioru

Alternatywnie można wysłowić definicję indukcyjną następująco:

$A$ jest zbiorem indukcyjnym wtw $A$ jest najmniejszym zbiorem spełniającym warunki 1 . i 2 .

Formalnie schemat takiej definicji można wyrazić następująco:

$A$ jest zbiorem indukcyjnym wtw:

1. $B \subset A$,

2. $C L(A, O)$,

3. $\forall_{C}(B \subset C \wedge C L(C, O) \rightarrow A \subset C)$,

gdzie $B$ to zbiór elementów wyjściowych, $C L(A, O)$ oznacza, że $A$ jest domknięty na każdą operację ze zbioru $O$, tzn. $x_{1}, \ldots, x_{n} \in A \rightarrow o\left(x_{1}, \ldots, x_{n}\right) \in$ $A$, dla każdej $n$-argumentowej operacji (reguły konstrukcji) $o \in O(n \geq 0)$, a war. 3. wyraża fakt, że $A$ jest najmniejszym zbiorem spełniającym 1. i 2. Istnienie takiego najmniejszego zbioru jest zagwarantowane przez teorię mnogości - jest to iloczyn wszystkich zbiorów zawierających $B$ i domkniętych na wszystkie operacje z $O$.

Przykład: definicja zbioru liczb naturalnych $N$

$N$ jest najmniejszym zbiorem spełniającym warunki:

1. $0 \in N$,

2. jeżeli $x \in N$, to $s x \in N$.

W tekście wielokrotnie pojawiały się definicje takich zbiorów, np. definicja zbioru formuł FOR dla KRZ i KRK. Obecnie popularnym alternatywnym sposobem definiowania jest użycie tzw. notacji Backusa/Naura. Definicja FOR wygląda wtedy tak:

$\varphi \in F O R$ wtw $\varphi:=p|\neg \varphi|(\varphi \wedge \psi)|(\varphi \vee \psi)|(\varphi \rightarrow \psi)$

Jest to forma definicji równoważna klasycznej definicji rekurencyjnej - dowody indukcyjne stosują się również do tak zdefiniowanych zbiorów. 


\subsubsection{Stosowanie dowodów indukcyjnych w logice}

Zasadniczo można wyróżnić dwa sposoby:

A. bezpośrednie zastosowanie indukcji matematycznej (zazwyczaj mocnej) do przyjętej miary, np.:

1. długość formuł (ilość symboli);

2. złożoność formuł (ilość stałych logicznych);

3. długość dowodu (ilość wierszy).

B. wprowadzenie zasady indukcji strukturalnej - np. w wersji dla FOR: Jeżeli:

1. każda zmienna zdaniowa ma własność $\theta$,

2a. jeżeli $\varphi$ ma własność $\theta$, to $\neg \varphi$ ma własność $\theta$,

2b. jeżeli $\varphi$ i $\psi$ ma własność $\theta$, to $(\varphi \wedge \psi),(\varphi \vee \psi),(\varphi \rightarrow \psi)$ ma własność $\theta$

to każda formuła ma własność $\theta$.

Przeanalizujmy trzy przykłady dowodów indukcyjnych w logice:

1. przykład ilustracyjny - parowanie nawiasów;

2. zachodzenie reguły ekstensjonalności;

3. twierdzenie o dedukcji.

Przykład 1 jest bardzo prosty.

Twierdzenie 11.3 W każdej formule $\chi$ ilość nawiasów lewych $(n l(\chi))$ jest równa ilości nawiasów prawych $(n p(\chi))$.

Indukcja strukturalna

a. baza: formuła $\chi$ jest zmienną, zatem $n l(\chi)=n p(\chi)=0$

b. teza: założenie indukcyjne: dowodzone twierdzenie zachodzi dla $\varphi$ i $\psi$

- jeżeli formuła $\chi$ ma postać $\neg \varphi$, to ma tyle samo nawiasów co $\varphi$, więc z założenia indukcyjnego $n l(\chi)=n p(\chi)$ 
- jeżeli formuła $\chi$ ma postać $(\varphi \star \psi)$, gdzie $\star$ to dowolny spójnik dwuargumentowy, to twierdzenie zachodzi, gdyż $n l(\chi)=n l(\varphi)+n l(\psi)+1$ i $n p(\chi)=n p(\varphi)+n p(\psi)+1$, a z założenia indukcyjnego mamy $n l(\varphi)=n p(\varphi)$ i $n l(\psi)=n p(\psi)$.

Zatem twierdzenie zachodzi dla dowolnej formuły.

Przykład 2 - reguła ekstensjonalności.

Twierdzenie 11.4 Reguła ekstensjonalności RE jest reguła wyprowadzalna.

DowóD: Wykażemy, że z $\varphi \leftrightarrow \psi$ jest $\mathrm{w}$ KRZ dedukowalne $\chi \leftrightarrow \chi[\varphi / / \psi]$, gdzie $\chi[\varphi / / \psi]$ oznacza zastąpienie co najmniej jednego wystąpienia $\varphi$ (jako podformuły $\chi)$ przez $\psi$.

Wstępnie odnotujmy bez dowodu następujący:

Lemat 11.1 Każda formuła podpadająca pod jeden z poniższych schematów jest teza dowolnego petnego systemu dedukcyjnego dla KRZ:
a. $(\varphi \leftrightarrow \psi) \rightarrow(\neg \varphi \leftrightarrow \neg \psi)$
b. $(\varphi \leftrightarrow \psi) \rightarrow(\varphi \wedge \chi \leftrightarrow \psi \wedge \chi)$
c. $(\varphi \leftrightarrow \psi) \rightarrow(\chi \wedge \varphi \leftrightarrow \chi \wedge \psi)$
d. $(\varphi \leftrightarrow \psi) \rightarrow(\varphi \vee \chi \leftrightarrow \psi \vee \chi)$
e. $(\varphi \leftrightarrow \psi) \rightarrow(\chi \vee \varphi \leftrightarrow \chi \vee \psi)$
f. $(\varphi \leftrightarrow \psi) \rightarrow(\varphi \rightarrow \chi \leftrightarrow \psi \rightarrow \chi)$
g. $(\varphi \leftrightarrow \psi) \rightarrow(\chi \rightarrow \varphi \leftrightarrow \chi \rightarrow \psi)$
h. $(\varphi \leftrightarrow \psi) \wedge(\gamma \leftrightarrow \delta) \rightarrow(\varphi \wedge \gamma \leftrightarrow \psi \wedge \delta)$
i. $(\varphi \leftrightarrow \psi) \wedge(\gamma \leftrightarrow \delta) \rightarrow(\varphi \vee \gamma \leftrightarrow \psi \vee \delta)$
j. $(\varphi \leftrightarrow \psi) \wedge(\gamma \leftrightarrow \delta) \rightarrow(\varphi \rightarrow \gamma \leftrightarrow \psi \rightarrow \delta)$

Dowodząc naszego twierdzenia stosujemy indukcję (mocną) po długości $\chi$ przy założeniu indukcyjnym, że RE zachodzi dla każdej formuły krótszej. Rozważamy pięć przypadków:

a. $\chi$ jest zmienną, zatem operacja jest wykonalna wtw $\chi:=\varphi$, ale wtedy jest to operacja trywialna, tj. $\chi[\varphi / / \psi]:=\psi$

b. $\chi:=\neg \gamma$. Z założenia indukcyjnego możemy z $\varphi \leftrightarrow \psi$ wydedukować $\gamma \leftrightarrow \gamma[\varphi / / \psi]$, więc przez lemat 11.1, a. otrzymujemy $\neg \gamma \leftrightarrow \neg \gamma[\varphi / / \psi]$.

c. $\chi:=(\gamma \wedge \delta)$. Do rozważenia mamy trzy przypadki:

- zastapienie $\varphi$ przez $\psi$ tylko w $\gamma$, czyli $\chi[\varphi / / \psi]:=(\gamma[\varphi / / \psi] \wedge \delta)$. Z założenia indukcyjnego mamy $\gamma \leftrightarrow \gamma[\varphi / / \psi]$, przez lemat 11.1, b. otrzymujemy $(\gamma \wedge \delta) \leftrightarrow(\gamma[\varphi / / \psi] \wedge \delta)$ 
- zastąpienie $\varphi$ przez $\psi$ tylko $\mathrm{w} \delta$, czyli $\chi[\varphi / / \psi]:=(\gamma \wedge \delta[\varphi / / \psi])$. Analogicznie jak w poprzednim przypadku tylko przez lemat 11.1, c.

- zastąpienie $\varphi$ przez $\psi$ zarówno w $\gamma$ jak i w $\delta$, czyli $\chi[\varphi / / \psi]:=(\gamma[\varphi / / \psi] \wedge$ $\delta[\varphi / / \psi])$. Z założenia indukcyjnego mamy zarówno $\gamma \leftrightarrow \gamma[\varphi / / \psi]$ jak i $\delta \leftrightarrow$ $\delta[\varphi / / \psi]$. Przez lemat 11.1, h. otrzymujemy $(\gamma \wedge \delta) \leftrightarrow(\gamma[\varphi / / \psi] \wedge \delta[\varphi / / \psi])$.

d. i e. dowodzimy tak jak c. w oparciu o lemat 11.1 (odpowiednie przypadki dla $\vee \mathrm{i} \rightarrow$ ).

Czytelnik może dla urozmaicenia udowodnić powyższe twierdzenie przez indukcję strukturalną.

Przykład 3 - twierdzenie o dedukcji dla aksjomatycznego systemu KRZ z rozdziału 1.

Twierdzenie 11.5 (Twierdzenie o dedukcji dla KRZ) Jeżeli $\Gamma, \varphi \vdash \psi$, to $\Gamma \vdash \varphi \rightarrow \psi$.

DowóD przez mocną indukcję po długości dowodu $\Gamma, \varphi \vdash \psi$.

$\mathrm{Z}$ definicji $\Gamma, \varphi \vdash \psi$ znaczy, że istnieje skończony ciąg $\gamma_{1}, \ldots, \gamma_{n}, \mathrm{z} \gamma_{n}:=\psi$. Wykazujemy, że dla dowolnego $1 \leq i \leq n$ zachodzi twierdzenie, tzn., że $\Gamma \vdash \varphi \rightarrow \gamma_{i}$ przy założeniu indukcyjnym, że zachodzi dla dowolnego $j<i$.

Mamy 4 przypadki do rozważenia:

a. $\gamma_{i} \in \Gamma$ : dołączamy do dowodu podstawienie aksjomatu 1. o postaci $\gamma_{i} \rightarrow\left(\varphi \rightarrow \gamma_{i}\right.$ i stosujemy MP otrzymując $\varphi \rightarrow \gamma_{i}$.

b. $\gamma_{i}:=\varphi$; włączamy do dowodu podstawienie aksjomatu 1 . o postaci $\varphi \rightarrow(\varphi \rightarrow \varphi$ i prze MP otrzymujemy $\varphi \rightarrow \varphi$.

Następującą sekwencję kroków (dowód $\varphi \rightarrow \varphi$ ):

c. $\gamma_{i}$ jest aksjomatem - postępujemy jak w przypadku a.

d. $\gamma_{i}$ zostało wydedukowane przez MP z wcześniejszych wierszy dowodu o postaci $\gamma_{j}(j<i)$ i $\gamma_{j} \rightarrow \gamma_{i}$. Ponieważ obie przesłanki podpadają pod założenie indukcyjne, zatem mamy $\varphi \rightarrow\left(\gamma_{j} \rightarrow \gamma_{i}\right)$ i $\varphi \rightarrow \gamma_{j}$. Wprowadzamy do dowodu podstawienie aksjomatu 2 postaci: $\left(\varphi \rightarrow\left(\gamma_{j} \rightarrow \gamma_{i}\right)\right) \rightarrow((\varphi \rightarrow$ $\left.\left.\gamma_{j}\right) \rightarrow\left(\varphi \rightarrow \gamma_{i}\right)\right)$. Podwójne zastosowanie MP daje nam $\varphi \rightarrow \gamma_{i}$.

Zatem $\mathrm{w}$ szczególności, twierdzenie zachodzi dla $\psi$ (przypadek $i=n$ ), czyli $\Gamma \vdash \varphi \rightarrow \psi$

Podana przez nas wyżej definicja drzewa nie była indukcyjna jednak można takie definicje zbudować i to na dwa sposoby. W jednym ujęciu jedynym elementem bazowym jest korzeń drzewa, a warunki indukcyjne precyzują jak drzewo budowane jest od korzenia do liści. W drugim, zbiorem elementów bazowych jest zbiór liści a warunki indukcyjne precyzują jak z liści generujemy 
kolejne węzły. W zależności od przyjętej definicji dowody indukcyjne własności drzew można prowadzić również na dwa sposoby stosując bądź indukcję wstępującą (od korzenia do liści) lub zstępującą (od liści do korzenia). Formalne ujęcie tych kwestii można znaleźć w Segerberg [126]; uważny czytelnik zauważy, że oba typy definicji indukcyjnych i zależnych od nich dowodów indukcyjnych pojawiły się $\mathrm{w}$ pracy (definicje dowodu i drzewa poszukiwania dowodu). 


\section{Bibliografia}

[1] D'Agostino, M., 'Tableau Methods for Classical Propositional Logic' w: M. D'Agostino (red.), Handbook of Tableau Methods, str. 45-123, Kluwer Academic Publishers, Dordrecht 1999.

[2] Aho A. V., i J. D. Ullman, Foundations of Computer Science in C, W. H. Freeman and CO, New York 1995.

[3] Ajdukiewicz, K., 'Sprache und Sinn', Erkenntniss, IV:100-138, 1934. Polskie tłumaczenie w: Język i Poznanie Tom I, str. 145-175, PWN 1985.

[4] Anderson, A., R. i N., D. Belnap, Entailment: the Logic of Relewance and Necessity, vol I Princeton University Press, Princeton 1975.

[5] Andrews, P., B. An Introduction to Mathematical Logic and Type Theory: to Truth through Proof, Harcourt Academic Press, Orlando 1986.

[6] Asser, G., Einführung in die Mathematische Logik, Leipzig 1959 (Teil I), 1972 (Teil II).

[7] Avron, A., 'Gentzen-type systems, Resolution and Tableaux', Journal of Automated Reasoning 10/2:265-281, 1993.

[8] Avron, A., 'The Method of Hypersequents in the Proof Theory of Propositional Non-Classical Logics', w: W. Hodges et al. (red.), Logic: From Foundations to Applications, str. 1-32, Oxford Science Publication, Oxford, 1996.

[9] Avron, A., 'Simple Consequence Relations', Information and Computation, 92: 105-139, 1991.

[10] Batóg T., Podstawy logiki, Wyd. Naukowe UAM 1994. 
[11] Bell, J., L. i M. Machover A Course in Mathematical Logic, NorthHolland, Amsterdam 1977.

[12] Belnap, N., D. 'Display Logic', Journal of Philosophical Logic, 11:375$417,1982$.

[13] Bernays, P., 'Betrachtungen zum Sequenzen-Kalkul' w: A., T. Tymieniecka (red.), Contributions to Logic and Methodology in honor of J. M. Bocheński, str. 1-44, North-Holland, Amsterdam 1965.

[14] Beth E., Semantic Entailment and Formal Derivability, Mededelingen der Kon. Ned. Akad. v. Wet. 18 13, 1955.

[15] Bibel, W., Deduction, Automated Logic, Academic Press, London 1993.

[16] Blamey S., L. Humberstone, 'A Perspective on Modal Sequent Logic', Publications of the Research Institute for Mathematical Sciences, Kyoto University, 27: 763-782, 1991.

[17] Boolos, G., 'Don't eliminate Cut', Journal of Philosophical Logic, 7:373-378, 1984.

[18] Borkowski L., J. SŁupecki, 'A Logical System based on rules and its applications in teaching Mathematical Logic', Studia Logica, 7: 71-113, 1958.

[19] Braüner, T., Hybrid Logic and its Proof-Theory, Roskilde 2009.

[20] Buss, S., R., 'An Introduction to Proof Theory' w: S. Buss (red.) Handbook of Proof Theory, Elsevier 1998.

[21] Carnielli, W.,A., 'On Sequents and Tableaux for Many-valued Logics', Journal of Non-Classical Logic 8(1):59-76, 1991.

[22] CASARI, E., Introduzione alla Logica, UTET, Torino 1997.

[23] Chang, C.,L. and R.,C.,T., Lee, Symbolic Logic and Mechanical Theorem Proving, Academic Press, Orlando 1973.

[24] Church, A. Introduction to Mathematical Logic, vol I, Princeton University Press, Princeton 1956.

[25] Ciabattoni, A. i K. Terui, 'Towards a Semantic Characterization of Cut-elimination', Studia Logica 82: 95-119, 2006. 
[26] Curry H. B., A Theory of Formal Deducibility, University of Notre Dame Press, Notre Dame 1950.

[27] Curry H. B., Foundations of Mathematical Logic, McGraw-Hill, New York 1963.

[28] Czelakowski, J., 'Some theorems on structural entailment relations' Studia Logica 42/4: 417-430, 1975.

[29] DošEn K., 'Sequent-systems for Modal Logic', Journal of Symbolic Logic, 50: 149-159, 1985.

[30] DošEn K., 'Logical constants as punctuation marks' Notre Dame Journal of Formal Logic, 30: 362-381, 1989.

[31] Dos̆en K. i P. Schroeder-Heister (red.), Substructural Logics, Oxford University Press, Oxford 1994.

[32] Dragalin, A.,G., Mathematical Intuitionism. Introduction to Proof Theory, American Mathematical Society, Providence 1988.

[33] Dreben B., Andrews P., i S. AanderaA, 'False lemmas in Herbrand', Bulletin of American Mathematical Society, 69: 699-706, 1963.

[34] Dreben B., i J. Denton, 'A supplement to Herbrand', Journal of Symbolic Logic, 31: 393-398, 1966.

[35] Dummett, M., Logiczna Podstawa Metafizyki, PWN 1998.

[36] Dunn, J., M., i G., M. Hardegree, Algebraic Methods in Philosophical Logic, Clarendon, Oxford 2001.

[37] Dyckhoff, R., 'Dragalin's proof of cut-admissibility for the intuitionistic sequent calculi G3i and G3i', Research Report CS/97/8, St Andrews 1997.

[38] Ebbinghaus H. D., J. Flum, W. Thomas Mathematical Logic, Springer, Berlin 1984.

[39] Ershow, Y., L. i E., A. Palyutin, Mathematical Logic, MiR, Moscow 1984.

[40] Feys, R., J. LADRIERE supplementary notes in: Recherches sur la deduction logique, french translation of Gentzen, Press Univ. de France, Paris 1955. 
[41] Fine K., Reasoning with arbitrary objects, Blackwell, Oxford 1985.

[42] Fitch, F., Symbolic Logic, Ronald Press Co, New York 1952.

[43] Fitting, M., First-Order Logic and Automated Theorem Proving, Springer, Berlin 1996.

[44] Font, J., M., i R. Jansana, A General Algebraic Semantics for Sentential Logics, Springer, Berlin 1996.

[45] Forbes, G., Modern Logic, New York 2001.

[46] Gabbay, D., LDS - Labelled Deductive Systems, Clarendon Press, Oxford 1996.

[47] Garson, J.W. Modal Logic for Philosophers, Cambridge University Press, Cambridge 2006.

[48] Gallier, J.,H., Logic for Computer Science, Harper and Row, New York 1986.

[49] Gentzen G., 'Über die Existenz unabhängiger Axiomensysteme zu unendlichen Satzsystemen', Mathematische Annalen, 107:329-350, 1932.

[50] Gentzen, G., 'Untersuchungen über das Logische Schliessen', Mathematische Zeitschrift 39:176-210 and 39:405-431, 1934.

[51] Gentzen, G., 'Die Widerspruchsfreiheit der reinen Zahlentheorie', $M a$ thematische Annalen 112:493-565, 1936.

[52] Gentzen, G., 'Neue Fassung des Widerspruchsfreiheitsbeweises für die reine Zahlentheorie', Forschungen zur Logik und zur Grundlegung der exakten Wissenschaften, New Series 4, Leipzig 19-44, 1938.

[53] Girard, J., Y., 'Linear Logic' Theoretical Computer Science, 50: 1-101, 1987.

[54] Goré, R. 'Tableau Methods for Modal and Temporal Logics', w: M. D'Agostino (red.), Handbook of Tableau Methods, str. 297-396, Kluwer Academic Publishers, Dordrecht 1999.

[55] GöDEL, K. 'Die Vollständigkeit der Axiome des Logischen Funktionenkalküls' Monatschefte für Mathematik und Physik 37: 349-360, 1930. 
[56] Grandy, R., E., Advanced Logic for Applications, Reidel, Dordrecht 1977.

[57] Hähnle, R. Automated Deduction in Multiple-Valued Logics, Oxford University Press, 1994.

[58] Hähnle, R. 'Tableaux and Related Methods', w: A. Robinson, A. Voronkov (red.), Handbook of Automated Reasoning, str. 101-177, Elsevier, Amsterdam 2001.

[59] M. D'Agostino (red.), Handbook of Tableau Methods, Kluwer Academic Publishers, Dordrecht 1999.

[60] Hacking, I., 'What is Logic?', The Journal of Philosophy 76: 285-319, 1979.

[61] Hasenjaeger,G., Introduction to the Basic Concepts and Problems of Modern Logic, Reidel, Dordrecht 1972.

[62] Herbrand J., abstrakt w: Comptes Rendus des Seances de l'Academie des Sciences 1928, vol. 186, 1275 Paris.

[63] Herbrand J., 'Recherches sur la theorie de la demonstration', in: Travaux de la Societe des Sciences et des Lettres de Varsovie, Classe III, Sciences Mathematiques et Physiques, Warsovie, 1930.

[64] Hermes H., Einführung in die Mathematische Logik, Teubner, Stuttgart 1963.

[65] Hertz P., 'Über Axiomensysteme für beliebige Satzsysteme', Mathematische Annalen, 101: 457-514, 1929.

[66] Hintikka J., 'Form and Content in Quantification Theory', Acta Philosophica Fennica, 8: 8-55, 1955.

[67] Hintikka J., 'Quantifiers in Deontic Logic', Societas Scientiarum Fennica, Commentationes Humanarum Literarum XXIII, 1957.

[68] Hodges, W., 'Elementary Predicate Logic', w: D. Gabbay, i F. Guenther (red.), Handbook of Philosophical Logic, Tom I str. 1-132, Kluwer, Dordrecht 1983.

[69] Hodges, W., 'Logical Features of Horn Clauses' w: D. Gabbay, C., J. Hogger i J., A. Robinson (red.), Handbook of Logic in AI and Logic Programming, Tom I str. 449-503, Clarendon, Oxford 1994. 
[70] Indrzejczak, A., 'Generalised Sequent Calculus for Propositional Modal Logics', Logica Trianguli 1:15-31, 1997.

[71] Indrzejczak, A., 'Jaśkowski and Gentzen Approaches to Natural Deduction and Related Systems' w: K. Kijania-Placek i J. Woleński (red.), The Lvov-Warsw School and Contemporary Philosophy, str. 253-264, Kluwer, Dordrecht 1998.

[72] Indrzejczak,A. 'Correspondence Theory in Proof Theory' Bulletin of the Section of logic 37/3-4:171-184, 2008.

[73] IndrzejCzAK,A. 'Suszko's Contribution to the Theory of Nonaxiomatic Proof Systems' Bulletin of the Section of logic 38/3-4:151-162, 2009.

[74] Indrzejczak,A., Natural Deduction, Hybrid Systems and Modal Logics, Springer 2010.

[75] JAŚKOwski, S., 'Teoria dedukcji oparta na dyrektywach założeniowych' in: Księga Pamiątkowa I Polskiego Zjazdu Matematycznego, Uniwersytet Jagielloński, Kraków 1929.

[76] JAŚKowski, S., 'On the Rules of Suppositions in Formal Logic' Studia Logica 1:5-32, 1934.

[77] Kalish, D., and R. Montague, 'Remarks on Descriptions and Natural Deduction', Archiv. für Mathematische Logik und Grundlagen Forschung 3:50-64, 65-73, 1957.

[78] Kalish, D., and R. Montague, Logic, Techniques of Formal Reasoning, Harcourt, Brace and World, New York 1964.

[79] Kanger S., Provability in Logic, Almqvist \& Wiksell, Stockholm 1957.

[80] Kashima R., 'Cut-free sequent calculi for some tense logics', Studia Logica, 53:119-135, 1994.

[81] Keisler, H. J., i J. RobBin, Mathematical Logic and Computability, The McGraw-Hill 1996.

[82] Ketonen, O., Untersuchungen zum Prädikatenkalkül, Annalea Acad. Sci. Fenn. Ser. A. I. 32, Helsinki 1944.

[83] Kleene S. C., Introduction to Metamathematics North Holland, Amsterdam 1952. 
[84] Kleene S. C., Mathematical Logic Willey, New York 1967.

[85] KLeEne S. C., 'Permutability of inferences in Gentzen's calculi LK and LJ' Memoirs of the American Mathematical Society, 10: 1-26, 1952.

[86] Kneale W., M. Kneale, The Development of Logic, Clarendon Press, Oxford 1962.

[87] KrajiceK, J., 'Lower bounds to the size of constant-depth propositional proofs' Journal of Symbolic Logic 59/1:73-85, 1994.

[88] Leblanc, H., 'Proof routines for the propositional calculus', Notre Dame Journal of Formal Logic 4/2: 81-104, 1963.

[89] Leblanc, H., 'Two separation theorems for natural deduction', Notre Dame Journal of Formal Logic 7/2: 81-104, 1966.

[90] Lemmon E. J., Beginning Logic Nelson, London 1965.

[91] Leśniewski, S., 'Gründzuge eines Neuen Systems der Grundlagen der Mathematik', Fundamenta Mathematicae, 14: 1-81, 1929.

[92] Letz, R., 'First-order Tableau Methods' w: M. D'Agostino (red.), Handbook of Tableau Methods, str. 125-196, Kluwer Academic Publishers, Dordrecht 1999.

[93] Lis, Z., 'Wynikanie semantyczne a wynikanie formalne', Studia Logica 10:39-60, 1960.

[94] Loveland D. W., Automated Theorem Proving: a Logical Basis, North Holland, Amsterdam 1978.

[95] Lyndon, R., O logice matematycznej, PWN, Warszawa 1968.

[96] ŁaWrow, I., A. i Ł., L. MAKsimowa, Zadania z teorii mnogości, logiki matematycznej i teorii algorytmów, PWN, Warszawa 2004.

[97] Maciaszek, J., Znaki logiczne, Wyd. UŁ, Łódź 2003.

[98] Marciszewski W., R. Murawski, Mechanization of Reasoning in a Historical Perspective, Rodopi, Amsterdam, Atlanta 1995.

[99] Mints G., 'Cut-free calculi of the S5 type', Studies in Constructive Mathematics and Mathematical Logic II: 79-82, 1970. 
[100] Mostowski, A., Logika matematyczna, Warszawa 1948.

[101] Negri, S., and J. von Plato, Structural Proof Theory, Cambridge University Press, Cambridge 2001.

[102] Negri S., 'Proof Analysis in Modal Logic', Journal of Philosophical Logic, 34: 507-544, 2005.

[103] Nishimura H., 'A Study of Some Tense Logics by Gentzen's Sequential Method', Publications of the Research Institute for Mathematical Sciences, Kyoto University, 16: 343-353, 1980.

[104] Ono, H., 'Proof-Theoretic Methods in Nonclassical Logic - an Introduction' w: M. Takahashi (red.), Theories of Types and Proofs, MSJMemoir 2, str. 207-254, Mathematical Society of Japan, 1998.

[105] Ortowska, E. i J. Golińska-Pilarek, Dual Tableaux: Foundations, Methodology, Case Studies, Springer 2011.

[106] PaOli, F., Substructural Logics: a Primer, Kluwer, Dordrecht 2002.

[107] Plato von J., 'Gentzen's proof of normalization for ND', The Bulletin of Symbolic Logic 14(2):240-257, 2008.

[108] Poggiolesi F., Gentzen Calculi for Modal Propositional Logic, Springer 2011.

[109] Pogorzelski W. A., Klasyczny rachunek zdań, PWN, Warszawa 1973.

[110] Popper, K., 'Logic without assumptions', Proceedings of the Aristotelian Society 47:251-292, 1947.

[111] Popper, K., 'New foundations for Logic', Mind 56: 1947.

[112] Prior, A.,N. 'A runabout inference ticket', Analysis 21:38-39, 1960.

[113] Prawitz, D. Natural Deduction, Almqvist and Wiksell, Stockholm 1965.

[114] Quine W. Van O., Z punktu widzenia logiki, Colt, New York 1950.

[115] Quine W. Van O., Methods of Logic, Colt, New York 1950.

[116] RagGio A., 'Gentzen's Hauptsatz for the systems NI and NK', Logique et Analyse 8:91-100, 1965. 
[117] Rasiowa H., R. Sikorski, The Mathematics of Metamathematics, PWN, Warszawa 1963.

[118] Restall, G. Proof Theory and Philosophy, available on: http://consequently.org/writing/ptp

[119] Rieger, L. Algebraic Methods of Mathematical Logic, Academia, Prague 1967.

[120] Robinson, J.,A., 'A Machine Oriented Logic based on the Resolution Principle', Journal of the Assoc. Comput. Mach., 12:23-41, 1965.

[121] Rousseau G., 'Sequents in Many Valued Logic', Fundamenta Mathematicae, LX, 1: 22-23, 1967.

[122] Schroeder-Heister, P., 'Popper's theory of deductive inference and the concept of a logical constant', History and Philosophy of Logic 5:79$110,1984$.

[123] Schütte K., Proof Theory, Springer, Berlin 1977.

[124] Schwichtenberg, H., 'Proof Theory' w: J. Barwise (red.), Handbook of Mathematical Logic, T. 1, North-Holland, Amsterdam 1977.

[125] Scott, D., 'Rules and derived rules' w: S. Stenlund (red.) Logical Theory and Semantical Analysis, str. 147-161, 1974.

[126] Segerberg, K. Classical Propositional Operators, Clarendon Press, Oxford 1982.

[127] Shoesmith, D., j. i T., J. Smiley, Multiple-conclusion Logic, Cambridge 1978.

[128] Simpson, A. The Proof Theory and Semantics of Intuitionistic Modal Logic, PhD thesis, University of Edinburgh, 1994.

[129] Smullyan, R., 'Analytic Natural Deduction', The Journal of Symbolic Logic, 30/2: 123-139, 1965.

[130] Smullyan, R., 'Trees and Nest Structures', The Journal of Symbolic Logic, 31/3: 303-321, 1966.

[131] Smullyan, R., First-Order Logic, Springer, Berlin 1968. 
[132] Sundholm, G., 'Systems of Deduction' w: D. Gabbay, F. Guenthner (red.), Handbook of Philosophical Logic, vol I, str. 133-188, Reidel Publishing Company, Dordrecht 2002.

[133] Suppes P., Introduction to Logic, Van Nostrand, Princeton 1957.

[134] Surma, S., J., Wprowadzenie do metamatematyki T. I, Kraków 1965.

[135] Suszko R., 'W sprawie logiki bez aksjomatów', Kwartalnik Filozoficzny, 17(3/4): 199-205, 1948.

[136] Suszko R., O analitycznych aksjomatach $i$ logicznych regułach wnioskowania, Poznańskie Towarzystwo Przyjaciół Nauk, Prace Komisji Filozoficznej 7/5, 1949.

[137] Suszko R., 'Formalna teoria wartości logicznych', Studia Logica 6:145$320,1957$.

[138] Suszko R., 'The Fregean Axiom and Polish Mathematical Logic in the 1920's', Studia Logica 36(4):377-380, 1977.

[139] Szabo M. E. The Collected Papers of Gerhard Gentzen, NorthHolland, Amsterdam 1969.

[140] Tait, W., W., 'Normal Derivability in Classical Logic' w: The Sintax and Semantics of Infinitary Languages, LNM 72, str. 204-236, 1968.

[141] Takano M., 'Subformula Property as a substitute for Cut-Elimination in Modal Propositional Logics', Mathematica Japonica, 37(6): 1129$1145,1992$.

[142] Takano M., 'A Modified Subformula Property for the Modal Logics K5 and K5D', Bulletin of the Section of Logic 30(2):115-123, 2001.

[143] Takeuti, G., Proof Theory, North-Holland, Amsterdam 1987.

[144] Tarski A., 'Fundamentale Begriffe der Methodologie der deduktiven Wissenschaften', Monatschefte für Mathematik und Physik, 37:361-404, 1930.

[145] Troelstra A. S. i H.Schwichtenberg Basic Proof Theory, Oxford University Press, Oxford 1996.

[146] TrzęSicki, K., Logika i teoria mnogości, Exit, Warszawa 2003. 
[147] WaAler, A. i L. Wallen, 'Tableaux for Intuitionistic Logics' w: M. D'Agostino (red.), Handbook of Tableau Methods, str. 255-296, Kluwer Academic Publishers, Dordrecht 1999.

[148] Wansing, H., Displaying Modal Logics, Kluwer Academic Publishers, Dordrecht 1999.

[149] Wansing, H., 'Sequent Systems for Modal Logics', w: D. Gabbay, F. Guenthner (red.), Handbook of Philosophical Logic, vol IV, str. 89-133, Reidel Publishing Company, Dordrecht 2002.

[150] Wójcicki, R. Theory of Logical Calculi, Kluwer, Dordrecht 1988.

[151] Vickers, S., Topology via Logic, Cambridge University Press, Cambridge 1988.

[152] Zeman, J.,J., Modal Logic, Oxford University Press, Oxford 1973.

[153] Zygmunt, J., 'Entailment Relations on Logical Matrices', Bulletin of the Section of Logic 8:112-115, 1979.

[154] Zucker, J. i R. Tragesser, 'The adequacy problem for inferential logic' Journal of Philosophical Logic 7:501-516, 1987. 


\section{Skorowidz}

Ackermann, 254

addytywny (Cut), 112, 122

addytywny spójnik, 35, 45

adekwatność, 11, 63

adekwatność ARS, 73, 217

adekwatność H-KRK, 186

adekwatność LK, 57, 202

Ajdukiewicz, 249

AK, 3

aksjomaty, 4

aksjomaty uogólnione, 63, 92

alfabetyczne warianty, 170, 207

algebry Boole'a, 175

algorytm, 22, 135

algorytm budujący wszerz, 141, 222

algorytmy budujące w głąb, 141

alternatywa elementarna, 159

alternatywy RS, 71

analityczne (Cut), 147, 134, 157

analityczność, 82, 132

Andrews, 162, 172, 192, 238, 241

ARS, 72, 88, 108

ARS-KRK, 211

arytmetyka, 129, 164

arytmetyka Peano, 175

Asser, 12, 16, 19

automatyczne dowodzenie twierdzeń, vi

Avron, 31, 39, 41, 44, 229, 263

backtracking, 140

Batóg, 13 bazowa geometryczna formuła, 177

bazowa teoria geometryczna, 177

Bell, 127, 198, 219, 221

Belnap, 31, 119, 121, 135

Bernays, 250, 256

Beth, 193, 263

bezpośredni potomek, 55

bezpośredni przodek, 55

bezpośrednia podformuła, 3, 200

Bibel, 263

Blamey, 31

Braüner, 230, 234, 236

Buss, vii, 51, 88, 90, 91, 115, 118, $122,125,127,141,221,224$, 229, 233

c-sekwenty, 72

c-systemy, 29, 71, 135, 238

Carnielli, 31

Casari, 29

Church, 172, 192

cięcie, 32

Craig, 142

Curry, 39, 85, 87, 88, 90, 118, 122, $125,127,248$

cut-formuła, 93, 94, 134

Czelakowski, 39

D'Agostino, 88, 89

długość dowodu, 50, 94

długość formuły, 2, 94

długość zastosowania (Cut), 109 
dedukcja naturalna, v, 23, 198

dedukcja sekwentu, 56, 136

dedukcyjny MP, 7

definicja indukcyjna, 15

definicja rekurencyjna, 2

De Morgan, 241

deskrypcje określone, 250

display calculus, 31, 135

display logic, 119, 121

DN, v, 23, 39, 89, 194, 235, 239

Došen, 31, 35, 238, 246

dopuszczalność (Cut), 108, 213

dopuszczalność kontrakcji, 76, 215

dopuszczalność osłabiania, 213

dowód analityczny pełności, 152

dowód indukcyjny, 5

dowód nadrzędny, 55

dowód nie wprost, 24

dowód rozgałęziony, 24

dowód sekwentu, 50, 136

dowód warunkowy, 24

Dragalin, 88, 90, 109, 112, 115, 116, $120,127,213$

Dreben, 192

drzewo dowodowe, 135

drzewo dowodowe kompletne, 136

Dummett, 83, 132

Dunn, 39, 44

Dyckhoff, 109

Ebbinghaus, 238, 243

eigenvariable, 201, 205

ekspansja formuły, 193

eksplicytność mocna, 82

eksplicytność słaba, 82

eliminacja cięcia, 133

eliminowalność definicji, 177

Ershow, 238, 240

Euklides, 133, 232 falsum, 2

falsyfikacja sekwentu, 59

Feys, 242

Fine, 197

Fitting, 88, 140, 197, 218

Flum, 238, 243

Font, 45

Forbes, 242

formuła atomowa, 165

formuła domknięta, 167

formuła geometryczna, 176

formuła KRZ, 1

formuła otwarta, 167

formuła parametryczna, 28, 49

formuła poboczna, 49, 210

formuła zasadnicza, 28, 49, 210

formuly podobne, 170

formuły preneksowe, 173, 225

funkcja interpretacji, 177

funkcje obliczalne, 192

Gödel, 12, 188

głębokość (Mix), 97

gałąź, 55

Gabbay, 31

Gallier, 72, 135, 140, 141, 193, 218, 221, 224

Garson, 198

GEN, 171, 187

Gentzen, v, 24, 30, 37, 38, 40, 51, 57, 58, 89-91, 95, 127, 128, 130, 164, 192, 196, 197, 200, 204, 216, 224, 228, 237, 238, $242,248,249,251,256,258$, 259, 261

Girard, 35, 229

Golińska-Pilarek, 263

Goré, 153, 155

Grandy, 84

grupy Abelowe, 175 
$\mathrm{H}, 57$

H-KRK, 171

H-KRKI, 191

H-KRZ, 146

H-system, 4, 52

Hähnle, 31

Hacking, 83

Hardegree, 39, 44

Hasenjaeger, 258

Hauptsatz, vi, 98, 204

Henkin, 12, 13, 16, 146, 147, 151, $152,187,218$

Herbrand, 192, 196, 224, 233, 249, 254

Hermes, 36, 238, 243, 244

Hertz, v, 37, 82, 237, 247, 254

Hilbert, v, 4, 40, 228, 250, 254

Hintikka, 12, 16, 19, 146, 147, 152, 153, 156, 158, 160, 196, 262

hipersekwenty, 30

Hodges, 21, 176

Horn, 192

Humberstone, 31

ID, 174

identyczność, 162

indeterminizm, 134

Indrzejczak, ix, 31, 88, 89, 194, 234, 250

indukcja strukturalna, 2, 94

inferencjalizm, 83, 132

inferencyjne definicje, 248

inferencyjny MP, 7

instancja podstawieniowa, 169, 201

instancja podstawieniowa ścisła, 169, 201

instancja podstawieniowa nieścisła, 169

INT, 4, 49, 84, 109, 255

int-sekwenty, 30, 49, 84 interpolacja, 22, 129

interpolant, 144

inwersja reguł, 75, 115

języki pierwszego rzędu, 162

Jaśkowski, v, 24, 25, 194, 239, 240, $242,249,261$

Jansana, 40, 45

Johansson, 255

K3, 252

KA, 3, 159, 176

Kalish, 255

Kalmar, 12, 22

Kartezjusz, 133

Kashima, 31

$\mathrm{KE}, 86,89$

Keisler, 218

Ketonen, 65, 66, 110

klasy abstrakcji, 191

klasyczne sekwenty, 30

klasyczny rachunek kwantyfikatorów, 6

klasyczny rachunek zdań, 1

klauzula, 3, 263

klauzula Horna, 3, 176

Kleene, 40, 49, 58, 88, 95, 142, 143, 200, 201, 203, 204, 221, 227, 233, 248, 252, 257, 258

Kolmogorov, 255

kompletne drzewo dowodowe, 154

koneksja, 261

kongruencja, 83

konsekwencja finitarna, 41

konserwatywne poszerzenie, 132

konserwatywność, 129, 201, 232, 236

konserwatywność systemu, 131

kontrakcja, 48, 95

KRK, 6, 57, 83, 141, 161

KRKI, 162, 174 
kroki redukcyjne, 91

kryteria logiczności, 247

KRZ, 1, 47, 52

kumulatywność, 82

Kuratowski, 15

kwantyfikator ogólny, 161

kwantyfikator szczegółowy, 161

L-dowód, 24

L-rank, 97

$\operatorname{L-rank}(\varphi), 98$

Ladriere, 242

Leśniewski, 131

Leblanc, 238, 245

LEM, 84

lemat Königa, 221, 223

lemat Kuratowskiego-Zorna, 15

lemat Lindenbauma, 13, 15, 19, 149, 187

lemat o inwersji, 75, 116

lemat prawdziwościowy, 20, 150, 189

lemat Tukeya, 15

Lemmon, 238, 242

Letz, 218

LF, 254

LI, 49

Lindenbaum, 13, 15, 19, 44, 146, $147,151,152,153,157$

Lis, 263

literał, 3, 160

LJ, 84, 201

LK, ix, 38, 46, 47, 57, 62, 92, 200, 238,256

$\mathrm{LK}^{*}, 256,259$

$\mathrm{LK}_{M I X}, 96$

LK-A, 67

LK-K, 67, 122, 139

LK-M, 67

LL, 174, 235

logika pierwszego rzędu, 161 logika drugiego rzędu, 161

logika inkluzywna, 194

logika intuicjonistyczna, 4, 227

logika linearna, 35

logika pozytywna, 4

logiki modalne, 30

logiki nieklasyczne, 30

logiki podstrukturalne, 35, 67

logiki relewantne, 35

logiki wielowartościowe, 30, 35

LS, 250

Lyndon, 40

Ławrow, 238, 240

Łukasiewicz, 252, 254

m-ARS, 72, 86, 110, 213

m-systemy, 29, 72, 108

Machover, 127, 198, 219, 221

Maciaszek, 83

Maehara, 129, 142

Maksimowa, 238, 240

maksymalna para zbiorów formuł, 149

Markow, 22

maszyna Turinga, 22, 192

matryca, 89

mid-sequent theorem, 224

minimalny rachunek zdań, 255

Mints, 134

mix-formuła, 97

MNSP, 13, 19, 187

mocne twierdzenie o eliminacji (Cut), 229

modalne logiki hybrydowe, 234

model, 9, 177, 179

model falsyfikujący, 155

model Herbranda, 220

Modus Ponens, 4, 89

Mondadori, 89 
Montague, 255

Mostowski, 162

MP, 4, 62, 171

MRZ, 255

multiplikatywny (Cut), 122

multiplikatywny spójnik, 35, 45

następnik sekwentu, 28, 46

nasycona para zbiorów formul, 152

nazwy indywiduowe, 163

Negri, vii, 51, 86, 87, 109, 111, 196,

$206,215,230,232,235,246$

niesprzeczność, 8, 129, 201

niesprzeczność LJ, 130

niesprzeczność LK, 130

niesprzeczność par zbiorów formuł, 147

niesprzeczność teorii, 232

nietwórczość definicji, 177

niezależność aksjomatów, 232

niezależność kontekstowa, 83, 122, 159

Nischimura, 31

NK, 57, 238

odwracalność reguł, 82

odwracalność reguł w ARS, 213

odwracalność syntaktyczna reguł ARS, 75

Ono, 142

operacja konsekwencji, 5, 41

operacja konsekwencji Tarskiego, 39, 41

Orłowska, 263

osłabianie, 48, 92

Palyutin, 238, 240

Paoli, 35

para Hintikki, 155

para nasycona względem $H, 219$

parametry, 84, 194, 197, 198 partycja sekwentu, 142

PB, 86

pełność ARS, 73

Peano, 238

permutacja, 48, 92

permutacja reguł, 227

Plato von, vi, vii, 51, 86, 87, 109, 111, 196, 206, 215, 230, 232, 235,246

poddedukcja, 56

poddowód, 55

podformuła, 3, 200

podsekwent, 56

podstawianie, 168

Poggiolesi, 29, 31, 131, 132, 247

Popper, 248, 256

poprawne podstawianie, 169

poprzednik sekwentu, 28, 46

Post, 8, 11, 12, 22, 38, 147, 160, $161,218,263$

postacie normalne, 159, 263

postać alternatywno-koniunkcyjna, 3

postać koniunkcyjno-alternatywna, 3

postać normalna KA, 174

potomek, 55

POZ, 4

pozytywny rachunek zdań, 255

Prawitz, vi, 83

prawo Peirce'a, 84

predykaty, 163

Prior, 132

prosta relacja konsekwencji, 45

PRZ, 255

przestrzeń poszukiwania dowodu, 140

przodek, 55

przystosowanie, 60

pseudokod, 140 
pure-variable property, 204

PV-dowody, 203, 204, 225

Quine, 162, 241

R-rank, 97

$\mathrm{R}-\operatorname{rank}(\varphi), 98$

rachunek sekwentów, v, 27, 47

Raggio, vi

rank (Mix), 97

$\operatorname{rank}(\varphi), 98$

$\operatorname{rank}(\mathcal{B}), 98$

Rasiowa, 262

RE, 8, 173

reguła atomowego prawa wyłączonego środka, 86

reguła cięcia, vii

reguła Dunsa Szkota, 244

reguła ekstensjonalności, 8, 173

reguła Peirce'a, 85

reguła sylogizmu, 248

reguły dopuszczalne, 7, 62

reguły eliminacji, 33

reguły eliminacji stałych, 133

reguły Gentzena, 66, 138

reguły inferencji, 24

reguły k-jednolite, 34, 49, 64, 139

reguły k-niezależne, 34, 49, 64, 138

reguły Ketonena, 65, 72, 139

reguły konstrukcji dowodu, 24

reguły kwantyfikatorowe, 83

reguły logiczne, 32,48

reguły niezawodne, 11, 60, 68, 187, 217

reguły normalne, 11

reguły odwracalne, 66, 68, 139

reguły pierwotne, 61

reguły sekwentowe, 27,34

reguły strukturalne, 32,47

reguły wprowadzania, 33 reguły wtórne, 7,61

reguły wyprowadzalne, 7, 58, 62

regularna relacja konsekwencji, 45

relacja dowiedlności, 5, 41, 172

relacja konsekwencji Scotta, 42

relatywna maksymalność, 157

relatywne zbiory maksymalne, 16

rezolucja, viii, 261

Rieger, 30, 259

Robbin, 218

Robinson, 193, 263

Rousseau, 31

rozdzielność, 82

rozstrzygalność, 22, 129, 158, 201, 211

rozstrzygalność KRZ, 135

RS, v, 27, 129

RS-INT, 85

RS-KRKI, 235

RS-T, 228

rząd dowodu, 225

rząd reguły kwantyfikatorowej, 225

S5, 134, 142

saturacja, 154, 221

Schütte, 88, 90, 112, 115, 119, 124, 127

schemat int-elim, 240

Schroeder-Heister, 35, 248

Schwichtenberg, vii, 109, 115

Scott, 39, 41, 43, 247

sekwent, 27, 46

sekwent atomowy, 46

sekwent domknięty na zastosowanie reguły, 153, 155

sekwent LK, 46

sekwent pośredniczący, 224

sekwent quasi-atomowy, 222

sekwent zamknięty, 140

sekwentowa dedukcja naturalna, 36 
sekwentowy system DN, 24, 39, 82, 237

sekwenty bazowe, 229

sekwenty niestandardowe, 30

sekwenty standardowe, 30

sekwenty zagnieżdżone, 30

sekwenty-przesłanki, 47

sekwenty-wnioski, 47

semi-formuła, 199

semi-rozstrzygalność, 161, 192

semi-term, 199

separowalność, 82, 129, 201

sharpened hauptsatz, 224

Shoesmith, 39

Sikorski, 262

Simpson, 177

skolemizacja termów, 242

Smiley, 39

Smullyan, 16, 18, 19, 88, 90, 111, $113,115,117,123,127,197$, 263

spełnialność, 10

sprzeczność, 8

stała logiczna, 247

stałe addytywne, 67

stałe multiplikatywne, 67

stałe indywiduowe (nazwowe), 198

standardowy system RS, 36, 81

strategie preferencji, 141

struktura ilorazowa, 191

struktura interpretacyjna, 177

strukturalna zupełność, 62

Sundholm, 83

Suppes, 238, 240, 242, 243

Surma, 259

Suszko, ix, 89, 238, 249, 251, 261

sylogizm Fregego, 52

sylogizm hipotetyczny, 89

symbole funkcyjne, 163

symetria mocna, 82 symetria słaba, 82

systemy analityczne, 129, 133

systemy ściśle analityczne, 133

systemy etykietowane, 31

systemy słabo analityczne, 134

systemy syntetyczne, 133

systemy tablicowe, viii, 18, 133, 198, 261

Szabo, vi

ścisła klauzula Horna, 176

T-dowód, 24, 240

Tait, 89-91, 115, 118, 122, 126

Takeuti, vii, 95, 142, 162, 197, 199, 204, 206

Tarski, 5, 39-41, 43

tautologia, 10, 179

TD, 7, 11, 172

teoria grup, 164, 175

teoria Hornowska, 176

teoria konsekwencji, 39

teoria krat, 164, 175

teoria mnogości, 164

teoria obliczalności, 22

teoria typów, 162

teoria złożoności obliczeniowej, 22

teorie pierwszego rzędu, 171

teorie elementarne, 162, 171, 228

teorie geometryczne, 176, 230

teorie uniwersalne, 176, 230

term wolny za zmienną, 169

teza Churcha-Turinga, 192

teza Suszki, 89

Thomas, 238, 243

TIM, 13, 19

tonk, 132

TP, 13

Tragesser, 41

Troelstra, vii, 109

Tukey, 15 
Turing, 22, 192

twiedzenie o pełności dla RS, 151

twierdzenia o eliminacji (Cut), 84, 90, 208

twierdzenia o pełności, 12

twierdzenia o przystosowaniu, 12

twierdzenie Assera, 16

twierdzenie Craiga o interpolacji, 23

twierdzenie Herbranda, 192, 224, 232

twierdzenie Löwenheima-Skolema, 191

twierdzenie o alfabetycznych wariantach, 204, 206

twierdzenie o dedukcji, 7, 24

twierdzenie o dedukcji nie wprost, 7

twierdzenie o definiowalności, 193 twierdzenie o dopuszczalności (Cut), 90

twierdzenie o eliminacji cięcia, vi twierdzenie o interpolacji, 141, 193 twierdzenie o istnieniu modelu, 13 twierdzenie o koincydencji, 181 twierdzenie o normalizacji, vi, 235 twierdzenie o pełności, 186 twierdzenie o podstawianiu, 181, 183, 206

twierdzenie o przystosowaniu, 186 twierdzenie o sekwencie pośredniczącym, 224

twierdzenie o zwartości, 191

twierdzenie Posta, 159

typ strukturalny RS, 248

typy RS, 36, 237

uniwersalna implikacja, 176

uniwersum Herbranda, 218, 221, 224

uogólniona własność podformuł, 232 verum, 2

Vickers, 176

Wójcicki, 44

właściwe reguły inferencji, 249

własność Henkina, 187

własność podformuł, 82, 129, 130, 132, 142, 201, 246

własność separacji, 131

własności niesprzeczności, 16

waluacja, 9

waluacja zmiennych, 178

Wansing, 31, 247

warianty RS, 36, 71

wartościowanie, 9

warunek progresywności, 81, 238

WH, 187

wielkość dowodu, 50

wyłączność, 82

wynikanie, 10, 180

wysokość dowodu, 50, 94

z-ARS, 72, 112

z-systemy, 29, 72

złożenie sekwentów, 56

złożoność formuły, 2, 94

zasada abstrakcji, 191

zasada dwuwartościowości, 89

zasięg kwantyfikatora, 165

zastępowanie, 170

zawartość struktury, 179

zbiór Hintikki, 17

zbiór maksymalnie niesprzeczny, 13, 146

zbiór nasycony, 16, 146

zbiór nasycony w dół, 17

zbiór przeliczalny, 15

zbiór rekurencyjnie przeliczalny, 192

zbiór sprzeczny, 5

zbieżność, 82, 138 
zdanie, 167

zmienna wolna, 166

zmienna związana, 166

zmienne indywiduowe, 163

Zorn, 15

Zucker, 41

Zygmunt, 39

$(=E), 235$

$(=), 236$

$(=\Rightarrow), 235$

$(A X), 48$

$\left(A X_{a}\right), 64$

$\left(A X_{n}\right), 64$

$(C), 48$

$(C \Rightarrow), 48$

(Cut), vii, 32, 48, 62, 88, 149, 216, 239

$(L E M-a t), 86$

$(M O N), 41$

(Mix), 95, 208

(Multicut), 95

$(P), 48,108$

$(P \Rightarrow), 48$

$(P e \Rightarrow), 85$

(Rep), 236

(Taut), 241

(TR), 41

$(U A X), 72$

$\left(U A X_{a}\right), 64$

$\left(U A X_{n}\right), 64$

$(W), 32,48$

$(W \Rightarrow), 48$

$(Z W R), 41$

$(\Rightarrow), 239$

$(\Rightarrow C), 48$

$(\Rightarrow P), 48$

$(\Rightarrow W), 48$

$(\Rightarrow \rightarrow 1), 67$

$(\Rightarrow \rightarrow 2), 67$
$(\Rightarrow \perp), 85$

$(\Rightarrow \exists E), 239$

$(\Rightarrow \exists), 201,212$

$(\Rightarrow \exists U), 241$

$(\Rightarrow \forall), 201,239$

$(\Rightarrow \forall E), 239$

$(\Rightarrow \forall U), 241$

$(\Rightarrow \neg), 48,239$

$(\Rightarrow \neg E), 239,240$

$(\Rightarrow \rightarrow E), 239$

$(\Rightarrow \rightarrow), 48,239$

$(\Rightarrow \vee), 48,239$

$(\Rightarrow \vee E), 239$

$(\Rightarrow \wedge), 48,239$

$(\Rightarrow \wedge E 1), 239$

$(\Rightarrow \wedge E 2), 239$

$(\perp), 24,87$

$(\exists D), 194$

$(\exists E), 194,238$

$(\exists \Rightarrow), 201$

$(\forall D), 194$

$(\forall E), 194$

$(\forall \Rightarrow), 201,212$

$(\neg), 41,42$

$(\neg D), 24$

$(\neg E \Rightarrow), 240,241$

$(\neg E), 25$

$(\neg \Rightarrow), 48$

$(\rightarrow), 41,42,247$

$(\rightarrow D), 24$

$(\rightarrow E), 24$

$(\rightarrow \Rightarrow), 48$

$\left(\rightarrow^{\prime}\right), 42$

(V), 41, 42, 247

$(\vee D), 24$

$(\vee E), 24$

$(\mathrm{V} \Rightarrow), 48$

$\left(\mathrm{V}^{\prime}\right), 42$

$(\wedge), 41,42,247$

$(\wedge D), 24$ 


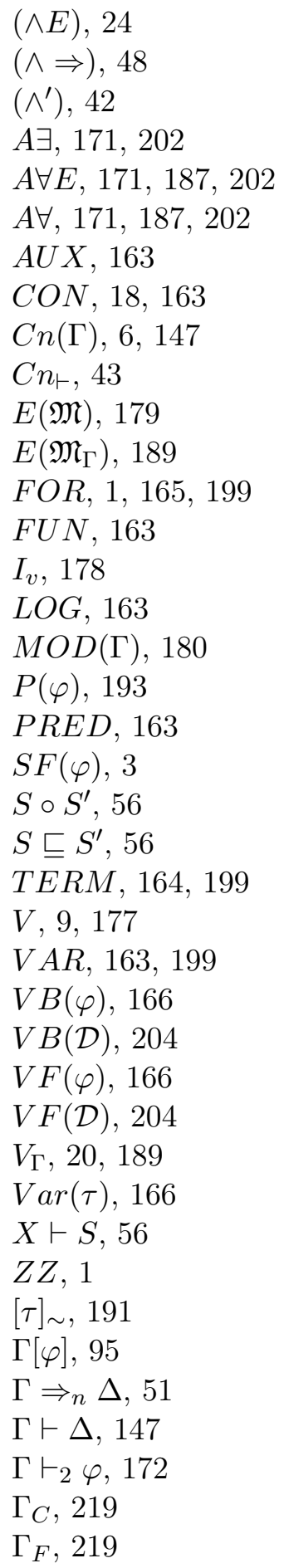

$\Gamma_{C}, 219$

$\Gamma_{F}, 219$

$$
\begin{aligned}
& \Gamma_{\varphi}, 95 \\
& \perp, 2,84 \\
& \exists, 161 \\
& \exists E, 173,202 \\
& \forall, 161 \\
& \forall I, 173,202 \\
& \leftrightarrow, 2 \\
& \mathfrak{M}, 9,59,177 \\
& \mathfrak{M}_{\Gamma}, 20,189 \\
& |\mathcal{D}|, 51 \\
& \models, 10 \\
& \neg, 1 \\
& \nvdash, 9
\end{aligned}
$$$$
\omega \text {-zupełność, } 188
$$$$
\|\mathcal{D}\|, 52
$$$$
\rightarrow, 1
$$$$
\tau \in \operatorname{Free}(x, \varphi), 169
$$$$
\tau_{1}\left[x / \tau_{2}\right], 168
$$$$
\tau_{1} \sim \tau_{2}, 191
$$$$
\top, 2
$$

$$
\begin{aligned}
& \vDash, 9 \\
& \varphi^{(1)}, 119 \\
& \varphi(x), 166 \\
& \varphi\left[\tau_{1} / / \tau_{2}\right], 170 \\
& \varphi[x / \tau], 168 \\
& \vdash, 5 \\
& \vdash \Gamma \Rightarrow \Delta, 50 \\
& \vdash \Gamma \Rightarrow{ }_{k}^{\varphi} \Delta, 112 \\
& \vdash_{2}, 251 \\
& \vdash_{H}, 57 \\
& \vdash_{n} \Gamma \Rightarrow \Delta, 51 \\
& \vdash_{L K}, 57 \\
& \vdash_{\text {max }}, 43 \\
& \vdash_{\min }, 43 \\
& \vee, 1 \\
& \wedge, 1 \\
& v_{o}^{x}, 178 \\
& x \text {-wariant, } 178 \\
& \mathcal{D}, 51
\end{aligned}
$$




\section{Summary}

In 1934 Jaśkowski and Gentzen independently published their groundbreaking works on natural deduction. Moreover, Gentzen introduced in his paper another formal system LK, nowadays commonly called sequent calculus. Although Gentzen presented sequent calculus as a kind of auxiliary system for showing some properties of natural deduction it appeared soon that it is a system of a great importance. Modern proof theory is developed mainly in Gentzen's tradition with sequent calculi as the basic tool for application. Unfortunately, in Poland, the country with great logical tradition, this approach is not very popular.

The book is meant as a detailed introduction to the subject of sequent calculi and their applications. However, it differs strongly from well known books on proof theory which use sequent calculi as a tool for exploration and presentation of metalogical results. Instead, this book focuses on sequent calculi, their properties, and techniques of proof. Hence it is not a book on proof theory as such, but rather methodological study of basic tools of modern proof theory. In particular, we pay special attention to different techniques of proving cut-elimination theorem which is often seen as the most fundamental result in the field. We restrict considerations to classical logic, hence we do not present generalizations of sequent calculi provided for nonclassical logics. We hope that these matters will be treated in the sequel to this volume.

Since the book is self-contained the first chapter contains the brief introduction to classical propositional logic (CPL). We describe propositional languages and notation, Hilbert calculus for CPL and standard semantics. Special attention is paid to adequacy proofs for Hilbert calculus; we present several approaches due to Post, Henkin, Asser, Hintikka and Smullyan. Finally, some properties of CPL, like decidability and interpolation are discussed and formalization in terms of natural deduction.

The general introduction to sequent calculi is provided in chapter 2. In particular, we discuss the notion of a sequent, sequent rules and sequent 
calculus; in each case several variants and generalizations of basic notions are presented. Finally, we discuss different possible interpretions of sequents and sequent rules and the connections with the theory of consequence relations. Chapter 3 is devoted to detailed description of original Gentzen's calculus LK and its basic properties. Syntactical equivalence with Hilbert formalization of CPL as well as soundness with respect to standard semantics is shown. In the next chapter we introduce a plethora of variants of sequent calculi for CPL. In particular, analytical sequent calculus is introduced with no structural rules and with invertible rules. Finally, we present a general result concerning equivalence of rules of several shapes on the basis of standard sequent calculus, and discuss the most interesting properties of rules.

The cornerstone of the book is chaper 5 which contains a detailed description of different proofs of cut-elimination. After informal discussion of the general idea of proving cut-elimination/admissibility, we present the original proof of Gentzen. Next, we introduce three different proofs due to Dragalin, Schütte and Smullyan. Despite the differences all are based on local transformation steps in proofs, similarly as Gentzen's proof. Rather different approach to the problem is represented by Curry and Buss. Their proofs, although different, are based on the strategy of global transformation of input proof containing applications of cut. A discussion of properties of presented proofs and their comparison finishes the chapter.

The next chapter focuses on some consequences of cut-elimination. First of all, we discuss subformula-property, several senses of analyticity, decidability of CPL and strategies of proof-search. Additionaly, the proof of interpolation for CPL by means of Maehara strategy is presented. In chapter 7 we show that sequent calculus may be applied succesfully also for presenting semantical results. We restrict our considerations to completeness proof. Firstly, Henkin-style non-constructive proof is presented in two variants for sequent calculus with cut. Next, Hintikka-style constructive proofs (also in two variants) are provided for cut-free sequent calculus. We present also a completeness proof for sequent calculus with analytical cut which mixes the properties of Henkin's and Hintikka's proofs. Finally, Post method based on normal forms is adapted to cut-free sequent calculus.

Next we turn to first-order logic. Chapter 8 has similar character to chapter 1; it is an introduction to first-order classical logic with special attention paid to some language-oriented problems important in the context of sequent calculi. In chapter 9 we extend to first-order logic the techniques and results introduced in chapters 3-7 for propositional logic. We focus on questions particularly important for, or hard to prove in the context of sequent formalization of first-order logic. In particular, we discuss in detail 
two approaches to characterization of the language (free variables versus paramaters) and the problem of semi-decidability and proof-search strategies. Except ordinary cut-elimination theorem (in Gentzen's and Dragalin's version) we present the strengtened version of this result (mid-sequent theorem) which may be seen as a version of Herbrand's theorem. Also four different approaches to formalization of elementary theories on the basis of sequent calculi are discussed.

The last chapter is devoted to brief presentation of some other kinds of sequent calculi which are essentially different from ordinary Gentzen's calculi explored so far. The first type is based on the idea of characterization of constants by means of rules, and in this respect is similar to ordinary Gentzen's calculi. The difference is that several calculi of this sort admit rules of different character than cumulative Gentzen's introduction rules. The second type is based on the idea of characterization of constants by means of primitive sequents, with structural rules only. The third type is of mixed character with rules and sequents equally applicable. We finish with an Appendix presenting briefly set-theoretical, algebraic and arithmetical notions used in the book; in particular, we pay special attentention to inductive proofs. 